\title{
GEOLOGICAL SURVEY RESEARCH 1963
}

Short Papers in Geology and Hydrology

Articles

$22-172$ 



\section{Short Papers in Geology and Hydrology}

Articles 122-172

\section{GEOLOGICAL SURVEY RESEARCH 1963}

\section{GEOLOGICAL SURVEY PROFESSIONAL PAPER 475-D}

Scientific notes and summaries of investigations prepared by members of the Conservation, Geologic, and Water Resources Divisions

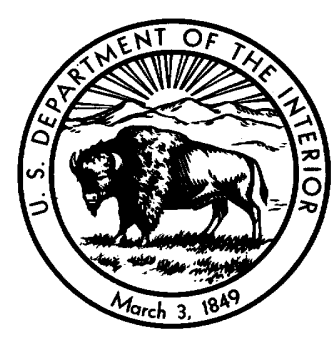

UNITED STATES GOVERNMENT PRINTING OFFICE, WASHINGTON : 1964 


\section{UNITED STATES DEPARTMENT OF THE INTERIOR \\ STEWART L. UDALL, Secretary \\ GEOLOGICAL SURVEY \\ Thomas B. Nolan, Director}

For sale by the Superintendent of Documents, U.S. Government Printing Office

Washington, D.C. 20402 


\section{FOREWORD}

This collection of 51 articles is the last of the chapters of Professional Paper 475. The articles report on scientific and economic results of current work by members of the Geologic and Water Resources Divisions of the U.S. Geological Survey. Some of the papers present results of completed parts of continuing investigations; others announce new discoveries or preliminary results of investigations that will be discussed in greater detail in reports to be published in the future. Still others are scientific notes of limited scope, and short papers on techniques and instrumentation.

Chapter A of this series presents a summary of investigations covering a wide range of work done during the 1963 fiscal year. It also includes maps showing the status of topographic mapping, a list of publications by Survey authors, a list of cooperating agencies, addresses of principal offices, and a list of investigations in progress.

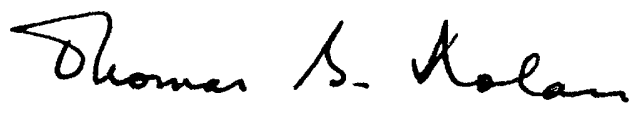

Thomas B. Nolan,

Director. 



\section{CONTENTS}

Foreword

Page

III

\section{Stratigraphy and structural geology}

\section{GEOLOGIC STUDIES}

122. Comparison of late Paleozoic depositional history of northern Nevada and central Idaho, by R. J. Roberts and

M. R. Thomasson

123. Thrust-fault relations in the northern Coast Ranges, Calif., by R. D. Brown, Jr

124. Upper Pliocene marine strata on the east side of the San Joaquin Valley, Calif., by R. L. Klausing and K. E. Lohman -

125. Miocene vertebrates of the Barstow Formation in southern California, by G. E. Lewis. .

126. The Thirsty Canyon Tuff of Nye and Esmeralda Counties, Nev., by D. C. Noble, R. E. Anderson, E. B. Ekren, and

J. T. O'Connor

127. St. Kevin Granite, Sawatch Range, Colo., by Ogden Tweto and R. C. Pearson

128. Reinterpretation of the late growth of the Gypsum Valley salt anticline, San Miguel County, Colo., by F. W. Cater-

129. A Pleistocene section at Leonards Cut, Burke County, N.C., by J. C. Reed, Jr., Bruce Bryant, E. B. Leopold, and Louise Weiler

130. Surface and subsurface stratigraphic sequence in southeastern Mississippi, by D. H. Eargle...

D1

7

14

18

24

28

33

38

43

\section{Mineralogy and petrology}

131. Magmatic differentiation in a volcanic sequence related to the Creede caldera, Colorado, by J. C. Ratté and T. A. Steven . . . . . . . . .

132. Revised Tertiary volcanic sequence in the central San Juan Mountains, Colo., by T. A. Steven and J. C. Ratté.-

133. Valleriite and the new iron sulfide, mackinawite, by H. T. Evans, Jr., Charles Milton, E. C. T. Chao, Isidore Adler, Cynthia Mead, Blanche Ingram, and R. A. Berner.

134. Eddies as indicators of local flow direction in rhyolite, by David Cummings.

\section{Geochemistry}

135. Cadmium in samples of the Pierre Shale and some equivalent stratigraphic units, Great Plains region, by H. A. Tourtelot, Claude Huffman, Jr., and L. F. Rader

136. Analysis of geochemical prospecting data from the Rocky Range, Beaver County, Utah, by J. J. Connor and A. T. Miesch._.

137. In vestigation of sampling-error effects in geochemical prospecting, by A. T. Miesch and J. J. Connor

138. Effect of cation exchange on the thermal behavior of heulandite and clinoptilolite, by A. O. Shepard and H. C. Starkey _. .

139. Determination of the ion-exchange capacity of a zeolitic tuff, by H. C. Starkey

140. Geological and geochemical reconnaissance, southern part of the Smyrna Mills quadrangle, Aroostook County, Maine, by Louis Pavlides and F. C. Canney

\section{Geochronology}

141. Age of basement rocks from the Williston basin of North Dakota and adjacent areas, by Z. E. Peterman and C. E.

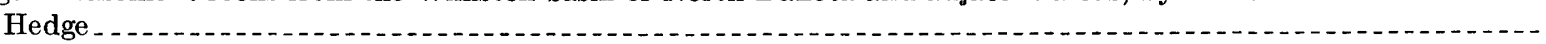

142. Isotopic ages of glaucophane schists from the area of Cazadero, Calif., by D. E. Lee, H. H. Thomas, R. F. Marvin, and R. G. Coleman.

\section{Geophysics}

143. Crustal structure in the vicinity of Las Vegas, Nev., from seismic and gravity observations, by J. C. Roller _ - - -

144. Hawaiian seismic events during 1962, by R. Y. Koyanagi

145. Seismic investigations on Cape Cod, Mass., by R. N. Oldale and C. R. Tuttle

\section{Economic geology}

146. Geologic setting of the Spar City district, San Juan Mountains, Colo., by T. A. Steven 147. Thorium and uranium in monazite from Spokane County, Wash., by J. W. Hosterman, W. C. Overstreet, and J. J. Warr, Jr

148. Rich oil shale from northern Alaska, by I. L. Tailleur 


\section{Sedimentation}

149. Dissimilarity between spatial and volocity-weighted sediment concentrations, by H. P. Guy and D. B. Simons _...

150. Temporary storage of fine sediments in islands and point bars and alluvial channels of the Rio Grande, New Mexico and Texas, by C. F. Nordin, Jr., and J. P. Beverage

151. Fluvial sedimentation in Mammoth Cave, Ky., by C. R. Collier and R. F. Flint

152. Quaternary mudflow deposits near Santiago, Chile, by Kenneth Segerstrom, Octavio Castillo U., and Eduardo Falcón M

\section{Paleontology}

153. New occurrences of the rugose coral Rhizophyllum in North America, by W. A. Oliver.

\section{Glacial geology}

154. Glacial chronology of Ullsfjord, northern Norway, by G. W. Holmes and B. G. Andersen

\section{Analytical techniques}

155. Effluent collector for gas chromatography, by D. F. Goerlitz and W. L. Lamar.

156. Use of sodium-sensitive glass electrodes for solubility determinations, by A. H. Truesdell and C. L. Christ.....--

157. Semimicro X-ray fluorescence analysis of tektites using 50-milligram samples, by H. J. Rose, Jr., Frank Cuttitta,

M. K. Carron, and Robena Brown

158. Determination of total iron in hematitic iron ores by X-ray fluorescence spectrometry, by W. W. Niles . . . . .

159. A gas jet for d-c arc spectroscopy, by A. W. Helz

\section{Geochemistry of water}

\section{HYDROLOGIC STUDIES}

160. Dolomite solubility in ground water, by Ivan Barnes and William Back

161. Effect of tree leaves on water quality in the Cacapon River, W. Va., by K. V. Slack

162. Relation of percent sodium to source and movement of ground water, National Reactor Testing Station, Idaho, by F. H. Olmsted.

163. Relation of fluoride content to recharge and movement of ground water in Oasis Valley, southern Nevada, by G. T. Malmberg and T. E. Eakin

\section{Analytical hydrology}

164. Reservoir storage on streams having log-normal distributions of annual discharge, by C. H. Hardison

\section{Marine hydrology}

165. Environmental factors affecting attached macro-organisms, Patuxent River estuary, Maryland, by R. L. Cory_-.--

\section{Surface water}

166. Anomalous streamflow-ground-water regimen in the Mad River basin, near Springfield, Ohio, by W. P. Cross and A. J. Feulner.

167. Height-frequency relations for New Jersey floods, by D. M. Thomas

\section{Ground water}

168. Seasonal temperature fluctuations in surficial sand near Albany, N.Y., by R. C. Heath...

169. Hydrogeology of the Santiago area, Chile, by W. W. Doyel, R. J. Dingman, and Octavio Castillo U

170. Ground water in the Arica area, Chile, by W. W. Doyel

\section{Hydrologic instrumentation}

171. "Lazy" thermometers and their use in measuring ground-water temperatures, by R. C. Heath

172. Television apparatus for borehole exploration, by J. E. Eddy 


\title{
COMPARISON OF LATE PALEOZOIC DEPOSITIONAL HISTORY OF NORTHERN NEVADA AND CENTRAL IDAHO
}

\author{
By RALPH J. ROBERTS and M. RAY THOMASSON, ${ }^{1}$ \\ Menlo Park, Calif., and Midland, Tex.
}

\begin{abstract}
Three major sequences of upper Paleozoic rocks have been mapped in northern Nevada: one deposited east of the Antler orogenic belt, one within the belt, and one west of the belt. Recognition of comparable sequences in central Idaho suggests similarity in depositional history of the two areas.
\end{abstract}

In 1960, sections of Paleozoic rocks in the area between Arco, Challis, and Hailey, Idaho (fig. 122.1), were visited by Roberts in company with C. P. Ross and other geologists of the U.S. Geological Survey. Thomasson had previously studied sections of upper Paleozoic rocks in central Idaho in 1956, 1957, and 1958 during fieldwork on his dissertation for the University of Wisconsin.

The authors independently noted similarities between upper Paleozoic rocks and tectonics of north-central Nevada and those of central Idaho, which suggest that the two areas have related depositional histories. Although rock units cannot be traced from one area to the other because of the intervening volcanic rocks of the Snake River Plain, the stratigraphic succession, lithology, and structural histories are comparable. Comparison of the sequences in the two areas is shown in the accompanying table and on figure 122.2.

\section{ROCK SEQUENCES}

In north-central Nevada, three contemporaneous major sequences ${ }^{2}$ have been described (Roberts and others, 1958) (fig. 122.2A): (1) the Eureka-Carlin sequence, a combination of the Eureka sequence,

1 Shell Oil Co.

2 The term "sequence" is used here in an informal sense to denote a geographically discrete succession of major rock units that were deposited under related environmental conditions (Silbering and Roberts, 1962). A single name is applied to a sequence in order to avoid repeating all the formation names. In the same way, comparable sequences in Idaho are given informal names of their own.

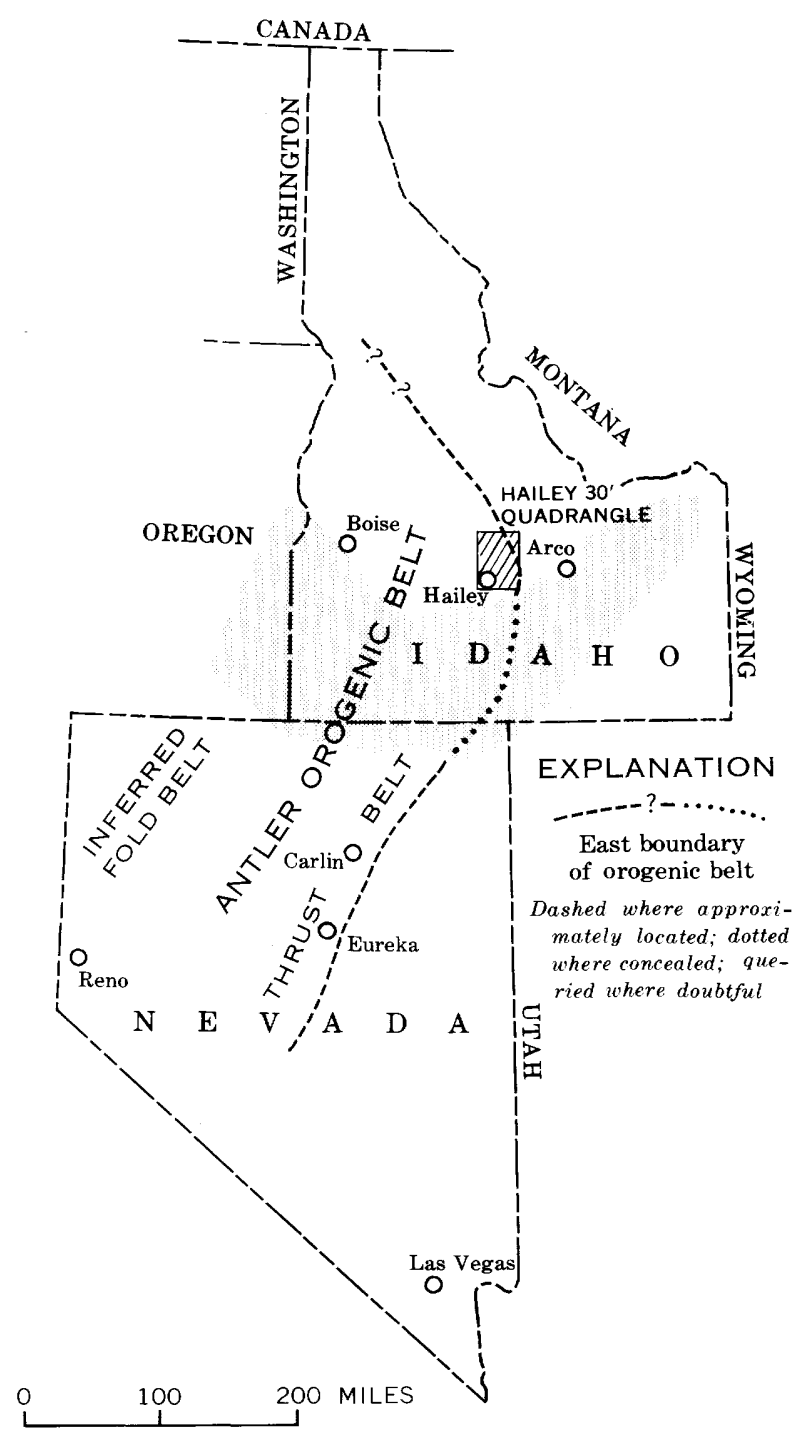

Figure 122.1.-Index map of report area in Nevada and Idaho, showing part of the Antler orogenic belt and the Snake River Plain (stippled pattern).

ART. 122 IN U.S. GEOL. SURVEY PROF. PAPER 475-D, PAGES D1-D6. 1964. 
Descriptions of late Paleozoic rocks in northern Nevada and central Idaho

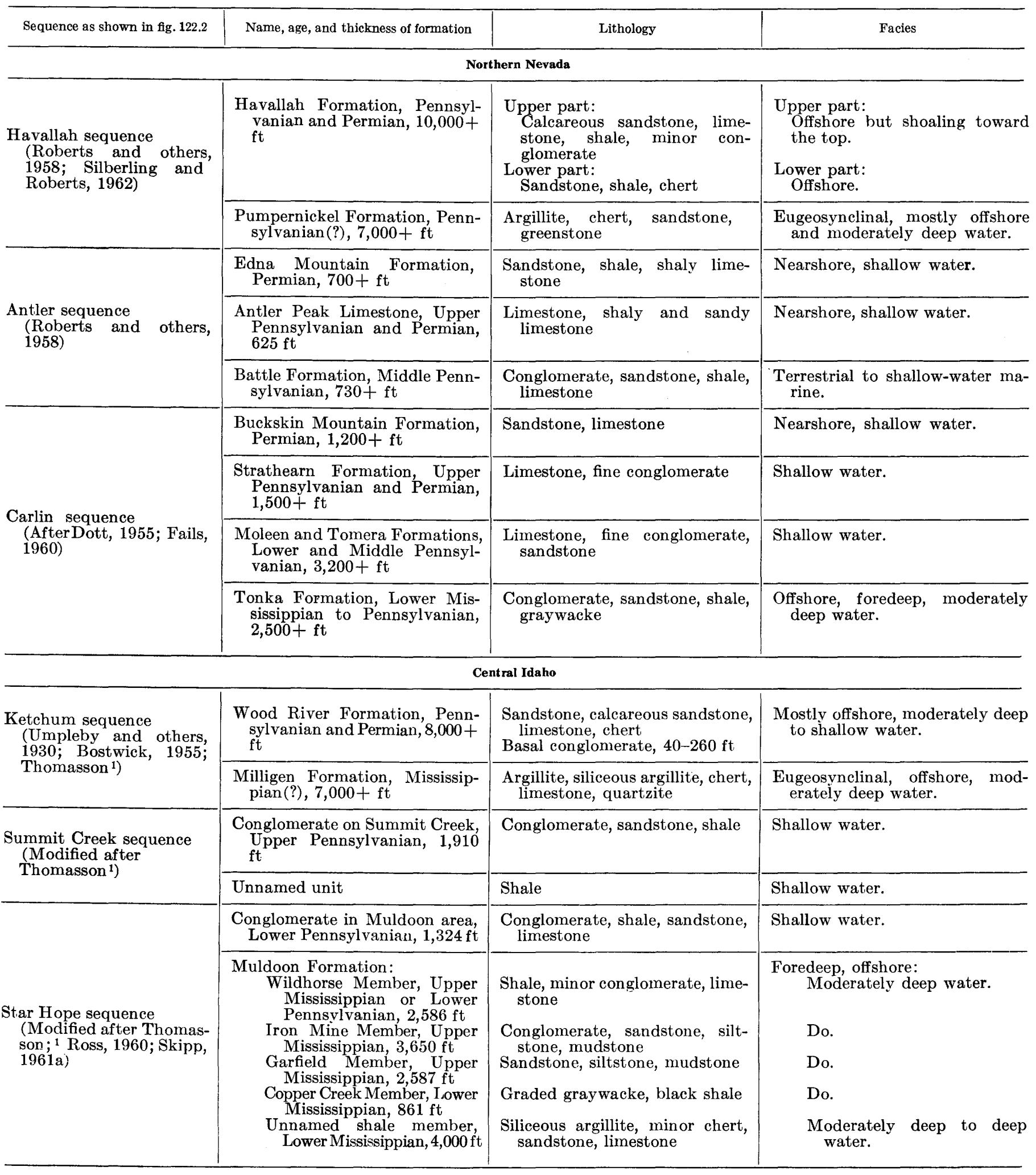

\footnotetext{
i See footnote 3, p. D4.
} 


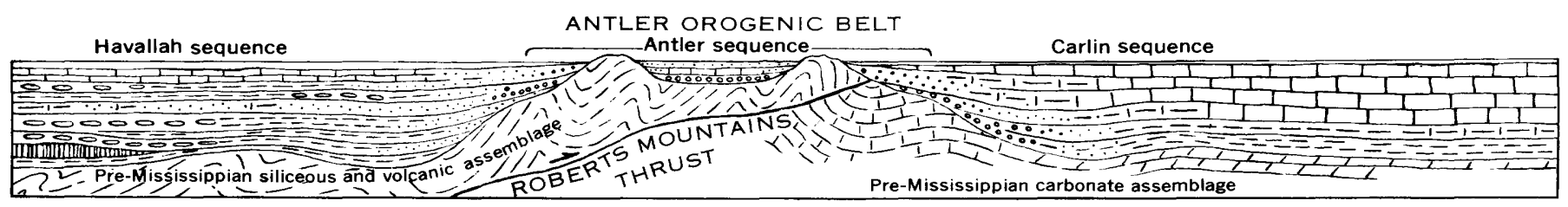

A. Northern Nevada, Mississippian through Early Permian. Following the Antler orogeny, sediments of the Antler sequence were deposited near the orogenic belt and those of the Havallah and Carlin sequence farther offshore

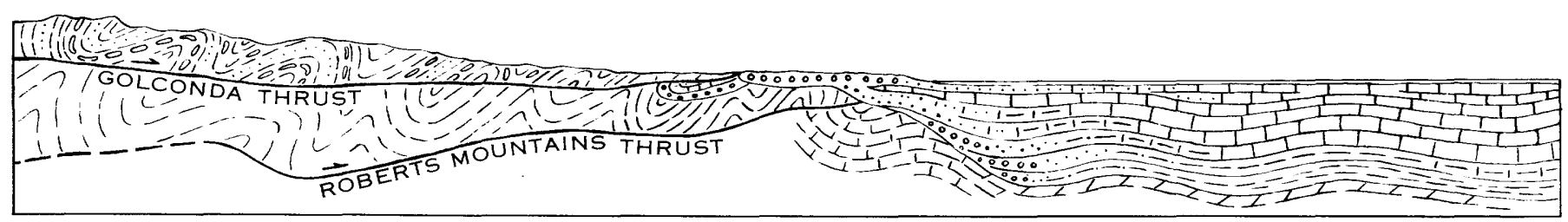

B. Northern Nevada, Late Permian. During the Sonoma orogeny, the Havallah sequence moved eastward on the Golconda thrust, and clastic rocks were shed into eastern Nevada

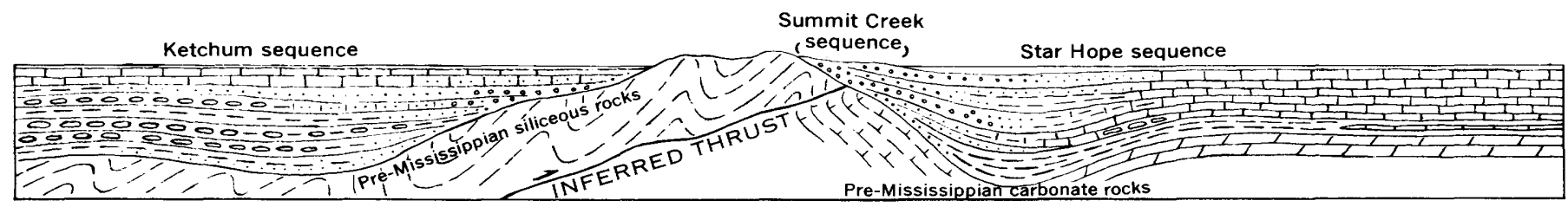

C. Central Idaho, Mississippian through Early Permian. Following the Mississippian orogeny, sediments of the Summit Creek sequence were deposted near the orogenic belt and those of the Ketchum and Star Hope sequences farther offshore

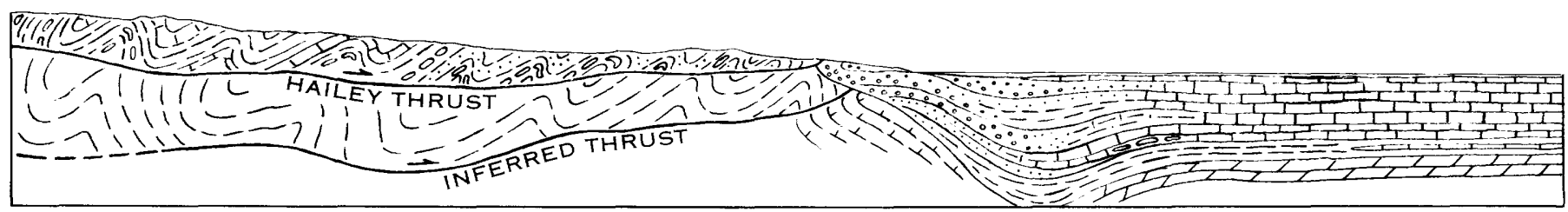

D. Central Idaho, post-Early Permian. During the post-Early Permian orogeny, the Ketchum sequence moved eastward on the Hailey thrust

\section{EXPLANATION}

\begin{tabular}{|c|c|c|}
\hline $\begin{array}{l}\because 0 \\
\therefore \therefore 0 \\
\because 0\end{array}$ & $\because \div$ & II \\
\hline Conglomerate & Shale and graywacke & Limestone \\
\hline$\left[\begin{array}{lll}0 & \\
\hdashline & \\
\hdashline\end{array}\right.$ & $\begin{array}{ll}0 & \infty \\
3 & 0\end{array}$ & $\begin{array}{l}-1-1- \\
1-1 \\
-1-1\end{array}$ \\
\hline Sandstone & Bedded chert & Shaly limestor \\
\hline$=$ & 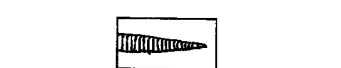 & $K^{2}$ \\
\hline Shale or argillite & Volcanic rock & Dolomite \\
\hline
\end{tabular}

Figure 122.2.-Diagrammatic sections showing a comparison of late Paleozoic depositional history in northern Nevada with that in central Idaho. 
(composed of the Chainman Shale, Diamond Peak Formation, Ely Limestone, and the Carbon Ridge and Garden Valley Formations, exposed in the Eureka area) (fig. 122.1), and the Carlin sequence exposed farther north (composed of the Tonka, Moleen and Tomera, Strathearn, and Buckskin Mountain Formations of Dott, 1955, and Fails, 1960); (2) the Antler sequence, composed of the Battle Formation, Antler Peak Limestone, and Edna Mountain Formation; and (3) the Havallah sequence, composed of the Pumpernickel and Havallah Formations (Ferguson, Muller, and Roberts, 1951; Silberling and Roberts, 1962). The Eureka and Carlin sequences were deposited east of the Antler orogenic belt; the Antler sequence was deposited within and near the belt; and the Havallah sequence was deposited west of the belt in a separate basin. The clastic rocks that predominate in these sequences were derived from the emergent Antler orogenic belt.

\section{Carlin and Star Hope Sequences}

Rocks comparable to the Carlin sequence have been described in central Idaho (Ross, 1934, 1960, 1962a; Skipp, 1961a, 1961b; Scholten, 1957; Thomasson, 1959a, 1959b, Thomasson; ${ }^{3}$ Shannon, 1961) and are here called the Star Hope sequence. In the Muldoon area, between Hailey and Mackay, the sequence is 15,340 feet thick (Thomasson ${ }^{3}$ ) and is composed of an unnamed shale at the base, the Muldoon Formation, and an upper conglomerate. Correlative units have been recognized in the Copper Basin area, 10 miles west of Mackay (Ross, 1960, 1962a, 1962b, 1962c; Skipp, 1961a, 1961b). The Carlin and Star Hope sequences are both characterized by shale and siliceous shale at the base of the section and by conglomerate, graywacke, sandstone, shale, and limestone in the middle and upper parts. In detail, the sections differ, but in general the rock types are similar. The conglomerates in both sequences are composed predominantly of fragments of chert and quartzite derived from eugeosynclinal rocks; these conglomerates coarsen westward, indicating derivation from a western source. Eastward, both sequences intertongue with finer clastic rocks and limestone of shelf facies.

\section{Antler and Summit Creek sequences}

Formations of the Antler sequence, which were deposited within and near the orogenic belt in northern Nevada, are much thinner and more lenticular than offshore correlative units on both sides of the belt (figs. 122.1 and $122.2 \mathrm{~A}$ ). Locally, uplift during the late Paleozoic caused erosion of parts or all of the sequence. In central Idaho, comparable rocks thus far have been

\footnotetext{
${ }^{3}$ Thomasson, M. R., 1959, Late Paleozoic stratigraphy and paleotectonics central and easteru Idaho: Wisconsin Univ., Ph. D. thesis, 244 p.
}

recognized only at one place, on the ridge at the head of Summit Creek. They are here called the Summit Creek sequence (figs. 122.2C and 122.3). This sequence consists of about 1,900 feet of conglomerate, sandstone, and shale of Pennsylvanian age (Thomasson ${ }^{3}$ ). The basal unit, like the Battle Formation of the Antler sequence, rests unconformably on folded Ordovician rocks.

\section{Havallah and Ketchum sequences}

In the Hailey area the Milligen and Wood River Formations, together here called the Ketchum sequence, are respectively similar to the Pumpernickel and Havallah Formations of the Havallah sequence in Nevada (Silberling and Roberts, 1962). The Milligen Formation, at the base, is mostly dark shale and chert; the Pumpernickel is mostly shale and radiolarian chert, but locally contains a good deal of volcanic rock; the Milligen apparently lacks volcanic rock. The Wood River Formation contains bedded chert, sandy limestone, and shale that are strikingly similar to comparable units of the Havallah Formation; the Wood River differs in that it contains coarser clastic rocks near the base.

The source of the clastic rocks in the Ketchum sequence has not yet been resolved. Thomasson ${ }^{3}$ measured current directions in the Wood River Formation; north of Hailey these suggest derivation from the southwest; near Hailey, current directions suggest derivation from the northwest. No diagnostic current marks were noted in the Milligen Formation. However, Roberts believes that some detritus in the Milligen and Wood River Formations must have been transported westward from the orogenic belt, as indicated in figure 122.2 , but agrees that other sources may also have supplied detritus.

\section{Contrasts of the Ketchum with other Idaho sequences}

The sharp contrasts in lithology and stratigraphy between the Ketchum, Summit Creek, and Star Hope sequences in Idaho are due to differences in their depositional environments. The Ketchum sequence represents mostly an offshore and deep-water facies in the lower part and shallow-water facies in the upper part, whereas the Summit Creek represents a nearshore facies that grades eastward into offshore facies of the Star Hope sequence. Ross (1962b, p. 385, 1962c, pl. 1) shows a depositional contact between rocks here assigned to the Ketchum and Star Hope sequences. On the geologic map of the Hailey quadrangle these rocks are shown in thrust-fault contact (Umpleby and others, 1930, pl. 1); moreover, the Ketchum sequence has been highly deformed (figs. 122.2, 122.3), in sharp contrast to the relatively simple deformation of the Summit Creek and Star Hope sequences. These con- 


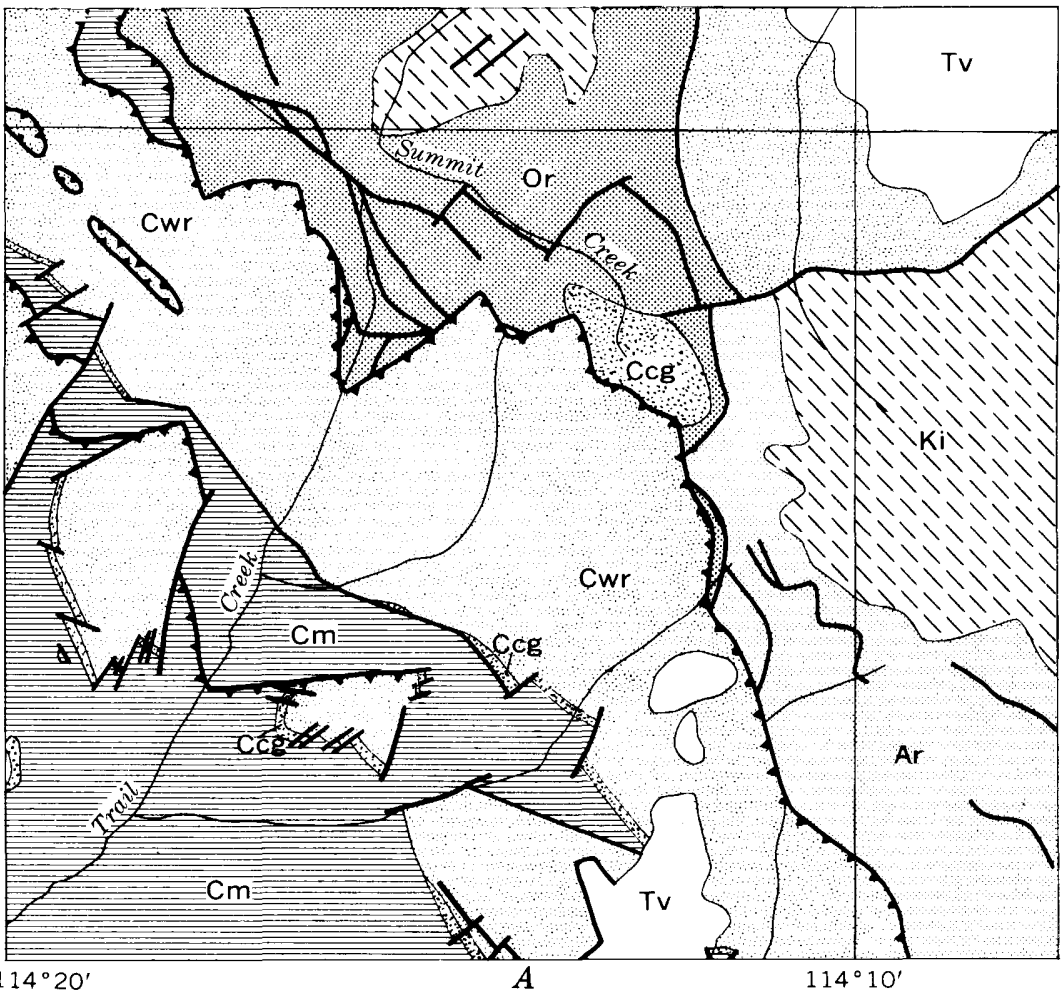

EXPLANATION

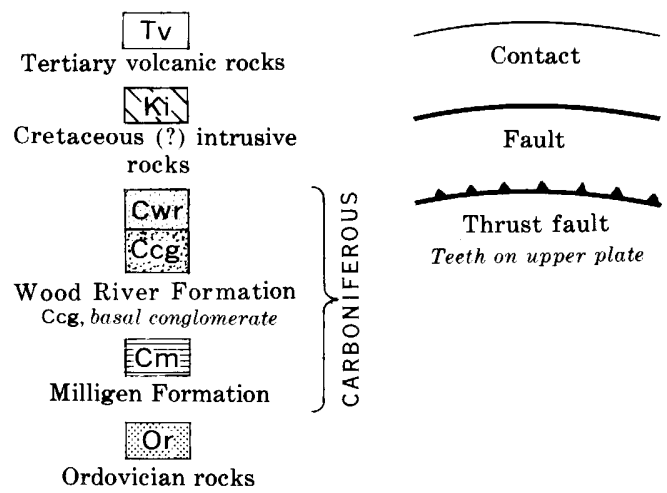

$$
\mathrm{Ar}
$$

Algonkian rocks $43^{\circ} 50^{\prime}$

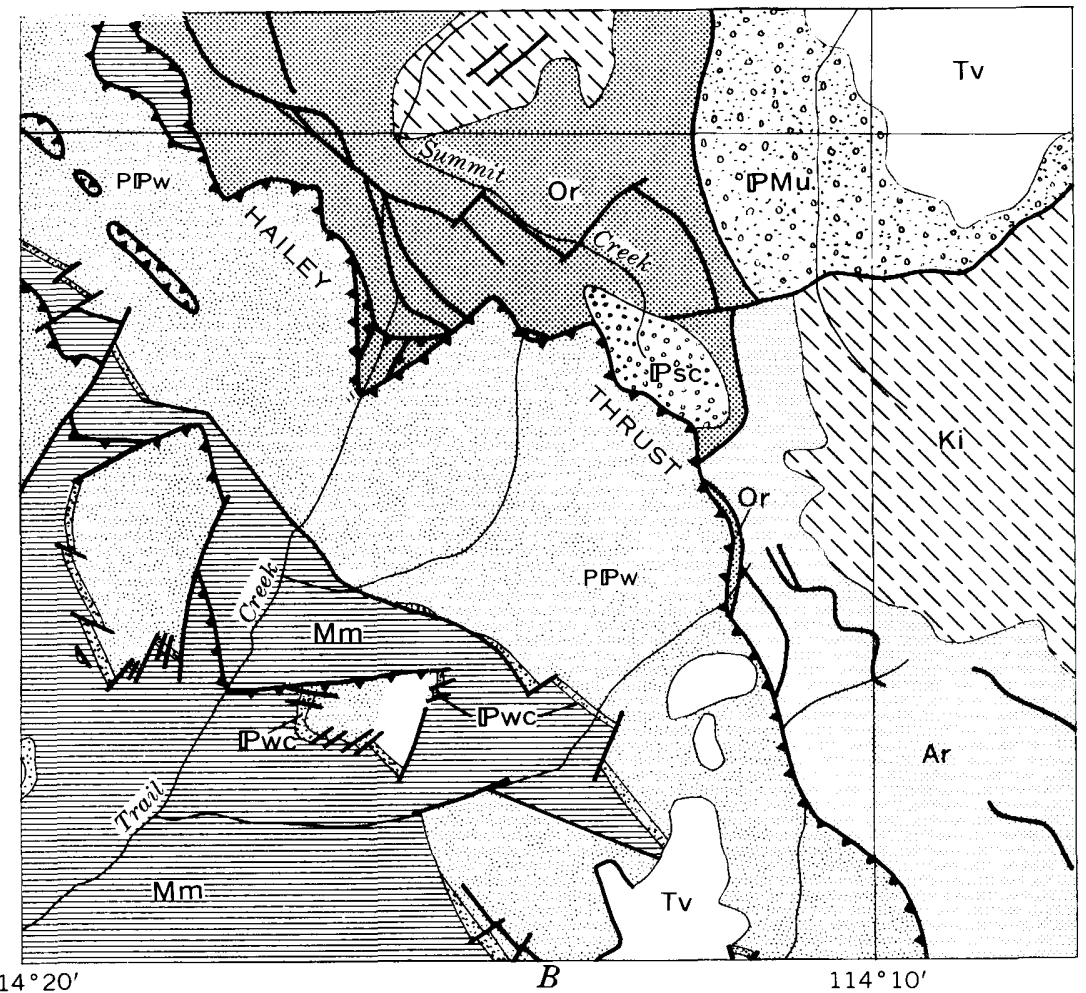

EXPLANATION

$$
\begin{gathered}
\text { TV } \\
\text { Tertiary volcanic rocks } \\
\text { KKi }
\end{gathered}
$$

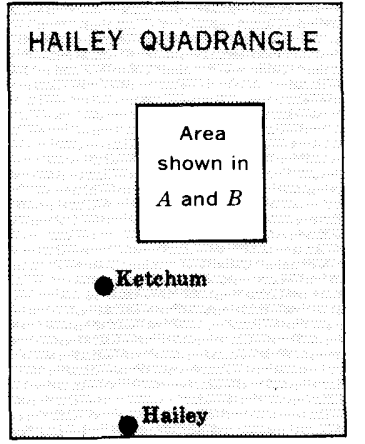

INDEX MAP
0 2 4 MILES
Cretaceous (?) intrusive

SUMMIT CREEK
SEQUENCE

\section{Conglomerate on Summit Creek}

ANGULAR
UNCONFORMITY Or:

Ordovician rocks

$$
\text { Ar }
$$

$\underset{\text { Algonkian rocks }}{\text { Ar }}$

FIGURE 122.3.-Geologic map of part of the Hailey quadrangle, Idaho, showing original and alternative interpretations. $A$, Original interpretation: generalized after Umpleby and others (1930, pl. 1). All Pennsylvanian clastic rocks are assigned to the Wood River Formation. B, Alternative interpretation: Pennsylvanian clastic rocks are differentiated and assigned to separate sequences; 
trasts are interpreted as evidence that the Ketchum sequence moved into the Hailey area from the west or southwest on a major thrust (here named the Hailey thrust), and is therefore allochthonous like the Havallah sequence in Nevada (Roberts and others, 1958, p. 2849 ; Silberling and Roberts, 1962).

\section{CONCLUSION}

The striking similarities in major sequences of upper Paleozoic rocks in northern Nevada and central Idaho indicate similarity in depositional and orogenic history. Nolan and others (1956, p. 54) suggest Carboniferous uplift of a landmass to the west of Eureka, Nev., which supplied coarse detritus to the Diamond Peak Formation; Thomasson, ${ }^{3}$ Ross (1960, p. B232; 1962a), and Skipp (1961a, p. 387-388) also recognized that coarse clastic rocks in the Mackay quadrangle, Idaho, indicate Mississippian to Pennsylvanian orogeny to the west. The orogenic movements in Nevada took place along the Antler orogenic belt which probably extends northward into central Idaho (fig. 122.1). This belt now may be largely covered in Idaho by younger thrust plates. Remnants of the orogenic belt in the Hailey area show characteristic structural features and allochthonous rock units like those of the orogenic belt in Nevada.

The picture presented here is no doubt oversimplified, and additional fieldwork in central Idaho should be undertaken to test these suggestions in the field. The terms Milligen and Wood River should be restricted to the formations in their type areas and to continuations of these lithologic units within the Milligen-Wood River depositional basin. New terms should be used for correlative units deposited within the orogenic belt, in the Muldoon trough, and on the shelf east of the trough.

\section{REFERENCES}

Bostwick, D. A., 1955, Stratigraphy of the Wood River formation, south-central Idaho: Jour. Paleontology, v. 29, no. 6, p. 941-950.

Dott, R. H., 1955, Pennsylvanian stratigraphy of Elko and northern Diamond Ranges, northeastern Nevada: Am. Assoc. Petroleum Geologists Bull., v. 39, p. 2211-2305.

${ }^{3}$ See footnote, p. D4.
Fails, J. G., 1960, Permian stratigraphy at Carlin Canyon, Nevada: Am. Assoc. Petroleum Geologists Bull., v. 44, no. 10, p. 1692-1703.

Ferguson, H. G., Muller, S. W., and Roberts, R. J., 1951, Geology of the Winnemucca quadrangle, Nevada: U.S. Geol. Survey Geol. Quad. Map GQ-11.

Nolan, T. B., Merriam, C. W., and Williams, J. S., 1956, The stratigraphic section in the vicinity of Eureka, Nevada: U.S. Geol. Survey Prof. Paper 276, 77 p.

Roberts, R. J., Hotz, P. E., Gilluly, James, ano Ferguson, H. G., 1958, Paleozoic rocks of north-central Nevada: Am. Assoc. Petroleum Geologists Bull., v. 42, no. 12, p. 2813-2857.

Ross, C. P., 1934, Correlation and interpretation of Paleozoic stratigraphy in south-central Idaho: Geol. Soc. America Bu!l., v. 45 , p. $937-1000$.

1960, Diverse interfingering Carboniferous strata in the Mackay quadrangle, Idaho: in U.S. Geol. Survey Prof. Paper 400-B, p. B232-B233.

1962a, Upper Paleozoic rocks in central Idaho: Am. Assoc. Petroleum Geologists Bull., v. 46, no. 3, p. 384-387. 1962b, Stratified rocks in south-central Idaho: Idaho Bur. Mines and Geology Pamph. 125, 126 p.

1962c, Paleozoic seas of central Idaho: Geol. Soc. America Bull., v. 73, p. 769-794.

Scholten, Robert, 1957, Paleozoic evolution of the geosynclinal margin north of the Snake River plain, Idaho-Montana: Geol. Soc. America Bull., v. 68, no. 2, p. 151-170.

Shannon, J. P., 1961, Upper Paleozoic stratigraphy of eastcentral Idaho: Geol. Soc. America Bull., v. 72, no. 12, p. 1829-1836.

Silberling, N. J., and Roberts, R. J., 1962, Pre-Tertiary rocks in northwestern Nevada: Geol. Soc. America Spec. Paper 72, $58 \mathrm{p}$.

Skipp, Betty A. L., 1961a, Interpretation of sedimentary features in Brazer Limestone (Mississippian) near Mackay, Custer County, Idaho: Am. Assoc. Petroleum Geologists Bull., v. 45 , no. 3 , p. $376-389$.

_ 1961b, Stratigraphic distribution of endothyrid Foraminifera in Carboniferous rocks of the Mackay quadrangle, Idaho: in U.S. Geol. Survey Prof. Paper 424-C, p. C239C244.

Thomasson, M. R., 1959a, Late Paleozoic stratigraphy and paleotectonics in central and eastern Idaho [abs.]: Geol. Soc. America Bull., v. 70, no. 12, p. 1687-1688.

$1959 \mathrm{~b}$, Paleocurrent and sedimentary structure studies in upper Paleozoic rocks in central Idaho [abs.]: Geol. Soc. America Bull., v. 70, no. 12, pt. 2, p. 1687.

Umpleby, J. B., Westgate, L. G., and Ross, C. P., 1930, Geology and ore deposits of the Wood River region, Idaho: U.S. Geol. Survey Bull. 814, 150 p. 
Article 123

\title{
THRUST-FAULT RELATIONS IN THE NORTHERN COAST RANGES, CALIFORNIA
}

\author{
By ROBERT D. BROWN, JR., Menlo Park, Calif.
}

\begin{abstract}
A klippe of volcanic rock which covers about $\mathbf{5 0}$ square miles in Glenn, Colusa, and Lake Counties provides evidence of a folded thrust fault that can be traced eastward into the Stony Creek fault zone. Rocks involved in the thrusting are of Late Jurassic and Cretaceous age.
\end{abstract}

The structural relations described in this article involve strata in the northern Coast Ranges of California and in the foothills along the western border of the Sacramento Valley (fig. 123.1). The structural
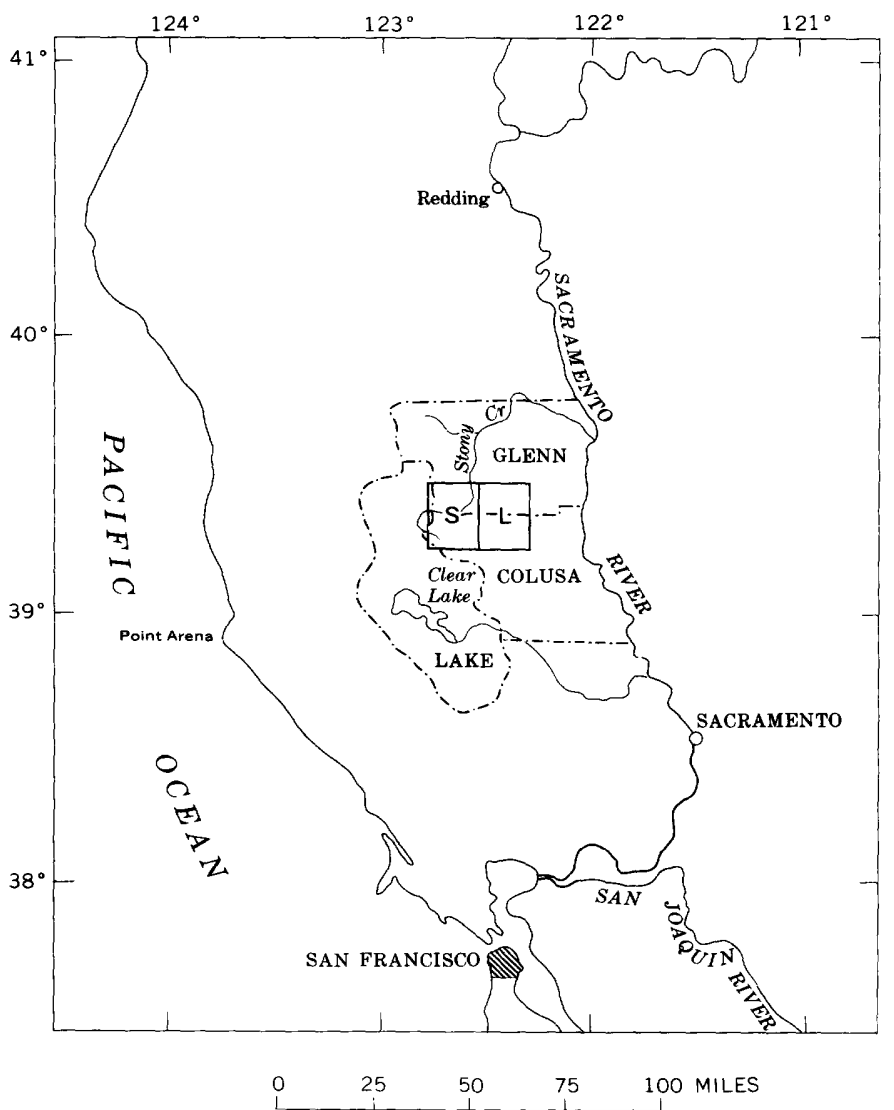

FigURE 123.1-Index map of part of northern California, showing location of Stonyford (S) and Lodoga (L) quadrangles. interpretations and the map data shown in figure 123.2 are based upon detailed mapping by the author and Ernest I. Rich in the Lodoga 15-minute quadrangle (Brown and Rich, 1961) and in the Stonyford 15-minute quadrangle (unpublished), which cover the area of figure 123.2 east of long. $122^{\circ} 45^{\prime} \mathrm{W}$. (fig. 123.1), and upon reconnaissance mapping by the author in areas to the north, west, and south.

\section{STRATIGRAPHIC NOMENCLATURE}

The existing nomenclature for the rocks described is avoided in the discussion of structural relations. This is in part because the application of existing names would involve cumbersome stratigraphic discussions that are not germane to this article, but also because some of the existing names involve stratigraphic and structural concepts that are incompatible with the field relations described here. The following brief discussion is intended to demonstrate some of the difficulties inherent in the use of the existing names.

Along the foothills west of the Sacramento Valley, sandstone, siltstone, and conglomerate totaling more than 40,000 feet in thickness have been subdivided into formations chiefly on the basis of contained faunal elements. Although some formational units are valid rock-stratigraphic units (for example, the Venado Formation of Kirby, 1943), those with which this paper is most concerned, the Knoxville, Paskenta, and Horsetown, are defined in age terms and the definitions differ slightly from author to author. Redefinition in strict lithologic terms is difficult because of complex interfingering of lithologies and because many of the rocks of differing age are lithologically alike. Where lithologic distinctions are apparent and extensive, they generally do not coincide with boundaries based on geologic age, so that naming new lithologic units would seem preferable to redefining existing biostratigraphic units. However, for a rock sequence so widespread and so variable in lithologic detail as that along the 
western border of the Sacramento Valley, new formation-name proposals should be based upon detailed mapping throughout several 15-minute quadrangles, and detailed geologic mapping of so large an area is not yet available. A more complex problem is involved in the sheared and deformed rock sequences that form the core of the Coast Ranges. These rocks have been assigned by previous workers to the Franciscan Formation, the Franciscan Group, or the Franciscan Series; by some the name has been used as a general term, but most recent workers have referred to the Franciscan Formation, thereby implying that the unit is a stratigraphic entity.

Regardless of the rank of classification of the Franciscan, geologists who use the term agree that it includes a diverse suite of lithologies, characterized by graywacke, siltstone, semischist, phyllonite, chert, basic pillow lava, and flow breccia that are locally altered to greenstone, minor hypabyssal intrusive rocks, and glaucophane schist; serpentine and ultramafic bodies are commonly found in association with all these rocks. The thickness and internal stratigraphy of the gross unit are unknown, and even estimates of thickness are subject to errors of several orders of magnitude because of the lack of structural and stratigraphic detail in Franciscan terranes. Neither the upper nor the lower age limit of the Franciscan is known, but some of the glaucophane schists have been radiometrically dated at 130 to 150 million years \pm 5 percent (Art. 142; and Lee and others, 1963), and fossils indicative of an age range from Late Jurassic to Late Cretaceous have been described from Franciscan sedimentary rocks (Irwin, 1957). The Franciscan must therefore range in age from Late Jurassic or older to as young as Late Cretaceous. The contact relations of the Franciscan with younger, older, or contemporaneous, less deformed strata are generally obscured by major faults, and in areas where younger strata are found resting upon Franciscan rocks, the two are separated by major unconformities representing long periods of geologic time.

In spite of the diversity in primary lithology and in degree of metamorphism, in spite of the uncertain age limits and little-known contact relations, and in spite of the general absence of internal stratigraphic and structural detail within the Franciscan, these rocks have long been considered a discrete lithologic unit. The concept of the Franciscan as a structural entity is a useful one for broad regional studies, but most workers have used the term in a stratigraphic sense (that is, Franciscan Formation) which does not seem to be justified by the field evidence that is now available. A further and more important objection to the use of the term Franciscan in local, detailed studies is that its use tends to compartmentalize the geologic problems into two fundamental units: the complex lithologic and structural assemblage of rocks referred to the Franciscan, and the more orderly rock sequences of the west border of the Sacramento Valley. The objections to this division are made obvious by the relations described in this paper, for in the part of northern California described here, the deformed rocks of the Coast Ranges (Franciscan) and those of the Sacramento Valley are intimately interrelated, both stratigraphically and structurally. Because of these interrelations, a twofold classification into Franciscan and Sacramento Valley rocks yields an oversimplified basic premise with which it is extremely difficult to reconcile the observed field relations.

\section{SUMMARY OF STRUCTURAL RELATIONS}

Evidence of major thrusting is found throughout a large part of the Stonyford quadrangle of the northern Coast Ranges. The complexly folded and crushed terrane involved in the thrusting is separated from the simple structures and uniform stratigraphy of the western border of the Sacramento Valley by the Stony Creek fault zone, a major north-trending tectonic feature that extends for more than 80 miles and is invaded by serpentinized peridotite along much of its length.

East of the Stony Creek fault zone, siltstone, sandstone, and conglomerate are more than 40,000 feet thick and range in age from Late Jurassic (Tithonian) to Late Cretaceous (Campanian). These rocks form a north-trending outcrop belt as much as 15 miles wide, which extends along the entire western border of the Sacramento Valley. Within this belt the major structures trend northward, and although folding and faulting locally reverse the dip and repeat parts of the section, an eastward dip predominates and the oldest rocks crop out to the west along the Stony Creek fault zone.

West of the Stony Creek fault zone, a more varied suite of rocks underlies the Coast Ranges. These consist in part of sandstone and siltstone that are indistinguishable from part of the rocks along the western border of the Sacramento Valley, but most of the sedimentary rock has been cataclastically metamorphosed to phyllonite or to cataclastic sandstone or semichist. The cataclastically deformed rocks may in places be partly recrystallized, but this is not generally apparent in the field; their most obvious lithologic characteristic is the crushing and shearing of mineral grains and bedding features along shear planes that parallel the bedding. Both the unmetamorphosed sedimentary rocks and their cataclastic counterparts contain one or more thin flows of basaltic pillow lava which 
grades locally to flow breccia and in places is overiain by manganiferous chert. Fossils of Early Cretaceous (Valanginian) age are found a few hundred feet stratigraphically below the basalt, and fossils of Late Jurassic (Tithonian) age are found a little lower in the section.

A much thicker sequence of volcanic rock crops out on the summit and slopes of St. John Mountain and Snow Mountain and in the area between them (fig. 123.2). These rocks consist of pillow lava and flow breccia with interbeds of chert and volcanic-rich sedimentary rock and sills of diabase. Because they form a mountainous area of rugged topography with as much as 5,000 feet of local relief, they can be studied in three dimensions. Detailed $(1: 48,000)$ geologic mapping has disclosed that they form a klippe which rests in different places upon: (1) a friction carpet of chaotically sheared sedimentary debris; (2) bodies of serpentinized peridotite, sill-like in form and emplaced along a basal thrust plane; or (3) phyllonite and cataclastic sandstone, derived by bedding-plane shearing from siltstone and sandstone. Similar thrust sheets of sedimentary rock or phyllonite can also be recognized but are less obvious than the klippe of volcanic rock.

\section{EVIDENCE OF THRUSTING}

The volcanic klippe on Snow Mountain and St. John Mountain consists of several thousand feet of basaltic lava, breccia, and tuffaceous sedimentary rock that are folded along west-trending axes. Except near the basal fault plane, primary textures and structures in the volcanic rocks are well preserved, the rocks are little altered, and they contrast sharply with the altered and intensely sheared phyllonitic sedimentary rocks that crop out elsewhere in the area west of the Stony Creek fault zone. Both the structural trends and mapped lithologic units within the klippe are truncated at a folded thrust fault that underlies the volcanic rocks and separates them from intensely deformed sedimentary rocks below. Additional evidence for the thrust fault is found in the relationship of the volcanic rocks to intensely sheared chaotic sedimentary rocks northwest, north, and northeast of St. John Mountain.

From Upper Nye Camp eastward, the fault surface at the base of the volcanic sequence traces a sinuous course along the northern face of St. John Mountain (fig. 123.3), decreasing in altitude from about 5,200 feet at Upper Nye Camp to about 2,000 feet at the eastern boundary of the klippe. Below the projection of this surface, a broad relatively low area that extends north and northeast for several miles is underlain by crushed and sheared siltstone and sandstone, so thoroughly faulted and mixed that they resemble shear-zone debris. These intricately faulted and folded rocks are cut by syntectonic quartz veins, and they contain scattered masses of resistant rock (fig. 123.3), a few feet to several hundred feet in diameter; many of the resistant masses show rounded altered borders and internal deformation features that suggest transport in a zone of tectonic movement. The resistant rock masses are predominantly volcanic rocks or chert and, except for the alteration and tectonic borders, they resemble rocks found on St. John Mountain and Snow Mountain; some of the masses, however, are of conglomerate, hard sandstone, or glaucophane schist. Although many of the resistant masses have clearly rotated or slumped downhill for short distances, others are clearly unaffected by landsliding and exhibit tightly sealed sinuous contacts with the enclosing crushed and sheared sedimentary rocks (figs. 123.4 and 123.5). In a few places, syntectonic quartz veins can be seen crossing the contacts between the country rock and the resistant masses.

Most of the large resistant masses of volcanic rock and chert are found in topographically high positions within a few tens of feet beneath the projection of the fault surface that forms the base of the volcanic sequence on St. John Mountain. A few of these are so large and so near the projection of the thrust surface that they may actually be small klippen, but most appear to be tectonic inclusions that have been ripped from the upper plate and incorporated into the shear zone immediately below. True klippen probably are represented by several basalt outliers north and northeast of Upper Nye Camp, for some of these lie at or above the projected thrust surface, and in a few places thin zones of serpentine crop out at the base of the outliers. A larger klippe forms the upper part of Elephant Hill, where bedded chert, volcanic-rich sedimentary rock, and minor basalt with a relatively uniform strike and dip crop out. These rocks overlie chaotically deformed sedimentary rocks that crop out at lower elevations around the base of the hill, and the base of the chert-sediment-basalt sequence is marked, on the southwest side of Elephant Hill, by saline springs, abundant landslides, and in at least one place by lenses of serpentine.

The chaotically deformed sedimentary rocks, together with the masses of chert, volcanic rock, and other resistant rock types, are interpreted as a flat-lying or gently east-dipping friction carpet, interposed between massive competent volcanic rocks above and less competent cataclastic sedimentary rocks below. The friction-carpet rocks superficially resemble landslide debris, and because they are weakly resistant to erosion and are lithologically and structurally heterogeneous they are subject to landslides. A few characteristics 


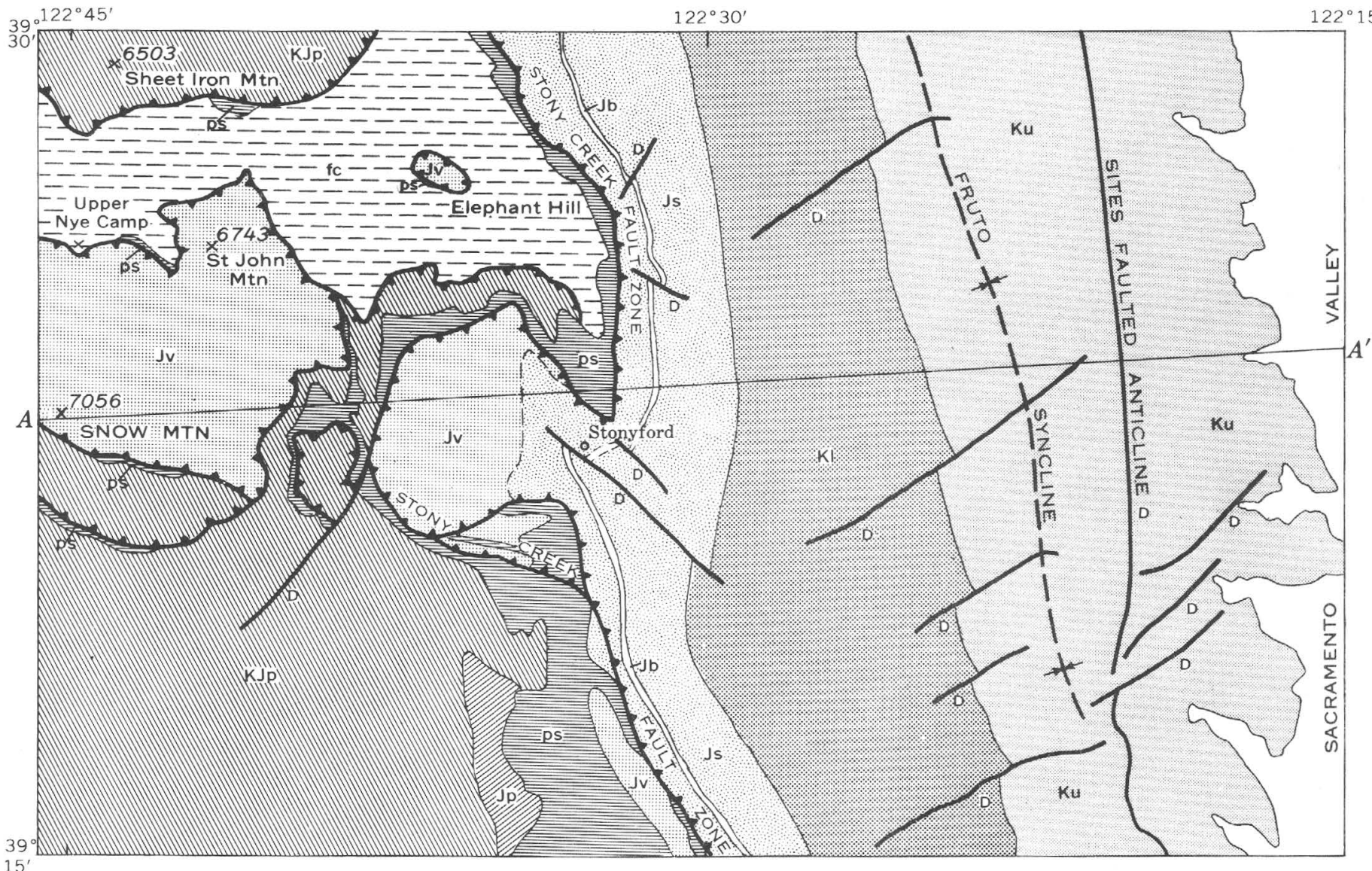

A

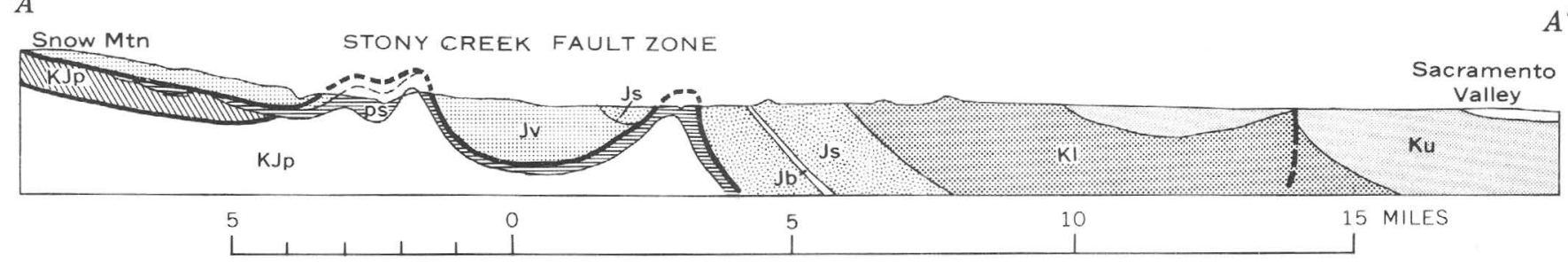

Rocks below (west of) Stony Creek fault zone

\section{NKMn}

Phyllonite and semischist with minor basaltic volcanic rocks Jp

Phyllonite and semischist

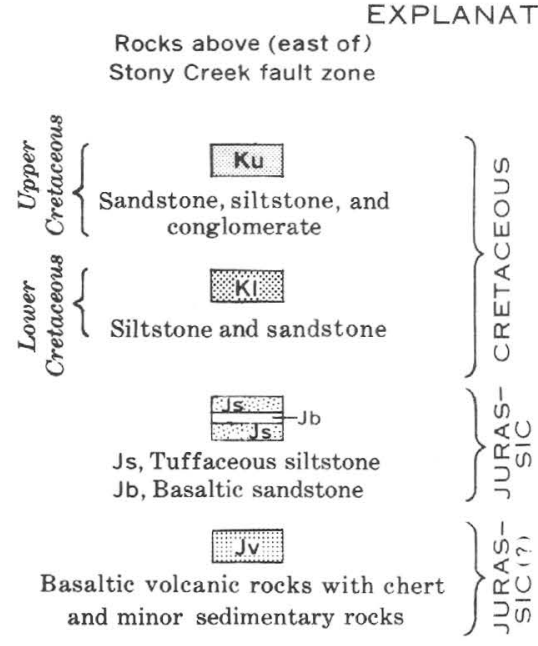

Rocks above (east of Stony Creek fault zone

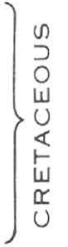

$$
\begin{aligned}
& \left\{\begin{array}{l}
1 \\
u \\
\frac{\mathbb{u}}{x}
\end{array}\right. \\
& \left\{\begin{array}{l}
1 \\
\text { ñ } \\
\mathbb{x} \bar{u}
\end{array}\right.
\end{aligned}
$$

Rocks emplaced or formed along Stony Creek fault zone or along related fault zone

$$
\text { }
$$

跜品

\section{$-\mathrm{fc}-$}

Friction-carpet debris

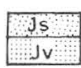

Sedimentary and volcanic rocks

Occurs in tectonic lenses along peridotite-invaded parts of Stony Creek fault zone

FIGURE 123.2.-Generalized geologic map and structure section showing thrust-fault relations near Stonyford, Calif. For simplicity, landslides, alluvium, and terrace deposits are not shown. 


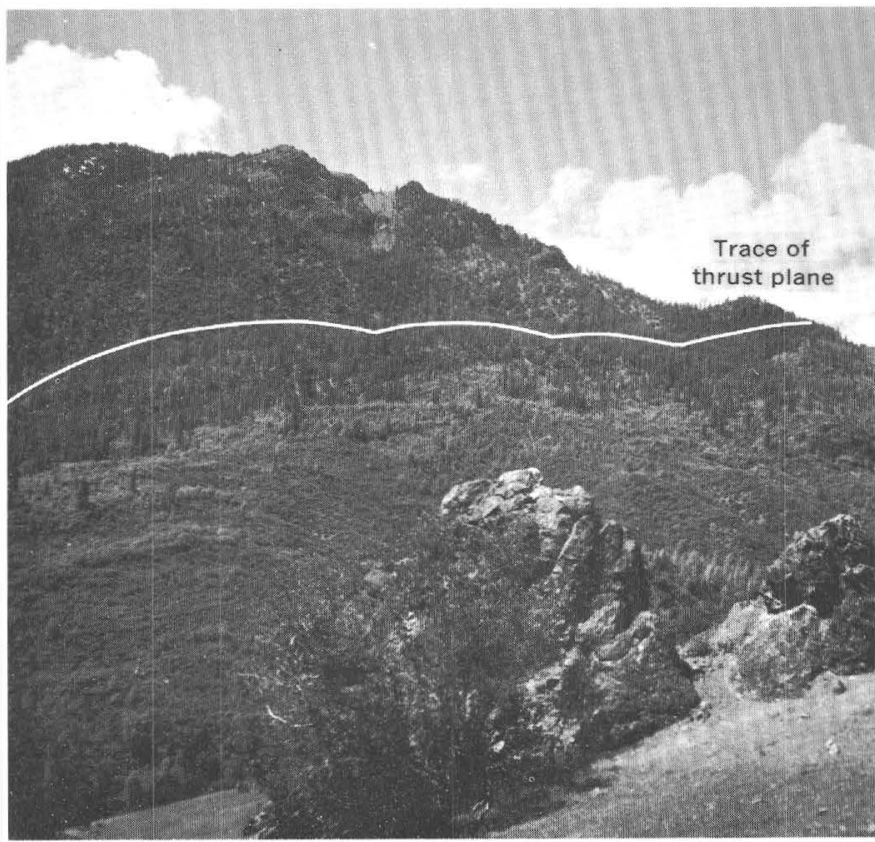

Figure 123.3--North face of St. John Mountain, showing approximate trace of thrust, with volcanic rocks above the fault trace and friction carpet below. Resistant mass in foreground is altered diabase. Ridge on right skyline, underlain by friction carpet, is drainage divide between coastal (Eel River) drainage and interior (Stony Creek-Sacramento River) drainage.

of the friction carpet that help distinguish it from landslides are:

1. Abundance of resistant masses of exotic lithology, for which no local source is available (that is, intensely altered volcanic rock, glaucophane schist, conglomerate, and sandstone masses of distinctive lithology).

2. Intense sublaminar shearing and quartz veining in sedimentary rock that encloses the resistant masses (fig. 123.5).

3. Map distribution independent of topography: friction-carpet rock several hundred feet thick is found on major drainage divides where no higher slopes are available to supply landslide debris (fig. 123.2).

4. Map distribution indicative of a widespread tabular unit.

In the area north and northeast of St. John Mountain, no clearly defined lower plate can be mapped, and in some parts of this area the friction carpet appears to be as much as 800 feet thick. In other areas, however, it is thinner and can be seen to grade down into relatively undeformed sedimentary rocks of the lower plate. Accurate thickness estimates of the blanket are difficult to make because these rocks are relatively weak and slump into topographic lows, because the lower contact is gradational, and because $716-6260-64-2$

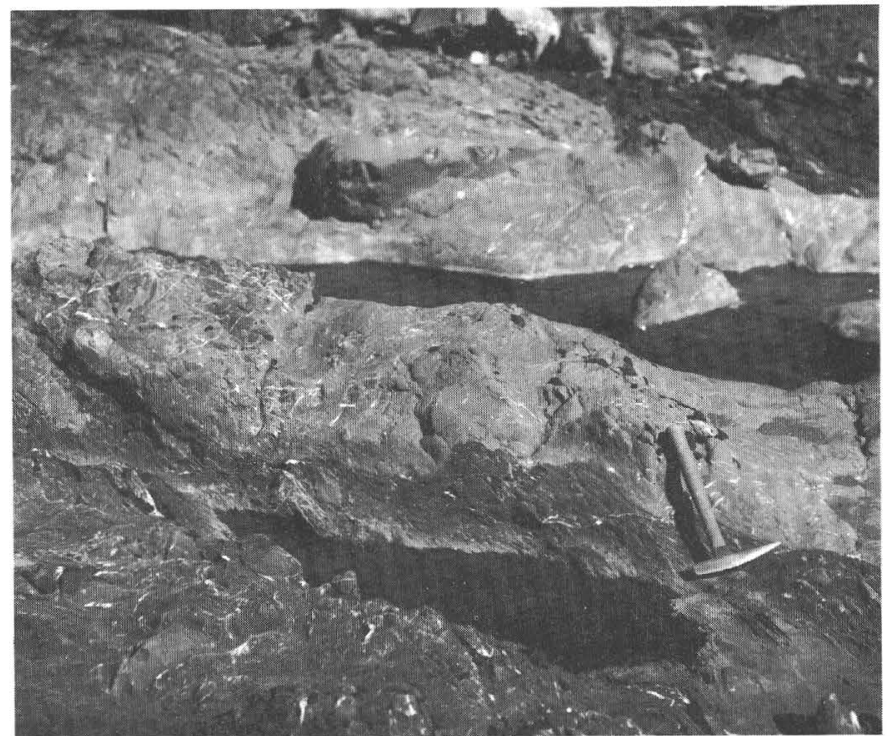

FIGURE 123.4-Resistant mass of altered volcanic rock (light gray), in North Fork of Stony Creek. Mass is about 50 feet by 30 feet across and is completely anclosed in chaotically sheared sedimentary rock (dark gray). Sealed contacts, shearing, and quartz veining of both rock types suggest a tectonic origin.

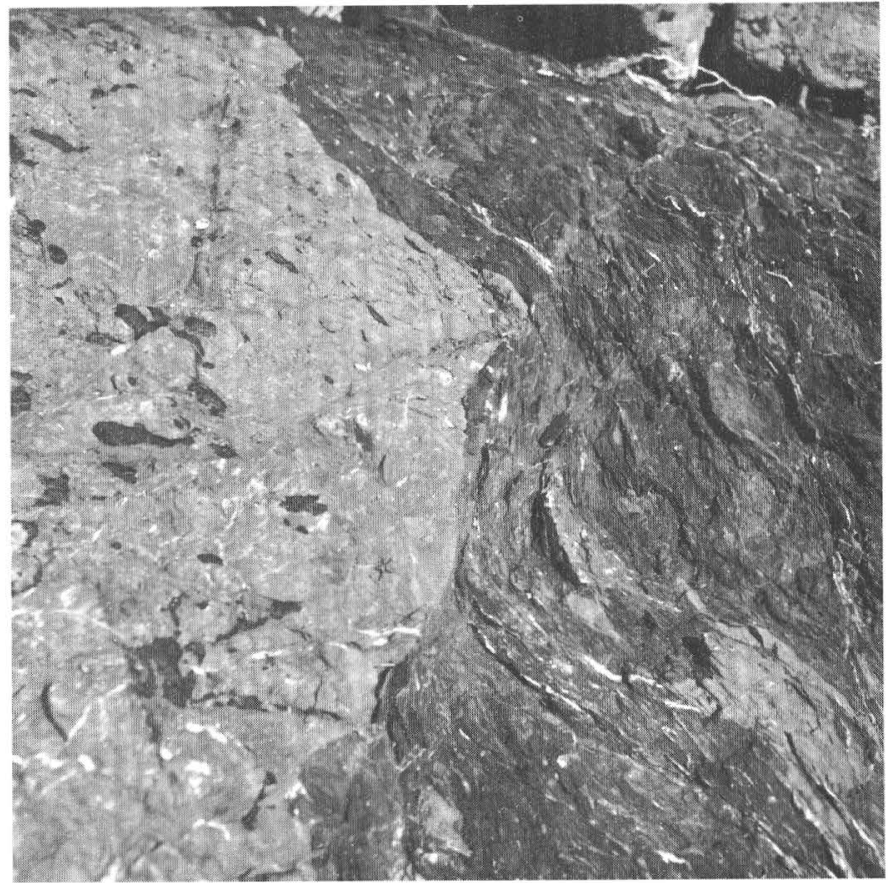

FIGURE 123.5-Detail of shearing and contact relations of resistant volcanic mass (light gray) shown in figure 123.4. Width of photographed area about 5 feet.

through-going faults or folds are unrecognizable within the terrane underlain by friction carpet. Nevertheless, the thickness estimate of 800 feet in the area north and northeast of St. John Mountain appears to be valid, for stream bottoms 800 feet beneath the projected surface of the thrust fault are underlain by chaotically 
sheared, quartz-veined, sedimentary rock containing resistant masses with healed borders and crosscutting quartz veins. This abnormal thickness of frictioncarpet debris may be related to a broad southeasttrending anticlinal flexure of the thrust surface. This flexure is reflected both in the mapped distribution of the thrust planes and in the plunging nose of serpentinized peridotite northwest of Stonyford. If the flexure predated or accompanied thrusting, the lower confining pressure along its crest would account for the abnormal thickness of friction carpet there.

Thrust relations are more difficult to recognize on the eastern and southern sides of the St. John Mountain-Snow Mountain klippe because on those sides the friction carpet is relatively thin and it, as well as other details along the base of the klippe, is obscured by landslide debris. Nevertheless, the tectonic nature of the basal surface of the volcanic sequence is still apparent, for where it can be examined the surface truncates structures and lithologies in the overlying rocks and is marked by intense shearing, saline springs, and sill-like bodies of serpentinized peridotite emplaced along the thrust zone.

The western boundary of the klippe, also much obscured by landslides, has not yet been mapped in detail, but reconnaissance west of Snow Mountain has shown that the thrust surface dips gently westward for about 6 miles and extends nearly to the Eel River. The base of the klippe at its western boundary has a northward component of dip of about 200 feet per mile and is found at altitudes ranging from about 3,250 feet on the south to about 2,500 feet on the north. Along the base, numerous landslides issue from a shear zone containing lenses of serpentine and finely comminuted serpentine debris. Bold exposures of volcanic rock are found immediately above the shear zone, and cataclastically deformed sedimentary rocks crop out below. The Snow Mountain-St. John Mountain klippe therefore extends from the North Fork of Stony Creek nearly to the Eel River and covers an area of about 50 square miles. The basal thrust plane is gently arched.along a north-trending axis that passes approximately through Snow Mountain, and the thrust surface exhibits about 4,000 feet of structural relief.

\section{RELATIONS OF THRUST FAULTING TO STONY CREEK FAULT ZONE}

Although the volcanic klippe is the most obvious, several other thrust sheets, involving chiefly sedimentary and cataclastically deformed sedimentary rocks, have also been mapped. These are less apparent because the rocks of both the upper and lower plates are lithologically similar, and they can be mapped best where friction-carpet debris or peridotite bodies can be traced along the fault zone. The amount and direction of dip of the mapped thrust surfaces varies locally, but all have an average inclination of a few degrees toward the east, and all appear to converge eastward and to join the Stony Creek fault zone. Detailed relations at the lines of juncture with the Stony Creek fault zone are difficult to interpret because this fault zone, like many of the thrust faults in the area, is invaded by peridotite and serpentinized peridotite. In most places the fault zone is vertical and trends northward, parallel to the bedding in the sedimentary rocks to the east, but near Stonyford the fault zone and the peridotite bodies along it swing sharply westward to outline an east-plunging structural basin. The stratigraphic and structural relations of the rocks within this basin and those to the west of it afford a key to the relation between the Stony Creek fault zone and the tectonic surface beneath Snow Mountain and St. John Mountain.

West of Stonyford and east of the Stony Creek fault zone, an eastward-dipping volcanic sequence, identical with that on Snow Mountain and St. John Mountain, crops out. The upper contact of these volcanic rocks is concealed by alluvium and terrace deposits, but their mapped distribution, their structural attitude, and lithologic similarities of parts of this sequence to parts of the Late Jurassic sedimentary rock sequence to the east indicate that the volcanic rocks conformably underlie the sedimentary rocks, and locally are probably interbedded with them. On this basis, the Stonyford volcanic rocks are tentatively assigned a Late Jurassic age and are considered a part of the predominantly sedimentary rock sequence that underlies the western border of the Sacramento Valley.

The volcanic sequence near Stonyford and that forming the klippe farther west are lithologically alike; both are floored by major fault surfaces, and where the two volcanic sequences are in closest proximity, serpentinized peridotite is emplaced along the fault boundaries of each. Mapping of the serpentinized peridotite shows that these thin sill-like bodies were originally a single continuous sheet that has either been folded along north-trending axes into a syncline and anticline or was emplaced along a pre-existing undulating shear surface. Erosion along the "anticlinal" axis has destroyed much of the original continuity, but in at least one place this continuity is preserved, and even where it is missing the map data are adequate to reconstruct it. The continuity of the serpentine together with the other stratigraphic and structural relations demonstrates that the thrust fault beneath Snow Mountain and St. John Mountain is at least a branch of the Stony Creek fault zone, and that it may be the structurally highest branch of that zone. 


\section{SUMMARY}

The described relations show that the Stony Creek fault zone is a bedding-plane thrust, near vertical for most of its mapped trace but flattening and branching into a complex set of thrust surfaces toward the west. In the Stonyford quadrangle, thrusting seems to be localized along the contact between a competent sequence of volcanic rocks and a thick overlying sequence of clastic sedimentary rock; locally, however, the volcanic rocks may be found in the upper plate, as they are in the two areas west of Stonyford. The rocks below, or west of, this thrust zone are predominantly cataclastically metamorphosed; those above, or east of the thrust are little deformed. Aside from the superimposed effects of cataclastic deformation the sedimentary rocks on opposite sides of the Stony Creek fault zone exhibit no marked differences in either lithology or age, but conglomerate, relatively common in the Upper Jurassic and Lower Cretaceous rocks of the upper plate, is rarely found below the thrust. Volcanic rocks are thickest and most widespread east of, or above, the Stony Creek fault zone, but at least one basalt flow of Early Cretaceous age is found in rocks west of, or below, the fault zone.
Field evidence is still inadequate to establish the mechanism of thrusting or to prove either its amount or direction, but drag folds immediately above some of the thrust surfaces suggest that the upper-plate rocks have moved northward. This direction of movement agrees with the westerly trend of fold axes and faults in the Snow Mountain-St. John Mountain klippe, but additional data are needed before the history of thrust movement can be reconstructed.

\section{REFERENCES}

Brown, R. D., Jr., and Rich, E. I., 1961, Geologic map of the Lodoga quandrangle, Glenn and Colusa Counties, California: U.S. Geol. Survey Oil and Gas Inv. Map OM-210.

Irwin, W. P., 1957, Franciscan group in Coast Ranges and its equivalents in Sacramento Valley, California: Am. Assoc. Petroleum Geologists Bull., v. 41, no. 10, p. 2284-2297.

Kirby, J. M., 1943, Upper Cretaceous stratigraphy of the west side of the Sacramento Valley south of Willows, California: Am. Assoc. Petroleum Geologists Bull., v. 27, no. 3, p. 279-305.

Lee, D. E., Thomas, H. H., Marvin, R. F., and Coleman, R. G., 1963, Isotope ages of glaucophane schists from Cazadero, California [abs.]: Geol. Soc. America 59th Ann. Mtg. Cordilleran Sec., Berkeley, Caiif., 1963, preprint, p. 42-43. 


\title{
Article 124
}

\section{UPPER PLIOCENE MARINE STRATA ON THE EAST SIDE OF THE SAN JOAQUIN VALLEY, CALIFORNIA}

\author{
By R. L. KLAUSING and K. E. LOHMAN, \\ Sacramento, Calif., and Washington, D.C.
}

Work done in cooperation with the California Department of Water Resources

\begin{abstract}
Recent drilling on the east side of the San Joaquin Valley in Tulare County has revealed marine Pliocene strata that are about 1,050 feet thick and contain diatoms. The diatom assemblage indicates a late Pliocene age and suggests a correlation with part of the San Joaquin Formation exposed on the west side of the valley.
\end{abstract}

The rocks of Pliocene age occurring in the subsurface along the southeast side of the San Joaquin Valley have generally been assigned to the Etchegoin and Chanac Formations of Pliocene age (Weaver and others, 1944, and Sperber, 1952). Evidence reported in this article indicates that at Richgrove, just north of the Tulare-Kern County line 8 miles east of Delano (fig. 124.1), the entire marine Pliocene sequence should be assigned to the upper Pliocene and may be the equivalent of a part of the San Joaquin Formation which is exposed on the west side of the valley.

In 1959 a core hole was drilled to a depth of 2,200 feet at Richgrove to obtain information on the lithology and the physical and engineering properties of the sediments in the depth penetrated by water wells. This core hole, $24 / 26-36 \mathrm{~A} 2$, is in the $\mathrm{NE}_{1}^{1} / 4 \mathrm{NE}^{1 / 4}$ sec. 36 , T. 24 S., R. 26 E., Mt. Diablo base line and meridian.

As shown by the composite logs (fig. 124.2), the core hole penetrated unconsolidated continental deposits from the Sierra Nevada to a depth of 744 feet, a thick section of siltstone and claystone ${ }^{1}$ containing a few sand interbeds from 744 to 1,900 feet and underlain by 300 feet of sand from 1,900 to 2,200 feet.

Thirty core samples spanning the depth interval from 754 to 2,101 feet were examined by Lohman, who

\footnotetext{
1 Claystone as logged from core inspection at well, but particle-size analyses indicate mostly siltstone.
}

identified an assemblage of marine diatoms in the interval between 1,141 and 1,641 feet (see accompanying table).

Most of the diatoms listed in the table have a wide stratigraphic range, occurring throughout the Pliocene and some even into the Miocene. However, two short-ranging species, Hemidiscus ovalis and Rhaphoneis fatula (Lohman, 1938, pl. 22), have not been reported from strata older than late Pliocene. Furthermore, 51 percent of the Richgrove species also occurs in the San Joaquin Formation in the Kettleman Hills. Therefore, Lohman concludes that the diatom assemblage in the Richgrove cores indicates a late Pliocene age for the interval from 1,141 to-1,641 feet and that it may be the equivalent of the late Pliocene San Joaquin Formation of the Kettleman Hills area.

The core interval between 744 feet and 1,141 feet, though unfossiliferous except for a few unidentifiable fragments of marine diatoms at 1,003 feet, is fine grained and lithologically similar to the underlying diatomaceous zone. On the basis of lithologic similarity, this upper unit is also tentatively assigned to the upper Pliocene.

A few marine invertebrate fossils were observed in the section between 1,641 and 1,900 feet. E. J. Moore (written communication, Nov. 10, 1960) identified 2 marine pelecypod genera, Macoma sp. and Cryptomya sp., in the interval between 1,733 and 1,767 feet. No definite age determination could be made. This marine section is lithologically similar to the overlying diatomaceous unit and is tentatively assigned to the Pliocene(?) in this article.

The sand below 1,900 feet is correlated with the Santa Margarita Formation of Diepenbrock (1933), 


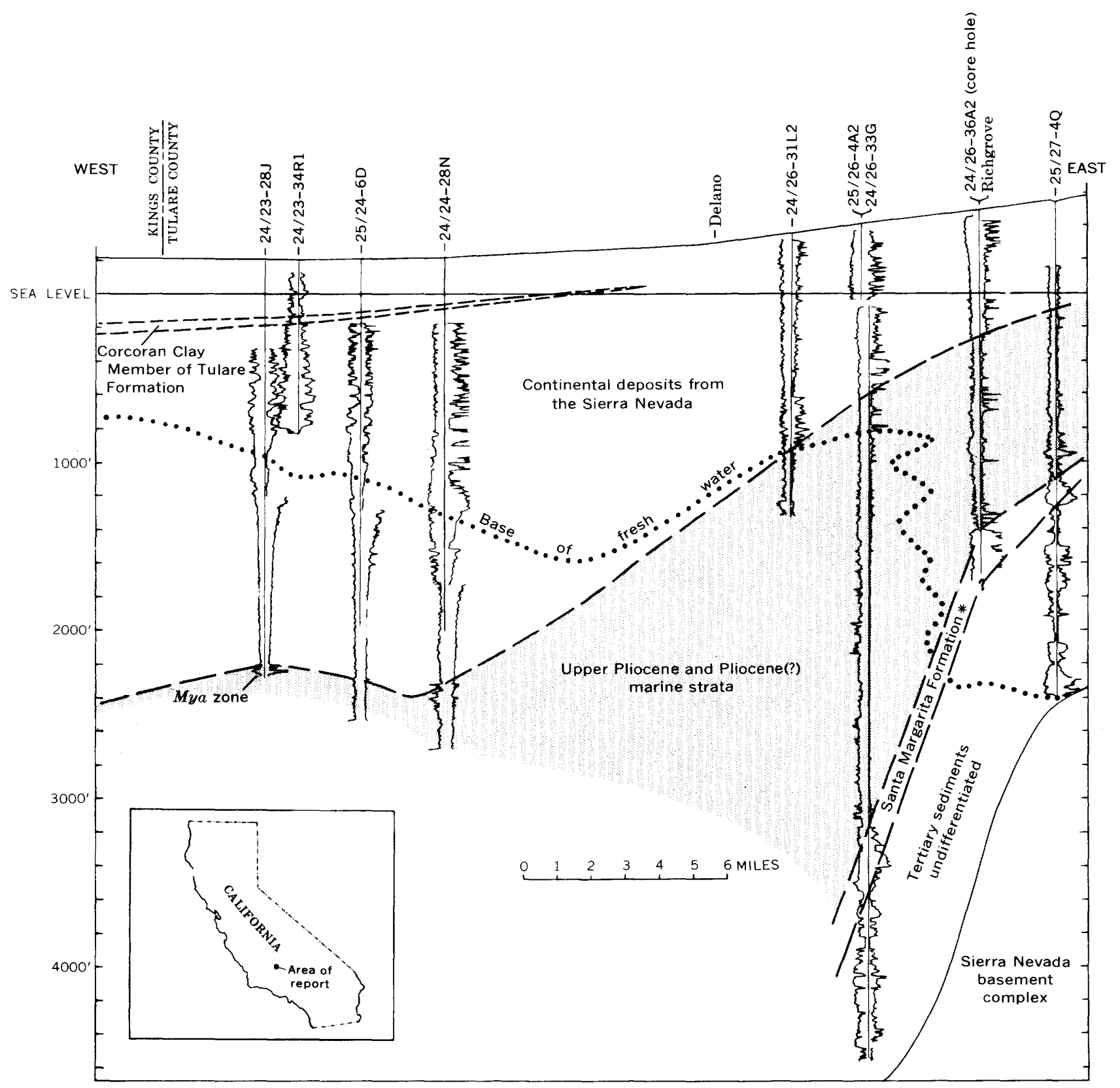

FiguRe 124.1.-Geologic section along north line of Kern County through the Richgrove core hole. *Santa Margarita Formation of Diepenbrock (1933). 


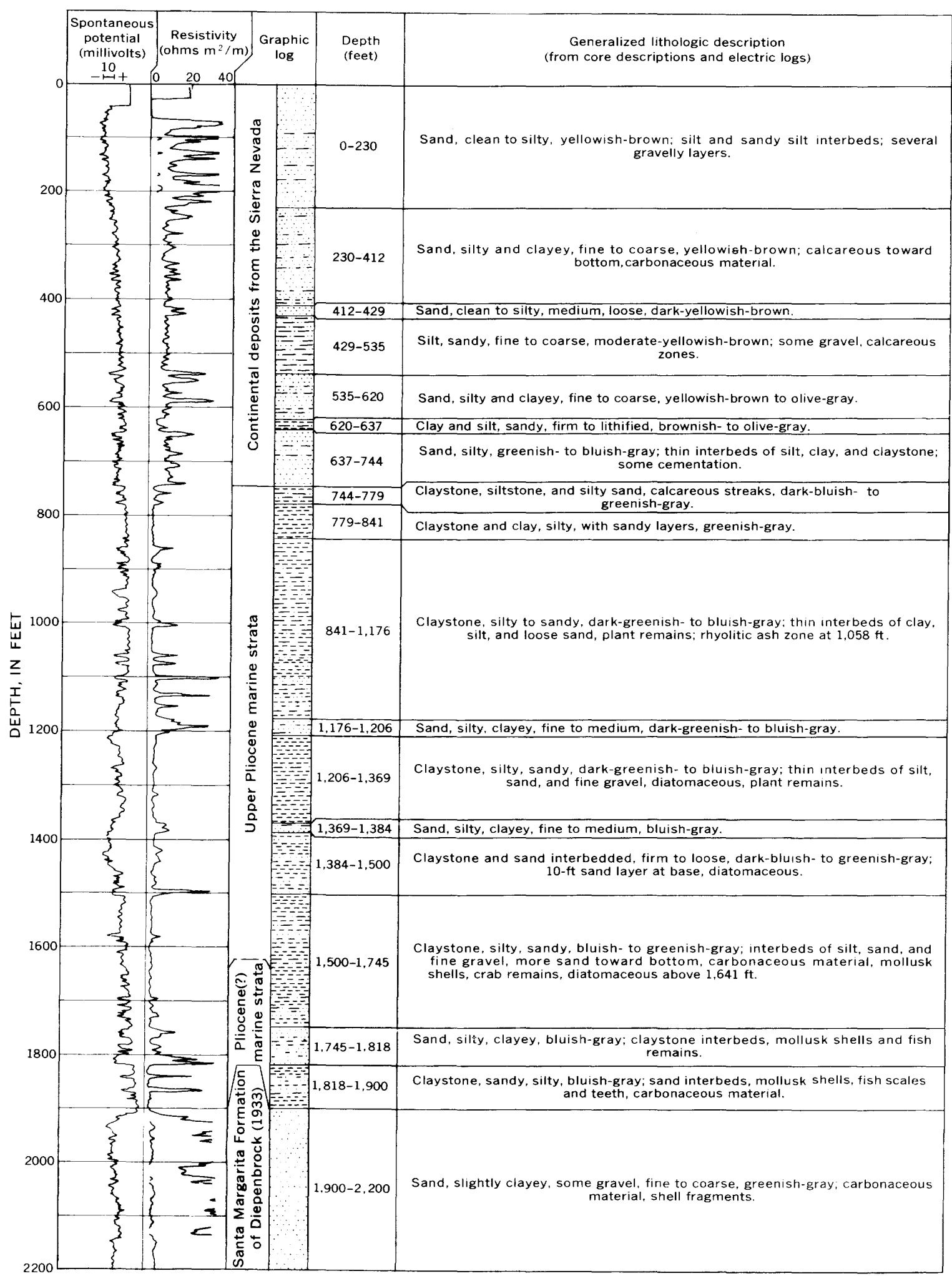

FIGURE 124.2.-Composite logs of test hole 24/26-36A2, Richgrove, Calif. 
Diatoms from U.S. Geological Survey core hole 24/26-36A2

[C, common; F, frequent; $R$, rare; *, fresh and brackish-water adventitious forms. Identifications by K. E. Lohman]

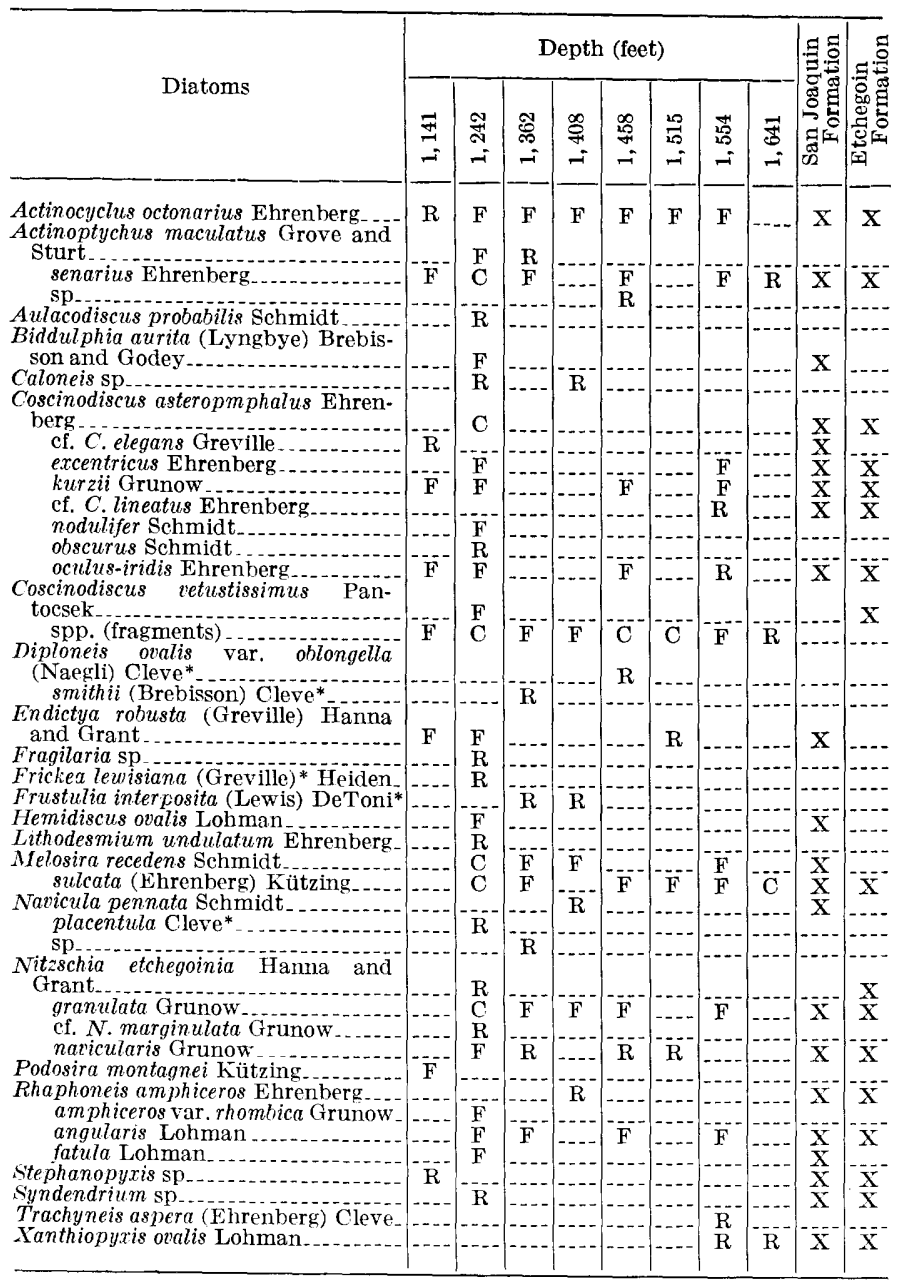

of Miocene age, on the basis of electric-log correlations north from the Mt. Poso oil field (Park and Weddle, 1959, pl. II).

In the Richgrove core hole the marine diatomaceoussiltstone unit is differentiated from the overlying continental deposits by a marked change in lithology. This lithologic change, which is clearly shown on the electric $\log$ for the core hole (fig. 124.2), can be recognized on electric logs as far west as well 24/26-31L2 (fig. 124.1). Westward from this point the top of the upper Pliocene is tentatively correlated with the upper Mya zone (Woodring and others, 1940, p. 28), which has been identified in numerous oil test wells.

\section{REFERENCES}

Diepenbrock, A., 1933, Mount Pozo oil field: Calif. Dept. Nat. Resources, Div. Oil and Gas, Summary of Operations, California Oil Fields, v. 19, no. 2, p. 12-29.

Lohman, K. E., 1938, Pliocene diatoms from the Kettleman Hills, California: U.S. Geol. Survey Prof. Paper 189-C, 22 p., 4 pls.

Park, W. H., and Weddle, J. R., 1959, Correlation study of southern San Joaquin Valley: Calif. Dept. Nat. Resources, Div. Oil and Gas, Summary of Operations, California Oil Fields, v. 45 , no. 1 , p. $33-34,3$ pls.

Sperber, F. H., 1952, Oilfields of central San Joaquin Valley province in AAPG-SEPM-SEG Guidebook field trip routes, Joint Ann. Mtg. Am. Assoc. Petroleum Geologists, Soc. Econ. Paleontologists and Mineralogists, and Soc. Exploration Geophysicists, p. 153-155.

Weaver, C. E., and others, 1944, Correlation of the marine Cenozoic formations of Western North America: Geol. Soc. America Bull., v. 55, p. 569-598.

Woodring, W. P., Stewart, Ralph, and Richards, R. W, 1940, Geology of the Kettleman Hills oil field, Calif.; stratigraphy, paleontology, and structure: U.S. Geol. Survey Prof. Paper 195. 


\title{
Article 125
}

\section{MIOCENE VERTEBRATES OF THE BARSTOW FORMATION IN SOUTHERN CALIFORNIA}

\author{
By G. EDWARD LEWIS, Denver, Colo.
}

\begin{abstract}
The U.S. Geological Survey has adopted the name Barstow Formation and abandoned Rosamond Series for the rock unit that crops out from Alvord Mountain to Black Mountain, San Bernardino County, Calif. Between 2,000 and 2,800 feet of sedimentary and pyroclastic rocks make up the Barstow Formation. About the upper third of the Barstow constitutes one of two unnamed members; it yields late Miocene vertebrates (Eucastor, Hemicyon, Merychippus sumani, Paracosoryx, Paramoceros). The upper half of the lower member yields middle Miocene vertebrates (Protohippus tehachapiensis, Brachycrus, Merriamoceros). No fossil vertebrates have been reported from the lowest third of the Barstow Formation.
\end{abstract}

In the Mojave Desert of southern California, fossil vertebrates of Miocene age are found in the Barstow Formation, which includes at least two (perhaps more) members and local faunas. The two known faunas from the Barstow range in age from middle to late Miocene; some authorities (Schultz and Falkenbach, $1940,1941,1947,1949)$ would extend this range to early Pliocene. Outcrops identified as the Barstow Formation have been mapped in the Mojave Desert, San Bernardino County, Calif., from lat $34^{\circ} 40^{\prime}$ to $35^{\circ} 15^{\prime} \mathrm{N}$., and from long $116^{\circ} 30^{\prime}$ to $117^{\circ} 20^{\prime} \mathrm{W}$. The belt of discontinuous outcrop stretches from Alvord Mountain on the east, through the Calico Mountains and Mud Hills, to Black Mountain on the west.

\section{NOMENCLATURE OF THE BARSTOW FORMATION}

More than a half a century ago, O. H. Hershey (1902a, facing p. 2) published a "Geological Reconnaissance Sketch Map of Southern California" that showed the Quaternary of the Hinckley-Barstow-Daggett area of the Mojave Desert and the underlying Tertiary Rosamond Series. This map clearly showed the Quaternary of the Mojave River valley at Barstow and for several miles eastward, where it overlies Tertiary rocks along the Santa Fe Railway. Two months later, Hershey formally named, defined, and designated the type section for the Rosamond Series, and identified outcrops north of the railroad "from Hinckley station eastward . . . Barstow . . . Daggett" as "typical of the Rosamond Series" (Hershey, 1902b, p. 365-368). These are the rocks mistakenly called Barstow formation by Merriam (1915, p. 252-253; 1919, p. 441-442). But Hershey had already pre-empted the name Barstow for one of the Quaternary formations shown on his map; in the same publication where he named the Rosamond, he also named, defined, and designated the type section of the Barstow, spoken of both as formation and series, "in Mohave River valley ... about one and one-half miles east of Barstow ... in ... a bluff just north of the railroad ... this formation is ... thin, overlies unconformably the earlier series [Rosamond], and remains generally in a horizontal position" (Hershey, 1902b, p. 369).

For many years after Hershey's original definition, geologists working in the Mojave Desert and specifically in the dissected, folded upper Miocene rocks of the Mud Hills and Rainbow Basin about 10 miles north of Barstow, consistently applied the name Rosamond to these sedimentary and pyroclastic rocks. In one recent published account, Durrell $(1953$, p. 24) says: "The Tertiary rocks of the Mud Hills, the higher beds of which are upper Miocene (Merriam, 1919, p. 454) in age, are generally known as the Rosamond Series, a name first applied by Hershey (1902, p. 349-372)." During this span of time, the same usage was followed by those later workers who were concerned with the mappable, physical, stratigraphic rock units, as exemplified by Baker (1911, p. 339-352, 357), Pack (1914, p. 146), Knopf (1918, p. 258), Hulin (1925, p. 42, 47, 48; 1934, p. 419-420), E. C. Simpson (1934, p. 395-396, 400 ), and Gardner (1940, p. 278, 281). Miller (1944) applied no formal name to this Miocene rock unit; he used Tertiary volcanics in his text and on his map of the area. Baker $(1911$, p. 341), in addition to 
following Hershey's usage of the Rosamond, also recognized the overlying Barstow of Hershey and used the term correctly.

Wilmarth (1938, p. 1843) cited Hershey's map legend (1902a) for the first usage of Rosamond, gave it an age assignment of "Tertiary (Miocene?)," and added (under his second contribution, 1902b) "uncon. underlies Barstow Series." She (1938, p. 119) cited Hershey's second contribution (1902b, p. 369-370) for the first usage of the term Barstow, complete with type section, and added "uncon. overlies Rosamond," thereby recognizing the validity of Hershey's Quaternary Barstow Formation. But, not realizing that two different formations were involved, she also cited Merriam (1915, 1919) in the seeming belief that his usage of Barstow was identical with Hershey's.

Merriam saw Hershey's (1902a) map but evidently did not see Hershey's formal description of the Rosamond and Barstow (1902b, p. 365-369) because Merriam (1911, p. 167-168) said: "According to a sketch map published by Hershey the point at which the collection was made would fall within what is designated by Hershey as the Rosamond Series. This series has not, however, been characterized in any way so that the nature of the formation is unknown. As geographic location is one of the important factors concerned, the horizon at which this collection was obtained may be referred to . . . as the Mohave beds." Merriam 2 years later referred to "the fauna ... representing a stage near Upper Miocene ... from the typical Mohave beds north of Barstow," (1913, p. 435-436). Then in 1915 he-inadvertently, it seems clear-began the misapplication of "the term Barstow ... used for the beds containing the Upper Miocene fauna" (1915, p. 251).

This mistaken application of the unavailable term Barstow was followed by those later workers who were not concerned with stratigraphy or other physical geology but with the morphology of the faunal elements and the correlation of the fauna collected from the area about 10 miles north of Barstow. Some of these paleontologists used the term Barstow formation: Merriam (1919, p. 441), Simpson (1933, p. 81, 90), Wood and others $(1941$, p. 12, 14), and Colbert (1942, p. 1494). Most have written of ages and faunas-not formations: Frick (1926, p. 27, 34) and Stirton (1930, p. 218) discussed fossils from the "Barstow Miocene." Frick also used "Barstow Mio-Pliocene" (1933, p. 607); and Osborn (1936, p. 742) and Stock (1937, p. 398) referred to fossils from the "Barstow beds." Stirton (1940, p. 178, 181-182) and Stirton and Teilhard de (hardin $(1934$, p. $279-282,284)$ used Barstow with the stipulation that such names refer to a fauna and not to a formation. Schultz and Falkenbach did not use the term Barstow to refer to either a fauna or a formation, but spoke of the "Miocene deposits, north of Barstow" (1940, p. 223; 1947, p. 244) and the "Pliocene deposits, north of Barstow" (1941, p. 32).

In short, when writing of the Tertiary rocks about 10 miles north of Barstow, many geologists, particularly the earlier writers, have avoided the use of Merriam's Barstow Formation. Many paleontologists since Merriam have not used the term Barstow Formation for these same rocks, but have applied the name Barstow to the fauna contained therein. Others, including the Wood (1941) Committee, have used the name Barstow Formation for these rocks of Miocene age. The confusion regarding the use of these names caused the U.S. Geological Survey, in 1924, formally to abandon the name Rosamond Series and formally to adopt the name Barstow Formation for the Miocene rocks in the Barstow syncline. It has been so used by all Survey geologists since that time. Hewett (1954) has published a summary of the up-to-date knowledge of the general geology of the area involved.

\section{FAUNAS OF THE BARSTOW FORMATION}

The mammalian genera known from all zones of the Barstow Formation, according to published reports, are listed below, with tentative synonymy, and authors' initials in parentheses according to the following scheme: Frick, 1926, 1933, 1937-(F); Hall, 1930$(\mathrm{H})$; Lewis in Byers, 1960-(L); Macdonald, 1949(MD); Merriam, 1919-(M); Schultz and Falkenbach, 1940, 1941, 1947-(SF) ; Stirton, 1930, 1935-(ST) ; and Stock, 1937-(S).

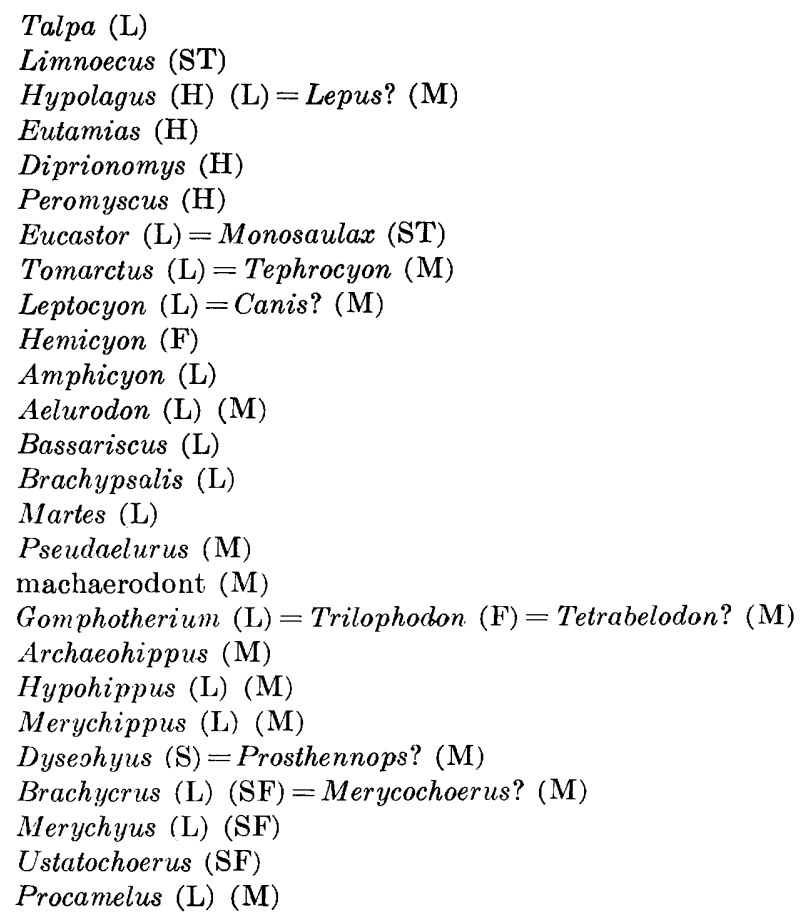


Aepycamelus $(\mathrm{L})=$ Alticamelus $(\mathrm{M})$

Hesperocamelus (L) (MD)

Rakomeryx $(\mathrm{F})=$ Dromomeryx $(\mathrm{M})$

Ramoceros $(\mathrm{F})=$ Merycodus? $(\mathrm{M})$

Cosoryx (F)

Meryceros $(\mathrm{F})(\mathrm{L})=$ Merycodus $(\mathrm{M})$

H. S. Mourning, J. R. Suman, C. I. Baker, and J. P. Buwalda carried on fieldwork north of Barstow between 1911 and 1913; their collections were those that Merriam first assigned to the Mohave Beds (1911) and later to his Barstow Formation (1915). These collections are at the Museum of Paleontology, University of California, Berkeley. By far the largest collection was made by the Frick Laboratory of the American Museum of Natural History, between 1920 and 1940. For these specimens no identifiable locations, geographic or stratigraphic, have been published, so that no comparisons can be made with specimens from other known horizontal (geographic) and vertical (rock unit) locations. For this reason, it is only possible to quote from Frick (1937):

"It has been deemed advisable to consider as broadly contemporaneous the . . . 'Middle Miocene' to 'Upper Pliocene' ... tentatively united as ... the 'Late' Tertiary" (p. 5). "Merycodont remains are of frequent occurrence in the main portion of the Late Tertiary . . . Certain collections have been secured, from .... restricted and well-defined horizons of . . . California" (p. 276). "The First, Second, Third and Fourth Divisions . . . in the Barstow area" (p. 436) are mentioned on numerous pages of this publication, but with no explanation of the sequence or stratigraphic significance of these "Divisions."

Merycodonts are recorded as having been collected from many distinctively - but not geographically-named localities whose stratigraphic position in the formation is not mentioned: they are only said to have come either "from Barstow, California" (Frick, 1937 , p. 331-333, 347-348, 367-368) or "Barstow localities" (p. 435-443). Although some few may be synonymous, there are 24 distinctively named localities: "bottom layer" (p. 368), "Green Hills deposit" (p. 332), "Lower Green Hills" (p. 443), "Green Hills, indefinite locality" (p. 333), "Hemicyon Stratum" (p. 368, 436, 438), "Hidden Quarry"* (p. 367), "Hidden Hollow Quarry" (p. 368, 440), "Leader Quarry"* (p. 367-440), "Mayday Quarry"* (p. 347), "New Year Quarry"* (p. 348, 436, 438), "North End"* (p. 347, 439), "North End, lower layer"* (p. 347), "Old Mill" (p. 368), "Skyline Quarry"* (p. 331, 347, 436, 437), above "Skyline Quarry" (p. 331), "Starlight Quarry"* (p. 347), "Steepside Quarry" (p. 332, 333, 347), "Valley View" (p. 368, 441), "Valley View Quarry" (p. 436), "White Layer" (p. 368), "White Operation" (p. 368, 436, 439), "Yermo" (p. 333), and "Yermo Quarry" (p. 442). The only information relative to stratigraphy is that the "Steepside Quarry" correlates with the "Green Hills horizon" (p. 332), and that the above listed localities marked with an asterisk $(*)$ correlate with the "First Division" (Frick, 1937 , p. $347-348,367)$. Frick also published on "the occurrence in one well-defined stratum of two forms of Hemicyon" from the "Hemicyon Stratum, Barstow Miocene" (1926, p. 34).

Schultz and Falkenbach described oreodonts from the Frick collections, and added the following information: "From the Miocene deposits, north of Barstow ... Brachycrus remains in the Barstow area are recorded only from the ... Steepside Quarry ... Ness Quarry ... Green Hills ... Green Hills horizon or Second Division which underlies the later deposits including the 'Hemicyon Stratum' of the First Division" (Schultz and Falkenbach, 1940, p. 223-228); "Merychyus (Metoreodon) relictus fetcheri ... from the Miocene deposits, north of Barstow . . f from 'Red or Third Division" " (1947, p. 244-245); and "Ustatochoerus medius mohavensis ... from the Pliocene deposits, north of Barstow ... from the 'Hemicyon Stratum' of the First Division" (1941, p. 32). Schultz and Falkenbach $(1949$, p. 80$)$ also published a stratigraphic distribution chart. This work gives the best idea of the stratigraphic succession of some elements of the Frick collections.

From 1950 to 1955 the U.S. Geological Survey was engaged in mapping much of the Mojave Desert; during this fieldwork a collection was made, chiefly by R. H. Tedford and R. L. Shultz, Jr. I studied this collection; one of my preliminary reports is a part of T. W. Dibblee, Jr.'s, report in preparation on the Opal Mountain and Fremont Peak quadrangles, California. Another of my reports is incorporated in F. M. Byers, Jr's, report (1960) on the Alvord Mountain quadrangle, California. The specimens discussed in these reports are a part of the U.S. Geological Survey collections at the Denver Federal Center. Both Byers (1960) and Dibblee (written communication) have mapped several carefully defined Tertiary formations, and have made illustrated sections to clarify the stratigraphic relations of the fossil-bearing beds.

One of the best continuous sections of the Barstow Formation has been measured and described by Durrell (1953, fig. 12, sections $A-A^{\prime}$ and $B-B^{\prime}$, pl. 4) in the Barstow syncline area about 10 miles north of Barstow. Section $\mathrm{A}-\mathrm{A}^{\prime}$ shows 1,955 feet of sedimentary and subordinate pyroclastic rocks within the formation, which is here overlain unconformably by Pleistocene sediments. Section $\mathbf{A}-\mathbf{A}^{\prime}$ does not include the basal beds of the formation, which are included in section $\mathrm{B}-\mathrm{B}^{\prime}$ about 4,000 feet west of section $\mathrm{A}-\mathrm{A}^{\prime}$. The basal 139 feet of 
granitic conglomerate overlies with angular unconformity an older formation of granitic breccia and rhyolitic tuff breccia. The total thickness of the formation included in Durrell's two measured sections is 2,149 feet, much less than in the fossil-yielding area of outcrop farther west in the Barstow syncline. The total thickness is far from constant; it and the thickness of each individual bed have a considerable range from one part of the Barstow syncline to another. Most of the fossil vertebrates have been collected from $2 \frac{1}{2}$ to 5 miles west-northwest of Durrell's sections, where the aggregate thickness of outcrops of different parts of the formation adds up to at least 2,500 and perhaps as much as 2,800 feet. The total original thickness is not known; the highest beds, having been eroded, are either still being eroded or are overlain unconformably by Pleistocene sediments.

There are at least two distinct faunal assemblages from the strata that have been called the Barstow Formation, but the lack of published stratigraphic data about the Frick collections makes a conclusive statement impossible. The U.S. Geological Survey collections from the Barstow syncline area all come from the uppermost third of the section exposed there, where many old diggings and large quarries were seen. These localities are all either above or only a few feet below (stratigraphically) a conspicuous bed of white tuff as much as 15 feet thick that crops out on the skyline as one travels northward up the canyon (E $1 / 2$ sec. 23 , $\mathrm{T}$. 11 N., R. 2 W.) on Fossil Bed Road (USGS Opal Mountain, Calif., quadrangle). Dibblee (written communication) considers this tuff as marking the base of the upper, unnamed member of the Barstow Formation.

Large quarries along the strike of this, Dibblee's lower marker tuff, may represent Skyline and other localities of Frick's (1937, p. 331, 347) First Division that yielded Meryceros (Meryceros), Cosoryx (Paracosoryx), and Ramoceros (Paramoceros). Specimens referable to the first of these subgenera and to the Merychippus (Protohippus) species described by Merriam (1919, p. 479-507) are by far the commonest fossils from the uppermost third of the formation, where the U.S. Geological Survey collected specimens of 15 genera. Eucastor, Merychippus (Merychippus) sumani, Paracosoryx, and Paramoceros are key fossils in this upper faunal assemblage. Merychippus sumani and Eucastor were collected, for example, at one locality 300 feet above the lower marker tuff. The age seems to be latest Miocene, most nearly equivalent to that of the Tonopah local fauna of Nevada and comparable to the oldest fauna from the Ogallala of Nebraska. Schultz and Falkenbach $(1941$, p. $32 ; 1949$, p. 80) also assigned this fauna to the same stratigraphic position on the basis of a single specimen of Ustatochoerus medius mohavensis.

A second distinct faunal assemblage seems to come from the middle third of the section that crops out in Coon Canyon of the Barstow syncline area (center NW $1 \frac{1}{4}$ sec. 23, T. 11 N., R. 2 W., Opal Mountain, Calif., quadrangle). Here several old diggings in greenish rocks were seen. They may represent Steepside and other localities of Frick's Green Hills (1937, p. 99-105, 332-333) or Second Division (Schultz and Falkenbach, 1940, p. 223-228) that yielded Brachycrus buwaldi, Ramoceros (Merriamoceros), and Rakomeryx.

This faunal assemblage is considered to be of the same age as the Sheep Creek local fauna according to Schultz and Falkenbach (1949, p. 80). This view is supported by the U.S. Geological Survey discovery ( $\mathrm{SE}^{1 / 4}$ sec. 34, T. 12 N., R. 4 E.) of Merychippus tehachapiensis (Buwalda and Lewis, 1955, p. 148-150) 1,200 feet above the base of the formation, and of Brachycrus buwaldi (NW1/4 sec. 30, T. 12 N., R. 4 E.) 1,700 feet above the base of the formation in the Alvord Mountain quadrangle, California. To be sure, the Merychippus tehachapiensis occurs 500 feet stratigraphically below the Brachycrus buwaldi and could possibly represent a fauna even older than the Brachycrus. But Buwalda and Lewis (1955, p. 150) believed that Merychippus tehachapiensis is close both in age and morphology to $M$. primus of the Sheep Creek local fauna of Nebraska. Perhaps the Frick collections contain evidence either for or against a common stratigraphic position for the two species found in the Alvord Mountain area. With the evidence now available, we must assume that Brachycrus is the least rare fossil in the fauna from the middle third of the formation, and is a key fossil together with Ramoceros (Merriamoceros) and perhaps Merychippus tehachapiensis.

Insofar as published information and known experience go, the lowest third of the formation has yielded no identifiable fossil vertebrates.

Merychippus tehachapiensis, as already stated, could possibly represent a third fauna older than either of the two that are definitely recognized. A fourth fauna, intermediate in age between those of the Tonopah and Sheep Creek faunas, may conceivably be present. Schultz and Falkenbach (1947, p. 244-245) record one subspecies of oreodont whose age they consider intermediate between that of $B$. buwaldi and that of $U$. $m$. mohavensis: It is "the holotype . . . the only specimen known" of "Merychyus (Metoreodon) relictus fletcheri. . . from the Miocene deposits, north of Barstow ... Red or Third Division." They show the "stratigraphic distribution of ... each genus and subgenus . . . species and subspecies" on a chart with 
corresponding epochs and Great Plains formations as follows (Schultz and Falkenbach, 1949, p. 80-81):

$\begin{array}{ccc}\text { "PLIOCENE } & \text { Valentine } & \begin{array}{c}\text { Ustatochoerus medius } \\ \text { mohavensis }\end{array} \\ \text { MIOCENE } & \text { 'Lower } & \text { Merychyus (Metoreodon) } \\ & \text { Snake } & \text { relictus fletcheri } \\ & \text { Creek' } & \\ & \text { 'Sheep Creek' } & \text { Brachycrus buwaldi." }\end{array}$

This opinion of these authorities must be given great weight. But it is based on a solitary fragment of maxilla with broken and badly worn cheek teeth of a subgenus whose stratigraphic range is shown to be exactly equivalent to that of Brachycrus on the same chart. The "Red or Third Division" of Frick (1937) is a stratigraphic nomen nudum, and of no help in the description of the formation; presumably it is lower than the lower marker tuff but higher than the rocks that yield Brachycrus, and thus within the middle third of the formation.

In résumé, then, we have: (1) undisputed evidence that the uppermost third of the formation corresponds to a zone that contains an assemblage of fossil vertebrates usually thought to occupy an upper Miocene stratigraphic position; (2) suggestive evidence that the middle third of the formation corresponds to a zone that contains an assemblage of fossil vertebrates usually thought to occupy a middle Miocene stratigraphic position; and (3) empirical negative evidence that the lower third of the formation contains no identified fossil vertebrates (there are undetermined algae near the base) and is of unknown age not younger than middle Miocene.

Differences of opinion do not exist as to the correlation with local faunas of the Great Plains, but only as to whether the uppermost fauna should be referred to the uppermost Miocene according to the usual practice (Merriam, 1919; Simpson, 1933; Wood and others, 1941) or to the lowermost Pliocene according to different authoritative opinion (Frick, 1933; Schultz and Falkenbach, 1941). Most of the diagnostic key fossilsequines, merycoidodontids, and antilocaprids-are exclusively New World forms that cannot be used for intercontinental correlation. Hemicyon and Gomphotherium are two genera that give direct evidence for intercontinental correlation of the youngest fauna; most authorities consider them to represent a late Miocene migration from the Old World to the New as part of "the most extensive faunal interchange between the early Oligocene and the latest Pliocene" (Simpson, 1947, p. 639).

\section{REFERENCES}

Baker, C. L., 1911, Notes on the later Cenozoic history of the Mojave Desert region in southeastern California: California Univ., Dept. Geol. Sci. Bull., v. 6, p. 333-383.

Buwalda, J. P., and Lewis, G. E., 1955, A new species of Merychippus: U.S. Geol. Survey Prof. Paper 264-G, p. 147-152.

Byers, F. M., Jr., 1960, Geology of the Alvord Mountain quadrangle, San Bernardino County, California: U.S. Geol. Survey Bull. 1089-A, 71 p. [1961].

Colbert, E. H., 1942, The geologic succession of the Proboscidea, in Osborn, H. F., Proboscidea; a monograph of the discovery, evolution, migration, and extinction of the mastodonts and elephants of the world, v. 2: New York, Am. Mus. Press, p. 1421-1521.

Durrell, Cordell, 1953, Geological investigations of strontium deposits in southern California: California Div. Mines Spec. Rept. 32, 48 p.

Frick, Childs, 1926, The Hemicyoninae and an American Tertiary bear: Am. Mus. Nat. History Bull., v. 56, p. 1-119.

1933, New remains of trilophodont-tetrabelodont mastodons: Am. Mus. Nat. History Bull., v. 59, p. 505-652.

1937, Horned ruminants of North America: Am. Mus. Nat. History Bull., v. 69, 669 p.

Gardner, D. L., 1940, Geology of the Newberry and Ord Mountains, San Bernardino County, California: California Jour. Mines and Geology, v. 36, p. 257-292.

Hall, E. R., 1930, Rodents and lagomorphs from the Barstow beds of southern California: California Univ., Dept. Geol. Sci. Bull., v. 19, p. 313-318.

Hershey, O. H., 1902a, The Quaternary of Southern California: California Univ., Dept. Geol. Sci. Bull., v. 3, p. 1-29, pl. 1. 1902b, Some Tertiary formations of Southern California: Am. Geologist, v. 29, p. 349-372.

Hewett, D. F., 1954, General geology of the Mojave Desert region, California [Pt.] 1 in Chap. 2 of Jahns, R. H., ed., Geology of southern California: California Dept. Nat. Res., Div. Mines Bull. 170, p. 5-20.

Hulin, C. D., 1925, Geology and ore deposits of the Randsburg quadrangle, California: California Div. Mines Bull. 95, $152 \mathrm{p}$.

- 1934, Geologic features of the dry placers of the northern Mojave Desert: California Jour. Mines and Geology, v. 30, p. 416-426 [1935].

Knopf, Adolf, 1918, Strontianite deposits near Barstow, California: U.S. Geol. Survey Bull. 660-I. p. 257-270.

Macdonald, J. R., 1949, A new Clarendonian fauna from northeastern Nevada: California Univ., Dept. Geol. Sci. Bull., v. 28 , p. $173-194$.

Merriam, J. C., 1911, A collection of mammalian remains from Tertiary beds on the Mohave Desert: California Univ., Dept. Geol. Sci. Bull., v. 6, p. 167-169.

- 1913, New protohippine horses from Tertiary beds on the western border of the Mohave Desert: California Univ., Dept. Geol. Sci. Bull., v. 7, p. 435-441.

- 1915, Extinct faunas of the Mohave Desert, their significance in a study of the origin and evolution of life in America: Popular Sci. Monthly, v. 86, p. 245-264.

- 1919, Tertiary mammalian faunas of the Mohave Desert: California Univ., Dept. Geol. Sci. Bull., v. 11, p. 437-585.

Miller, W. J., 1944, Geology of parts of the Barstow quadrangle, San Bernardino County, California: California Jour. Mines and Geology, v. 40, p. 73-112. 
Osborn, H. F., 1936, Proboscidea; a monograph of the discovery, evolution, migration, and extinction of the mastodonts and elephants of the world, v. 1: New York, Am. Mus. Press, $802 \mathrm{p}$.

Pack, R. W., 1914, Reconnaissance of the Barstow-Kramer region, California: U.S. Geol. Survey Bull. 541, p. 141-154.

Schultz, C. B., and Falkenbach, C. H., 1940, Merycochoerinae, a new subfamily of oreodonts: Am. Mus. Nat. History Bull., v. 77, p. 213-306.

1941, Ticholeptinae, a new subfamily of oreodonts: Am. Mus. Nat. History Bull., v. 79, p. 1-105.

1947, Merychyinae, a subfamily of oreodonts: Am. Mus. Nat. History Bull., v. 88, p. 157-286.

1949, Promerycochoerinae, a new subfamily of oreodonts: Am. Mus. Nat. History Bull., v. 93, p. 69-198.

Simpson, E. C., 1934, Geology and mineral depcsits of the Elizabeth Lake quadrangle, California: California Jour. Mines and Geology, v. 30, p. 371-415.

Simpson, G. G., 1933, Glossary and correlation charts of North American Tertiary mammal-bearing formations: Am. Mus. Nat. History Bull., v. 67, p. 79-121.
Simpson, G.G., 1947, Holarctic mammalian faunas and continental relationships during the Cenozoic: Geol. Soc. America Bull., v. 58 , p. $613-687$.

Stirton, R. A., 1930, A new genus of Soricidae from the Barstow Miocene of California: California Univ., Dept. Geol. Sci. Bull., v. 19, p. 217-228.

1935, A review of the Tertiary beavers: California Univ. Dept. Geol. Sci. Bull., v. 23, p. 391-458.

1940, Phylogeny of North American Equidae: California Univ., Dept. Geol. Sci. Bull., v. 25, p. 163-197.

Stirton, R. A., and Teilhard de Chardin, Pierre, 1934, A correlation of some Miocene and Pliocene mammalian assemblages in North America and Asia with a discussion of the MioPliocene boundary: California Univ., Dept. Geol. Sci. Bull., v. 23 , p. $277-290$.

Stock, Chester, 1937, A peccary skull from the Barstow Miocene of California: Natl. Acad. Sci. Proc., v. 23, p. 398-404.

Wilmarth, M. G., 1938, Lexicon of geologic names of the United States: U.S. Geol. Survey Bull. 896, 2396 p.

Wood, H. E., 2d, and others, 1941, Nomenclature and correlation of the North American continental Tertiary: Geol. Soc. America Bull., v. 52, p. 1-48. 


\title{
Article 126
}

\section{THIRSTY CANYON TUFF OF NYE AND ESMERALDA COUNTIES, NEVADA}

\author{
By D. C. NOBLE, R. E. ANDERSON, E. B. EKREN, and J. T. O'CONNOR, Denver, Colo.
}

Work done in cooperation with the U.S. Atomic Energy Commission

\begin{abstract}
Rhyolitic ash-flow and air-fall tuffs assigned to a new formation, Thirsty Canyon Tuff, of Pliocene age crop out from Beatty to Goldfield. The formation is subdivided into five newly defined formal members - the Spearhead, Trail Ridge, Dry Lake, Gold Flat, and Labyrinth Canyon Members-and an informal upper member.
\end{abstract}

A sequence of rhyolitic ash-flow and air-fall tuffs here named the Thirsty Canyon Tuff crops out over a large area in the general vicinity of Beatty and Goldfield, Nev. The presently known extent of the formation, based on recent geologic mapping in twelve $7 \frac{1}{2}$-minute and three 15-minute quadrangles and on reconnaissance in parts of four additional 15-minute quadrangles, is shown on figure 126.1.

The Thirsty Canyon Tuff is best exposed and attains its maximum thickness north-northeast of Beatty in the general vicinity of Thirsty Canyon (fig. 126.1), for which the formation is here named. The formation is here subdivided into five formal members and an informal upper member. The formal members are, from bottom to top, the Spearhead, Trail Ridge, Dry Lake, Gold Flat, and Labyrinth Canyon. A complete stratigraphic section of the Thirsty Canyon Tuff is nowhere exposed; therefore, only a type area located in the headward part of Thirsty Canyon (fig. 126.1) is designated. Type localities are designated for the members.

In addition to being practical cartographic units, the five formal members of the Thirsty Canyon Tuff are genetic rock units. Welding and cooling characteristics indicate that each member was deposited within a relatively restricted interval of time, and that each nember cooled to a greater or lesser degree as a single unit. The Spearhead Member is a composite sheet; the Trail Ridge Member a multiple ash-flow simple cooling unit; the Dry Lake Member a simple cooling unit, probably a single flow; the Gold Flat Member a compound cool- ing unit; and the Labyrinth Canyon Member a single ash-flow simple cooling unit. (The terminology of ash-flow cooling units is that of Smith, 1960.) Although in most places the members are conformable or paraconformable, locally they are separated by lenses of conglomerate and sandstone and by intertonguing lava flows. These rocks are excluded from the Thirsty Canyon Tuff.

The Thirsty Canyon Tuff shows much lateral variability, chiefly because of the marked topographic irregularity of the surface on which it was deposited. The formation as a whole and the individual units within the formation thin and thicken laterally in a complex and often unsystematic manner. Pronounced lateral variation in degree of welding and in the amount and character of devitrification and vapor-phase crystallization are associated with changes in thickness of individual members and of smaller units within members.

Preliminary studies indicate that the rocks of the Thirsty Canyon Tuff have similar mineralogic and chemical compositions. Phenocrysts, which comprise 5 to 30 percent of the rock, include soda-rich sanidine, pigeonite, a green clinopyroxene probably containing appreciable amounts of aegirene and (or) hedenbergite, fayalite, strongly absorptive brown amphibole, and zircon. Rare quartz phenocrysts have been found only in the Gold Flat Member. Chemically the rocks are soda rhyolites and pantellerites. The chemical and mineralogical similarities strongly suggest that the members of the Thirsty Canyon Tuff are comagmatic.

Despite these similarities, the members differ appreciably both in general appearance and petrography. Also, there is significant lateral and vertical variation in phenocryst, lithic-fragment, and pumice content within the individual members. 

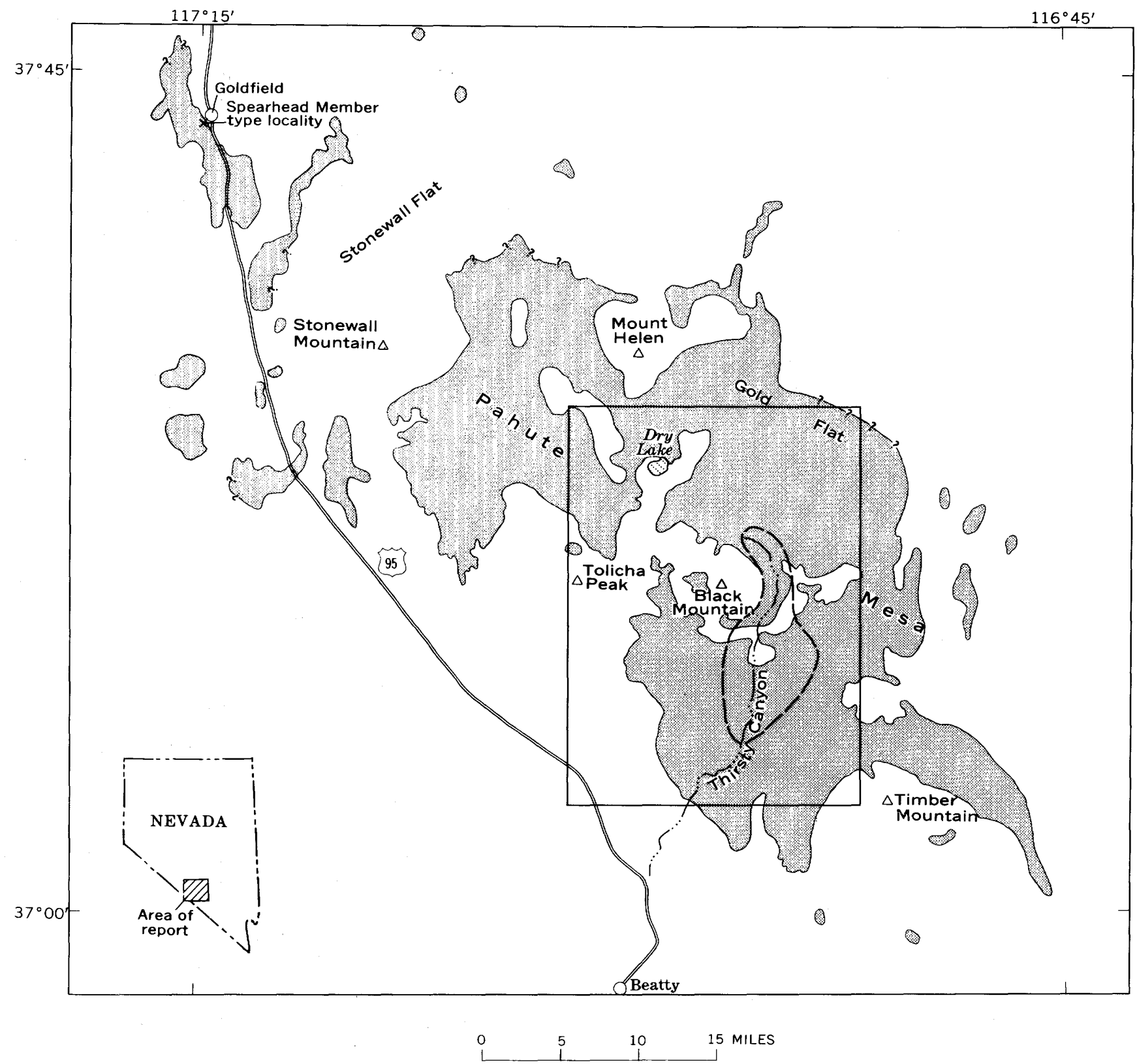

FIGURE 126.1-Generalized map showing presently known surface and subsurface distribution of the Thirsty Canyon Tuff (stippled). The formation may extend beyond queried contacts. Type area of the Thirsty Canyon Tuff is enclosed by dashed line. Rectangle shows area covered by figure 126.2 .

The Thirsty Canyon Tuff unconformably overlies the Rainier Mesa Member of the Piapi Canyon Formation (Poole and McKeown, 1962). Although it postdates most of the Tertiary faulting of the area, it is cut by numerous north-south trending normal faults and, south of Goldfield, has undergone strong hydrothermal alteration. The formation is deeply incised by canyons and has been eroded from large areas. In most areas it is the youngest sequence of volcanic strata, but locally it is overlain by intermediate to mafic lavas.
The Thirsty Canyon 'Tuff is dated, primarily on isotopic evidence, as Pliocene in age. A potassium-argon age of approximately 7.5 m.y. (R. W. Kistler, written communication, 1963) has been obtained on sanidine from the lower part of the Spearhead Member. Potassium-argon ages of less than 13 m.y., the MiocenePliocene boundary of Kulp (1961), have also been obtained on six units stratigraphically below the Thirsty Canyon Tuff. In addition to the potassiumargon age of $7.5 \mathrm{~m} . y$. , the structural involvement, hydrothermal alteration, and degree of erosion that the 
Thirsty Canyon Tuff has undergone indicate that the formation is of Pliocene rather than Pleistocene age.

\section{SPEARHEAD MEMBER}

Ransome (1909) applied the name Spearhead Rhyolite to an ash-flow tuff that crops out west of Goldfield. The unit is ". . . well exposed at Rabbit Spring . . . and in Pozo Canyon" (Ransome, 1909, p. 71), about three-quarters of a mile southwest of the center of Goldfield (fig. 126.1), where it is overlain by basalt. Regional mapping shows that Ransome's Spearhead Rhyolite is part of a large composite sheet forming the lower part of the Thirsty Canyon Tuff.

Where described by Ransome, the Spearhead Rhyolite is a simple cooling unit 20 to 80 feet thick. However, traced to the south, this cooling unit incorporates additional ash flows and in a short distance becomes a compound cooling unit several hundred feet thick. South of Gold Flat this cooling unit is underlain by another compound cooling unit of similar composition that overlies a sequence of rhyolitic lava flows and minor tuffs informally termed the rhyolites of Pillar Spring. The break between the 2 units becomes progressively less distinct to the south, and disappears completely approximately 8 miles south of Black Mountain. Because of this merger, the lower compound cooling unit is also included in the Spearhead Rhyolite, which is here reassigned as the Spearhead Member of the Thirsty Canyon Tuff.

Where the two compound cooling units of the Spearhead Member are distinguishable, they are informally designated the upper and lower parts of the member. The upper part is distinguished by numerous red to brown lenses of scoriaceous to massive devitrified glass that are commonly several feet in diameter and as much as a foot thick.

The rocks of the Spearhead Member are highly variable in lithology, ranging from shard tuffs to tuffs containing abundant pumice, lithic fragments, and phenocrysts, and from air-fall tuffs and poorly velded ash-flow tuffs to densely welded vitric and devitrified ash-flow tuffs. Very commonly the tops of both the upper and lower parts of the Spearhead Member are composed of lithic-, pumice-, and crystal-poor shard tuff. The present volume of the Spearhead Member exceeds that of the other members of the Thirsty Canyon Tuff combined. The lower part of the member reaches a maximum thickness of about 400 feet in the lower part of Thirsty Canyon. East of Stonewall Mountain, rocks of the upper part of the Spearhead Member locally reach a thickness of almost 300 feet.

\section{TRAIL RIDGE MEMBER}

The Trail Ridge Member is here named for Trail Ridge (fig. 126.2). In most outcrops the member in- cludes a basal bed of air-fall pumice, generally less than 5 feet thick but locally as much as 30 feet thick. In the vicinity of Black Mountain and Thirsty Canyon the bulk of the member consists of lithic-rich moderately to densely welded ash-flow tuff, which is capped by a thin unit of densely-welded shard tuff containing very few pumice fragments or lithic inclusions and few phenocrysts. To the north the lithic-rich part of the member is absent, and the member consists entirely of shard tuff.

At the type locality (fig. 126.2), north of Black Mountain (lat $37^{\circ} 21^{\prime}$ N., long $116^{\circ} 39^{\prime}$ W.), about 7 miles west of Trail Ridge, the Trail Ridge Member is well exposed for several miles along the walls of a northsouth-trending canyon. Here the member, approximately 100 feet thick, overlies the upper part of the Spearhead Member and is paraconformably overlain by the Gold Flat Member. Both the lower lithic-rich zone and the upper shard tuff zone are well developed.

The Trail Ridge Member locally reaches a thickness of almost 200 feet in the general vicinity of Thirsty Canyon, but in most places is much thinner. The member is essentially coextensive with the Spearhead Member; it is generally densely welded and forms the caprock of a large part of Pahute Mesa.

\section{DRY LAKE MEMBER}

The Dry Lake Member, as here named for Dry Lake, crops out northeast and southwest of Dry Lake and north of Tolicha Peak (fig. 126.2). The member, which nowhere exceeds 30 feet in thickness, is lithologically distinct from both the underlying Trail Ridge Member and the overlying Gold Flat Member. Approximately 25 percent of a typical outcrop is composed of black to brown coarsely vesicular blocks of pumice as much as 3 feet in diameter. Only the uppermost part of the member is devitrified.

At the type locality (lat $37^{\circ} 26^{\prime}$ N., long $116^{\circ} 41^{\prime}$ W., fig. 126.2) a section extending from the Trail Ridge Member through the Gold Flat Member is exposed.

\section{GOLD FLAT MEMBER}

The Gold Flat Member is here named for outcrops near Gold Flat. However, its type locality is about 10 miles south of Gold Flat in the upper reach of Thirsty Canyon (lat $37^{\circ} 15^{\prime}$ N., long $116^{\circ} 36^{\prime}$ W., fig. 126.2). Here approximately 170 feet of the member is exposed on the walls of Thirsty Canyon and its tributaries.

The base of the member consists of several inches to about 8 feet of densely to partially fused light-brown tuff probably of air-fall origin. This unit is succeeded by densely welded generally devitrified dark-green to bluish-gray tuff as much as 20 feet thick which passes abruptly upward into densely to moderately welded yellow-brown or brownish-red devitrified tuff. 


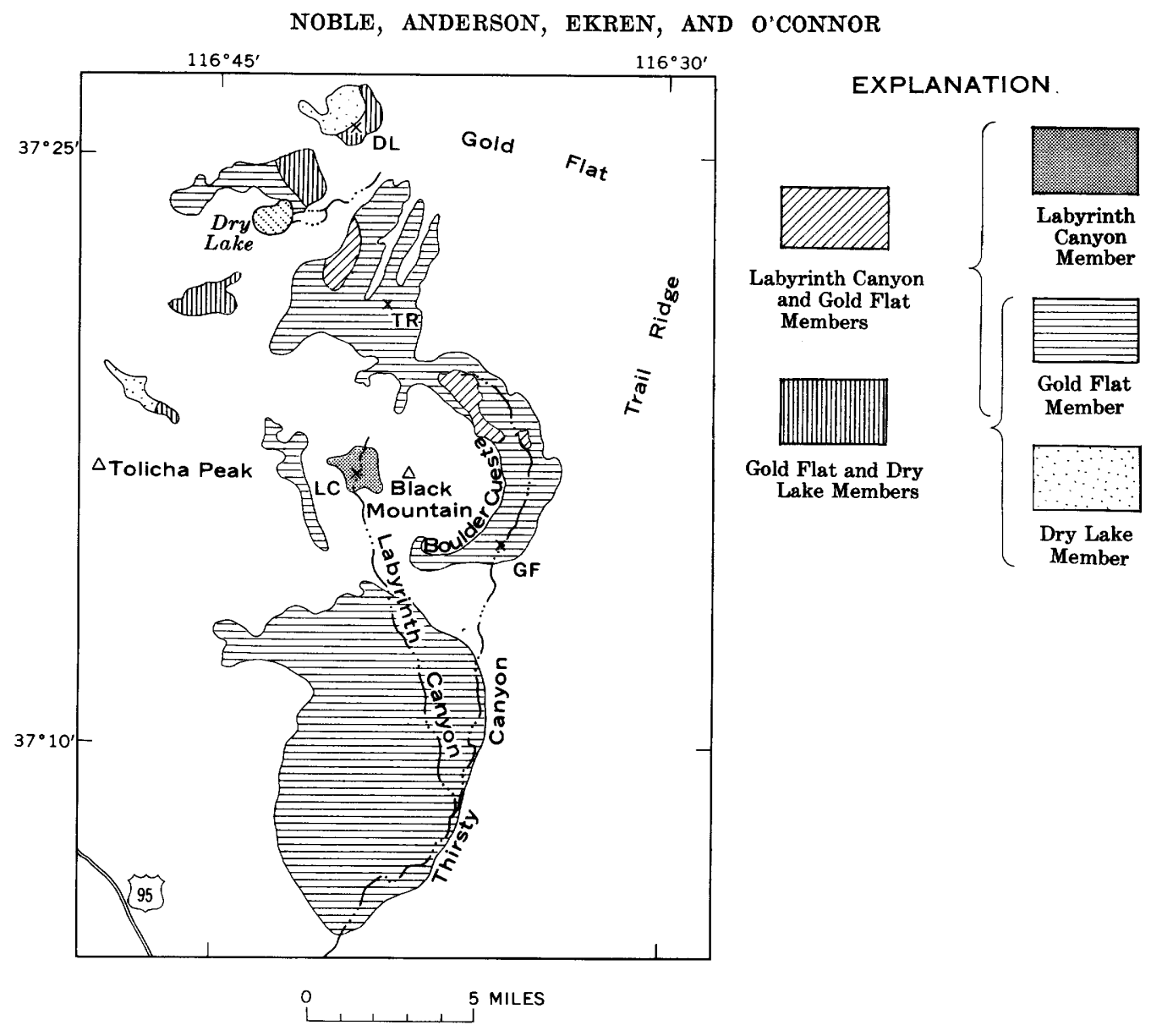

Frgure 126.2.- Map showing the distribution of the Dry Lake, Gold Flat, and Labyrinth Canyon Members and type localities of the Trail Ridge (TR), Dry Lake (DL), Gold Flat (GF), and Labyrinth Canyon (LC) Members.

The Gold Flat Member is characterized by abundant lithic fragments and by complexly twinned euhedral phenocrysts of alkali feldspar as much as $3 \mathrm{~cm}$ long, in addition to the soda-rich sanidine crystals 1 to $5 \mathrm{~mm}$ in diameter that are typical of the Thirsty Canyon Tuff. A distinctive ash flow, characterized by very abundant phenocrysts and by numerous cognate ejecta as much as several feet in diameter and composed dominantly of phenocrysts, forms the top of the member in the vicinity of the type locality.

The member reaches a maximum thickness of about 200 feet in several places in the Thirsty Canyon-Black Mountain area.

\section{LABYRINTH CANYON MEMBER}

The Labyrinth Canyon Member, here named for Labyrinth Canyon, crops out west, north, and east of Black Mountain (fig. 126.2). At the type locality (lat $37^{\circ} 17^{\prime}$ N., long $116^{\circ} 41^{\prime}$ W.) in the headward part of Labyrinth Canyon (fig. 126.2), the Labyrinth Canyon Member reaches its maximum thickness of approximately 50 feet. The lower 5 to 20 feet of the member is composed of slightly to moderately welded light-gray or light-brown vitric ash-flow tuff containing about 20 percent white pumice fragments. The basal vitric zone is sharply overlain by pink to bluish-gray devitrified tuff.

\section{UPPER MEMBER}

The upper member consists of two beds of white to gray pumice-rich air-fall(?) tuff 1 to 8 feet thick that crop out on the dip slope of Boulder Cuesta (fig. 126.2), approximately 2 miles southeast of the summit of Black Mountain. The upper member overlies the Gold Flat Member. Although the Labrinth Canyon Member and the upper member are nowhere in contact, colluvial gravels below the upper member appear to overlie the Labyrinth Canyon Member.

\section{REFERENCES}

Kulp, J. L., 1961, Geologic time scale: Science, v. 133, p. 1105-1114.

Poole, F. G., and McKeown, F. A., 1962, Oak Spring Group of the Nevada Test Site and vicinity, Nevada: Art. 80 in U.S. Geol. Survey Prof. Paper 450-C, p. C60-C62.

Ransome, F. L., 1909, Geology and ore deposits of Goldfield, Nevada: U.S. Geol. Survey Prof. Paper 66, 253 p.

Smith, R. L., 1960, Zones and zonal variations in welded ash flows: .U.S. Geol. Survey Prof. Paper 354-F, p. 149-159. 


\title{
Article 127
}

\section{ST. KEVIN GRANITE, SAWATCH RANGE, COLORADO}

\author{
By OGDEN TWETO and ROBERT C. PEARSON, Denver, Colo.
}

\begin{abstract}
Granitic rocks of a batholith in the Sawatch Range were in part intrusive and in part generated in place. They constitute a unit that originated independently of the Silver Plume Granite in the Front Range, to which they were once speculatively assigned.
\end{abstract}

The name St. Kevin Granite is here given to the rocks of a small Precambrian batholith and related plutons in the northern Sawatch Range and part of the adjoining Mosquito Range near Leadville, Colo. In the past, these rocks have been called Silver Plume Granite (Stark, 1935) or Silver Plume(?) Granite (Behre, 1953, p. 20-22). This correlation with the well-known Silver Plume Granite of the Front Range assumes an identity that has not been proved. The two granites have in common only the facts that they are both biotite-muscovite granites that have conspicuous trachytoid porphyritic facies, and that each is the youngest major Precambrian granite in its respective area. They differ in minor degree in petrographic details, range of composition, and characteristic accessory minerals, and, in part, in form of the intrusive bodies and conditions of emplacement. Most importantly, however, they seem to have been derived from separate bodies of magma. Isotopicage data currently available suggest that the two granites are of the same general age, but data for precise comparisons are not yet available.

The St. Kevin Granite occurs principally in a batholith about 25 miles long and 12 miles wide centered near the crest of the Sawatch Range west of Leadville. About a third of the batholith lies in the Holy Cross quadrangle (fig. 127.1), where it has been mapped in detail; the remainder has been examined only in reconnaissance. Many satellitic bodies of the granite lie in the mapped areas north and east of the batholith; others probably exist in the unmapped areas to the south and west. The granite takes its name from
St. Kevin Lake and the adjoining St. Kevin mining district (fig. 127.1).

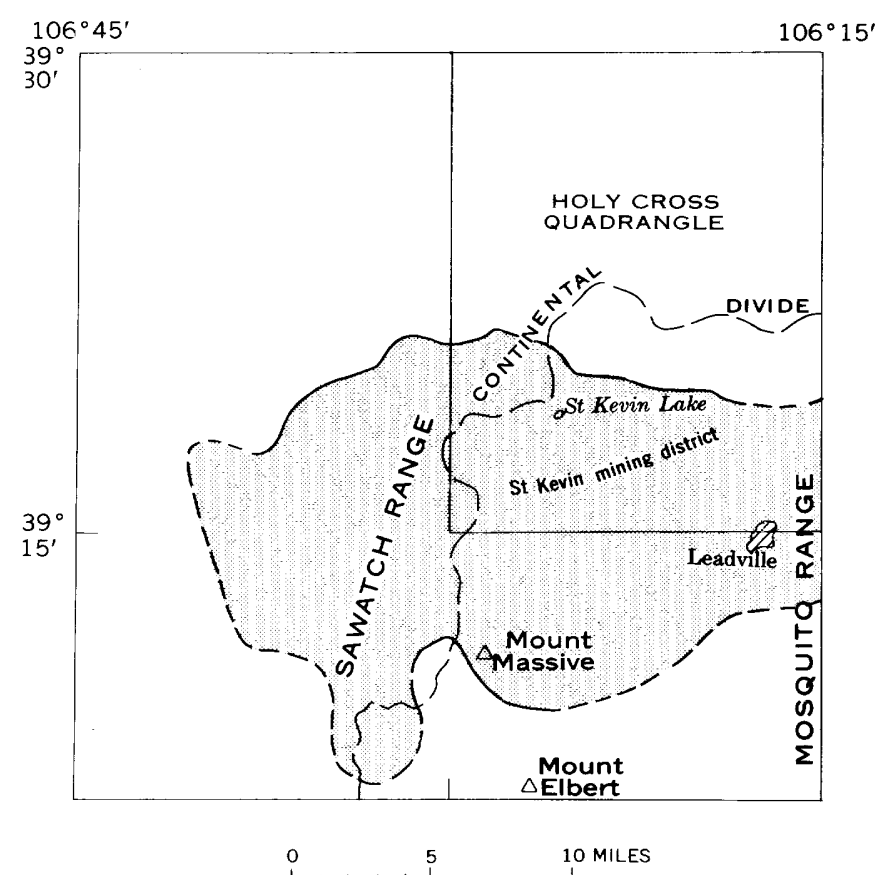

Frgure 127.1.-Generalized outline of the St. Kevin batholith.

Where it has been mapped in detail, the batholith is characterized by extremely intricate borders, as indicated in figure 127.2. Similar complex interfingering of granite and the wallrocks of metasedimentary gneisses is known to exist in the southern part of the batholith, near Mount Massive, and in places, at least, in the western part. The only part of the batholith relatively free of "islands" and projecting fingers of gneiss is an area 3 or 4 miles in diameter near its center. Although many of the bodies of gneiss within the batholith are clearly xenoliths, many are in structural continuity and thus appear to 


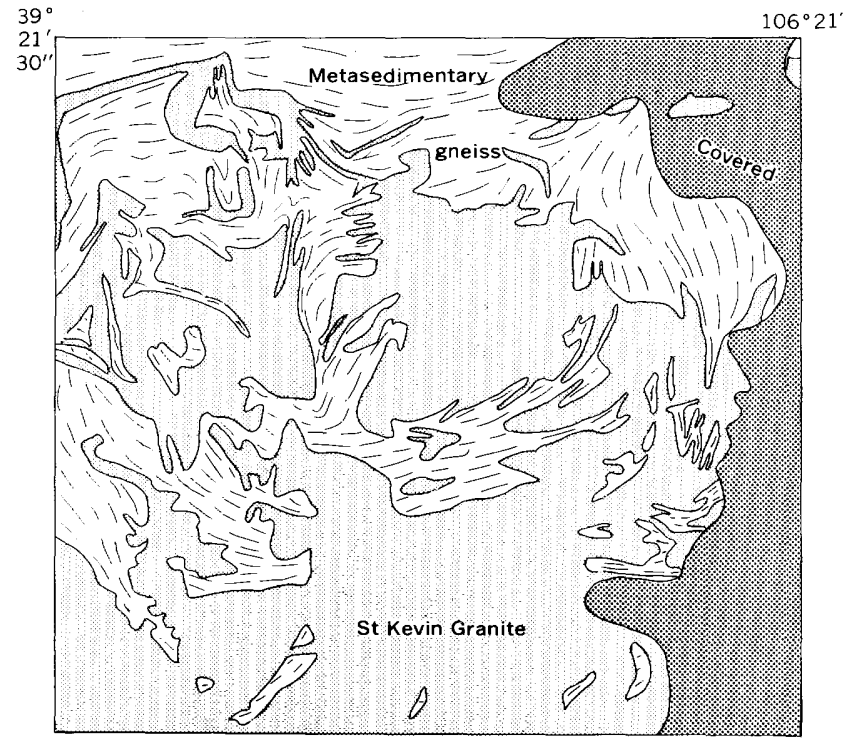

$\stackrel{2}{0} 1 \quad 2$ MILES

Figure 127.2.-Generalized map of part of the St. Kevin batholith.

be parts of large, attached bodies only incipiently sundered by the granite. Contacts between the granite and the metasedimentary gneisses are predominantly concordant but in detail are discordant in many places. Some are of knife-edge sharpness, particularly in crosscutting bodies, but typically the contacts are gradational. In places, sill-like bodies of granite a few inches to tens of feet wide alternate with strips of gneiss of the same general dimensions through contact zones hundreds of feet wide. Elsewhere the transition takes place in a broad pegmatitic zone that consists on one side of pegmatite and granite in complex mixture, and on the other, of pegmatite and gneiss in equally complex arrangement. In many places the gradation from granite to gneiss is almost imperceptibly gradual for distances of tens or hundreds of feet and then is completed abruptly in distances of only inches or a few feet. In the abrupt parts of such zones, gneiss is peppered with feldspar and muscovite crystals typical of the granite. In the remainder of the zone, the granite is streaked with ghosts or delicate screens of partly granitized gneiss. The screens outline structural features that commonly are in strict continuity with those in the adjoining gneiss. Locally, streaky granite of this type loses its organized fold structure in a mass of complex swirls that presumably mark the site of liquid flow.

The St. Kevin Granite comprises many textural and compositional varieties of granitic rocks. Four main facies-(1) trachytoid hybrid, (2) normal, (3) granodioritic, and (4) fine grained-were distinguished in mapping, but each of these has variants, and all intergrade. A fifth major facies, called Hell Gate Porphyry by Stark and Barnes (1932, p. 34), occurs in the unmapped western and southern parts of the batholith. As recognized later by Stark and Barnes (1935, p. 474), this rock is merely a textural facies of what is here called the St. Kevin Granite, and it therefore does not warrant a formal name. We shall refer to the rock hereafter as the coarse porphyritic facies of the St. Kevin Granite.

The trachytoid hybrid facies is a coarse-grained inhomogeneous rock that appears at first glance to consist principally of closely packed parallel crystals of microcline $1 / 2-1$ inch long and coarse flakes of muscovite. The feldspar crystals lie in a matrix that ranges from little-altered biotite gneiss through partly reconstituted gneiss to fine- or medium-grained granitoid rock. The composition of the hybrid rock varies with the content of gneiss, but most of it has the composition of quartz monzonite (see accompanying table and fig. 127.3). The hybrid facies typically contains abundant inclusions of gneiss in addition to the films and fine laminae between the feldspar crystals. Irregular biotite- and sillimanite-rich clots sheathed in coarse muscovite are especially characteristic. The hybrid facies is largely confined to the border zone of the batholith, where it forms long streaks ranging from a few inches to hundreds of feet in width. It characteristically lies between gneiss on one side and some other facies of the St. Kevin Granite on the other although it occurs also as streaks within other facies. Many bodies of gneiss within the batholith have selvages of the trachytoid hybrid granite, which clearly is a reaction product. In such bodies, the foliation of the hybrid granite generally parallels that of the gneiss, but it parallels the contacts wherever they transect the foliation of the gneiss.

The normal facies of the St. Kevin is a light-gray to light-pink even-grained to markedly porphyritic biotite-muscovite granite or quartz monzonite (see table and fig. 127.3). The microcline in it is generally in prismatic or tabular subhedral crystals, even in the nonporphyritic facies; in many places, but especially near contacts and in small bodies, these crystals are oriented in trachytoid texture. In many places the normal facies has border zones a few feet to half a mile wide characterized by abundant thin mica-rich wisps and streaks, many of which are clearly remnants of earlier gneiss. Elsewhere, the granite appears compositionally uniform and uncontaminated, but the widespread occurrence of accessory sillimanite, and locally, of garnet and packets of metamorphic(?) biotite, suggests a derivation in part at least from older rocks. Nowhere has the granite been found to contain 
Chemical analyses, norms, and modes of St. Kevin Granite from Holy Cross quadrangle, Colorado

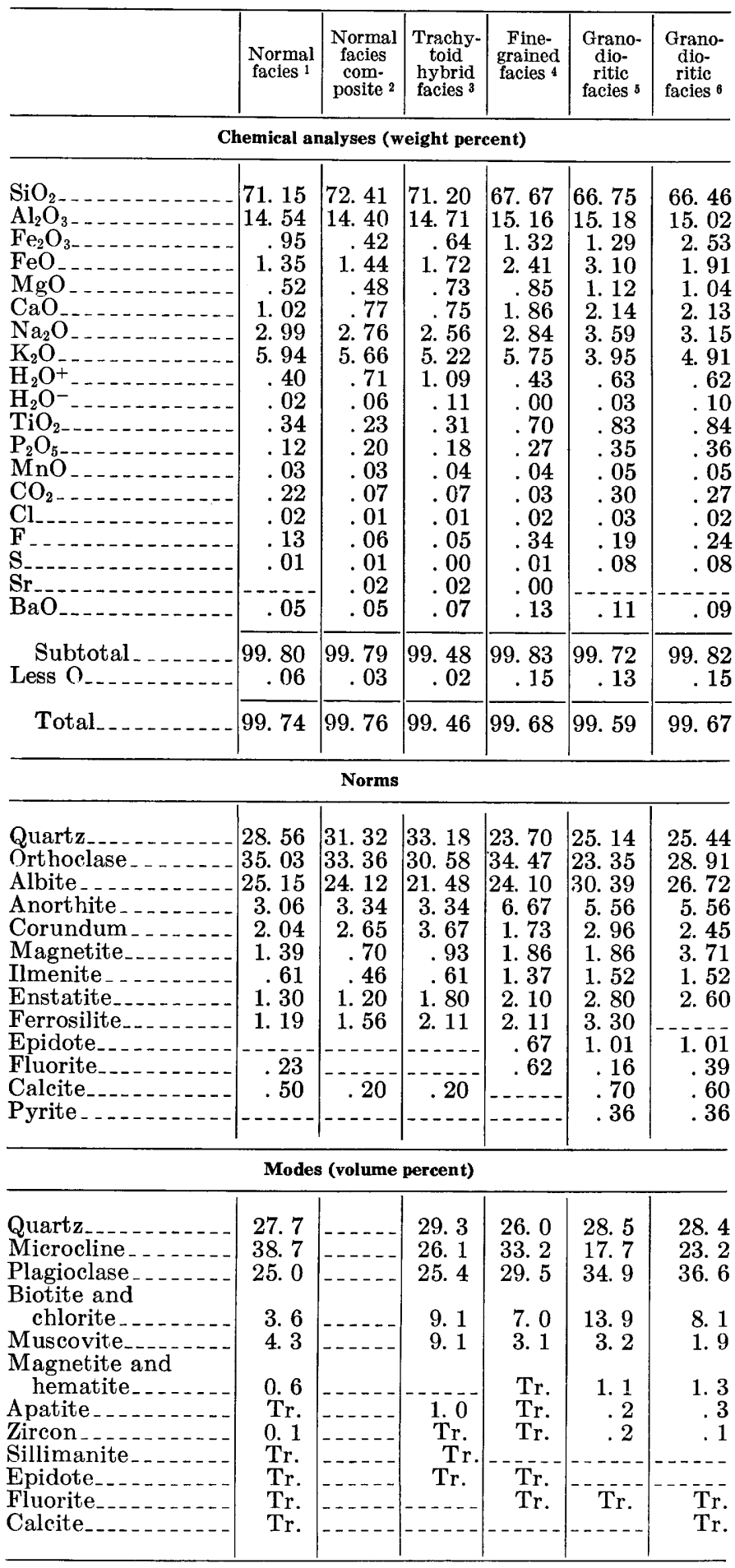

1 From dump at west portal Hagerman tunnel, southwest corner of quadrangle. Analyst, V. C. Smith (Field No 48T57, analytical lahoratory No. D1773.) 2 Composite sample from head of Longs Gulch. Analyst, M. Seerveld. (Field No. 69T55, analytical laboratory No. D1417.

3 From 0.65 miles southwest of Deckers Lake. Analyst, M. Seerveld. (Field No. 72T55, analytical laboratory No. D1410.)

a From west side St Kevin Lake. Analyst, M Seerveld. (Field No 149T56, analytical laboratory $N 0.01418$ )

5 From elevation 10,500 feet on old Colorado Midand Railroad grade on east side of Busk Creek. Analyst, Paula Montalto, (Field No, 25T57, analytical laboratory No. E-2208.)

${ }_{6}$ From prospect pit at elevation 11,625 feet on east face of Bald Eagle Mountain. Analyst, Paula Montalto. (Field No. 30T57, analytical laboratory No. E-2209.)
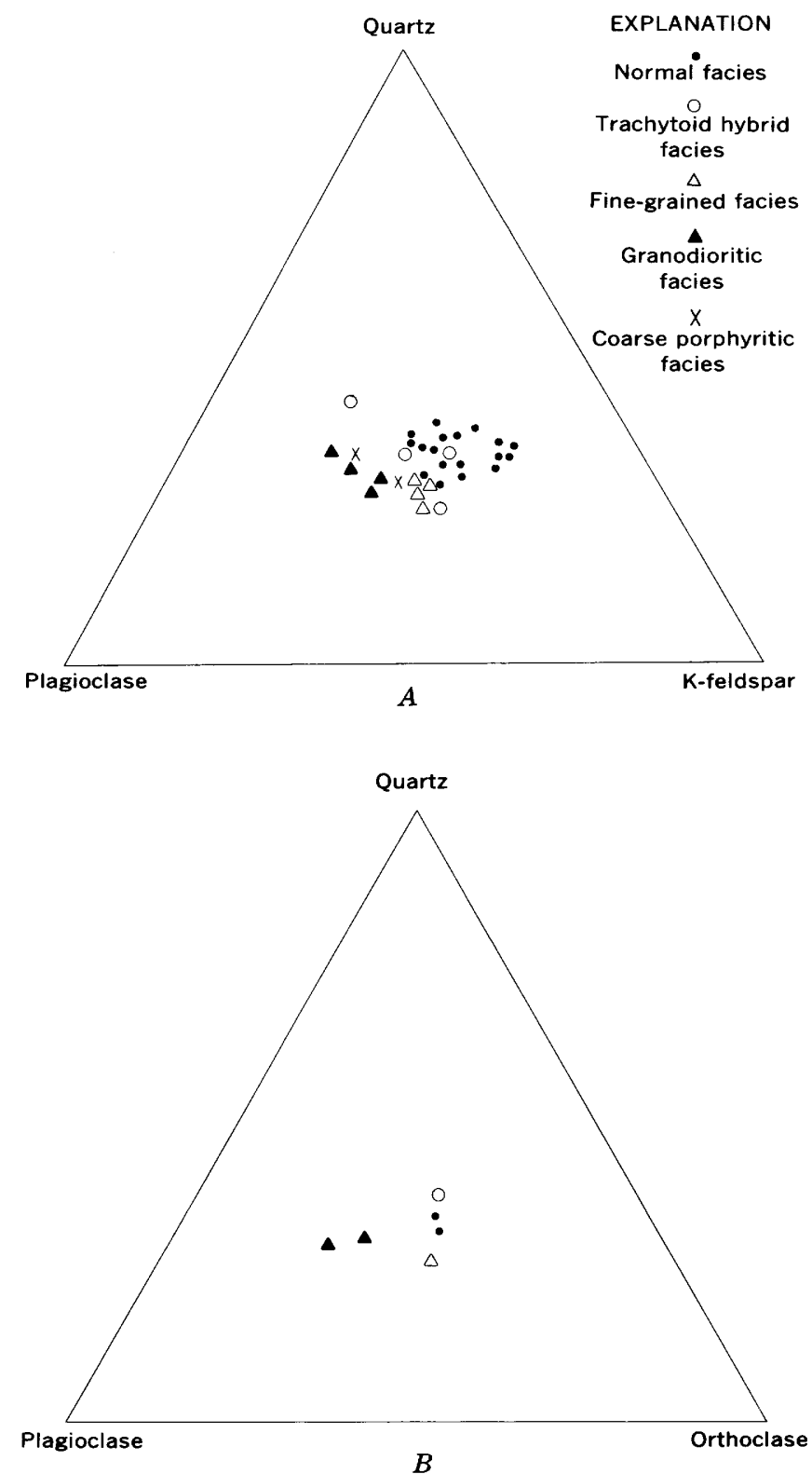

Figure 127.3.- $A$, Plot of modal quartz, $\mathrm{K}$ feldspar, and plagioclase in St. Kevin Granite. $B$, Plot of normative quartz, orthoclase, and plagioclase in St. Kevin Granite.

monazite, a characteristic accessory mineral of the Silver Plume Granite in the Front Range. The normal facies is the principal rock of the batholith; it occurs at the borders as well as in the interior of the batholith, and also as the sole facies in many isolated bodies of granite.

The granodioritic facies is darker than any of the other facies and is porphyritic to seriate porphyritic, fine to medium grained, and weakly foliated. Compositionally it is on the borderline between granodiorite and quartz monzonite (see table and fig. 127.3). It is characterized by sparsely and irregularly scattered white to buff rounded feldspar grains that give it a 
spotted appearance. The granodioritic facies is confined largely to the interior of the batholith, where it forms vaguely to sharply defined streaks a few tens of feet to several hundreds of feet wide in granite of the normal facies.

The fine-grained facies is a gray, buff-weathering; fine-grained, equigranular, massive to weakly foliated biotite-muscovite quartz monzonite (see table and fig. 127.3). Except for scattered large flakes or clusters of muscovite that weather in relief, the rock is homogeneous. It is restricted to the border zones of the batholith, where it forms sharply defined bodies as much as 2 miles long and 1 mile wide.

The coarse porphyritic facies of the St. Kevin Granite is biotite-muscovite granite or quartz monzonite characterized by abundant blocky microcline phenocrysts about 1 inch long. The groundmass is almost identical to nonporphyritic granite of the normal facies, but the large and thick microcline phenocrysts give the rock an appearance different from that of any of the other facies of St. Kevin Granite. Relicts of gneiss are locally abundant in the rock. The coarse porphyritic facies seems to be restricted to the western and southern sides of the batholith, but it is not nearly so widespread as the map of Stark and Barnes $(1935, \mathrm{pl} .1)$ showed the Hell Gate Porphyry to be.

Contact relations and gradations between the various facies of the St. Kevin Granite suggest that all the facies are of the same general age. In places, granite of the normal facies clearly cuts the trachytoid hybrid facies, but as the hybrid facies is almost certainly a reaction front generated by magma of the normal facies, there can be little difference in age at any one place. Although some contacts between the normal and the granodioritic facies are sharp and show a sequence of intrusion, the time relations are inconsistent from body to body, or even from outcrop to outcrop; moreover, the two rocks intergrade imperceptibly in many places, and they evidently crystallized simultaneously. Similar almost imperceptible gradation between the normal and the coarse porphyritic facies is displayed conspicuously along the west side of the batholith, where the two facies alternate many times in a distance of a few hundred feet, and where no clear contacts exist. Only the fine-grained facies shows in part a definite and consistent age relation to the other facies; in places it cuts both the trachytoid hybrid and the normal facies and contains inclusions of these rocks. In other places, however, the fine-grained facies seems to grade both into normal and granodioritic facies, and we therefore consider it to be of the same general age as the other facies.

The St. Kevin Granite evidently was in part generated in place and in part crystallized from a mobile melt that was a magma in every sense of the word. Metasomatism or granitization in place is shown by the reaction selvages of trachytoid hybrid granite, and by the faithful preservation of folds and other structural features of the gneissic wall rocks in granite half a mile or more from the edge of the batholith. On the other hand, evidence of intrusion is compelling. Many dikes and sills as well as parts of the border of the main batholith have sharp contacts that show no sign of granitization; foliation in the granite faithfully follows the contacts wherever they crosscut the gneiss; inclusions of unaltered wallrocks that can be traced with certainty to a nearby source lie within the granite; metasomatic rocks identified by their ghost gneissic structure are disrupted by local zones of flow, some of which extend as dikes into the wallrock gneisses; and the long, straight or arcuate, diffuse contacts between different varieties of rocks in the interior of the batholith suggest boundaries between streams of magma rather than any structure inherited from pre-existing metamorphic rocks.

We conclude that (1) from the widespread evidence of liquid movement, most of the St. Kevin batholith was intruded as magma at the crustal level now exposed; (2) from the widespread evidence of metasomatism, an additional substantial fraction of the St. Kevin Granite was generated at the level now exposed; (3) from the evidence of local mobilization of metasomatic rock, and from the intricate, generally concordant, form of the batholith borders, the wallrocks were at practically the same temperature as the invading granite and in a relatively plastic state; (4) from the occurrence of probable relict metamorphic minerals such as sillimanite and garnet in the intrusive part of the batholith, the batholithic magma was generated by melting of gneisses similar to those which it intrudes; and (5), from conclusions 2,3 , and 4 , the intrusive magma may have been generated at a crustal level little deeper than the one now exposed.

Thus we believe we see the St. Kevin batholith at about the top of its root zone, or the zone of transition from one of magma generation by crustal melting below to one of intrusion above. If this is so, and the batholith is a product of local melting, the granite is a unit genetically distinct from the Silver Plume Granite and its cognates in the Front Range, even though it is probably of the same general age. 


\section{REFERENCES}

Behre, C. H., Jr., 1953, Geology and ore deposits of the west slope of the Mosquito Range: U.S. Geol. Survey Prof. Paper 235.

Stark, J. T., 1935, Migmatites of the Sawatch Range, Colorado: Jour. Geology, v. 43, p. 1-26.
Stark, J. T., and Barnes, F. F., 1932, The structure of the Sawatch Range: Am. Jour. Sci., 5th ser., v. 24, p. 471-480. 1935, Geology of the Sawatch Range, Colorado: Colorado Sci. Soc. Proc., v. 13, p. 467-504. 
Article 128

\title{
REINTERPRETATION OF THE LATE GROWTH OF THE GYPSUM VALLEY SALT ANTICLINE, SAN MIGUEL COUNTY, COLORADO
}

\author{
By FRED W. CATER, Denver, Colo.
}

\begin{abstract}
Reinvestigation of outcrops in the southeast end of the anticline indicates that the relation of Cretaceous beds to Paleozoic rocks is explained best by faulting and landsliding rather than by sedimentary pinchouts and thinning as proposed previously.
\end{abstract}

Reexamination of the Gypsum Valley area, San Miguel County, Colo., (fig. 128.1) has suggested changes in an earlier stratigraphic and structural interpretation of the area by the author. In an earlier report (Cater, 1955), the author stated that although upthrusting of salt into the core of the salt anticline underlying the valley seemed generally to have ceased by the beginning of Morrison (Late Jurassic) time, inconclusive field relations in the southeast end of the valley indicated that Paradox beds (Pennsylvanian) had intruded rocks as high as the Mancos Shale (Late Cretaceous). Earlier, Stokes and Phoenix (1948) reached virtually the same conclusion. Landis and others (1961) stated, however, that: "The overall distribution of the Mancos and Mesaverde relative to the salt structures appears to be best explained by a pinchout of pre-Mancos Cretaceous rocks and a thinning of the Mancos on the salt structures." Inasmuch

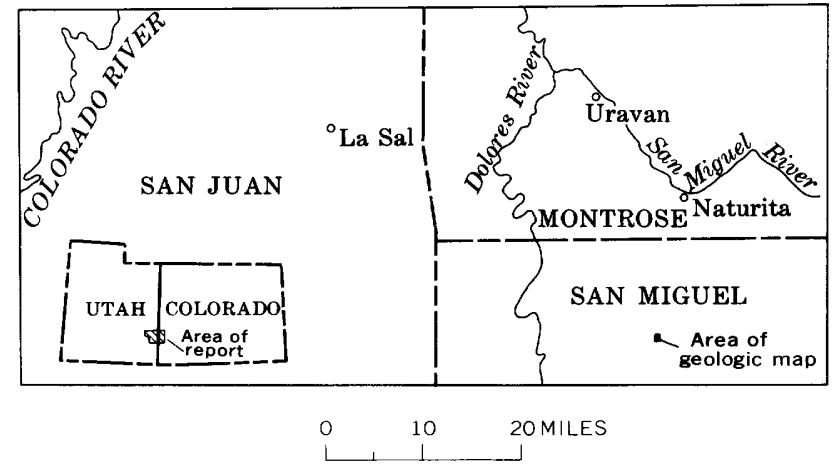

Figure 128.1.-Index map showing location of area described in this article. as this interpretation differs radically from that of the earlier writers and because the scientific and economic implications of a correct explanation of the observable geologic relations are of considerable importance, the author reexamined part of the area. This reexamination indicates that neither of the preceding explanations is entirely consistent with the mappable relations. It now seems that Stokes, Phoenix, and the author were wrong in postulating possible late intrusion of Paradox beds into the Mancos, and that Landis and others were wrong in explaining the relations as a thinning and pinchout of Cretaceous rocks on salt structures. Mancos that rests on Paradox is explained best by landsliding, whereas the pinchout proposed by Landis and others is explained best by faulting, as indicated in an earlier paper (Cater, 1955).

The differences between the interpretation presented herein and that of Landis and others (1961) arise from the identification of formations at some outcrops and from evaluation of evidence of faulting and landsliding. These differences are shown in figure 128.2. The map in figure $128.2 \mathrm{~A}$ is reproduced from part of figure 197.2 of Landis and others (1961); that in figure $128.2 B$ is of the same area, showing this author's revisions. The differences, though minor, are critical. The geologic section in figure $128.2 \mathrm{~A}$ is reproduced from part of their figure 197.3 , and that in figure $128.2 B$ is the author's revision of the same geologic section.

In a gully in the southeast corner of the area (fig. $128.2 A$ ) the Salt Wash Member of the Morrison Formation is shown by Landis and others as a thin sliver adjacent to a fault between the 7,180-foot and the 7,240-foot contours, whereas according to the author's interpretation (fig. 128.2B) the Salt Wash is relatively flat lying and much more extensive and does not extend as far northwest down the gully. To the northwest, Landis and others have mapped outcrops in three localities as Burro Canyon(?); the author interprets them differently. At locality A (fig. 128.2B), in 

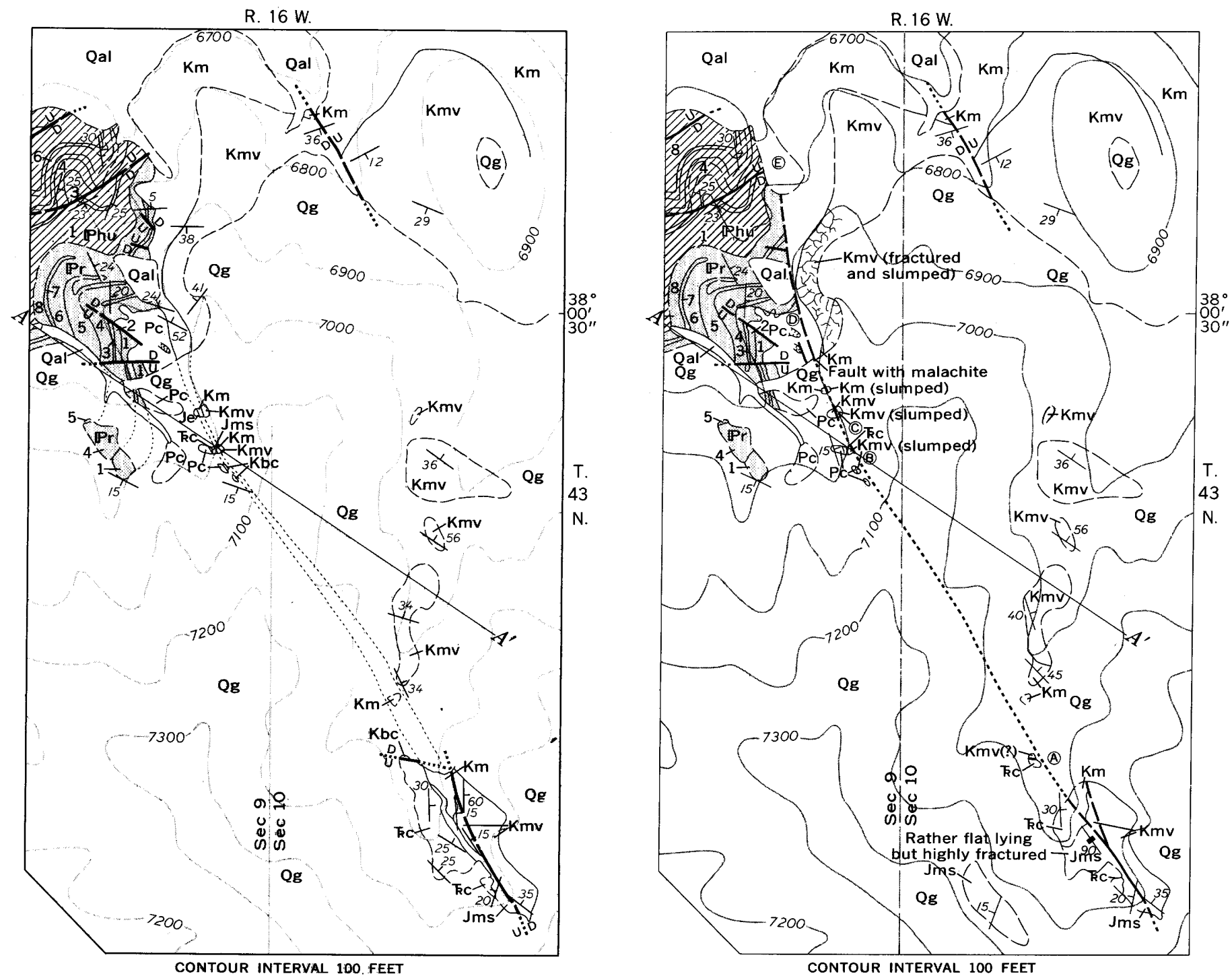

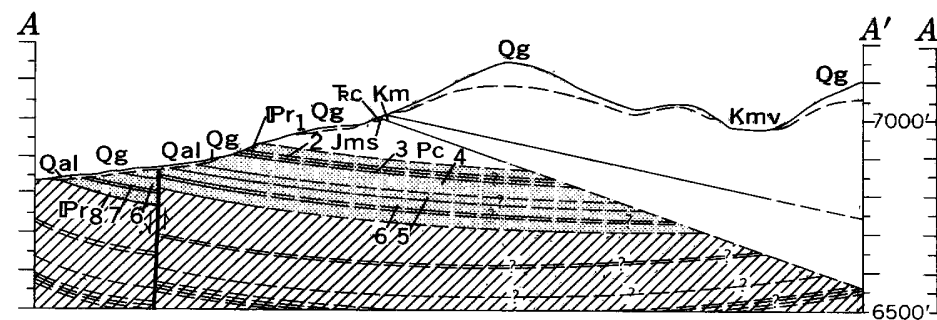

$A$

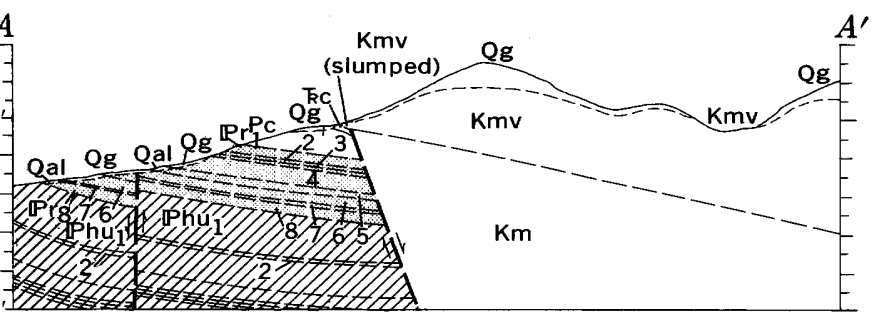

$B$

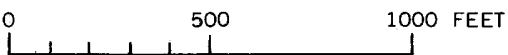

Frgure 128.2.-Geologic maps and sections of part of southeastern Gypsum Valley, San Miguel County, Colo. A, mapping and interpretation by Landis and others (1961, parts of figs. 197.2, 197.3); $B$, mapping and interpretation by the author. Circled letters in $B$ are localities discussed in text. Numbers in sections refer to subdivisions of the Rico Formation and the upper member of the Hermosa Formation shown by Landis and others (1961, fig. 197.4). 


\section{EXPLANATION}
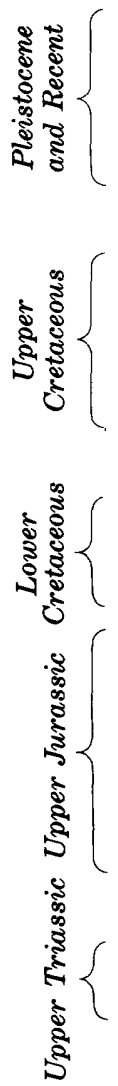
Shown only on Map A

$$
\text { Jms }
$$

Salt Wash Sandstone Member of Morrison Formation

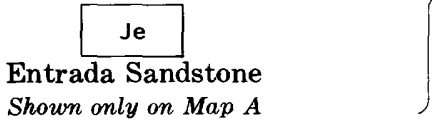

UNCONFORMITY

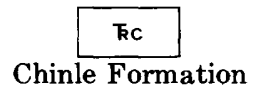

UNCONFORMITY

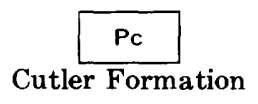

UNCONFORMITY

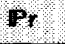

Rico Formation
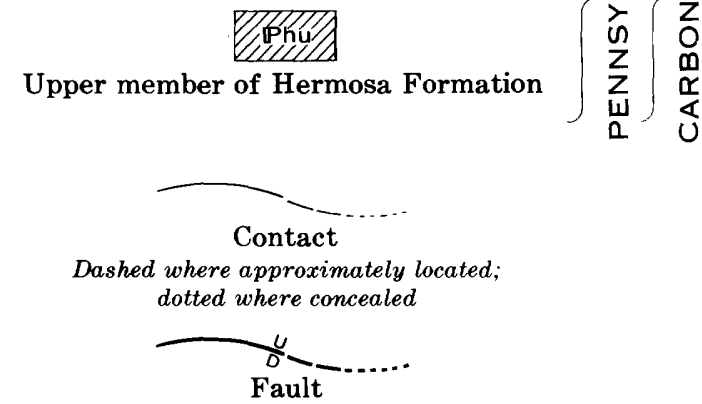

Dashed where approximately located; dotted where concealed. U, upthrown side; D, downthrown side

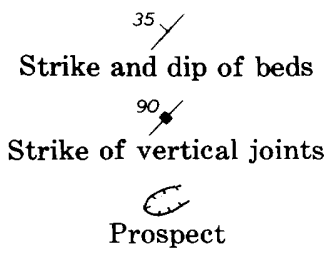

FIG URE 128.2.-Continued the gully at 7,060 feet altitude, an outcrop only 3 feet wide and 5 feet long is shown by them on figure $128.2 \mathrm{~A}$ as Burro Canyon(?) Formation. It is fine-grained buff sandstone, and although it is conceivable that a bed of similar material thick enough to have produced a block of this size could be found in the Burro Canyon, the author has never seen one in the course of several field seasons of mapping in the region Furthermore, the outcrop possesses none of the diagnostic features characteristic of the Burro Canyon. It is, on the contrary, almost identical with sandstones of the Mesaverde Formation on the east side of the gully and apparently is a slice of that formation caught in a fault subsidiary to the main fault zone of the area. About 1,200 feet north-northwest of this outcrop, at an altitude of 7,050 feet (locality B, fig. 128.2B), the outcrop called Burro Canyon(?) by Landis and others resembles conglomerates of that formation, but on close examination the rock is seen to be a conglomeratic arkose. As the Burro Canyon is nonarkosic, this outcrop is interpreted by the author as Permian Cutler Formation. Less than a hundred feet northwest of this outcrop is another, also shown by Landis and others as Burro Canyon(?). This second outcrop at locality B is fine-grained sandstone identical with the Mesaverde concealed beneath gravel deposits uphill to the east and is almost certainly a slumped block of Mesaverde resting on the Cutler. The actual contact with the Cutler is not visible. In summary, the Burro Canyon does not crop out in the area; thus it cannot be used as evidence in an argument favoring deposition of Cretaceous rocks on formations older than the Morrison.

Other questionable identifications in this area are strata shown as Salt Wash on the 7,000-foot contour, where it crosses section $A-A^{\prime}$ (fig. 128.2A), and almost certainly the rock shown as Entrada Sandstone about 200 feet to the north at an altitude of 6,990 feet (locally C, fig. 128.2B). The rock shown as Salt Wash is Mesaverde. That shown as Entrada resembles the Entrada superficially but differs from it in that it contains subangular pebbles of clear quartz $1 / 8$ inch in diameter, it is less well sorted, and, although it contains large round frosted grains of quartz, the grains are scattered haphazardly through the rock rather than deposited in distinct layers. In all probability this rock also is Mesaverde, for there is similar material uphill in nearby outerops of Mesaverde. At the northwest corner of the area, between the 6,700-foot and 6,800-foot contours (locality E), Mancos is mapped as resting on Rico where, in fact, there are no exposures. There is little doubt, however, that beneath the soil cover and overburden, Mancos does rest on Rico, but it is a mass of Mancos that has slumped downhill. 
A few feet north of the pit that Landis and others show at an altitude of 6,690 feet on the map (locality $D$ ) is a second pit that they do not show; this pit exposes a contact of Mancos and Cutler. Bedding in the Mancos is not badly disturbed and is roughly parallel to the surface of the underlying Cutler to within about 15 inches of the contact. Bedding in this lower part, however, is completely destroyed; fragments are slickensided and crushed, and the basal 4 to 6 inches contains stretched out lentils of pulverized Cutler as much as an inch thick and a foot longsuggesting a fault on the base of a landslide. All other isolated masses of Cretaceous rocks that rest on older rocks mentioned in the foregoing paragraphs are almost certainly masses of similar material that have moved downhill. In fact, were this an area where Cretaceous rocks wedged out against Paleozoic rocks, it would be reasonable to expect to find at least a few outcrops of Mesaverde to the west of the gully that generally follows the west edge of the Cretaceous rocks in the northwest part of the mapped area; however, none are found there. Furthermore, the Mesaverde on the east side of this gully is fractured and broken into jumbled but still juxtaposed blocks, a fact hinted at by Landis and others on their map (fig. 128.2A), which shows a strike-and-dip symbol east of the gully near the lower contact of the Mesaverde at 6,910 feet. This symbol shows beds striking east and dipping $38^{\circ} \mathrm{S}$., an attitude unrelated to the mapped contact immediately below. The jumbled nature of the Mesaverde results from slumping of the underlying Mancos, a formation unsurpassed in the region for its ability to form landslides, some of them of enormous size.

Although the trace of the fault that separates Cretaceous rocks from older rocks is covered by Mancos and Mesaverde rocks and by gravel of Quaternary age, north of where Landis and others mapped the fault in the southeast corner of the area of figure 128.2, fairly direct evidence for its north-northwestward continuation shows in the face of the previously mentioned pit at 6,960 feet (locality D). In the face of this pit is a north-northwesterly trending fault which is not shown on their map. Although this fault is in the Cutler Formation, it is parallel to and only a few feet from the edge of the Cretaceous rocks and is probably subsidiary to a much larger fault. Considerable quantities of copper minerals (malachite) have been deposited in and adjacent to this fault, and it is perhaps significant that other similar copper occurrences in the area are closely associated with large faults (Vogel, 1960).

To the southeast, beyond the area shown in figure 128.2 , the fault swings to the southeast and for 6 miles forms the southwest margin of the synclinal graben occupying the collapsed crest of the Gypsum Valley anticline. Vogel (1960) shows the throw on this fault to exceed 3,500 feet immediately southeast of the mapped area. It seems unlikely that a fault of this magnitude could die out completely along the strike in a distance that is less than the throw.

At a number of localities shown by Landis and others (1961, fig. 197.2), but not shown on figure $128.1 \mathrm{~A}$ of this article, Mancos rests directly on Paradox beds. Landis and others consider the contact to be sedimentary, whereas Stokes and Phoenix (1948) and Cater (1955) believed that the salt was intruded into the Mancos. It is doubtful whether either of these explanations is valid. With collapse and erosion of the crestal rocks in the anticline, conditions became ideal for landsliding of the Mancos from the partly surrounding uncollapsed masses of Mancos and Mesaverde that formed relative highlands. It seems most likely that these masses of Mancos that now rest on the Paradox are but the partly eroded remnants of former landslide blocks. In this connection it is interesting to note that Vogel (1960) described a butte in Disappointment Valley, a few miles south of this area, that is capped by a landslide consisting of the upper part of the Mancos and the Mesaverde; this slide rests on Mancos that belongs stratigraphically 1,300 feet below the top of the formation. The slide is several miles from the nearest outcrops of the Mesaverde.

A more spectacular structural history than that shown by the evidence is implied if the thesis of Landis and others is accepted. For the Mancos to wedge out against Rico and Cutler beds would require a spire of the Rico and Cutler less than a mile across to rise more than 4,000 feet above the base of the surrounding Salt Wash during Mancos time. Field observation does not support this supposition; in fact, one of the reasons why the history of development of the salt anticlines is so well preserved in the southeast end of Gypsum Valley is that the rise of salt was less pronounced in this area. Upper Paleozoic beds are preserved as are pre-Morrison Mesozoic formations, and the unconformities between these formations preserve the record of anticlinal growth. In other places the salt rose more vigorously; overlying beds were turned up sharply and removed from the crest of the salt cores, and pinchouts of preMorrison beds are abrupt and mostly buried under younger rocks in the flanks of the anticlines. Yet here in the very area where the rise of salt had been relatively slow during growth of the salt cores, the interpretation of Landis and others requires that a spire of Rico and Cutler beds be thrust upward several thousand feet, tens of millions of years after substantial flowage of salt had ceased (at the beginning of Morrison time). Then, by their interpretation, this same spire would have had to subside to a position lower than the one it 
originally occupied, and all without appreciable faulting.

\section{REFERENCES}

Cater, F. W., Jr., 1955, Geology of the Gypsum Gap quadrangle Colorado: U.S. Geol. Survey Geol. Quad. Map GQ-59.

Landis, E. R., Shoemaker, E. M., and Elston, D. P., 1961, Early and late growth of the Gypsum Valley salt anticline, San
Miguel County, Colorado: Art. 197 in U.S. Geol. Survey Prof. Paper 424-C, p. C131-C136.

Stokes, W. L., and Phoenix, D. A., 1948, Geology of the EgnarGypsum Valley area, San Miguel and Montrose Counties, Colorado: U.S. Geol. Survey Oil and Gas Inv. Prelim. Map 93.

Vogel, J. D., 1960, Geology. and ore deposits of the Klondike Ridge area, Colorado: U.S. Geol. Survey open-file report, $205 \mathrm{p}$. 


\title{
Article 129
}

\section{A PLEISTOCENE SECTION AT LEONARDS CUT, BURKE COUNTY, NORTH CAROLINA}

\author{
By JOHN C. REED, JR., BRUCE BRYANT, ESTELLA B. LEOPOLD, and LOUISE WEILER, \\ Denver, Colo.
}

\begin{abstract}
An exposure of peat described by Kerr in 1875 at Leonards Cut probably accumulated on a former flood plain of the Catawba River well below the Piedmont Upland surface. Pollen assemblages and field relations show that the deposit is nonglacial and probably represents an interglacial episode of Pleistocene age. The Piedmont Upland surface in the area may therefore be pre-Pleistocene.
\end{abstract}

Organic remains in surficial deposits are very unusual in the Piedmont Province in North Carolina. We were therefore surprised and interested when R. A. Laurence of the U.S. Geological Survey (written communication, 1961) called attention to the following description of Leonards Cut by Kerr (1875, p. 157):

The railroad cuts through the piedmont region, especially from Morganton to the foot of the Blue Ridge furnish many admirable sections of hill side drift. The most interesting is 9 miles beyond Morganton, known as Leonards cut. On the upper slope of a high hill a cut of 80 feet exposes a bed of peat and drift wood 15 feet thick with the underlying soil filled with stumps and roots. Above the peat is a bed of rudely stratified gravel and sand, 10 to 15 feet deep, on which grows the present forest. In the peat are numerous shining wing-covers of beetles and seeds of many species of plants, cones of several kinds of pine, and of hemlock, squirrel-gnawed hickory nuts, seed pods of kalmia, etc. No species have been observed which are not found at present living in the region ... .

With the aid of Mrs. M. R. McVey of the MorgantonBurke County Public Library in Morganton, we located Leonards Cut 2.45 miles west of the Glen Alpine railroad station along the Southern Railroad (figs. 129.1 and 129.2).

Leonards Cut is in the southwestern part of the Morganton basin, a northwestern extension of the Piedmont physiographic province enclosed by the Blue Ridge on the northwest, the Hickorynut Mountains on the southwest (outside the area shown on fig. 129.1),

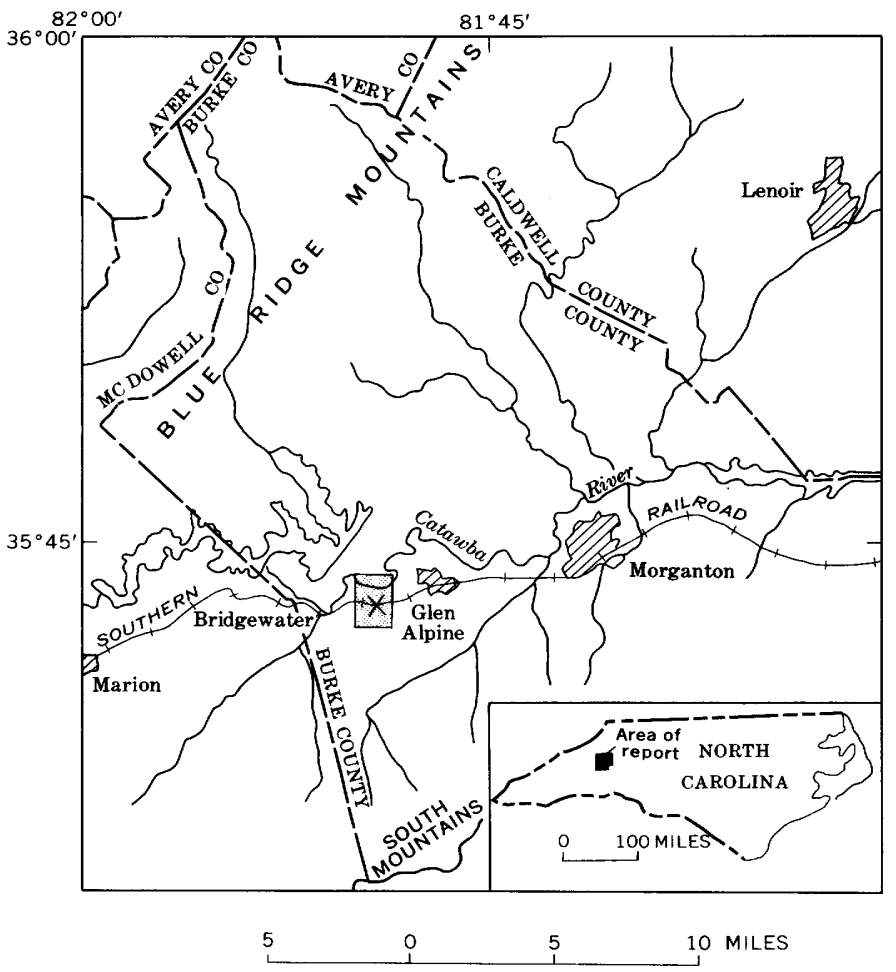

FIGURE 129.1.-Map of part of western North Carolina, showing location of Leonards Cut $(X)$. The outlined area surrounding Leonards Cut is shown on figure 129.2.

the South Mountains on the southeast, and the Brushy Mountains on the northeast (outside the area shown on fig. 129.1). The basin is drained by the Catawba River and its tributaries, which have excavated steepsided flat-bottomed valleys 100 to 300 feet deep separated by flat even-crested interfluves. Farther east the interfluves are less dissected and form the flat surface of the Piedmont Upland. 


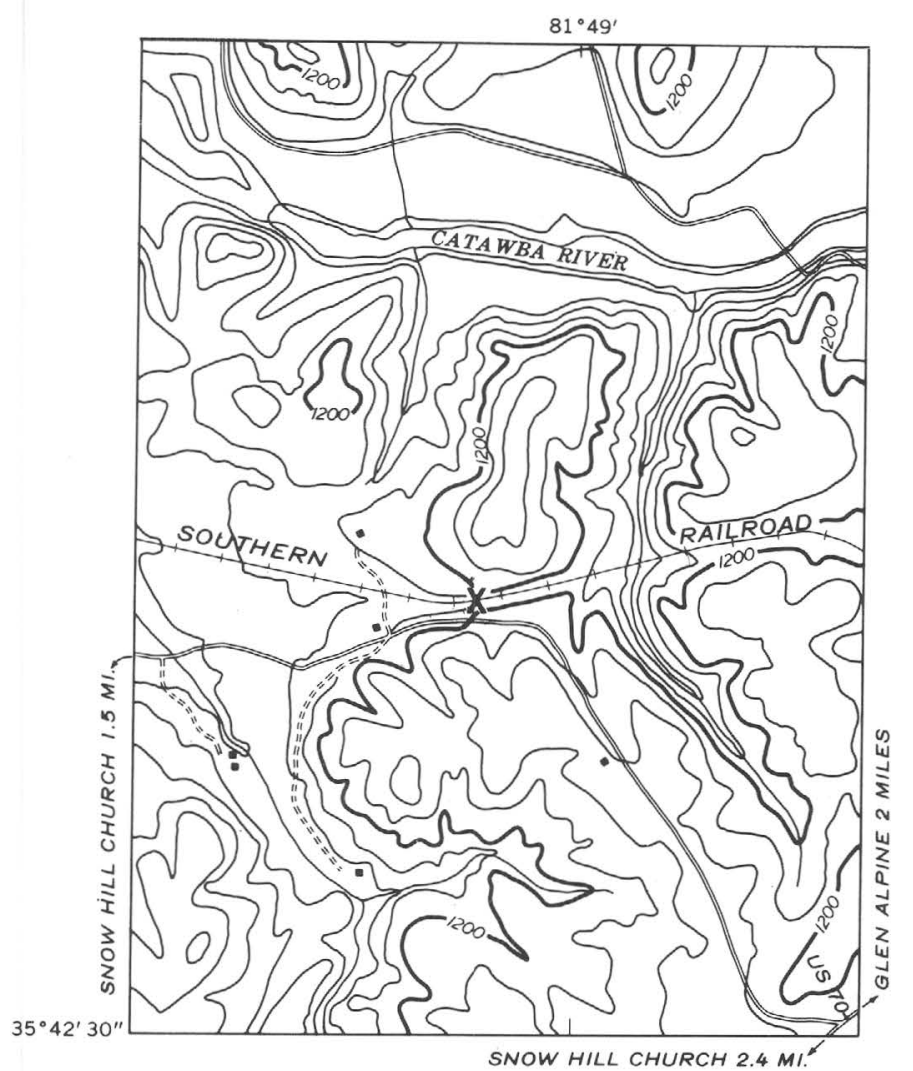

$\underbrace{1000}_{\text {CONTOUR INTERVAL }} \stackrel{1}{11}^{3000}$ FEET

FIGURE 129.2.-Topographic map of the area surrounding Leonards Cut $(X)$.

Near Leonards Cut the interfluve surfaces are at altitudes of about 1,300 feet; the surface of the Catawba River, 0.6 mile north of Leonards Cut, is at an altitude of about 1,040 feet.

Since Kerr made his visit the cut has slumped and become much overgrown with honeysuckle, but a small gully (fig. 129.3) south of the tracks exposes a fairly complete section of surficial material, including Kerr's peat bed (table 129.1, fig. 129.4).

The peat bed does not extend more than 50 feet east of the erosion gully, and it is absent on the north side of the tracks opposite the exposure in the gully. It may extend several hundred feet farther west.

The deepest part of the cut, several hundred feet east of the gully, exposes only 10 to 15 feet of red colluvial clay overlying 30 to 40 feet of saprolitized mica schist and gneiss. In the north side of the cut, less than 40 feet north of the gully, yellow-gray alluvial silt and clay rest directly on saprolitized bedrock.

The uppermost surficial deposits are exposed in cuts along the north side of a dirt road parallel to and about 200 feet south of the railroad (fig. 129.2). This material is rudely sorted angular gravel and coarse brown sand

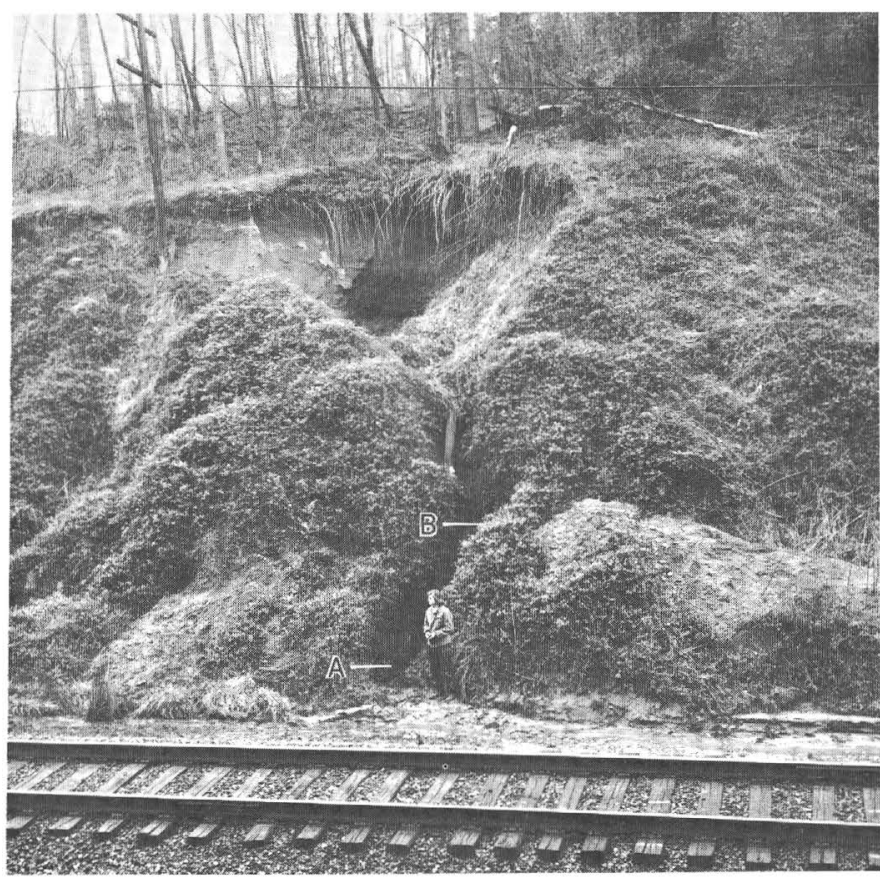

Figure 129.3-Gully on south side of Leonards Cut in which peat and overlying unconsolidated deposits are exposed U.S. Geological Survey paleobotanical localities D1995A and D1995B indicated by $A$ and $B$, respectively.

containing saprolitized fragments of gneiss, schist, and pegmatite arranged in crude foreset beds that dip $30^{\circ}-40^{\circ} \mathrm{W}$. To the west it grades into finer grained material that overlies the red clay layer at the top of the measured section. The sand and gravel deposit is absent in cuts on the south side of the road and in the railroad cut to the north.

The peat probably accumulated in a shallow pond or swampy area at the edge of a former flood plain of the Catawba River. Similar swampy areas are common along modern streams in the area. The overlying stratified silt and clay is similar to material underlying the present flood plain of the Catawba. The red clay is typical of the residual and colluvial clay that mantles most slopes in the area. The rudely stratified sand and gravel probably filled a gully cut into the colluvial clay before the Catawba assumed its present course. The field relations of the gully-fill deposit indicate considerable modification of the topography since its deposition.

The deposits at Leonards Cut offer the only known clue to the minimum age of the Piedmont Upland surface in the Morganton basin. The organic material lies well below the level of the upland surface, but more than 120 feet above the present master drainage. A radiocarbon age of $2,270 \pm 200$ years for organic material near the base of the alluvial deposits on the present flood plain of Muddy Creek about 7 miles southwest of Leonards Cut (Suess, 1954) indicates that the master 


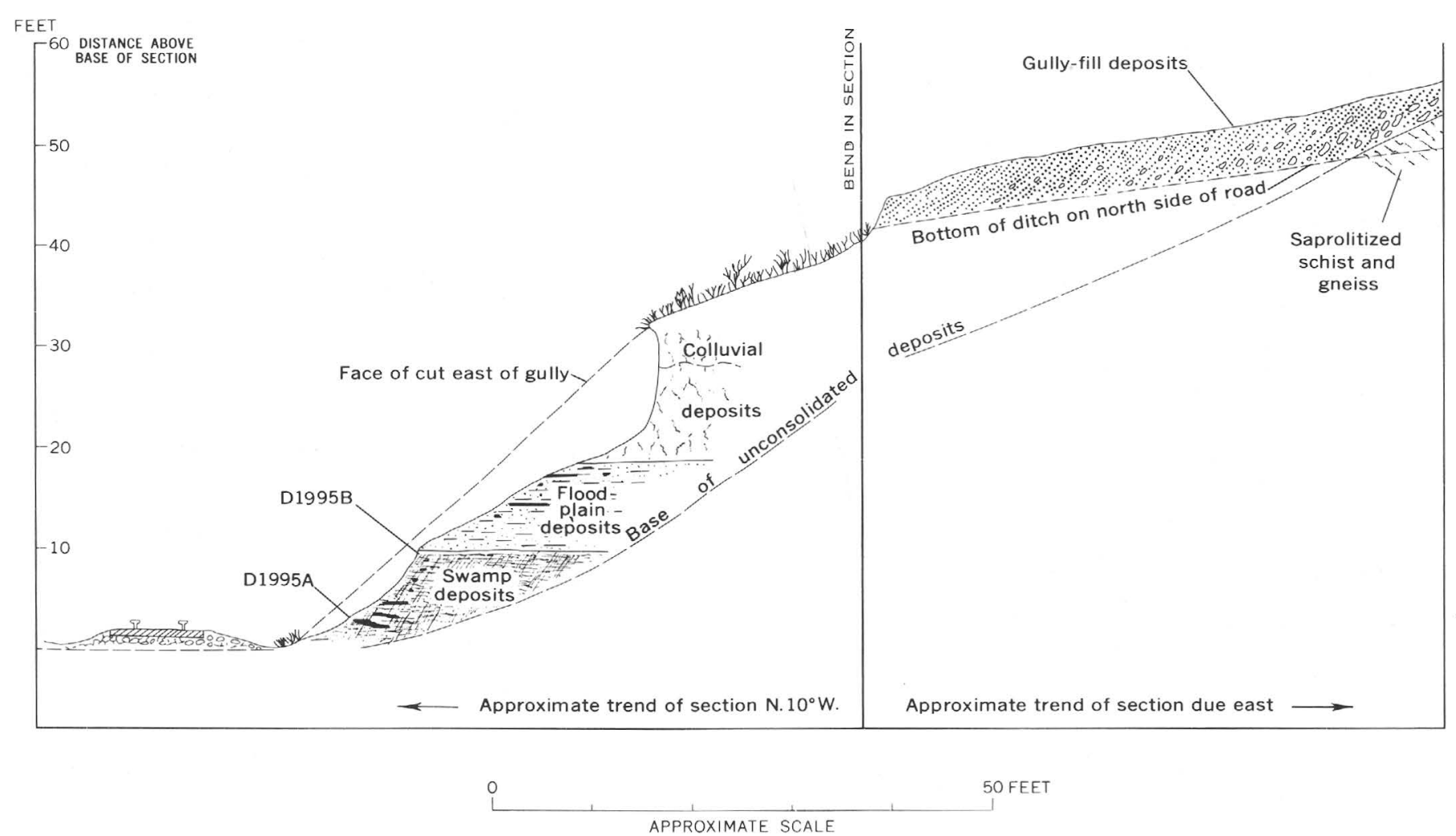

FIGURe 129.4.-Diagrammatic section of unconsolidated deposits exposed in gully on south side of Leonards Cut. D1995A and D1995B, locations of pollen samples described in table 129.2 .

TABLE 129.1. - Stratigraphic section of unconsolidated deposits exposed in a gully on the south side of Leonards Cut [Base of section 2 feet below level of top of railroad tracks; elevation about 1,160 feet]

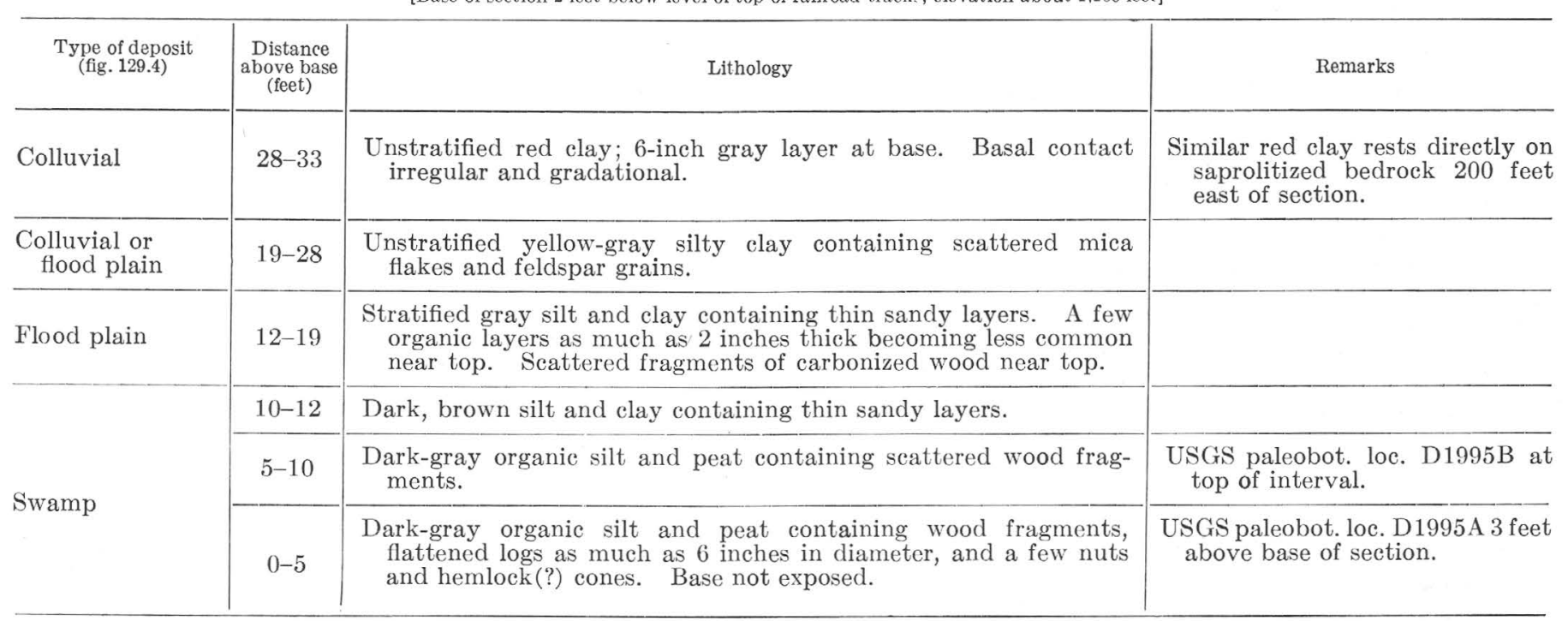


drainage has been at about the present level for at least that length of time.

Pollen and spores from samples of organic silt and peat from 3 feet (USGS paleobot. loc. D1995A) and 10 feet (USGS paleobot. loc. D1995B) above the base of the exposed section in Leonards Cut have been examined and the pollen assemblages compared with those from samples of organic muck from nearby modern bogs (table 129.2). All identified pollen and spores in the Leonards Cut fossil material are representative of plants that grow in the area today; no relict Tertiary genera and no northern elements were found. The main difference between the assemblages of fossil and modern pollen is that spruce and fir, which make up between 1 and 4 percent of the fossil material,

TA BLE 129.2-Pollen types identified in organic layer at Leonards Cut and in nearby muck deposits of Recent age (percent of total pollen)

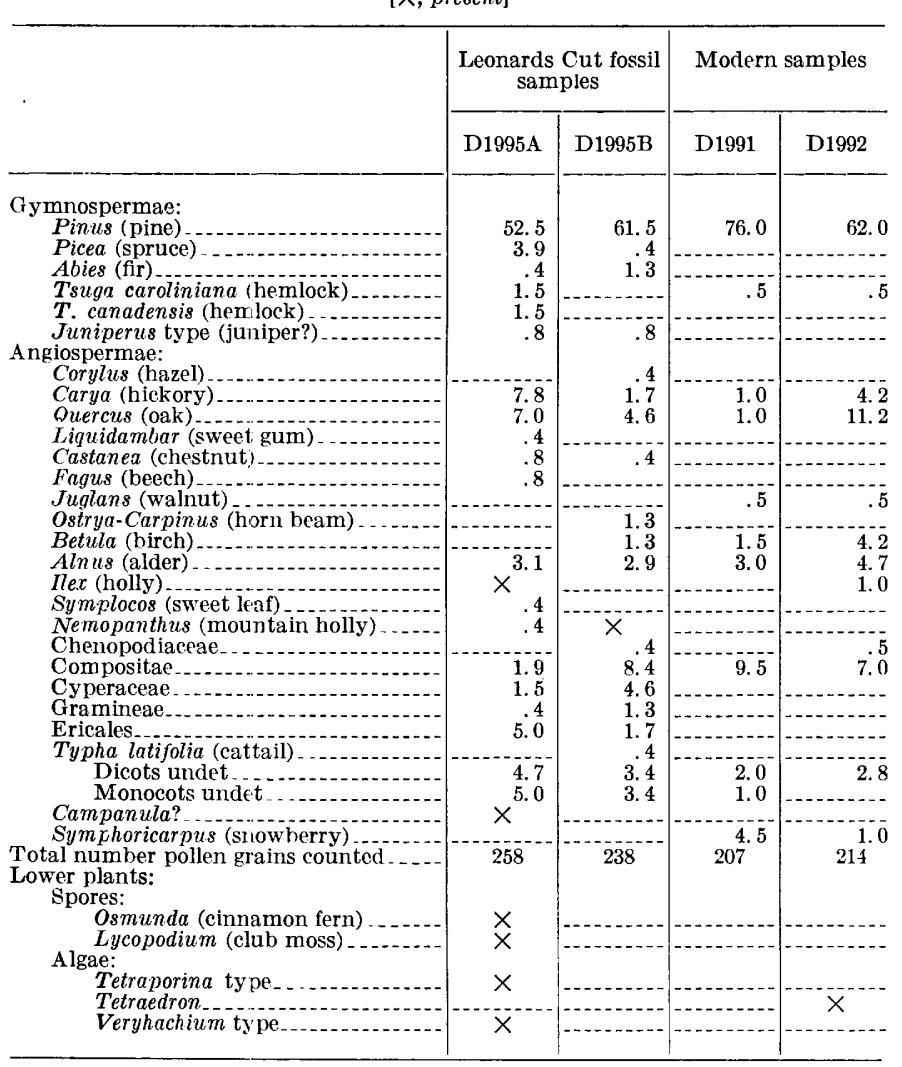

U.S. Geological Survey paleohotanical localities.

D1995A. Leonards Cut locality, Burke County, N.C. Peat 3 fect ahove hase of section exposed in gully on south side of railroad. Location indicated on figures 129.2 and 129.3 .

D1995B. Leonards Cut locality, Burke County, N.C. Peat 10 feet above hase of section exposed in gully on south side of railroad. Location indicated on figures 129.2 and 129.3 .

D1991. Organic muck from depression on flood plain of Catawha River immediately north of hridge at Bridgewater (fig. 129.1). 2.05 miles N. $85^{\circ} \mathrm{W}$. of

Leonards Cut (collected by C. T. Sumsion).
D1992. Organie muck from spring or seep on hillside about 200 feet south of Leonards Cut (collected by C. T. Sumsion). are absent in the modern material. Since these genera now grow at higher elevations 25 miles west of the fossil locality, this suggests that these gymnosperms were growing at least in small numbers closer to the Leonards Cut locality at the time of deposition than at the present time, but the climate was probably not much different than the present one.

Deposits similar to those at Leonards Cut are unusual in the Piedmont province, although logs associated with organic clays have been discovered in exhumed gully fills in Cleveland County, N.C., and Spartanburg County, S.C. (Whitehead and Barghoorn, 1962). The radiocarbon age of a log from near the base of one deposit north of Shelby in Cleveland County is greater than 30,000 years (Suess, 1954). A pollen profile from this locality (Whitehead and Barghoorn, 1962) records little change within the 4-foot section, and contains an assemblage very similar to that at Leonards Cut. However, it contains two elements not found at Leonards Cut: Ephedra (Mormon's tea), a western shrub now exotic to the eastern United States, and Arceuthobium (dwarf mistletoe) now occurring in the northeastern United States. This locality is about 40 miles from the nearest present day occurrence of spruce and fir; it is about 100 feet lower than Leonards Cut and is about 30 miles to the southeast.

Eargle (1940) has described deposits of organic material deeply buried by soil in Spartanburg County, S.C. The radiocarbon age of $\operatorname{logs}$ imbedded in two of these deposits is greater than 34,000 years (Rubin and Alexander, 1958) or greater than 35,000 years (Whitehead and Barghoorn, 1962). Cain (1944) studied pollen from four sections of these buried soils. Assemblages near the top of one of his sections closely resemble pollen rain one would expect at the localities today, but near the base of two of his sections the abundance of spruce and fir (as much as 25 percent of the total pollen) suggests a climate cooler than the present.

Whitehead and Barghoorn (1962) studied three other localities in Spartanburg County about 30 miles due south of Leonards Cut. They found relatively little change within two sections and a pronounced shift from hemlock to pine in the third. Although the nearest spruce and fir trees are now from 30 to 45 miles away, fossil spruce pollen comprises as much as 8 percent of the tree-pollen count, and fir pollen is present. Northern and montane elements recorded in all three sections (Whitehead, 1963) strengthen the interpretation that these localities record a climate somewhat cooler than now. 
Frey (1953) found that pollen from Singletary Lake near the coast of North Carolina indicates a climate consistently cooler than the present from more than 20,000 to about 10,000 years ago.

The absence of relict Tertiary genera in the Leonards Cut material is indicative of Quaternary age. Frey (1953) has shown that cool, glacial climates during the Pleistocene extended as far south as the coastal plain of North Carolina. The similarity between the fossil pollen assemblages from Leonards Cut and modern assemblages in the same area shows, however, that the deposit is not glacial. The present elevation of the deposit above the modern master stream suggests that it is not Recent; it is therefore believed to be of interglacial or interstadial Pleistocene age. The surface of the Piedmont Upland in the Morganton basin is older than the Leonards Cut deposit and may be pre-Pleistocene.

\section{REFERENCES}

Cain, S. A., 1944, Pollen analysis of some buried soils, Spartanburg County, South Carolina: Torrey Bot. Club Bull., v. 71, p. $11-22$.

Eargle, D. H., 1940, The relations of soils and surface in the South Carolina Piedmont: Science, v. 91, p. 337-338.

Frey, D. G., 1953, Regional aspects of the late-glacial and postglacial pollen succession of southeastern North Carolina: Ecol. Mon., v. 23, p. 289-313.

Kerr, W. C., 1875, Report of the Geological Survey of North Carolina, v. 1, Physical geography, resumé, economical geology: Raleigh, North Carolina, 325 p., map.

Rubin, Meyer, and Alexander, Corrine, 1958, U.S. Geological Survey radiocarbon dates IV: Science, v. 127, p. 1476-1487.

Suess, H. E., 1954, U.S. Geological Survey radiocarbon dates I: Science, v. 120 , p. $467-473$.

Whitehead, D. R., 1963, "Northern" elements in the Pleistocene flora of the Southeast: Ecology, v. 44, p. 403-406.

Whitehead, D. R., and Barghoorn, E. S., 1962, Pollen analytical investigations of Pleistocene deposits from western North Carolina: Ecol. Mon., v. 32, p. 347-369. 


\title{
SURFACE AND SUBSURFACE STRATIGRAPHIC SEQUENCE IN SOUTHEASTERN MISSISSIPPI
}

\author{
By D. HOYE EARGLE, Austin, Tex.
}

\author{
Work done on behalf of the Atomic Energy Commission
}

\begin{abstract}
The stratigraphic sequence in southeastern Mississippi includes outcropping units of Miocene to Recent age; many subsurface units of Tertiary, Cretaceous, and Jurassic age down to the Jurassic(?) salt; and possibly older sedimentary rocks that are underlain by the basement crystalline rocks. Two newly named units are described-the Tatum Limestone Member, a basal unit of the Catahoula Sandstone of Miocene and Oligocene(?) age; and the Andrew Formation of Early Cretaceous age.
\end{abstract}

A detailed knowledge of the stratigraphic section of southeastern Mississippi was required for use in geologic and geophysical studies of the Tatum salt dome, Lamar County, Miss., for the U.S. A tomic Energy Commission. The deepest well in the southeastern Mississippi region penetrated only a few feet of bedded salt believed to be the Louann; consequently, the rocks below the salt are not known. Because detonations at the site, however, are expected to give geophysical data on rocks beneath the salt, the units that are found below the salt in adjoining areas are shown in the accompanying table.

Subsurface sections were constructed radiating outward from the salt dome at least 25 miles in all directions in which velocity surveys of wells were available. Study of the continuous-velocity logs of wells shows, as expected, a close correlation between lithology and zones of relatively uniform velocity characteristics. The zones compare closely with named stratigraphic units. The stratigraphic nomenclature is here brought up to date and, for several units, names that more nearly conform to the rules of stratigraphic nomenclature are herein introduced. Some names in common usage have been adopted, and some lithologic names have been changed to indicate more specifically the lithology of the subsurface units. Type sections in wells are designated and briefly described. The accompanying table shows the names and stratigraphic relations of the units. ${ }^{1}$

As described by Matson (1916) the Citronelle Formation (Pliocene) (1, in table) is the sequence of sediments, chiefly nonmarine, above the Pascagoula Formation (Miocene) and below stream-terrace deposits. Its type locality at the town of Citronelle (Mobile County) in nearby southwestern Alabama includes (a) sand and gravel, considered to be Pleistocene in age (Roy, 1939; Carlston, 1951), that caps the uplands and lies unconformably on the deposits below, and (b) littoral, estuarine, and shallow marine deposits considered to be Pliocene in age (Berry, 1916; Stringfield and LaMoreaux, 1957). In Mississippi, only the sand and gravel deposits have been mapped as Citronelle, and they are considered by some geologists to be Pleistocene in age (Brown and others, 1944; Fisk, 1938; Doering, 1956). More recently Brown is of the opinion that the Citronelle is Pliocene in age (written communication to G. V. Cohee, June 23, 1959). The Citronelle is several hundred feet thick along the coast of southeastern Mississippi and contains important aquifers. Inland it is thinner than along the coast and forms extensive upland plains and caps interstream divides. Remnants are found as far north as 140 miles from the Gulf of Mexico.

\footnotetext{
1 Formal use of these names was considered at a conference in Jackson, Miss., on September 17, 1962, arranged by Esther R. Applin, of the U.S. Geological Survey, and attended by representatives of the U.S. Geological Survey, the Mississippi Geological Survey, the Mississippi Geological Society, and the Trowbridge Sample Service. Thicknesses given in the accompanying table were obtained from well logs of southeastern Mississippi and from data from Andrews (1960), Nunnally and Fowler (1954), Rainwater $(1960,1961)$, and Scott and others (1961). The author thanks his colleagues of the U.S. Geological Survey and Jules Braunstein, Shell Oil Co.; E. H. Rainwater, Shell Development Co.; and Eleanor Caldwell, Humble Oil and Refining Co.; for discussions and advice as to the use of these names.
} 
The Pascagoula and Hattiesburg Formations (2) together form an indivisible stratigraphic unit. The Pascagoula Formation was described near the coast, along the Pascagoula River, where the beds are chiefly marine, and the Hattiesburg was described about 50 miles or more inland at Hattiesburg, Miss., where the beds are less marine and consist in large part of sands that are important fresh-water aquifers.

The Catahoula Sandstone is divided into an upper part, chiefly nonmarine sand and clay, and a lower part termed the Tatum Limestone Member (3), a new name introduced to replace "Iimestone of the Heterostegina

Surface and subsurface units in southeastern Mississippi and adjoining areas

[Numbers in parentheses keyed to text discussion]

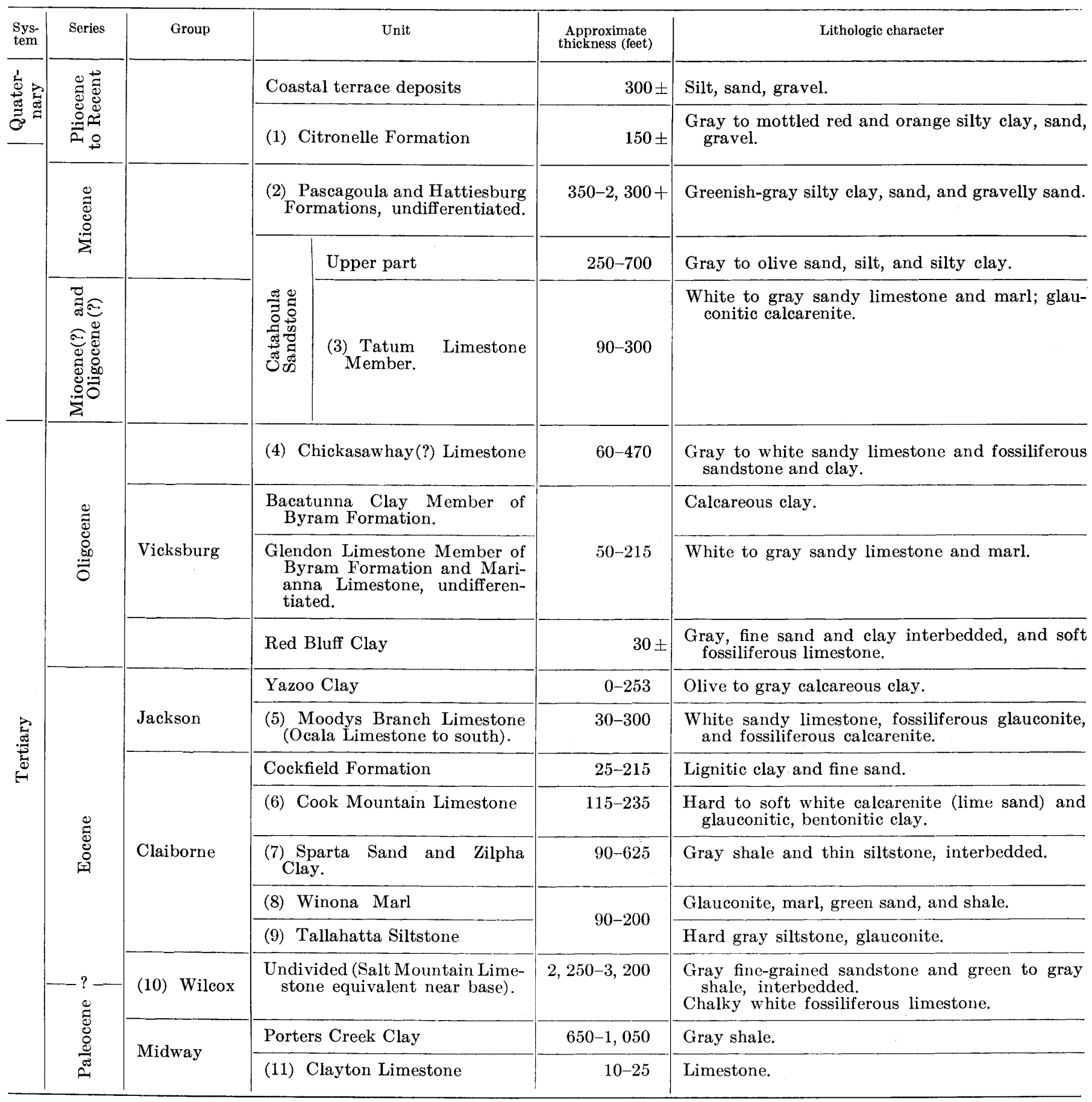


Surface and subsurface units in southeastern Mississippi and adjoining areas-Continued

[Numbers in parentheses keyed to text discussion]

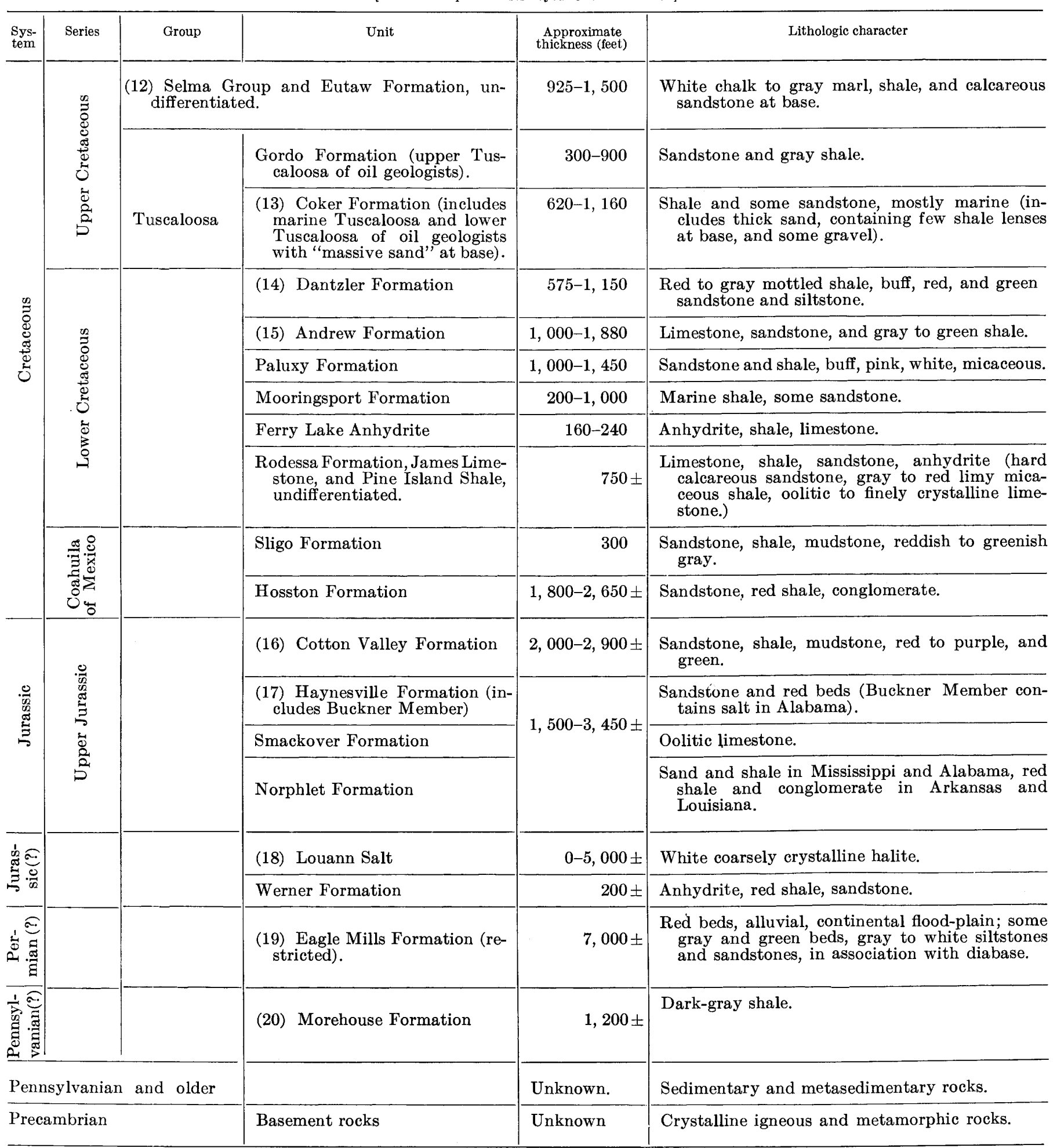

zone" or "Heterostegina limestone." The following is a description of the Tatum Limestone Member.

Type section.-U.S. Atomic Energy Commission hydrologic test well 1, Tatum dome area, Lamar County, Miss., is the type section. Well 1 is in the NE 14 SW 14 sec. 12 , T. 2 N., R. 16 W., and the datum is 321 feet above sea level. Hydrologic test well 2 in the SW1/4 SW14 sec. 14 , T. 2 N., R. 16 W., for which the datum is $302 \mathrm{feet}$, is a reference section. 
Areal extent.-Southern Mississippi to northern Florida and the northern part of the Florida parishes of Louisiana.

Thickness.-In well 1, 163 feet, from a depth of 1,373-1,536 feet; in well 2, 170 feet, from $1,470-1,640$ feet. The Tatum thins to about 90 feet in the southeastern part of the area and thickens to 300 feet toward the west.

Lithology.-Sandy limestone, marl, glauconitic calcarenite, and calcirudite (made up chiefly of fossil and limestone fragments).

Electrical-log characteristics.--High resistivity; generally very low self-potential, which is characteristic of a fresh-water aquifer.

Sonic-log characteristics.-High in sonic velocity. It is the first zone of high velocity found in drilling and in geophysical exploration of southern Mississippi.

Paleontology.-Larger foraminifers are chiefly Heterostegina sp., Miogypsina sp., and Sorites sp. Many species of smaller Foraminifera have been identified from cores from well 1 by Ruth Todd and Doris Low.

Age.-Miocene(?) and Oligocene(?). Larger foraminifers are said to be definitely Oligocene in age (Cole and Applin, 1961); smaller foraminifers suggest Miocene age (Ruth Todd and Doris Low, personal communication, 1962), although an Oligocene age is not necessarily precluded. The Tatum is tentatively correlated with fossiliferous limestones and marls of the Paynes Hammock Sand (Miocene) and the upper bed of the Chickasawhay Limestone (Oligocene) as described by MacNeil (1944).

Chickasawhay Limestone (4) has been defined from surface outcrops only, and use of the name for a unit of the subsurface is questioned because exact correlation with surface outcrops is uncertain.

Moodys Branch Limestone (5) is used in southeastern Mississippi instead of Moodys Branch Formation to indicate the characteristic subsurface lithology of the unit. The Ocala Limestone, in the southern part of the report area, as in western Florida and southern Alabama, is equivalent to the Moodys Branch Limestone and the Yazoo Clay farther updip.

Cook Mountain Limestone (6) is used instead of Cook Mountain Formation to indicate the characteristic subsurface lithology of the unit. It has been called the Camerina limestone by some geologists, but this genus is also present in other formations.

The terms Sparta Sand and Zilpha Clay (7) are used collectively in this article for the unit that underlies the Cook Mountain Limestone. "Upper part of Cane River equivalent" (of Louisiana) has been used for this unit in southwestern Mississippi. Some sandy beds in the middle of the chiefly clayey and silty unit are the downdip equivalents of the Sparta Sand.

Winona Marl (8) is used for the green sand and shale and glauconitic marl whose equivalent is the Winona Sand of the outcrop. The term "Cane River Marl" (or, as used by some geologists, "Lower part of Cane River equivalent") is commonly used by oil geologists for this subsurface unit in southwestern Mississippi.

Tallahatta Siltstone (9) is used in the report area instead of Tallahatta Formation to indicate more definitely the characteristic subsurface lithology of the unit.

Recent studies in Mississippi show that the different units in the Wilcox section (10) are closely correlative with the various formations of the Wilcox Group in Alabama. However, in this subsurface study, the Wilcox Group has not been subdivided.

Clayton Limestone (11) is used instead of Clayton Formation of the outcrop to indicate the characteristic subsurface lithology of the unit.

Some geologists consider that the shale and sandstone section below the chalk of the Selma Group and Eutaw Formation, undifferentiated (12), correlates with the basal part of outcropping Eutaw Formation equivalents in Arkansas.

"Massive sand" (13) for the basal beds of the Upper Cretaceous is used informally (a formal name is not recommended) since the beds are not of uniform lithologic character and they vary in stratigraphic position.

The Dantzler Formation (14) was originally described by Hazzard, Blanpied, and Spooner (1947). The following is a description of the formation.

Type section.-Humble Oil and Refining Co. No. B-1 Dantzler Lumber Co. well, Jackson County, Miss. The well is in sec. 30, T. 5 S., R. 8 W., and the derrick floor elevation is 108 feet above sea level (datum, 1 foot above rotary, or about 110 feet). Depth 8,905-9,910 feet (Nunnally and Fowler, 1954, p. 25).

Areal extent and thickness.- Southeastern Mississippi, extending into the southwest corner of Alabama; 1,200 feet thick (Nunnally and Fowler, 1954, p. 28) but thins rapidly to the west. Western limit, Franklin and Amite Counties; northern limit, from northern boundaries of Lincoln and Covington Counties southeast to Greene County. Beyond these limits the formation cannot be distinguished from the underlying Andrew Formation.

Lithology.-Nonmarine sands, fine- to medium-grained, white to dull-red, and green; shales, dark-purplish-red, generally mottled with white, yellow, ochre, and gray; some shales are dark gray; some are micaceous, slightly chloritic, silty. Some beds are carbonaceous and lignitic, others are calcareous and contain gray, red, or white limestone nodules

Electrical-log characteristics.-Generally lower resistivity and self-potential than beds above and below.

Sonic-log characteristics.-Generally lower sonic velocity than beds above and below.

Paleontology.-F. W. Rolshausen, of the Humble Oil and Refining Co., has found oyster shells, ostracods, and Chara in some cores from the type well, and one specimen of Haplophragmoides in one core from a depth of 9,779-9,789 feet.

Age.-May include beds of Cenomanian age at top, as originally correlated by Hazzard, Blanpied, and Spooner, but is unconformably overlain by beds of known Cenomanian age, the Tuscaloosa Group.

The Andrew Formation (15) is here named and described as generally marine rocks previously called "Pre-Dantzler rocks of Washita and Fredericksburg Groups, undifferentiated" (Nunnally and Fowler, 1954, 
p. 22-25). The following is a description of the Andrew Formation.

Type section.-Gulf Oil Co. No. 25 J. M. Andrew well, sec. 6, T. 1 N., R. 16 W., Baxterville oil field, Lamar County, Miss. Elevation of the derrick floor is 233 feet above sea level (datum is 1 foot above rotary, about 2 feet above derrick floor, or about 235 feet). Cuttings and cores were examined by Esther R. Applin (written communication, October 1962), who found that the formation extends in depth from 9,800 feet (electrical-log point, or the 9,810-9,820-foot sample) to 11,360 feet (electricallog point, or the 11,380-11,390-foot sample).

Areal extent and thickness.-Across southern Mississippi and into adjoining States. Northern limit is defined by a change in facies to nonmarine sands and shales whose lithology is similar to overlying and underlying formations. Northern limit of recognizable Andrew Formation extends from Claiborne County on the northwest to southeastern Greene County on the southeast (Nunnally and Fowler, 1954).

Lithology.-According to Mrs. Applin's sample and core descriptions the Andrew Formation consists, toward the top, of dull- to dark-red, gray, and olive-gray shale containing beds of brownish-gray finely sandy limestone, some shell fragments, and some beds of olive-gray dolomite and light-cream limestone. This grades down into gray and greenish-gray to dull-red micaceous shale alternating with limestone, minor beds of fine-grained sandstone containing some carbonaceous matter, and grayishgreen siltstone. Much of the lower part is dark-gray shale.

Electrical-log characteristics.-Generally low self-potential and alternating zones of moderately high and low resistivity.

Sonic-log characteristics.-Generally high sonic velocity, but thin zones of strongly contrasting velocities.

Paleontology.-According to Mrs. Applin, the upper part of the Andrew Formation contains abundant bivalves and ostracods. A few specimens of Lituola inflata were found in samples from depths of 10,280-10,300 and 10,360-10,370 feet. Ostrea fragments were common throughout the section; ostracods were abundant and scattered throughout. Quinqueloculina and other Miliolids were found at 10,596-10,601 and at 10,626-10,6281/2 feet. Plicatula- and Pecten-like pelycypods were found at 10,611-10,616 feet.

Age.-The formation has been correlated with the lower part of the Washita and Fredericksburg Groups of Texas. Exact correlations on the basis of diagnostic faunas, however, are unknown to the author.

Cotton Valley Formation (16) is used instead of Cotton Valley Group because the formations making up the group in other States have not been differentiated in southeastern Mississippi.

Haynesville Formation (17) includes the Buckner Member in the subsurface of southestern Mississippi. The Buckner is believed to include some salt beds in Alabama.

The Louann Salt (18) (greatly contorted) has been intruded as diapirs into overlying sediments. One well in the report area is reported to have penetrated the bedded Louann Salt. Applin and Applin (1953) state that a core composed of 1 foot of anhydrite and 1 foot of rock salt was recovered in a basket core barrel from the lowermost 9-foot interval of George Vasen fee well No. 1, Stone County, Miss., drilled to a depth of 20,450 feet. The units listed here as occurring below the Louann have not been drilled in southeastern Mississippi and are, therefore, not known to be present there. They have been found, however, in one or more States adjoining Mississippi, where the salt occurs at shallower depths.

The Eagle Mills (19) was originally described (Imlay, 1940) to include beds now included in the Norphlet, Louann, Werner, and the Eagle Mills, restricted. The exact age of this sequence is unknown, but has been considered by various authors as Permian(?), Triassic(?), or Jurassic(?). Scott, Hayes, and Fietz (1961) tentatively include the Eagle Mills in the Triassic, partly on the basis of identification by Erling Dorf of a plant fossil that is similar to one of the Chinle Formation of Arizona and the Newark Group of Virginia, and partly on lithologic similarities to the Newark Group.

The structural and stratigraphic relations of the Morehouse Formation (20) to the Eagle Mills Formation, restricted, are not known.

\section{REFERENCES}

Andrews, D. I., 1960, The Louann salt and its relationship to Gulf Coast salt domes: Gulf Coast Assoc. Geol. Societies Trans., v. 10, p. 215-240.

Applin, P. L., and Applin, E. R., 1953, The cored section in George Vasen's fee well 1, Stone County, Mississippi: U.S. Geol. Survey Circ. 298, 29 p.

Berry, E. W., 1916, The flora of the Citronelle Formation: U.S. Geol. Survey Prof. Paper 98-L, p. 193-208.

Brown, G. F., and others, 1944, Geology and ground-water re sources of the coastal area in Mississippi: Mississippi Geol. Survey Bull. 60, $232 \mathrm{p}$.

Carlston, C. W., 1951, Profile sections in Citronelle Formation in southwestern Alabama: Am. Assoc. Petroleum Geologists Bull., v. 35, no. 8, p. 1888-1892.

Cole, W. S., and Applin, E. R., 1961, Stratigraphic and geographic distribution of larger Foraminifera occurring in a well in Coffee County, Georgia, in Contributions from the Cushman Foundation for Foraminiferal Research, v. 12, pt. 4: p. 127-135.

Doering, J. A., 1956, Review of Quaternary surface formations of Gulf Coast region: Am. Assoc. Petroleum Geologists Bull., v. 40, no. 8, p. 1816-1862

Fisk, H. N., 1938, Geology of Grant and LaSalle Parishes: Louisiana Dept. Conserv., Geol. Bull. 10, 246 p.

Hazzard, R. T., Blanpied, B. W., and Spooner, W. C., 1947, Notes on correlation of the Cretaceous of east Texas, south Arkansas, north Louisiana, Mississippi, and Alabama: Shreveport Geol. Soc. 1945 Reference Rept., v. 2, p. 472481.

Imlay, R. W., 1940, Lower Cretaceous and Jurassic Formations of southern Arkansas and their oil and gas possibilities: Arkansas Geol. Survey Inf. Circ. 12.

MacNeil, F. S., 1944, Oligocene stratigraphy of southeastern United States: Am. Assoc. Petroleum Geologists Bull., v. 28 , no. 9 , p. $1313-1354$. 
Matson, G. C., 1916, The Pliocene Citronelle Formation of the Gulf Coastal Plain: U.S. Geol. Survey Prof. Paper 98, p. $167-192$.

Nunnally, J. D., and Fowler, H D., 1954, Lower Cretaceous stratigraphy of Mississippi: Mississippi Geol. Survey Bull. $79,45 \mathrm{p}$.

Rainwater, E. H., 1960, Stratigraphy and its role in the future exploration for oil and gas in the Gulf Coast: Gulf Coast Assoc. Geol. Societies Trans., v. 10, p. 33-75.
Rainwater, E. H., 1961, Outline of geological history of Mississippi: Gulf Coast Assoc. Geol. Societies Trans., v. 11, p. 43-45.

Roy, C. J., 1939, Type locality of Citronelle Formation, Citronelle, Alabama: Am. Assoc. Petroleum Geologists Bull., v. 23 , no. 10 , p. $1553-1559$.

Scott, K. R., Hayes, W. E. and Fietz, R. P., 1961, Geology of the Eagle Mills Formation: Gulf Coast Assoc. Geol. Societies Trans., v. 11, p. 1-14.

Stringfield, V. T., and LaMoreaux, P. E., 1957, Age of Citronelle Formation in Gulf Coastal Plain: Am. Assoc. Petroleum Geologists Bull., v. 41, no. 4, p. 742-746. 


\title{
MAGMATIC DIFFERENTIATION IN A VOLCANIC SEQUENCE RELATED TO THE CREEDE CALDERA, COLORADO
}

\author{
By JAMES C. RATTÉ and THOMAS A. STEVEN, Denver, Colo.
}

Work done in cooperation with the Colorado State Metal Mining Fund Board

\begin{abstract}
Arranged in order of age, the ash-flow sheets and interlayered lava flows related in origin to the Creede caldera display progressive changes in (a) the abundance and composition of phenocrysts, (b) chemical composition, and (c) mode of eruption. These changes are evidence of continuing differentiation of the source magma.
\end{abstract}

A complex pile of welded ash-flow tuffs, lava flows, and intrusive rocks surrounds the Creede caldera, a nearly circular subsidence structure 10 to 12 miles in diameter in the central San Juan Mountains, Colo. The volcanic rocks were in part derived from a source area in the vicinity of the caldera and in part from other sources. Those from the caldera source area comprise 5 ash-flow units (terminology of Smith, 1960; Ross and Smith, 1961) and 3 lava-flow units. These units are listed according to order of eruption in figure 131.1, which also lists formational names defined by the authors in another article (Art. 132). When considered in order of age, the volcanic units show an irregular progression from early phenocryst-poor rhyolites to later phenocryst-rich quartz latites. Parallel with these changes in composition, the mode of erup-

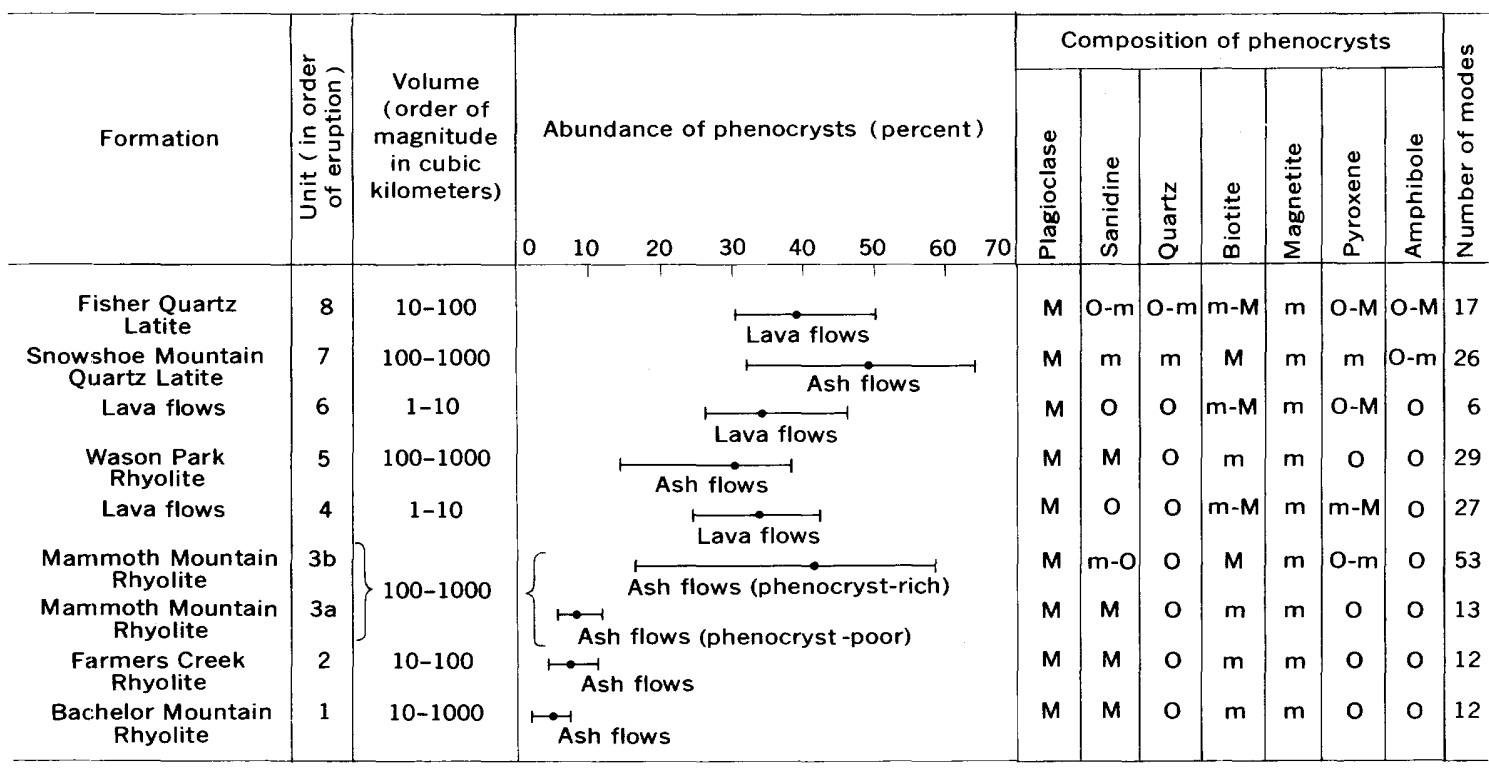

Figure 131.1.-Abundance and composition of phenocrysts in the volcanic sequence related to the Creede caldera source area. These rocks have porosity ranging generally from 2 to 10 percent; thus compaction effects are negligible for purposes of comparison of abundance of phenocrysts. Lines represent range of abundance; dots, a verage abundance; M, generally greater than 10 percent of total phenocrysts; $\mathrm{m}$, generally less than 10 percent of total phenocrysts; O, phenocrysts not observed, or present only in trace amounts.

ART. 131 IN U.S. GEOL. SURVEY PROF. PAPER 475-D, PAGES D49-D53. 1964. 
tion changed from predominantly ash-flow eruption through alternating ash-flow and lava-flow eruptions to a final predominance of lava-flow eruptions. We interpret these changes as evidence of differentiation in the source magma chamber throughout the general period of eruptivity. Progressive changes in the Mammoth Mountain Rhyolite, a single ash-flow sheet, illustrate the stratified nature of the magma in the chamber during a particular eruptive stage. We shall first discuss the evidence from the entire sequence of flows, and then the details displayed by the Mammoth Mountain.

\section{DIFFERENTIATION EXHIBITED BY FLOW SEQUENCE}

The early phenocryst-poor rhyolites consist of ash flows of the Bachelor Mountain Rhyolite, Farmers Creek Rhyolite, and the older ash flows of the Mammoth Mountain Rhyolite. The phenocryst content of these ash flows ranges from about 2 to 12 percent. The phenocrysts are predominantly sodic plagioclase and sanidine in nearly equal amounts and some biotite and magnetite. The younger ash flows of the Mammoth Mountain Rhyolite range in composition from rhyolitic quartz latite to quartz latite and contain 15 to nearly 60 percent phenocrysts. With the change to quartz latite, sanidine decreases relative to plagioclase, and mafic phenocrysts become more abundant.

Beginning with the Mammoth Mountain, lava flows are interlayered with the ash flows and become more abundant upward. Near the top of the sequence, the ratio of ash flows to lava flows is about 1:10. The bulk of the lava flows are quartz latites with an average of 30 to 40 percent phenocrysts, predominantly plagioclase of intermediate composition, although mafic minerals, including biotite, magnetite, pyroxene, and hornblende are abundant. Sanidine and quartz are present in some flows of the Fisher Quartz Latite which range in composition from rhyolite to rhyodacite.

The two ash-flow units in the upper part of the sequence, the Wason Park Rhyolite and the Snowshoe Mountain Quartz Latite, range in composition from rhyolite to quartz latite and are rich in phenocrysts. The Wason Park contains about 30 percent phenocrysts, mainly plagioclase and sanidine with some biotite, magnetite, and a trace of pyroxene, and is definitely less mafic than the ash flows of the underlying Mammoth Mountain. The Snowshoe Mountain, the uppermost ash-flow unit, contains 30 to 60 percent phenocrysts; plagioclase is dominant, but mafic crystalsbiotite, magnetite, pyroxene, and amphibole-are more abundant than in any of the earlier ash-flow units. Sanidine and quartz also are present in small amounts.

The mineralogic changes outlined above express progressive changes in chemical composition. Analyses of samples practically free from alteration effects, other than hydration of the glass of vitrophyres, are given in table 131.1. The changes in composition with time, or with the position in the sequence, are shown graphically in figure 131.2 by plotting the differentiation index (D.I.) of Thornton and Tuttle (1960) against silica in the various rock units. The D.I. is simply the sum of normative quartz, orthoclase, and albite, and is described by Thornton and Tuttle as a measure of the basicity of a rock and as an indication of the position of a rock along the path toward petrogeny's residua system (Bowen, 1937).

The chemical analyses (table 131.1) and the differentiation diagram (fig. 131.2) indicate that: (a) the younger units of the sequence are generally more mafic in composition than older units; (b) the ash flows and lava flows, considered as separate series, show a similar trend toward more mafic rocks in the younger units; (c) the lava-flow series (units 4, 6, and 8) is slightly out of step with the ash-flow series, as each lava-flow unit is more mafic than the ash-flow unit that follows in the order of eruption; (d) the Wason Park Rhyolite (unit 5) plots out of the order of eruption in the ashflow series on the differentiation diagram because these ash flows are considerably more rhyolitic than the lava flows (unit 4) and phenocryst-rich Mammoth Mountain ash flows (unit $3 \mathrm{~b}$ ) that precede the Wason Park.

\section{COMPOSITIONAL STRATIFICATION IN THE MAMMOTH MOUNTAIN RHYOLITE}

The Mammoth Mountain Rhyolite is a thick composite ash-flow sheet representing many successive ash flows. It is exposed for at least $300^{\circ}$ around the margin of the Creede caldera, and it ranges in thickness from 0 , where it wedges out against a local high in the underlying topography northwest of Creede, to about 1,700 feet on the north side of the caldera. Although the full extent of the sheet is incompletely known, its original volume was well in excess of 100 cubic kilometers.

The composite sheet changes laterally from a simple cooling unit, near its probable source within the caldera, through a compound cooling unit, to separate cooling units farther from the source. The successive ash flows of the Mammoth Mountain Rhyolite were not all coextensive; early ash flows were confined by an irregular topography and had a more limited distribution than some of the later ash flows. Several representative sections of the ash-flow sheet are located by letters on figure 131.3, and approximate thicknesses of the sheet are given in parentheses. The formation is exposed almost continuously east of the caldera between sections $\mathrm{A}$ and $\mathrm{F}$, but the area near Rat Creek and Miners Creek stood high when 
TABLE 131.1.-Chemical analyses and differentiation index of volcanic rocks in the sequence related to the Creede caldera source area

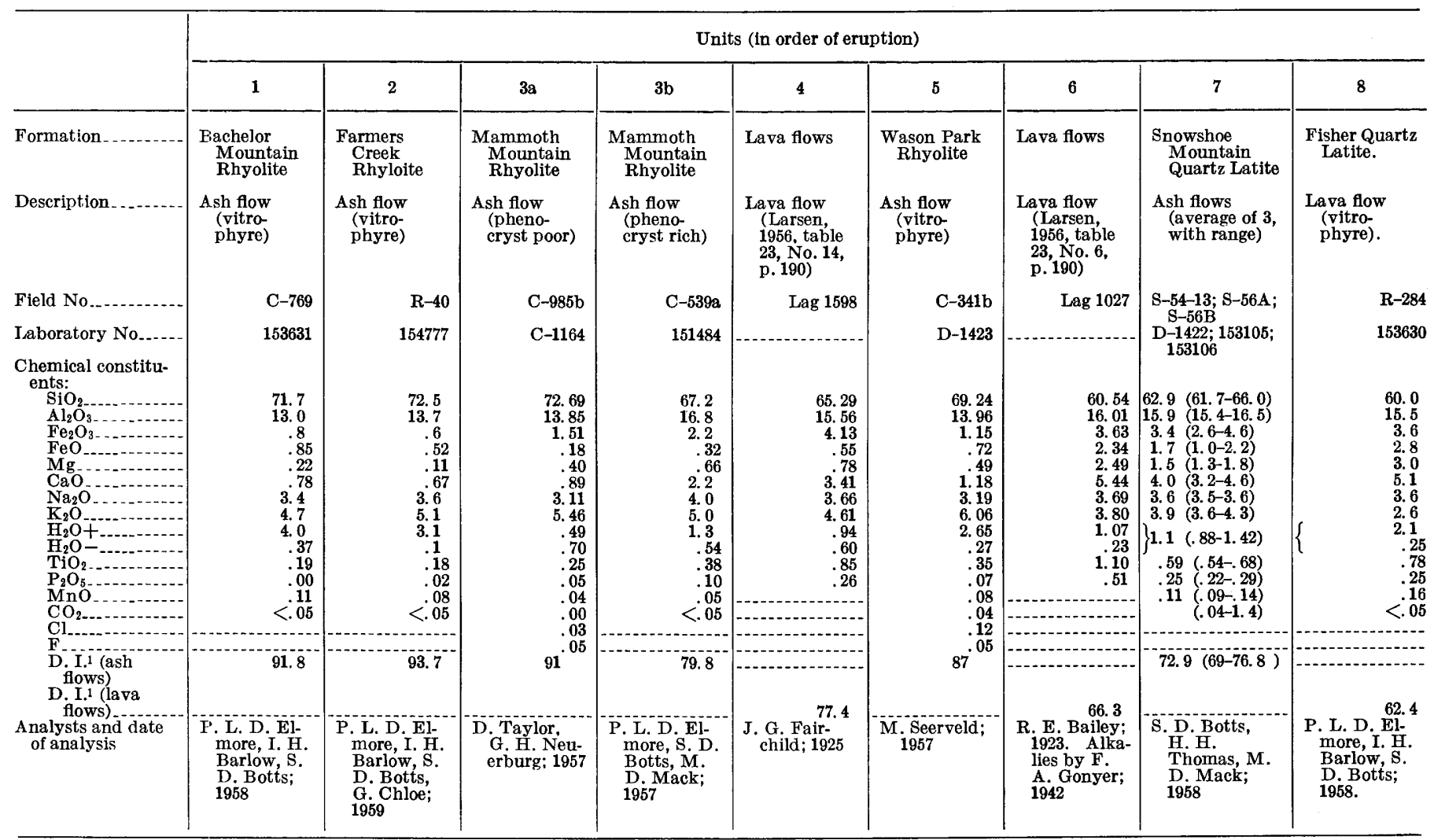

1 Differentiation index (Thornton and Tuttle, 1960).

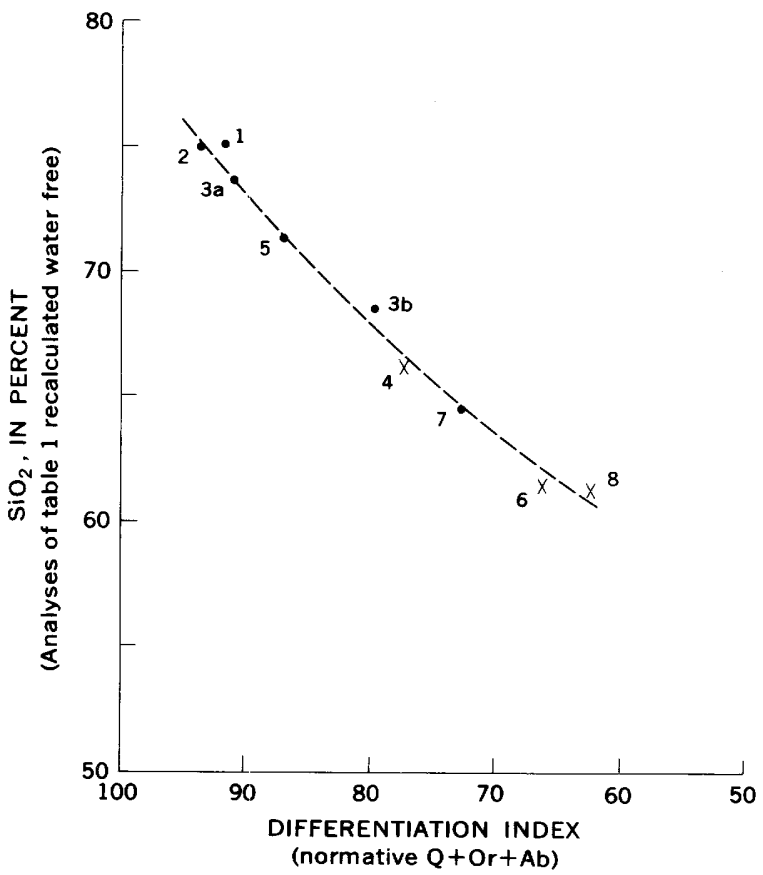

FrguRE 131.2.-Differentiation diagram, showing differentiation index versus silica in the volcanic sequence derived from the Creede caldera source area. Numbers refer to units listed in table 131.1, and indicate order of eruption. Dots represent ash flows, and $X$ 's lava flows.

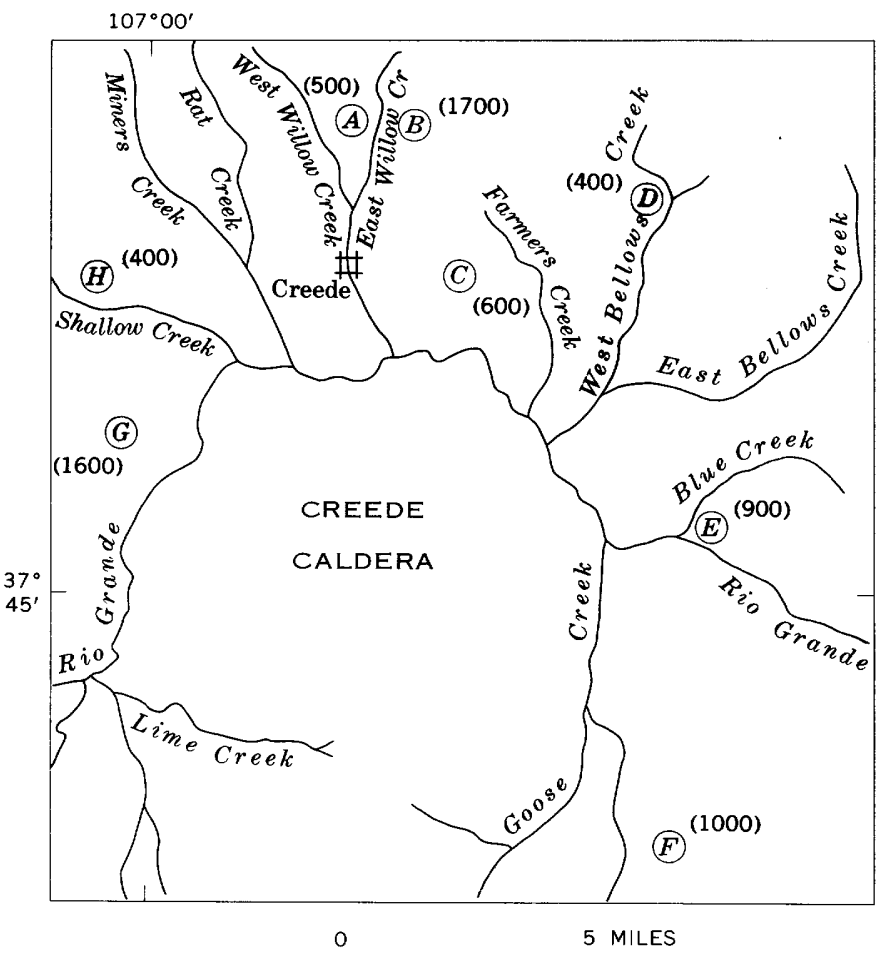

FIGURE 131.3.--Location map for representative sections (letters in circles) of Mammoth Mountain Rhyolite. Thickness of sections, in feet, shown in parentheses. 
TABLE 131.2.-Modes of Mammoth Mountain Rhyolite

\begin{tabular}{|c|c|c|c|c|c|c|c|c|c|c|c|c|}
\hline \multirow[b]{2}{*}{$\begin{array}{c}\text { Representative } \\
\text { section (fig. 131.3) }\end{array}$} & \multirow[b]{2}{*}{ Description } & \multirow[b]{2}{*}{$\begin{array}{l}\text { Num- } \\
\text { ber of } \\
\text { modes }\end{array}$} & \multicolumn{10}{|c|}{ Rock constituents (percent) } \\
\hline & & & \multicolumn{2}{|c|}{$\begin{array}{l}\text { Total pheno- } \\
\text { crysts }\end{array}$} & \multicolumn{2}{|c|}{ Sanidine } & \multicolumn{2}{|c|}{ Plagioclase } & $\begin{array}{l}\text { Blotite } \\
\text { (avg) }\end{array}$ & $\underset{\text { (avg) }}{\text { Magnetite }}$ & $\underset{\text { (avg) }}{\text { Pyroxene }}$ & $\underset{\text { (avg) }}{\text { Amphibole }}$ \\
\hline $\begin{array}{l}\mathrm{A}, \mathrm{B}, \mathrm{C} \\
\mathrm{B}_{-} \\
\mathrm{D}_{-} \\
\mathbf{E}_{-} \\
\mathrm{G}_{-}\end{array}$ & $\begin{array}{l}\text { Phenocryst poor } \\
\text { Phenocryst rich } \\
\text { Phenocryst rich } \\
\text { Phenocryst rich } \\
\text { Phenocryst rich }\end{array}$ & $\begin{array}{r}13 \\
4 \\
2 \\
41 \\
6\end{array}$ & $\begin{array}{r}8 \\
27 \\
27 \\
43 \\
39\end{array}$ & $\begin{array}{r}5-11 \\
16-33 \\
26-28 \\
39-53 \\
18-58\end{array}$ & $\begin{array}{c}3 \\
10 \\
<1 \\
\operatorname{Tr} . \\
31 / 2\end{array}$ & $\begin{array}{c}2-4 \\
6-12 \\
0-\mathrm{Tr} . \\
\operatorname{Tr}-6\end{array}$ & $\begin{array}{r}4 \\
14 \\
21 \\
34 \\
29\end{array}$ & $\begin{array}{r}2-5 \\
8-18 \\
20-22 \\
25-44 \\
11-45\end{array}$ & $\begin{array}{l}<1 \\
2 \\
3^{1 / 2} \\
5 \\
3^{1 / 2}\end{array}$ & $\begin{array}{r}<1 \\
1 \\
1 \\
2 \\
2\end{array}$ & $\begin{array}{r}\operatorname{Tr} . \\
\operatorname{Tr} . \\
1 \\
1 \\
\operatorname{Tr} .\end{array}$ & $\begin{array}{l}\operatorname{Tr} \\
\operatorname{Tr} \\
\operatorname{Tr} \\
\operatorname{Tr}\end{array}$ \\
\hline
\end{tabular}

these ash flows were deposited, and sections $\mathrm{G}$ and $\mathrm{H}$ are not continuous with the sections to the east.

The abundance and modal composition of phenocrysts in the Mammoth Mountain Rhyolite change both vertically and laterally, and no one section shows the full range of either (table 131.2). The rhyolite near sections $A$ and $B$, north of the caldera (fig. 131.3), is poorest in phenocrysts. At section $A$, the rock contains less than 10 percent phenocrysts, and at section $\mathrm{B}$, the lower 1,000 feet contains less than 10 percent phenocrysts, but grades upward into rock that contains 15 to 30 percent phenocrysts. Phenocryst-rich rocks become more abundant southeastward from sections $\mathrm{A}$ and $\mathrm{B}$; they constitute all but the basal few feet of section $\mathrm{C}$, and all of sections D, E, and F. Sections G and $H$ have a wide range in phenocryst content; welded tuff near section $G$ contains 18 to 58 percent phenocrysts, and rocks with relatively few phenocrysts predominate in the lower part of the section.

In general, the change from early phenocryst-poor rocks to later phenocryst-rich rocks in the Mammoth Mountain ash-flow sheet is paralleled by a change from rhyolitic composition to one progressively more quartz latitic, as indicated by phenocryst modes (table 131.2) and by chemical analyses (table 131.1, units $3 \mathrm{a}$ and $3 \mathrm{~b}$ ). Where phenocrysts are scarce, as in sections $A$ and $B$, they are mainly sanidine and sodic to intermediate plagioclase in nearly equal proportions, and sparse mafic minerals. Where they are abundant, as in sections $\mathrm{D}, \mathrm{E}$, and $\mathrm{F}$, plagioclase predominates over sanidine, and mafic minerals including green pyroxene are more abundant.

Chemical analyses of samples of Mammoth Mountain Rhyolite from section B (fig. 131.3) indicate that the change from phenocryst-poor rocks in the lower part of the section (table 131.1, unit 3a) to phenocryst-rich rocks above (table 131.1, unit $3 \mathrm{~b}$ ) is accompanied by significant decreases in silica and by notable increases in $\mathrm{Al}_{2} \mathrm{O}_{3}, \mathrm{MgO}$, and $\mathrm{CaO}$. The ratio $\mathrm{K}_{2} \mathrm{O}: \mathrm{Na}_{2} \mathrm{O}$ decreases from 1.76 in the lower part of the section to 1.14 above. Chemical analyses of Mammoth Mountain Rhyolite from other sections were made only for $\mathrm{K}_{2} \mathrm{O}$ and $\mathrm{Na}_{2} \mathrm{O}$ content. Changes in composition laterally in the ash-flow sheet are shown by comparing $\mathrm{K}_{2} \mathrm{O}: \mathrm{Na}_{2} \mathrm{O}$ ratios at the different sections (table 131.3).

$\mathrm{T}_{\mathrm{ABLE}}$ 131.3-- $\mathrm{K}_{2} \mathrm{O}$ and $\mathrm{Na}_{2} \mathrm{O}$ in the Mammoth Mountain Rhyolite [Analysts: Wayne Mountjoy and George T. Burrow, 1959-60]

\begin{tabular}{|c|c|c|c|c|c|c|c|}
\hline \multirow{2}{*}{$\begin{array}{l}\text { Repre- } \\
\text { sentative } \\
\text { section } \\
\text { (fig. 131.3) }\end{array}$} & \multirow{2}{*}{ Description } & \multirow{2}{*}{$\begin{array}{l}\text { Num- } \\
\text { ber of } \\
\text { anal- } \\
\text { yses }\end{array}$} & \multicolumn{2}{|c|}{$\begin{array}{c}\mathrm{K}_{2} \mathrm{O}^{1} \text { (weight } \\
\text { percent) }\end{array}$} & \multicolumn{2}{|c|}{$\begin{array}{l}\mathrm{Na}_{2} \mathrm{O}^{1} \text { (weight } \\
\text { percent) }\end{array}$} & \multirow{2}{*}{$\begin{array}{l}\text { Aver- } \\
\text { age } \\
\text { ratio of } \\
\mathrm{K}_{2} \mathrm{O}: \\
\mathrm{Na}_{2} \mathrm{O}\end{array}$} \\
\hline & & & Avg & Range & Avg & Range & \\
\hline 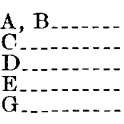 & $\begin{array}{l}\text { Phenocryst poor-- } \\
\text { Phenocryst poor-- } \\
\text { Phenocryst rich-- } \\
\text { Phenocryst rich.-- } \\
\text { Phenocryst rich.-- }\end{array}$ & $\begin{array}{l}4 \\
3 \\
2 \\
3 \\
6\end{array}$ & $\begin{array}{l}5.1 \\
5.5 \\
4.5 \\
4.2 \\
4.6\end{array}$ & $\begin{array}{l}4.65-5.50 \\
5.41-5.65 \\
4.21-4.83 \\
4.05-4.31 \\
4.15-5.05\end{array}$ & $\begin{array}{l}3.1 \\
3.2 \\
3.9 \\
3.9 \\
3.7\end{array}$ & $\begin{array}{l}2.90-3.24 \\
3.10-3.34 \\
3.90-3.96 \\
3.81-3.91 \\
3.50-3.92\end{array}$ & $\begin{array}{l}1.65 \\
1.73 \\
1.15 \\
1.08 \\
1.22\end{array}$ \\
\hline
\end{tabular}

1 Analyses by flame photometrie methods.

\section{DISCUSSION}

The volcanic rocks from the Creede caldera source area form a genetic sequence that represents the crystallization and differentiation of a magma that lay beneath the area. We can only speculate on the processes of differentiation that were operative, but whether they were gaseous transfer of alkalies, crystal setting, filter pressing, or some other process, we believe it evident that the magma had a layered aspect. The early phenocryst-poor rhyolitic ash flows were erupted from a differentiated magmatic "cream" rich in alkalies, silica, and volatiles at the top of the magma. Later phenocryst-rich rhyolitic to quartz latitic rocks show progressive changes in the composition of the magma. Changes in phenocryst content and chemical composition within the Mammoth Mountain Rhyolite indicate that successively deeper levels of a layered magma were tapped during the eruption of this single ash-flow sheet. In addition, the change in the type of eruptive activity from dominant ash-flow eruptions to alternating ashflow and lava-flow eruptions is in accord with loss of alkalies and the effective devolatilization of the magma during the sequence of eruptions. Eruptive cycles are suggested by alternating ash-flow and lava-flow pairs (units 3 and 4,5 and 6,7 and 8 , table 131.1), and temporary reversals in compositional trends may be explained if a relatively silicic fraction were generated 
in the upper part of the magma during periods of quiescence in the eruptive history.

The geologic importance of recording changes in physical character and chemical composition in successive ash flows from a common source was recognized by Smith (1960, p. 833), who also suggested that changes in the abundance of phenocrysts (crystal: glass ratio) and changes in magma chemistry may be recorded in single compound cooling units. Roberts and Peterson (1961) observed that welded "ash" tuffs (phenocrystpoor rocks) in the Great Basin province are more rhyolitic and have higher differentiation indices than welded "crystal" tuffs (phenocryst-rich rocks). On the basis of these data, they discussed possible relationships between magma composition, eruptive activity, and phenocryst content of ash flows that are similar in many respects to the conclusions reached in this article.

\section{REFERENCES}

Bowen, N. L., 1937, Recent high-temperature research on silicates and its significance in igneous geology: Am. Jour. Sci., v. 33, p. 1-21.

Larsen, E. S., Jr., and Cross, Whitman, 1956, Geology and petrology of the San Juan region, southwestern Colorado: U.S. Geol. Survey Prof. Paper 258, 301 p.

Roberts, R. J., and Peterson, D. W., 1961, Suggested magmatic differences between welded "ash" tuffs and welded crystal tuffs, Arizona and Nevada: Art. 320 in U.S. Geol. Survey Prof. Paper 424-D, p. D73-D79.

Ross, C. S., and Smith, R. L., 1961, Ash-flow tuffs: their origin, geologic relations and identification: U.S. Geol. Survey Prof. Paper 366.

Smith, R. L., 1960, Ash flows: Geol. Soc. America Bull., v. 71, no. 6 , p. $795-842$.

Thornton, C. P., and Tuttle, O. F., 1960, Chemistry of igneous rocks; differentiation index: Am. Jour. Sci., v. 258, p. 664684 . 


\title{
Article 132
}

\section{REVISED TERTIARY VOLCANIC SEQUENCE IN THE CENTRAL SAN JUAN MOUNTAINS, COLORADO}

\author{
By THOMAS A. STEVEN and JAMES C. RATTÉ, Denver, Colo.
}

Work done in cooperation with the Colorado State Metal Mining Fund Board

\begin{abstract}
Rock units record a complex sequence of volcanic events in which eruptions were in part concurrent and in part sequential, and many of the larger pyroclastic eruptions culminated in cauldron subsidence. The previously used volcanic sequence in the area is inadequate to explain the geology; several older stratigraphic names are not used in the report area, others are redefined, and new names are given to many of the rock units.
\end{abstract}

Most of the rock units in the central San Juan Mountains, southwestern Colorado, have been described previously as belonging to a sequence of six formations in the Potosi Volcanic Series (Larsen and Cross, 1956, p. 90-167); rocks exposed within the area discussed here were assigned largely to the upper three of these units, the Alboroto Rhyolite, Huerto Quartz Latite, and
Piedra Rhyolite (table 132.1). The Creede Formation and Fisher Quartz Latite were believed by Larsen and Cross $(1956$, p. 168,172$)$ to have accumulated after the Potosi Volcanic Series, and to be separated from the older rocks and from each other by unconformities representing deep erosion and significant periods of time. The Potosi units were believed to have wide lateral extent, and correlations were made principally on topographic position and rock type.

In contrast, our investigations, covering several hundred square miles in the vicinity of Creede, Colo., (fig. 132.1), have shown that the rock units record a complex sequence of volcanic events in which eruptions from local centers were in part concurrent and in part sequential, and in which many of the larger

TABLE 132.1.-Comparison of stratigraphic names used for volcanic units in the central San Juan Mountains

\begin{tabular}{c|c|c}
\hline Rock units interpreted by Larsen and Cross (1956) & Rock units interpreted by Emmons and Larsen (1923) & Correlative units used in this article (see table 132.2 for \\
correct startigraphic sequence)
\end{tabular}




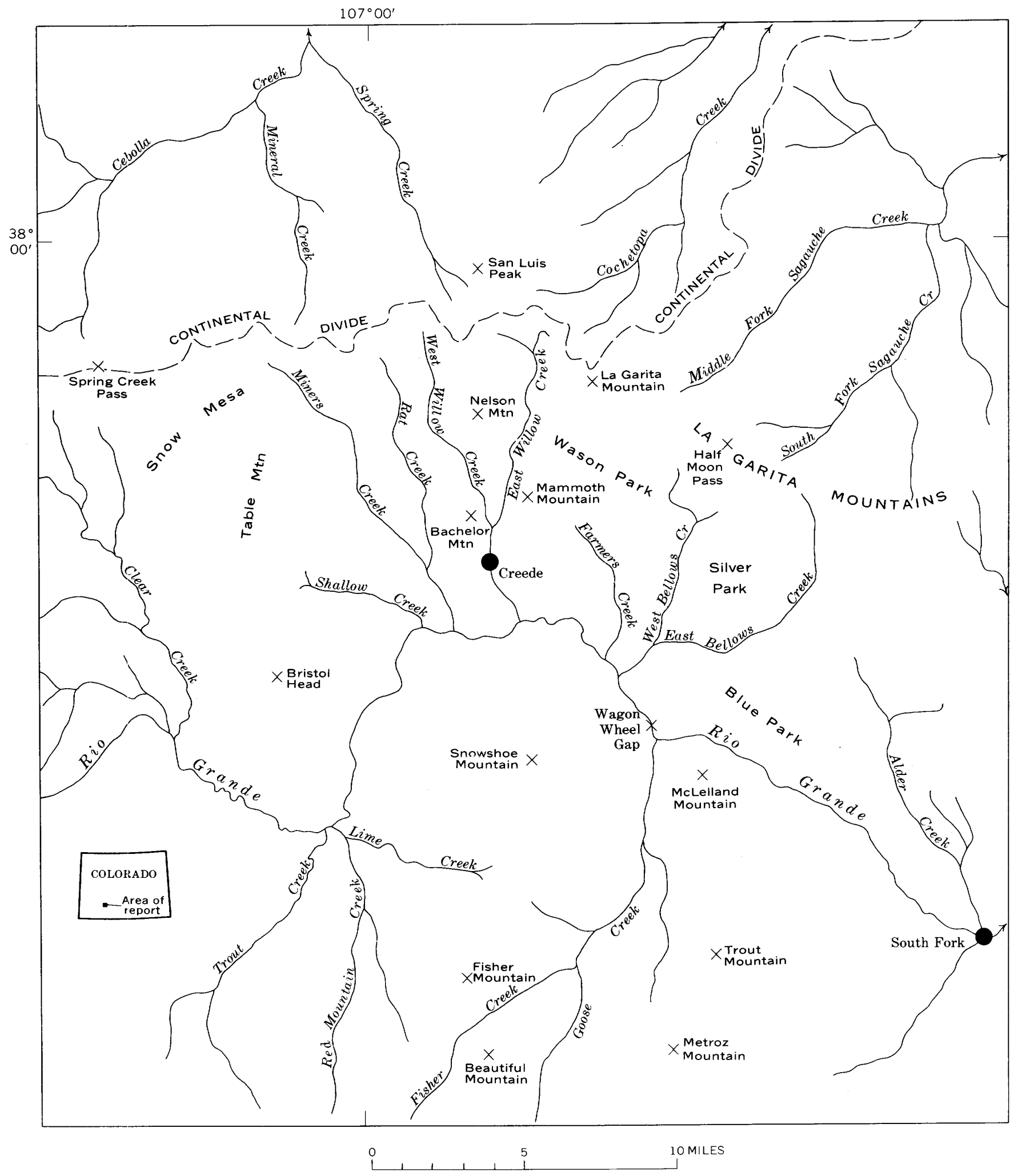

Figure 132.1.-Locality map of the central San Juan Mountains, Colo. 
pyroclastic eruptions in the Potosi culminated in cauldron subsidence (table 132.2). Three major cauldrons are well documented, and a fourth is known but has not yet been studied in detail. As a result, many of the units were confined by rough preexisting structural topography, and topographic position may have little bearing on the relative age of a unit. In addition, typical rocks from many of the formations appear so nearly identical that lithologic similarity alone is not a reliable basis for correlation. The Creede Formation and Fisher Quartz Latite in part intertongue, and both units filled the margin of the Creede caldera (Steven and Ratté, 1960b) shortly after subsidence and doming of the caldera core; the pyroclastic and flow rocks appear to represent a continuation of the same period of volcanic activity and to be comagmatic with the earlier so-called Potosi units.

'The previously established volcanic sequence (table 132.1) in the central San Juan Mountains (Emmons and Larsen, 1923; Cross and Larsen, 1935; Larsen and Cross, 1956) is inadequate to explain the geology. Because so many of the rock units are miscorrelated, we are unable to accommodate the terminology of the Potosi Volcanic Series to the revised volcanic sequence we have determined (tables 132.1 and 132.2), and thus we do not use the Potosi Volcanic Series in the Creede area. Likewise, the Alboroto and Piedra Rhyolites include units so widely scattered within our local sequence that we have not been able to retain them in any sense equivalent to their original intent, and we do not use them in the Creede area either.

In the western San Juan Mountains, Luedke and Burbank (1963) have recently redefined the Potosi Volcanic Series to Potosi Volcanic Group, an assemblage of rocks which is not believed to contain any of the units in the central San Juan Mountains discussed here.

The age of the volcanic rocks in the central San Juan Mountains is uncertain, as no diagnostic fossils have been found anywhere within the volcanic succession. The Telluride Conglomerate and Blanco Basin Formation underlying the volcanic rocks have been considered to be Oligocene(?) in age (Larsen and Cross, 1956, p. 61 ), but the evidence admittedly was not conclusive. So far as we can ascertain, the succeeding volcanic activity could have begun any time within the middle Tertiary. The Creede Formation, which is among the youngest of the units related to volcanic activity in the San Juan Mountains, contains abundant well-preserved plant fossils, but none have proved diagnostic. Esti-

Table 132.2.-Volcanic stratigraphy of the central San Juan Mountains, Colo.

[* redefined name; ${ }^{* *}$ new name]

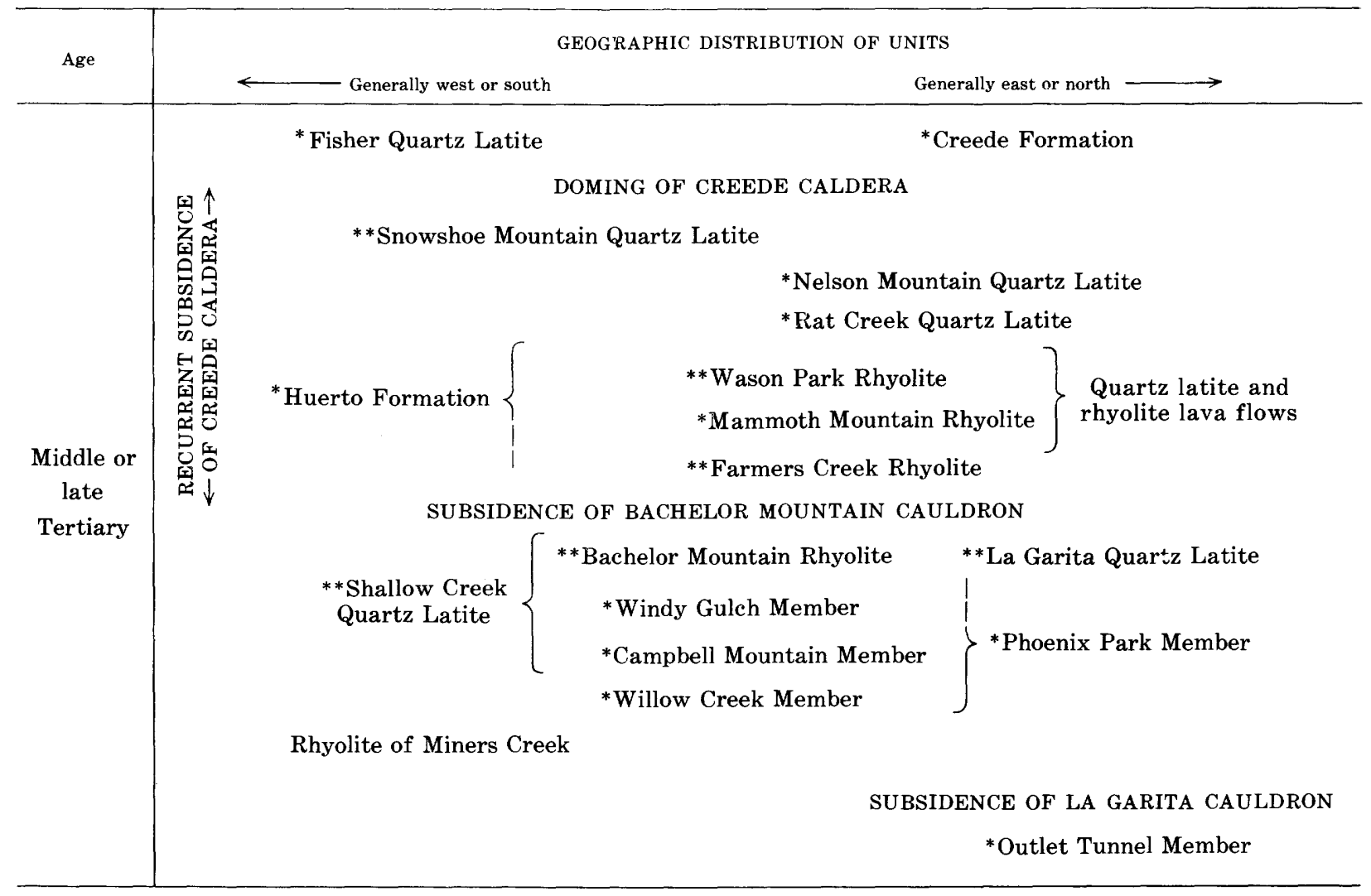


mates of the age of the formation based on the same fossils have ranged from very late Miocene or very early Pliocene (Brown, R. W., in Larsen and Cross, 1956, p. 167) to early to middle Pliocene (MacGinitie, 1953, p. 60-75). Pollen studies by Estelia Leopold (written communication, 1961) suggest an age between late Miocene through middle Pliocene.

The rock units in the central San Juan Mountains near Creede, and their relations to recurrent cauldron subsidence, are summarized in table 132.2. The relations of these units to those from other centers of eruption in the San Juan Mountains are not as yet fully established.

\section{LA GARITA QUARTZ LATITE}

La Garita Quartz Latite is a new name here given to a part of the assemblage of rocks formerly included in the Alboroto Rhyolite by Larsen and Cross (1956, p. 132). The La Garita Quartz Latite is well exposed along the upper canyon of East Willow Creek north of Creede, and forms the bulk of La Garita Mountain farther northeast (fig. 132.1), which serves as type area for the formation.

The La Garita Quartz Latite consists largely of identical densely welded ash-flow tuffs that are equivalent to the former Outlet Tunnel and Fhoenix Park Quartz Latites of Emmons and Larsen (1923, p. 18, 30). The Outlet Tunnel unit was described by them as underlying rocks here called Bachelor Mountain Rhyolite and the Phoenix Park unit as interbedded with and overlying them. In addition to the difference in stratigraphic position noted by Emmons and Larsen, we have determined that accumulation of the two units was separated by subsidence of the La Garita cauldron (table 132.2). We are calling those rocks that accumulated before the Bachelor Mountain Rhyolite and before cauldron subsidence the Outlet Tunnel Member, and those that accumulated concurrently with and after the Bachelor Mountain Rhyolite and after cauldron subsidence the Phoenix Park Member. Emmons and Larsen (1923, p. 30) erroneously believed that the bulk of these rocks along upper East Willow Creek and La Garita Mountain belonged to their Phoenix Park unit, whereas we have found that they formed before cauldron subsidence and clearly belong to the redefined Outlet Tunnel Member.

Typical rocks from both members of the La Garita Quartz Latite appear identical and consist of crystal-rich ashflow tuff, largely densely welded, that consists of about half reddish, lithoidal matrix, and half phenocrysts and fragments of foreign rock types. Plagioclase phenocrysts constitute about 30 percent of the rock, sanidine 6 percent, quartz 4 percent, biotite 4 percent, hornblende 4 percent, and magnetite and accessory minerals 2 percent.
The Outlet Tunnel Member is more than 2,000 feet thick in the type area, but the base of the member is nowhere exposed in this vicinity and the full thickness could not be determined. The Phoenix Park Member is between 350 and 500 feet thick along the east flank of East Willow Creek, and it wedges out a short distance northeast against steep underlying topography.

\section{RHYOLITE OF MINERS CREEK}

The oldest rock unit known in the western part of the Creede area in the central San Juan Mountains is an accumulation of rhyolite flows and pyroclastic rocks more than 1,200 feet thick exposed along the flanks of Miners Creek. It is overlapped on its southeast margin by the Bachelor Mountain Rhyolite, and the abrupt character of the overlap suggests that the main mass of the underlying rhyolite may be a bulbous volcanic dome or steep-sided flow. The rock is a gray to pink porphyry consisting of about 20 percent phenocrysts and 80 percent lithoidal groundmass. Plagioclase and sanidine predominate among the phenocrysts, but sparse, small biotite crystals are widespread.

A formal name is not proposed for the rhyolite of Miners Creek because there is little evidence of its areal extent or of its relations with rock units other than the Bachelor Mountain Rhyolite.

\section{BACHELOR MOUNTAIN RHYOLITE}

Bachelor Mountain Rhyolite is a new name given here to all the rhyolitic rocks included by Emmons and Larsen (1923) in their Willow Creek Rhyolite, Campbell Mountain Rhyolite, Windy Gulch Rhyolite Breccia, and intrusive rhyolite porphyry. Emmons and Larsen (1923, p. 19-30) described the Willow Creek and Campbell Mountain Rhyolites as two sequences of rhyolitic lava flows and flow breccias separated by an irregular erosion surface, and included both in their Alboroto Group. They believed (1923, p. 38-40) that the Windy Gulch Rhyolite Breccia was separated from the Campbell Mountain Rhyolite by a major unconformity, and that it belonged to their younger Piedra Group. Instead, we have found the Willow Creek, Campbell Mountain, and Windy Gulch units to be members of an intergradational sequence of pumiceous pyroclastic rocks that warrants formation rank. These rocks range upward from densely welded tuff closely resembling fluidal rhyolite flow rock (Willow Creek Member), through compact welded tuff in the middle (Campbell Mountain Member), to a porous moderately welded to nonwelded tuff at the top (Windy Gulch Member). Breaks within this sequence occur only where the Bachelor Mountain rocks intertongue with other volcanic rocks at the margins of the deposit. 
Bachelor Mountain Rhyolite is named for discontinuous but representative exposures in the type area of the formation on Bachelor Mountain, northwest of Creede. No single complete section of the formation is exposed anywhere in the central San Juan Mountains. The greatest thickness observed of the Willow Creek Member is more than 2,000 feet thick, and the base is not exposed. More than 1,000 feet of the Campbell Mountain Member and more than 900 feet of the Windy Gulch Member are exposed locally, but the full thickness of either unit could not be measured.

The Campbell Mountain and Windy Gulch Members intertongue laterally with flows and breccias of Shallow Creek Quartz Latite to the west, and a lens of typical Campbell Mountain welded tuff is interlayered with the Phoenix Park Member of the La Garita Quartz Latite to the east.

The Bachelor Mountain Rhyolite consists mainly of microcrystalline to cryptocrystalline matrix with 5 percent or less of phenocrysts and 20 percent or less of foreign rock fragments. The phenocrysts are largely sanidine and plagioclase, with sparse biotite and magnetite. Inclusions of foreign rock fragments range from a few percent in the Willow Creek Member, to as much as 20 percent in parts of the Campbell Mountain and Windy Gulch Members.

Eruption of the Bachelor Mountain Rhyolite culminated in collapse of the Bachelor Mountain cauldron (table 132.2) near the town of Creede, and in the development of a series of normal faults that extend north to northwest out from the more strongly subsided area.

\section{SHALLOW CREEK QUARTZ LATITE}

Shallow Creek Quartz Latite is a new name here applied to a group of lava flows and volcanic breccias that crop out in the drainage basins of Rat Creek, Miners Creek, and Shallow Creek 2 to $4 \frac{1}{2}$ miles west of Creede. The flows and breccias are irregularly mixed, and the unit varies so greatly from place to place that no single section is representative; the largest known body, along the northern flank of the Shallow Creek drainage basin, is designated as the type area of the formation. Maximum thickness in this vicinity is 600 to 700 feet.

The rocks included in the Shallow Creek Quartz Latite were originally described by Emmons and Larsen (1923, p. 36-38) under the informal name hornblende quartz latite. This unit marked the base of their Piedra Group in the western part of the Creede district, and they believed that it was separated from the underlying Alboroto rocks by an irregular erosional unconformity. Larsen and Cross (1965, p. 143) called the same rocks hornblende rhyolitic latites, and agreed with the earlier stratigraphic interpretations. Our mapping, on the other hand, has shown that the Shallow Creek Quartz Latite intertongues laterally with the upper members of the gradational sequence of rocks in the Bachelor Mountain Rhyolite, and that the supposed unconformity between rocks included by Emmons and Larsen (1923) in their Alboroto and Piedra Groups does not exist.

The Shallow Creek Quartz Latite consists largely of volcanic breccias; lava flows are thin and are estimated to make up less than 10 percent of the formation. The rock is porphyritic, with small phenocrysts, rarely exceeding a few millimeters in maximum dimensions, set in an aphanitic groundmass. The phenocrysts consists mainly of plagioclase, 15 percent; hornblende, 5 percent; and a few percent each of biotite and magnetite. Sanidine and clinopyroxene occur locally. Much of the Shallow Creek Quartz Latite is irregularly altered, and either is oxidized and burnt in appearance, or is irregularly altered to clay and crisscrossed with veinlets of quartz and carbonate.

\section{FARMERS CREEK RHYOLITE}

Farmers Creek Rhyolite is a new name here given to a heterogeneous assemblage of pyroclastic rocks and minor flow rocks that was deposited locally on the rough topography left by subsidence of the Bachelor Mountain cauldron. Larsen and Cross (1956, p. 146-147) refer the rocks here called Farmers Creek Rhyolite to the basal part of the lower member of their Piedra Rhyolite. The different rock types in the Farmers Creek Rhyolite are well exposed in its type area along Farmers Creek, $2 \frac{1}{2}$ to $4 \frac{1}{2}$ miles east of the town of Creede where a thickness of more than 1,000 feet is indicated.

The Farmers Creek Rhyolite can be divided into three subequal parts in the type area and along West Bellows Creek to the east. The lower third is a soft, cavernous-weathering pumiceous tuff breccia that forms massive, unsorted layers a few feet to a few tens of feet thick. Foreign rock fragments constitute 15 to 26 percent of the rock. Some of the rocks are moderately welded, but most are only slightly welded or are nonwelded. A few lenses of red porphyritic flow breccia are interlayered with the predominant tuff breccias.

The middle third of the formation consists of a succession of layers of differentially welded tuffs whose harder units form prominent ledges along the hill slopes. Massive dark-brown densely welded tuff is the most widely exposed rock type. This grades both vertically and laterally into a lighter brown obviously fragmental welded tuff with good eutaxitic texture. Phenocrysts constitute 5 to 10 percent of the rock and 
consist of sanidine, plagioclase, biotite, and magnetite. Foreign rock fragments constitute 5 to 10 percent of the rock.

Crystal-rich welded tuff forming the upper third of the Farmers Creek Rhyolite is exposed only along the canyon of West Bellows Creek. Phenocrysts of plagioclase, sanidine, biotite, hornblende, clinopyroxene, sphene, quartz, and magnetite are so abundant that the matrix is largely obscured and most of the rock appears structureless in hand specimen. The composition of these rocks appears anomalous with respect to the rest of the formation, and its inclusion in the Farmers Creek Rhyolite is provisional.

\section{MAMMOTH MOUNTAIN RHYOLITE}

Mammoth Mountain Rhyolite was originally named by Emmons and Larsen (1923, p. 40-44), who believed it to be a single thick lava flow. An overlying unit consisting largely of partially welded to nonwelded tuffs was mapped separately. Larsen and Cross (1956, p. 147) later assigned all these rocks, as well as the underlying Farmers Creek Rhyolite, to the lower rhyolite member of their Piedra Rhyolite. As redefined here, the Mammoth Mountain Rhyolite includes the Mammoth Mountain and the overlying soft tuffs of Emmons and Larsen (1923), as well as all laterally equivalent rocks, which together form a great composite ash-flow sheet (Smith, 1960, p. 158).

The Mammoth Mountain Rhyolite is widespread in the central San Juan Mountains, and good exposures have been recognized as far as 15 miles southeast, 10 miles southwest, and 18 miles south of Creede. It is absent along the Continental Divide north of Creede, where mountainous terrain stood above the level of accumulation at the time the Mammoth Mountain ash flows were erupted. The formation is locally as much as 2,000 feet thick, and is 500 to 1,000 feet thick over wide areas.

The Mammoth Mountain Rhyolite ranges from crystal-poor welded ash-flow tuffs with 5 to 10 percent phenocrysts to crystal-rich welded ash-flow tuffs with 30 to 60 percent phenocrysts. The matrix of the densely welded tuff is typically lithoidal and reddishbrown except for the black glass of the basal vitrophyre layer. Plagioclase phenocrysts are predominant in all of the rock. Sanidine phenocrysts are common in the crystal-poor rocks, but are absent in most of the crystalrich phase. Biotite is the most prevalent mafic phenocryst in the Mammoth Mountain Rhyolite; green clinopyroxene phenocrysts are characteristic of and are restricted to the crystal-rich rocks. The ash-flow tuffs range in composition from rhyolite to quartz latite.

\section{WASON PARK RHYOLITE}

Wason Park Rhyolite is a new name given to a distinctive sheet of rhyolitic welded tuff that forms prominent cliffs throughout much of the central San Juan area near Creede. It forms the floor of Wason Park, a high flat bench on the southern flank of the La Garita Mountains northeast of Creede, which is taken as the type area. Wason Park Rhyolite is equivalent to the tridymite latite unit of Emmons and Larsen (1923, p. 45), and in its type area and in most other places was included by Larsen and Cross (1956, p. 152-153) in the tridymite' rhyolitic latite member of their Piedra Rhyolite.

The Wason Park Rhyolite is 600 to 700 feet thick over wide areas in the central San Juan Mountains; it wedges out northward toward the Continental Divide. The formation is largely coextensive with the underlying Mammoth Mountain Rhyolite, except that it extends somewhat farther laterally over the rough underlying topography. A tongue of Huerto Formation separates the Mammoth Mountain and Wason Park Rhyolites south of Bristol Head, about 10 miles southwest of Creede, and several quartz latite lava flows intervene between the formations east of Wagon Wheel Gap, 8 to 15 miles southeast of Creede.

Typical Wason Park Rhyolite is a crystal-rich densely welded tuff with 25 to 30 percent phenocrysts set in a reddish-brown lithoidal matrix. Distinctive white to light-gray tridymitic streaks representing collapsed pumice fragments are widespread and are characteristic of the formation. The phenocrysts are predominantly plagioclase and sanidine, with minor biotite and magnetite. A dense black vitrophyre 10 to 15 feet thick is generally present at the base of the formation, and the top locally retains a few feet to a few tens of feet of less welded rock.

\section{HUERTO FORMATION}

The name Huerto Formation was originally used by Patton (1917, p. 20), and later by Emmons and Larsen (1923, p. 12) and Knowlton (1923, p. 184). The same rocks were called Huerto Andesite by Cross and Larsen (1935, p. 82), and Huerto Quartz Latite by Larsen and Cross (1956, p. 143); they believed that the Huerto rocks accumulated during a separate period of volcanic activity between eruption of their Alboroto and Piedra Rhyolites.

In contrast, we have found that the Huerto rocks were erupted from a number of separate but areally associated centers in the central San Juans concurrently with many of the units included by Larsen and Cross in their Piedra Rhyolite. Also, a local assemblage of lavas and breccias 6 to 10 miles southwest of Creede, 
called Conejos Quartz Latite by Larsen and Cross (1956, p. 99), is now known to be part of the compound Huerto accumulation. Although it eventually may be possible to separate out individual mappable units, present limited data make it expedient to refer to the volcanic accumulation as a whole as the Huerto Formation.

The main mass of the Huerto Formation lies southwest of Creede, where three main centers of accumulation were reported by Larsen and Cross (1956, p. 143). Marginal rocks of the Huerto Formation intertongue with the widespread welded tuff units north and northeast of these centers. The dark lavas and breccias underlie Mammoth Mountain Rhyolite; a thin tongue of breccias intervenes locally between the Mammoth Mountain and Wason Park Rhyolites; and a tongue of lavas and breccias above the Wason Park Rhyolite extends nearly to Creede.

The Huerto Formation thickens and thins markedly from place to place, and the different flow and breccia accumulations may originally have ranged widely in thickness. More than 2,000 feet of rudely bedded Huerto breccias is exposed on the west face of Bristol Head, southwest of Creede; the local accumulation of Huerto underlying the Mammoth Mountain Rhyolite south of Bristol Head is more than 800 feet thick; and the maximum preserved thickness of Huerto rocks overlying the Wason Park Rhyolite near Creede is about 450 feet.

Most rocks in the Huerto Formation are dark, finegrained lavas and breccias. They range widely in composition, but most appear to be dacitic. Phenocrysts are generally small and inconspicuous, and consist of predominant plagioclase and minor associated clinopyroxene, hornblende, and magnetite.

\section{INTRACALDERA LAVA FLOWS}

Local thick quartz latitic to rhyolitic lava flows are interlayered with the widespread ash-flow sheets in the central San Juan Mountains (table 132.2). Most of these flows and some related volcanic necks are exposed around the outer margin of the Creede caldera, suggesting that this margin served to localize many of the eruptions. Most of the rocks are drab gray, coarsely porphyritic quartz latites; some lighter colored rhyolitic flows are interspersed with the quartz latite flows or occur singly.

The oldest of these local lava-flow accumulations underlies the Mammoth Mountain Rhyolite east of Goose Creek and 5 miles south of Wagon Wheel Gap. A number of flows intervene between the Mammoth Mountain and Wason Park Rhyolites east and northeast of Wagon Wheel Gap, and a distinctive white rhyolite flow occupies the same position near Shallow Creek, northwest of the caldera. A quartz latite flow overlies the Wason Park Rhyolite and forms the floor of Silver Park northeast of the Creede caldera. Similar flows and a related neck are exposed about $5 \frac{1}{2}$ miles north of Creede; these rocks are believed to underlie the Rat Creek Quartz Latite, but available evidence is not conclusive.

\section{RAT CREEK QUARTZ LATITE}

Rat Creek Quartz Latite as here redefined is a widespread sequence of welded and nonwelded ash-flow tuffs, with both the base and top of the formation marked by surfaces that show evidence of erosion, but with no erosional break recognized within the sequence. A local near-vent accumulation of lavas and pyroclastic rocks along West Willow Creek intertongues laterally with the more widespread ash-flow tuffs.

As originally defined by Emmons and Larsen (1923, p. 57-58), the name Rat Creek Quartz Latite was applied only to the upper part of this sequence. They believed the rocks to be interlayered lava flows and tuffs, but recognized that they were closely related to the underlying tuff to which they gave the informal name "quartz latite tuff" (Emmons and Larsen, 1923, p. 54-57). Larsen and Cross (1956, p. 153-156) generally followed Emmons and Larsen in separating the lower tuff from the upper mixed unit. The lower unit was called the tuff member of their Piedra Rhyolite, and the upper mixed unit was lumped with the overlying Nelson Mountain Quartz Latite of Emmons and Larsen (1923, p. 59) into the rhyolitic latite member of their Piedra Rhyolite. Hence their upper rhyolitic member included an erosional surface representing a significant break in deposition of the pyroclastic rocks, and their upper and lower members met at a gradational contact.

The Rat Creek Quartz Latite is now found only in the high mountains extending east from the Spring Creek Pass area, 13 miles northwest of Creede, through the Nelson Mountain area north of Creede, to the La Garita Mountains area northeast of Creede. It is excellently exposed at Wheeler Monument, just south of Half Moon Pass. The formation consists largely of soft pyroclastic rocks, which typically form steep debriscovered slopes beneath the highest cliff-forming welded tuff unit in the area. The formation is 600 to 800 feet thick over wide areas, but ranges in thickness from 0 where it wedges out against older hills to nearly 1,000 feet locally.

Most of the Rat Creek rocks are slightly welded to nonwelded ash-flow tuffs. A distinctive pink welded tuff 50 to 100 feet thick forms a prominent ledge in the middle of the unit north of Creede. Thin layers of air-fall tuff or reworked sedimentary tuff intervene locally between the ash-flow layers. The welded tuffs 
contain 20 to 30 percent phenocrysts, chiefly plagioclase, minor biotite and clinopyroxene, and sparse sanidine, quartz, hornblende, and magnetite.

\section{NELSON MOUNTAIN QUARTZ LATITE}

As redefined in this report, Nelson Mountain Quartz Latite includes all rocks in the former Equity Quartz Latite (Alboroto Group), and Nelson Mountain Quartz Latite (Piedra Group) of Emmons and Larsen (1923, p. 32-34, 59-60). Larsen and Cross (1956) did not mention the former Equity unit specifically, but show the area underlain by it as Alboroto Rhyolite on their geologic map, and the former Nelson Mountain Quartz Latite was included in the rhyolitic latite member of their Piedra Rhyolite. We have found that these units intergrade and form a single genetic unit to which we have extended the name Nelson Mountain Quartz Latite. The name Equity Quartz Latite is herewith abandoned.

Nelson Mountain Quartz Latite characteristically forms resistant capping ledges on flat-topped ridges from the Nelson Mountain area north of Creede to the Snow Mesa area, 12 miles northwest of Creede, and on the flat crest of the La Garita Mountains eastward from the Half Moon Pass area 9 miles northeast of Creede. In addition, a great mass of Nelson Mountain Quartz Latite underlies the San Luis Peak area 9 miles north of Creede, where it apparently fills a cauldron structure. The widespread sheet of Nelson Mountain Quartz Latite ranges generally from 0 to 500 feet in thickness, but according to Larsen and Cross (1956, p. 132) nearly 4,000 feet of the unit (which they called Alboroto Rhyolite) is exposed in the San Luis Peak area.

The Nelson Mountain Quartz Latite is a composite ash-flow sheet that changes from a simple cooling unit (Smith, 1960, p. 157) of predominantly densely welded tuff in the Nelson Mountain area, north of Creede, laterally, both to the east and the west into a compound cooling unit, and eastward at least into several individual cooling units that range from predominantly densely welded to predominantly nonwelded.

Phenocrysts range from 20 to 50 percent of the Nelson Mountain Quartz Latite, and consist for the most part of plagioclase, with lesser quantities of biotite, and minor or accessory clinopyroxene, quartz, sanidine, hornblende, and magnetite.

\section{SNOWSHOE MOUNTAIN QUARTZ LATITE}

Snowshoe Mountain Quartz Latite is a new name given to the mass of quartz latite ash-flow tuffs, mostly densely welded, that constitutes most of the core of the Creede caldera. The type area of the formation is Snowshoe Mountain which forms the highest part of the caldera core, south of Creede.
Larsen and Cross $(1956$, p. 132, 138) believed that the great mass of quartz latite under Snowshoe Mountain was a local accumulation, possibly a single large flow, within the upper rhyolitic latite member of their Alboroto Rhyolite. In contrast, we have found the Snowshoe Mountain Quartz Latite to be the youngest major ash-flow unit in the central San Juan Mountains, and it is thus more equivalent to the upper part of the Piedra Rhyolite of Larsen and Cross (1956, p. 144-155).

The Snowshoe Mountain Quartz Latite is restricted to the core of the Creede caldera, and the sum of several partial sections indicates that the formation is at least 4,000 feet and perhaps more than 6,000 feet thick. Talus breccias are intertongued marginally with at least the upper 2,000 feet of this unit, indicating that it accumulated within an existing depression. Caldera subsidence and accumulation are believed to have been concurrent.

The Snowshoe Mountain Quartz Latite consists entirely of crystal-rich ash-flow tuff. Most of the rock is densely welded, and toward the center of the caldera only a few local less welded partings indicate the compound cooling characteristics of the deposit. Toward the southern part of the caldera, however, at least two different segments of the formation, each several hundred feet thick, soften laterally from densely welded to slightly or moderately welded. The top of the formation is everywhere marked by less welded rocks that range up to several hundred feet in thickness.

The Snowshoe Mountain Quartz Latite is a drab crystal rich welded tuff that closely resembles much of the more densely welded rock in the Nelson Mountain Quartz Latite. Snowshoe Mountain rocks consist of an average of nearly half phenocrysts, and have a distinctly granular aspect in hand specimen. As in the other quartz latitic ash-flow units, plagioclase predominates among the phenocrysts, followed in abundance by biotite, and by minor clinopyroxene, hornblende, quartz, sanidine, and magnetite.

\section{FISHER QUARTZ LATITE}

As used by Larsen and Cross (1956, p. 172), the Fisher Quartz Latite (or latite-andesite) was a sequence of local accumulations of coarsely porphyritic flows and breccias in the San Juan Mountains and was believed to be younger than the Potosi Volcanic Series and the Creede Formation, and older than the Hinsdale Formation. Larsen and Cross (1956, p. 172) state that these rocks have certain textural and mineralogical characteristics which distinguish them from rocks of the Potosi Volcanic Series, and that at different places they rest unconformably on the Silverton Volcanic Series, the Potosi Volcanic Series, and the Creede Formation. Rocks assigned to this formation 
occur throughout the central San Juan Mountains.

Our work has shown that this earlier concept must be revised in important aspects. The rocks in the type area of the formation on Fisher Mountain were erupted after the last main subsidence of the Creede caldera and followed doming of the caldera core. We therefore restrict the Fisher Quartz Latite to lavas of this age. Some Fisher flows around the Creede caldera underlie the Creede Formation, others intertongue with it, and still others appear somewhat younger; the bulk of the Fisher Quartz Latite, however, appears to have been erupted concurrently with Creede sedimentation. The evidence for the Fisher being equivalent in age to the Creede Formation directly contradicts Larsen and Cross (1956, p. 168, 172), who believed that the Fisher lavas flowed down deep valleys cut into the Creede.

Many Fisher rocks appear identical with coarsely porphyritic flows interlayered with earlier widespread ash-flow sheets adjacent to the Creede caldera (Piedra Rhyolite of earlier terminology), and Larsen and Cross (1956, pl. 1) have included several of these older flows in their Fisher Quartz Latite. The only clear distinction between these different flows is in age relative to caldera subsidence. Thus the contention of Larsen and Cross (1956, p. 172) that Fisher Quartz Latite is distinct from all rocks in the Potosi Volcanic Series in time and petrologic character does not appear tenable, and in our opinion the Fisher eruptions represent merely a continuation of a related sequence of volcanic events.

Most Fisher Quartz Latite near Creede was erupted around the margin of the Creede caldera, or along grabens extending outward from the caldera. The largest mass underlies Fisher Mountain and adjacent areas south of the caldera; another substantial body accumulated in the Wagon Wheel Gap area 5 to 8 miles southeast of Creede. A smaller accumulation is exposed on the west flank of the caldera core 7 miles southwest of Creede, and several flows cap the ridge between upper Rat and Miners Creeks northwest of Creede.

Possibly some of the other relatively late accumulations of coarsely prophyritic lava through the central San Juan Mountains correlate with the Fisher Quartz Latite as we have redefined it, but we would prefer not to extend the name to these until their age relations can be established more definitely.

Fisher Quartz Latite consists of coarsely porphyritic lava, predominantly quartz latite but with some rhyolite. Plagioclase, biotite, and clinopyroxene are the most abundant phenocrysts, and small quantities of magnetite are invariably present. In addition, some flows contain significant quantities of hornblende, sanidine, and quartz.

\section{CREEDE FORMATION}

The Creede Formation was originally named and described by Emmons and Larsen (1923, p. 61-70), who divided it into a lower member consisting largely of fine-grained well-bedded deposits with interbedded travertine, and an upper member consisting of coarser material, largely stream deposits, and a few thin lava flows. Larsen and Cross (1956, p. 167-172) closely followed the earlier description. We also include the same assemblage of rocks in the Creede Formation, but have found that the earlier recognized subdivisions are in a large part laterally equivalent facies not readily separated.

The Creede Formation consists largely of sedimentary rocks that were deposited in a structural trough around the margin of the domed core of the Creede caldera. These deposits follow the western, northern and eastern margin of the caldera for nearly $270^{\circ}$ of arc, from Lime Creek, down the Rio Grande to Wagon Wheel Gap, and up Goose Creek for nearly 5 miles. The original thickness of the formation is not known, but present remnants extend over a vertical range of at least 2,400 feet.

The Creede Formation consists of several distinct facies that are so complexly intermixed that it is not practical to separate them. Thin-bedded tuffaceous lake beds, largely shale and sandstone with some tuff beds, intertongue marginally with fluviatile sandstone and conglomerate beds in the vicinity of old tributary valleys, and with fanglomerate and coarse sedimentary breccias of local derivation elsewhere along the margins. The edge of the formation against buried rough topography is commonly marked by accumulations of talus, landslide, slopewash, and similar debris. Travertine and calcareous tufa were deposited widely by mineral springs that were active concurrent with sedimentation. Some volcanic breccia and a few layers of welded tuff are interlayered locally.

\section{REFERENCES}

Cross, Whitman, and Purington, C. W., 1899, Description of the Telluride quadrangle [Colorado]: U.S. Geol. Survey Geol. Atlas, Folio 57.

Cross, Whitman, Howe, Ernest, and Ransome, F. L., 1905, Description of the Silverton quadrangle [Colorado]: U.S. Geol. Survey Geol. Atlas, Folio 120.

Cross, Whitman, and Larsen, E. S., 1935, A brief review of the geology of the San Juan region of southwestern Colorado: U.S. Geol. Survey Bull. 843, 138 p.

Emmons, W. H., and Larsen, E. S., 1923, Geology and ore deposits of the Creede district, Colorado: U.S. Geol. Survey Bull. 718, 198 p. 
Knowlton, F. H., 1923, Fossil plants from the Tertiary lake beds of south-central Colorado: U.S. Geol. Survey Prof. Paper 131, p. 183-192.

Larsen, E. S., Jr., and Cross, Whitman, 1956, Geology and petrology of the San Juan region, southwestern Colorado: U.S. Geol. Survey Prof. Paper 258, 303 p.

Luedke, R. G., and Burbank, W. S., 1963, Tertiary volcanic stratigraphy in the western San Juan Mountains, Colorado: Art. 70 in U.S. Geol. Survey Prof. Paper 475-C, p. C39C44.

MacGinitie, H. D., 1953, Fossil plants of the Florissant beds, Colorado: Carnegie Inst. Washington Pub. 599, 198 p.

Patton, H. B., 1917, Geology and ore deposits of the PlatoroSummitville mining district, Colorado: Colorado Geol. Survey Bull. 13, 122 p.
Smith, R. L., 1960, Zones and zonal variations in welded ash flows: U.S. Geol. Survey Prof. Paper 354-F.

Smith, R. L., and Bailey, R. A., 1962, Resurgent cauldronstheir relation to granitic ring complexes and large volume rhyolitic ash-flow fields, [abs.] in International Symposium on Volcanology, Japan: Internat. Assoc. Volcanology, 1962, p. 67-68.

Steven, T. A., and Ratté, J. C., 1960a, Geology and ore deposits of the Summitville district, San Juan Mountains, Colorado: U.S. Geol. Survey Prof. Paper 343, 70 p.

- 1960b, Relation of mineralization to caldera subsidence in the Creede district, San Juan Mountains, Colorado: Art. 8 in U.S. Geol. Survey Prof. Paper 400-B, p. B14-B17. 


\title{
Article 133
}

\section{VALLERIITE AND THE NEW IRON SULFIDE, MACKINAWITE}

\author{
By HOWARD T. EVANS, JR., CHARLES MILTON, E. C. T. CHAO, ISIDORE ADLER, \\ CYNTHIA MEAD, BLANCHE INGRAM; and RICHARD A. BERNER; ${ }^{1}$ Washington, D.C.; La Jolla, Calif.
}

\begin{abstract}
Valleriite from Loolekop, South Africa, and Kaveltorp, Sweden, is rhombohedral, space group $R 3 m$ or $R \overline{3} m$, with $a=3.792 \mathrm{~A}$, and $c=34.10 \mathrm{~A}$, and its probable unit-cell content is $6 \mathrm{CuFeS}_{2}$. Mackinawite, a new copper-free iron sulfide from the Mackinaw mine, Snohomish County, Wash., is tetragonal, space group $P 4 / n m m$, with $a=3.679 \mathrm{~A}, c=5.047 \mathrm{~A}$, and a unitcell content of $2 \mathrm{FeS}$. Both minerals evidently have layer structures, in accord with their extreme optical anisotropy. Many occurrences of mackinawite have probably been mistaken for valleriite.
\end{abstract}

Few minerals have caused mineralogists more justified uncertainty or unsound assurance than the sulfide valleriite. Since its discovery at Nya Kopparberg, Sweden, by Blomstrand (1870) almost a century ago, it has led an uneasy life in the mineralogical literature. Its first description was encumbered with a complex and implausible proposal for composition, which led Petrén (1898) to reject the work of Blomstrand and consign the mineral to the limbo of species discredited as mixtures. It was revived by Ramdohr and Ödman (1932) on the basis of a restudy of the Swedish material already described by Blomstrand and Petrén. Only recently has the existence been suspected of another distinct sulfide phase occurring in mineral assemblages similar to those which contain valleriite (Milton and Milton, 1958; Kouvo and Vuorelainen, 1959). This new phase, which we designate mackinawite, is so similar in physical properties to valleriite that it has evidently been the object of a great deal of confusion. In this article we present new data for valleriite and descriptive data for a previously undefined mineral which we call mackinawite; and we take note of the difficulties that have arisen from confusion of the two minerals.

\section{NEW DATA FOR VALLERIITE}

We have not had available Blomstrand's type material from Nya Kopparberg, but our specimen from

1 Scripps Institution of Oceanography; work done in preparation of a thesis at II arvard University, Cambridge, Mass.
Kaveltorp, described in detail by Ödman (1933), is closely similar. The apparently homogeneous bronzy graphitic mineral gives a characteristic powder pattern, but attempts to obtain single-crystal patterns from tiny flakes yielded such poor information that a unit cell could not be deduced. Fortunately, new material of much better quality from Loolekop in northeast Transvaal, South Africa, recently became available to us through the courtesy of L. R. Page, of the U.S. Geological Survey. The mineral occurrence, in small pea-sized masses in carbonate rock associated with other iron-copper sulfides, is quite like that of the Swedish mineral, but the crystal flakes are generally larger and better formed. The chemical composition is entirely analogous to that found for the Kaveltorp material, and to that given by Blomstrand (see table 133.1), showing again the anomalous presence of about

TABLE 133.1.-Chemical analyses of valleriite

\begin{tabular}{|c|c|c|c|c|}
\hline Constituent & & San & & \\
\hline & 1 & 2 & $s$ & 4 \\
\hline $\mathrm{Cu}$ & $\overline{17.7}$ & $\overline{17.6}$ & $\overline{19.8}$ & 18.6 \\
\hline & 26. 3 & 21.2 & 20.0 & 21.1 \\
\hline - - - & 22.5 & 21.4 & 21.6 & 21. 3 \\
\hline $\mathrm{Al}_{2} \mathrm{O}_{3}$ & 5. 1 & 8.1 & 8. 5 & $-\ldots$ \\
\hline $\mathrm{MgO}_{-}$ & 10.6 & 16. 2 & 16. 0 & \\
\hline $\mathrm{CaO}$ & 0.3 & 1.7 & 1. 3 & - \\
\hline- & 0.3 & - - - - & ..... & $\cdots$ \\
\hline$a_{2}$ & 0.6 & & & $-\cdots-$ \\
\hline 4 & 10.8 & 12. 2 & 10. 8 & -- \\
\hline $\mathrm{able}+\mathrm{SiO}_{2} \ldots$ & $\ldots$ & 1.8 & 3. 3 & \\
\hline tal. & 94. 2 & 100. 2 & 101. 3 & \\
\hline
\end{tabular}

1. Nya Kopparberg, Sweden; Blomstrand (1870), from 5 partial analyses.

2. Kaveltorp, Sweden; Blanche Ingram, analyst; $\mathrm{MnO}, 0.5$ percent.

3. Loolekop, South Africa; Blanche Ingram, analyst; $\mathrm{MnO}$, 0.5 percent.

4. Theoretical for $\mathrm{CuFeS}_{2}$, corresponding to 61.0 percent of total.

the same amount of aluminum and magnesium hydroxides together with iron, copper, and sulfur. The characteristic X-ray powder-diffraction pattern, shown in table 133.2, conclusively establishes the identity 
EVANS, MILTON, CHAO, ADLER, MEAD, INGRAM, AND BERNER

TABLE 133.2-X-ray powder-diffraction data for valleriite

\begin{tabular}{|c|c|c|c|c|c|c|c|}
\hline \multicolumn{2}{|c|}{ Calculated 1} & \multicolumn{2}{|c|}{ Loolekop 2} & \multicolumn{2}{|c|}{ Kaveltorp $^{2}{ }^{2}$} & \multicolumn{2}{|c|}{ Kaveltorp ${ }^{3}$} \\
\hline hlkl & $\underline{d(A)}$ & $\underline{d(A, o b s .)}$ & $\underline{I}$ & $\underline{d(A, o b s .)}$ & $\underline{I}$ & $\underline{d(A, o b s .)}$ & $I$ \\
\hline 00.3 & 11. 367 & 11. 39 & 10 & 11. 48 & 9 & 11.5 & 10 \\
\hline 00.6 & 5. 683 & 5. 71 & 10 & 5. 68 & 10 & 5. 75 & 10 \\
\hline 00.9 & $\begin{array}{l}\text { 3. } 789 \\
3.260\end{array}$ & 3. 80 & 5 & 37 & 7 & 3. 83 & 8 \\
\hline $\begin{array}{l}10 . \frac{1}{2} \\
10.2\end{array}$ & $\begin{array}{l}\text { 3. } 269 \\
3.295\end{array}$ & 3. 27 & 6 & 3.27 & 7 & 3. 29 & 10 \\
\hline 10.4 & 3. 064 & $\begin{array}{l}\text { J. } 25 \\
\text { 3. } 07\end{array}$ & $\begin{array}{l}5 \\
2\end{array}$ & - & -- & $\begin{array}{l}\text { 3. } 23 \\
3.08\end{array}$ & 8 \\
\hline $10 . \overline{5}$ & 2. 959 & 2.958 & 1 & $2.97 \overline{4}$ & $\overline{1}$ & & 2 \\
\hline 00.12 & 2. 842 & 2. 846 & 5 & 2. 842 & 5 & $2.8 \overline{7}$ & 8 \\
\hline $10 . \overline{8}$ & $\begin{array}{l}\text { 2. } 601 \\
\text { 2. } 601\end{array}$ & 2. 604 & 1 & -- & -- & $\cdots$ & -- \\
\hline & & & & 2. 531 & $\overline{3}$ & 2. 48 & $\overline{2}$ \\
\hline 10.10 & 2. 365 & 2. 346 & 2 & 2.364 & 1 & 2.37 & 8 \\
\hline $00 . \frac{15}{11}$ & $\begin{array}{l}2.273 \\
2.254\end{array}$ & 2050 & & 2.275 & 6 & 2. 29 & 8 \\
\hline $\begin{array}{l}\text { 10. } 11 \\
10.13\end{array}$ & $\begin{array}{l}\text { 2. } 254 \\
\text { 2. } 050\end{array}$ & $\begin{array}{l}\text { 2. } 259 \\
\text { 2. } 041\end{array}$ & 2 & ---- & -- & 205 & 6 \\
\hline 10. $\overline{14}$ & 1. 956 & $\begin{array}{r}2.01 \\
-\ldots . .--\end{array}$ & $\begin{array}{c}2 \\
--\end{array}$ & $\cdots$ & $\begin{array}{l}-- \\
--\end{array}$ & 2. 05 & 6 \\
\hline 11. 0 & 1. 896 & & - & & - & 1. 91 & 10 \\
\hline 00. 18 & 1. 894 & 1. 885 & 5 & 1. 894 & 6 & 1.90 & 10 \\
\hline $\begin{array}{l}11.3 \\
11.6\end{array}$ & $\begin{array}{l}1.870 \\
1.799\end{array}$ & 1. 860 & 5 & 1. 870 & 5 & 1. 87 & 10 \\
\hline 10. 16 & 1. 788 & 1.780 & $\overline{1}$ & $1 . \overline{79}$ & $\overline{1}$ & 1. 80 & $\overline{8}$ \\
\hline $10 . \overline{17}$ & 1. 712 & $\ldots$ & -- & $\ldots$ & -- & $\ldots$ & -. \\
\hline 11. $\frac{9}{7}$ & 1. 696 & $\ldots$ & -- & $\ldots$ & -- & $\ldots$ & -- \\
\hline 20.1 & 1. 640 & -- & -- & 1636 & & 1 & $\bar{A}$ \\
\hline $\begin{array}{l}20.2 \\
00.21\end{array}$ & $\begin{array}{l}1.634 \\
1.624\end{array}$ & $1.62 \overline{9}$ & $\overline{1}$ & $\begin{array}{l}1.636 \\
1.620\end{array}$ & 1 & 1. 64 & 4 \\
\hline $20 . \frac{4}{4}$ & $\begin{array}{l}1.024 \\
1.612\end{array}$ & --- & $\ldots$ & 1.020 & 1 & $\ldots$ & -- \\
\hline 20.5 & 1. 596 & $\ldots$ & _- & - & -- & 1.59 & 6 \\
\hline 11. 12 & 1. 577 & $\ldots$ & -- & $\ldots$ & - & $\ldots$ & $-z_{0}$ \\
\hline 10.19 & 1. 575 & $\ldots$ & -- & $\ldots$ & $\ldots$ & $\ldots$ & $\ldots$ \\
\hline 20.7 & 1. 556 & 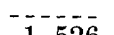 & $i$ & ーーンー & - & & \\
\hline 20. $\frac{8}{20}$ & 1. 532 & 1.526 & 1 & 1.534 & 2 & 1. 54 & 6 \\
\hline $20 . \frac{20}{10}$ & $\begin{array}{l}\text { 1. } 013 \\
1.479\end{array}$ & - & $\begin{array}{l}-- \\
--\end{array}$ & 1.485 & $-\overline{1}$ & $\begin{array}{l}1.52 \\
1.50\end{array}$ & 2 \\
\hline 11. 15 & 1. 456 & $\ldots$ & -- & $\ldots$ & $\ldots$ & 1. 47 & 2 \\
\hline 20.11 & 1. 451 & $\ldots$ & - - & $\ldots$ & -. & & \\
\hline$\cdots-$ & $-\ldots-$ & .. & -- & $\ldots$ & -- & 1. 23 & 2 \\
\hline & $\cdots--1$ & & -- & - & -- & 1. 22 & 3 \\
\hline & $\ldots$ & $\ldots$ & - & $\cdots$ & -- & $\begin{array}{l}\text { 1. } 14 \\
\text { 1. } 09\end{array}$ & $\begin{array}{l}4 \\
4\end{array}$ \\
\hline-- & $\ldots-\ldots$ & $\ldots$ & - - & $\ldots \ldots$ & -- & 1. 06 & 6 \\
\hline & $\ldots-$ & - & -- & $\ldots \ldots$ & -- & 1. 04 & 10 \\
\hline-- & $\cdots$ & $\cdots$ & -- & $-\cdots-$ & -- & 1. 03 & 10 \\
\hline-- & -+ & & & -- & -- & 1. 01 & 10 \\
\hline
\end{tabular}

1 Calculated for unit cell given in table 3 .

2 Patterns made by the authors with FeK $\alpha$ radiation, camera diameter $114.6 \mathrm{~mm}$. Intensities are on a geometric scale.

3 Data from Hiller (1939).

of the South African and Swedish minerals. The powder-diffraction data given by Berry and Thompson (1962) for Kaveltorp valleriite agrees well with that obtained by us.

Single flakes isolated from specimens from Loolekop, South Africa, were studied with the Buerger precession camera in an attempt to obtain single-crystal diffraction patterns. The best photographs were readily interpreted in terms of a rhombohedral unit cell with the properties shown in table 133.3. The similarity in symmetry and dimensions of the valleriite unit cell to that of the recently described iron sulfide, smythite, is striking and significant, although the character of diffraction-intensity distribution on the single-crystal patterns precludes any type of isostructural relationship. The crystallographic studies of Hiller (1939) are not supported by these findings. On the basis of powder
TABLE 133.3.-Unit-cell data for valleriite, smythite, and mackinawite

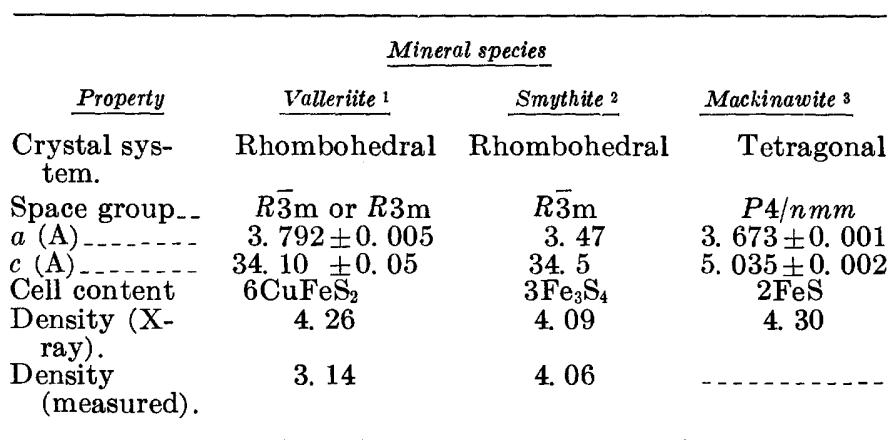

1 Loolekop, South Africa; unit cell derived from least-squares analysis of first 12 -spacings of data for Loolekop material, table 133.2; density from Blomstrand $(1870)$.

2 Bloomington, Ind.; Erd and others (1957)

3 Synthetic, Berner (1962); parameters derived by least-squares analysis of Berner's diffraction data as shown in table 133.4.

data alone, which correspond well with ours (table 133.2), he deduced an orthorhombic unit cell and even a crystal structure for valleriite. Evidently, his overextended hypotheses need not be further considered.

The crystal structure of valleriite is not yet known, but its crystallography places severe restrictions on its constitution. Just as in smythite, the space-filling sulfur atoms must lie on the threefold symmetry axes, and the hexagonal unit cell is sufficiently large to contain three $\mathrm{S}_{4}$ units. Accordingly, the $c$ axis length of $34.3 \mathrm{~A}$ corresponds to 12 layers of sulfur atoms in closest packing. Further, it is readily deduced that not less than 3 nor more than 4 cations also lie on the threefold axes. This reasoning leads us to the possible formulas: $\mathrm{CuFe}_{2} \mathrm{~S}_{4}, \mathrm{Cu}_{2} \mathrm{FeS}_{4}$, and $\mathrm{Cu}_{2} \mathrm{Fe}_{2} \mathrm{~S}_{4}$. The chemical analyses, apart from the magnesium and aluminum hydroxides, conform closely with the last. Thus it appears most probable that valleriite is a dimorph of chalcopyrite, $\mathrm{CuFeS}_{2}$.

All single-crystal patterns of valleriite show the presence of a second, much weaker lattice originating from some other phase. This lattice is also rhombohedral, with a hexagonal $a$ axis of about $3.0 \mathrm{~A}$. Its smaller dimension corresponds well to that expected of an oxide compound of some sort. There is little doubt that this lattice is to be associated with the magnesium and aluminum hydroxides which have always appeared in chemical analyses of valleriite. Evidently these hydroxides correspond to a foreign mineral phase, hexagonal or rhombohedral in crystal character, interleaved in syntactical orientation on a submicroscopic scale with the valleriite. The identity of this foreign phase and its genetic relationship to valleriite remain a mystery.

\section{MACKINAWITE}

Recently, Milton and Milton (1958) described the occurrence of a sulfide mineral from the Mackinaw 
mine in Snohomish County, Wash., which they identified as valleriite, mainly on the basis of its physical properties. The identification was tentative, and the doubt which arose late in their study was explained in a footnote:

Preliminary studies in progress by C. Milton, E. C. T. Chao and H. T. Evans, Jr. indicate that the mineral identified as valleriite is this paper is, in fact, distinct from the type valleriite from Kaveltorp, Sweden. The Mackinaw mineral is probably an undescribed iron sulfide, the Kaveltorp valleriite is perhaps a copper-iron-magnesium sulfide. Probably both these phases, if not others also, are to be found among material from other localities that has been called valleriite.

Both valleriite and mackinawite are extremely anisotropic and strongly reflection pleochroic. This feature is so outstanding that ore microscopists for many years have frequently labelled phases as "valleriite" on the basis of its anisotropism alone. We have observed that the pleochroism differs slightly between the two, valleriite appearing pale yellow to deep creamy brown (Skinner and Milton, 1955), while mackinawite shows a pale pink to pinkish gray color.

The existence of a mineral different from valleriite was first definitely suspected when enough powder was successfully isolated from a chalcopyrite matrix by means of an ultrasonic vibrating needle (Kehl and others, 1957) to obtain a characteristic X-ray diffraction pattern. The pattern showed that a large amount of chalcopyrite and a small amount of cubanite were still present in the sample, but when the characteristic reflections for these minerals were discounted, 14 reflections remained to be associated with the new phase, as shown in table 133.4. These $d$-spacings bore no relation to those of valleriite.

Examination of individual grains of the mineral in a polished section with an electron-microprobe apparatus by Birks and others (1959) showed that the copper content is very low and that the composition of the mineral is approximately FeS. This finding has been confirmed by new analyses with the electron-probe apparatus in our laboratory. Figure 133.1 (upper left) shows a polished section of ore from the Mackinaw mine containing feathered inclusions of mackinawite, which show as gray regions in the light-gray chalcopyrite matrix. Dark round spots indicate points probed by the electron beam and analyzed by X-ray spectroscopy. Copper was not detected, and on the basis of 16 determinations the following composition was determined by the authors:

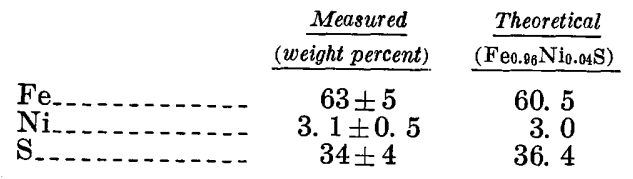

The determinations were made by comparison with
TABLE 133.4.-X-ray powder-diffraction data and unit-cell parameters for mackinawite.

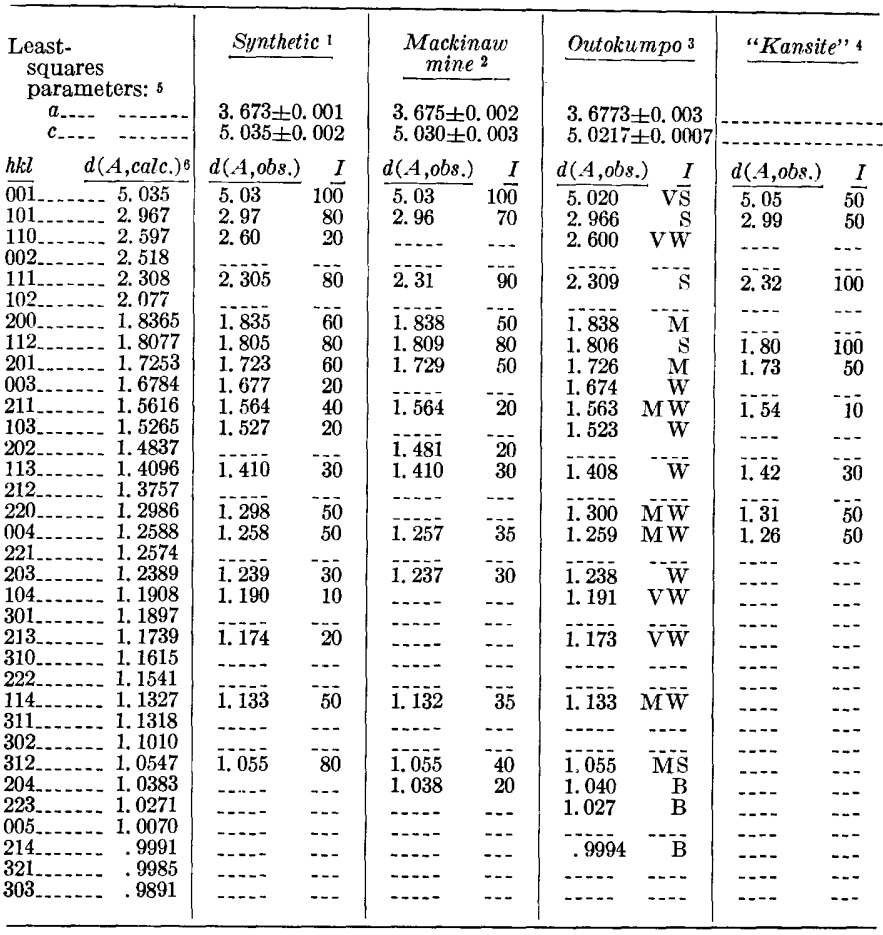

1 Berner (1962).

2 Measured by E. C. T. Chao on material removed from chalcopyrite matrix with an ultrasonic needle; 13 reflections due to chalcopyrite and 5 due to cubanite are Ted. FeK $\alpha$ radiation, 114.6-mm-diameter camera.

Kouvo and others (1963). V=very strong, $S=$ strong, $M=$ medium, $W=$ weak,

= Artificial product, measured by Meyer and others (1958); ASTM powder data Unit-cell

Unit-cell parameters and standard deviations calculated from the powder-diffrac$6 d$-spacing least-squares analysis.

the space group $P 4 / \mathrm{nmm}$.

analyzed pyrite, pyrrhotite, and pentlandite as primary standards. Accuracy was limited by the small size of the grains, which are only a little larger than the electron beam, and the difficulty of obtaining quite plane surfaces on the relatively soft mackinawite. It is apparent that the determined composition is not significantly different from that corresponding to the formula, $\left(\mathrm{Fe}_{0.96} \mathrm{Ni}_{0.04}\right) \mathrm{S}$.

The key distinguishing characteristic of this mineral, namely, its X-ray powder-diffraction pattern, was soon found to resemble that of an artificial iron sulfide labelled "kansite" by Meyer and others (1958). This substance was identified by its X-ray pattern in the corrosion product caused by the action of hydrogen sulfide on pipeline steel. It could not be isolated for ordinary chemical and physical tests, but it did yield a rather diffuse X-ray pattern of 10 measurable lines (see table 133.4). These matched approximately the recorded pattern for pentlandite, and Meyer and others derived from it a cubic unit cell with $a=10.1 \mathrm{~A}$. Following this lead, they suggested a composition of $\mathrm{Fe}_{9} \mathrm{~S}_{8}$ for this phase, by analogy with pentlandite. Our X-ray data (table 133.4) showed a close relationship 

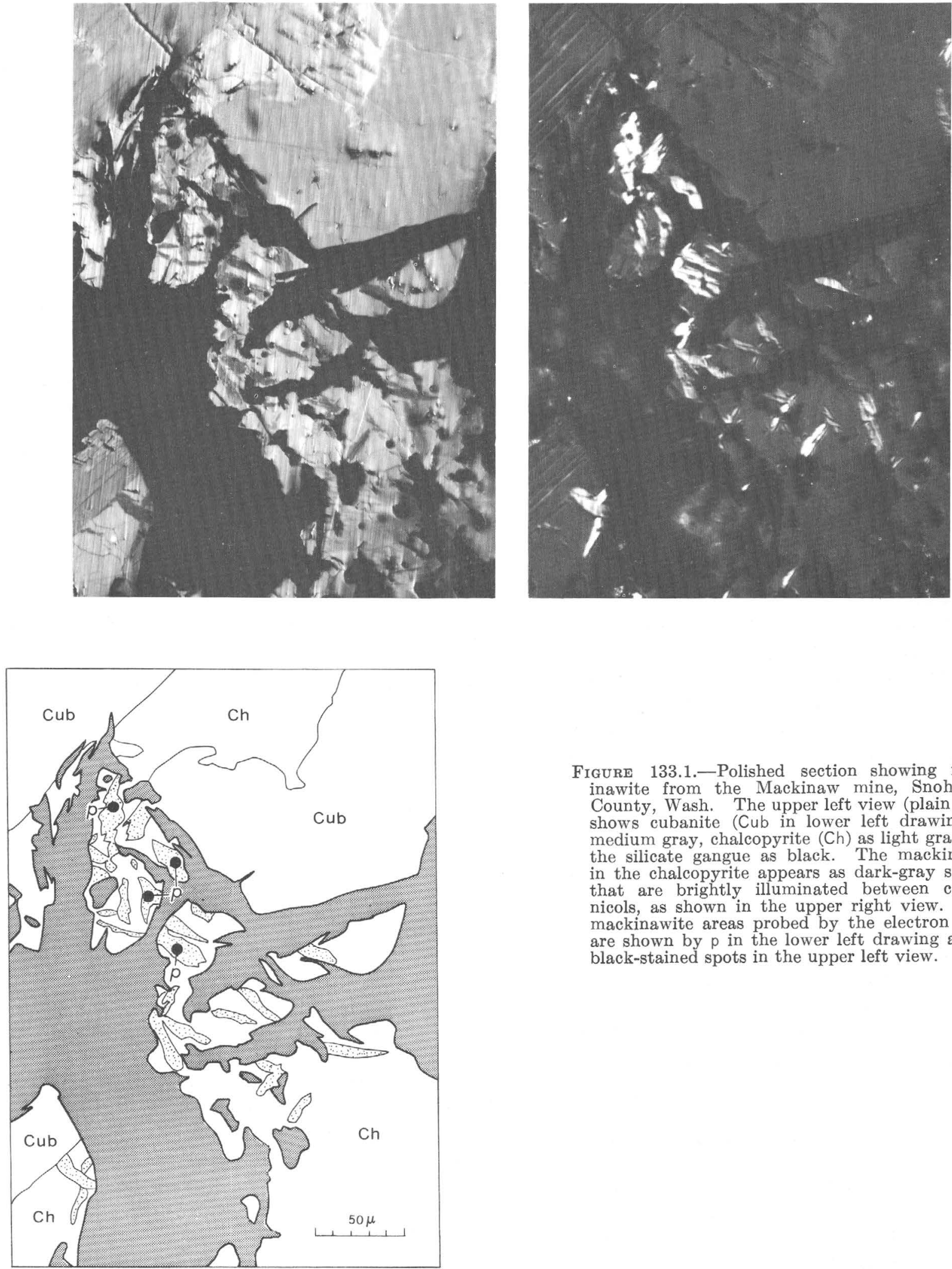

Figure 133.1.-Polished section showing mackinawite from the Mackinaw mine, Snohomish County, Wash. The upper left view (plain light) shows cubanite (Cub in lower left drawing) as medium gray, chalcopyrite (Ch) as light gray, and the silicate gangue as black. The mackinawite in the chalcopyrite appears as dark-gray streaks that are brightly illuminated between crossed nicols, as shown in the upper right view. Four mackinawite areas probed by the electron beam are shown by $p$ in the lower left drawing and as black-stained spots in the upper left view. 
with "kansite," but on the other hand it was certain that the Mackinaw mine iron sulfide could not be cubic because of its high anisotropy in polished section (fig. 133.1, upper right).

Meanwhile, Kouvo and Vuorelainen (1959) published a short paper describing a new iron sulfide mineral resembling vallerite but distinct from it. They list the X-ray diffraction data obtained from this mineral, consisting of 23 lines (table 133.4). These contain the lines found by us for the Mackinaw mineral and also, as they noted, for "kansite," as well as many other lines. They found the mineral in chalcopyrite assemblages, showing strong pleochroism and very strong optical anisotropy, quite analogous to the Mackinaw mineral. Evidently, Kouvo and Vuorelainen were able to prepare pure samples from which they could obtain sharper and stronger X-ray patterns than we have been able to get.

Subsequently, evidence for the formation of an iron sulfide phase in the sediments of the Mystic River, Boston, Mass. was found by Berner (1962). He noted that this phase, as identified by its $\mathrm{X}$-ray diffraction pattern, is the same as one which he prepared synthetically by the action at room temperature of an aqueous solution of $\mathrm{H}_{2} \mathrm{~S}$ on reagent-grade iron wire in the absence of air. The pattern corresponds well with those of the Mackinaw mine and Outokumpo minerals, and "kansite." Berner discovered that all these patterns can be quite satisfactorily indexed on the basis of a primitive tetragonal unit cell with parameters which he gave as $a=3.679 \pm 0.002 \mathrm{~A}$ and $c=5.0471 \pm 0.002 \mathrm{~A}$. It was found that this crystallography closely resembled that described by Hägg and Kindström (1933) for FeSe, for which they determined the crystal structure. Berner further showed that a similar structure for tetragonal FeS yielded calculated diffraction intensities which agreed well with those observed for the natural and artificial iron sulfide phase. Thus, the key to the constitution of these phases is provided.

Kouvo and others (1963) have now described their study of the new iron sulfide in detail, based on beautifully crystallized material associated with cubanite, pyrrhotite, and chalcopyrite from Outokumpo and other Finnish localities. Single crystals up to $1 \mathrm{~mm}$ in size allowed these authors to determine the unit-cell dimensions and symmetry by the Weissenberg method. They found a tetragonal unit cell in the probable space group $P 4 / \mathrm{nmm}$, with parameters which they reported as $a=3.676 \pm 0.002 \mathrm{~A}$ and $c=5.032 \mathrm{~A}$.

Kouvo and others (1963) also were able to obtain good chemical and electron-probe analyses leading to a formulation $\left(\mathrm{Fe}_{0.91} \mathrm{Ni}_{0.13} \mathrm{Co}_{0,007}\right) \mathrm{S}$, with no $\mathrm{Cu}$ present. The slight departure from stoichiometry is also reminiscent of the behavior of other iron sulfide phases. The close correspondence between the chemical and physical data given by Kouvo and others for their "tetragonal iron sulfide" and those found by us for the Mackinaw material leaves no doubt that the two are the same mineral. We have named the mineral "mackinawite" in allusion to the locality name. Dr. Olavi Kouvo, who gave the first clear description of this new mineral (Kouvo and others, 1963), has generously agreed to this choice of name.

The X-ray powder-diffraction data given by Berner for synthetic iron sulfide and by Kouvo and others for the Mackinaw mine material are given in table 133.4. We have subjected all these data to least-squares analysis in order to find the best unit-cell parameters for each set. For this purpose we have used a new self-indexing computer program written for our Burroughs B220 digital computer, which extracts the standard deviations of the parameters from the inverse matrix of the normal equations based on the residuals of the measured $2 \theta$ angles. These unit-cell parameters and standard deviations are shown at the beginning of table 133.4. The result for Berner's data is given in table 133.3 to represent the pure FeS phase. The differences between the cell parameters as we found them and the published values are hardly significant. The variation in the three sets of cell parameters doubtless reflects the influence of the substitution of varying amounts of $\mathrm{Ni}$ for $\mathrm{Fe}$, but the data available now are not sufficient to define this variation quantitatively.

\section{CONFUSION OF VALLERIITE AND MACKINAWITE}

To the ore microscopist, the outstanding characteristic of both valleriite and mackinawite is their extreme anisotropism. Ramdohr and Ödman (1932) in their restudy of Blomstrand's material evidently considered the evidence of this striking anisotropism to be more significant than the available chemical information and assumed on this basis that the material was identical with a mineral found by Schneiderhöhn (1929) in the platinum-ore deposits of the Transvaal. In his careful studies, Schneiderhöhn noticed in sections of chalcopyrite and pentlandite, lamellar or irregular inclusions of a highly birefringent mineral, which he termed an "unbekanntes Nickelerz." Most important, he was able to isolate enough pure sample from a pentlandite matrix for a spectrographic analysis, which showed that the anisotropic mineral was primarily an ironnickel sulfide, with no detectable copper. All aspects of his description match the properties of mackinawite as we now know them, and it seems entirely probable that mackinawite is actually the mineral he describes in "Lehrbuch der Erzmikroskopie" (Schneiderhöhn and Ramdohr, 1931), without mentioning the Swedish mineral, and without giving it a name. Ramdohr, in subse- 
quent editions of his "Die Erzmineralien" (Ramdohr, 1960), combined the information about the South African and Swedish occurrences into one description under the name "Valleriit." Consequently, most subsequent descriptions of a soft sulfide mineral having: extreme anistropism and occurring as fine inclusions in chalcopyrite or pentlandite have given it the name "valleriite," even though no other evidence was available to establish the identification. Thus, the numerous literature references to valleriite are ambiguous and could equally well apply to mackinawite.

In conclusion, we believe that the occurrence in other sulfide crystals of tiny inclusions giving the appearance of an exsolution phase is quite characteristic of mackinawite and not valleriite, and that as this feature is usually mentioned in most literature references to "valleriite," probably what these references describe is actually mackinawite. Authentic valleriite, on the other hand, has been established from only two localities, Loolekop in South Africa, and southern Sweden. A probable third locality has been reported by Skinner and Milton (1955) at the Elizabeth mine, South Stratford, Vt. $\mathrm{X}$-ray powder patterns of a soft highly birefringent sulfide mineral from this mine show reflections for chalcopyrite, pyrrhotite, and a third phase. The $d$ spacings for this phase match those determined for Kaveltorp valleriite, and the data given by Hiller (1939). Kouvo and Vuorelainen (1959) also mention an occurrence of valleriite at Vihauti, Finland, verified by its diffraction pattern. The validity of any given occurrence of valleriite or mackinawite may evidently be established only by X-ray diffraction or electron-microprobe techniques. From what we know now, it appears that mackinawite is a common and widespread mineral, while valleriite is quite rare.

\section{REFERENCES}

Berner, R. A., 1962, Tetragonal iron sulfide: Science, v. 137, p. 669.

Berry, L. G., and Thompson, R. M., 1962, X-ray powder data for ore minerals; The Peacock atlas: Geol. Soc. America Mem. 85, p. 61.
Birks, L. S., Brooks, E. J., Adler, Isidore, and Milton, Charles, 1959, Electron probe analysis of minute inclusions of a copper-iron mineral: Am. Mineralogist, v. 44, p. 974-978.

Blomstrand, C. W., 1870, On some new Swedish minerals and the composition of pyrrhotite: Öfversigt af Kungl. VetenskapsAkademiens Förhandlingar (Stockholm), v. 27, p. 19-27. [In Swedish]

Erd, R. C., Evans, H. T., Jr., and Richter, D. H., 1957, Smythite, a new iron sulfide, and associated pyrrhotite from Indiana: Am. Mineralogist, v. 42, p. 309-333.

Hägg, G., and Kindström, A.-L., 1933, X-ray study of the system iron-selenium: Zeitschr. für physik. Chem., v. B22, p. 453-464. [In German]

Hiller, J. E., 1939, On the crystal structure of valleriite: Zeitschr. Kristallographie, v. 101, p. 425-434. [In German]

Kehl, G. L., Steinmetz, H., and McGonnagle, W. J., 1957, The removal of inclusions for analysis by an ultrasonic jackhammer: Metallurgia, v. 55, p. 151-154.

Kouvo, Olavi, and Vuorelainen, Yrjö, 1959, On valleriite: Geologi, v. 11, p. 32-33.

Kouvo, Olavi, Vuorelainen, Yrjö, and Long, J. V. P., 1963, A tetragonal iron sulfide: Am. Mineralogist, v. 48, p. 511-524.

Meyer, F. H., Riggs, O. L., MeGlasson, R. L., and Sudbury, J. D., 1958, Corrosion products of mild steel in hydrogen sulfide environment: Corrosion, v. 14, p. 69-75.

Milton, Charles, and Milton, D. J., 1958, Nickel-gold ore of the Mackinaw mine, Snohomish County, Washington: Econ. Geology, v. 53, p. 426-447.

Ödman, O. H., 1933, Ore-microscopic study of the sulfide ores of Kaveltorp: Geol. Förenings Förhandlingar, v. 55, p. 563611. [In German]

Petrén, J., 1898, On so-called valleriite: Geol. Förenings Förhandlingar, v. 187, p. 183-192. [In Swedish]

Ramdohr, P., 1960, Die Erzmineralien: Berlin, Akademie Verlag, p. 527-531.

Ramdohr, P., and Ödman, O. H., 1932, Valleriite: Geol. Förenings Förhandlingar, v. 54, p. 89-98. [In German]

Schneiderhöhn, Hans, 1929, The mineragraphy, spectrography and genesis of the platinum-bearing nickel-pyrrhotite ores of the Bushveld igneous complex; chap. 17 in Wagner, P. A., Platinum deposits and mines of South Africa: London, Oliver and Boyd, p. 206-246.

Schneiderhöhn, Hans, and Ramdohr, P., 1931, Lehrbuch der Erzmikroskopie: Berlin, Verlag von Gebrüder Borntraeger, v. 2, p. 127-130.

Skinner, B. J., and Milton, D. J., 1955, The Elizabeth copper mine, Vermont-a discussion: Econ. Geology, v. 50, p. $751-752$. 


\title{
Article 134
}

\section{EDDIES AS INDICATORS OF LOCAL FLOW DIRECTION IN RHYOLITE}

\author{
By DAVID CUMMINGS, Denver, Colo.
}

Work done in cooperation with the U.S. Atomic Energy Commission

Abstract.-Eddies form on the downflow side of inclusions in rhyolite and indicate a single local direction of flow. The more commonly made observations of flow folds and lineations of phenocrysts in rhyolite indicate two possible directions of flow.

Eddies or eddy zones develop on the downflow side of inclusions in rhyolite flows. Because a phenocryst or lithic inclusion has a greater inertia than the flowing lava, the inclusion moves more slowly than the surrounding fluid. Friction and drag result. The velocity of the lava is less on the downstream side of the inclusion than on the upstream side because part of the kinetic energy of the fluid particles is dissipated in overcoming resistance caused by shear stresses as the flow passes around the inclusion. As a result, the fluid particles are unable to flow completely around the inclusion. At some point beyond the center of the inclusion, fluid particles become momentarily static, accumulate, and are given a rotary motion by the surrounding flow (fig. 134.1). The pattern of the flow lines differs with differently shaped inclusions. If the long axis of a rectangular inclusion is not oriented parallel to the flow direction, the flow lines are offset slightly (fig. 134.2).

The hypothetical outcrop shown on figure 134.3 illustrates the determination of flow direction from eddy

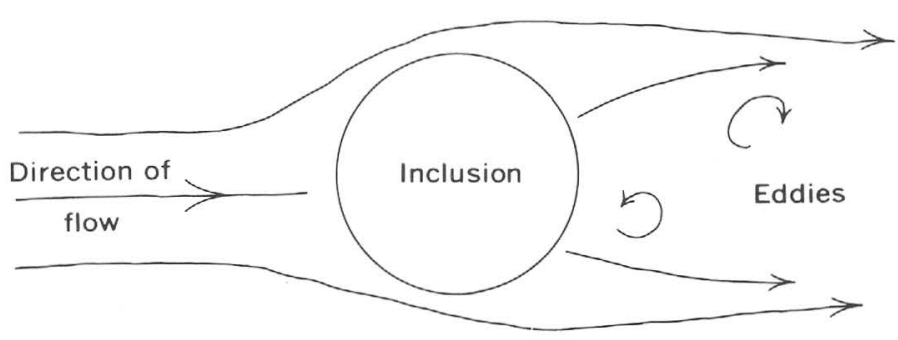

Figure 134.1-Development of eddies on the downflow side of an inclusion.
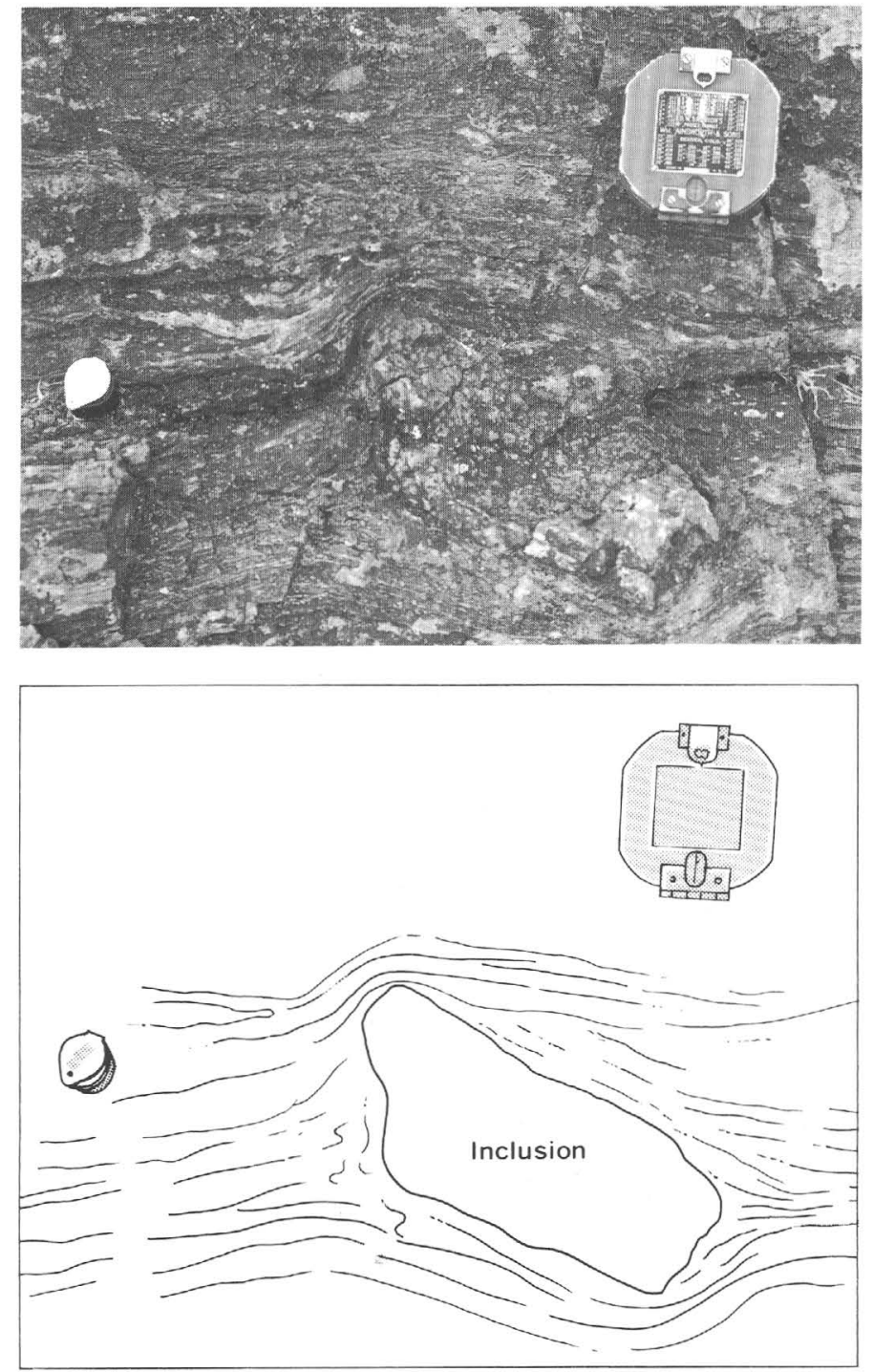

Figure 134.2-An inclusion and eddy zone in a rhyolite flow. Top, eddy zone and inclusion as seen in outcrop; bottom, diagrammatic view of outcrop. Eddy zone to the left of the lithic inclusion indicates that the flow moved to the left. 
zones. As can be seen, the outcrop face need not be parallel to the direction of flow but should be no more than $45^{\circ}$ from that direction. Eddy zones are most clearly seen in the devitrified parts of a lava flow but can also be seen in vitrophyres.

The generalized geologic map (fig. 134.4) shows the inferred direction of movement of a rhyolite flow as determined by the direction of eddy zones. Flow foliation and lineation are also shown on the map. The eddy-zone directions are all northerly, ranging from about $\mathrm{N} .45^{\circ} \mathrm{W}$. to $\mathrm{N} .30^{\circ} \mathrm{E}$. The strike of the flow foliations is most commonly east-west, and the trend of the lineations is generally north-south. The foliations and lineations suggest either a north or a south direction of flow. The eddy zones, however, indicate that the flow direction is northerly.

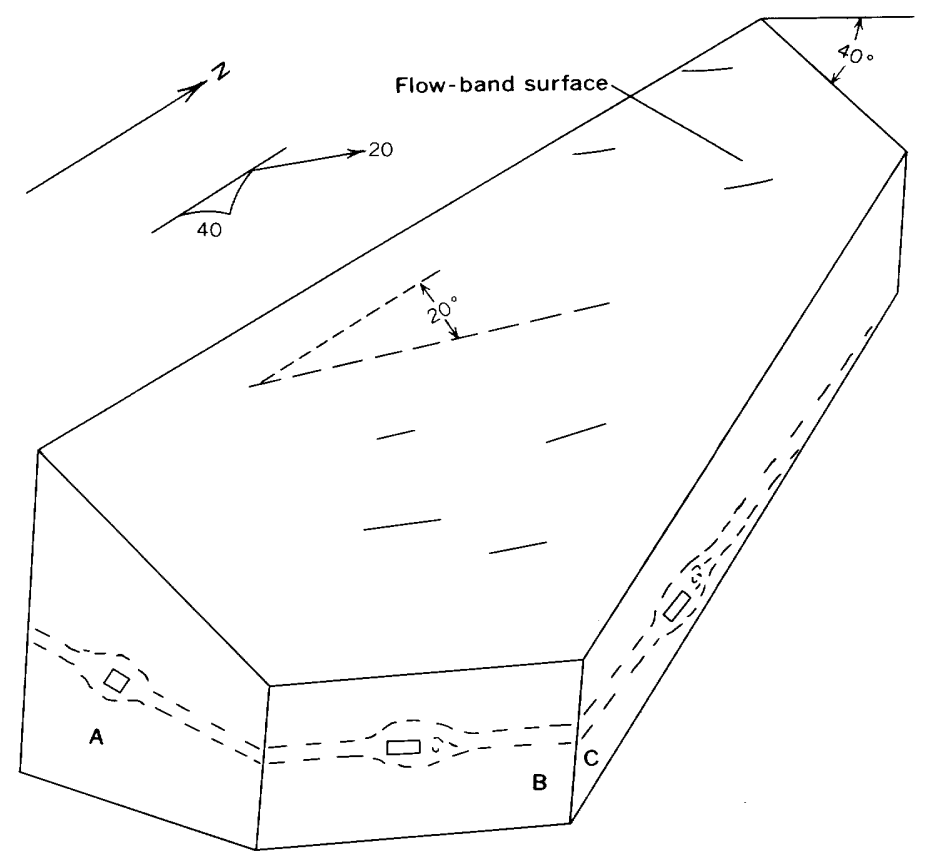

FiguRe 134.3-Determination of flow direction by use of eddy zones. Dip of flow layer, $40^{\circ}$; plunge of lineation, $20^{\circ}$. Lineation shows that direction of flow is either northeast or southwest. Face A is almost normal to direction of flow and shows no eddy zone. Faces $\mathrm{B}$ and $\mathrm{C}$ show east and north components of flow direction. Direction of flow is northeast. 


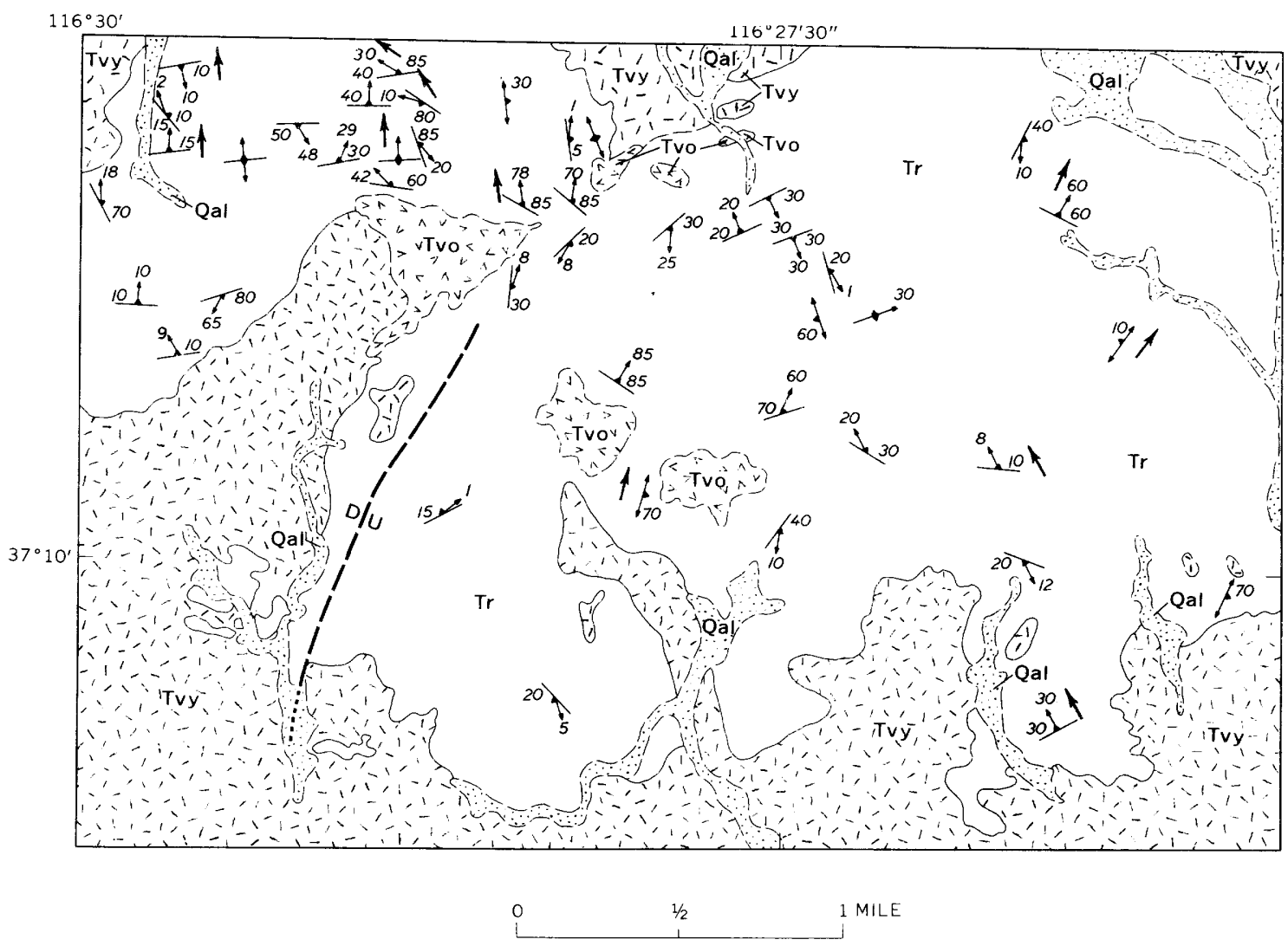

EXPLANATION
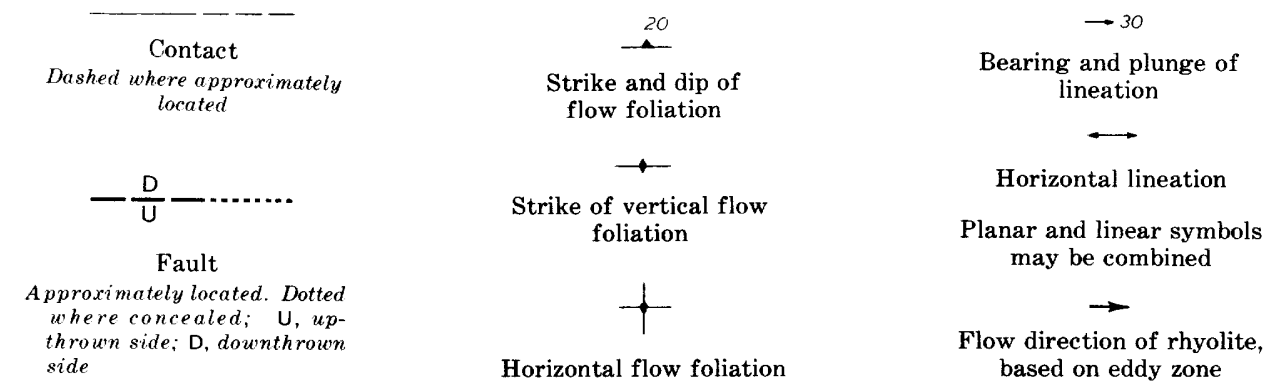

Figure 134.4.-Flow direction of rhyolite, based on eddy zones, Scrugham Peak quadrangle, Nye County, Nev. Alluvium (Qal) is of Quaternary age; rhyolite ( $T r$ ), older volcanic rocks (Tvo), and younger voleanic rocks (Tvy) are of Tertiary age. Geology by David Cummings and F. M. Byers, Jr., 1962-63. 
Article 135

\title{
CADMIUM IN SAMPLES OF THE PIERRE SHALE AND SOME EQUIVALENT STRATIGRAPHIC UNITS, GREAT PLAINS REGION
}

\author{
By HARRY A. TOURTELOT, CLAUDE HUFFMAN, JR., and LEWIS F. RADER, Denver, Colo.
}

\begin{abstract}
The cadmium content of 84 samples ( 10 of bentonite, 66 shale and claystone, and 8 marlstone) averages $1.4 \mathrm{ppm}$ and ranges from $<0.3$ to $11.0 \mathrm{ppm}$. The median value of $0.8 \mathrm{ppm}$ probably represents the cadmium content of the average shale. Some of the samples with high cadmium content contain relatively large amounts of organic matter which may serve as a collector for cadmium. Other high-cadmium samples, however, contain as little organic matter as most of the low-cadmium samples, suggesting that there may have been variation in the amount of available cadmium in the sea water in which these rocks were deposited.
\end{abstract}

Data on the cadmium content of sedimentary rocks are very sparse. Preuss' (1941, p. 19) spectrographic analysis showing 0.3 parts per million of cadmium in a composite sample of 36 shales from Germany is the basis for most estimates of the abundance of cadmium (Rankama and Sahama, 1950, p. 713; Turekian and Wedepohl, 1961, p. 184 and table 2). Mullin and Riley (1956) report cadmium contents ranging from 0.39 to $0.45 \mathrm{ppm}$ for marine oozes. Cadmium is concentrated in zinc sulfides (Fleischer, 1955, p. 992) and has long: been known to be concentrated in coal ashes and black marine carbonaceous shales (Krauskopf, 1955, p. 417).

The cadmium content is reported here for 10 samples of bentonite, 8 of marlstone, and 66 of shale and claystone from the Pierre Shale, a thick and widespread marine unit of Late Cretaceous age in South Dakota and adjacent parts of Nebraska, Wyoming, and Montana. The samples come mostly from the Black Hills and Missouri River areas in these States. The samples were analyzed by Huffman using a method by which cadmium is separated and concentrated by ion exchange before its spectrophotometric determination with dithizone (Huffman, 1962). Under the conditions of the determinations, 1 division on the transmission scale of the spectrophotometer is equal to $0.12 \mathrm{ppm}$ cadmium. The lower limit of detection is taken as $0.3 \mathrm{ppm}$, and the standard deviation for concentrations near $1 \mathrm{ppm}$ is also about $0.3 \mathrm{ppm}$ cadmium.

Cadmium content was determined for two groups of samples. The first group consists of samples described by Tourtlelot (1962) in part of a reconnaissance investigation of the composition of the Pierre Shale. Table 135.1 shows the cadmium analyses for most of these samples for which other analytical data have been published. This group includes two sets of closely spaced samples representing weathering profiles (Tourtelot, 1962, p. 28-32); only the freshest samples are included in the statistical discussions that follow. The second group of samples analyzed for cadmium is from the Pierre Shale of South Dakota and parts of adjacent States and was selected for more detailed investigation than the first group. Stratigraphic, mineralogic, chemical, and spectrographic data for this group have been summarized by Tourtelot and others (1960). The cadmium content of both groups of samples is shown graphically in figure 135.1 and is included in the statistical treatment of all samples in which cadmium has been determined.

The analytical methods, their precision, and the names of analysts determining the elements reported in this and other shale studies have been described by Rader and Grimaldi (1961) and Barnett (1961). The method for determining total carbon has been changed since some of the early analyses were made. Since the present method is more precise and has a lower limit for the total carbon determination of 0.05 percent $\mathrm{C}$, all of the samples containing too little carbon for determination previously have now been analyzed, and certain other samples reanalyzed to make all the data comparable. The carbon data in table 135.1 should 
TABLE 135.1.-Analyses for cadmium and forms of carbon [Cadmium analyses by Claude Huffman, Jr., carbon analyses by I. C. Frost. See Tourtelot (1962) for rock analyses and spectrographic and chemical analyses for mincr

\begin{tabular}{|c|c|c|c|c|c|c|c|c|c|c|c|c|}
\hline \multirow{2}{*}{ Sample } & \multicolumn{5}{|c|}{ Location } & \multicolumn{3}{|c|}{ Description } & \multirow{2}{*}{$\underset{(\mathrm{ppm})}{\text { Cad- }}$} & \multicolumn{3}{|c|}{ Carbon (percent) } \\
\hline & Section & $\begin{array}{l}\text { Town- } \\
\text { ship }\end{array}$ & Range & County & State & $\begin{array}{c}\text { Forma- } \\
\text { tion }\end{array}$ & Member & Material & & $\begin{array}{c}\text { Total } \\
\text { carbon }\end{array}$ & $\begin{array}{c}\text { Car- } \\
\text { bonate } \\
\text { carbon }\end{array}$ & $\begin{array}{l}\text { Organ- } \\
\text { ic car- } \\
\text { bon }\end{array}$ \\
\hline 871 & NW $1 / 431$ & $18 \mathrm{~N}$. & $19 \mathrm{E}$. & Fergu & Montana. & Claggett_ & & Shale, black, soft. & 0.5 & 1.3 & $<0.03$ & \\
\hline 6872 & NW $1 / 431$ & $18 \mathrm{~N}$. & $19 \mathrm{E}$ & & ...do do & & & de & .5 & 1.4 & $<.03$ & \\
\hline $\mathrm{C} 873$ & NW $1 / 431$ & $18 \mathrm{~N}$ & $19 \mathrm{E}$ & $\ldots d$ &..$- d o$ & d & ...-. & hale, brow & 8 & .8 & $<.03$ & \\
\hline C874 & NW! & $18 \mathrm{~N}$ & $19 \mathrm{E}$. & ...-do. & -..do & -. do & & Residual soillike w & 1.6 & 1.0 & $<.03$ & \\
\hline $\mathrm{C} 870$ & & $6 \mathrm{~s}$ & $23 \mathrm{E}$. & Carbon & do_- & do & & Shale, dark-gray, silty .. & .5 & 1.6 & 1.3 & \\
\hline $\mathrm{C} 876_{-}$ & NE $1 / 432$ & $54 \mathrm{~N}$ & $67 \mathrm{~W}$. & Crook & Wyoming. & Pierre & Mitten & Shale, black, hard, flaky & .5 & 1.5 & $<.03$ & \\
\hline C886 & NW $1 / 418$ & $18 \mathrm{~N}$. & $30 \mathrm{E}$ & Corson. & South & do. & Upper part of & Shale, dark-gray, hard, flaky & .8 & 1.3 & .5 & \\
\hline $\mathrm{C} 887$ & SE $1 / 429$ & $16 \mathrm{~N}$. & $31 \mathrm{E}$. & Dewe & $\begin{array}{l}\text { Dakot } \\
\text {.._do..... }\end{array}$ & $\ldots \mathrm{d}$ & Virgit & olack, flaky - . & 8 & 1 & $<.03$ & \\
\hline $\mathrm{C} 881$ & SE $1 / 436$ & $6 \mathrm{~N}$. & $30 \mathrm{E}$. & Stanley & - do & do. & Verendrye. & Claystone, dark-gray with brownish & 1.0 & 1.0 & .05 & \\
\hline $\mathrm{C} 882$ & $\mathrm{SE} 1436$ & $6 \mathrm{~N}$. & $30 \mathrm{E}$. & -..9 & $\ldots$ do & $\ldots d$ & $\ldots \mathrm{do}$ & Cast. & .6 & 9 & $<.03$ & \\
\hline $\mathrm{C} 883$ & $\mathrm{SE} 1436$ & $6 \mathrm{~N}$. & $30 \mathrm{E}$. &..$- d o$ & -..do & -. do & .....do & Residual soillike weathering product & 8 & 1.5 & .07 & \\
\hline $\mathrm{C} 884$ & $\mathrm{SE} 1 / 436$ & $6 \mathrm{~N}$. & $30 \mathrm{E}$. & -..do &..$- \mathrm{do}$ &.$- \mathrm{do}$ & do & Claystone, dark-gray with brownish & .5 & 2.0 & .5 & \\
\hline C885 - & SE1/4 36 & $6 \mathrm{~N}$. & $30 \mathrm{E}$ & ... do & $---d o_{-}$ & -. do.. & ..... do & $\begin{array}{l}\text { cast. } \\
\text { Claystone, dark-gray to black; some }\end{array}$ & .8 & 2.2 & .7 & \\
\hline $\mathrm{C} 878$ & 1 & $111 N$. & $80 \mathrm{~W}$. & Hughes. & $-\ldots$ do & -...do_.. & DeGrey..- & $\begin{array}{l}\text { silty layers. } \\
\text { Claystone, black; some silt layers (core }\end{array}$ & .8 & 1.1 & $<.05$ & \\
\hline $\mathrm{C} 879$. & 1 & $111 \mathrm{~N}$ & $80 \mathrm{~W}$. & ... do... & -..do.. & ... de. & Crow Creek..... & $\begin{array}{l}\text { sample from } 32.8 \mathrm{ft} \text { ). } \\
\text { MarIstone, yellowish-gray, slightly }\end{array}$ & .8 & 7.5 & 6.6 & \\
\hline $\mathrm{C} 880$ & 1 & $111 \mathrm{~N}$. & $80 \mathrm{~W}$. & ....do_. & $\ldots$ do & $\ldots$ do & Gregory & $\begin{array}{l}\text { sandy (core sample from } 51.0 \mathrm{ft} \text { ). } \\
\text { claystone, black, bentonitic (core }\end{array}$ & .8 & 1.1 & .1 & \\
\hline C888. & 17 & 104 & $71 \mathrm{~W}$ & Lym & $\ldots$ do & dr & DeG & $\begin{array}{l}\text { rom } 66.8 \mathrm{ft}) \\
\text { dark-gray, bentonitic }\end{array}$ & 1.4 & .7 & $<.03$ & \\
\hline C889. & 17 & 104 & $71 \mathrm{~W}$ & ...de & -... do n & - do & Crow Creek & Marlstone, cream & 1.2 & 5.3 & 4.7 & \\
\hline $\mathrm{C} 890 \ldots$ & 17 & $104 \mathrm{~N}$ & $71 \mathrm{~W}$. & ... do &..$- \mathrm{do}$ & do & Gregor & Claystone, gray, highly bentonitic ..... & 1.5 & 1.1 & .5 & \\
\hline C891 . & 17 & $104 \mathrm{~N}$ & $71 \mathrm{~W}$ & - do & - do... & do & Sharon Springs .- & $\begin{array}{l}\text { Shale, black, hard; rich in organic } \\
\text { matter. }\end{array}$ & 3.5 & 10.3 & .03 & \\
\hline
\end{tabular}

1 Samples represent a weathering profile from the center of a roadcut (C871) into the coluvium and soil zone on the flank of the hill (C874). The samples were taken about a foot above a tuffaceous siltstone bed, 1 to 2 inches thick, that could be traced into the colluvium.

2 Not included in statistical discussion of cadmium.

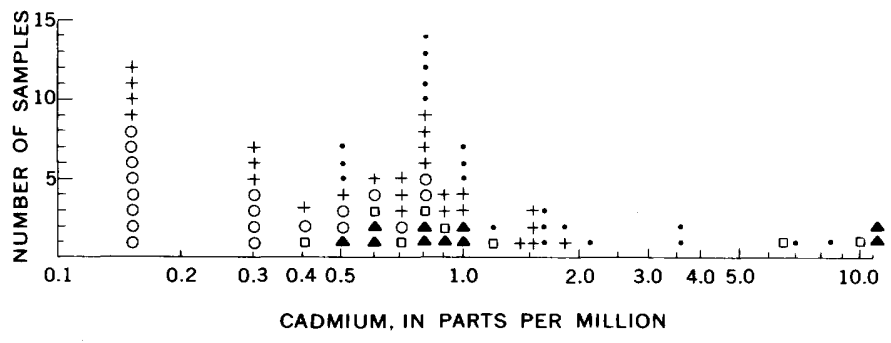

Figure 135.1.-Distribution of cadmium in 84 samples of Pierre Shale. Triangles, bentonite; squares, marlstone; circles, shale and claystone containing $<0.5$ percent organic carbon; crosses, shale and claystone containing 0.5 to 1.0 percent organic carbon; dots, shale and claystone containing $>1.0$ percent organic carbon. Such samples containing less than $0.3 \mathrm{ppm}$ cadmium are plotted arbitrarily at $0.15 \mathrm{ppm}$, half of the lower limit of detection.

be substituted for those shown previously by Tourtelot (1962, p. 57).

Currently, total carbon is determined by burning a weighed sample at $1350^{\circ} \mathrm{C}$ in a stream of oxygen. Iron chips and tin metal act as burning accelerators and catalysts, the evolved gases being passed through manganese dioxide and hot copper oxide to remove sulfur and to convert carbon monoxide to carbon dioxide. The volume of the gas, collected in a closed system under standard conditions of temperature and pressure, is measured; then the gas is scrubbed with potassium hydroxide solution to remove the carbon dioxide, and the volume is redetermined. Total carbon is calculated, carbon dioxide from carbonates deter- mined separately is subtracted, and the remainder reported as organic carbon.

The 10 samples of bentonite studied represent beds throughout the section of the Pierre Shale; 4 of these samples are of beds of practically the same age. The 8 marlstone samples include 3 from the Crow Creek Member in the lower-middle part of the Pierre Shale, and 5 from the Mobridge Member in the upper part of the Pierre Shale in the Missouri River area of South Dakota. The 66 samples of shale and claystone represent rocks throughout the Pierre Shale and equivalent stratigraphic units; these samples are grouped for convenience according to organic-carbon content: $<0.5$ percent (19 samples), 0.5 to 1.0 percent ( 26 samples), and $>1.0$ percent organic carbon ( 21 samples). Of the samples containing $>1.0$ percent organic carbon, 14 come from the Sharon Springs and Mitten Members in the lower part of the Pierre Shale and from the Claggett Shale, which make up a relatively thin unit of generally organic-rich shale of the same age from South Dakota to central Montana.

\section{CADMIUM CONTENT}

The statistical distribution of cadmium according to rock type is shown in figure 135.1 and, with other data, is summarized in table 135.2. The cadmium content of all samples ranges from $<0.3 \mathrm{ppm}$ to $11.0 \mathrm{ppm}$ and averages $1.4 \mathrm{ppm}$. Samples reported with $<0.3 \mathrm{ppm}$ of cadmium, the lower limit of detection, are arbitrarily 
assumed to contain $0.15 \mathrm{ppm}$. The graphic distribution (fig. 135.1) shows, however, that the average is too much influenced by the few high values to represent the expectable cadmium content of clayey rocks. The modal value of $0.8 \mathrm{ppm}$ cadmium, which is the median value (table 135.2), seems to be a more reasonable figure.

TABLE 135.2-Cadmium, zinc, total sulfur as sulfur, organic carbon, and vanadium in groups of samples

[Values reported as less than respective limits of detection are as counted half the limit of detection in calculating averages. Number of samples shown in parentheses]

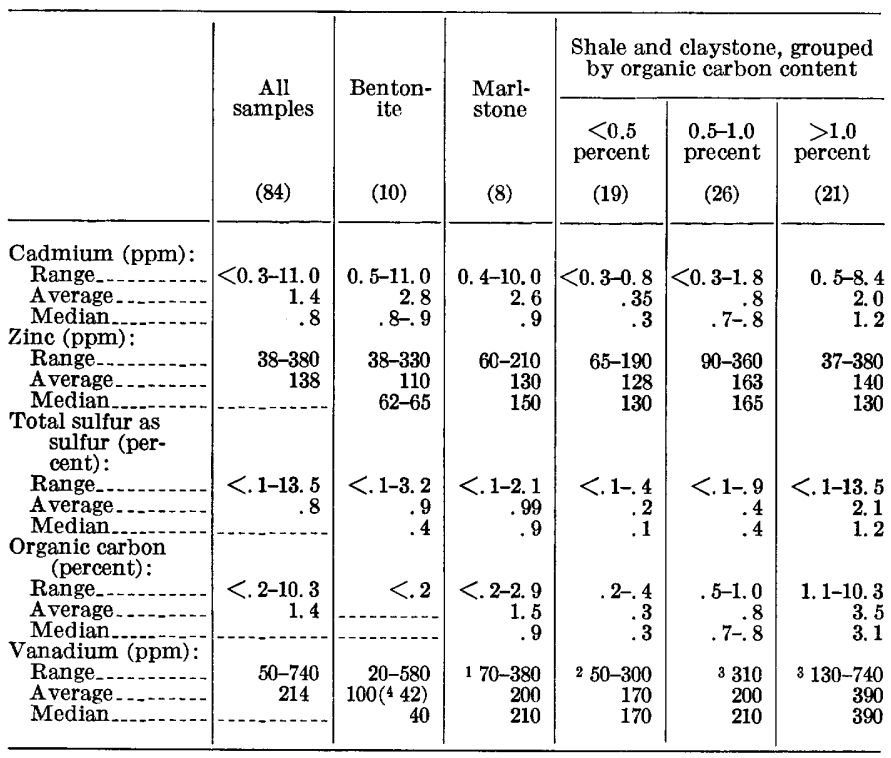

1 Excluding 2 samples for which only semiquantitative spectrographic analyses are available.

2 Excluding 1 sample for which only semiquantitative spectrographic analyses are vailable.

available.

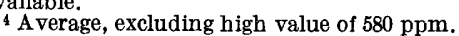

The average composition of 17 samples of Pierre Shale discussed by Tourtelot $(1962$, p. $37-44,67)$ is very similar to that of several other average shales, mostly of pre-Cretaceous age (Clarke, 1915, p. 23; Vinogradov and Ronov, 1956, p. 6, 7; and others). The differences between these and the published averages are chiefly in alumina, silica, and potassium. The differences in silica and alumina reflect the variable admixtures of quartz and clay typical of such rocks; the lower potassium content of the Pierre Shale is attributable to the greater abundance in it of montmorillonite relative to potassium-rich clays. Data from the Pierre Shale thus are applicable to problems of average composition. These 17 samples provided 15 of the samples analyzed for cadmium (table 135.1). The average cadmium content of these 15 samples is $1.1 \mathrm{ppm}$ and the median value is $0.8 \mathrm{ppm}$.

Many uncertainties surround selection of an average value for the content of any element in shale. Clearly, there is much rock in the Pierre Shale that contains
$<0.3 \mathrm{ppm}$ cadmium, and the analysis of additional samples of Pierre Shale and of other shales, particularly those with low organic content, no doubt would lower the modal value. It is probably unlikely that any rocks in the Pierre contain more than about $10 \mathrm{ppm}$ cadmium, although other black shales for which analytical data were published by Davidson and Lakin $(1961,1962)$ contain as much as $300 \mathrm{ppm}$ cadmium, as determined by semiquantitative spectrographic analysis (D. F. Davidson, oral communication, March 1963). Cissarz $(1930$, p. 64) also reports spectrographic analyses of 100 to $1,000 \mathrm{ppm}$ cadmium in parts of the Mansfeld Kupferschiefer in Germany. Such high values, even though they are typical of a special kind of shale, must be taken into account as well as the low values. No rational basis for doing so, however, is apparent, and the median and modal value of $0.8 \mathrm{ppm}$ cadmium derived from the Pierre samples seems to be an acceptable and usable average content for shale until much more work has been done.

\section{RELATION TO OTHER CONSTITUENTS}

All statistical measures of the cadmium content of the samples increase as the organic carbon content increases, but the relation is a general one (fig. 135.1 and table 135.2). Most of the bentonite and marlstone samples contain $1.0 \mathrm{ppm}$ cadmium or less, but 2 of each contain $>5.0 \mathrm{ppm}$ cadmium. The organic-carbon content of bentonite is negligible, being less than the arbitrary cutoff of 0.2 percent for the peroxide-bomb analytical method (Rader and Grimaldi, 1961, p. 37). Hence, cadmium in the bentonite samples is independent of organic-carbon content. The 2 samples of marlstone that contain the most cadmium each contain 2.0 percent or more organic carbon, but 1 other sample of marlstone that contains $>2.0$ percent organic carbon contains only $0.7 \mathrm{ppm}$ cadmium. Thus, cadmium in marlstone may be related to organic carbon, but the relation is not evidently a genetic one.

The organic carbon in the Pierre samples is similar in composition to lignite or subbituminous coal and is inferred to be derived largely from land plants (Breger and others, 1960; see also Breger and Brown, 1962). Cadmium and other metals in the Pierre organic-rich samples may be original constituents of the plants, derived from their growing sites, or the metals may have been adsorbed by the plant material from the sea water during the transport, accumulation, and diagenesis of the plant material in the Pierre rocks. Each of these explanations has been advanced for metals in coal and marine carbonaceous rocks, and it seems likely that both could be operative. The data on the Pierre samples are not helpful in identifying 
which mode of origin may have played the largest role in controlling the accumulation of cadmium.

The zinc/cadmium ratio plotted against the zinc content (fig. 135.2) has been used to divide the samples into

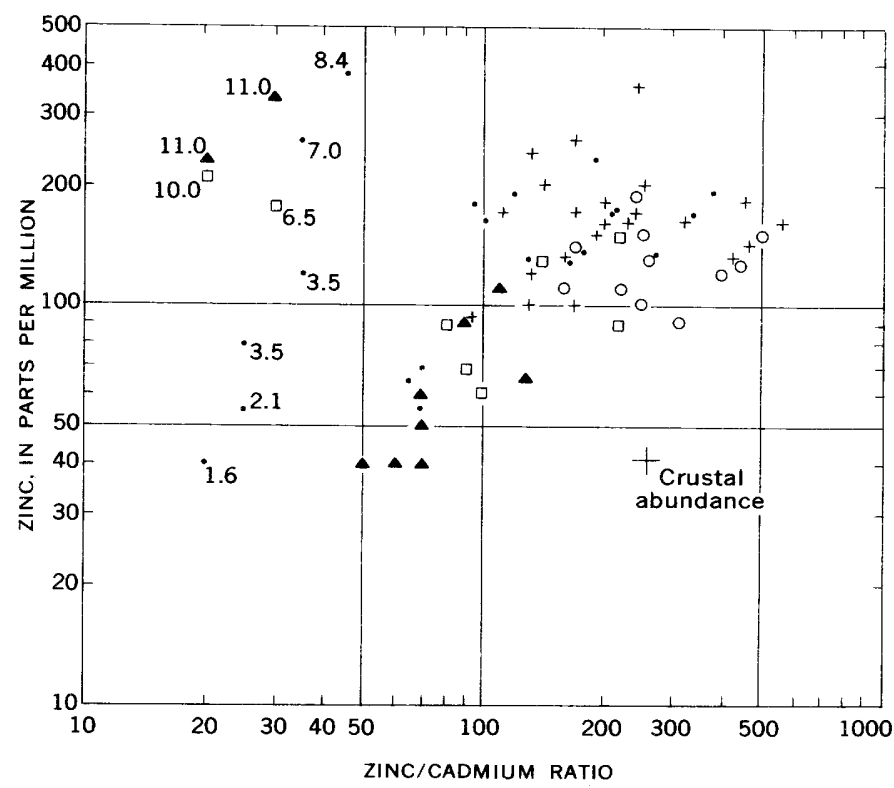

FIGURE 135.2.- Relation between the zinc/cadmium ratio and zinc content of the Pierre Shale. Numbers on symbols show cadmium content, in parts per million. Triangles, bentonite; squares, marlstone; circles, shale and claystone containing $<0.5$ percent organic carbon; crosses, shale and claystone containing 0.5 to 1.0 percent organic carbon; dots, shale and claystone containing $>1.0$ percent organic carbon.

two groups-one with ratios of $<50$ and the other with ratios of $>50$. The zinc/cadmium ratio of the earth's crust is 270 , using $0.15 \mathrm{ppm}$ for cadmium (Brooks and Ahrens, 1961, p. 112) and $40 \mathrm{ppm}$ for zinc (Wedepohl, 1953 , p. 94). Both zinc and cadmium are concentrated in most samples of Pierre Shale considerably above their crustal abundance. The group with ratios less than 50 includes the 9 samples of bentonite, marlstone, and organic-rich shale with a cadmium content of $2.0 \mathrm{ppm}$ or more. The remaining sample contains $1.6 \mathrm{ppm}$ cadmium. The ratio of zinc to cadmium is relatively constant, and the cadmium content is related directly to the zinc content.

Results of semiquantitative spectrographic analyses show that zinc/cadmium ratios of 10-30 are common for black-shale samples which contain as much as 1,000 ppm zinc (D. F. Davidson, oral communication, March 1963).

In the group with ratios of $>50$, the cadmium content ranges from $<0.3 \mathrm{ppm}$ to only $1.8 \mathrm{ppm}$, and the zinc/ cadmium ratio increases in direct proportion to the zinc content. A subgroup of nine samples lies somewhat above the main trend but parallel to it. The cadmium content of these 9 samples ranges from 1.5 to $1.8 \mathrm{ppm}$, whereas the main trend includes only a few samples that contain $>1.0 \mathrm{ppm}$ cadmium.

These relations suggest that where the cadmium content is more than about $2 \mathrm{ppm}$, it is directly proportional to the zinc content at a relatively uniform ratio. Where the cadmium content is less than about $2 \mathrm{ppm}$, it does not vary systematically with zinc content and tends to be rather uniform in amount while the zinc content fluctuates.

These relations may mean that (1) the proportions of cadmium and zinc in sea water varied at the depositional sites, either because of different amounts delivered to the sea water from source areas or because of the chemical composition of the sea water itself, or that (2) the conditions under which the sediments accumulated varied in controlling the fixation of both cadmium and zinc. For example, the stronger chalcophile tendencies of cadmium at low and moderate temperatures in acid solutions, compared with those of zinc (Goldschmidt, 1954 , p. 269), may account for the enrichment of cadmium in the organic-rich shales, which are also rich in syngenetic sulfide minerals. These tendencies may even account for enrichment of cadmium in marlstone. Samples that contain sulfide minerals, but only relatively small amounts of cadmium, may have accumulated where there was little cadmium in the environment, or the sulfide minerals may be late diagenetic to secondary in origin and thus have had no chance to reflect the cadmium content of the environment as a whole.

The high cadmium content and low zinc/cadmium ratio of both bentonite and black shale in a single widespread stratigraphic unit suggest that these compositional features have a common origin. The generally low zinc/cadmium ratios of the bentonites studied here may be interpreted as reflecting the original relations of zinc and cadmium in the volcanic material that was altered to form the bentonite. The bentonites that accumulated on the bottom of the Pierre sea hundreds of miles east of the source of the volcanic material in Montana (Tourtelot, 1962, p. 10-11) must represent only a fraction of the total amount erupted. Bentonitic material is also abundant in the shales, as indicated by high montmorillonite content. Much of the total eruption product accumulated on land, but much also must have been moved aerially into the sea, along with whatever volatile substances accompanied the eruptions. The metal content of the sea water could be increased by solution of the volatile substances and the elements in the disseminated volcanic material. The elements then would be adsorbed by organic matter and by clay minerals that themselves were partly the result of alteration of the volcanic material. The volcanic material in discrete beds that 
altered to bentonite would either retain its minorelement content, or lose it to sea water, depending on the nature of the alteration process. Cadmium and zinc thus were available in the sea water at a time when organic matter was abundant enough to participate directly in adsorption reactions or to make possible the formation of syngenetic sulfides by generally reducing the oxidation potential of the bottom sediments. The volcanic material did not necessarily contain more cadmium and zinc than volcanic material delivered at other times to the Pierre sea.

Zinc, total sulfur as sulfur, organic carbon, and vanadium (table 135.2) have much the same distribution pattern among the rock types that cadmium has, and statistical correlations between many of them are positive and significant. This is not surprising, of course, because most past work has shown the co-enrichment of these elements in similar rocks. The mode of occurrence of these elements in such rocks still is largely unknown, so that the explicit factors that operated to produce at one place a sulfide-rich organicrich rock with a relatively high content of cadmium and other elements, and at another place a similar rock with little cadmium, also are unknown. Variations from place to place of temperature, pressure, $\mathrm{pH}$, and oxygen potential obviously would affect, directly or indirectly, the amount of cadmium that would be incorporated in clayey rocks. Such factors were different for a site where marlstone was deposited, compared to one where a sulfide-rich shale was deposited, yet the cadmium contents of some samples of such rocks are similar. At the same time, the cadmium contents of organic-rich shales differ considerably, and yet the enumerated factors, excepting oxygen potential, must have been of nearly the same order of magnitude during the deposition of the sediments represented by the samples. Consequently, other variable factors also must have been operating.

\section{RELATION TO STRATIGRAPHIC AND GEOGRAPHIC POSITION}

Eight of the 10 samples with the highest cadmium content and a zinc/cadmium ratio of $<50$ include 2 samples of bentonite and 6 of organic-rich shale from the Sharon Springs Member in the lower part of the Pierre Shale. These samples are from widely scattered localities in the lower part of the Missouri River valley in South Dakota and the southern part of the Black Hills in South Dakota and Wyoming. One sample comes from the Irish Creek well (Tourtelot and Schultz, 1961), almost halfway between the Black Hills and the Missouri River. The high cadmium content of the two bentonite samples may be related to the strati- graphic association of high-cadmium organic-rich shale and bentonite in the Sharon Springs Member. No regularity in relative position of samples with high cadmium content in the shale and in the bentonite can yet be seen-the high-cadmium shale may be either above or below the high-cadmium bentonite. Two additional samples of bentonite from the Sharon Springs have a cadmium content of 0.6 and $0.8 \mathrm{ppm}$ and a zinc/cadmium ratio of only 70 . Relatively low zinc/cadmium ratios seem characteristic of bentonites from other units, too, all having a ratio of less than about 100 .

The two marlstone samples with a high cadmium content and low zinc/cadmium ratio are from the Mobridge Member in the upper part of the Pierre Shale. They suggest the possibility that there were local areas in the Pierre sea in which the content of cadmium and other metals was higher than elsewhere during the same span of time. The samples are from localities about 35 miles apart, in southeastern Gregory County, S. Dak., and Knox County, Nebr. These two samples also contain relatively large amounts of molybdenum, selenium, and arsenic that, like cadmium, cannot be explained on the basis of what is known of the geochemistry of these elements in carbonate-rich rocks. Three other marlstone samples from the Mobridge Member at localities 50 miles or more northwest of Gregory County contain less than $1 \mathrm{ppm}$ cadmium, and 6 samples of the same age but from a noncarbonate facies also have a low cadmium content. The mineralogical composition of these and other samples from the upper part of the Pierre Shale in this part of the Missouri River valley in southern South Dakota and adjacent parts of Nebraska differs from samples of rocks of the same age at other localities in a way that suggests that some of the materials were derived from land areas bordering the Pierre sea on the east. It is possible that the high cadmium content of the two marlstone samples reflects unusual amounts of cadmium and other elements in the sea water in this area during the latter part of Pierre time. The metals may have come from the eastern shore area, although no discrete sources for them are known. The metals could also have become locally concentrated in the water of the Pierre sea by physical and chemical processes of oceanic circulation after having been derived from sources west of the Pierre sea. Although they are unsatisfying, such speculations are about all that the present data permit. Bur'yanova (1960, p. 217) also postulates unknown metal-rich source areas for the cadmium minerals and camouflaged cadmium in Devonian sandstones in Tuva, south-central Siberia. 


\section{SUMMARY}

The cadmium content of 84 samples (10 of bentonite, 66 shale, and 8 marlstone) averages $1.4 \mathrm{ppm}$ and ranges from $<0.3$ to $11.0 \mathrm{ppm}$. The median value of $0.8 \mathrm{ppm}$ probably represents the cadmium content of the average shale.

Cadmium tends to be concentrated in the same pattern as sulfur and vanadium in rocks of the Pierre Shale rich in organic carbon. Much of the cadmium in such rocks may be in syngenetic sulfide minerals. Bentonite that contains no organic carbon itself but which is associated with organic-rich shale also may contain relatively large amounts of cadmium. High-cadmium samples of bentonite and organic-rich shale are from the Sharon Springs Member at widespread localities. The close geographic association of two high-cadmium samples from the Mobridge Member in southern South Dakota and adjacent Nebraska may indicate that locally the sea in this area was enriched in cadmium and other metals during the deposition of the Mobridge Member.

\section{REFERENCES}

Barnett, P. R., 1961, Spectrographic analysis for selected minor elements in Pierre shale: U.S. Geol. Survey Prof. Paper 391-B, p. B1-B10, 13 figs.

Breger, I. A., and Brown, Andrew, 1962, Kerogen in the Chattanooga Shale: Science, v. 137, no. 3525, p. 221-224.

Breger, I. A., Tourtelot, H. A., and Chandler, J. C., 1960, Geochemistry of kerogen from the Sharon Springs Member of the Plerre Shale: Geol. Soc. America Bull., v. 71, no. 12, pt. 2, p. 1832-1833.

Brooks, R. R., and Ahrens, L. H., 1961, Some observations on the distribution of thallium, cadmium and bismuth in silicate rocks and the significance of covalency on their degree of association with other elements: Geochim. et Cosmochim. Acta, v. 23, p. 100-115.

Bur'yanova, E. Z., 1960, Mineralogy and geochemistry of cadmium in the sedimentary rocks of Tuva: Geokhimija, no. 2, p. 177-182 [in Russian]: translation in Geochemistry, 1960, no. 2 , p. $209-217$

Cissarz, Arnold, 1930, Quantitative-spektralanalytische Untersuchung eines Mansfelder Kupferschieferprofiles: Chemie d. Erde, v. 5, (Linck-Festschr.) p. 48-75.

Clarke, F. W., 1915, Analyses of rocks and minerals from the laboratory of the United States Geological Survey, 1880 to 1914: U.S. Geol. Survey Bull. 591, 376 p.
Davidson, D. F., and Lakin, H. W., 1961, Metal content of some black shales of the Western United States: Art. 267 in U.S. Geol. Survey Prof. Paper 424-C, p. C329-C331.

- 1962, Metal content of some black shales of the western conterminous United States, pt. 2: Art. 85 in U.S. Geol. Survey Prof. Paper 450-C, p. C74.

Fleischer, Michael, 1955, Minor elements in some sulfide minerals, in pt. 2 of Bateman, A. M., ed., Economic Geology, 50th anniversary volume, 1905-55: Urbana, Ill., Econ. Geology Pub. Co., p. 970-1024

Goldschmidt, V. M., 1954, Geochemistry: London, Oxford Univ. Press, $730 \mathrm{p}$.

Huffman, Claude, Jr., 1962, Ion-exchange separation and spectrophotometric determination of cadmium: Art. 214 in U.S. Geol. Survey Prof. Paper 450-E, p. E126-E127 [1963].

Krauskopf, K. B., 1955, Sedimentary deposits of rare metals, in pt. 1 of Bateman, A. M., ed., Economic Geology, 50th anniversary volume, 1905-1955: Urbana, Ill., Econ. Geology Pub. Co., p. 411-463.

Mullin, J. B., and Riley, J. F., 1956, The occurrence of cadmium in seawater and in marine organisms and sediments: Jour. Marine Research, v. 15, no. 2, p. 103-122.

Preuss, E., 1941, Beitrage zur spektralanlytichen Methodik. II. Bestimmung von $\mathrm{Zn}, \mathrm{Cd}, \mathrm{Hg}$, In, Tl, Ge, Sn, Pb, Sb, Bi durch fraktionierte Destillation: Zeitschr. angew. Mineralogie, v. 3, p. 8-20.

Rader, L. F., and Grimaldi, F. S., 1961, Chemical analyses for selected minor elements in Pierre Shale: U.S. Geol. Survey Prof. Paper 391-A, p. A1-A45, 19 figs.

Rankama, Kalervo, and Sahama, Th. G., 1950, Geochemistry: Chicago, Chicago Univ. Press, 912 p.

Tourtelot, H. A., 1962, Preliminary investigation of the geologic setting and chemical composition of the Pierre Shale, Great Plains region: U.S. Geol. Survey Prof. Paper 390, 74 p.

Tourtelot, H. A., and Schultz, L. G., 1961, Core from the Irish Creek well, Ziebach County, South Dakota: U.S. Geol. Survey open-file report, $20 \mathrm{p}$.

Tourtelot, H. A., Schultz, L. G., and Gill, J. R., 1960, Stratigraphic variations in mineralogy and chemical composition of the Pierre Shale in South Dakota and adjacent parts of North Dakota, Nebraska, Wyoming, and Montana: Art. 205 in U.S. Geol. Survey Prof. Paper 400-B, p. B447-B452.

Turekian, K. K., and Wedepohl, K. H., 1961, Distribution of the elements in some major units of the Earth's crust: Geol. Soc. America Bull., v. 72, p. 175-192.

Vinogradov, A. P., and Ronov, A. B., 1956, Composition of sedimentary rocks of the Russian platform in relation to the history of their tectonic movements: Geokhimiya 1956, no. 6, p. 3-24 [In Russian; translation in Geochemistry, 1956, v. 6, p. $533-559]$.

Wedepohl, K. H., 1953, Untersuchungen zur Geochemie des Zinks: Geochim. et Cosmochim. Acta., v. 3, p. 93-142. 
Article 136

\title{
ANALYSIS OF GEOCHEMICAL PROSPECTING DATA FROM THE ROCKY RANGE, BEAVER COUNTY, UTAH
}

\author{
By J. J. CONNOR and A. T. MIESCH, Denver, Colo.
}

\begin{abstract}
A spatial relation has been found between copper in alluvium and a copper ore body 20 to 225 feet beneath the surface. The relation became clear through statistical procedures used to reduce the effects of local variation and area-wide trends.
\end{abstract}

Methods of trend analysis used in interpretations of geophysical data (Grant, 1957, p. 309; Oldham and Sutherland, 1955, p. 295) and applied to geologic problems by Krumbein (1956, p. 2163;1959, p. 823), Whitten (1959, p. 835), and others have not been adequately tested for their application to data-interpretation problems in geochemical prospecting. This article presents the results of such an application.

The geochemical data used in this study were collected by Erickson and Marranzino (1960, p. B98) in the Rocky Range of southwestern Utah and consist of 110 chemical analyses for trace amounts of copper in samples of pediment alluvium. The samples were col- lected on approximately 100 -foot centers and were taken at a depth of 8 to 12 inches below the surface. The sampled area overlies a small copper ore body which lies at a depth of 20 to 225 feet below the surface. The alluvium over the ore body ranges from $6 \frac{1}{2}$ to 45 feet in thickness.

Trend analysis, and analysis of variance tests of the trends, show statistically significant lateral variations in the data that can be described by low-order polynomial surfaces, but small-scale local variation (probably due to sampling error) obscures subtle features of the data important to geochemical prospecting. These subtle features are brought out by applying a "moving average" operation (which serves to reduce random local variation) in conjunction with the ordinary methods of trend analysis.

Figure 136.1 is a map of the sampled area showing deviations of the copper values from their mean and is equivalent to figure 47.1 of Erickson and Marranzion

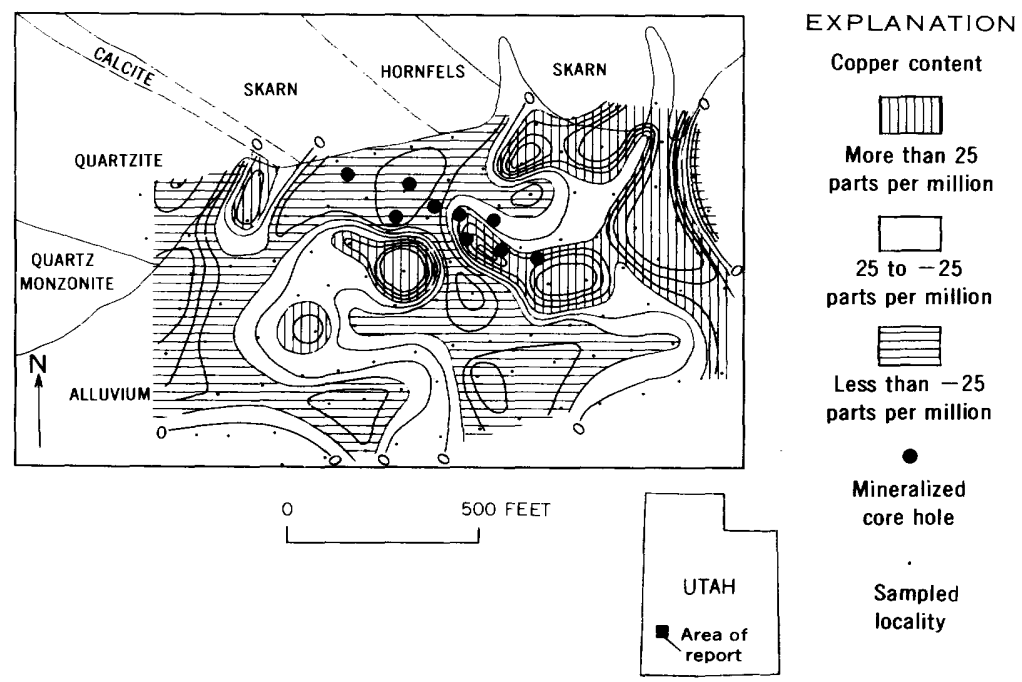

Figure 136.1-Copper content of alluvium in the Rocky Range, Utah (contoured on deviations from the mean). Contour interval $25 \mathrm{ppm}$; values larger than $100 \mathrm{ppm}$ and smaller than $-100 \mathrm{ppm}$ not contoured. Modified from Erickson and Marranzino (1960).

ART. 136 IN U.S. GEOL. SURVEY PROF. PAPER 475-D, PAGES D79-D83. 1964. 
(1960, p. B99). The ore body is roughly outlined by the black dots, which show locations of mineralized drill holes. There is no obvious spatial relation of copper values at the surface to ore, a conclusion also reached by Erickson and Marranzino. Cursory examination of figure 136.1, however, reveals that, in general, the copper content tends to be high on the east side of the map and low on the west.

Using methods of trend analysis, described fully in papers previously eited, seven polynomial surfaces were fitted by least-square techniques to the data of figure 136.1. Four of these surfaces or trends, of degree 1 through 4 , and deviations from the trends, are shown in figures $136.2 A-D$. The deviations identify variance in the data that cannot be described by loworder polynomial equations, and is ascribed to local effects, in part geologic factors that do not act in a continuous fashion across the entire area of investigation. Some part of the variance of the deviations is due to analytical error and possibly other nongeologic factors.

Analysis of variance tests of the computed trends are given in columns 1 through 4 of the accompanying table. Deviations of observed data from the trends were not tested for fit to a normal curve or for degree of independence, but the $F$ ratios may be used in a relative sense, at least, to judge the degree of fit for vorious trends. Significance levels for the $F$ ratios should be viewed cautiously.

Analysis of variance of polynomial surfaces fitted to the data of
figures 136.1 and 136.3

The proportions of the total sum of squares accounted for by the linear through quartic trends (see table, first column) amount to $16,23,26$, and 40 percent, respectively. Though the $F$ ratios suggest that the

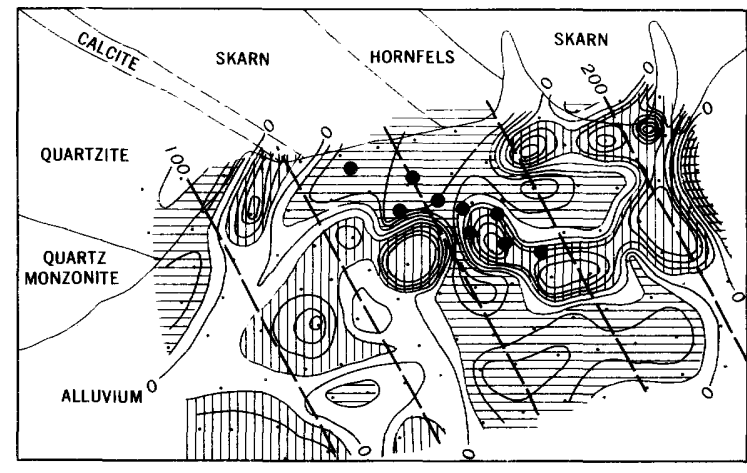

A. LINEAR TREND AND DEVIATIONS FROM LINEAR TREND

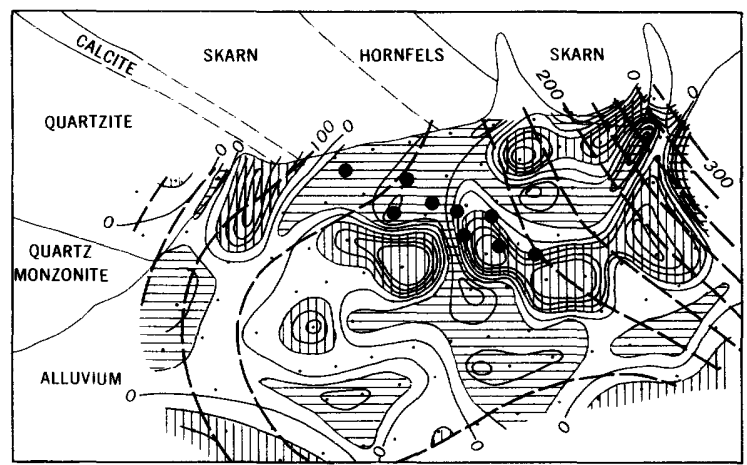

C. CUBIC TREND AND DEVIATIONS FROM CUBIC TREND

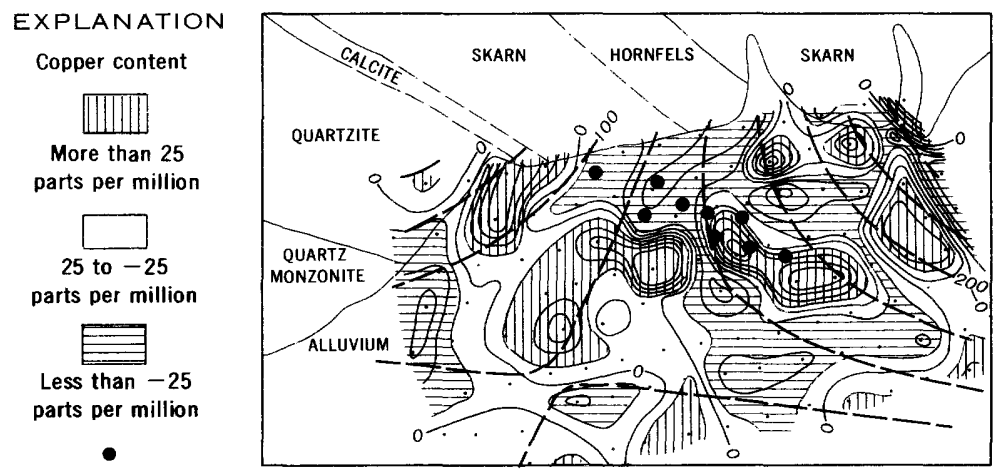

B. QUADRATIC TREND AND DEVIATIONS FROM QUADRATIC TREND

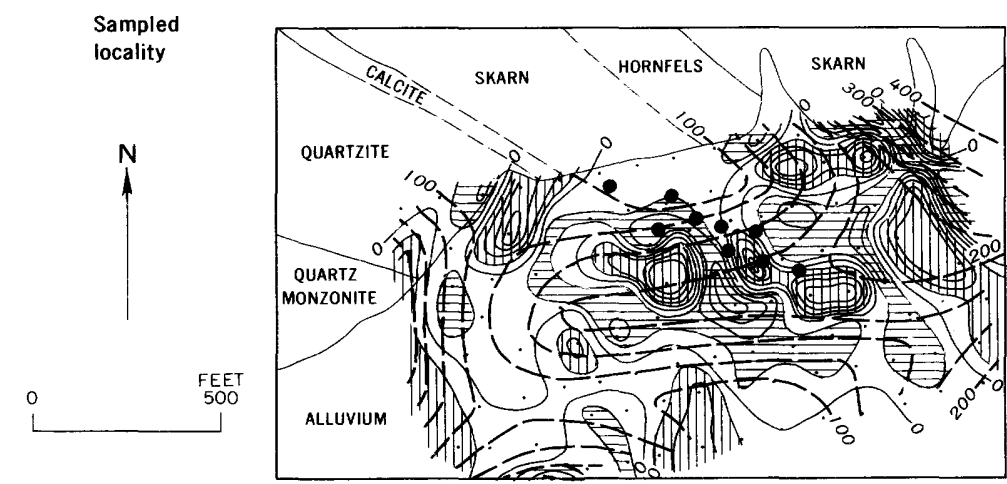

D. QUARTIC TREND AND DEVIATIONS FROM QUARTIC TREND

FIgURE 136.2-Trends (dashed line), in parts per million, and trend deviations of copper in alluvium, Rocky Range, Utah. Contour interval $25 \mathrm{ppm}$; values larger than $100 \mathrm{ppm}$ and smaller than $-100 \mathrm{ppm}$ not contoured. 
linear, quadratic, and quartic trends may be statistically significant, the low-percentage sum of squares associated with the trends partially explains the similarities between the deviation maps (figs. 136.2A$D$ ) and the map of the original data (fig. 136.1).

Sampling error appears to be one major factor displayed by the deviation maps, and it gives rise to sharp local fluctuations of both the original data and the deviations of values about the trends. Comparison of replicate analyses made on the same sample indicates that analytical variation is comparatively small. Sampling error does not imply mistakes in selection of samples or in the sampling procedure, but refers only to the difference between the value obtained on a sample and the mean value that would have been obtained had all possible samples occurring at the sample site been taken. Such complete sampling, of course, is impossible and all samples contain error; the error is inversely proportional to the number of samples taken at the site and directly proportional to the natural local variation in the alluvium.

The map in figure 136.3 shows the moving-average copper content of the alluvium across the area. In construction of this map, each original copper value was replaced by an unweighted average of that value and the four values closest to it on the map in figure 136.1. The effect of the moving average is to smooth out local variation - to reduce the effects of sampling error and other small-scale fluctuations in the data. A trend in the data across the area is now more apparent.

Four trends computed on the moving-average data, and deviations of the averages from the trends, are shown in figures $136.4 A-D$. Analysis of variance tests of the trends could not be made because of interdependence of data imposed by the moving-average method. The proportions of the total sums of squares accounted for by the linear through quartic trends, however, range from 35 to 78 percent.

Deviations of moving-average values from trends fitted to the averages appear to clearly outline the major part of the copper ore body beneath the alluvial cover. Deviations from the quartic trend may be especially significant. Although "negative anomalies" are commonly not regarded as ore indicators by geochemical prospectors (Hawkes and Webb, 1962, p. 27), the presence of the negative deviations over the ore body in figures 136.3 and $136.4 A-D$ necessitates consideration of their importance here. The possibility that the negative deviations over the ore body (figs. 136.3 and 136.4) are merely a result of the adjacent high values that elevate the trend in this region may be excluded for two reasons: (1) the negative deviations correspond closely to the ore body, except over the southern part, and (2) they occur on only one side of the high, the side where the ore body is located. It is assumed, therefore, that the copper low over the ore body is real and originated from natural processes. The copper high southwest of the ore body, though pronounced (figs. 136.3 and 136.4), is caused in very large part by one extreme value $(600 \mathrm{ppm})$ in this area. Recomputation of the trends and trend deviations, excluding the extreme value, results in severe depression of the high, although the low deviations over the ore persist.

Low copper contents in alluvium over the ore body might have resulted from circulation of sulfate solutions and consequent leaching of copper in this area; cores taken from the ore body contain tactite, abundant sulfide minerals, and secondary copper oxides.

The positive deviations adjacent to the ore body on its southwest side (figs. 136.3 and $136.4 A-D$ ) may have resulted from precipitation of leached copper downdip
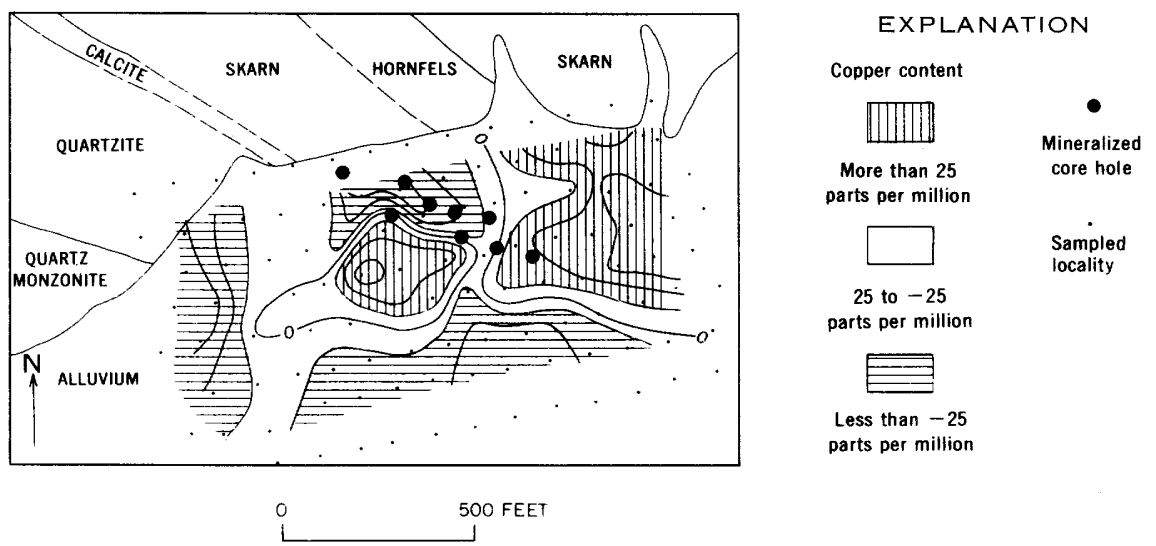

FIGURE 136.3.-Moving-average copper content of alluvium in soils, Rocky Range, Utah (contoured on deviations from the mean). Contour interval $25 \mathrm{ppm}$; values larger than $100 \mathrm{ppm}$ and smaller than $-100 \mathrm{ppm}$ not contoured. 


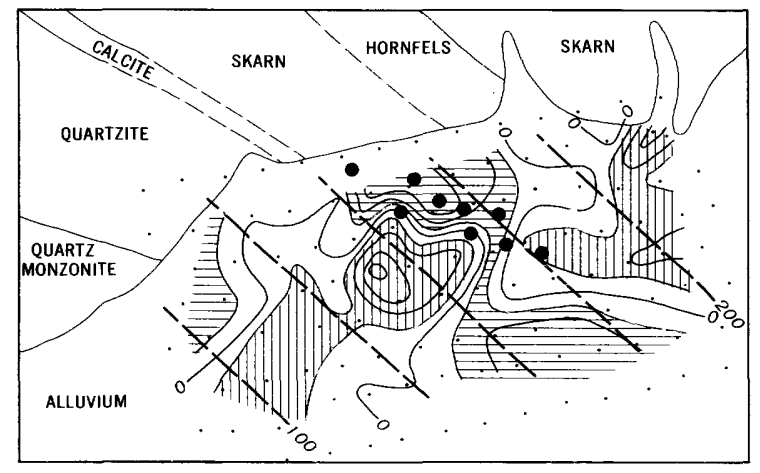

A. LINEAR TREND AND DEVIATIONS FROM LINEAR TREND

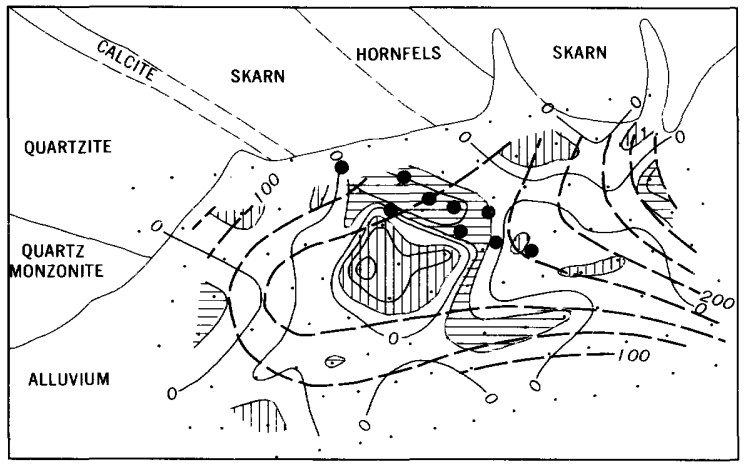

C. CUBIC TREND AND DEVIATIONS FROM CUBIC TREND

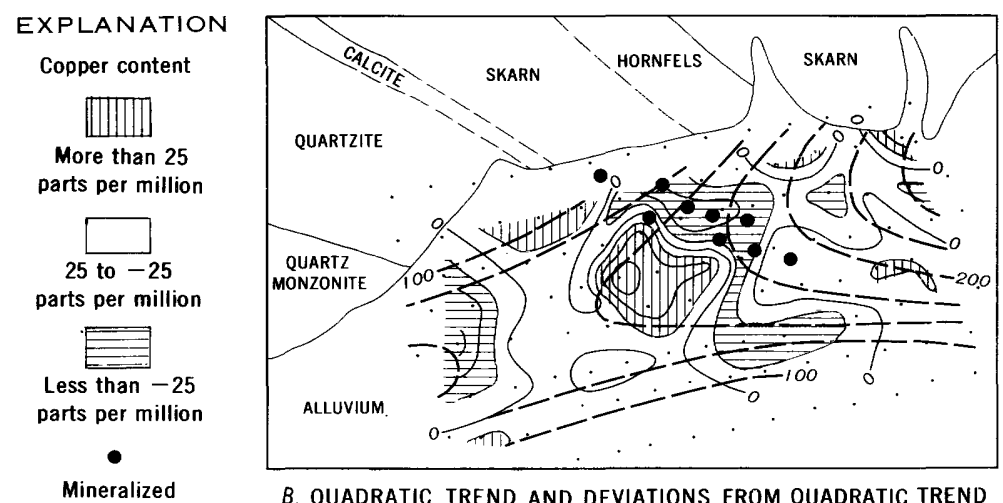

core hole

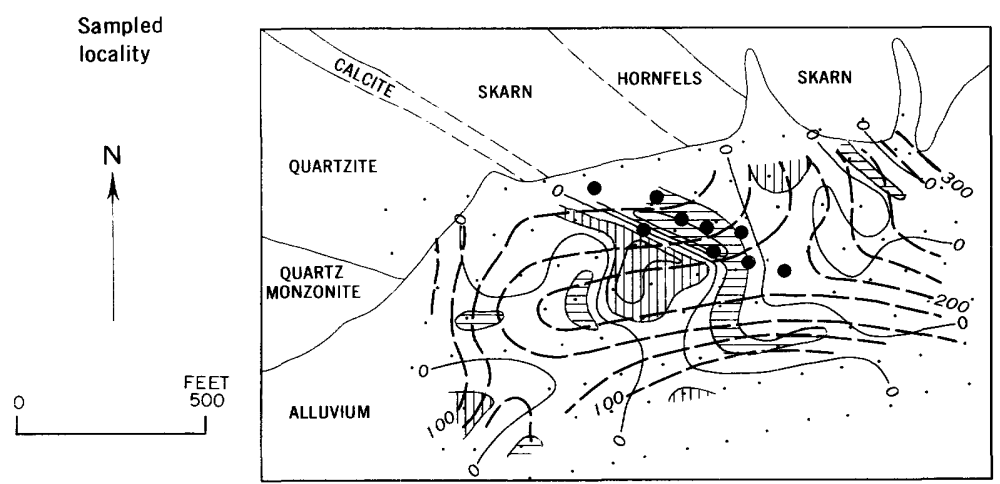

D. QUARTIC TREND AND DEVIATIONS FROM QUARTIC TREND

FIgURE 136.4.-Trends (dashed lines), in parts per million, and trend deviations of moving-average copper content in alluvium, Rocky Range, Utah. Contour interval $25 \mathrm{ppm}$; values larger than $100 \mathrm{ppm}$ and smaller than $-100 \mathrm{ppm}$ not contoured.

from its source, or from mechanical transportation of copper downhill during formation of the alluvial cover.

This geologic interpretation of the trend-analysis results is only one of a number that could be advanced, but whether it is correct or not has no bearing on the value, or the potential value of these results or results from future work. There can be little doubt that deviations from progressively higher order trends, 1st through 4th degree, show an increasingly better spatial correspondence to the known ore body in the area, or that the moving-average trend deviations in general show a clearer correspondence to the ore body than do the original data.

Polynomial terms of 5 th, 6 th, and 7 th degree account for nonsignificant portions of the variance of the original data and, similarly, small portions of the total sum of squares in the moving averages (see table). Consequently, the quartic trend is regarded as the probable appropriate model to describe the trend (Ostle, 1954, p. 141-142). The question of selecting a model to describe the trend in a particular set of data (that is, how to decide whether the trend should be described by a 1 st, $2 \mathrm{~d}$, or higher order equation in a particular problem) has not been completely resolved by previous workers, and a great deal of experimentation needs to be done. Trend analysis of geologic data is not yet developed to the stage where it can be applied with preset objective rules.

Statistical tests for trend significance, employing the $F$ ratio, are not strictly valid if local concentrations of positive or negative deviations are present. Such concentrations imply the absence of independence of the deviations, a fundamental assumption prerequisite to the test. Thus, the very property of the data being sought is a hindrance to an important part of the statistical analysis. The use of moving averages further reduces the independence of the deviations, to a point where $F$ tests should not be presented as even approximately correct tests of significance. On the other hand, if the statistical significance determined for trends in the original data is accepted, there may be little need to test the almost identical trends in the moving-average data.

The computation of trends in the moving-average data may be circumvented by applying the movingaverage method to the deviations from trends in the original data. Contour maps constructed in this manner are given in figures $136.5 A-D$. In this partic- 


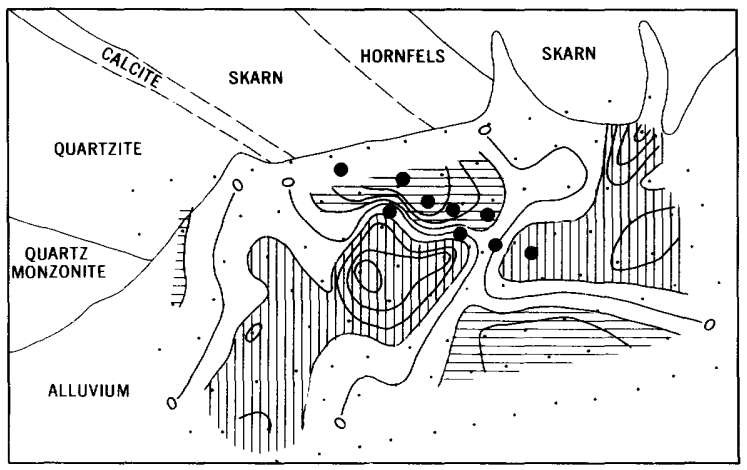

A. MOVING AVERAGES OF DEVIATIONS FROM LINEAR TREND SHOWN IN FIGURE 136.2A

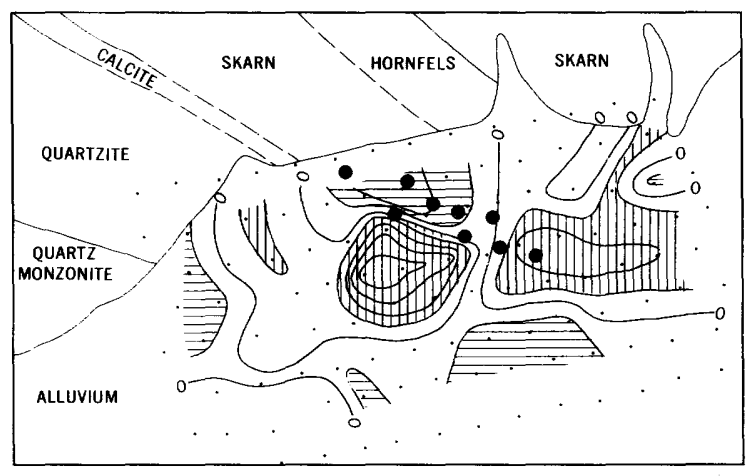

C. MOVING AVERAGES OF DEVIATIONS FROM CUBIC TREND SHOWN IN FIGURE $136.2 \mathrm{C}$

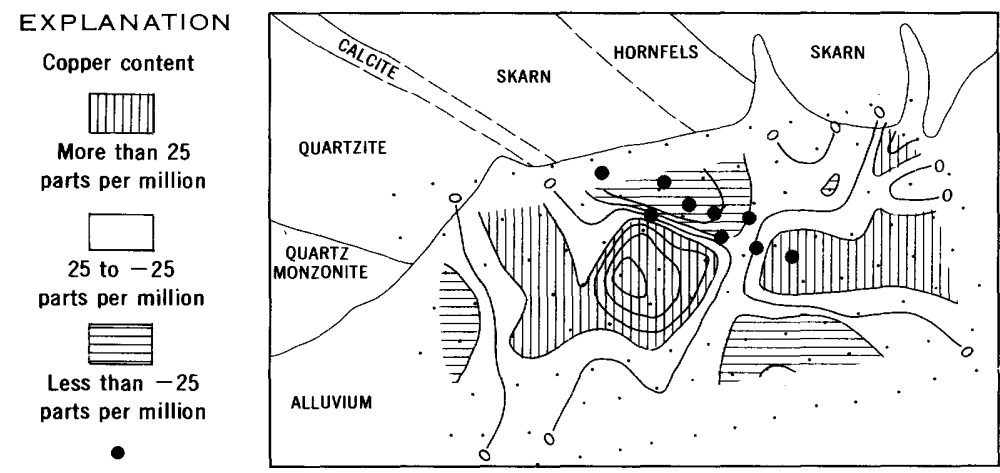

B. MOVING AVERAGES OF DEVIATIONS FROM QUADRATIC TREND SHOWN IN FIGURE $136.2 B$

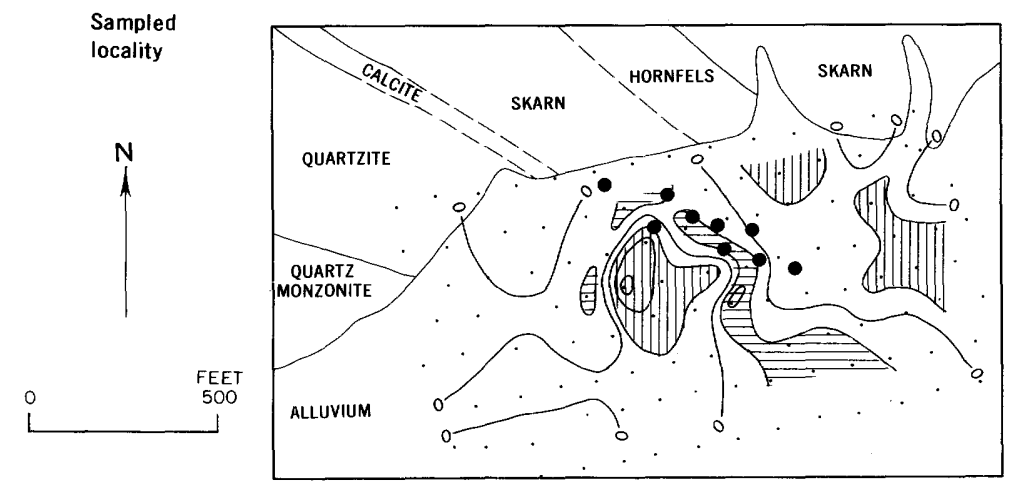

D. MOVING AVERAGES OF DEVIATIONS FROM QUARTIC TREND SHOWN IN FIGURE $136.2 D$

FigURE 136.5.-Moving averages of trend deviations shown in figure 136.2. Contour interval 25 ppm. Values larger than $100 \mathrm{ppm}$ and smaller than $-100 \mathrm{ppm}$ not contoured.

ular study such maps do not exhibit as clear a reltioan of alluvial copper to the ore body as observed in the moving-average deviations (figs. $136.3 A-D$ ), but the patterns are similar. Which method, if either, will prove to be the better one on further application is unknown.

One additional and highly pertinent matter deserves attention here; this is the problem of anomaly definition. In the trend-analysis method, a geochemical anomaly (a local feature of the data deserving of investigation) should be defined in terms of its magnitude, both in lateral extent and in intensity, but such definition must await additional experience with trend analysis in geochemical prospecting problems.

\section{REFERENCES}

Erickson, R. L., and Marranzino, A. P., 1960, Geochemical prospecting for copper in the Rocky Range, Beaver County,
Utah: Art. 47 in U.S. Geol. Survey Prof. Paper 400-B, p. B98-B101.

Grant, Fraser, 1957, A problem in the analysis of geophysical data: Geophysics, v. 22, p. 309-344.

Hawkes, H. E., and Webb, J. S., 1962, Geochemistry in mineral exploration: New York, Harper and Row, $413 \mathrm{p}$.

Krumbein, W. C., 1956, Regional and local components in facies maps: Am. Assoc. Petroleum Geologists Bull., v. 40, no. 9, p. 2163-2194.

_ 1959, Trend surface analysis of contour-type maps with irregular control-point spacing: Jour. Geophys. Research, v. 64 , no. 7 , p. $823-834$.

Oldham, C. H. G., and Sutherland, D. B., 1955, Orthogonal polynomials: their use in estimating the regional effect: Geophysics. v. 20, p. 295-306.

Ostle, Bernard, 1954, Statistics in research: Ames, Iowa, The Iowa State College Press, $487 \mathrm{p}$.

Whitten, E. H. T., 1959, Composition trends in a granite: modal variation and ghost stratigraphy in part of the Donegal granite, Eire: Jour. Geophys. Research, v. 64, no. 7, p. 835-848. 


\title{
Article 137
}

\section{INVESTIGATION OF SAMPLING-ERROR EFFECTS IN GEOCHEMICAL PROSPECTING}

\author{
By A. T. MIESCH and J. J. CONNOR, Denver, Colo.
}

\begin{abstract}
Large local variation in soils and rocks causes large sampling error, and may obscure variation that is of interest in geochemical prospecting. A simulation experiment illustrates how the effects of sampling error may be overcome by dividing the area into cells and randomly selecting a number of samples per cell.
\end{abstract}

Analysis of geochemical data from the Rocky Range, Utah, by Connor and Miesch (Art. 136) points to the probable importance of sampling error in obscuring subtle relations between minor elements in alluvium and buried ore deposits. Sampling error does not imply incorrect sampling procedures or mistakes in carrying out the procedures, but merely the difference between a sample and the total material that might have been sampled at the same locality. Locality here can mean a point on a sampling grid, a cell within a grid, an outcrop, or an entire rock body, depending on what the sample is intended to represent. In the following discussion, we shall assume that there is no sampling bias, that the average of a number of values representing a sampling locality tends toward the true average value for that locality, as the number of sample values is increased. In this sense, we are concerned here with sampling precision, one specific aspect of sampling error. Sampling precision obtained in any specific sampling program is determined entirely by local variation or local heterogeneity in the material being sampled.

In the design of a geochemical prospecting sampling plan, the selection of the sampling interval is of particular importance. For the plan to be efficient, the interval must depend on the dimensions of the target being sought. An unnecessarily coarse sampling interval may prevent detection of the target and too fine an interval will result in sample and analytical waste. Actually, too little can be predicted about target sizes (that is, dimensions of dispersion halos) resulting from various sizes and types of ore deposits in different geologic environments to select the interval rigidly on this basis. The interval is commonly selected by consideration of target size gained through experience in specific areas or types of geologic environments.

Once the sampling interval has been selected, on whatever basis, the area may be divided into a number of square cells, each cell having the dimensions of the sampling interval. The purpose of the sampling, then, is to examine variation among cells. Variation within cells is not of particular interest, except to evaluate the effects of sampling error. Due to natural local heterogeneity in many rocks and soils, the variation within cells may be significantly larger than that among cells. If this happens to be the case, any variation among cells will probably be obscure if one collects one or a number of samples per cell and plots the individual sample values on maps. Plotting average values for each cell will help clarify the pattern of variation among cells because the variation of an average is less than that of the individual values. The number of values on which each average should be computed in order to reduce the effects of within-cell variation sufficiently can be estimated from preliminary results, as shown in the following discussion.

A simulation experiment has been conducted to illustrate the approach. A linear trend identical to that shown in figure $136.2 \mathrm{~A}$ of Connor and Miesch (Art. 136), having the form $\mathrm{Cu}=90.4+0.88 X-0.31 Y$, is assumed to represent a trace-copper trend (fig. 137.1A). Copper is measured in any arbitrary unit (for example, parts per million) and $X$ and $Y$ are units of distance from an arbitrarily selected origin. The map area measures 80 by 120 units and has been divided into cells 20 units on a side; values of the trend were calculated for 2 randomly selected positions in each cell. To each of these trend values was added a random 


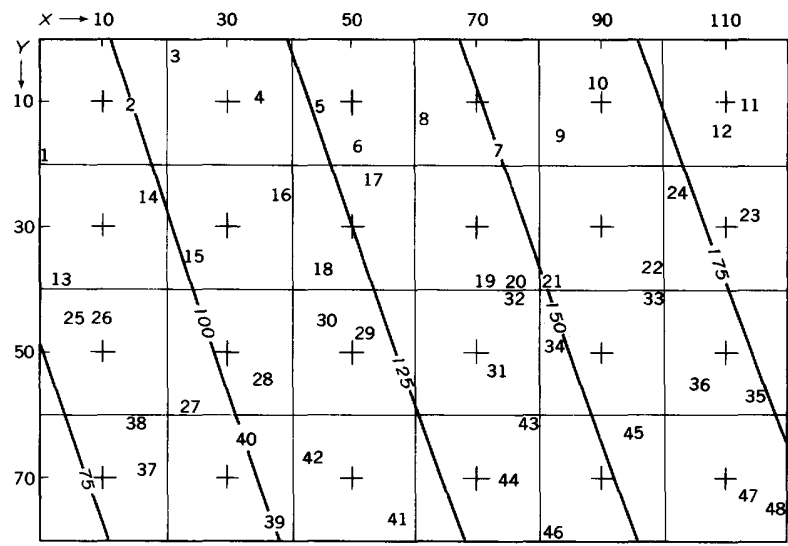

A. ORIGINAL TREND $(\mathrm{Cu}=90.4+0.88 X-0.31 Y)$
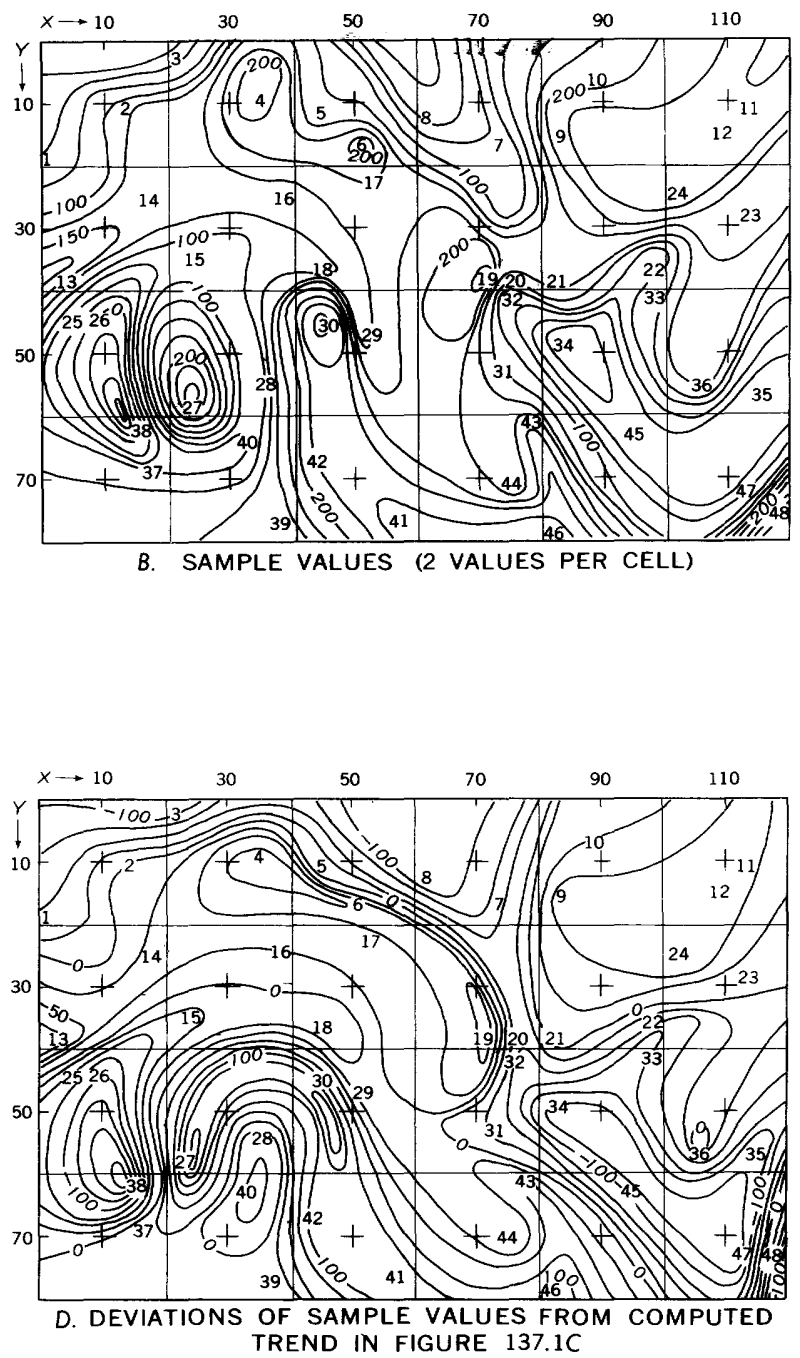

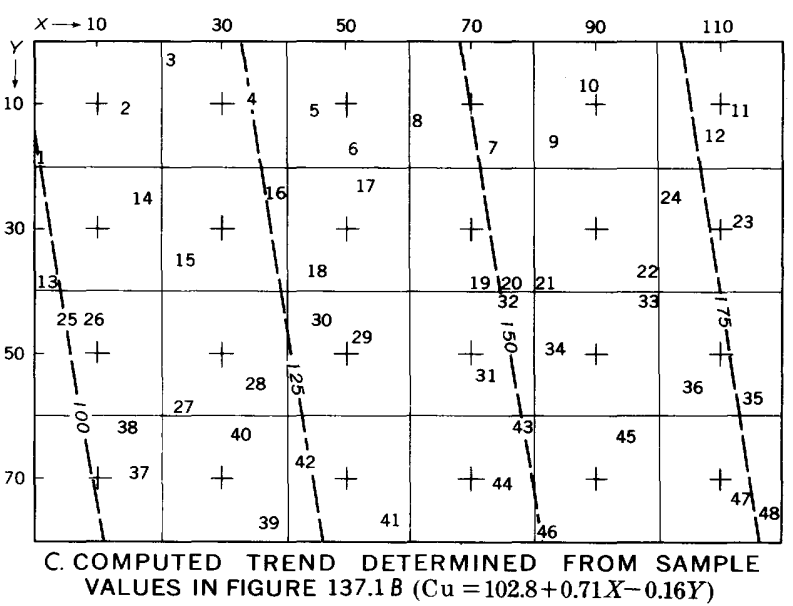

FIgURE 137.1.-Contour maps of original trend, sample values, computed trend, and trend deviations (contour interval equivalent to 25 parts per million).

deviation drawn from a normal population with $\mu=0$ and $\sigma^{2}=7,487$, providing 48 "sample values."

A sample value, $V$, is determined by:

$V=90.4+0.88 X-0.31 Y+\sigma d$,
where $\sigma=\sqrt{7487}=86.52$, and $d$ is a normal random deviate with $\mu=0$ and $\sigma^{2}=1$ taken from tables of The Rand Corp. (1955). The symbol $\mu$ refers to the population mean, the mean of an infinite number of deviates that could have been used. The symbol $\sigma^{2}$ refers to the population variance, and $\sigma$ is the population standard deviation.

The variance of the random deviations, 7,487, is identical to the mean sum of squares computed for the linear-trend deviations in the table of Connor and Miesch (Art. 136). The 48 sample values, each consisting of a trend value and a random-error deviation, are contoured in figure $137.1 \mathrm{~B}$. The random error has obliterated the trend of figure $137.1 A$. Table 137.1
TABLE 137.1.-Estimation of variance components

\begin{tabular}{|c|c|c|c|c|c|}
\hline Source of variation & $\begin{array}{l}\text { Sum of } \\
\text { squares }\end{array}$ & $\begin{array}{c}\text { Degrees } \\
\text { of } \\
\text { free- } \\
\text { dom }\end{array}$ & $\begin{array}{l}\text { Mean } \\
\text { square }\end{array}$ & $\begin{array}{l}\text { Mean } \\
\text { square is } \\
\text { estimate } \\
\text { of- }\end{array}$ & $\begin{array}{c}\text { Estimate } \\
\text { of } \\
\text { variance } \\
\text { com- } \\
\text { ponent }\end{array}$ \\
\hline A. 48 trend values (fig. & \multirow{4}{*}{$\begin{array}{r}44,109 \\
1,260 \\
45,369\end{array}$} & \multirow{4}{*}{$\begin{array}{l}23 \\
24 \\
47\end{array}$} & \multirow{3}{*}{$\begin{array}{r}1,918 \\
53\end{array}$} & \multirow{3}{*}{$\sigma^{2}+2 \sigma c^{2}$} & \multirow{3}{*}{$\begin{array}{r}933 \\
53\end{array}$} \\
\hline $\begin{array}{l}137.1 A) \text { : } \\
\text { Between cells.. }\end{array}$ & & & & & \\
\hline Within cells...- & & & & & \\
\hline B. 48 sample values (fig. & & & & \multirow{3}{*}{$\sigma^{2}+2 \sigma_{c^{2}}$} & \multirow{3}{*}{$\begin{array}{r}892 \\
6,705\end{array}$} \\
\hline $\begin{array}{l}137.1 B) \\
\text { Between cells.- }\end{array}$ & \multirow{3}{*}{$\begin{array}{l}195,224 \\
160,917 \\
356,141\end{array}$} & \multirow{3}{*}{$\begin{array}{l}23 \\
24 \\
47\end{array}$} & \multirow{2}{*}{$\begin{array}{l}8,488 \\
6,705\end{array}$} & & \\
\hline $\begin{array}{l}\text { Between cells.-.- } \\
\text { Within cells.....- }\end{array}$ & & & & & \\
\hline Total & & & & & \multirow{4}{*}{$\begin{array}{r}638 \\
8,865\end{array}$} \\
\hline C. 192 sample values (fig. & \multirow{3}{*}{$\begin{array}{r}321,199 \\
1,489,298 \\
1,810,497\end{array}$} & \multirow{4}{*}{$\begin{array}{r}23 \\
168 \\
191\end{array}$} & \multirow{3}{*}{$\begin{array}{r}13,965 \\
8,865\end{array}$} & \multirow{3}{*}{$\begin{array}{l}\sigma^{2}+8 \sigma^{2} \\
\sigma^{2}\end{array}$} & \\
\hline $\begin{array}{l}137.2 \mathrm{C}) \\
\text { Between cells.-. }\end{array}$ & & & & & \\
\hline Within cells & & & & & \\
\hline D. 384 sample values (fig. & $1,810,497$ & & & & \\
\hline $\begin{array}{l}137.2 \tilde{E}) \\
\text { Between cells }\end{array}$ & 372,560 & 23 & 16.198 & $\sigma^{2}+16 \sigma^{2}$ & 509 \\
\hline Within cells & $2,894,465$ & 360 & 8,040 & & 8,040 \\
\hline Total & $3,206,020$ & & & & \\
\hline
\end{tabular}

(parts A and B) shows estimates of the within- and between-cell variance components of values contoured 
in figures $137.1 A$ and $137.1 B .^{1} \quad$ The variation of trend values from figure $137.1 A$ is predominantly between cells, whereas the variation of sample values contoured in figure $137.1 B$ is predominantly within cells.

A least-squares regression surface, fitted to the values of figure $137.1 \mathrm{~B}$ using a technique described by Krumbein $(1959$, p. 826$)$, is shown in figure $137.1 C$. It approximates the original trend in figure $137.1 \mathrm{~A}$, is statistically significant at the 80-percent confidence level (table 137.2, part A), but accounts for only 8 percent

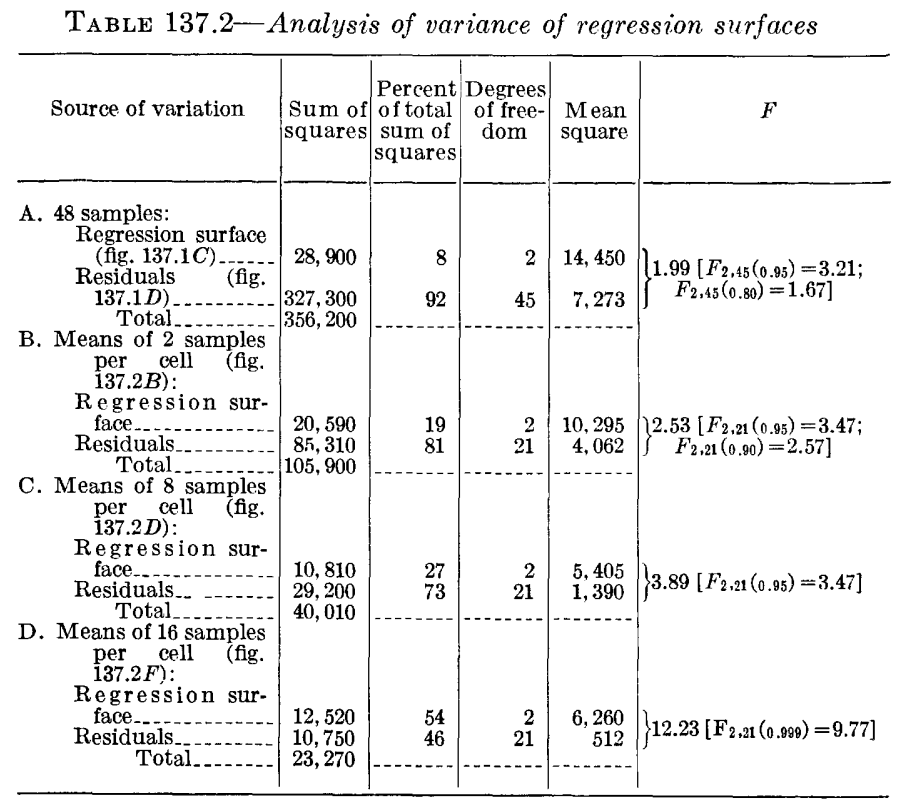

of the total sum of squares. The remaining portion of the total sum of squares is contained in the residuals, or the deviations of values from the trend. Contours of the residuals (fig. 137.1D) are very similar to those drawn on the original data (fig. 137.1B), before the trend was removed.

The only stable part of the simulated copper distribution is the trend; the deviations are entirely random with respect to position on the map. If the simulation experiment were repeated, it may be expected that something approximating the imposed trend would again be recovered, but the second deviation map is likely to be entirely different from that in figure 137 . $1 D$. The patterns of variation among cells as shown by the original values (fig. $137.1 B$ ) and by the trend deviations (fig. 137.1D) are unstable, due in large part to variation within cells, or to cell-sampling error. Inasmuch as the analysis of variance shows the importance of sampling error in this problem, average values for each cell are computed to reduce the sampling-error

\footnotetext{
1 The method of estimation of variance components is described in numerous statistical tests, such as Tippett (1952, p. 172). Krumbein and Slack (1956) also present a discussion of the method applied to a geochemical problem.
}

effects. The variance of an average is $1 / N$ th of the variance of the $N$ values: $\sigma_{\overline{\mathbf{x}}}^{2}=\sigma^{2} / N$.

Figure 137.2A shows the distribution as determined from 24 cell means, each mean computed on the 2 values in the cell. The extreme variation of figure $137.1 B$ is subdued, but the original trend is still not apparent. A regression surface fitted to the data of figure 137.2A and deviations from the surface are shown in figure $137.2 B$. The surface is nearly significant at the 90-percent confidence level, and accounts for 19 percent of the total sum of squares in the average data. The deviations from the trend are still pronounced.

The effects of within-cell variance can be further reduced by "collecting" a number of additional "samples" per cell sufficient to reduce the variance of their mean to an amount more similar to the between-cell variance. This number can be approximated from variance-component estimates, using a method applied to soil sampling by Youden and Mehlich (1937, p. 68). Their method applied to these data show that the collection of $n$ samples per cell should provide a mean for each cell that tends to have less variance than means among cells: $\sigma^{2} / n \leq \sigma_{c}^{2}$, where $\sigma^{2}$ is the variance within cells and $\sigma_{c}^{2}$ is the variance between cells. Table 137.1 (part B) gives variance components for the 48 initial samples of figure $137.1 B$. Accordingly, by the above inequality, $6,705 / n \leq 892 ; n \geq 8$.

Instead of 2 samples per cell, 8 are needed to provide a cell-mean variance roughly equal to the estimate of between-cell variance.

Accordingly, 6 additional samples were collected from each cell, using the same procedures used in obtaining the first 48. Figure $137.2 \mathrm{C}$ shows the distribution of copper based on means of eight values per cell. The strong highs and lows of figure $137.2 \mathrm{~A}$ are reduced, but the imposed trend is still not particularly apparent. A regression surface fitted to the data of figure $137.2 \mathrm{C}$ and deviations from the surface are shown in figure $137.2 \mathrm{D}$. Analysis of variance (table 137.2, part C) indicates that the trend is statistically significant at the 95-percent confidence level and accounts for 27 percent of the total sum of squares in the average data. The trend deviations are becoming less impressive.

Variance components within and between cells are estimated in table 137.1 (part C) for the 192 sample values used in figure $137.2 \mathrm{C}$. It is presumed that the new estimate of within-cell variance, based on 4 times as many samples per cell, is more stable than that previously estimated from the 48 samples (table 137.1, part B). Applying the technique of Youden and Mehlich again to the revised component estimates, a new estimate of samples needed per cell to reduce within-cell effects to an amount equal to or less than 


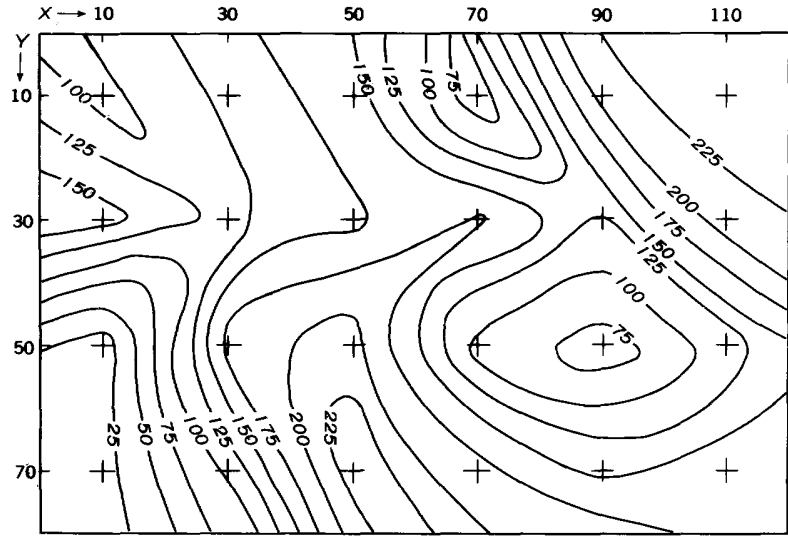

A. CELL MEANS, EACH COMPUTED FROM 2 SAMPLE VALUES, USING THE 48 SAMPLE VALUES FROM FIGURE 137. $2 B$
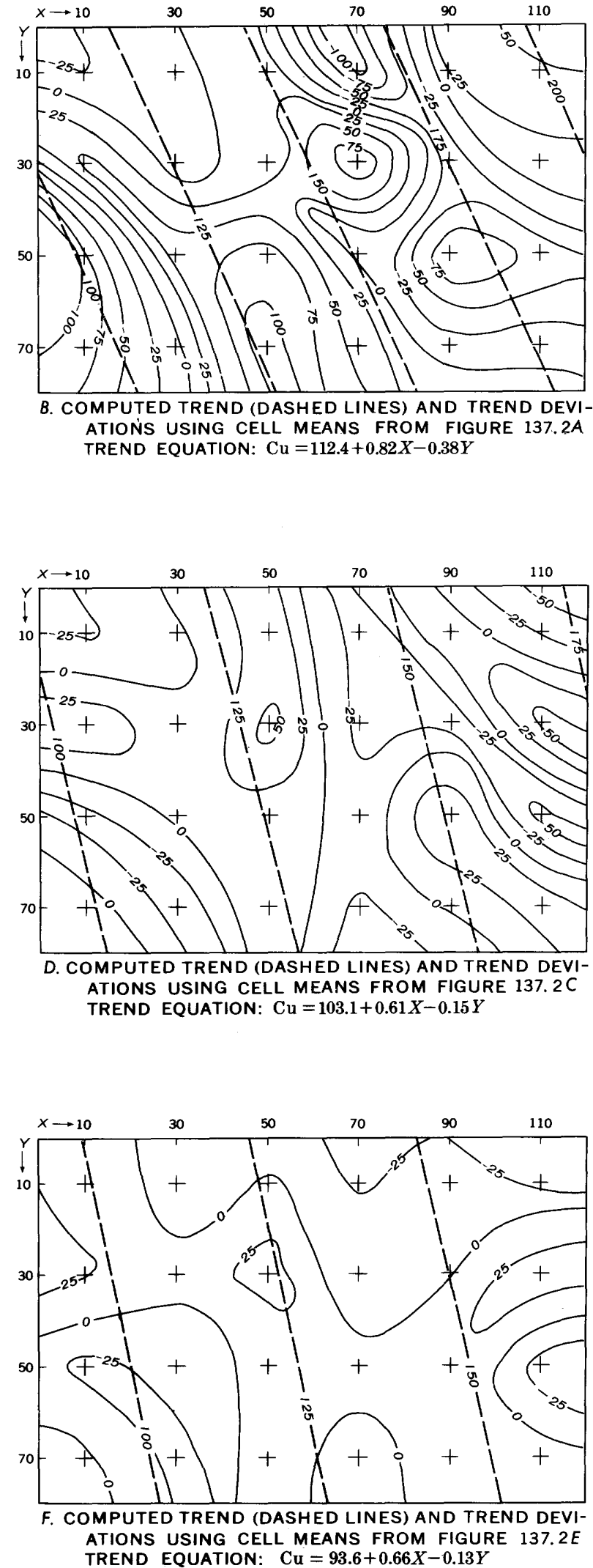

FIGURE 137.2.-Contour maps of cell mean sample values, computed trends, and trend deviations (contour interval equivalent to 25 parts per million). 
those among cells is obtained: $8,865 / n \leq 638 ; n \geq 14$. In an attempt to insure that within-cell effects are reduced below those between cells, 8 additional samples (rather than the indicated 6) were taken from each cell of figure $137.1 A$ using the same procedures used in obtaining the previous 192. A total of 384 samples have now been collected.

Figure $137.2 E$ is a contour map of the 24 cell means based on 16 samples per cell. The regression surface fitted to the 24 cell means and the deviations from the surface are shown in figure $137.2 F$. The analysis of variance test of the trend is given in table 137.2 (part D). This trend is highly significant and accounts for 54 percent of the total sum of squares in the average data. A comparison of figure $137.2 F$ with figure $137.1 D$ indicates the large reduction of local or withincell effects when cell means are computed from a larger number of samples.

A new estimate of the number of samples per cell needed to reduce within-cell effects to an amount less than those between cells may be obtained from the components of table 137.1 (part D): 8,040; $n \leq 509$; $\mathrm{n} \geq 16$. This estimate is equal to the actual number of samples used in the analysis and is twice that of the initial estimate ( 8 samples) computed from the original 48 values. The initial estimate was based on too few samples to be stable, but did serve as a rough estimate or guide to the number of samples required from each cell. Increasing the number of samples per cell beyond 16 would clarify the trend and suppress the effects of within-cell variance on trend deviations even farther.

In order to use the variance-component technique provided by Youden and Mehlich, it is not necessary to sample every cell in the preliminary survey. Cells to be examined in a preliminary survey might be picked randomly. Reliability of the results will in all cases depend on randomization procedures, the validity of other assumptions prerequisite to analysis of variance (Eisenhart, 1947), the number of cells sampled, and the number of samples taken per cell.

Geochemical prospecting by soil analysis is well suited to the use of statistical designs. The restriction on sampling design imposed by lack of outcrops in most geologic sampling is, for the most part, not present.
Generally, samples are taken over an area at more or less equal spacing, frequently on a square grid. Merits of grid samples, unalined stratified samples, and random samples and stratified random samples, are discussed by Quenouille (1945), Krumbein (1954), and Berry (1962), but the variance-component approach used here requires random sampling within each cell (stratified random samples).

In the geochemical prospecting study in the Rocky Range (Connor and Miesch, Art. 136), the problem of sampling error was tentatively resolved by using a moving-average method to smooth out the data, but even though this procedure clarified the possible geologic relations shown by the data, it did introduce other problems. Variation among adjacent cells is suppressed, and independence of deviations from computed trends, important from statistical considerations, is partially destroyed. It is suggested that the estimation of variance components to determine within- and between-cell effects, and estimation of the number of samples required to sufficiently reduce the within-cell effects, is a more satisfactory method for reducing effects of local variation or sampling error in geochemical prospecting.

\section{REFERENCES}

Berry, B. J. L., 1962, Sampling, coding, and storing flood plain data: U.S. Dept. Agriculture, Agriculture Handb. 237, 27 p.

Eisenhart, Churchill, 1947, the assumptions underlying the analysis of variance: Biometries, v. 3, no. 1, p. 1-21.

Krumbein, W. C., 1954, Statistical significance of beach sampling methods: Beach Erosion Board, Tech. Memo. 50, 33 p. - 1959, Trend surface analysis of contour-type maps with irregular control-point spacing: Jour. Geophys. Research, v. 64 , no. 7 , p. 823-834.

Krumbein, W. C., and Slack, H. A., 1956, Statistical analysis of low-level radioactivity of Pennsylvanian black fissle shale in Illinois: Geol. Soc. America Bull., v. 67, no. 6, p. 739-761.

Quenouille, M. H., 1945, Problems in plane sampling: Math. Statistics Annals, v. 20, p. 355-375.

The Rand Corporation, 1955, A million random digits, with 100,000 normal deviates: Glencoe, Ill., The Free Press, $600 \mathrm{p}$.

Tippett, L. H. C., 1952, The methods of statistics, 4th ed.: New York, John Wiley and Sons, Inc., 395 p.

Youden, W. S., and Mehlich, A., 1937, Selection of efficient methods for soil sampling: Boyce Thompson Inst. Contr., v. 9, p. 59-70. 


\title{
EFFECT OF CATION EXCHANGE ON THE THERMAL BEHAVIOR OF HEULANDITE AND CLINOPTILOLITE
}

\author{
By ANNA O. SHEPARD and HARRY C. STARKEY, Denver, Colo.
}

Work done in cooperation with the U.S. Atomic Energy Commission

\begin{abstract}
Heulandite has the thermal stability of clinoptilolite when the calcium is largely replaced by potassium. Clinoptilolite has the thermal behavior of a heulandite-like mineral, associated with some natural clinoptilolites, when calcium replaces most of the alkalis. X-ray analysis was used in the experiments.
\end{abstract}

Heulandite and clinoptilolite, zeolites with nearly identical X-ray patterns, differ in thermal behavior. The crystal structure of heulandite is changed on heating; that is, the mineral inverts. The higher temperature form has been referred to as heulandite B (Slawson, 1925; Milligan and Weiser, 1937; Koizumi and Kiriyama, 1953; and Mumpton, 1960). The temperature of inversion varies with the length of time that it is heated. Clinoptilolite does not invert on heating, and it withstands higher temperatures and longer heating than heulandite (Mumpton, 1960; Shepard, 1961). In chemical composition, these minerals differ in two respects: (1) the calcium content is higher than that of alkalis in heulandite, whereas alkalis exceed calcium in clinoptilolite, and (2) clinopiilolite has the higher silica-alumina ratio. Mumpton (1960, p. 363) considered that the essential difference between the two minerals is in the silica-alumina ratio: he reasoned that a mineral should not be defined by its exchangeable cation. Mason and Sand (1960, p. 348-349) emphasized the difference in cations and illustrated graphically that the two minerals differ more in content of $\mathrm{CaO} \cdot \mathrm{Al}_{2} \mathrm{O}_{3}$ and $(\mathrm{Na}, \mathrm{K})_{2} \mathrm{O} \cdot \mathrm{Al}_{2} \mathrm{O}_{3}$ than in silica content. Mumpton, Mason, and Sand, contrary to Hey and Bannister (1934), all considered heulandite and clinoptilolite distinct minerals because of the apparent absence of minerals of intermediate composition that would characterize an isomorphous series.

Investigation of the effect of chemical composition on the thermal behavior of these two zeolites has been difficult because clinoptilolite, unlike heulandite, is not easily obtained in a pure state. A possible means of studying the effects of alkalis and alkaline earths is by the exchange of cations in the minerals. Results of preliminary tests that were limited largely to a single set of conditions are reported at this stage of the study because the properties of some of the products are similar to those of certain natural minerals that occur as intergrowths with clinoptilolite.

The samples used in these cation-exchange experiments included heulandite from Summit and Paterson, N.J., and Berufiord, Iceland, and clinoptilolite from the Pierre Shale, Buffalo County, S. Dak. The heulandites were well crystallized. Clinoptilolite from the Pierre Shale had an exceptionally strong X-ray pattern that showed no impurities, but minute inclusions could be detected optically. Normal solutions of calcium, potassium, and sodium chlorides, neutralized with their respective hydroxides, were used to provide the exchangeable cations. Samples were of two grain sizes, less than 100 mesh and less than 2 microns. The process of exchange was accelerated by heating samples in a pressure cooker for 16 hours (Starkey, Art. 139), a method that might be classed as mildly hydrothermal. The thermal behavior of the minerals before and after exchange was determined by X-ray analysis of samples heated for 10 minutes at $50^{\circ} \mathrm{C}$ temperature intervals (Shepard, 1961). Samples were $\mathrm{X}$-rayed as soon as cool enough to handle and scanned rapidly $\left(2^{\circ} / \mathrm{min}\right)$ because heulandite $\mathrm{B}$ begins to change back to the low-temperature form 15 minutes after cooling.

With the heating schedule adopted, the natural heulandite samples started to invert at $250^{\circ} \mathrm{C}$, the pattern of heulandite $B$ attained maximum intensity between $300^{\circ} \mathrm{C}$ and $350^{\circ} \mathrm{C}$, and its structure was nearly 


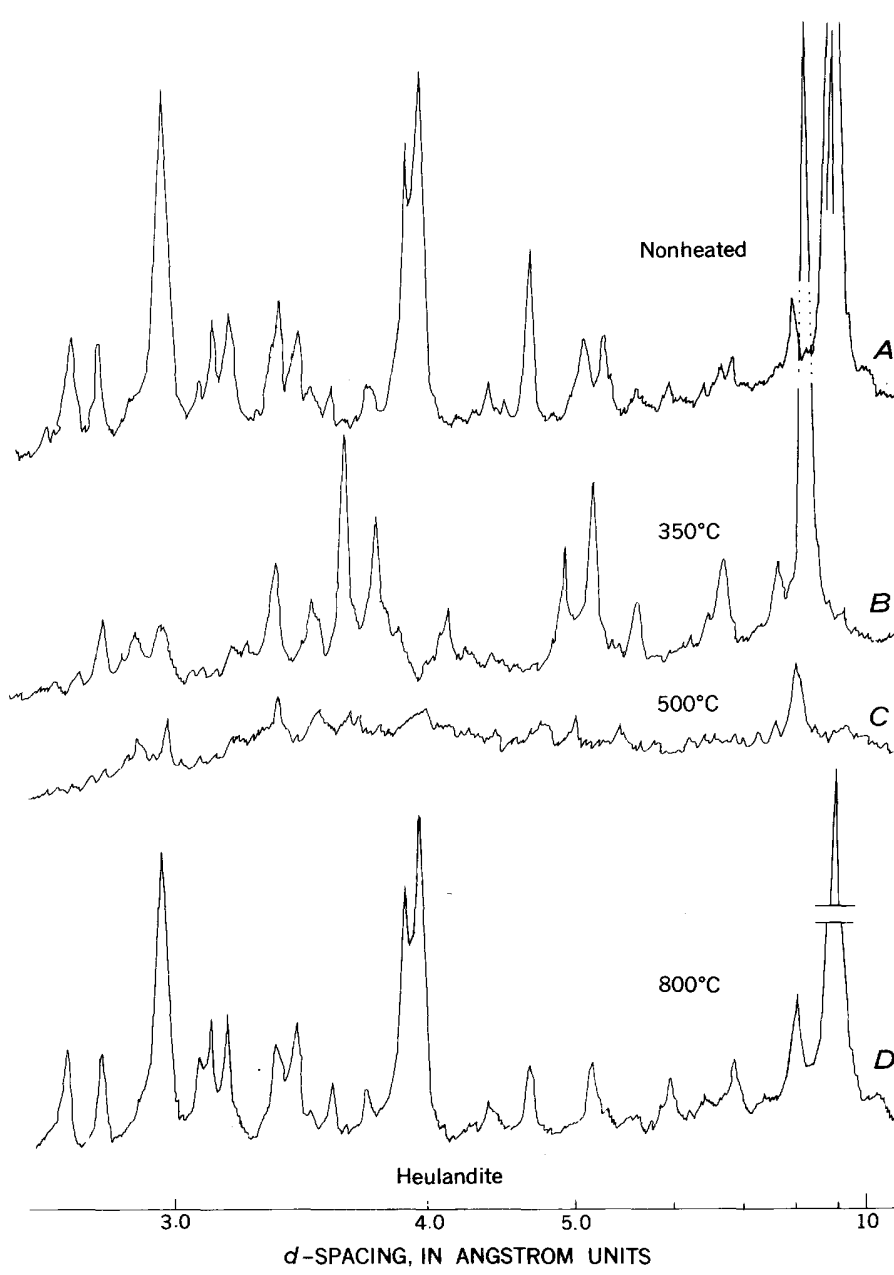

FigURE 138.1.-X-ray diffractograms illustrating thermal behavior of heulandite. $A-C$, untreated mineral; $D$, mineral treated with $1 N \mathrm{~K} 61$.

destroyed at $500^{\circ} \mathrm{C}$ (fig. 138.1, $A-C$ ). When these samples were treated with $1 N \mathrm{KCl}$ and heated, some did not invert at all and others contained only a minor constituent that inverted, forming a weak 020 heulandite-B peak. Like clinoptilolite, the heulandite that did not invert could be heated above $800^{\circ} \mathrm{C}$ before its structure was destroyed (fig. 138.1, D).

The effects of the length of time the sample was heated, grain size, and concentration of the solution used for cation exchange were tested in samples that showed a small amount of heulandite $B$ after exchange with potassium chloride. Increase of the heating period from 16 to 48 hours did not eliminate the weak heulandite-B 020 peak, but when grain size was reduced to less than 2 microns, a dimension still well above the limits of X-ray resolution, no trace of the peak remained. Increase of the concentration of the potassium chloride solution from $1 N$ to $2 N$ affected the inversion of the 020 heulandite-B peak without decreasing its intensity; contraction of the peak was more gradual than it is in typical heulandite (fig. 138.7, $A, B$ ). A similar behavior has been observed in some heulandite-like minerals from the Nevada Test Site.

Clinoptilolite from the Pierre Shale (fig. 138.2, $C$ ) treated with a $1 \mathrm{~N} \mathrm{CaCl}_{2}$ solution is rendered less stable; it inverts and the positions of nine strong peaks are similar to those of heulandite B (fig. 138.2, D). This modified clinoptilolite is not identical with heulandite, however; the temperatures of inversion and of destruction are both approximately $100^{\circ} \mathrm{C}$ higher than those of heulandite.

The stabilizing effect of potassium on heulandite and the loss of stability of clinoptilolite when alkalis are replaced by calcium indicate that potassium is an important factor in determining the thermal stability of these two zeolites.

Treatment with $1 N \mathrm{NaCl}$ did not affect the thermal behavior of either clinoptilolite or heulandite. The sodium content is usually higher than potassium in natural clinoptilolite, and the amount of exchange of

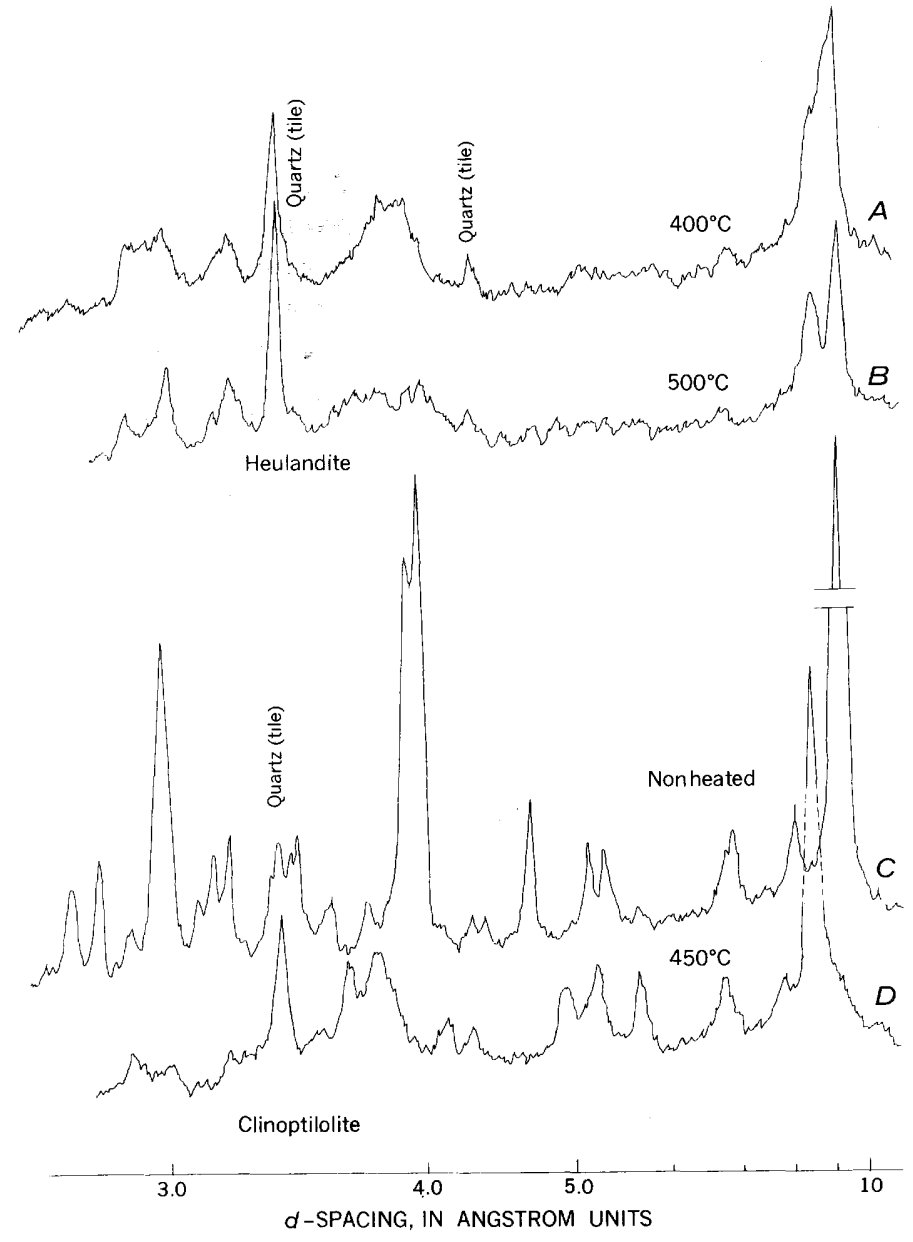

Figure 138.2.-X-ray diffractograms illustrating thermal behavior of heulandite and clinoptilolite. $A, B$, heulandite treated with $2 N \mathrm{KCl} ; C, D$, clinoptilolite treated with $1 N$ $\mathrm{CaCl}_{2}$. 
potassium is as yet undetermined. Lack of change in the thermal behavior of heulandite treated with $1 N$ $\mathrm{NaCl}$ emphasizes the importance of determining the extent of exchange. If the cations of the heulandite after treatment with sodium chloride are comparable to those of natural clinoptilolite and the heulandite retains its original thermal behavior, the possibility that the silica-alumina structure also affects thermal behavior has to be considered.

The composition of the minerals after the cation exchange has not yet been determined by wet chemical analysis. Estimations of the extent of alteration induced by these exchange procedures are based on results of analyses of leachates. The cations of the natural and the treated minerals were released by $1 N$ neutral ammonium chloride by exchange methods. Comparison of results is therefore limited to exchangeable cations. In the analysis of leachates, alkalis were determined with a flame photometer and calcium by versene titration.

\section{TABLE 138.1.-Comparison of cations released by $\mathrm{NH}_{4}^{+1}$ from natural and from previously heated minerals \\ [Cations in milliequivalents per $100 \mathrm{~g}$ of sample]}

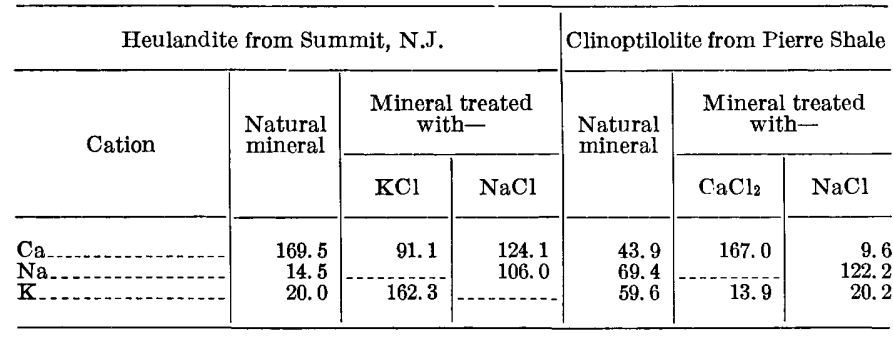

The analyses show high percentages of critical cations in the treated minerals. Expressed in meq/100 $\mathrm{g}$ of sample, potassium made up 63 percent of the exchanged cations in the leachate of the KCl-treated heulandite that did not invert, and calcium made up 93 percent of the exchanged cations in the leachate of the $\mathrm{CaCl}_{2}$ treated clinoptilolite that inverted. The calciumpotassium ratios of the determined cations (meq/100 g of sample) in the leachates from the natural and comparable treated minerals are in similar ranges: natural heulandite, 8.48, calcium-treated clinoptilolite, 12.01; natural clinoptilolite, 0.74 ; KCl-treated heulandite, 0.56 .

Analyses of the ammonium chloride leachate of the sodium-treated heulandite indicate a complete replacement of the potassium with sodium and depletion of the calcium; nevertheless, the amount (in milliequivalents) of calcium is still greater than the amount of sodium, a fact that may account for the typical heulandite-like thermal behavior of the mineral. $716-626 \quad 0-64-7$
Sodium did not fully replace the potassium in the clinoptilolite, but it constitutes 80 percent of the sum of the three cations, expressed in milliequivalents, and calcium is reduced to 6 percent.

The extent of exchange with ammonium chloride in these tests is indicated by comparison of the calcium, potassium, and sodium cations determined in leachates of heulandite and clinoptilolite with the determination of these ions by wet chemical analysis of these minerals. (table 138.2). TABLE 138.2.-Percentage of original cations in leachate from cation
exchange
[Cations in meq/100 $\mathrm{g}$ of sample]

\begin{tabular}{|c|c|c|c|c|c|c|}
\hline \multicolumn{4}{|c|}{ Heulandite from Summit, N.J. } & \multicolumn{3}{|c|}{ Clinoptilolite from Pierre Shale } \\
\hline Cation & Mineral 1 & Leachate & $\begin{array}{c}\text { Percent } \\
\text { exchanged }\end{array}$ & Mineral & Leachate & $\begin{array}{l}\text { Percent } \\
\text { exchanged }\end{array}$ \\
\hline $\begin{array}{l}\mathrm{Ca} \\
\mathrm{Na} \\
\mathbf{K}\end{array}$ & $\begin{array}{r}244.0 \\
21.0 \\
29.3\end{array}$ & $\begin{array}{r}169.5 \\
14.5 \\
20.8\end{array}$ & $\begin{array}{l}69.5 \\
69.0 \\
71.0\end{array}$ & $\begin{array}{l}51.8 \\
78.3 \\
56.1\end{array}$ & $\begin{array}{l}43.8 \\
69.4 \\
56.9\end{array}$ & $\begin{array}{r}84.7 \\
88.6 \\
101.4\end{array}$ \\
\hline
\end{tabular}

1 Cations in original mineral determined by wet chemical analysis and converted to meq/100 $\mathrm{g}$ of sample.

Approximately 70 percent of the cations expressed in meq/100 $\mathrm{g}$ in samples of heulandite and an average of 90 percent of those in samples of clinoptilolite were exchanged.

The refractive indices of the minerals also show the effects of exchange, although they are less definitive than the thermal effects. The untreated Paterson heulandite with indices in white light of $\alpha, 1.494$, $\beta, 1.495+$, and $\gamma, 1.500-1.501$ appeared as a fine aggregate with an average index of 1.482 after treatment with potassium chloride. The average index of the untreated Pierre clinoptilolite, also an aggregate, was 1.470. Treatment with calcium chloride raised it to 1.480 , not quite as high as that of the KCl-treated heulandite.

Natural zeolites that behave thermally as though both clinoptilolite and heulandite or a "heulandite-like" mineral are present occur in tuffs of the Nevada Test Site (Shepard, 1961) and in other areas where clinoptilolite is the principal zeolite. Some of these zeolites are zoned, but most crystals are too fine to determine their optical homogeniety. The "heulandite-like" component of these samples does not invert at as low a temperature as typical heulandite. Its thermal behavior is similar to that of calcium-exchanged clinoptilolite.

Natural zeolites with the thermal behavior of both clinoptilolite and a heulandite-like mineral may have been formed by continuous crystallization under a changing environment to produce zoning comparable to that of plagioclase or they may have been formed by partial natural exchange of cations of clinoptilolite 
during some period after crystallization. The preliminary tests of the effects of cation exchange on the thermal behavior of heulandite and clinoptilolite suggests that partial natural exchange may have been the cause of the anomalous behavior of the heulandite-like mineral. Anomalous effects that have been reproduced in the laboratory include the higher temperatures as compared with those of heulandite at which the mineral inverts and is destroyed, the modification of the contraction of the 020 reflection during inversion, and the change in refractive indices.

Cation size and charge must both affect the results obtained in the attempt to exchange cations of heulandite and clinoptilolite. It has seemed doubtful that a univalent cation larger than calcium could replace it and balance the negative charge of heulandite, but the thermal behavior of the $\mathrm{KCl}$-treated heulandite clearly indicates that an effective amount of potassium was introduced. The replacement of potassium and sodium by bivalent calcium in the clinoptilolite structure should not be difficult, yet a heulandite-like mineral rather than typical heulandite was produced in the attempted exchange. 'The extent of exchange and the effect of the silica-alumina ratio of the two minerals are both factors to be considered in future experiments.

\section{REFERENCES}

Ames, L. L., Jr., Sand, L. B., and Goldich, S. S., 1958, A contribution on the Hector, California, bentonite deposit: Econ. Geology, v. 53, p. 22-37.

Bramlette, M. N., and Posnjak, E., 1933, Zeolitic alteration of pyroclastics: Am. Mineralogist, v. 18, p. 167-171.

Hay, R. L., 1963, Stratigraphy and zeolitic diagenesis of the John Day Formation of Oregon: Univ. Calif. Publ. in Geologv, v. 42, p. 199-262.

Hey, M. H., and Bannister, F. A., 1934, Studies on the zeolites, Part VIII, "Clinoptilolite," a silica-rich variety of heulandite; Mineralogical Mag., v. 23, p. 556-559.

Koizumi, M., and Kiriyama, R., 1953, Structural changes of some zeolites due to their thermal dehydrations: Univ. Osaka Sci. Rept. no. 2, p. 67-85.

Mason, B., and Sand, L. B., 1960, Clinoptilolite from Patagonia; the relationship between clinoptilolite and heulandite: Am. Mineralogist, v. 45, p. 341-351.

Milligan, W. D., and Weiser, H. B., 1937, The mechanism of the dehydration of heulandite: Jour. Phys. Chemistry, v., 41, p. 1029-1041.

Mumpton, F. A., 1960, Clinoptilolite redefined: Am. Mineralogist, v. 45, p. 351-370.

Piersson, L. V., 1890, On mordenite: Am. Jour. Sci., v. 40, p. $232-237$.

Shepard, A. O., 1961, A heulandite-like mineral associated with clinoptilolite in tuffs of Oak Spring Formation, Nevada Test Site, Nye County, Nevada: Art. 264 in U.S. Geol. Survey Prof. Paper 424-C, p. C320-C323.

Slawson, C. B., 1925, The thermo-optic properties of heulandite: Am. Mineralogist, 10, p. 305-331. 


\title{
DETERMINATION OF THE ION-EXCHANGE CAPACITY OF A ZEOLITIC TUFF
}

\author{
By HARRY C. STARKEY, Denver, Colo.
}

\begin{abstract}
Determination of the exchange capacity of some zeolitic tuffs may require an extremely long time for the reaction rate to attain a constant value. A heating method is suggested whereby the rate of the reaction is increased, so that the exchange-capacity determinations can be made within a period of time as short as 24 hours.
\end{abstract}

Studies of the ion-exchange capacities of volcanic tuffs collected at the Nevada Test Site showed that the longer the samples were leached, the higher were the observed capacities. A method was sought which would enable a constant value to be attained within a reasonably short time.

The sample used for most of the experimental work, sample $\mathrm{B}$, had the following mineralogical composition, based on X-ray diffraction analysis using nickel-filtered copper radiation: Approximately two-thirds consisted of quartz and feldspar with a trace of montmorillonite; one-third was made up of a zeolite which appeared to be a heulandite-clinoptilolite type. The latter had a strong (004) peak at $22.3^{\circ} 2 \theta$ which, according to Mumpton (1960), indicates clinoptilolite.

Mumpton described clinoptilolite, however, as having a structure which, on heating, persisted to above $700^{\circ} \mathrm{C}$, whereas heulandite showed a phase change at $230^{\circ} \pm 10^{\circ} \mathrm{C}$. For sample B, the intensity of the diffraction peaks began to diminish at about $270^{\circ} \mathrm{C}$ and the peaks disappeared at about $600^{\circ} \mathrm{C}$. Mason and Sand (1960) state that heulandite and clinoptilolite have the same structure, but that heulandite is a calcium-rich zeolite and clinoptilolite is a sodium-potassium-rich mineral. The leachate of sample B contained about three times as much calcium as sodium and potassium. These data indicate that the zeolite is better described, following Mason and Sand (1960), as heulandite than as clinoptilolite.

An ammonium chloride batch method was used to determine the exchange capacity of the experimental material. The sample was crushed lightly to break up aggregates and then put through a 60 -mesh sieve; no grinding was necessary except for some quartz and feldspar. One hundred fifty $\mathrm{ml}$ of $1.0 \mathrm{~N} \mathrm{NH}_{4} \mathrm{Cl}$ solution neutralized with ammonium hydroxide was added to 1 gram of sample. After soaking without agitation for specified times in covered beakers at room temperatures which ranged from $17^{\circ} \mathrm{C}$ to $30^{\circ} \mathrm{C}$, the mixtures were centrifuged and the supernatant liquids retained for cation analysis. To samples which were leached longer than 24 hours, distilled water was added periodically to maintain the volume. The samples were then washed 4 times with ethyl alcohol, the first 2 washings being added to the supernatant liquid. The sodium and potassium in the supernatant liquid were analyzed by flame photometry; the calcium and magnesium by versene titration. The amount of ammonia adsorbed on the sample was determined by distillation.

Sample A, a soil containing montmorillonite, mica, kaolinite, quartz, and feldspar, as determined by X-ray diffraction, was run for comparative purposes. As can be seen on figure 139.1, sample A reached a constant value almost immediately, but the exchange-capacity values of sample $B$ increased with time. The values are plotted on semilog paper. Other tuff samples, not shown, exhibited the same characteristics.

In an attempt to reduce the long leaching times necessary to achieve a constant value in the observed capacities of the tuff, a series of experiments was carried out at a temperature $\left(95^{\circ} \mathrm{C}\right)$ just short of boiling, using the same leaching times as in the studies at room temperature. As can be seen in figure 139.2, the heated samples reached a constant value at 84 milliequivalents $/ 100$ grams in about 16 days. By extending both curves, and assuming no leveling off of the room-temperature curve, it appears that it would take at least 4 years to reach a constant value at room temperature. 


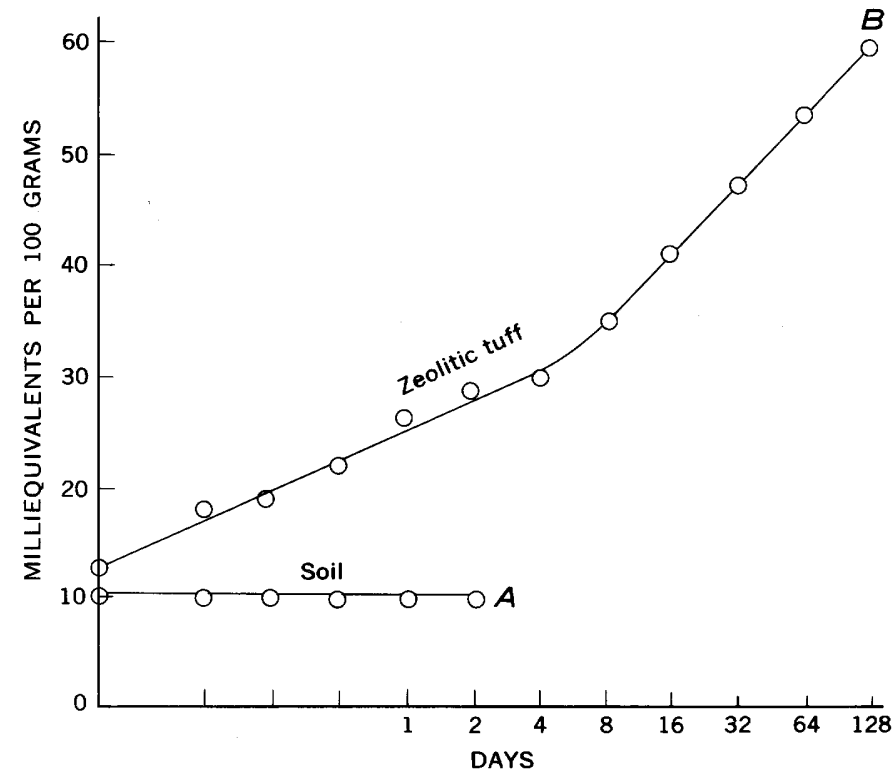

Figure 139.1-Exchange capacity of samples A (soil) and B (zeolitic tuff), determined at room temperature as a function of time.

To see if the rate of exchange could be further increased, a series of runs was made in which the time remained constant at 24 hours but in which the temperatures were varied. The values produced a straight line when plotted on arithmetic graph paper (fig. 139.3). The highest temperature was obtained by heating the covered samples in an atmosphere of 100 percent relative humidity in a household pressure cooker, which produced approximately 2 atmospheres of pressure. The temperature, $118^{\circ} \mathrm{C}$, was calculated from the pressure. The exchange capacity measured after 24 hours was $84 \mathrm{meq} / 100 \mathrm{~g}$, identical with that determined at $95^{\circ} \mathrm{C}$, indicating that a constant value had been obtained. The $\mathrm{pH}$ of the ammonium chloride was lowered from 7.0 to 6.4 . Increasing the heating time at $118^{\circ} \mathrm{C}$ to 48 hours on another sample resulted in no change in the measured exchange capacity.

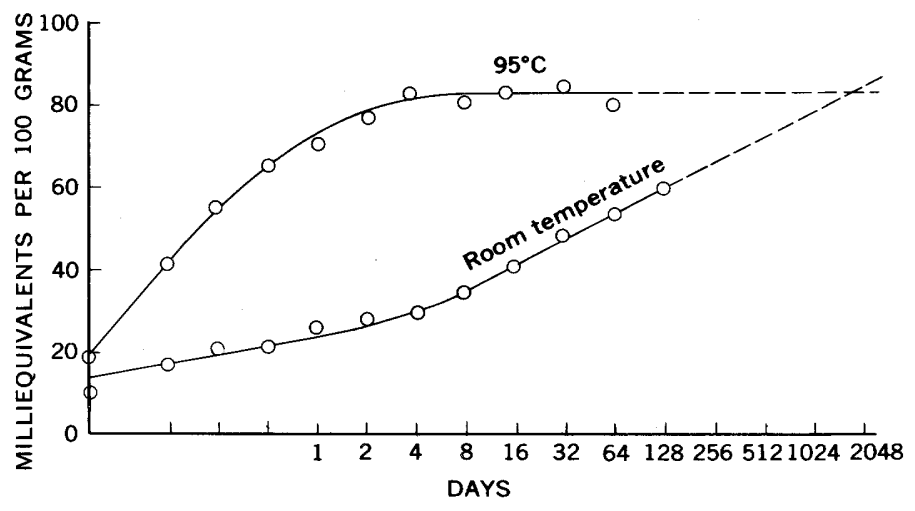

FIGURE 139.2.-Comparison of rates of exchange in zeolitic tuff, as determined at room temperatures and at $95^{\circ} \mathrm{C}$.

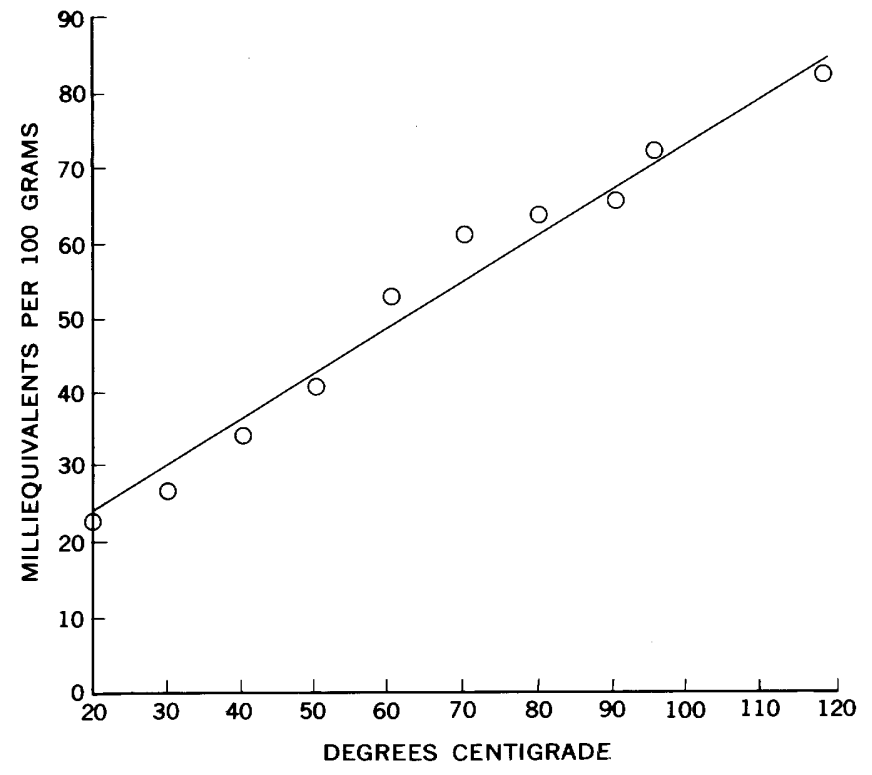

Figure 139.3.-Determined exchange capacity of zeolitic tuff (heated for 24 hours) as a function of temperature.

As the exchange reaction approached a constant value, the ratio of the magnesium to the sum of the cations in the leachate increased (see accompanying table). In the unheated series the ratio increased from 0.10 at half an hour to 0.20 after 128 days; in the series heated at $95^{\circ} \mathrm{C}$ the ratio increased from 0.14 to 0.26 . Ratios of 0.26 were also obtained for samples heated at $118^{\circ} \mathrm{C}$ for 24 and 48 hours.

As determined by visual estimation of $\mathrm{X}$-ray diffraction pattern, which may be in error by \pm 10 percent, approximately a third of sample $B$ is zeolite. If the determined exchange capacity is multiplied by 3 a value of $252 \mathrm{meq} / 100 \mathrm{~g}$ is obtained. This value is reasonable when compared with the exchange capacity of heulandite $(330 \mathrm{meq} / 100 \mathrm{~g})$ given by Barrer (1958), who obtained the value by calculation from the hydrated formula weight.

Effect of time and temperature on exchange capacity and ratio of magnesium to sum of cations in zeolitic tuff

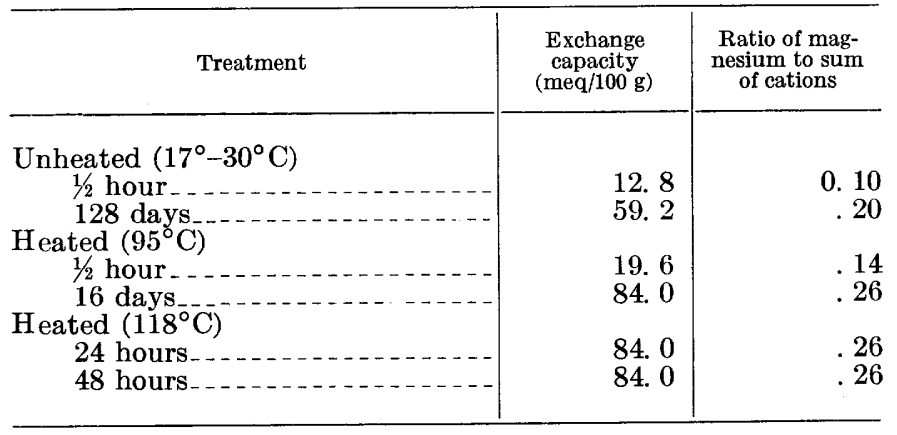


Comparison of X-ray diffraction patterns made of samples both before and after treatment did not indicate any structural changes in the sample.

In summary, the long period of time for the exchange reaction of some zeolites to reach a constant value at room temperatures may be shortened by heating. The identical values obtained at both $95^{\circ} \mathrm{C}$ and $118^{\circ} \mathrm{C}$ indicate that heating does not alter the exchange capacity or the ratios of the cations. The increase, with time, in the ratio of magnesium to the sum of the cations indicates that the magnesium is more difficult to exchange in this type of sample.

\section{REFERENCES}

Barrer, R. M., 1958, Crystalline ion-exchanges: Chem. Soc. (London) Proc., April 1958, p. 99-112.

Mason, Brian, and Sand, L. B., 1960, Clinoptilolite from Patagonia; the relationship between clinoptilolite and heulandite: Am. Mineralogist, v. 45, p. 341-350.

Mumpton, F. A., 1960, Clinoptilolite redefined: Am. Mineralogist, v. 45, p. 351-369. 


\title{
Article 140 \\ GEOLOGICAL AND GEOCHEMICAL RECONNAISSANCE, SOUTHERN PART OF THE SMYRNA MILLS QUADRANGLE, AROOSTOOK COUNTY, MAINE
}

\author{
By LOUIS PAVLIDES and F. C. CANNEY, Beltsville, Md., and Denver, Colo.
}

\begin{abstract}
Closely folded Paleozoic rocks, mostly impure calcic and ankeritic limestone, micaceous siltstone and quartzite, and slate, comprise the principal sedimentary rocks of the southern part of the Smyrna Mills quadrangle. Felsic plutons locally have intruded and thermally altered these regionally metamorphosed rocks (chlorite zone) to cordierite-biotite and calc-silicate hornfels. Thus, the plutons are enclosed by hornfels aureoles up to 2 miles wide. Stream-sediment sampling revealed a slightly higher-than-background molybdenum content in four streams draining an area underlain by felsic rocks and plutons. Tests also were made for antimony, zinc, and heavy metals. Seasonal variations of copper and molybdenum were detected.
\end{abstract}

Closely folded sedimentary rocks of Paleozoic age in the chlorite zone of regional metamorphism have been locally intruded and thermally metamorphosed by felsic plutons in the southern part of the Smyrna Mills quadrangle. Thin glacial till mantles much of the upland areas, whereas stratified deposits of sand and gravel cover the lowlands. The topography is controlled by the bedrock except for local eskers and kames. High ridges of hornfels surround areas of rounded and subdued hills and ridges underlain by felsic plutons (fig. 140.1). The northwest part of the area is underlain by folded sedimentary rocks and is mostly a lowland with gently rolling hills, except for the ridge formed by a small felsic mass and its associated hornfels aureole.

The ribbon rock member of the Meduxnekeag Formation (Pavlides, 1962, p. 11-12 and 21-23) of Middle Ordovician and probably Late Ordovician age contains the oldest rocks of the region. It consists chiefly of thin- to medium-bedded gray-blue impure calcic and ankeritic limestones, interlayered with each other and with slate. Fossils have not been found in the green and gray-green phyllite that lies between the Meduxnekeag Formation and the Silurian rocks, and these phyllites can only be dated as of Late Ordovician or
Early Silurian age or both. Locally this phyllite is calcareous and contains minor amounts of conglomerate.

The undifferentiated Silurian rocks span Early through Late Silurian time as determined from the graptolite faunas identified by W. B. N. Berry (written communications, 1961, 1962) from several localities within them. Gray and gray-green micaceous siltstone and quartzite, commonly interlayered with gray and gray-green slate, are the dominant rock types in this unit; conglomerate is locally abundant. Manganeseand iron-bearing lenses are also present at several horizons.

Calcareous slate that contains brachiopods of Silurian or Devonian age (A. J. Boucot, oral communication, 1963) may be the youngest sedimentary unit of the area.

The sedimentary rocks are closely folded along steep to vertical axial planes that trend east to northeast. Bedding normally dips $70^{\circ}$ to vertical and well-developed fracture cleavage with equally steep dips trends east to the northeast, except in the northeast part of the area where it locally trends northwest. The final folding of the region occurred during the Acadian disturbance, following which the folded rocks were intruded by felsic plutons.

The felsic plutons are not well exposed. The Hunt Ridge pluton appears to contain mostly fine to mediumgrained biotite-hornblende granodiorite, whereas in the Pleasant Lake pluton porphyritic medium- to coarsegrained hornblende-biotite quartz monzonite is present near the center and biotite granodiorite along the southwest margin. The two much smaller masses (fig. 140.1) are granitic. Thermal aureoles up to 2 miles wide rim the plutons and consist of cordieritebiotite and calc-silicate hornfels in which stratification is preserved but cleavage is obliterated. On the northeast side of the Hunt Ridge pluton, hornfels formed 

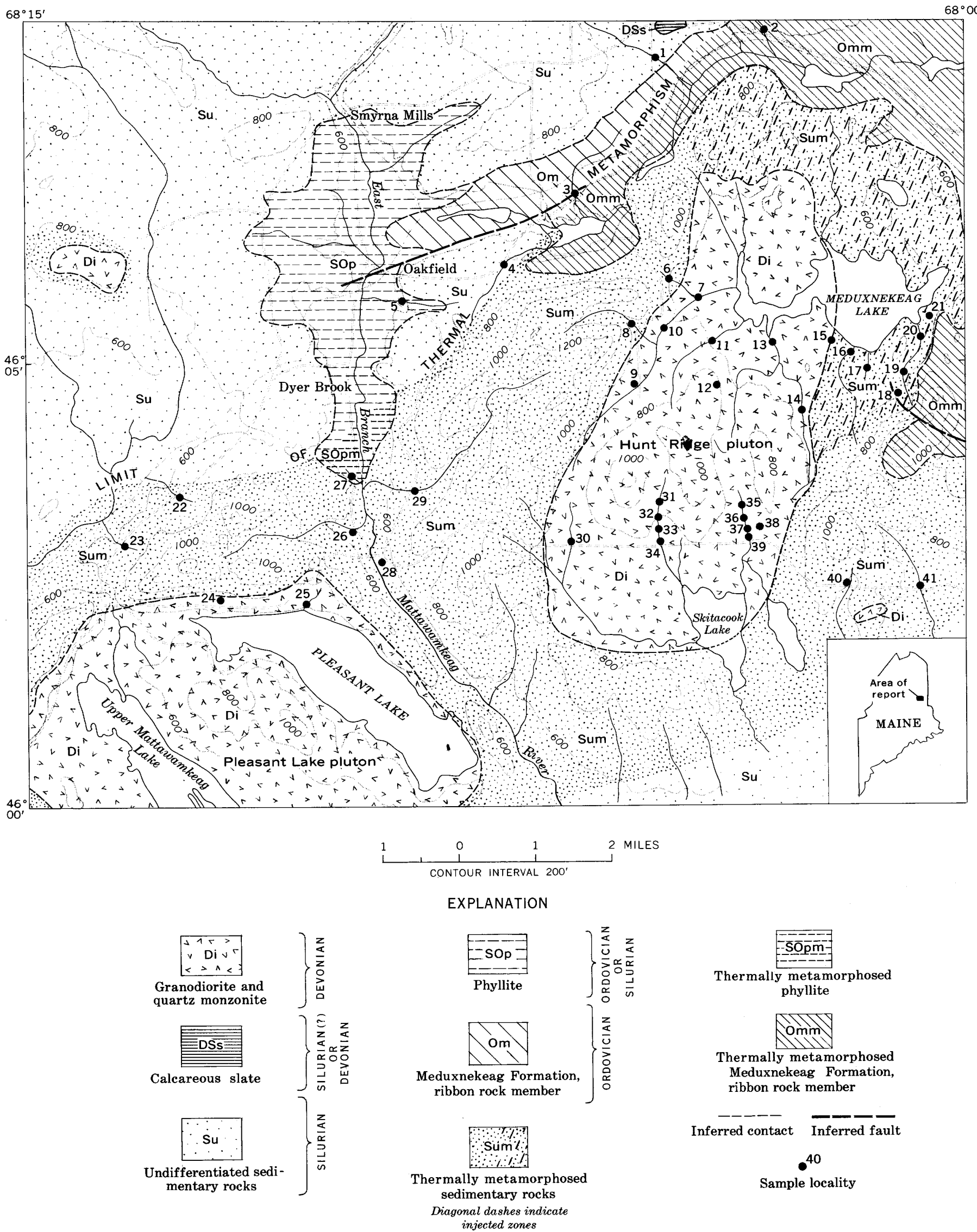

Figure 140.1.-Reconnaissance bedrock geology and stream-sediment sample sites, southern part of Smyrna Mills quadrangle, Maine. 
from sedimentary rocks of Silurian age is intruded by sills and minor dikes of granodiorite, quartz monzonite, and granite of Devonian age.

Many magnetic anomalies, some of considerable magnitude, are present in the hornfels aureoles (Dempsey, 1962). The formation of abundant magnetite by thermal metamorphism of the ferruginous lenses present in the undifferentiated Silurian unit is believed to be the cause of these local magnetic anomalies.

Small amounts of galena, chalcopyrite, and stibnite occur in quartz veins in hornfels on the east side of Meduxnekeag Lake (Houston, 1956, p. 109-110), just beyond the east margin of figure 140.1.

A reconnaissance geochemical drainage survey was made in 1960 and 1961 of the felsic plutons and their aureoles. Samples of fine-grained active stream sediment were collected at the 41 sites shown on figure 140.1. The samples were dried, screened through a 50 -mesh sieve $(0.25-\mathrm{mm}$ opening), and the fine fractions (1g to $25 \mathrm{~g}$ ) analyzed by geochemical prospecting field methods (Ward and others, 1963). All samples were analyzed for copper, lead, zinc, molybdenum, cold-extractable copper, and cold-extractable heavy metals (see accompanying table); the 1960 samples were also analyzed for tungsten and antimony.

In general, the values are quite low and with a few exceptions fall within normal background ranges elsewhere in Maine in similar geologic terrane. Interpretation of these data, however, is complicated because the copper and molybdenum contents of the active alluvium in some of the streams appear to show time variations.

The eight paired samples listed in the table were collected in 1960 and 1961. The data for these show that the copper and molybdenum contents of many of the 1961 samples are appreciably lower than the corresponding 1960 values. No significant differences were noted in the zinc content, however. Although the variability between the 1960 and 1961 copper and molybdenum values is such that no single normalizing factor would be entirely correct, all the data for these can be made more directly comparable by doubling the 1961 values wherever a definite figure is given.

Variations in the metal content of stream sediments with time are known to exist. Barr and Hawkes (1963), who described time variations in the copper content of the stream sediments in two areas in British Columbia, also noted a weak inverse relationship between stream discharge and metal content of the sediments. In the Smyrna Mills area, too, both rainfall and average stream discharge were distinctly less in the summer of 1960 than in the corresponding period of 1961. The
Partial chemical analyses of stream-sediment samples taken in 1960 and 1961 in the southern part of the Smyrna Mills quadrangle, Maine

[Asterisk on sample number indicates 1961 sample. Analyses by G. A. Nowlan, G. H. Van Sickle, and M. J. Bright, Jr.]

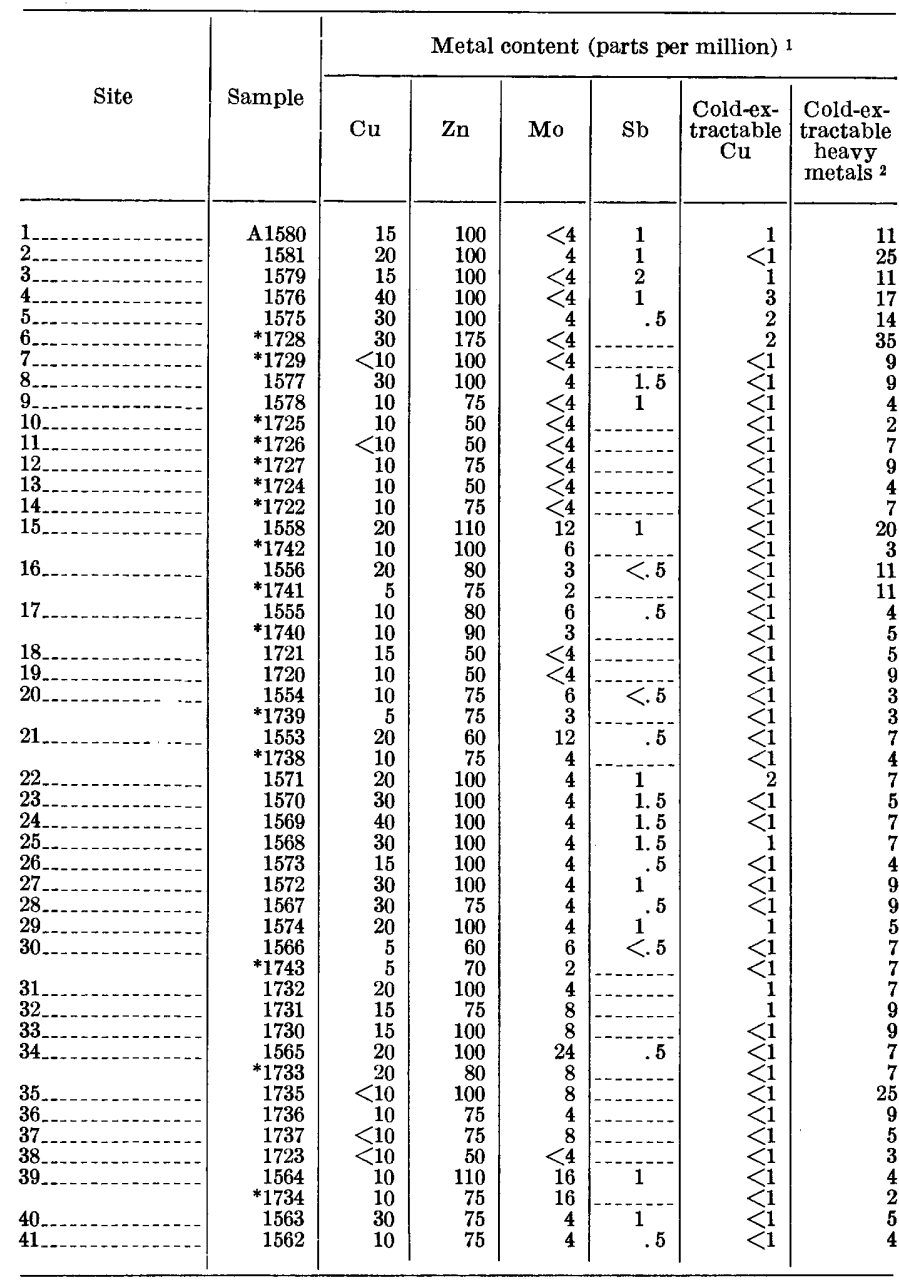

1 Lead (all samples) $\leqq 25 \mathrm{ppm}$. Tungsten (1960 samples only) $<20 \mathrm{ppm}$. 2 Undifferentiated copper, lead, and zinc, expressed as equivalent parts per million zinc.

reasons for such variations of metal content are imperfectly understood. Because the metal content normally is higher in the finer fractions of a sediment sample, possible variations in the average grain size of the sediment with stream discharge must be considered. For the Smyrna Mills samples, however, mechanical analyses revealed only erratic and generally small differences in the percentage of fines between corresponding sample pairs.

In at least 4 streams (sites 15, 21,34, and 39) that drain areas underlain either by the Hunt Ridge pluton or its contact zone, the molybdenum content is slightly anomalous if background is taken as $4 \mathrm{ppm}$ or less. Appraisal of these weak anomalies is impossible on the basis of the available data because little is known about 
the dispersion of molybdenum from molybdenitebearing rock in the northern Appalachians. Several felsic plutons elsewhere in eastern and southeastern Maine, however, are associated with small noneconomic deposits of molybdenite (Canney and others, 1961). The molybdenum anomalies in the two streams in the southern part of the Hunt Ridge pluton (sites 34 and 39) can be considered slightly more significant because their watersheds are contiguous and the contrast of the anomalies is slightly greater.

The sample at site 6 from a stream draining the northwestern contact zone of the Hunt Ridge pluton is weakly anomalous in zine (175 ppm), cold-extractable heavy metals (35 ppm), and possibly anomalous in copper. However, we believe that this anomaly is caused by contamination, because much metallic trash is present in the headwaters of the stream.

\section{REFERENCES}

Barr, D. A., and Hawkes, H. E., 1963, Seasonal variations in copper content of stream sediments in British Columbia [abs.]: Mining Eng., v. 15, p. 61.

Canney, F. C., Ward, F. N., and Bright, M. J., Jr., 1961, Molybdenum content of glacial drift related to molybdenitebearing bedrock, Aroostook County, Maine: Art. 117 in U.S. Geol. Survey Prof. Paper 424-B, p. B276-B278.

Dempsey, W. J., 1962, Aeromagnetic map of the Smyrna Mills quadrangele, Aroostook County, Maine: U.S. Geol. Survey Geophys. Inv. Map GP-294.

Houston, R. S., 1956, Genetic study of some pyrrhotite deposits of Maine and New Brunswick: Maine Geol. Survey Bull. 7, p. 1-117.

Pavlides, Louis, 1962, Geology and manganese deposits of the Maple and Hovey Mountains area, Aroostook County, Maine: U.S. Geol. Survey Prof. Paper 362 [1963].

Ward, F. N., Lakin, H. W., and Canney, F. C., 1963, Analytical methods used in geochemical exploration by the U.S. Geological Survey: U.S. Geol. Survey Bull. 1152. 


\title{
Article 141
}

\section{AGE OF BASEMENT ROCKS FROM THE WILLISTON BASIN OF NORTH DAKOTA AND ADJACENT AREAS}

\author{
By Z. E. PETERMAN and C. E. HEDGE, Washington, D.C.
}

\begin{abstract}
Eleven Rb-Sr age determinations of bottom-hole well samples confirm subsurface extensions of the Churchill and Superior provinces of the Canadian Shield in the Williston basin of North Dakota and of adjacent areas. The boundary between the Churchill (1.7 b.y.) and the Superior (2.5 b.y.) provinces trends south through western North Dakota.
\end{abstract}

Recent radioactivity dating of rocks from the Canadian Shield by laboratories in the United States and Canada has indicated that the geologic provinces of the shield (fig. 141.1) originally defined on the basis of dominant structural trends, rock types, and mineralization (Wilson, 1941; Gill, 1949; Wilson, 1949) are age provinces as well. Tracing of these age provinces in the subsurface is possible by radioactivity dating of basement samples obtained in deep oil-well tests. The Williston basin area is of special interest because of the availability of samples of basement rocks and because of the existence of two age provinces.

Eleven samples, including $8 \mathrm{~K}$-feldspar concentrates and 1 whole-rock sample from drill cores and 2 biotite separates from drill cuttings, were dated by the Rb-Sr method. The approximate location of the wells in
North Dakota, Montana, and Saskatchewan is shown on figure 141.2 (locs. 1-11). Well names, locations, and sample descriptions are given in table 141.1. The material dated, analytical data, and computed ages are given in table 141.2. Potassium-argon age determinations for biotite, hornblende, and pyroxene from seven of the cores, as well as other samples from the area, have been reported earlier by Burwash and others (1962) and by Peterman (unpublished PhD. thesis, 1962). Sample depths below the Precambrian contact range from a few feet to 150 feet. These ages are included in table 141.2 or are shown on figure 141.2. The writers are indebted to R. A. Burwash, University of Alberta at Edmonton; J. P. Gries, South Dakota School of Mines and Technology, Rapid City, S. Dak.; and H. L. Hurley, Amerada Petroleum Corp., Williston, N. Dak., for supplying the samples.

The shield area of northern Saskatchewan and northern Manitoba is part of the extensive Churchill province which was last affected by a major orogeny 1.7-1.8 b.y. $\left(10^{9}\right.$ years) ago. In Minnesota and adjacent regions this event is called the Penokean orogeny (Goldich and others, 1961), whereas in Canadian terminology it is

TABLE 141.1.-Descriptions of dated samples from oil-well tests to the basement

\begin{tabular}{|c|c|c|c|c|c|c|c|}
\hline \multirow{2}{*}{$\begin{array}{l}\text { Locality } \\
\text { (fig. 141.1) }\end{array}$} & \multirow{2}{*}{ Sample } & \multirow{2}{*}{ Well } & \multicolumn{3}{|c|}{ Location } & \multirow{2}{*}{ Sample depth (feet) } & \multirow{2}{*}{ Rock type } \\
\hline & & & Sec. & T. & R. & & \\
\hline $1 \ldots \ldots$ & 3633 & $\begin{array}{l}\text { Mobile Oil Woodley Sinclair } \\
\text { Cantuar X-2-21. }\end{array}$ & 21 & 16 & $17 \mathrm{~W} .3$ & $7,285-7,305_{-}--$ & Porphyritic biotite granite. \\
\hline 2 & 3634 & British American Wilhelm 1-9.. & 9 & 17 & 14 W.3 & $6,735-6,755$ & Porphyritic rhyolite. \\
\hline $3 \ldots \ldots$ & 4219 & Ceepee Baildon 2-11 & 11 & 15 & $26 \mathrm{~W} .2$ & $7,738 \ldots \ldots$ & Biotite-quartz monzonite. \\
\hline $4 \ldots \ldots$ & 4483 & Imperial Stoughton $3-27$ & 27 & 8 & 8 W.2 & $8,830 \ldots$ & Cordierite gneiss. \\
\hline $5 \ldots$ & 4234 & $\begin{array}{l}\text { Socony Western Prairie Imperial } \\
\text { Carievale } 1 .\end{array}$ & 4 & 3 & $32 \mathrm{~W} .1$ & $8,328 \ldots$ & Biotite-quartz monzonite. \\
\hline & 3798 & Shell N. P. $32-33 B$ & 33 & $22 \mathrm{~N}$ & $48 \mathrm{E}$. & $11,050_{-}$ & Pegmatite and amphibolite. \\
\hline & $4679 \ldots$ & Amerada 1 Iverson-Nelson Unit_ & 2 & $155 \mathrm{~N}$ & $96 \mathrm{~W}$ & 13,603 & Altered syenite. \\
\hline & BT-85_- & Amerada N.D. "A" Unit 9 & 16 & $156 \mathrm{~N}$ & $95 \mathrm{~W}$. & $14,825-14,827 \ldots$ & Garnet-biotite gneiss. \\
\hline & 4678 & Amerada 1 Antelope Unit $A \ldots$ & 1 & $152 \mathrm{~N}$ & $95 \mathrm{~W}$. & $15,128 \ldots$ & Hornblende-hypersthene gneiss. \\
\hline $10 \ldots$ & $\mathrm{BT}-86$ & Amerada 8 Scoria Unit & 10 & $139 \mathrm{~N}$. & $101 \mathrm{~W}$ & 13,645 & Biotite-quartz monzonite (?). \\
\hline $11 \ldots$ & 4680 & Herman Hanson 1 Mueller & 20 & $140 \mathrm{~N}$ & $65 \mathrm{~W}$. & 3,305 & Biotite-quartz monzonite. \\
\hline
\end{tabular}




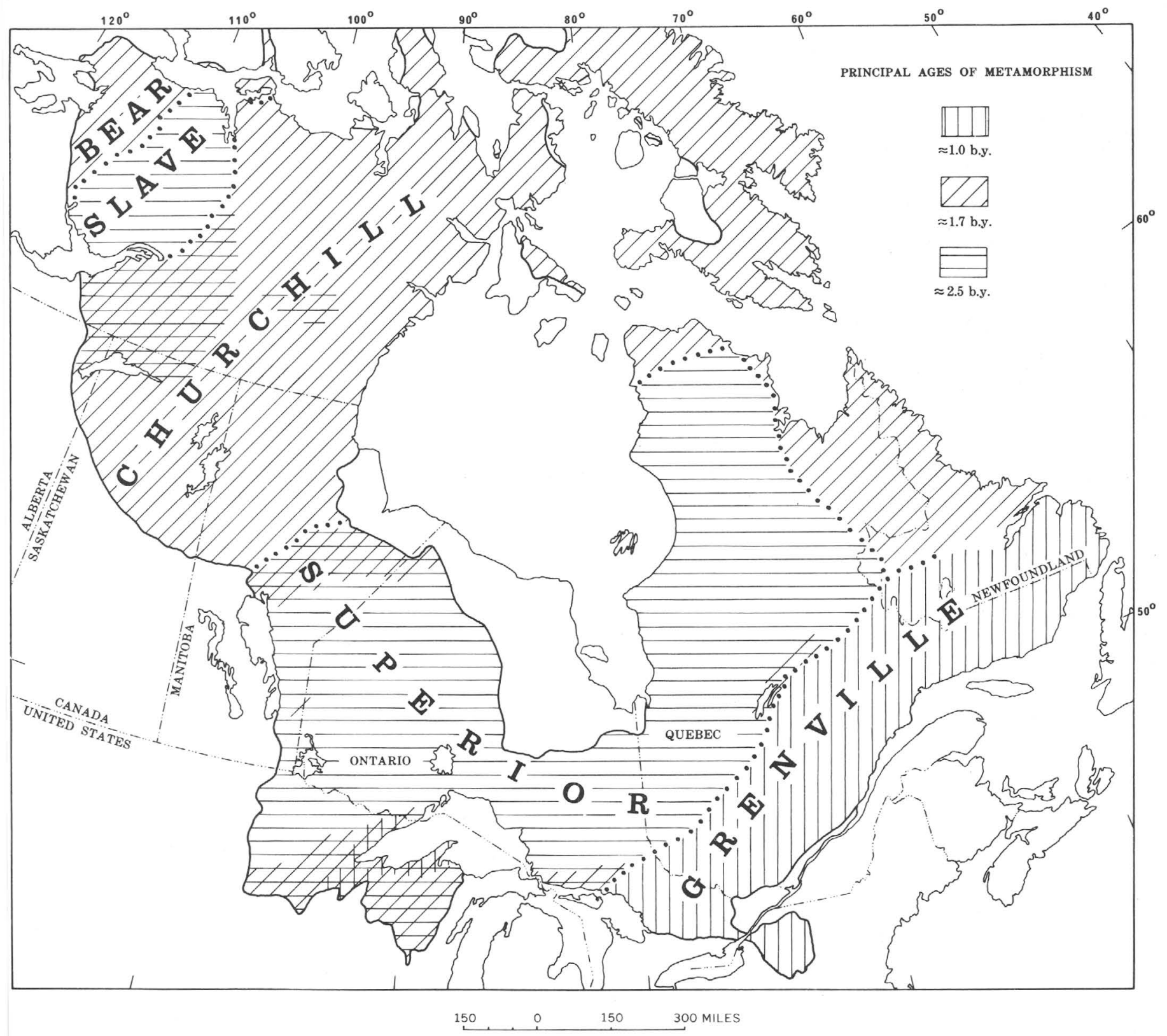

Figure 141.1.- Structural provinces of the Canadian Shield showing age of major orogenies. Combinations of patterns show some principal areas of mixed isotopic ages resulting from overlap of orogenic belts. Boundaries between provinces are shown by dotted lines.

called the Hudsonian orogeny (Stockwell, 1961). The western part of the Superior province includes the shield areas of Ontario and parts of Manitoba and northern Minnesota. Rocks from this province yield ages commonly ranging from 2.4 to $2.6 \mathrm{~b}$.y. and represent the Algoman (Goldich and others, 1961) or Kenoran (Stockwell, 1961) orogeny. In the exposed Precambrian of northern Manitoba, the boundary between the Churchill and Superior provinces is marked by well-developed faulting, ultramafic intrusions, and a regional gravity low paralleled by gravity highs. On the basis of geologic and gravity data, Innes (1960) and Wilson and Brisbin (1961) have suggested that this zone is the remnant of an island are or alpine mountain system. The gravity anomalies (Innes, 1960; Wilson and Brisbin, 1961) and the K-Ar ages of subsurface samples (Burwash and others, 1962) indicate a southward extension of the boundary zone in the subsurface to the international border. The location of the boundary in North Dakota, as shown in figure 141.2, is a projection from Canada fitted to the isotopic ages of basementrock samples. The terminology used in this report is that of Goldich and others (1961). 
TABLE 141.2.- Rb-Sr and K-Ar ages of samples of basement rocks from the Williston basin area

[K-Ar ages from Burwash and others (1962), except Nos. 3 and 6 (hornblende), from Peterman (unpublished PhD. thesis, 1962)]

\begin{tabular}{|c|c|c|c|c|c|c|c|}
\hline \multirow{2}{*}{$\begin{array}{l}\text { Locality } \\
\text { (fig. 141.1) }\end{array}$} & \multicolumn{5}{|c|}{$\mathrm{Rb}-\mathrm{Sr}$} & \multicolumn{2}{|r|}{$\mathrm{K}-\mathrm{Ar}$} \\
\hline & Material & $\mathrm{Rb}^{87}(\mathrm{ppm})$ & $\begin{array}{l}\text { Radiogenic } \\
\mathrm{Sr}^{87}(\mathrm{ppm})\end{array}$ & $\frac{\text { Radiogenic } \mathrm{Sr}^{87}}{\text { Total } \mathrm{Sr}^{87}}$ & Age (b.y.) & Age (b.y.) & Mineral \\
\hline 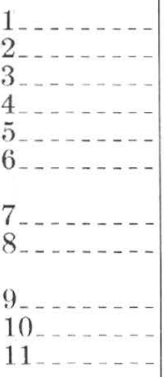 & 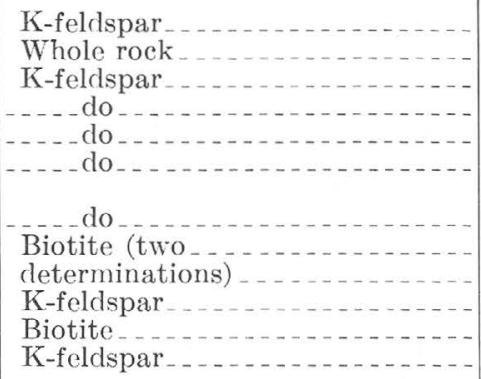 & $\begin{array}{r}184 \\
52.1 \\
95.8 \\
61.8 \\
64.8 \\
75.6 \\
65.1 \\
128 \\
128 \\
131 \\
187 \\
103\end{array}$ & $\begin{array}{l}\text { 4. } 55 \\
\text { 1. } 33 \\
\text { 2. } 52 \\
\text { 2. } 35 \\
\text { 1. } 63 \\
\text { 2. } 02 \\
\text { <. } 90 \\
.992 \\
\text {. } 988 \\
\text { 3. } 32 \\
\text { 4. } 32 \\
\text { 3. } 29\end{array}$ & $\begin{array}{r}0.52 \\
.12 \\
.12 \\
.24 \\
.16 \\
.10 \\
<.01 \\
.35 \\
.37 \\
.16 \\
.77 \\
.25\end{array}$ & $\begin{array}{l}\text { 1. } 66 \pm .08 \\
\text { 1. } 71 \pm .19 \\
\text { 1. } 77 \pm .19 \\
\text { 2. } 54 \pm .15 \\
\text { 1. } 69 \pm .15 \\
\text { 1. } 79 \pm .22 \\
<.93 \\
.52 \pm .03 \\
\text {. } 52 \pm .03 \\
\text { 1. } 70 \pm .15 \\
\text { 1. } 55 \pm .08 \\
\text { 2. } 14 \pm .13\end{array}$ & \begin{tabular}{r} 
1. 20 \\
1. 49 \\
1. 71 \\
1. 57 \\
1. 51 \\
1. 72 \\
1. 77 \\
- \\
\hdashline \\
-
\end{tabular} & $\begin{array}{l}\text { Biotite. } \\
\text { Hornblende. } \\
\text { Biotite. } \\
\text { Do. } \\
\text { Do. } \\
\text { Do. } \\
\text { Hornblende. }\end{array}$ \\
\hline
\end{tabular}

Decay constants, abundances, and normal isotopic ratios used in calculations:

$\mathrm{Rb}^{87}: 1.47 \times 10^{-11} \mathrm{yr}^{-1}$

$\mathrm{K}^{40}: 0.585 \times 10^{-10} \mathrm{yr}^{-1}$ (electron capture)

$4.72 \times 10^{-10} \mathrm{yr}^{-1}$ (beta decay)

$\mathrm{Rb}^{\mathrm{x}}: 0.283 \mathrm{~g} / \mathrm{g} \mathrm{Rb}$

$\mathrm{K}^{40}: \quad 1.22 \times 10^{-4} \mathrm{~g} / \mathrm{g} \mathrm{K}$

$\mathrm{Sr}^{87} / \mathrm{Sr}^{86}=0.703$ (assumed initial)

$\mathrm{Sr}^{86} / \mathrm{Sr}^{88}=0.1194$

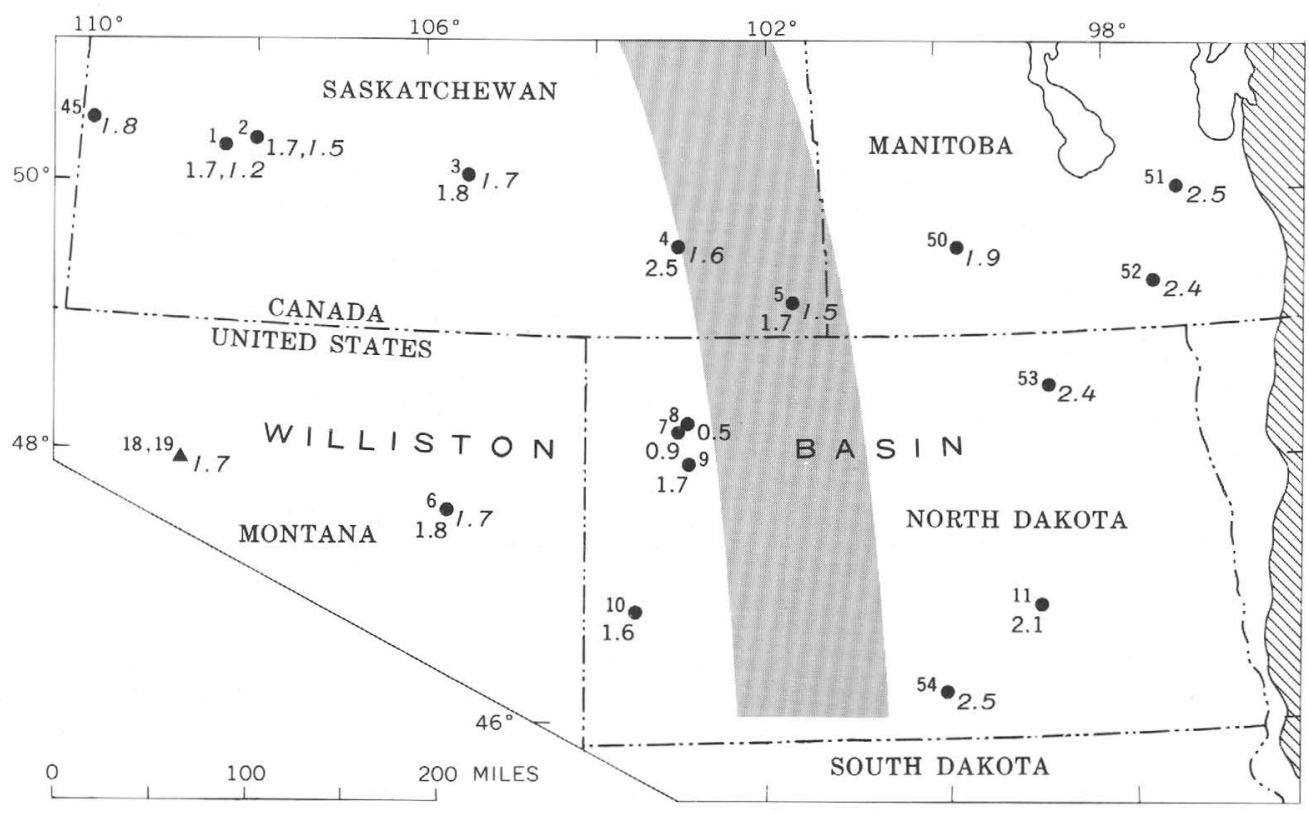

EXPLANATION

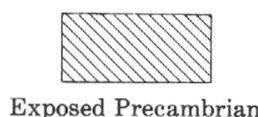

Shield rocks

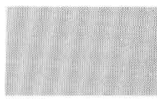

Boundary zone between subsurface extension of Churchill province to west and Superior province to east

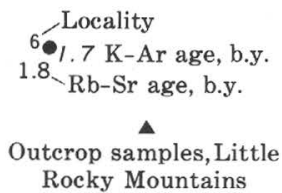

Rocky Mountains

Figure 141.2.- Rb-Sr and K-Ar ages of samples of basement rocks from the Williston basin of North Dakota and of adjacent areas. Locality numbers 1-11 refer to this article (see tables 141.1 and 141.2); locality numbers 18, 19, 45, and 50-54 refer to Burwash and others (1962). 


\section{DISCUSSION}

Isotopic ages, ranging from 0.5 to 2.5 b.y., are available for a total of 18 localities in an area of over 220,000 square miles (fig. 141.2). The age determinations, however, fall into a useful and interpretable pattern (fig. 141.3). Two major periods of metamorphism and orogeny, the Algoman approximately 2.5 b.y. ago and the Penokean approximately 1.7 b.y., are indicated and one or more younger events suggested. The pattern of ages, in part, shows the cumulative effects of two or more thermal events in which the $\mathrm{Rb}-\mathrm{Sr}$ and $\mathrm{K}-\mathrm{Ar}$ systems are variously affected in different minerals. For example, at locality 4 in Saskatchewan, the Rb-Sr age of 2.5 b.y. for feldspar indicates an Early Precambrian rock, and the K-Ar age of 1.6 b.y. for biotite reflects the Penokean event at the close of Middle Precambrian time. Similarly, at locality 50 in Manitoba a K-Ar age of 1.93 for biotite was reported by Burwash and others (1962, p. 1621). The hornblendebiotite gneiss represented in the core is probably also of Early Precambrian age. If the lowering of the K-Ar age is attributed to the Penokean event 1.7-1.8 b.y. ago, as is suggested in figure 141.3 , loss of the radiogenic argon was incomplete, and the somewhat older age of 1.9 b.y. for the biotite may be referred to as a survival value. The quartz monzonite cored at locality 5 between localities 4 and 50 may have been emplaced during the Penokean orogeny. The $\mathrm{Rb}$-Sr age for feldspar from this rock is $1.7 \mathrm{~b} . \mathrm{y}$., and the K-Ar age for biotite is 1.6 b.y.
The pattern of the isotopic ages from east to west clearly indicates that two age provinces are present in the basement rocks. The buried Precambrian rocks of Manitoba are related to the Superior province of the Canadian Shield exposed to the east in Manitoba, Ontario, and Minnesota. The buried basement rocks of southestern Saskatchewan show isotopic ages that are characteristic of the Churchill province. There appears to be a broad transitional zone (fig. 141.2) between the Superior province age of 2.4-2.5 b.y. and the Churchill province age of $1.7-1.8$ b.y. A similar broad zone of mixed ages, between 2.5 and 1.7 b.y., was found (Lowdon and others, 1963; Burwash and others, 1962; Moore and others, 1960) for rocks of the Superior province adjacent to the ChurchillSuperior boundary zone in northern Manitoba (fig. 141.1).

The subsurface extension of the Superior province in eastern North Dakota is indicated by K-Ar ages of 2.4-2.5 b.y. for biotite from gneissic rocks at localities 53 and 54 (Burwash and others, 1962). K-feldspar from a quartz monzonite cored at locality 11 was dated at 2.14 b.y. The analytical error is estimated at \pm 130 m.y. (table 141.2), but it cannot be assumed that the feldspar remained a closed system. It cannot be said, therefore, whether the determined age marks the time of origin of the quartz monzonite or represents a survival value.

The ages for the samples from western North Dakota, Montana, and Saskatchewan give the peak at
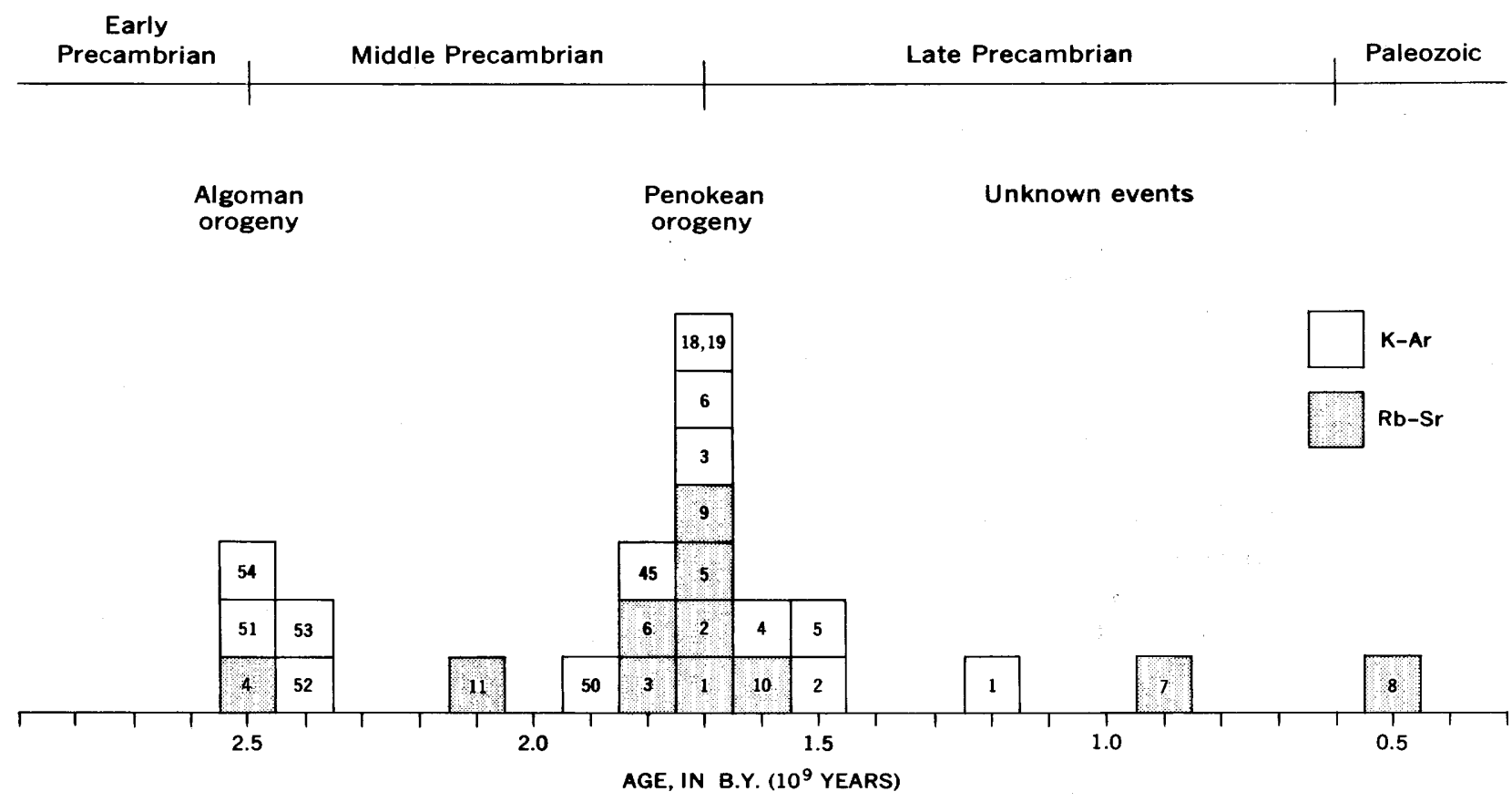

Figure 141.3.--Bar graph of $\mathrm{Rb}-\mathrm{Sr}$ and $\mathrm{K}-\mathrm{Ar}$ age determinations shown in figure 141.2. Locality numbers are indicated. Terminology is that of Goldich and others (1961). 
1.7 b.y. shown in the histogram (fig. 141.3). The $\mathrm{Rb}-\mathrm{Sr}$ age of $1.7 \mathrm{~b} . \mathrm{y}$. for the whole-rock sample of rhyolite (loc. 2) and 5 feldspar ages in the range 1.66 to 1.79 b.y. suggest a specific event, the Penokean. The range of $130 \mathrm{~m} . y$. in the ages may represent differences in ages of the igneous rocks, but analytical errors must also be considered, and the time differences may be apparent rather than real. The Rb-Sr ages, however, are more consistent than the K-Ar ages for which the overall analytical precision of 5 percent is generally much better than that of the $\mathrm{Rb}-\mathrm{Sr}$ method. The K-Ar age of 1.2 b.y. for biotite from the granite at locality 1 clearly indicates some disturbance in the area subsequent to the Penokean orogeny, and this is substantiated by $\mathrm{Rb}-\mathrm{Sr}$ ages of $520 \mathrm{~m}$.y. for biotite (loc. 8) and of approximately $900 \mathrm{~m} . \mathrm{y}$. for K-feldspar (loc. 7).

Altered syenite was cored at a depth of 13,603 feet at locality 7. The age of 930 m.y. (table 141.2) computed for K-feldspar from the syenite is a maximum value, and the age calculation is uncertain because of the small content of radiogenic $\mathrm{Sr}^{87}$. The biotite with a Cambrian age of 520 m.y. is from a garnet-biotite gneiss cored at a depth of 14,825 feet. The low ages at localities 7 and 8 might be attributed to thermal effects due to the depth of burial except that K-feldspar from a hornblende-hypersthene gneiss at locality 9 , cored at a depth of 15,128 feet, had an $\mathrm{Rb}-\mathrm{Sr}$ age of 1.7 b.y. Hypersthene from this core was dated by $\mathrm{K}-\mathrm{Ar}$ at 2.20 b.y., but this age is suspect because it has been shown that pyroxenes may contain excess argon (Hart and Dodd, 1962).

It should be noted that the wells at localities 7 and 8 were drilled on a basement high. Localities 1 and 2, which yielded low $\mathrm{K}$-Ar ages for biotite, are also a basement high. Possibly these high points of the buried basement were centers of later igneous or metamorphic activity. The Little Rocky Mountains in Montana (locs. 18 and 19) contain Tertiary intrusive rocks in Precambrian gneisses. The Penokean age of 1.7 b.y. (fig. 141.2) represents $\mathrm{K}-\mathrm{Ar}$ ages for hornblende from the gneisses (Burwash and others, 1962).

\section{CONCLUSIONS}

The major part of the Williston basin of western North Dakota and adjacent areas is underlain by Precambrian rocks which yield isotopic ages of 1.7-1.8 b.y., indicating that the buried basement rocks are an extension of the Churchill province of the Canadian Shield. The eastern part of the basin is floored by a subsurface extension of the Superior province with rocks approximately 2.5 b.y. in age. The projection of the Churchill-Superior boundary trends southward through eastern Saskatchewan and western North Dakota. Mixed isotopic ages in the range 2.5 to 1.6 b.y. indicate that Early Precambrian rocks were affected in varying degree by the Penokean orogeny approximately 1.7 b.y. ago. The Churchill-Superior boundary in the subsurface, as delimited by isotopic age determinations, probably is a broad zone rather than a sharp line. Younger thermal events in the area are indicated by $\mathrm{Rb}-\mathrm{Sr}$ and $\mathrm{K}-\mathrm{Ar}$ ages in the range 0.5 to $1.5 \mathrm{~b} . \mathrm{y}$. The data, however, are too few for evaluation, and these ages may represent survival values via updating through Tertiary activity or one or more events in Late Precambrian or Cambrian time.

\section{REFERENCES}

Burwash, R. A., Baadsgaard, H., and Peterman, Z. E., 1962, Precambrian K-Ar dates from western Canada sedimentary basin: Jour. Geophys. Research, v. 67, no. 4, p. 1617-1625.

Gill, J. E., 1949, Natural divisions of the Canadian shield: Royal Soc. Canada Trans., sec. 4, v. 43, p. 61-69.

Goldich, S. S., Nier, A. O., Baadsgaard, H., Hoffman, J. H., and Krueger, H. W., 1961, The Precambrian geology and geochronology of Minnesota: Minnesota Geol. Survey, Bull. 41, 193 p.

Hart, S. R., and Dodd, R. T., Jr., 1962, Excess radiogenic argon in pyroxenes: Jour. Geophys. Research, v. 67, no. 7, p. 2998-2999.

Innes, M. J. S., 1960, Gravity and isostasy in northern Ontario and Manitoba: Canada Dominion Observatories Pub., v. 21, no. 6, p. 263-338.

Lowdon, J. A., Stockwell, C. H., Tipper, H. W., and Wanless, R. H., 1965, Age determinations and geological studies: Canada Geol. Survey Pap. 62-17, 140 p.

Moore, J. M., Jr., Hart, S. R., Barnett, C. C., and Hurley, P. M., 1960, Potassium-argon ages in northern Manitoba: Geol. Soc. America Bull., v. 71, no. 2, p. 225-230.

Stockwell, C. H., 1961, Structural provinces, orogenies, and time classification of rocks of the Canadian Precambrian Shield: Canada Geol. Survey Pap. 61-17, p. 108-118.

Wilson, H. D. B., and Brisbin, W. C., 1961, Regional structure of the Thompson-Moak Lake nickel belt: Canadian Mining and Metall. Bull., no. 595, p. 815-822.

Wilson, J. T., 1949, The origin of continents and Precambrian history: Royal Soc. Canada Trans., sec. 4, v. 43, p. 157-184.

Wilson, M. E., 1941, Pre-Cambrian; in Geology, 1888-1938 (Fiftieth anniversary volume); Geol. Soc. America, p. 269305. 
Article 142

\title{
ISOTOPIC AGES OF GLAUCOPHANE SCHISTS FROM THE AREA OF CAZADERO, CALIFORNIA
}

\author{
By D. E. LEE, ${ }^{1}$ H. H. THOMAS, $^{2}$ R. F. MARVIN, ${ }^{2}$ and R. G. COLEMAN, ${ }^{1}$ \\ ${ }^{1}$ Menlo Park, Calit., ${ }^{2}$ Washington, D.C.
}

\begin{abstract}
Glaucophane-bearing tectonic blocks are stratigraphically out of place with respect to the glaucophane-bearing bedrock terrain on which they rest. Five isotope age determinations ranging from 130 to 150 m.y. indicate that both the tectonic blocks and the bedrock schists were recrystallized as part of a Late Jurassic and Early Cretaceous metamorphic event.
\end{abstract}

Field study has shown that muscovite-bearing glaucophane schists are present in two different structural positions within the Franciscan Formation in the area of Cazadero, Sonoma County, Calif., north of the San Francisco area (fig. 142.1) (Coleman and Lee, 1963). Glaucophane-bearing tectonic blocks are stratigraphically out of place with respect to the glaucophanebearing bedrock terrain on which they rest. Laboratory study shows also that the tectonic blocks can be distinguished mineralogically from the bedrock terrain, even though glaucophane and muscovite are present in both (Coleman and Lee, 1963; Lee and others, 1963). This article presents isotope-age data determined for muscovites from three samples of tectonic blocks (type-IV rocks of Coleman and Lee) and two samples of bedrock schist (type-III rocks).

Franciscan rocks designated types III and IV are described by Coleman and Lee (1963) as follows:

Bedrock glaucophane schists [type III] as exemplified by a conformable sequence of metabasalts and metasediments exposed at the bottom of Ward Creek canyon near Cazadero, California. Some of the minerals present along with glaucophane and muscovite in these rocks are aragonite (Coleman and Lee, 1962), lawsonite, and almandine-spessartine-grossular garnet.
Coarsely crystalline gneissic schists [type IV] that occur as large isolated blocks; these blocks cannot be mapped as in place or as stratigraphically equivalent to the bedrock terrain on which they rest. Some of the minerals present along with glaucophane and muscovite in these rocks are epidote, rutile, and almandinegrossular garnet. The mineral assemblages present in these tectonic blocks indicate that they were recrystallized at higher pressure-temperature conditions than were the bedrock schists. Near Cazadero these tectonic blocks are concentrated in a band that conforms to some of the major faulting in the area.

The $\mathrm{K}-\mathrm{Ar}$ and $\mathrm{Rb}-\mathrm{Sr}$ ages of muscovite from glaucophane schists near Cazadero (fig. 142.1) are listed in the accompanying table. Potassium was determined by a flame photometer using lithium as an internal standard. Rubidium and strontium were determined by isotope-dilution techniques described by Goldich and others (1961, p. 8-35). The overall analytical error is approximately \pm 5 percent of the quoted age value.

Although type-III glaucophane schists may be distinguished from those of type IV, both on the basis of mineralogy and on the basis of field occurrence, the isotope-age results listed in the table indicate that both type-III and type-IV rocks were recrystallized as part of a metamorphic event that took place during Late Jurassic and Early Cretaceous time (Holmes, 1960). Pending further isotope-age work on these rocks, it appears that some of the glaucophane schists in this area represent the metamorphic equivalents of volcanic and sedimentary rocks that were laid down during preCretaceous time. 

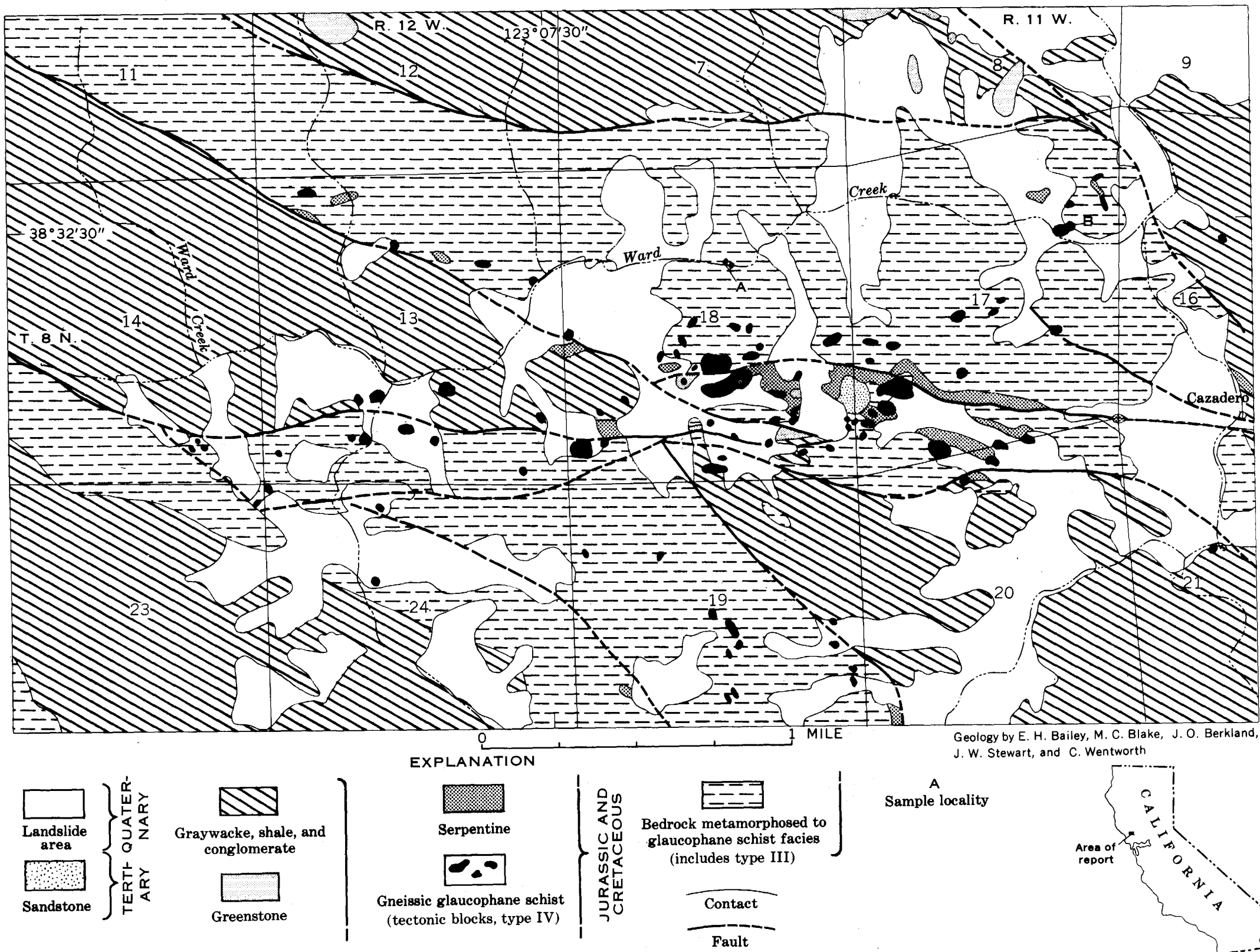

A

Dashed where approximately located

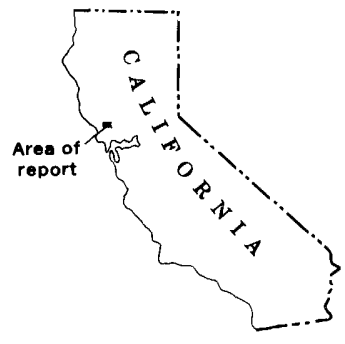

FIGURE 142.1.-Geologic map of area surrounding Ward Creek, Cazadero, Calif. 


\title{
Article 143
}

\section{CRUSTAL STRUCTURE IN THE VICINITY OF LAS VEGAS, NEVADA, FROM SEISMIC AND GRAVITY OBSERVATIONS}

\author{
By JOHN C. ROLLER, Denver, Colo.
}

Work done under Advanced Research Projects Agency Order No. 193-62

\begin{abstract}
According to a seismic-refraction profile the thickness of the crust north of the Las Vegas Valley shear zone is $32 \mathrm{~km}$, but it thins to $27 \mathrm{~km}$, south of that structure, within the short distance of $25 \mathrm{~km}$. This decrease correlates with an increase in the Bouguer anomaly and a decrease in the average surface altitude. The data imply that (1) major fracture zones may extend to the Mohorovicic discontinuity, and probably penetrate the mantle, and (2) the Mohorovicic discontinuity is not flat, but instead includes major flexures over relatively short horizontal distances.
\end{abstract}

The U.S. Geological Survey recorded a seismic-refraction profile 265 kilometers long from a shot point near Kingman, Ariz., northwest across the Las Vegas Valley shear zone (Longwell, 1960) toward the Nevada Test Site (NTS) during June 1962 (fig. 143.1). Seismic waves, generated by 4 chemical explosions that ranged in size from 2,000 to 10,000 pounds, were recorded at 24 positions.

Standard seismic-refraction procedures and wide-band recording on both photographic paper and magnetic tape were used in the field (Warrick and others, 1961). Recording positions were spaced approximately $10 \mathrm{~km}$ apart along the profile, and at each position 6 vertical seismometers were spaced $0.5 \mathrm{~km}$ apart in a line generally parallel to the line of profile. Two horizontal seismometers (radial and transverse) were placed beside one of the vertical seismometers.

The area traversed by the seismic profile is characterized by a series of mountain ranges composed mainly of Paleozoic sedimentary rocks and Tertiary volcanic rocks. The ranges are separated by alluvial basins (Bowyer and others, 1958). The profile crosses a major geologic structure, the Las Vegas Valley shear zone, north of Las Vegas, Nev. (fig. 143.1). North of this zone the ranges and many geologic features strike generally north and the average surface altitude is significantly higher than in the area south of the shear zone, where the structural and topographical pattern is more complex (Longwell, 1960).

The generalized Bouguer anomaly contours (fig. 143.1) show a relatively flat, although locally complex, pattern immediately south and east of Las Vegas, and a general regional decrease to the north. The Bouguer anomaly contours are based on data from stations on pre-Tertiary bedrock.

This profile approximately reverses a seismic-refraction profile recorded by the U.S. Geological Survey from NTS to Kingman during nuclear testing in 1957 and 1958 (Diment and others, 1961).

\section{RESULTS}

Results of observations of the previous profile, from NTS to Kingman, show that the crust is about $28 \mathrm{~km}$ thick with an apparent compressional-wave velocity of $6.15 \mathrm{~km} / \mathrm{sec}$, and is underlain by the mantle with an apparent velocity of $7.81 \mathrm{~km} / \mathrm{sec}$ (Diment and others, 1961). These data were based on first-arrival direct waves $\left(P_{g}\right)$ through the crust from NTS to a point near Boulder City, Nev., and on first-arrival waves refracted along the mantle from Boulder City to a point near Kingman. The reversed profile from Kingman toward NTS indicates a thin surface layer with an apparent velocity of $5.2 \mathrm{~km} / \mathrm{sec}$ overlying a crustal layer with an apparent velocity of $6.1 \mathrm{~km} / \mathrm{sec}$ (fig. 143.2).

The seismic waves that are refracted from the mantle $\left(P_{n}\right)$ south of the Las Vegas Valley shear zone fit a line with an apparent velocity of $7.8 \mathrm{~km} / \mathrm{sec}$, and indicate that the crust is $27 \mathrm{~km}$ thick. $P_{n}$ waves that are refracted from the mantle north of the shear zone 


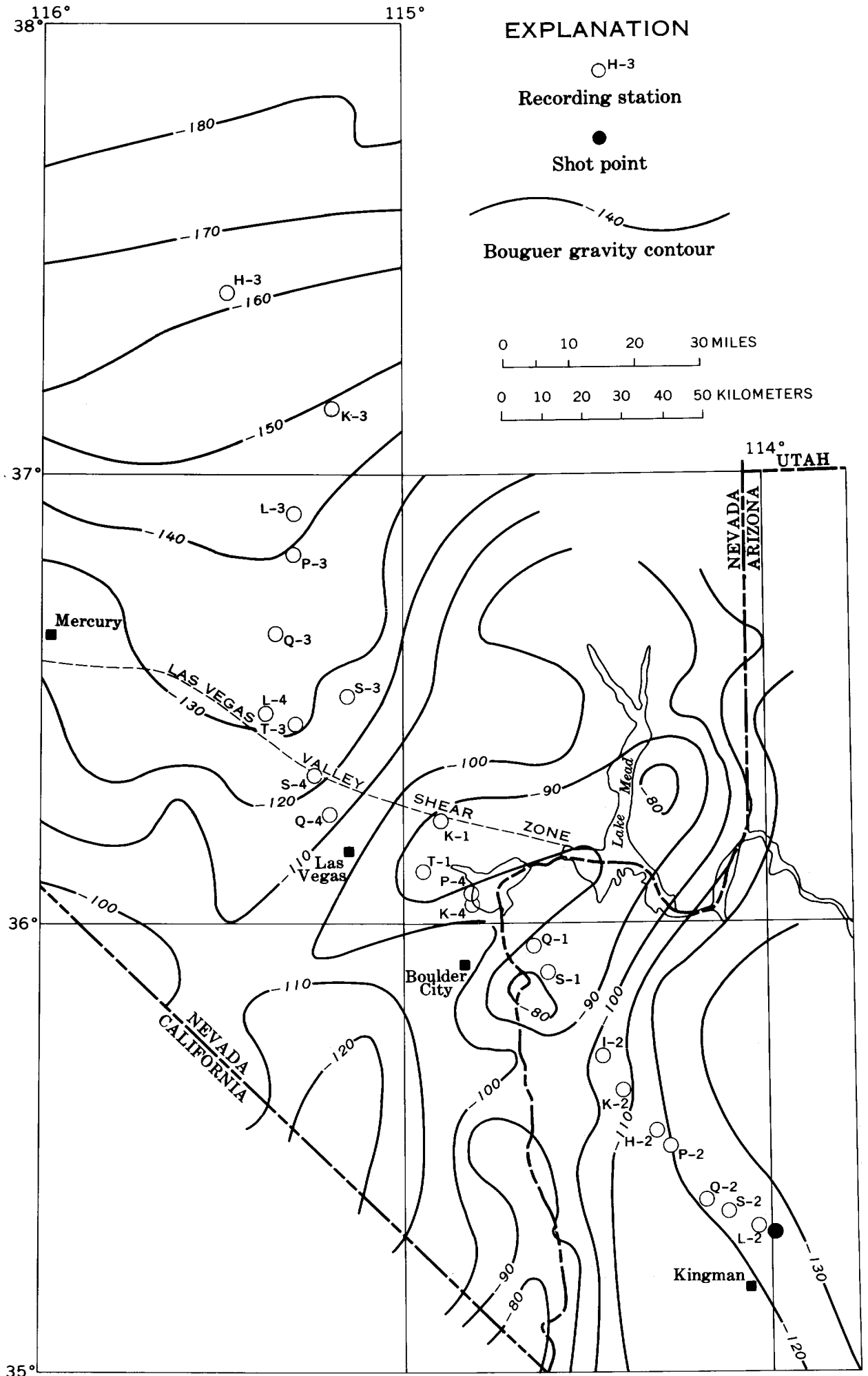

FIGURE 143.1.--Index map showing the location of the Kingman, Ariz., shot point, seismicrecording stations, and generalized Bouguer anomaly contours. The Bouguer anomaly contours are from Diment and others (1961). 


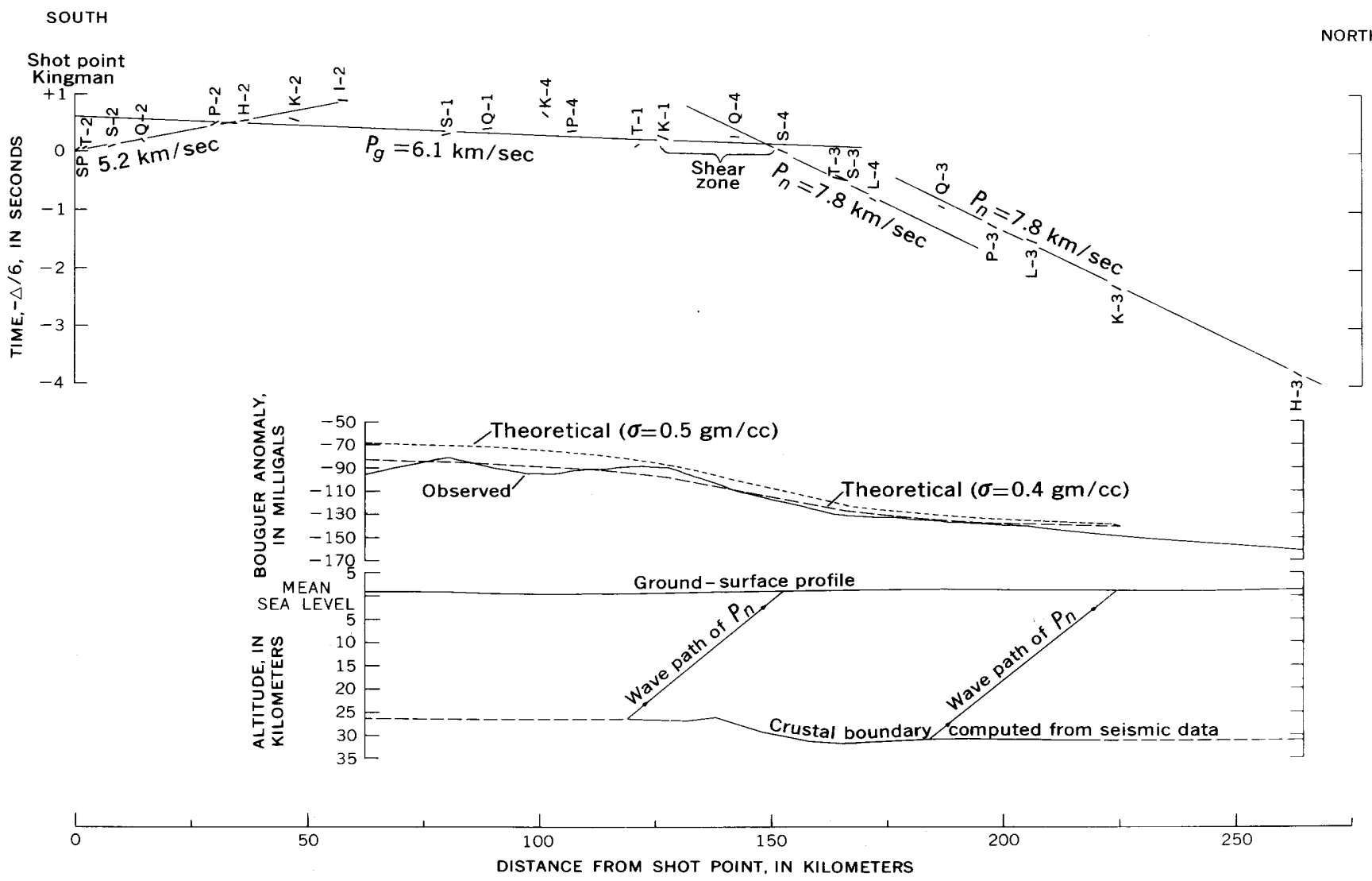

FIgURE 143.2-Seismic and gravity profiles, showing traveltimes of first arrivals in the report area, generalized theoretical and observed Bouguer anomalies for the seismic crustal model, and the crustal boundary as computed from seismicrefraction data. Location numbers refer to recording stations shown in figure 143.1.

are delayed $0.55 \mathrm{sec}$ with respect to those south of the shear zone, and indicate a crustal thickness of $32 \mathrm{~km}$. The change in thickness occurs within a horizontal distance of $25 \mathrm{~km}$ or less, and may even be due to a vertical or near-vertical displacement. The $P_{n}$ arrivals at station Q-3 and possibly at P-3 (fig. 143.1) that produce the apparent slope in the flexure (fig. 143.2) could actually be diffracted waves from a fault-type structure (Heiland, 1940). The delayed arrivals may be related in part to the thickening of Paleozoic sedimentary rocks northwest of Lake Mead. The seismic profile crosses the Las Vegas Valley shear zone in the same general area that the Paleozoic section increases in thickness (Bowyer and others, 1958).

The above crustal models were computed assuming flat layers with constant velocities. The velocity in the crust probably increases with depth, as shown by several authors (Berg and others, 1960; Healy, 1963; and Ryall and Stuart, 1963), so these depths are minimums. The relative depths should be correct, however.

The first-arrival times (fig. 143.2) that define the 5.2$\mathrm{km} / \mathrm{sec}$ line and the $6.1-\mathrm{km} / \mathrm{sec}$ line are the uncorrected observed times. Arrival times that define the $P_{n}$ lines have been corrected for low-velocity material near the surface, either from gravity and seismic data or by estimating the thickness of these low-velocity sediments from the geologic environment of the recording positions. The seismograms also contain many secondary arrivals, the discussion of which is beyond the scope of this article.

The observed Bouguer anomaly profile (fig. 143.2) shows a general regional correlation with the crustal cross section, as computed from a delay-time analysis of the seismic-refraction data (Pakiser and Black, 1957). An area of relatively high Bouguer gravity values is observed over the thinner crust, and an area of lower gravity values is observed over the thicker crust.

Two theoretical Bouguer anomaly curves based on assumed density contrasts between the crust and mantle of $0.4 \mathrm{~g} / \mathrm{cc}$ and $0.5 \mathrm{~g} / \mathrm{cc}$ were computed (fig. 143.2). If a density of $3.3 \mathrm{~g} / \mathrm{cc}$ for the mantle is assumed, which corresponds to a compressional-wave velocity of $7.8 \mathrm{~km} / \mathrm{sec}$ (Talwani and others, 1959), the density contrast of $0.5 \mathrm{~g} / \mathrm{cc}$ gives a crustal density of $2.8 \mathrm{~g} / \mathrm{cc}$, which corresponds to the observed $P_{g}$ velocity of 6.1 $\mathrm{km} / \mathrm{sec}$. The density contrast of $0.4 \mathrm{~g} / \mathrm{cc}$ corresponds to 
a compressional-wave velocity of $6.5 \mathrm{~km} / \mathrm{sec}$ and a density of $2.9 \mathrm{~g} / \mathrm{cc}$. The theoretical curve using a density contrast of 0.4 fits the observed curve within 10 mgals. This may indicate an increase in crustal velocity with depth.

The most significant difference between the theoretical and the observed Bouguer anomalies is that the gradient on the observed curve is steeper, which indicates that only part of this gradient can be attributed to the crust-mantle boundary; part must be attributed to density contrasts within the crust. Immediately east of Las Vegas, the trends of the gravity contours deviate northward from the shear zone and generally follow a line between predominantly Paleozoic outcrops to the northwest and Precambrian outcrops to the southeast.

The surface altitude of the area also shows a general correlation with the seismic and gravity data (Mabey, 1960 ). South of the shear zone the average altitude is less than $1 \mathrm{~km}$ above sea level and the Bouguer anomaly is about -100 mgals. North of the shear zone the altitude above sea level averages about $1 \frac{11}{2} \mathrm{~km}$ and the Bouguer anomaly decreases to -160 mgals at station $\mathrm{H}-3$.

Three major implications can be drawn from these data: major fracture zones may extend to the Mohorovicic discontinuity and probably penetrate the mantle; the Mohorovicic discontinuity is not a flat surface but may include major flexures over relatively short horizontal distances; and in the report area there is a regional correlation between thickness of the crust, Bouguer gravity anomaly, and average surface altitude.

\section{REFERENCES}

Berg, J. W., Jr., Cook, K. L., Narans, H. D., and Dolan, W. M., 1960 , Seismic investigations of crustal structure in the eastern part of the Basin and Range province: Bull. Seismol. Soc. America, v. 50, p. 511-536.

Bowyer, Ben, Pampeyan, E. H., and Longwell, C. R., 1958, Geologic map of Clark County, Nevada: U.S. Geol. Survey Min. Inv. Map MF-138.

Diment, W. H., Stewart, S. W., and Roller, J. C., 1961, Crustal structure from the Nevada Test Site to Kingman, Arizona, from seismic and gravity observations: Jour. Geophys. Research, v. 66, p. 201-214.

Healy, J. H., 1963, Crustal structure along the coast of California from seismic-refraction measurements: Jour. Geophys. Research, v. 68, p. 5777-5787.

Heiland, C. A., 1940, Geophysical exploration: New York, Prentice-Hall, p. 514-521.

Longwell, C. R., 1960, Possible explanation of diverse structural patterns in southern Nevada: Am. Jour. Sci., v. 258-A, p. 192-203.

Mabey, D. R., 1960, Regional gravity survey of part of the Basin and Range province: Art. 130 in U.S. Geol. Survey Prof. Paper 400-B, p. B283-B285.

Pakiser, L. C., Jr., and Black, R. A., 1957, Exploring for ancient channels with the refraction seismograph [Ariz.-Utah]: Geophysics, v. 22, p. 32-47.

Ryall, Alan, and Stuart, D. J., 1963, Traveltimes and amplitudes from nuclear explosions-Nevada Test Site to Ordway, Colorado: Jour. Geophys. Research, v. 68, p. 5821-5835.

Talwani, Manik, Sutton, G. H., and Worzel, J. L., 1959, A crustal section across the Puerto Rico trench: Jour. Geophys. Research, v. 64 , no. 10, p. 1545-1555.

Warrick, R. E., Hoover, D. B., Jackson, W. H., Pakiser, L. C., and Roller, J. C., 1961, The specification and testing of a seismic-refraction system for crustal studies: Geophysics, v. 26 , p. $820-824$. 


\title{
Article 144
}

\section{HAWAIIAN SEISMIC EVENTS DURING 1962}

\author{
By ROBERT Y. KOYANAGI, Hawaiian Volcano Observatory
}

\begin{abstract}
Six hundred ninety two earthquakes of magnitude 2.0 and greater were recorded in the Hawaiian Islands region during 1962. Most of these quakes were of magnitude less than $3 \frac{1}{2}$, and only one was of magnitude greater than 6 . The Kaoiki fault, the east rift of Kilauea, the Kalapana Trail region, and Kilauea caldera at $30 \mathrm{~km}$ depth were areas of concentrated earthquake activity.
\end{abstract}

The U.S. Geological Survey Volcano Observatory maintains a seismic net primarily for monitoring seismicity of the island of Hawaii. Limitations on station location imposed by the geographic linearity of the Hawaiian Islands leads to moderate uncertainty in the determination of focal depths and epicenters beyond the Hawaii Island net. Nevertheless, it is possible to locate earthquakes of magnitude greater than 2.5 beneath the island of Hawaii within a 5-kilometer sphere of error. Similar quakes offshore are subject to an uncertainty in location of perhaps $10 \mathrm{~km}$.

Epicenter-location maps and lists presented here were compiled from the work of the author, Arnold Okamura, Harold Krivoy, and George Kojima. With some exceptions, these epicenters have been reported by Koyanagi and others (1963), Okamura, Koyanagi, and Krivoy (1963), Okamura, Kojima, and Yamamoto (1963), and Krivoy and others (1963); quakes smaller than magnitude 2.0 were not reported. Epicenter, depth, and magnitude determinations are based on travel-time studies and methodology instituted and applied at the Hawaiian Volcano Observatory by Jerry P. Eaton between 1956 and 1961. Generally, all earthquakes of magnitude 2.5 and greater which occur in the Hawaiian Ridge, within the geographical coordinates lat. $18^{\circ} \mathrm{N}$. to $23^{\circ} \mathrm{N}$. and long. $154^{\circ} \mathrm{W}$. to $161^{\circ} \mathrm{W}$., are detected by the island of Hawaii seismic network.

A map of Hawaiian earthquake distribution prepared by Eaton for the period April 1958 to September 1959 showed a high earthquake concentration in the southeast sector of the island of Hawaii (Eaton, 1962, p. 14). A similar pattern of distribution was noted in 1962 .
Throughout 1962, many earthquakes took place in the region of the east rift zone of Kilauea (fig. 144.1). Most of these epicenters plot south of the surface trace of the rift zone (figs. 144.2 and 144.3), and hence support the concept that the rift dips south (Richter and others, 1964).

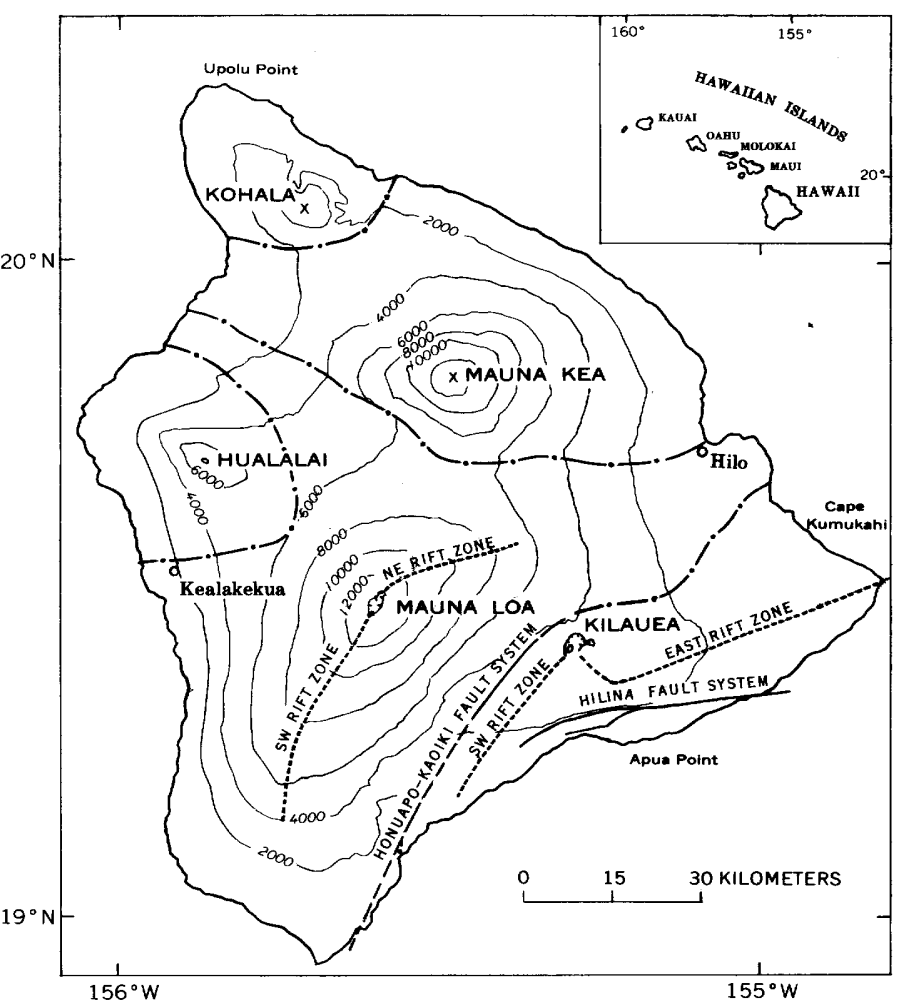

FIGURE 144.1.-Map of the island of Hawaii, showing significant geologic features and towns used for earthquake-epicenter location references. The five volcanic systems are after Macdonald (1956). Contour interval is 2,000 feet; datum is mean sea level. Lines made up of dots and dashes are boundaries of voleanic systems.

Three other conspicuous zones of seismic activity during 1962 were Kilauea caldera, at a depth of 30 
$\mathrm{km}$; the Honuapo-Kaoiki fault system, at a depth of 5 to $8 \mathrm{~km}$; and the Kalapana Trail region, at a depth of about $3 \mathrm{~km}$. In plotting quakes of these groups, symbols were placed at the respective epicenters, and quakes of magnitude 2.0 and greater were counted for each quarter year.

\section{HIGHLIGHTS OF EARTHQUAKE ACTIVITY}

The first quarter of 1962 (fig. 144.2, top) was marked by a swarm of $30-\mathrm{km}$-deep quakes which began on February 7 and diminished greatly in frequency by the following day. Several of these were felt; the largest exceeded magnitude 4.

During the second quarter the Honuapo-Kaoiki fault system, on the southeast boundary of Mauna Loa, was the site of greatest activity (fig. 144.2, bottom). For several weeks, 15 to 20 small quakes were recorded daily in that area until the evening of June 27 (HST), when a quake of magnitude 6.1 occurred. Several thousand aftershocks were recorded in diminishing frequency during the week that followed; however, most of the aftershocks were smaller than magnitude 2 .

In the third quarter there was a pronounced increase in activity off the west coast of Hawaii (fig. 144.3, top). Two shocks of shallow origin were felt throughout the island on July 23 and 24 ; the magnitudes were 4.5 and 4.9 , respectively. Numerous deeper earthquakes occurred throughout this quarter off the southwest shore of the island of Hawaii.

In the fourth quarter, increased activity was noted on the south and west flanks of Mauna Loa (fig. 144.3, bottom). Also, a flurry of intermediate-depth quakes was recorded in the Mauna Kea region in November and December.

A swarm of quakes began on November 20 and continued until November 23 in the Kalapana Trail region, on the southeast flank of Kilauea. Several of these were felt by some residents of the eastern section of the island, but most were of magnitude less than 2 and were not felt.

On December 7, 8, and 9 a small eruption occurred in and near Aloi Crater (about $10 \mathrm{~km}$ from Kilauea caldera on Kilauea's east rift). At about 1930 hours (HST) December 6, harmonic tremor and small shallow quakes commenced. These shallow quakes originated several kilometers southeast of Kilauea caldera along the east rift zone and are grouped as "Upper east rift zone" on figure 144.3 (bottom). At about 0100 hours (HST) on December 7, an eruption began at Aloi Crater. Tremor and quakes decreased and died out on December 9 after five more small eruptive outbreaks in the same region.

Earthquakes recorded by the volcano observatory but outside the area of figures 144.2 and 144.3 are listed in the accompanying table.

Earthquakes in 1962 within lat $18^{\circ} \mathrm{N}$. to $29^{\circ} \mathrm{N}$., long $154^{\circ} \mathrm{W}$. to $161^{\circ} \mathrm{W}$., and outside the area shown in figures 144.2 and 144.3

[All times are Hawaiian standard time]

Date

Jan. 10 Time (hrs.,

16:59:52. $1125 \mathrm{~km}$ northeast of Upolu Point, Hawaii, at a depth of $12 \frac{1}{2} \mathrm{~km}$; long $155^{\circ} 25^{\prime} \mathrm{W}$., lat $21^{\circ} 16^{\prime} \mathrm{N}$. Magnitude 2.9 .

Feb. 1 19:30:08. $325 \mathrm{~km}$ east of Cape Kumukahi (eastern point of Hawaii) at a depth of $121 / 2 \mathrm{~km}$; $154^{\circ} 35^{\prime} \mathrm{W} ., 19^{\circ} 31^{\prime} \mathrm{N}$. Magnitude 2.5 .

Feb. $10 \quad 16: 00: 46.6 \quad 35 \mathrm{~km}$ southeast of Cape Kumukahi at a depth of $3 \mathrm{~km} ; 154^{\circ} 33.0^{\prime}$ W., $19^{\circ} 18.2^{\prime}$ N. Magnitude 4.0.

Feb. 23 19:03:59. $3102 \mathrm{~km}$ north-northeast of Upolu Point at a depth of $12 \frac{1}{2} \mathrm{~km} ; 155^{\circ} 38^{\prime}$ W., $21^{\circ} 09^{\prime} \mathrm{N}$. Magnitude 2.8.

April $8 \quad 07: 08: 15.4 \quad 70 \mathrm{~km}$ west-southwest of Kealakekua, at a depth of $8 \mathrm{~km} ; 156^{\circ} 33.0^{\prime} \mathrm{W} ., 19^{\circ} 16.0^{\prime}$ N. Magnitude 2.8.

May 1 18:58:13. $4117 \mathrm{~km}$ southwest of Kealakekua at a depth of $12 \frac{1}{2} \mathrm{~km} ; 156^{\circ} 40^{\prime} \mathrm{W} ., 18^{\circ} 40^{\prime}$ N. Magnitude 3.7 .

June $22 \quad 00: 21: 59.1 \quad 128 \mathrm{~km}$ northeast of Kamuela at a depth of $12 \frac{1}{2} \mathrm{~km} ; 155^{\circ} 01^{\prime}$ W., $20^{\circ} 58^{\prime} \mathrm{N}$. Magnitude 2.9.

June $29 \quad 14: 41: 53.0 \quad 87 \mathrm{~km}$ north-northeast of Upolu Point at a depth of $12 \frac{1 / 2}{\mathrm{~km}} ; 155^{\circ} 22^{\prime} \mathrm{W} ., 20^{\circ} 52^{\prime}$ N. Magnitude 3.0.

June $29 \quad 21: 13: 33.0 \quad 85 \mathrm{~km}$ west-southwest of Upolu Point at a depth of $12 \frac{1}{2} \mathrm{~km} ; 156^{\circ} 39^{\prime}$ W., $20^{\circ} 06^{\prime}$ N. Magnitude 2.7.

July $16 \quad 13: 03: 53.6 \quad 62 \mathrm{~km}$ south-southeast of Apua Point at a depth of $12 \frac{1}{2} \mathrm{~km} ; 155^{\circ} 01^{\prime}$ W., $18^{\circ} 14^{\prime}$ N. Magnitude 2.8 .

Aug. $1 \quad 09: 57: 39.2100 \mathrm{~km}$ northeast of Upolu Point at a depth of $12 \frac{1}{2} \mathrm{~km} ; 155^{\circ} 08^{\prime}$ W., $20^{\circ} 57^{\prime}$ N. Magnitude 3.0.

Aug. $1322: 32: 06.0 \quad 40 \mathrm{~km}$ southeast of Cape Kumukahi at a depth of $5 \mathrm{~km} ; 154^{\circ} 34^{\prime}$ W., $19^{\circ} 14^{\prime} \mathrm{N}$. Magnitude 2.4.

Sept. $19 \quad 03: 29: 45.1 \quad 55 \mathrm{~km}$ north-northeast of Upolu Point at a depth of $12 \frac{1}{2} \mathrm{~km} ; 155^{\circ} 49^{\prime}$ W., $20^{\circ} 46^{\prime}$ N. Magnitude 2.8 .

Sept. 20 22:46:05. $9 \quad 108 \mathrm{~km}$ east-northeast of Upolu Point at a depth of $121 / 2 \mathrm{~km} ; 155^{\circ} 01^{\prime}$ W., $20^{\circ} 46^{\prime}$ N. Magnitude 3.7 .

Sept. 28 12:44:43. $7 \quad 165 \mathrm{~km}$ northwest of Upolu Point at a

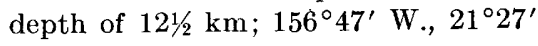
N. Magnitude 3.3.

Oct. $17 \quad 21: 59: 01.0 \quad 120 \mathrm{~km}$ west-southwest of Upolu Point at a depth of $12 \frac{1}{2} \mathrm{~km} ; 156^{\circ} 59^{\prime}$ W., $20^{\circ} 05^{\prime}$ N. Magnitude 3.0.

Dec. $21 \quad 16: 20: 08.0 \quad 140 \mathrm{~km}$ east-northeast of Upolu Point at a depth of $8 \mathrm{~km} ; 154^{\circ} 38^{\prime}$ W., $20^{\circ} 40^{\prime}$ N. Magnitude 2.8 . 


\begin{tabular}{|l|c|c|}
\hline \multirow{2}{*}{$\begin{array}{c}\text { Location of } \\
\text { concentrations } \\
\text { of quakes }\end{array}$} & \multicolumn{2}{|c|}{$\begin{array}{c}\text { Numbers of quakes of } \\
\text { Imagnitude 2.0 to } 3.5 \\
\text { (first figure) and }>3.5 \\
\text { (second figure) }\end{array}$} \\
\cline { 2 - 4 } & 1st quarter & 2nd quarter \\
\hline $\begin{array}{c}\text { Kilauea area } \\
\text { (30 km depth) } \\
\text { Kalapana Trail (1) } \\
\text { area }\end{array}$ & 42,4 & 36,3 \\
$\begin{array}{c}\text { Kaoiki fault } \\
\text { system }\end{array}$ & 17,0 & 26,1 \\
\hline
\end{tabular}

\begin{tabular}{|c|c|c|}
\hline \multirow{2}{*}{ Depth (km) } & \multicolumn{2}{|c|}{ Magnitude } \\
\cline { 2 - 3 } & $2.0-3.5$ & $>3.5$ \\
\hline$<10$ & $\bullet$ & 0 \\
$10-20$ & + & + \\
$20-60$ & $\mathrm{x}$ & $\mathrm{x}$ \\
\hline
\end{tabular}

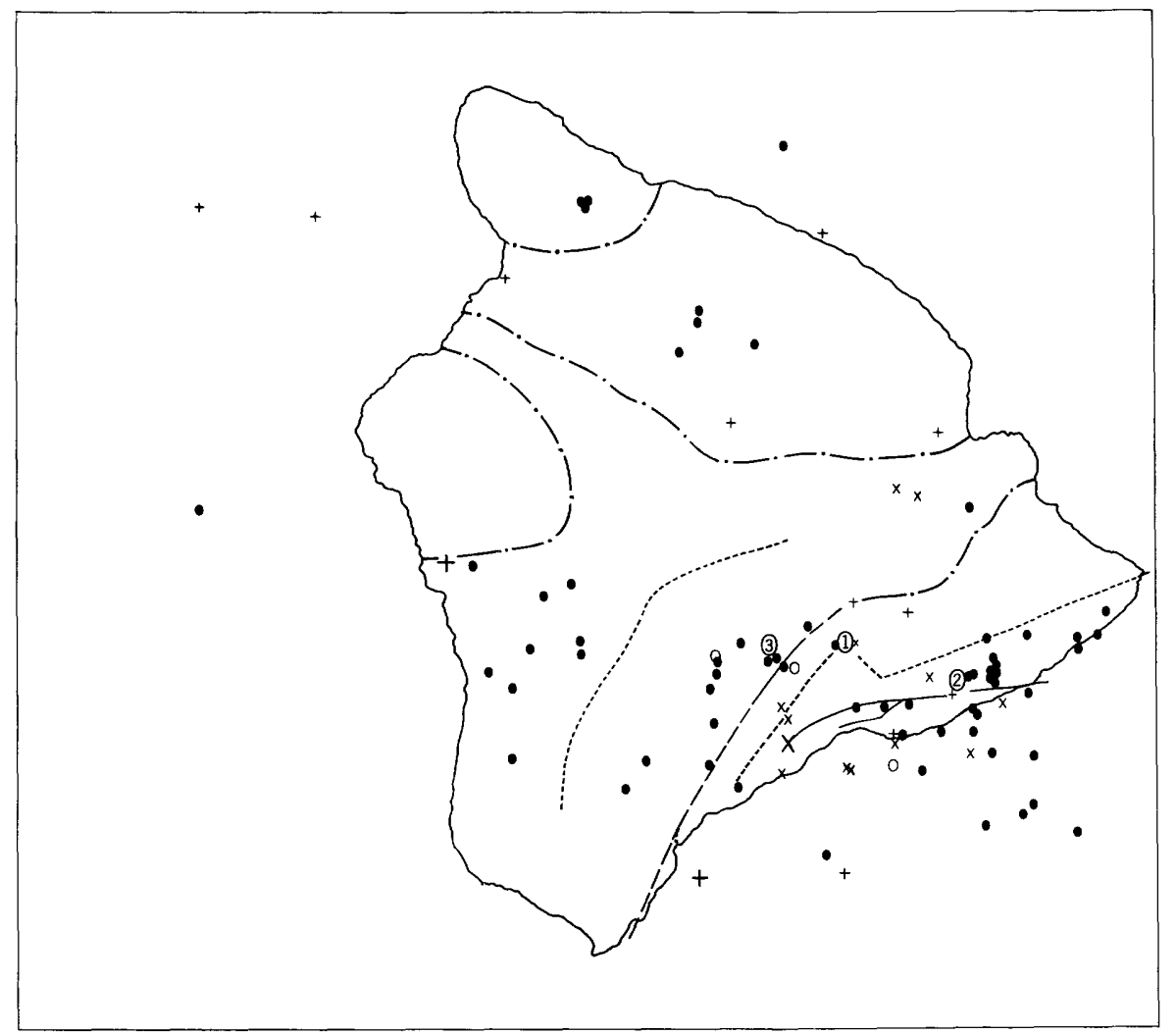

Figure 144.2.-Epicenter plot of earthquakes of magnitude 2.0 and greater for the first quarter of 1962 (top) and second quarter (bottom). The large number of quakes located $30 \mathrm{~km}$ beneath Kilauea and those located along the Kalapana Trail and Kaoiki fault system were counted and listed numerically. Epicenters which were located off the map are listed in the accompanying table. Geographic names are shown on figure 144.1.s 


\begin{tabular}{|c|c|c|}
\hline \multirow[t]{2}{*}{$\begin{array}{l}\text { Location of } \\
\text { concentrations } \\
\text { of quakes }\end{array}$} & \multicolumn{2}{|c|}{$\begin{array}{l}\text { Numbers of quakes of } \\
\text { magnitude } 2.0 \text { to } 3.5 \\
\text { (first figure) and }>3.5 \\
\text { (second figure) }\end{array}$} \\
\hline & 3rd quarter & 4th quarter \\
\hline $\begin{array}{c}\text { Kilauea area } \\
\text { (30 km depth) }\end{array}$ & 23,2 & 20,1 \\
\hline $\begin{array}{c}\text { Kalapana Trail } \\
\text { area }\end{array}$ & 25,0 & 19,2 \\
\hline $\begin{array}{l}\text { Kaoiki fault } \\
\text { system }\end{array}$ & 26,0 & 15,0 \\
\hline $\begin{array}{l}\text { Upper east } \\
\text { rift zone }\end{array}$ & (4) & 6,0 \\
\hline
\end{tabular}

\begin{tabular}{|c|c|c|}
\hline \multirow{2}{*}{ Depth $(\mathrm{km})$} & \multicolumn{2}{|c|}{ Magnitude } \\
\cline { 2 - 3 } & $2.0-3.5$ & $>3.5$ \\
\hline$<10$ & $\bullet$ & 0 \\
$10-20$ & + & + \\
$20-60$ & $x$ & $x$ \\
\hline
\end{tabular}
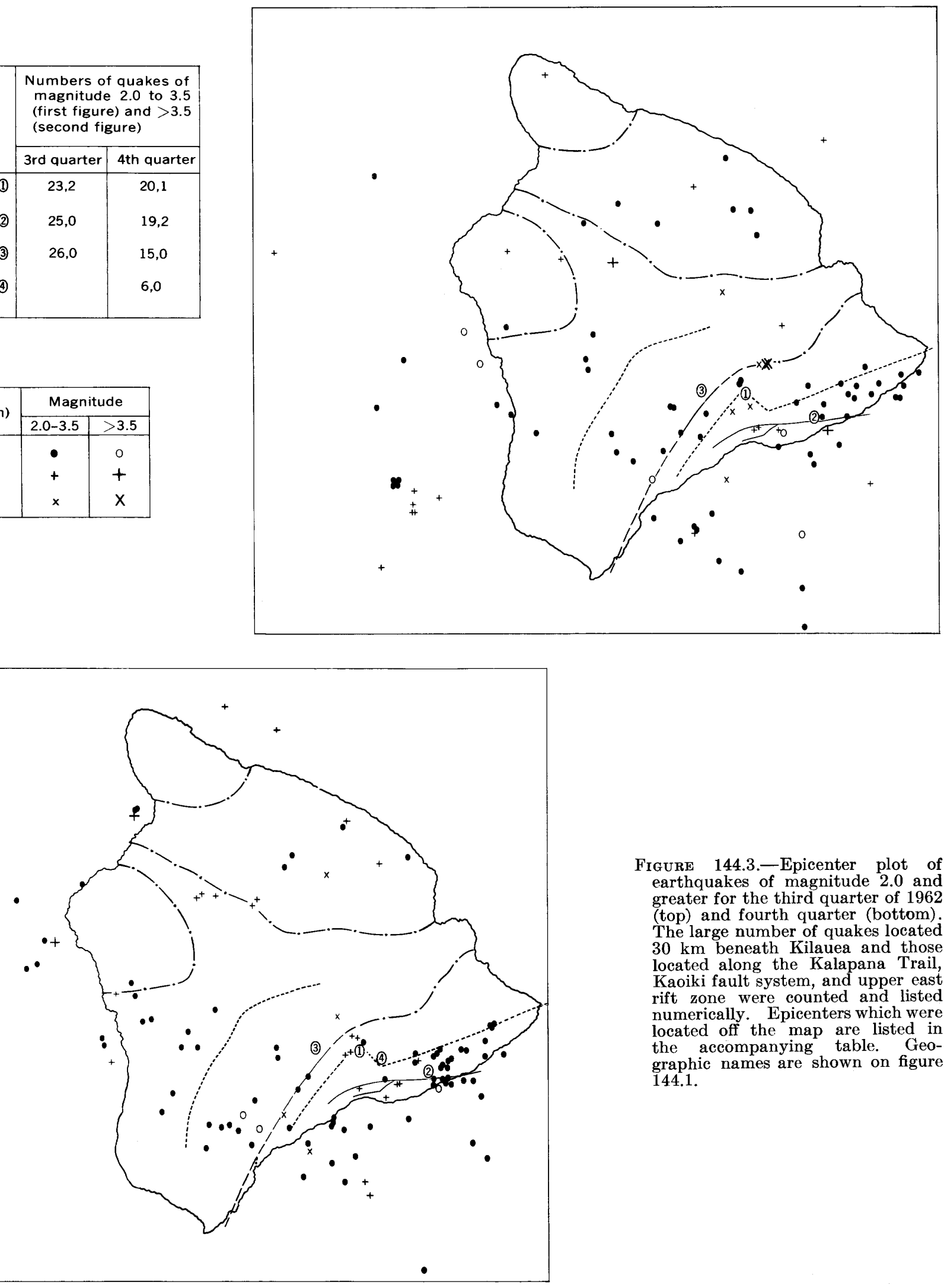

Figure 144.3.-Epicenter plot of earthquakes of magnitude 2.0 and greater for the third quarter of 1962 (top) and fourth quarter (bottom). The large number of quakes located $30 \mathrm{~km}$ beneath Kilauea and those located along the Kalapana Trail, Kaoiki fault system, and upper east rift zone were counted and listed numerically. Epicenters which were located off the map are listed in the accompanying table. Geographic names are shown on figure 144.1. 


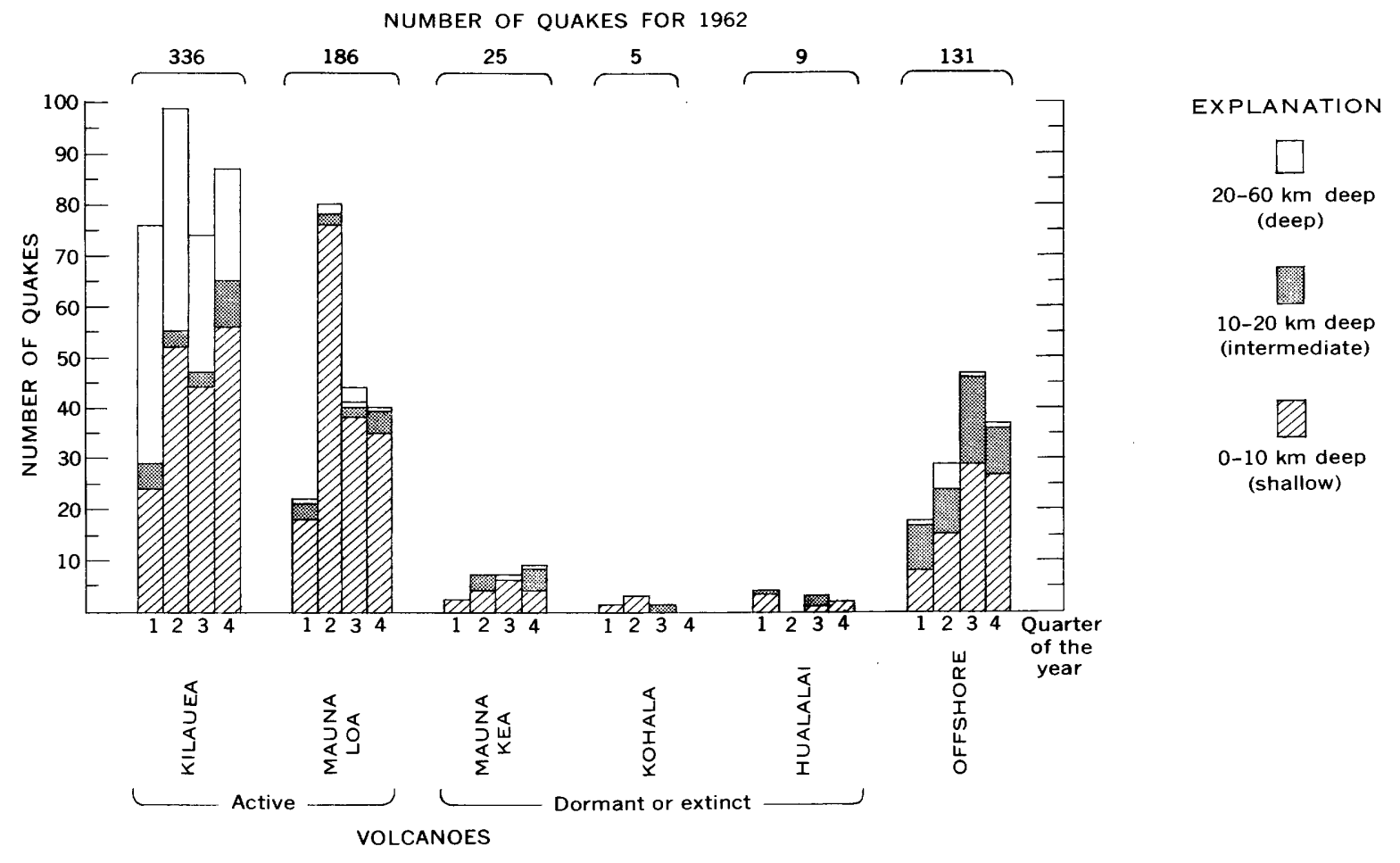

FIGURE 144.4.-Bar graph showing earthquakes of magnitude 2.0 or greater on, and offshore from, the island of Hawaii in 1962 .

\section{VOLCANOES AND SEISMICITY}

Seismic activity on the island of Hawaii during 1962 was greatest beneath Kilauea Volcano (fig. 144.4), although the number of quakes in the Mauna Loa region was also high. Seventy-five percent of all quakes were from the Mauna Loa and Kilauea systems. The large number of quakes originating from a highly seismic zone at a depth of $30 \mathrm{~km}$ beneath Kilauea caldera was responsible for the high count of deep quakes from the Kilauea system. However, 66 percent of the quakes from Mauna Loa and Kilauea were of shallow origin. Many shallow quakes occurred north of the Honuapo-Kaoiki fault system and therefore have been assigned to the Mauna Loa system (fig. 144.4). Such quakes, located near the surface trace separating two volcanic systems, have been assigned somewhat arbitrarily to one system or the other.

The dormant or extinct volcanoes Hualalai, Mauna Kea, and Kohala accounted for few earthquakes in comparison with the active volcanoes Kilauea and Mauna Loa.

A relatively high proportion of offshore quakes were assigned to intermediate-depth sources. Seismograms of earthquakes more than $50 \mathrm{~km}$ from the nearest station yield little information on focal depth; there- fore, "normal" depth travel-time curves are used to locate them.

Relative to previous years, there was in 1962 a marked decrease in the number of quakes deeper than $30 \mathrm{~km}$. This fact is not obvious on the maps and bar graph but it marks an important difference between 1962 and recent years since 1956 . Those years were characterized by almost quarterly swarms of thousands of quakes beneath Kilauea and Mauna Loa from depths between 45 and $60 \mathrm{~km}$. Such deeper events prior to 1962 (and their sudden cessation) are being studied further.

\section{REFERENCES}

Eaton, J. P., 1962, Crustal structures and volcanism in Hawaii, in Macdonald, G. A., and Kuno, Hisashi, eds., Crust of the Pacific Basin: Am. Geophys. Union Geophys. Mon. 6, p. 13-29.

Koyanagi, R. Y., Krivoy, H. L., and Okamura, A. T., 1963, Hawaiian Volcano Observatory summary: U.S. Geol. Survey Hawaiian Volcano Observatory Summary 25 (Jan., Feb., and March 1962). [In press]

Krivoy, H. L., Koyanagi, R. Y., Okamura, A., and Kojima, G., 1963, Hawaiian Volcano Observatory summary: U.S. Geol. Survey Hawaiian Volcano Observatory Summary 28 (Oct., Nov., and Dec. 1962). [In press]

Macdonald, G. A., 1956, The strueture of Hawaiian volcanoes: Gravenhage, K. Nederlandsch Geol.-Mijn. Genootschap Verh. Geol. Ser., Deel 16, p. 274-295. 
Okamura, A. T., Koyanagi, R. Y., and Krivoy, H. L., 1963, Hawaiian Volcano Observatory summary: U.S. Geol. Survey Hawaiian Volcano Observatory Summary 26 (April, May, and June 1962). [In press]

Okamura, A. T., Kojima, G., and Yamamoto, A., 1963, Hawaiian Volcano Observatory summary: U.S. Geol. Survey Ha- waiian Volcano Observatory Summary 27 (July, Aug., and Sept. 1962). [In press]

Richter, D. H., Ault, W. U., Eaton, J. P., and Moore, J. G., 1964, The 1961 eruption of Kilauea Volcano, Hawaii: U.S. Geol. Survey Prof. Paper 474-D. [In press] 


\title{
Article 145
}

\section{SEISMIC INVESTIGATIONS ON CAPE COD, MASSACHUSETTS}

\author{
By R. N. OLDALE and C. R. TUTTLE, Boston, Mass.
}

Work done in cooperation with the Massachusetts Department of Public Works and U.S. Bureau of Public Roads

\begin{abstract}
Seismic studies on Cape Cod show that sedimentary deposits of post-Paleozoic age, ranging from 250 to possibly more than 960 feet in thickness, overlie crystalline basement rocks. A trough in the basement surface extending to about 900 feet below sea level was found on outer Cape Cod near Truro.
\end{abstract}

Thirteen seismic-refraction traverses made on Cape Cod between 1958 and 1963 form the basis for interpretations presented here. Additional traverses in the Harwich and Dennis areas have been reported previously (Oldale and others, 1962). Three of the 13 traverses reported were made in the Falmouth area in October 1958 to determine the nature of the surficial deposits and the depth to bedrock along the proposed relocation of Massachusetts Route 28. The 10 other traverses, made for a similar purpose, were along the outer arm of Cape Cod between Orleans Beach and Race Point (fig. 145.1). Nine of these traverses were made in 1962 (Oldale and Tuttle, 1962); the other, an unreversed traverse (traverse 3, fig. 145.1), was made in 1960 at Pilgrim Spring State Park in Truro at a deep borehole drilled by the Woods Hole Oceanographic Institution (Zeigler and others, 1960).

All seismic traverses were of the inline refraction type. Traverses before 1962 were made with a 12 channel portable refraction amplifier and oscillograph. The 1962 traverses were made using the same equipment coupled in "series" with a 12-channel refraction amplifier and oscillograph designed to record very low frequencies. The original equipment was used to record the first set of 12 geophones, and the very low frequency equipment recorded a second set of 12 geophones. Traverses in the Falmouth area were 1,100 feet long and those made in 1962 on outer Cape Cod between Orleans Beach and Race Point were 1,800 to 2,100 feet long. The unreversed traverse made at Pilgrim Spring State Park in 1960 was 1,555 feet long. Thickness of layers and the depth to bedrock were calculated for each traverse, using recorded velocities and critical distances.

\section{OUTER CAPE COD}

The upper two seismic layers $\left(L_{1}\right.$ and $\left.L_{2}\right)$ recorded in this area probably represent unconsolidated deposits of Pleistocene or, in places, possibly of Tertiary age. A third seismic layer $\left(L_{3}\right)$ recorded at traverse 4 may represent semiconsolidated or consolidated deposits of Cretaceous(?) age.

The uppermost layer $\left(L_{1}\right)$, having velocities of 1,300 to 3,800 feet per second, was recorded at traverses 4,7 , and 8 (see accompanying table). This layer, which is thought to represent the unsaturated Pleistocene glacio-

Thickness of the seismic layers, and depth, altitude, and average seismic velocity of the basement rocks at 13 traverses on Cape Cod

[Minimum thickness, depth, and altitude indicated where traverse was not long enough to detect underlying material]

\begin{tabular}{c|c|c|c|c|c|c}
\hline $\begin{array}{c}\text { Traverse } \\
\text { (fig. 145.1) }\end{array}$ & \multicolumn{2}{|c|}{ Thickness of layers (feet) } & $\begin{array}{c}\text { Computed } \\
\text { depth to } \\
\text { basement } \\
\text { (feet) }\end{array}$ & $\begin{array}{c}\text { Altitude of } \\
\text { basement, } \\
\text { mean } \\
\text { sea level } \\
\text { datum } \\
\text { (feet) }\end{array}$ & $\begin{array}{c}\text { A verage } \\
\text { seismic } \\
\text { velocity of } \\
\text { basement } \\
\text { (feett/ } \\
\text { second) }\end{array}$ \\
\hline
\end{tabular}

\begin{tabular}{|c|c|c|c|c|c|c|}
\hline \multicolumn{7}{|c|}{ Outer Cape Cod } \\
\hline 1. & & 510 & & 510 & -500 & 21,250 \\
\hline 3 & $\cdots$ & $\begin{array}{r}510 \\
>620\end{array}$ & $\cdots$ & $\begin{array}{r}510 \\
>620\end{array}$ & $\begin{array}{l}-500 \\
-580\end{array}$ & $\begin{array}{r}21,250 \\
\ldots\end{array}$ \\
\hline & 60 & 440 & $>460$ & $>960$ & $>-910$ & \\
\hline & $\cdots$ & 400 & 然 & $\begin{array}{l}390 \\
400\end{array}$ & $\begin{array}{l}-380 \\
-370\end{array}$ & $\begin{array}{l}14,750 \\
19,500\end{array}$ \\
\hline - & 30 & 470 & ( & 500 & -450 & $\begin{array}{l}19,200 \\
02\end{array}$ \\
\hline $9_{9}^{8}$ & 50 & 470 & $\cdots$ & $\begin{array}{l}530 \\
470\end{array}$ & $\begin{array}{l}-480 \\
-430\end{array}$ & $\begin{array}{l}23,500 \\
14,100\end{array}$ \\
\hline 10 & {$[-\ldots$} & 400 & . & 400 & -390 & 20,500 \\
\hline
\end{tabular}

Falmouth Area

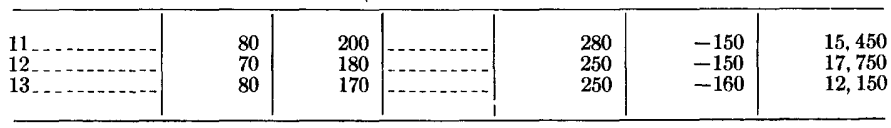




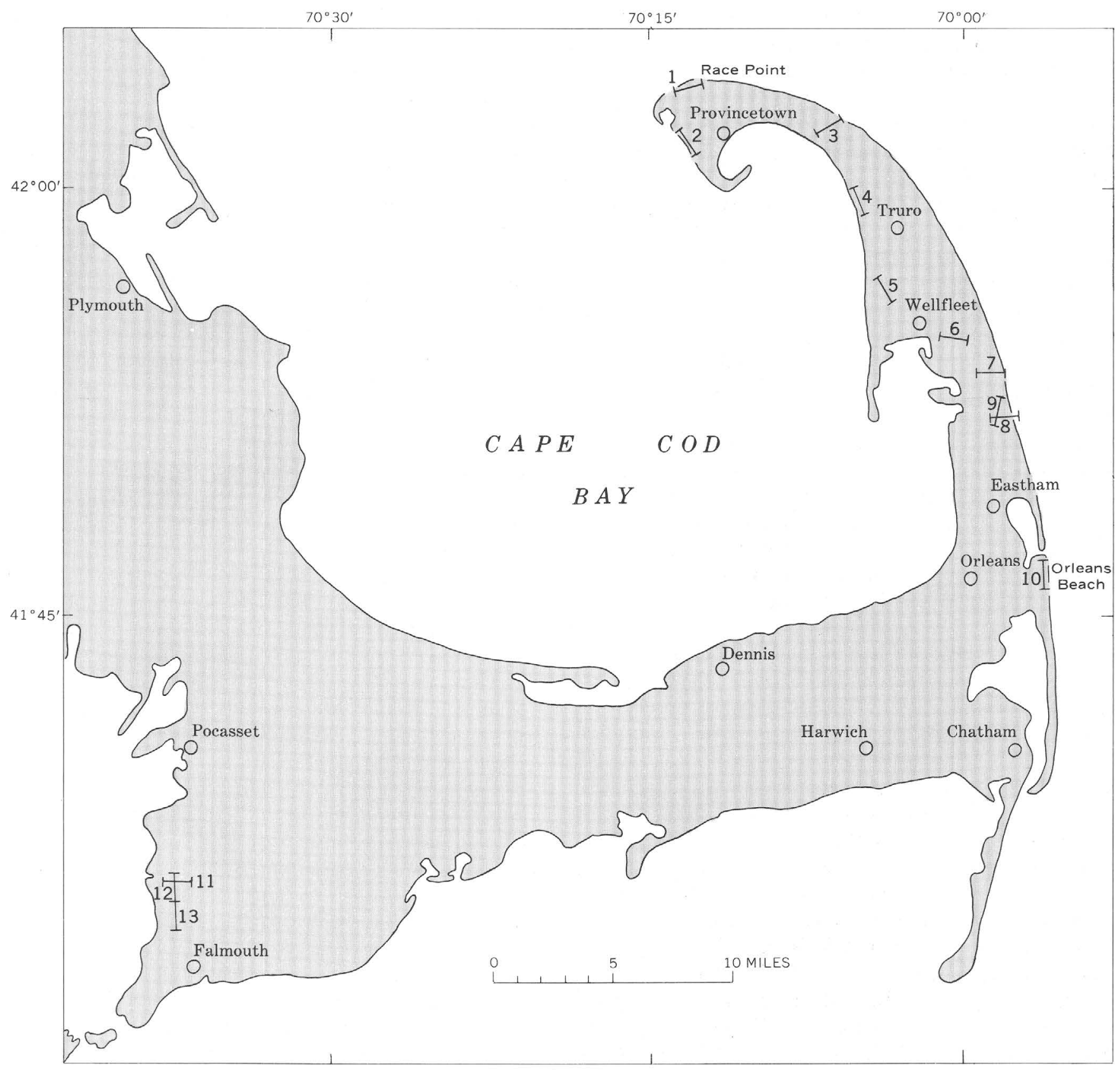

Figure 145.1.-Map of Cape Cod showing the location of seismic traverses described. Symbol shows approximate azimuth, but not length, and number of seismic traverse.

fluvial deposits above the water table, ranges from 30 to 60 feet in thickness. A second layer $\left(L_{2}\right)$ was recorded at all traverses and has average velocities in the range from 4,700 to $5,700 \mathrm{fps}$. The $L_{2}$ layer presumably represents glaciofluvial sand and gravel of Pleistocene age underlain by sand, silt, and clay of Pleistocene and, in some places, of Tertiary age (Woodworth and Wigglesworth, 1934, and Zeigler and others, 1960).

At traverse 3 the $L_{2}$ layer is made up of 2 distinct acoustic layers with velocities of 4,600 and 5,900 fps. This traverse was made at a deep borehole drilled by the Woods Hole Oceanographic Institution at Pilgrim Spring State Park that found Eocene deposits at a depth of only 86 feet, overlain by materials of Pleistocene age. However, the contact between the acoustic layers was at 175 feet, indicating no correlation between the acoustic boundaries and geologic-time boundaries at this site.

Two seismic traverses ( 1 and 2 , fig. 145.1) near Provincetown in the vicinity of a second borehole made by the Woods Hole Oceanographic Institution indicated average velocities of 5,250 and 5,500 fps, respectively, 
for the $L_{2}$ layer. The borehole penetrated 193 feet of glaciofluvial material above 10 feet of sand and silt of Eocene age (Zeigler and others, 1960). The seismic data gave no suggestion of this contact, indicating that materials of Pleistocene and Eocene age have similar acoustic characteristics. Therefore, it is impossible to tell from seismic data alone whether unconsolidated deposits of Tertiary age occur beneath the Pleistocene glaciofluvial deposits in this part of Cape Cod. The $L_{2}$ layer ranges in thickness from 390 feet at traverse 5 to more than 620 feet at traverse 3 , where the traverse was not long enough to detect the velocity and depth of the underlying material.

The absence of velocities in the 6,000 to $9,000 \mathrm{fps}$ range indicates that there is little or no compact till beneath the glaciofluvial deposits in this part of Cape Cod; compact till commonly has velocities between 6,000 and 9,000 fps in other parts of Massachusetts (Tuttle, 1961). Near Harwich, Mass., material having an average seismic velocity of $10,500 \mathrm{fps}$ and underlying 313 feet of stratified drift was identified in a borehole as compact till (Koteff and Cotton, 1962). In seismic studies in the Harwich and Dennis areas, material having velocities of 6,000 to $11,000 \mathrm{fps}$ and overlain by 82 to 357 feet of stratified drift has been interpreted to be compact till (Oldale and others, 1962).

A third seismic layer $\left(L_{3}\right)$ recognized at traverse 4 is thought to represent semiconsolidated or consolidated deposits overlying crystalline basement rocks. The average velocity computed for the material below the $L_{2}$ layer at this traverse is $12,100 \mathrm{fps}$. This velocity is about 7,000 fps slower than the average of the velocities of crystalline basement rocks in the area and more than 2,000 fps slower than the lowest basement velocity recorded in this area by the authors. Similar velocities have been recorded on Block Island, R.I. (Tuttle and others, 1961), and from offshore seismic-refraction studies in Cape Cod Bay (Hoskins and Knott, 1961), in Nantucket Sound south of Woods Hole, Mass. (Ewing and others, 1950), in the Gulf of Maine (Drake and others, 1954), and south of Nova Scotia (Officer and Ewing, 1954). In these investigations, velocities of 9,750 to $13,000 \mathrm{fps}$ were interpreted to represent semiconsolidated or consolidated rock of Cretaceous age or rocks of Triassic age similar to the sediments found in the Connecticut Valley. These interpretations were based on other seismic measurements from areas where these lithologic units crop out or where seismic velocities and lithology can be correlated on the basis of borehole data.

If the velocity recorded at traverse 4 for the $L_{3}$ seismic layer actually represents a semiconsolidated or consolidated layer, the layer is more than 450 feet thick and overlies crystalline basement rocks at an altitude on the order of 900 feet below sea level. The $L_{3}$ layer occurs in what appears to be an eastward extension of a trough found in Cape Cod Bay by Hoskins and Knott (1961), the bottom of which is more than 700 feet below sea level. This trough is in part filled with material having velocities of 10,000 to $12,500 \mathrm{fps}$, interpreted by Hoskins and Knott to be a semiconsolidated deposit of Cretaceous age.

The crystalline basement in this area presumably consists of Paleozoic or Precambrian rocks similar to those exposed along the shore of Massachusetts Bay from Plymouth northward, because the average seismic velocities of 14,100 to $23,500 \mathrm{fps}$ are comparable to the seismic velocities measured in the outcrop areas of the crystalline rocks. Comparison of variation in velocities with azimuth suggests that in the Wellfleet area the basement is composed of a bedded or foliated rock striking eastward, possibly similar to phyllite identified in a borehole near Harwich, Mass. (Koteff and Cotton, 1962). At traverse 8 the average of the rock velocities measured in an easterly direction was $23,500 \mathrm{fps}$, and at traverse 9 the average of the rock velocities measured in a northerly direction was $14,100 \mathrm{fps}$. Similar results were noted near Harwich, where seismic studies in the immediate vicinity of the borehole indicated an average velocity of $23,250 \mathrm{fps}$ in an easterly direction, and a traverse 1.1 miles southeast of the borehole indicated an average velocity of $15,650 \mathrm{fps}$ in a northerly direction (Oldale and others, 1962).

As portrayed on figure 145.2 the basement surface is deepest at traverses 3 and 4 , where the seismic lines were not long enough to detect basement rocks. Instead, minimum depths were computed on the assumption that the critical distance for the basement surface was equal to the length of the traverse. On this assumption the basement surface at traverse 3 was computed to be more than 580 feet below sea level.

At traverse 4, two interpretations for the depth to the basement surface are possible, depending upon whether the 12,100 fps velocity recorded for the $L_{3}$ layer is interpreted as representing crystalline basement rocks or a semiconsolidated to consolidated rock overlying the basement. By the latter interpretation and on the assumption that the critical distance for the basement is equal to the total length of traverse 4 , the altitude of the basement surface is computed to be 910 feet below sea level. However, if the 12,100 -fps velocity actually represents the basement rocks, the surface of the basement in this area would be 440 feet below sea level and the maximum depth would then be at traverse 3. The authors' preferred interpretation is that the basement surface dips steeply north of traverse 5 and south of traverse 2 to form a valley whose floor is 


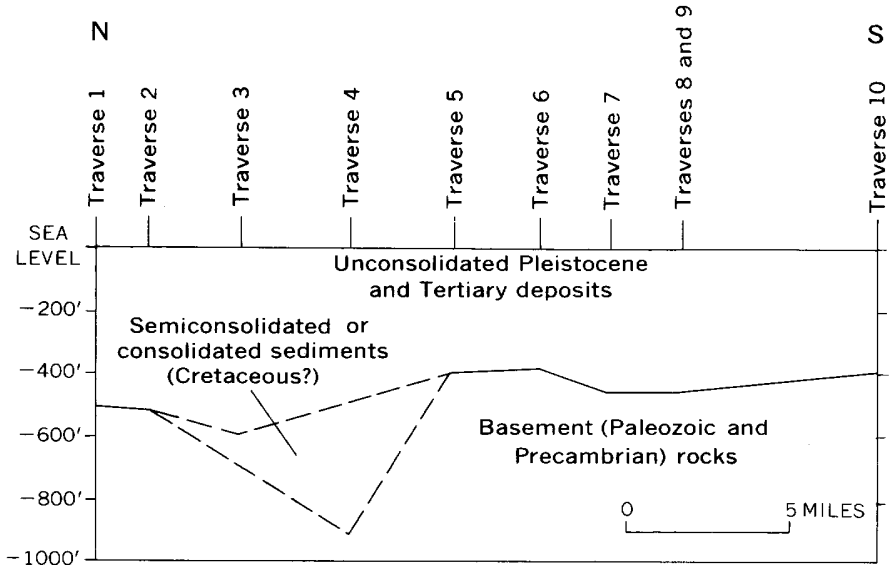

Figure 145.2-Generalized cross section of outer Cape Cod from Orleans Beach to Race Point, showing computed average altitude of the basement surface at 8 seismic traverses. Dashed lines indicate alternate interpretations in area of deepest basement rock.

more than 900 feet below sea level in the vicinity of traverse 4 (fig. 145.2).

\section{FALMOUTH AREA}

At 3 traverses on the Buzzards Bay moraine in Falmouth (fig. 145.1), 2 seismic layers $\left(L_{1}\right.$ and $L_{2}$ ) representing unconsolidated deposits of Pleistocene and possibly Tertiary and Cretaceous age were recorded over crystalline basement rocks. Velocities in the $L_{1}$ layer ranged from 1,400 to $2,300 \mathrm{fps}$ and are thought to represent an unconsolidated layer composed in part of unsaturated Pleistocene glaciofluvial sand and gravel and in part of unsaturated loose till similar to sandy till found in other areas of Massachusetts. The $L_{1}$ layer ranged in thickness from 70 to 80 feet. Velocities in the $L_{2}$ layer ranged from 2,900 to 6,600 fps. The lower velocities in this layer probably represent loose sandy till. The intermediate and higher velocities are thought to represent a layer composed for the most part of compact till similar to high-velocity till in other parts of Massachusetts (Tuttle, 1961). On the other hand, it may be a complex layer composed of glaciofluvial deposits and till of Pleistocene age, and unconsolidated marine and lacustrine deposits of Pleistocene, Tertiary, and Cretaceous age. Unconsolidated marine and nonmarine deposits of sand, silt, and clay of Pleistocene, Tertiary, and Cretaceous age crop out 20 miles to the southwest on Marthas Vineyard and 7 miles to the south on Nonamesett Island. Similar deposits of Tertiary and possibly Cretaceous age are exposed 31 miles to the north at Duxbury and Marshfield (Woodworth and Wigglesworth, 1934; Emerson, 1917). The $L_{2}$ layer ranges in thickness from 170 feet at traverse 13 to 200 feet at traverse 11 .
The basement in this area is thought to be Paleozoic sedimentary and crystalline rock, possibly the Dedham Granodiorite that crops out along the west shore of Buzzards Bay. Average velocities measured on the basement rocks range from 12,150 to $17,750 \mathrm{fps}$, and seismic measurements on the bedrock in areas mapped as Dedham Granodiorite by Emerson in New Bedford, Dartmouth, and Westport, Mass. (Emerson, 1917), ranged from 11,900 to $16,600 \mathrm{fps}$. At traverse 13 the 12,150 -fps velocity could represent a semiconsolidated or consolidated deposit of Mesozoic age similar to that recorded at traverse 4 in Truro, but is thought to more likely represent a low-velocity facies of the Dedham Granodiorite similar to those recorded in New Bedford, Dartmouth, and Westport. The high percentage of Dedham Granodiorite stones in the drift of the Buzzards Bay moraine (Mather and others, 1942) also suggests that the bedrock in this area is Dedham Granodiorite.

\section{REFERENCES}

Drake, C. L., Worzel, J. L., and Beckmann, W. C., 1954, Geophysical investigations in the emerged and submerged Atlantic Coastal Plain, Part IX, Gulf of Maine: Geol. Soc. America Bull., v. 65, p. 957-970.

Emerson, B. K., 1917, Geology of Massachusetts and Rhode Island: U.S. Geol. Survey Bull. 597.

Ewing, W. M., Worzel, J. I., Steenland, N. C., and Press, Frank, 1950, Geophysical investigations in the emerged and submerged Atlantic Coastal Plain, Part V, Woods Hole, New York, and Cape May sections: Geol. Soc. America Bull., v. 61, p. $877-892$.

Hoskins, Hartley, and Knott, S. T., 1961, Geophysical investigation of Cape Cod Bay, Massachusetts, using the continuous seismic profiler: Jour. Geology, v. 69, p. 330-340.

Koteff, Carl, and Cotton, J. E., 1962, Preliminary results of recent deep drilling on Cape Cod, Massachusetts: Science, v. 137, p. 34 .

Mather, K. F., Goldthwait, R. P., and Thiesmeyer, L. R., 1942, Pleistocene geology of western Cape Cod, Massachusetts: Geol. Soc. America Bull., v. 53, p. 1127-1174.

Officer, C. B., and Ewing, M., 1954, Geophysical investigations in the emerged and submerged Atlantic Coastal Plain, Part VII, Continental shelf, continental slope, and continental rise south of Nova Scotia: Geol. Soc. America Bull., v. 65, p. $653-670$.

Oldale, R. N., and Tuttle, C. R., 1962, Preliminary report on the seismic investigations in the Orleans, Wellfleet, North Truro, and Provincetown quadrangles, Massachusetts: U.S. Geol. Survey open-file report.

Oldale, R. N., Tuttle, C. R., and Currier, L. W. 1962, Preliminary report on the seismic investigations in the Harwich and Dennis quadrangles, Massachusetts: U.S. Geol. Survey open-file report.

Tuttle, C. R., 1961, Seismic high-speed till in Massachusetts [abs]: Geol. Soc. America Spec. Paper 68, p. 288-289.

Tuttle, C. R., Allen, W. B., and Hahn, G. W., 1961, A seismic record of Mesozoic rocks on Block Island, Rhode Island: Art. 240 in U.S. Geol. Survey Prof. Paper $424-$ C, p. C254C256. 
Woodworth, J. B., and Wigglesworth, Edward, 1934, Geography and geology of the region including Cape Cod, the Elizabeth Islands, Nantucket, Marthas Vineyard, No Mans Land and Block Island: Harvard Coll. Mus. Comp. Zoology Mem., v. 52, 322 p.
Zeigler, J. M., Hoffmeister, W. S., Geise, Graham, and Tasha, Herman, 1960, A discovery of Eocene sediments in the subsurface of Cape Cod, Massachusetts: Science, v. 132, p. 1397-1398. 


\title{
Article 146
}

\section{GEOLOGIC SETTING OF THE SPAR CITY DISTRICT, SAN JUAN MOUNTAINS, COLORADO}

\author{
By THOMAS A. STEVEN, Denver, Colo.
}

Work done in cooperation with the Colorado Metal Mining Fund Board

\begin{abstract}
The district is along the south margin of the Creede caldera, near the intersection of a narrow graben cutting the core of the caldera and a reactivated fault along the margin of the caldera. The exposed veins appear to have been deposited in a near-surface environment and may represent the upper parts of the original vertical range of ore deposition.
\end{abstract}

The Spar City district, a small mineralized area along the south flank of the Creede caldera in the central San Juan Mountains, southwest Colorado (fig. 146.1), has been prospected sporadically since the early 1900's. Several mine workings were driven in the early days to explore some of the exposed veins in the district, and vein fragments containing galena, sphalerite, barite, manganese oxides, and jaspery to amethystine quartz are strewn over several of the old dumps. Systematic exploration, however, has been discouraged by thick soil and dense forest cover, and by widespread landslides and glacial drift. Recent regional geologic studies in and adjacent to the Creede caldera have outlined the geologic framework of the Spar City district, and although many specific details remain obscure, the additional knowledge should help guide future prospecting and exploration programs.

The mineralized area in the Spar City district is localized near the intersection of two differently trending structures that were active during volcanic activity, and the known veins appear to be along minor faults associated with this intersection. Mineralization took place late in the local sequence of volcanic and structural events, and was associated with or later than the last main period of faulting. Exposed veins were deposited in a near-surface environment.
The Creede caldera (Steven and Ratté, 1960) is a subcircular collapse structure 10 to 12 miles in diameter whose margin is clearly marked in the present topography for nearly $300^{\circ}$ of arc by the valley of the Rio Grande and its tributaries (fig. 146.1). This caldera is the youngest of at least four separate overlapping cauldron structures that together caused an area at least 25 miles long and 5 to 15 miles wide in the central San Juan Mountains to subside now and again in response to voluminous ash-flow eruptions during middle or late Tertiary time (Steven and Ratté, 1963, and Art. 132). The last period of subsidence of the Creede caldera accompanied eruption of the Snowshoe Mountain Quartz Latite, a crystal-rich ash-flow tuff, largely densely welded, that consists of 40 to 60 percent phenocrysts in a drab gray to brownish matrix. The phenocrysts consist largely of intermediate plagioclase, with lesser biotite, clinopyroxene, hornblende, sanidine, and quartz. The Snowshoe Mountain Quartz Latite accumulated to a thickness of more than 6,000 feet within the caldera, but has not been recognized outside. Talus and landslide breccias from the walls of the caldera intertongue marginally with the Snowshoe Mountain and indicate that subsidence and accumulation were concurrent over an extended period of time.

Final subsidence of the Creede caldera left a flatfloored basin at or below the level of the present Rio Grande, and talus and rockfall breccias spread widely over the floor. Northwest-trending tangential grabens, now followed by the Rio Grande both upstream and downstream from the caldera, formed late in the period of subsidence, and some faults in the recurrently active Creede graben extending north-northwest from the 

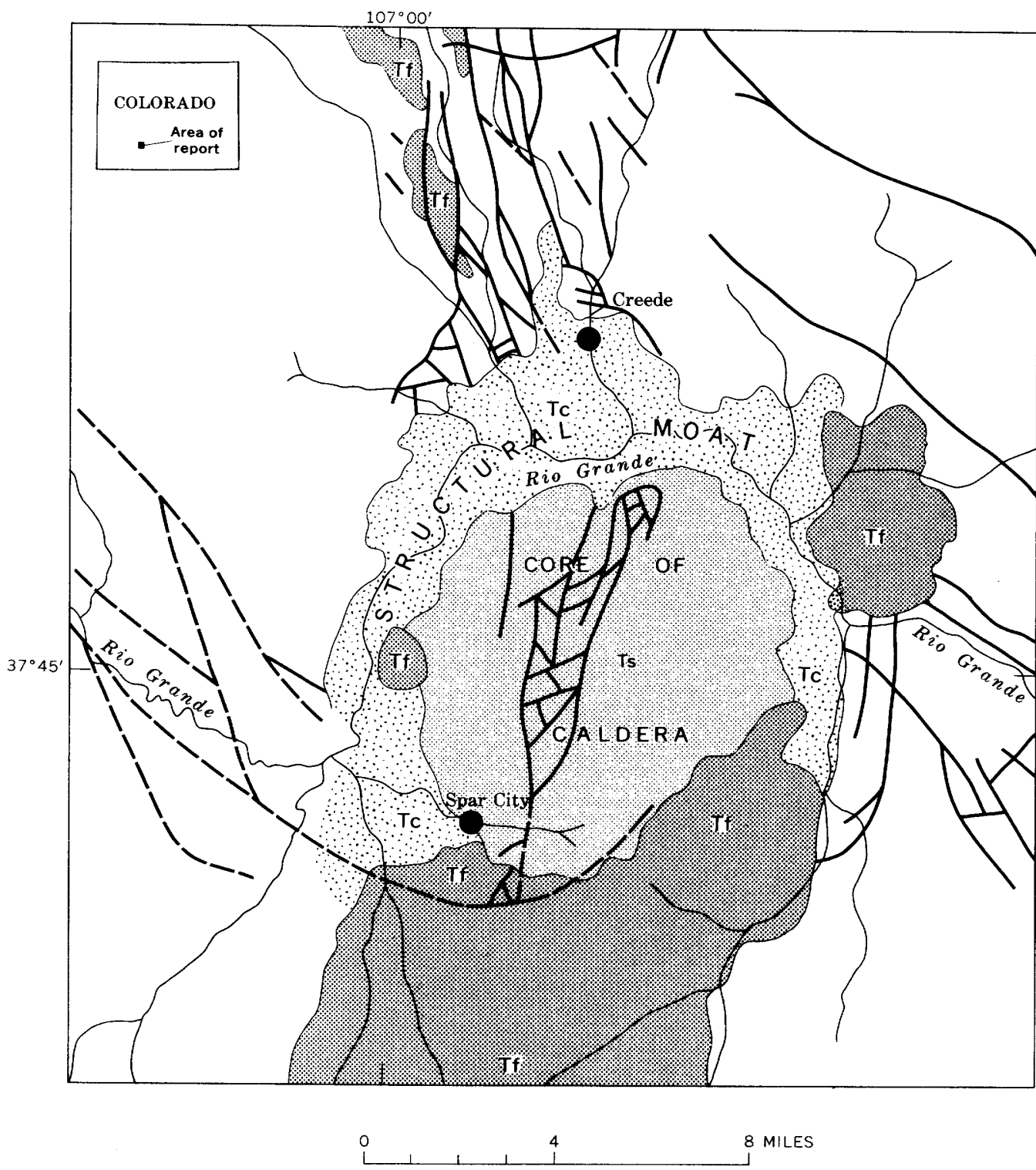

Figure 146.1-Geologic sketch map of the Creede caldera and adjacent areas. Snowshoe Mountain Quartz Latite (Ts) accumulated in core of caldera during subsidence. Sedimentary rocks of the Creede Formation (Tc) filled a structural moat around the domed core of the caldera, and viscous lava flows and breccias of Fisher Quartz Latite (Tf) were erupted locally around the margin of the caldera. Undifferentiated volcanic rocks that accumulated outside: the caldera before and during subsidence are shown as blank. Contact lines indicate the general limit of distribution of the formations. Heavy lines are generalized faults, dashed where poorly known or hypothetical.

northern margin of the caldera may have been active at the same time.

The core of the creede caldera was resurgently domed (Smith and Bailey, 1962) following final subsidence, and some parts near the center were uplifted more than 4,000 leet above a residual topographic moat left all around the margin. A complex keystone graben formed across the center of the core during doming; displacement in this graben was minor near the northern and southern margins of the caldera, but some blocks near the center are nearly 4,000 feet below equivalent rocks in the adjacent uplifted blocks.

Volcanic activity broke out around the margin of the caldera following doming, and viscous flows and domes of Fisher Quartz Latite formed several local accumulations, particularly along the south margin of the caldera (fig. 146.1). Concurrently, stream and lake sediments, volcanic ash, and travertine from mineral springs were deposited elsewhere around the caldera to form the Creede Formation. 
The last major period of faulting known around the Creede caldera followed accumulation of the Fisher Quartz Latite and Creede Formation. Many of the faults that formed earlier during the period of recurrent volcanic eruptions and cauldron subsidence were reactivated at this time. Faults active at this time are economically significant, as the important ore deposits in the Creede district north of the caldera formed concurrently with or shortly following movement, and the active or recently active faults were favored sites for mineralization (Steven and Ratté, 1960). The mineral deposits in the Spar City district were formed at about the same time.

Erosion of the Creede Formation has reexposed the margin of the Creede caldera. Although the adjacent slopes have been considerably dissected, the original form of the domed caldera core, as well as other constructional landforms in adjacent areas can still be recognized in many places.

In detail, the Spar City district is localized near the intersection of a fault marking the southern extension of the core graben of the Creede caldera and a reactivated fault linking the northwest-trending tangential graben with the caldera margin (figs. 146.1 and 146.2). The exposed faults near the Bird Creek mine and Emma mine (fig. 146.2) all appear to be minor fractures subsidiary to larger faults that seem required under the adjacent landslide and moraine cover. At its southern end, the core graben changes southward from a wide zone of jumbled fault blocks between persistent marginal faults to a single fracture that can be followed closely north of Lime Creek, although it has not been seen in outcrop farther south. The position of the fracture shown in figure 146.2, adjacent to the mineralized area of the Spar City district, is hypothetical and depends strictly on projection from the well-defined trends farther north.

The arcuate but generally east-trending fault postulated to separate the mineralized area of the Spar City district from the top of Fisher Mountain to the south (fig. 146.2) also has not been seen in outcrop. A fault south of the Emma mine seems certainly required, however, by the relations of the distinctive coarsely porphyritic quartz latite flow that caps Fisher Mountain. The base of this flow is clearly exposed along the west side of the spur ridge extending north from the summit of Fisher Mountain. The base ranges generally from an elevation of 11,250 feet near the north end of the spur, to 11,400 feet near the south end. The same capping flow comprises all the island of outcrop containing the Emma mine and the Denver Tunnel a short distance northwest across the postulated fault; the flow extends as low as 10,750 feet near the Denver Tunnel, but the base is not exposed.

No bedrock is exposed where the hypothesized easttrending fault crosses the ridge extending northwest from the summit of Fisher Mountain, and no evidence either for or against the fault was seen in the soil or float that covers the ridge in this vicinity. Unbroken exposures of the capping flow, short distances north and south of the projected trend, limit the position of the fault to a span about 1,000 feet wide.

The east-trending fault required between the Emma mine area and the top of Fisher Mountain projects northwesterly toward the southwest margin of the tangential graben that extends northwestward from the Creede caldera (fig. 146.1). Overlap relations at the southeastern end of the graben clearly indicate that the graben formed before the Creede Formation and Fisher Quartz Latite were deposited, and thus the arcuate east-trending fault in the Spar City district appears to represent post-Fisher reactivation of older trends related to caldera subsidence.

The capping auartz latite flow on Fisher Mountain appears to have been the youngest lava flow deposited in this area. To the west, marginal breccias along the flank of this flow intertongue with sediments of the Creede Formation, and to the north a thin wedge of Creede Formation appears to separate the flow from the underlying Snowshoe Mountain Quartz Latite near the Bird Creek mine (fig. 146.2). All these younger rocks are cut by mineralized minor faults, indicating that late faulting and mineralization here as well as in the Creede district north of the caldera postdated accumulation of the Creede and Fisher.

The exposed veins must have been deposited very near the surface, as the youngest Tertiary rocks deposited in the area form the host rocks. The common occurrence of barite, manganese oxides, and dense jaspery quartz in the gangues further suggests a near-surface environment of deposition. Deductively it would seem more probable that the present exposures represent the upper rather than the lower parts of the original vertical range of ore deposition, and that somewhat deeper levels may be more favorable for the discovery of ore deposits. 


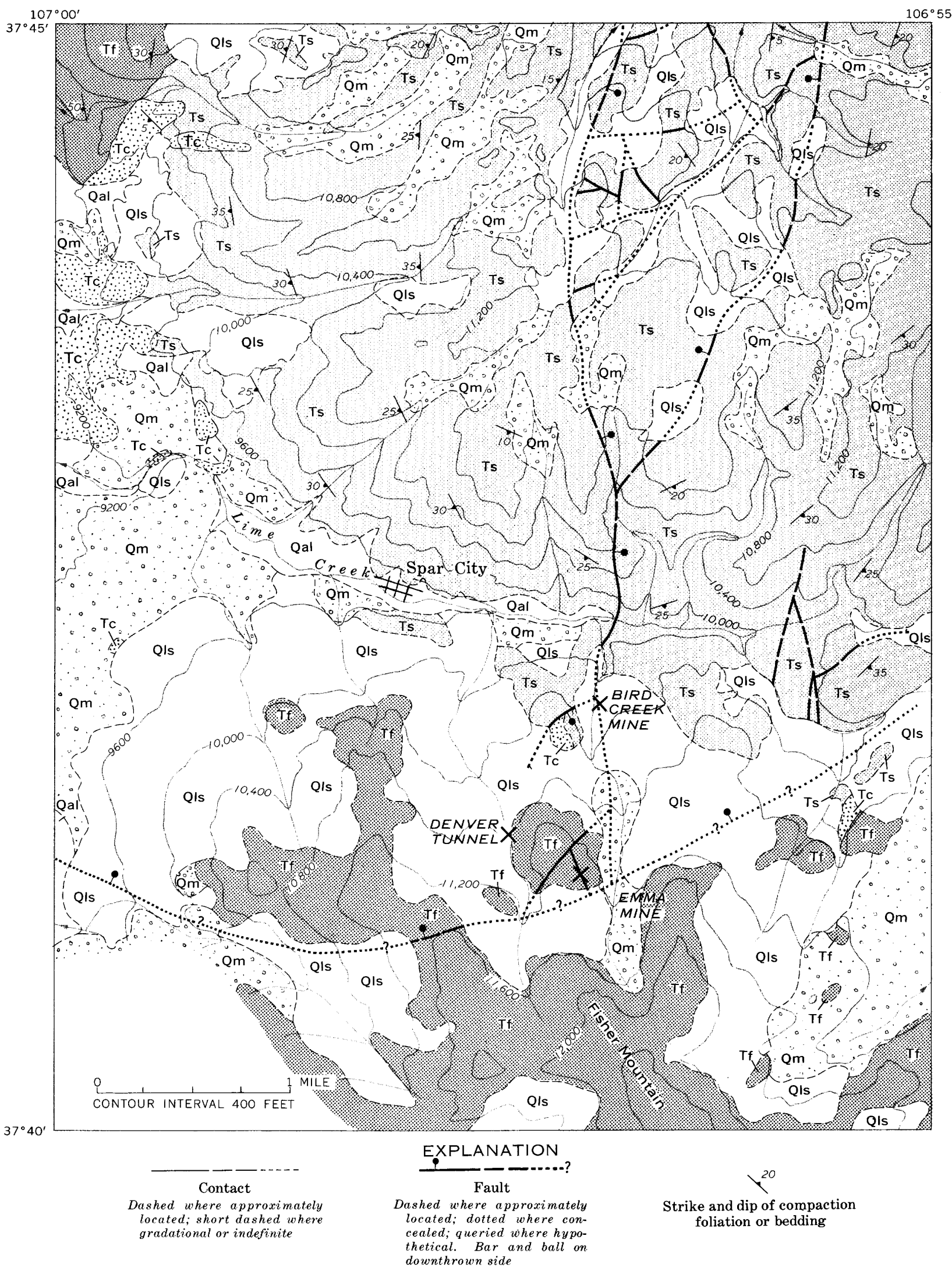

Figure 146.2-Geologic map of the Spar City district, Colorado. Tertiary rocks: Ts, Snowshoe Mountain Quartz Latite (in core of caldera); Tf, Fisher Quartz Latite; Tc, Creede Formation (in structural moat). Quaternary rocks: Qm, moraine; QIs, landslide debris; Qal, alluvium. Base from U.S. Geological Survey topographic quadrangle: Spar Citv, 1957. 


\section{REFERENCES}

Smith, R. L., and Bailey, R. A., 1962, Resurgent cauldronstheir relation to granitic ring complexes and large volume rhyolite ash-flow fields [abs.], in International symposium on volcanology, Japan: Internat. Assoc. Volcanology, 1962, p. 67-68.
Steven, T. A., and Ratté, J. C., 1960, Relation of mineralization to caldera subsidence in the Creede district, San Juan Mountains, Colorado: Art. 8 in U.S. Geol. Survey Prof. Paper 400-B, p. B14-B17.

1963, Resurgent cauldrons in the Creede area, San Juan Mountains, Colorado [abs.]: Am. Geophys. Union 44th Ann. Mtg., April, 1963, Program, p. 112-113. 


\title{
Article 147
}

\section{THORIUM AND URANIUM IN MONAZITE FROM SPOKANE COUNTY, WASHINGTON}

\author{
By JOHN W. HOSTERMAN, W. C. OVERSTREET; and J. J. WARR, JR., Beltsville, Md.; and Washington, D.C.
}

\begin{abstract}
Monazite occurs in residual clay derived from granodiorite and related rocks (saprolite) and sedimentary clay deposits of the Latah Formation. In three samples of monazite separates, thorium oxide $\left(\mathrm{ThO}_{2}\right)$ averages 3.6 percent and uranium oxide $\left(\mathrm{U}_{3} \mathrm{O}_{8}\right)$ averages 0.37 percent. The tenor of the monazite is not high enough to be considered commercial.
\end{abstract}

\section{OCCURRENCE}

Monazite, an anhydrous phosphate of the cerium earths containing variable amounts of thorium, has been known for a number of years to occur in saprolite of crystalline rocks in Spokane County (fig. 147.1) (Goodspeed and Weymouth, 1928, p. 687-695), but determinations of the amount of thorium and uranium in the monazite have not been reported heretofore. In this article, analyses are given of monazite collected by the senior author in 1962 during investigations of residual and sedimentary clay deposits in Spokane County. Analyses of two samples of monazite from residual clay deposits and one sample from sedimentary clay show that the amount of thorium is below the normal commercial specifications for monazite, but they add to information on the composition and resources of monazite in the Pacific Northwest.

Monazite-bearing residual clay deposits occur on quartzose gneiss and granodiorite exposed in the Freeman clay pit, and on sillimanite gneiss reached in an auger hole located on the point of a hill 0.95 mile south of Saltese Flats. The deposits consist chiefly of kaolinite and halloysite formed by the weathering of aluminasilicate minerals, variable amounts of unaltered quartz, and minor quantities of resistate accessory minerals (Hosterman, 1960, p. 289--291). The residual deposits are soft compared to the underlying crystalline rocks. They preserve the textures and structures of the original gneiss and granodiorite even though much of the rock has been replaced by minerals formed during weathering. The term "saprolite" has been widely used by geologists and soil scientists for such decomposed rocks since it was introduced by Becker (1895, p. 289-290), and it will be used here for these materials. The conclusion that the residual clay deposits are saprolites formed by weathering is supported by the wide distribution of clay deposits in eastern Washington and northern Idaho (Hosterman and others, 1960, fig. 1), and the observations that extensive kaolinitic and halloysitic saprolites are now known to develop during weathering in many parts of the world (Campbell, 1917, p. 67; Fox, 1923, p. 4; 1936, p. 419; Harrassowitz, 1926, p. 320-382; Gordon and others, 1958, p. 137-146).

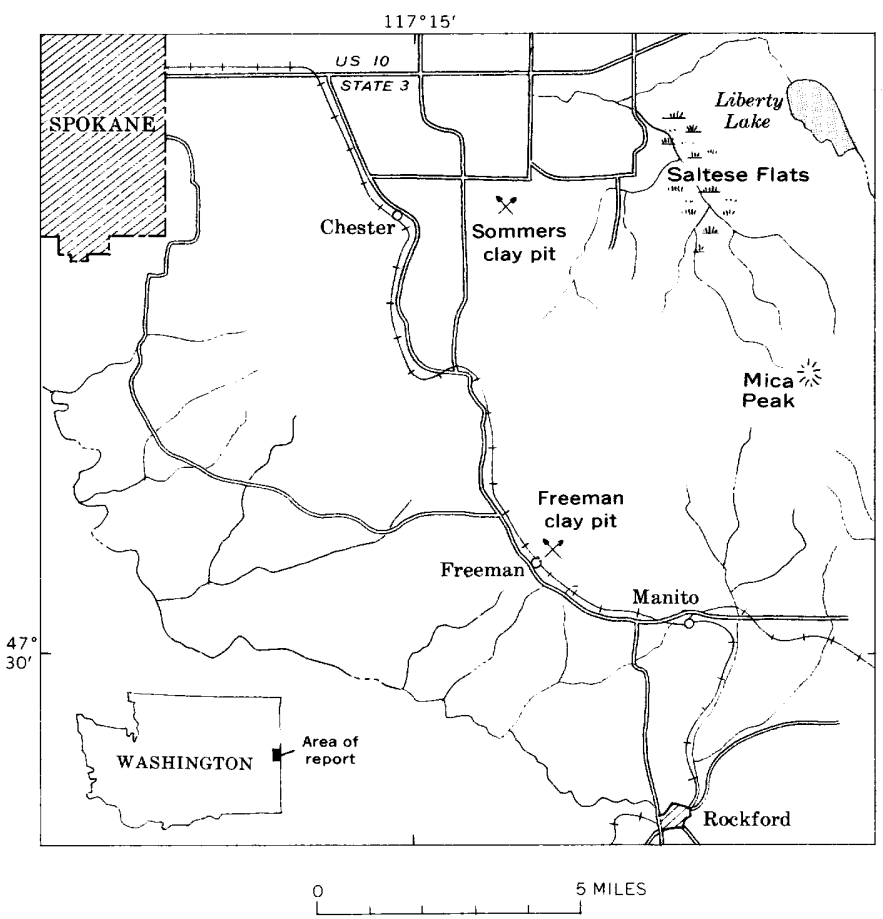

Figure 147.1- Index map showing location of monazite deposits, Spokane County, Wash. 
Three monazite-bearing concentrates were panned from saprolite of the quartzose gneiss, granodiorite, and sillimanite gneiss, but only the concentrates from granodiorite saprolite (sample 160816, accompanying table) and sillimanite gneiss saprolite (sample 160817) contained a sufficient percentage of monazite for analysis. In these two samples monazite made up about 20 percent of the concentrate. Less than 5 percent of the concentrate from the quartzose gneiss saprolite was monazite. Monazite was estimated to make up from less than 0.001 percent to about 0.003 percent of the original rock from which the saprolite was derived.

Thorium and uranium in monazite from Spokane County, Wash. [Analyses by J. J. Warr, Jr.]

\begin{tabular}{|c|c|c|c|c|}
\hline \multirow{2}{*}{$\begin{array}{c}\text { Laboratory } \\
\text { sample } \\
\text { No. }\end{array}$} & \multirow{2}{*}{$\begin{array}{l}\text { Source of } \\
\text { monazite }\end{array}$} & \multirow{2}{*}{ Location } & \multicolumn{2}{|c|}{ Percent } \\
\hline & & & $\mathrm{ThO}_{2}$ & $\mathrm{U}_{3} \mathrm{O}_{8}$ \\
\hline 160816 & Granodioritic & Clay pit at Freeman; sec. 1, T. 23 & 2.74 & 0.65 \\
\hline 160817 & $\begin{array}{l}\text { saprolte. } \\
\text { Sillimanite } \\
\text { gneiss } \\
\text { saprolite. }\end{array}$ & $\begin{array}{l}\text { Auger hole on point of hill } 0.95 \\
\text { mile south of Saltese Flats; sec. }\end{array}$ & 4.06 & .20 \\
\hline $160818_{-}$ & $\begin{array}{l}\text { Sedimentary } \\
\text { clay. }\end{array}$ & $\begin{array}{l}\text { Sommers clay pit; sec. } 35, \text { T. } 25 \text { N., } \\
\text { R. } 44 \text { E. }\end{array}$ & 3. 92 & .26 \\
\hline
\end{tabular}

The mineralogic composition of the monazite-bearing concentrates varies with the type of rock from which the saprolite developed. Concentrates from saprolite of quartzose gneiss in the clay pit at Freeman were observed by Goodspeed and Weymouth $(1928$, p. 687692 ) and the senior author to contain monazite, zircon, magnetite, ilmenite, cassiterite, rutile, tourmaline, and staurolite relict from the original rock. Concentrates from this saprolite also have accessory anatase, which is probably a secondary mineral formed by weathering. Concentrates from saprolite of granodiorite exposed at the same locality contain monazite (sample 160816), zircon, magnetite, ilmenite, cassiterite, rutile, tourmaline topaz, and lepidolite, but lack staurolite. They also have anatase of probable secondary origin. A concentrate panned from saprolite of sillimanite gneiss sampled with the aid of an auger at a locality west of the Saltese Flats consisted of monazite (sample 160817), zircon, ilmenite, spessartite, tourmaline, sillimanite, and actinolite.

The resistate heavy minerals recovered from the saprolites are not abraded. The minerals occur mostly as discrete grains, some of which are euhedral, and as inclusions in quartz, or as intergrowths with quartz or other heavy minerals. Most monazite grains are subhedral to anhedral, and they are up to about 0.02 inch in maximum dimension. About 10 percent of the monazite grains from granodiorite saprolite are euhedral tabular crystals, but only a percent or two of the grains from the saprolite of gneiss are euhedral. The monazite is uniformly dark yellow with no per- ceptible difference in color relatable to kind of source rock.

A monazite-bearing clayey sand bed occurs in a sedimentary clay deposit in the Tertiary age Latah Formation at the Sommers clay pit, about $61 / 2$ miles north of Freeman and $3 \frac{1}{2}$ miles west of Saltese Flats. The sedimentary material is thought to have been derived from local sources inasmuch as the heavy minerals show few if any effects of transportation. Weathered gneiss seems to be the most likely source because the sedimentary rock contains detrital heavy minerals of the same species that occur as accessory minerals in the gneisses and because the detrital monazite in the clay has uranium and thorium contacts similar to the monazite in the sillimanite gneiss saprolite. Detrital monazite (sample 160818) was estimated to make up approximately 0.01 percent by weight of the total sample from the Sommers clay pit. This may not be appreciably greater than the amount of monazite in saprolite of the gneisses if there is a large loss of heavy minerals in panning clay (Theobald, 1957, p. 16-17).

\section{COMPOSITION OF THE MONAZITE}

Monazite for analysis was prepared from the panned concentrates by standard procedures of heavy liquids and magnetic separation, and the final monazite separate from each sample was handpicked using a miniature vacuum cleaner with a small orifice under a binocular microscope. J. J. Warr, Jr., determined the amount of thorium in the monazite (see table) by colorimetric methods slightly modified from the procedure described by Grimaldi and others (1957), and the amount of uranium was determined by the visual fluorimetric methods discussed by Grimaldi and Levine (1954).

The analyzed samples of monazite contain an average of 3.6 percent thorium oxide $\left(\mathrm{ThO}_{2}\right)$. This is similar to the average of 3.3 percent $\mathrm{ThO}_{2}$ observed for a large number of samples of monazite from placers in northern and central Idaho (Schrader, 1910, p. 188), but less than the average of 4 percent $\mathrm{ThO}_{2}$ shown by 34 published analyses of detrital monazite in the area of the Idaho batholith (Staley, 1952, p. 306; Kauffman and Baber, 1956, p. 6). The amount of uranium in the three samples is similar to that found in monazite from central Idaho (Kauffman and Baber, 1956, p. 6).

\section{ECONOMIC ASPECTS}

The samples of monazite were collected primarily as part of an investigation of clays. They are neither large enough nor sufficiently numerous to furnish a basis for an estimate of the amount of monazite in the rocks. However, in the few samples taken, monazite was appreciably less than 0.01 percent of the rock, showing that at the sampled localities the amount of 
monazite in gneiss, granite, and clay is unacceptably low for mining. Moreover, the most thorium-rich monazite sample contained 4.06 percent $\mathrm{ThO}_{2}$, an amount falling near the lower end of the range shown by monazite in sillimanite gneiss and associated granite elsewhere (Overstreet, 1960, table 27.1), and considerably less than the present commercially accepted minimum grade of 6 percent. On the basis of results of analyses of the three samples reported in this article, it is not to be expected that monazite containing significantly higher tenor of $\mathrm{ThO}_{2}$ will prove to be of widespread occurrence in this part of Washington.

\section{REFERENCES}

Becker, G. F., 1895, Reconnaissance of the gold fields of the southern Appalachians: U.S. Geol. Survey 16th Ann. Rept., pt. 3 , p. $251-319$.

Campbell, J. M., 1917, Laterite: its origin, structure, and minerals: Mining Mag. [London], v. 17, no. 2, p. 67-77: no. 3 , p. $120-128$; no. 4 , p. $171-179$; no. 5 , p. $220-229$.

Fox, C. S., 1923, The bauxite and aluminous laterite occurrences of India: India Geol. Survey Mem., v. 49, pt. 1, p. 1-287.

1936, Buchanan's laterite of Malabar and Kanara: India Geol. Survey Recs., v. 69, pt. 4, p. 389-422.

Goodspeed, G. E., and Weymouth, A. A., 1928, Mineral constituents and origin of a certain kaolin deposit near Spokane, Washington: Am. Ceramic Soc. Jour., v. 11, no. 9, p. 687-695.

Gordon, Mackenzie, Jr., Tracey, J. I., Jr., and Ellis, M. W., 1958, Geology of the Arkansas bauxite region: U.S. Geol. Survey Prof. Paper 299, p. 1-268.
Grimaldi, F. S., Jenkins, L., and Fletcher, M. H., 1957, Selective precipitation of thorium iodate from a tartaric acid-hydrogen peroxide medium: Anal. Chemistry, v. 29, p. 848-851.

Grimaldi, F. S., and Levine, Harry, 1954, The visual fluorimetric determination of uranium in low-grade ores, pt. 6 in Grimaldi, F. S., May, Irving, Fletcher, M. H., and Titcomb, Jane, 1954, Collected papers on methods of analysis for uranium and thorium: U.S. Geol. Survey Bull. 1006, p. $43-48$.

Harrassowitz, Hermann, 1926, Laterit Material und Versuch erdgeschichtlicher Auswertung: Fortschr. Geol. Palaeont., v. 4 , no. 14 , p. $253-566$.

Hosterman, J. W., 1960, Clay deposits in parts of Washington and Idaho, in Clays and clay minerals: Proc. of the 7th Natl. Conf. on Clays and Clay Minerals, p. 285-292.

Hosterman, J. W., Scheid, V. E., Allen, V. T., and Sohn, I. G., 1960, Investigations of some clay deposits in Washington and Idaho: U.S. Geol. Survey Bull. 1091, p. 1-147.

Kauffman, A. J., Jr., and Baber, K. D., 1956, Potential heavymineral-bearing alluvial deposits in the Pacific Northwest: U.S. Bur. Mines Inf. Circ. 7767, 36 p.

Overstreet, W. C., 1960, Metamorphic grade and the abundance of $\mathrm{ThO}_{2}$ in monazite: Art. 27 in U.S. Geol. Survey Prof. Paper 400-B, p. B55-B57.

Schrader, F. C., 1910, An occurrence of monazite in northern Idaho, in Hayes, C. W., and Lingren, Waldemar, 1910, Contributions to economic geology, 1909: U.S. Geol. Survey Bull. 430, pt. 1, p. 184-191.

Staley, W. W., 1952, Monazite in Idaho: The Compass, v. 29, no. 4 , p. 303-312.

Theobald, P. K., Jr., 1957, The gold pan as a quantitative geologic tool: U.S. Geol. Survey Bull. 1071-A, p. 1-54. 


\title{
RICH OIL SHALE FROM NORTHERN ALASKA
}

\author{
By IRVIN L. TAILLEUR, Menlo Park, Calif.
}

\begin{abstract}
Samples of oil shale of Jurassic(?) age from the foothills along the north edge of the Brooks Range assay 26-146 gallons of oil per ton of rock. The oil yield is greater than that of the Green River Formation, but owing to insufficient information the economic potential of the oil shale cannot be determined.
\end{abstract}

Samples of an organic shale of Jurassic(?) age, which crops out in the foothills along the north edge of the Brooks Range (fig. 148.1), assay 26-146 gallons of oil per ton of rock, several times more than assays of the minable beds of oil shale in the Green River Formation in the Rocky Mountain region. This Alaskan oil shale may be a significant resource, but more stratigraphic and structural information will be required for its assessment.

The oil shale seems to have been utilized for fuel in prehistoric times. Abnormal distribution of float, especially near old trailways and encampments, indicates that the Eskimos who lived in the interior before 1900 collected and transported the rock. It was probably carried for fuel. This is suggested by their identificaof the material as wood in the times before the arrival of the white man (Stoney, 1900, p. 69).

Material inferred to have been oil shale was observed on several early expeditions to northern Alaska, and oil shale was specifically identified along later geologic traverses. Dr. John Simpson, surgeon aboard the H.M.S. Plover wintering at Point Barrow during 1852 to 1854 , noted that "there is strewed along the beach a quantity of coal, . . . bituminous enough to make an excellent fire for cooking. It is of the sort called candle-coal, and some of the pieces are sound enough to be carved by the natives into lip ornaments" (Collinson, 1875, p. 125). On his overland trek in 1886 Ltt. Howard found a substance on the middle Etivluk River "called wood by the natives; it was hard, brittle, light brown in color, very light in weight and burned readily, giving out quantities of gas" (Stoney, 1900, p. 69). Specimens collected from the mouth of the Kukpuk River in 1904 that Collier (1906, p. 45) described as cannel coal were more likely to have been fragments of oil shale, for such fragments have been found on gravel bars upstream by the present writer. Smith (Smith and Mertie, 1930, p. 282-286) collected and identified oil shale from bedrock along the Kivalina River and from float along the Etivluk River in the 1920's. The material was composed chiefly of megaspores. He speculated that the rock occurred at the base of the geosynclinal sedimentary deposits of Mesozoic age in northern Alaska and might be the source of the petroleum shows in the region.

Geologic mapping of Naval Petroleum Reserve No. 4 (1948-53) indicated that oil shale similar to that from the Green River Formation occurs in the Tiglukpuk Formation (Jurassic) (W. W. Patton, Jr., written communication, 1959) and in rock units that appear to be correlative with the Tiglukpuk. Highly organic shales also occur in the Shublik Formation (Triassic) and in the Lisburne Group locally (Missis-

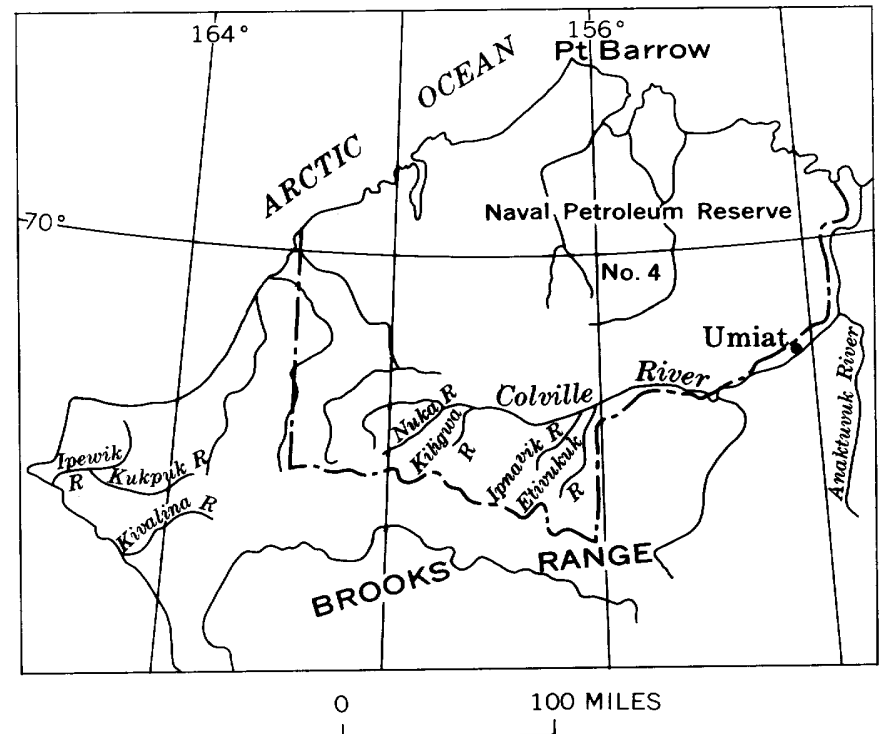

FIGURE 148.1.- Index map of northern Alaska. 
sippian) but lack the massive woody aspect of the Jurassic(?) shale (see accompanying table). The oil shale is known to crop out sporadically from the Ipewik River on the west to the Anaktuvuk River on the east, a distance of more than 300 miles. Owing to its low density and toughness, the shale is distributed widely as float and as outsized clasts in coarse-grained younger rocks.
Exposures of oil-shale strata are sparse and incomplete, and most show strong deformation. Thickness and other stratigraphic details, therefore, are difficult to determine. Oil shale apparently is present in at least two distinct stratigraphic successions. One consists of oil shale and chert near the base of the Tiglukpuk Formation, which overlies the Shublik and Siksikpuk (Permian) Formations and the Lisburne Group; the

Analyses and descriptions of organic shale samples

[Spceific gravity determined by author; Fischer analyses by J. Budinsky]

\begin{tabular}{|c|c|c|c|c|c|c|c|c|c|}
\hline \multirow[b]{2}{*}{ Stratigraphic unit } & \multirow[b]{2}{*}{$\begin{array}{l}\text { Laboratory No. } \\
\text { and (field No.) }\end{array}$} & \multirow[b]{2}{*}{ Location ${ }^{1}$ (coordinates) } & \multirow[b]{2}{*}{$\begin{array}{l}\text { Specific } \\
\text { gravity }\end{array}$} & \multicolumn{6}{|c|}{ Fischer analyses } \\
\hline & & & & $\underset{\text { ton) }}{\text { Oil (gal/ }}$ & $\begin{array}{l}\text { Water } \\
\text { (gal/ton) }\end{array}$ & $\begin{array}{c}\text { Oil } \\
\text { (percent) }\end{array}$ & $\begin{array}{c}\text { Water } \\
\text { (percent) }\end{array}$ & $\begin{array}{l}\text { Gas, plus } \\
\text { loss } \\
\text { (percent) }\end{array}$ & $\begin{array}{c}A \operatorname{shl} \text { at } \\
900^{\circ} \mathrm{C} \\
(\text { percent })\end{array}$ \\
\hline 1. Jurassic(?) & $\begin{array}{c}160127 \\
(51 \mathrm{ATr} 220)\end{array}$ & $\begin{array}{l}\text { Mid part of Kiligwa } \\
\text { River } \\
\left(68^{\circ} 41^{\prime} 50^{\prime \prime} \mathrm{N} .\right. \\
\left.158^{\circ} 28^{\prime} 00^{\prime \prime} \text { W. }\right)\end{array}$ & 1. 22 & 146 & 6.3 & 53.7 & 2. 6 & 8. 9 & 30.0 \\
\hline 2. Jurassic(?) & $\begin{array}{c}160134 \\
(50 \mathrm{AKt} 261)\end{array}$ & $\begin{array}{l}\text { East of mid part of } \\
\text { Kuna River } \\
\left(68^{\circ} 40^{\prime} 05^{\prime \prime} \mathrm{N} .,\right. \\
\left.157^{\circ} 32^{\prime} 15^{\prime \prime} \text { W. }\right)\end{array}$ & 1. 27 & 144 & 17. 7 & 60.6 & 7. 4 & 13. 7 & 23. 1 \\
\hline 3. Jurassic(?) & $\begin{array}{c}160 \quad 129 \\
(51 \mathrm{AKt} 67)\end{array}$ & $\begin{array}{l}\text { Mid part of Kiligwa } \\
\text { River } \\
\left(68^{\circ} 39^{\prime} 45^{\prime \prime} \mathrm{N} . \text {, }\right. \\
\left.158^{\circ} 28^{\prime} 10^{\prime \prime} \mathrm{W} .\right)\end{array}$ & 1. 20 & 52.6 & 25. 2 & 19.7 & 10. 7 & 18. 7 & 12.7 \\
\hline 4. Jurassic(?) & $\begin{array}{c}160 \quad 128 \\
\left(51 A^{\prime T r} 228\right)\end{array}$ & $\begin{array}{l}\text { Mid part of Kiligwa } \\
\text { River } \\
\left(68^{\circ} 42^{\prime} 25^{\prime \prime} \mathrm{N} .\right. \\
\left.158^{\circ} 27^{\prime} 45^{\prime \prime} \text { W. }\right)\end{array}$ & 1. 51 & 40. 9 & 12. 9 & 17.1 & 5. 3 & 8. 0 & 26. 0 \\
\hline 5. Tiglukpuk Formation & $\begin{array}{c}160133 \\
(50 \mathrm{AKt} 237)\end{array}$ & $\begin{array}{l}\text { Wrst of mid part of } \\
\text { Ipnavik River } \\
\left(68^{\circ} 41^{\prime} 30^{\prime \prime} \mathrm{N} .\right. \\
\left.157^{\circ} 17^{\prime} 40^{\prime \prime} \text { W. }\right)\end{array}$ & 1. 61 & 48. 8 & 14. 9 & 20.3 & 6. 3 & 6.1 & 48. 1 \\
\hline 6. Tiglukpuk Formation & $\begin{array}{c}160 \quad 132 \\
(50 A \operatorname{Tr} 60)\end{array}$ & $\begin{array}{l}\text { West of mid part of } \\
\text { Etivluk River } \\
\left(68^{\circ} 37^{\prime} 40^{\prime \prime} \mathrm{N} .\right. \\
\left.156^{\circ} 43^{\prime} 00^{\prime \prime} \mathrm{W} .\right)\end{array}$ & 1. 86 & 26.6 & 9.8 & 11.1 & 4. 1 & 6.0 & 57.6 \\
\hline 7. Shublik Formation & $\begin{array}{cc}160 & 130 \\
\left(51 \mathrm{ATr}^{2} 48\right)\end{array}$ & $\begin{array}{l}\text { Mid part of Kiligwa } \\
\text { River } \\
\left(68^{\circ} 44^{\prime} 50^{\prime \prime} \mathrm{N} .\right. \\
\left.158^{\circ} 24^{\prime} 50^{\prime \prime} \text { W. }\right)\end{array}$ & 1. 90 & 24.7 & 8. 8 & 8. 2 & 3. 7 & 4. 1 & 59. 2 \\
\hline 8. Lisburne Group & $\begin{array}{c}160131 \\
(50 \mathrm{AKt} 106)\end{array}$ & $\begin{array}{l}\text { East of mid part of } \\
\text { Ipnavik River } \\
\left(68^{\circ} 40^{\prime} 05^{\prime \prime} \mathrm{N} .\right. \\
\left.156^{\circ} 57^{\prime} 40^{\prime \prime} \text { W. }\right)\end{array}$ & 2. 4 & 6.7 & 3. 4 & 2. 8 & 1. 4 & 1. 8 & 58. 3 \\
\hline
\end{tabular}

1. Cutbank. Brownish-black woody shale; tough, compact, incipient very thin plates with conchoidal, resinous transverse fracture; weathers pale brown; thinly interbedded with varicolored chert; within 70 feet of unconformable basal contact of Okpikruak Formation on south flank of anticline.

2. Float along small stream. I)ark-ycllowish-brown woody shale; tough, compact; resinous, irrcgular fracture; crenulated varicolored chert and Okpikruak Formation nearby.

3. Cutbank. Grayish-black papery to woody shale; platy, weakly exfoliated; 12 feet thick; overlies moderately dipping, faulted, varicolored chert. Oil shale and oilstained sandstone exposed in adjacent cutbanks.

4. Cutbank. Black organic shale; compact with incipient parting; dull with very fine resinous layers; grayishyellow bloom; 20-foot thickness exposed, subordinate chert;

associated with strongly deformed varicolored chert, shale, sandstone, and very finely stratified limestone.

5. Rubble bank. Grayish-black organic shale; compact, very fine, platy partings, dull luster; associated with chert Apparently cremulated with underlying Shublik Formation and overlying Fortress Mountain Formation. Float of asphaltum also in rubble.

6. Outcrop Dark brownish-gray papory shale; calcareous; belemnites; weathers light gray and pale brown; 15 feet of 2-3 meh layers, subordinate thin dark chert beds; overlies crenulated Shublik Formation.

7. Cutbank. Brownish-black papery shale; calcareous; abundant Halobia (pectenoid mollusk) imprints; 2-4-inch beds with interbods of dark, very fine limestone and black chert.

8. Rubble. Gravish-brownish-black, platy shale; calcareous; associated with thin platy, brittle, very dark gray limestone.

1 From 1:63,360 manuscript maps for Howard Pass quadrangle, Alaskan Topographic Series. 
other consists of oil shale and chert lying between ill-defined stratigraphic units of Permian and Jurassic age and the Okpikruak Formation (lowermost Cretaceous). ${ }^{1}$ Oil-stained sandstone crops out near exposures of oil shale in the second succession on the Kiligwa River.

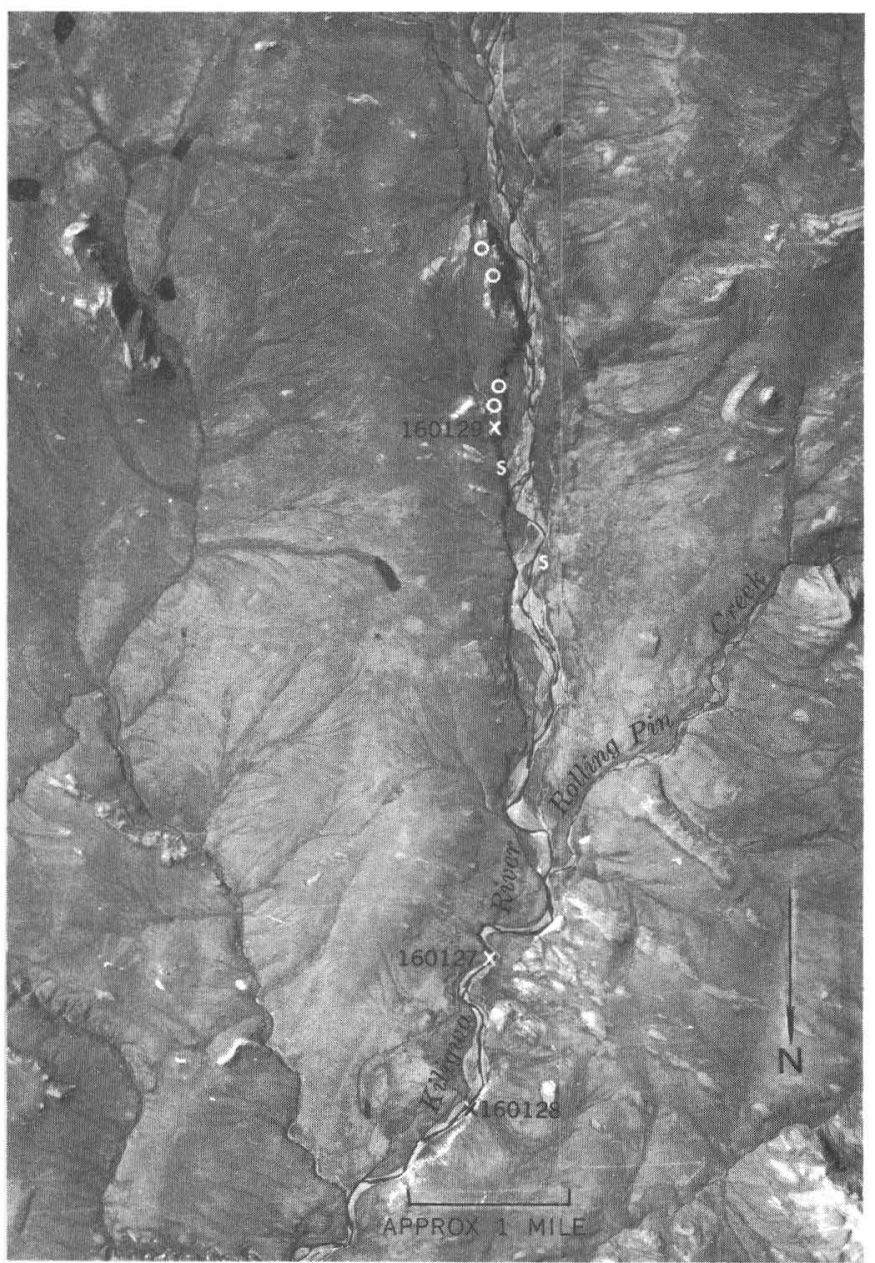

Figure 148.2.--Location of oil-shale samples ( $x$ ), other exposures of oil shale (o), and outcrops of oil-stained sandstone (s) on the middle Kiligwa River (from rectified twinplex photo GS TAL 18-104L).
The oil shale has not been given special attention during current mapping because of the structural complexity and an apparent lack of appreciable thickness. However, samples of organic shale from the Nuka-Etivluk Rivers region were analyzed recently as part of a general compilation of oil-shale data (D. Duncan and V. Swanson, oral communication,-1962). Assayed yields of 26-146 gallons/ton of the Jurassic(?) samples are high in comparison with yields of the Green River Formation, in which reserves are computed in terms of 15 and 25 gallons/ton yields, with a maximum yield of 60-90 gallons/ton (Cashion, 1957, p. 135).

Stratigraphic descriptions of the samples, location of outcrops, and Fischer analyses are given in the accompanying table.

Additional study of the oil shale will be required to assess its potential. In the author's experience, shale along the Kiligwa River offers the most promise. Known exposures of oil shale along this river are shown on figure 148.2.

\section{REFERENCES}

Cashion, W. B., 1957, Stratigraphic relations and oil shale of the Green River Formation in the eastern Uinta Basin, in Guidebook to the geology of the Uinta Basin: Intermountain Assoc. Petroleum Geologists, p. 131-135.

Collier, A. J., 1906, Geology and coal resources of the Cape Lisburne region, Alaska: U.S. Geol. Survey Bull. 278, 54 p.

Collinson, R., 1875, Notes on the state of the ice, and on the indications of open water from Behring Strait to Bellot Strait, along the coasts of Aretic America and Siberia, including the accounts of Anjou and Wrangell, in Royal Geographical Society, A selection of papers on Arctic geography and ethnology: London, John Murray, p. 105162.

Smith, P. S., and Mertie, J. B., Jr., 1930, Geology and mineral resources of northwestern Alaska: U.S. Geol. Survey Bull. $815,351 \mathrm{p}$.

Stoney, G. M., 1900, Naval explorations in Alaska: Annapolis, Md., U.S. Naval Inst., 105 p.

1 R. A. Scott (written communication, 1964) palynologically examined seven oilshale samples and found that they contained only planktonic forms (chiefly dinoflagellates and hystrichosphaerids) and presumably rew orked pollen of Permian or Eariy Triassic age. He inferred that the samples were of post-'Triassic age and possibly were deposited far enough from shore to exclude contemporaneous pollen. 


\title{
Article 149
}

\section{DISSIMILARITY BETWEEN SPATIAL AND VELOCITY-WEIGHTED SEDIMENT CONCENTRATIONS}

\author{
Rv H. P. GUY and D. B. SIMONS, Fort Collins, Colo.
}

\begin{abstract}
Theoretical and measured differences between spatial and velocity-weighted concentrations show (1) that the spatial concentration is normally the greater and increases as the velocity and concentration gradients increase, (2) that velocity-weighted concentration must be used to compute sediment discharge, and (3) that spatial concentration must be used to compute the pressure or specific weight on the bed.
\end{abstract}

Sediment-concentration data in natural streams are used mostly to determine the amount of solids, either by weight or by volume, moving with streamflow. Such concentration data must be discharge weighted; that is, they must be a mean of velocity-weighted concentrations at many points in the stream cross section. The depth-integrating suspended samplers give a velocity-weighted concentration when a uniform vertical transit rate is used at evenly spaced verticals in the cross section. A discharge-weighted concentration is also obtained by traversing the nappe of flow from a flume at a uniform transit rate with an interception device having a uniform width of slot.

The sediment concentration computed from a spatialcollection procedure is defined as the relative quantity of sediment contained in an immobilized prism of water-sediment mixture over a specific area of the channel. The chief distinction between velocityweighted and spatial concentrations is that one is based on sediment and water discharged through a cross section and the other on sediment and water in motion above an area of streambed at a particular instant. The difference between the two concentration measures (velocity-weighted and spatial) has been understood, to some degree, by a few sedimentologists for several years. Much confusion still exists, however, and the quantitative differences between the measures have seldom been determined even approximately. The purposes of this article are (1) to explain the differences between, and some uses of, these concentrations and (2) to show differences between the two concentrations as determined experimentally by use of plastic pellets transported by water in a small flume.

\section{THEORETICAL DIFFERENCES}

Differences between the velocity-weighted and spatial concentrations can be evaluated theoretically by consideration of the four equations that follow.

Equation 1 is the Prandtl-von Karman relation used by Einstein (1950)

$$
\frac{U_{y}}{U_{*}}=5.75 \log \frac{30.2 y x}{K_{s}},
$$

where $U_{y}=$ average point velocity at distance $y$ above the streambed;

$$
\begin{aligned}
U_{*} & =\text { shear velocity, } \sqrt{g D S} ; \\
g & =\text { acceleration due to gravity; } \\
D & =\text { depth of flow; } \\
S & =\text { slope of the energy grade line; } \\
x & =\text { a corrective parameter; and } \\
K_{s} & =\text { grain roughness. }
\end{aligned}
$$

For the distribution of sediment concentration with respect to depth,

$$
\frac{C_{y}}{C_{a}}=\left[\frac{D-y}{y} \cdot \frac{a}{D-a}\right]^{z},
$$

where $C_{y}=$ concentration of particles at distance $y$ above the bed,

$C_{a}=$ concentration of particles having the settling velocity $w$ at distance $a$ from the bed, and $z=w / 0.40 U_{*}$.

The concentration, $C$, obtained by velocity-weighted samples, and the water discharge in the sampled zone, $Q_{m}$, are used to compute the sediment discharge per unit of time, $q_{s}$, through the sampled zone

$$
q_{s}=Q_{m} C .
$$

ART. 149 IN U.S. GEOL. SURVEY PROF. PAPER 475-D, PAGES D134-D137. 1964. 
Equation 3 is also equivalent in concept to the sediment discharge, $q_{s}$, determined by the relation

$$
q_{s}=\int_{a}^{D} C_{y} U_{y} d y
$$

where $C_{y}$ and $U_{y}$ are defined by equations 1 and 2 .

Figure 149.1 shows the approximate variation of velocity, sediment concentration, and sediment discharge with depth. This illustration and the preceding equations show that the mean concentration as weighted with velocity is considerably lower than the spatial concentration. The relatively low velocity-weighted concentration is due to the integration with depth ranging from low concentration and high velocity near the stream surface to high concentration and low velocity near the streambed. The spatial concentration, on the other hand, is the mean of the concentration from top to bottom and thus is considerably greater than the velocity-weighted concentration. Under the rare condition when all the sediment being transported is very fine, the concentration may be uniform from top to bottom. Under this condition, spatial and velocity-weighted concentrations are equal.

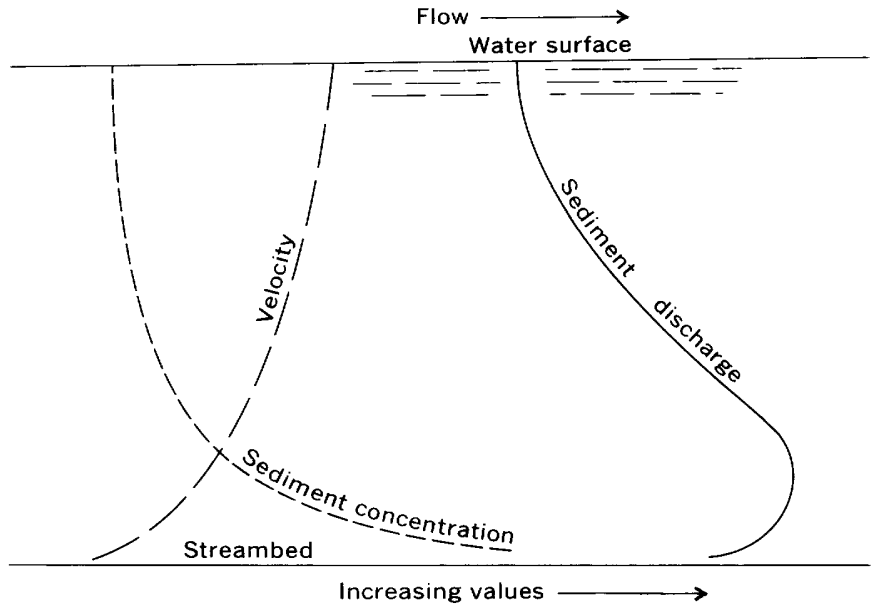

Frgure 149.1.-Relative gradients of velocity, sediment concentration, and sediment discharge with depth.

Streamflow data show that neither $U_{y}$ nor $C_{y}$ are spatially or temporally consistent as defined in the equations; therefore, a sample of sediment or velocity at a point in a stream vertical or cross section cannot define the concentration or velocity distribution in such a vertical or cross section. To overcome this difficulty, the "precise method" was developed. This method, as described by the U.S. Inter-Agency Committee on Water Resources, Report 1 (1940, p. 63)

involves collection of a relatively large number of point sediment samples simultaneously with velocity measurements. Sufficient data are collected to construct accurate vertical velocity and sediment distribution curves, the corresponding abscissas of which are multiplied to obtain a sediment-velocity curve. The area under this curve represents the sediment discharge in the vertical.

Needless to say, the "precise method" was too laborious for routine investigations of sediment movement in streams. The velocity-weighting technique, commonly called the depth-integration method, was developed to facilitate sediment-data collection and analysis. The technique, as described by the U.S. Inter-Agency Committee on Water Resources, Report 6 (1952, p. 14) is as follows:

The discharge of the depth-integrating sampler was predicated on the hypothesis that an integrated sample of the watersediment mixture existing at the place and time of sampling would be obtained if the filling rate were such that the velocity at the point of intake is equal to the local stream velocity while the sampler is moved at a uniform vertical speed in the stream.

The spatial concentration may be used to determine the actual load (weight per unit area) in transport over the streambed. It is also the correct concentration for determining the specific weight of the water-sediment complex. The spatial concentration can be obtained in streamflow by averaging the concentration of several equally spaced point samples in the stream cross section. In the laboratory, Bagnold (1955) used a mechanical device for isolating a rectangular slug of flow in a flume (fig. 149.2). A representative sample of spatial concentration is generally difficult to obtain because of the unsteady motion of particles near the bed. Most point samplers do not operate closer than within 0.3 or 0.4 foot of the bed. The mechanical-isolation device cannot distinguish between stationary and moving particles and thus cannot be used on an alluvial bed.

\section{EXPERIMENTAL RESULTS}

The difference between the velocity-weighted and spatial concentrations was studied by a series of runs in an 8-inch-wide recirculating flume. Plastic pellets with a specific gravity of 1.04 to 1.06 and with a median diameter of about $3 \mathrm{~mm}$ were used to represent the sediment grains. Samples were taken with a mechanical-isolation device after the velocity was sufficient to insure that all sediment over the bed was in motion, even though some particles were moving very slowly. The variation of sediment concentration and velocity with depth appeared to approximate that indicated by equations 1 and 2 and as illustrated in figure 149.1.

Sediment concentration was sampled by both methods for six different series of runs whereby each series contained a different amount of sediment circulating in the flume. To maintain the same amount of sediment in circulation, an equivalent volume of sample was returned to the flume for each sample removed. Two of these series were sampled at three widely different 
velocities. Velocity-weighted samples were taken by collecting in a nylon-mesh basket all particles discharged at the tail end of the flume. Sampling periods ranged from 8 to 15 seconds. Spatial-concentration samples were taken by quickly isolating with a sharpedged frame having wire mesh ends, the water and sediment moving in a 1-foot length of the flume. This device is similar to the sampler illustrated in figure 149.2.

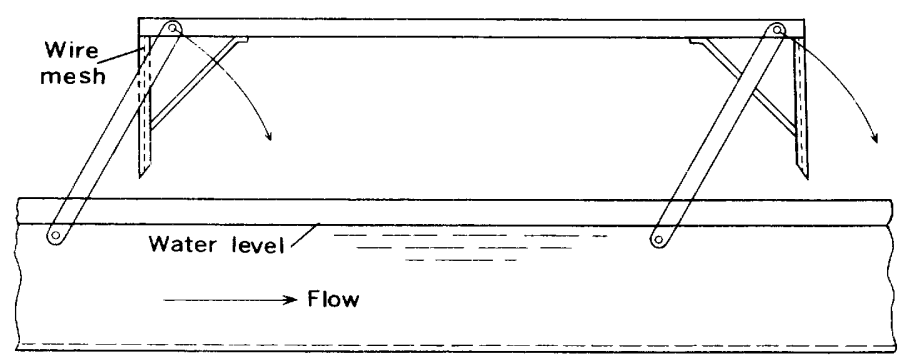

Figure 149.2.- Side view of sampling device for determining the spatial concentration of sediment moving in an open channel (after Bagnold, 1955).

The flow was stopped immediately after isolating the sample, and the particles were removed by siphoning from the known volume of water.

The concentrations in parts per million by weight for both methods of sampling are summarized in the accompanying table. This shows the concentration mean, the

Concentration of velocity-weighted and spatial samples of plastic pellets from 8-inch flume

\begin{tabular}{|c|c|c|c|c|c|c|c|}
\hline \multirow{2}{*}{$\begin{array}{l}\text { Flume } \\
\text { run }\end{array}$} & \multirow{2}{*}{$\begin{array}{l}\text { Mean } \\
\text { velocity } \\
\text { (ft/sec) }\end{array}$} & \multicolumn{3}{|c|}{$\begin{array}{l}\text { Velocity-weighted concentra- } \\
\text { tion at tailbox (ppm) }\end{array}$} & \multicolumn{3}{|c|}{$\begin{array}{c}\text { Spatial concentration on flume } \\
\text { bed (ppm) }\end{array}$} \\
\hline & & Mean & $\begin{array}{l}\text { Standard } \\
\text { deviation }\end{array}$ & $\begin{array}{c}\text { Limit of } \\
\text { prohable } \\
\text { error }{ }^{3}\end{array}$ & Mean & $\begin{array}{l}\text { Standard } \\
\text { deviation }\end{array}$ & $\begin{array}{c}\text { Limit of } \\
\text { probable } \\
\text { error }{ }^{1}\end{array}$ \\
\hline $\begin{array}{l}1 \ldots \\
2 \\
3 \\
4 \\
4 \\
4 \\
4 \\
4 \\
5 \\
6 \\
6 \\
6 \\
-\end{array}$ & $\begin{array}{l}2.09 \\
1.72 \\
1.66 \\
1.18 \\
1.67 \\
1.67 \\
2.46 \\
1.81 \\
1.13 \\
1.42 \\
2.87\end{array}$ & $\begin{array}{r}85,000 \\
63,200 \\
41,300 \\
20,900 \\
24,800 \\
24,800 \\
24,400 \\
10,800 \\
3,500 \\
3,440 \\
3,890\end{array}$ & $\begin{array}{r}1.350 \\
6.950 \\
1.900 \\
890 \\
1,140 \\
1,140 \\
750 \\
560 \\
130 \\
260 \\
105\end{array}$ & $\begin{array}{r}2,290 \\
11,700 \\
3,220 \\
2,610 \\
2,690 \\
2,690 \\
1.280 \\
940 \\
220 \\
440 \\
180\end{array}$ & $\begin{array}{r}110,600 \\
92,100 \\
58,700 \\
40,300 \\
29,400 \\
21,400 \\
26,800 \\
13,400 \\
5,760 \\
5,250 \\
3,870\end{array}$ & $\begin{array}{r}6,920 \\
10,300 \\
7,310 \\
4,450 \\
5,140 \\
950 \\
2,500 \\
2,760 \\
890 \\
970 \\
670\end{array}$ & $\begin{array}{r}6,830 \\
12,200 \\
7,050 \\
7,530 \\
4,920 \\
1,161 \\
4,220 \\
3,260 \\
850 \\
1,140 \\
640\end{array}$ \\
\hline
\end{tabular}

${ }^{1}$ Limit of probable error of measurement at 90-percent confidence level.

2 Spatial samples collected near headbox of flume.

standard deviation, and the limit of probable error of measurement at the 90-percent confidence level for each run. The sediment concentration ranges from a velocity-weighted value of $85,000 \mathrm{ppm}$ and a spatial value of $110,600 \mathrm{ppm}$ on the flume bed for run 1 to a velocityweighted value of $3,440 \mathrm{ppm}$ and a spatial value of 5,250 ppm on the flume bed for run 6 . The error of measurement is appreciably less at the tailbox because of the greater time of sampling; hence, only 3 samples were taken at the tailbox for each run, whereas 5 were taken on the flume bed for most runs.
The sample concentrations compared in figure 149.3 illustrate the differences between the two methods of determining concentration. As expected, the spatial concentration is greater than the velocity-weighted concentration. The limits of the probable error of concentration measurement (90-percent confidence level) are shown (fig. 149.3) in the form of a rectangle approximately centered over each concentration mean. These rectangles indicate that the variability in the movement of sediment, and consequently the measurement error, is greater for the spatial means than for the velocityweighted means.

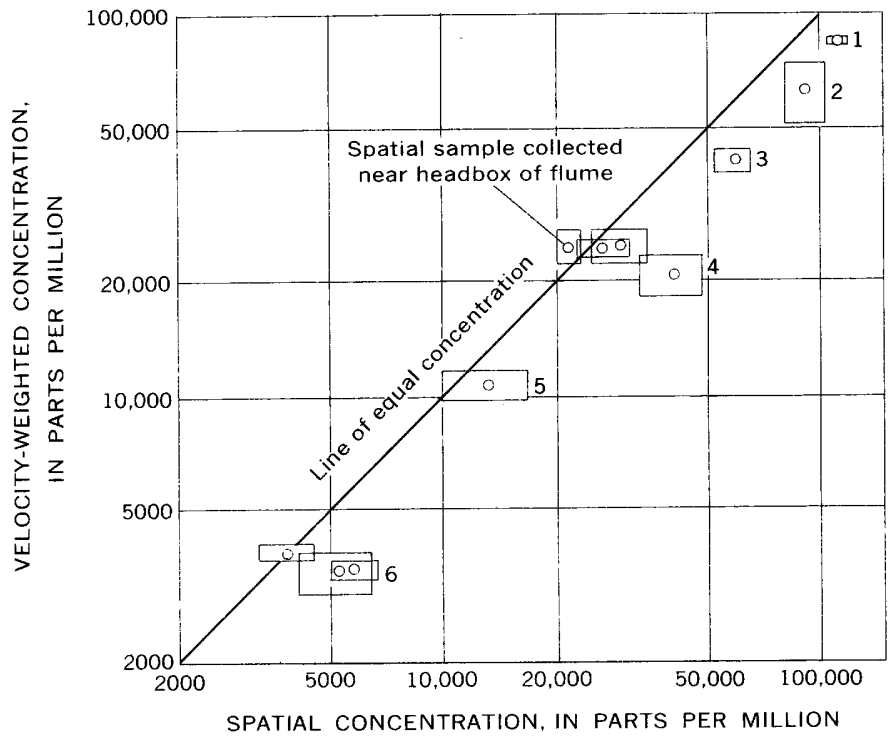

FIGURE 149.3.--Relation of velocity-weighted concentration to spatial concentration. The rectangle centered approximately around each concentration shows the limit of probable error of measurement at the 90 -percent confidence level. Numbers correspond to flume runs described in table.

The larger the variation of velocity and sediment concentration with respect to depth (comparatively high $V$ near the surface and a comparatively large $C$ near the bed) the greater the difference between the two concentrations. As indicated by the highest velocities sampled (runs 4 and 6 ) the two methods may be comparable when the sediment is thoroughly suspended. In fact, the reverse of the normal result was found by comparing spatial concentrations from near the headbox with the velocity-weighted concentrations at the tailbox. The lower mean concentration of the spatial samples (see table and fig. 149.3) is caused by an inversion of the normal concentration gradient due to centrifugal force on the sediment particles.

\section{CONCLUSIONS}

Velocity and sediment-concentration distributions in a cross section of streamflow can be predicted only 
within rough limits. Theoretical and measured differences between spatial and velocity-weighted concentrations show that:

1. The dissimilarity between the two measures of concentration widens as the velocity and concentration gradients increase with respect to depth.

2 . Sediment discharge in a stream should be computed from a velocity-weighted concentration obtained by sampling at several points or verticals in the stream cross section. Routine measurements of velocity-weighted concentration are made with several kinds of depth-integrating samplers.

3. Spatial concentration is needed when either the actual load or amount of sediment exerting pressure on the bed or the average specific weight of the sediment-water mixture over the bed is desired.
Measurement of spatial concentration is usually difficult because immobile particles cannot be distinguished from moving particles.

\section{REFERENCES}

Bagnold, R. A., 1955, Some flume experiments on large grains but little denser than the transporting fluid, and their implications: Civil Engineers Proc., Excerpt pt. III, London, p. 192.

Einstein, H. A., 1950, The bed-load function for sediment transport in open channels: U.S. Dept. Agriculture Tech. Bull. 1026, p. 7-17.

U.S. Inter-Agency Committee on Water Resources, 1940, Report 1-Field practice and equipment used in sampling suspended sediment: U.S. Army Corps of Engineers, Iowa City, Iowa.

U.S. Inter-Agency Committee on Water Resources, 1952, Report 6-The design of improved types of suspended sediment samplers: U.S. Army Corps of Engineers, St. Paul, Minn. 


\title{
Article 150
}

\section{TEMPORARY STORAGE OF FINE SEDIMENT IN ISLANDS AND POINT BARS OF ALLUVIAL CHANNELS OF THE RIO GRANDE, NEW MEXICO AND TEXAS}

\author{
By CARL F. NORDIN, JR, and JOSEPH P. BEVERAGE, \\ Fort Collins, Colo., and Albuquerque, N. Mex.
}

\begin{abstract}
Islands and point bars are semipermanent features of alluvial channels. They contain as much as 20 percent surficial material finer than $0.062 \mathrm{~mm}$ which is deposited during receding flows. Some of the scatter generally noted in discharge-transport relations probably derives from the transient storage of the fine material, which is flushed during higher discharges.
\end{abstract}

The fine material transported by a stream is obtained from the soil of the watershed, from old flood plains by bank cutting and sloughing, and from deposits within the active channel of the stream. Deposits in the channel include islands, point bars, and other slackwater deposits. Although islands and point bars may be semipermanent channel features, they are periodically inundated and reworked in streams that have fairly wide variations in flow. The Rio Grande in New Mexico is such a stream.

Figure 150.1 shows the particle-size distribution of channel bed material and bar material from the Rio Grande near Bernalillo, N. Mex., on June 1, 1962, at a sampling location designated section $\mathrm{F}$. At the time of sampling, the bar projected 0.1-0.4 feet above the water surface and occupied about half of the high-flow channel width. Samples from the bar contained about 9 percent more fine material (diameter $<0.062 \mathrm{~mm}$ ) than samples from the wetted perimeter. Figure 150.2 shows similar curves for the Rio Grande, downstream, near Anthony, Tex., on April 16, 1962. Bar material at this site contained about 17 percent more fine material (diameter $<0.062 \mathrm{~mm}$ ) than channel material. These samples were collected from bars or islands formed in areas of decreased velocity during receding flows. At both sampling sites the bars occupied a third to a half of the bankfull channel width.

Islands and point bars are generally considered to be deposits of coarser material, which is transported in appreciable quantities only at high flows. The samples

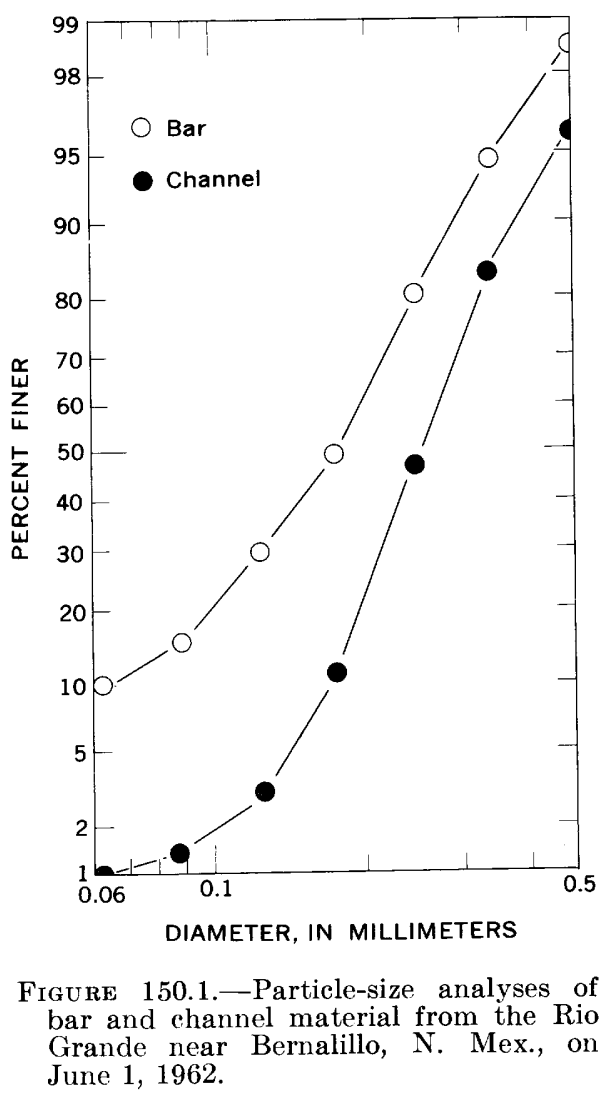

from the Rio Grande near Bernalillo, N. Mex., and Anthony, Tex., indicate, however, that the bars and islands of the river may include from 10 to 20 percent fine material. Wolman and Leopold (1957, p. 95) reported three point-bar samples from Watts Branch near Rockville, Md., that averaged 20 percent fine material. They concluded that part of the material eroded from the drainage basin "is stored temporarily in point bars and in the flood plain at various places in the channel system." 


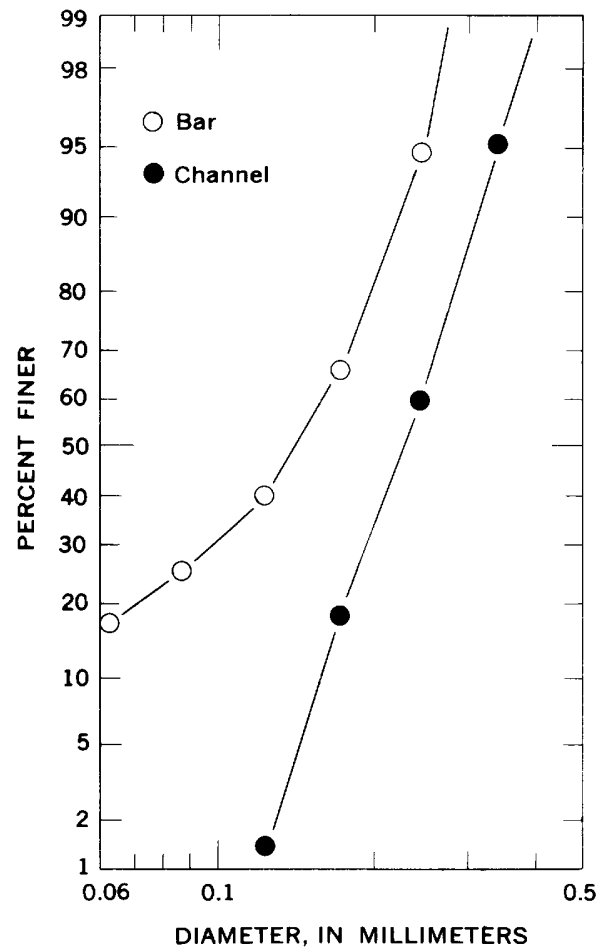

FiguRE 150.2.-Particle-size analyses of bar and channel material from the Rio Grande near Anthony, Tex., on April 16,1962 .

The fine material in islands and point bars of the Rio Grande is generally flushed out by high flows, such as spring snowmelt and sustained reservoir releases. The accompanying table lists discharge and concentration of various size classes of suspended sediment for the Rio Grande near Bernalillo during two spring runoff periods. In both runoff periods, the concentration of fine material decreased with time regardless of wide variations in discharge.

Discharge and concentration of suspended sediment, by size class, in the Rio Grande near Bernalillo, N. Mex., during the spring runoff of 1952 and 1958

\begin{tabular}{|c|c|c|c|c|}
\hline \multirow{2}{*}{ Date } & \multirow{2}{*}{$\begin{array}{c}\text { Discharge } \\
\text { (cfs) }\end{array}$} & \multicolumn{3}{|c|}{ Concentration, by size class (ppm) } \\
\hline & & $\underset{\mathrm{mm}}{<0.062}$ & $\begin{array}{c}0.062-0.125 \\
\mathrm{~mm}\end{array}$ & $\begin{array}{c}0.125-0.250 \\
\mathrm{~mm}\end{array}$ \\
\hline 1952: & & & & \\
\hline April 25 & 2,910 & 1,270 & 959 & 42 \\
\hline May 12 & 6,390 & 1,160 & 646 & 75 \\
\hline June 17 & 6,100 & 375 & 390 & 5 \\
\hline June 20 & 4,720 & 321 & 336 & 55 \\
\hline June 26 & 2,850 & 222 & 264 & 27 \\
\hline 1958: & & & & \\
\hline May 8 & 6,730 & 2,020 & 1,080 & 1,360 \\
\hline May 13 & 8,310 & 1,650 & 1,270 & 1,060 \\
\hline May $21_{-}$ & 8,700 & 1, 210 & 904 & 1,070 \\
\hline May 27 & 9,970 & 1,040 & 796 & 1,04 \\
\hline June 4. & 7,790 & 750 & 575 & 67 \\
\hline June 10 & 5,450 & 621 & 476 & 72 \\
\hline June 1 & 4,380 & 318 & 418 & 856 \\
\hline
\end{tabular}

$716-6260-64-10$

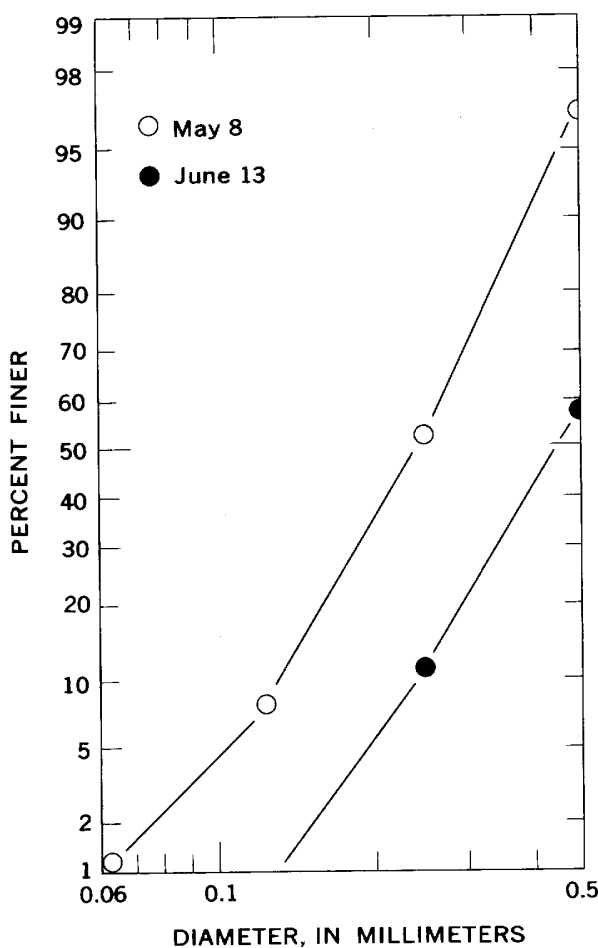

Figure 150.3.-Particle-size analyses of bed material from the Rio Grande near Bernalillo, N. Mex., May 8 and June 13, 1958.

The apparent lack of relation between discharge and concentration of the sand sizes $(>0.062 \mathrm{~mm})$ suggests that these fractions, like the fine material, behave as "wash load." Wash load is that part of suspended sediment "which is washed through the stream channel without any deposition" at a rate dependent only on its availability from the watershed (Einstein and Chien, 1953 , p. 31). Although changes in availability of material from the watershed may explain some of the lack of relation for the sand fractions, changes in the size distribution of the bed material should be considered as well. Figure 150.3 indicates that the diameter of the bed material can increase markedly during several weeks of sustained high flow. As the size of bed material increases, the amount of the finer sand fractions available for suspension and transport by the stream decreases.

During receding and low flows, clayey silt and fine sand are stored on islands and point bars and, to some extent, within the active channel (fig. 150.3). During rising stages and during sustained high flow, the bars and islands serve as a source for fine material. Throughout sustained high flows, the concentrations of the fine material and of the fine sand fractions seem to vary as a function of time rather than of discharge (see table). Both the magnitude of the concentration and the rate of change in concentration with time probably 
depend partly upon antecedent conditions, that is, upon how much fine material was stored during previous low flows.

Storage time of fine material in bars and islands of the Rio Grande ranges from several months to a year and depends on subsequent climatic and hydrologic conditions, which determine when the channel features again become part of the wetted perimeter. When the stage rises, the stream begins to erode the deposits and to resuspend the fine material.

This study indicates that some of the apparently random scatter in discharge-transport relations can be explained in terms of the time dependency of the concentration of the finer sand classes and of material finer than $0.062 \mathrm{~mm}$. This time dependency is due, in part, to temporary storage within the active channel.

\section{REFERENCES}

Einstein, H. A., and Chien, N., 1953, Transport of sediment mixtures with large ranges of grain sizes: California Univ. Inst. Eng. Research, Missouri River Div. Sediment Ser. 2.

Wolman, M. G., and Leopold, L. B., 1957, River flood plainssome observations on their formation: U.S. Geol. Survey Prof. Paper 282-C, p. 87-109. 


\title{
FLUVIAL SEDIMENTATION IN MAMMOTH CAVE, KENTUCKY
}

\author{
By CHARLES R. COLLIER and RUSSELL F FLINT, \\ Columbus, Ohio
}

Work done in cooperation with the National Park Service

\begin{abstract}
Alternating deposition and erosion occur in Mammoth Cave by flooding from the Green River. In $2 \frac{1}{2}$ years, numerous low floods deposited 0.5 foot of sediment in the lowest levels. Three high floods removed that sediment, but caused thinner deposits at higher levels. The coarsest sediment is deposited in the lower parts of the cave.
\end{abstract}

The sources of sediment and rate at which it is being deposited in Mammoth Cave, Ky., have long been of interest to geologists and speleologists. Detailed measurements by the U.S. Geological Survey of erosion and deposition between October 1959 and June 1962 indicate that sedimentation in the cave is closely related to flooding of the nearby Green River.

The Green River, which is hydraulically connected to Mammoth Cave by Echo River spring and River Styx spring, is the chief source of sediment and floodwater to the cave. These springs are submerged during floods of the Green River, and water then enters the cave through them so that the water level in the cave corresponds closely to the level of the Green River (Hendrickson, G. E., 1961). W. E. Davies and E. C. T. Chao (written communication, 1959) found in their studies of Mammoth Cave that the sediments in the lower levels of the cave are similar in physical character and mineralogy to the sediments on the flood plain of the Green River. The turbulence and velocity of the floodwater entering the cave are sufficient to transport sediment into the care, particularly during rapidly rising water levels. These same forces may cause a flushing of sediment from the cave during rapidly falling water levels.

Thirteen lines were surveyed across cave passageways that are subject to Hooding, and the elevations above gage datum of the sediment deposits on these lines were determined. These lines, or ranges, served as bases from which changes in deposition were determined by later surveys. The approximate locations of the ranges are shown in figure 151.1, and the elevations of the cave floor at each range are shown in the accompanying table.

Resurveys of the ranges in August 1961 and in January and June 1962 indicated that the greatest changes in deposition occurred at the lowest elevations (see table). Alternating deposition and erosion were observed at some ranges. Movement and redeposition of sediments were shown by recovery of ribbons placed vertically in the deposits of sediment. The lower and more frequent floods apparently caused deposition in the boat-ride section of Echo River. The higher and less frequent floods, however, tend to remove these deposits from the Echo River channel but cause deposition at the highest flooded and intervening levels.

From October 1959 to January 1962, as much as 0.4 foot of sediment was deposited in the boat-ride section of Echo River (ranges 1, 2, 3, table). In the higher passages, at elevations of 5 to 25 feet above the gage datum, only small changes in deposition or erosion were observed. No floods exceeded 31.4 leet during this period, although 2 floods exceeded 21.5 feet and 8 exceeded 17.7 feet.

'Three floods exceeded 21.5 feet in January, February, and early March 1962. One of these floods reached 57.1 feet and is the highest flood of record. All three floods generally caused deposition in the passages above the 5 -foot elevation, but they removed about 0.5 foot of sediment from the boat-ride section of Echo River.

The particle size of the deposited sediment is somewhat related to the elevation of the deposit. Deposits at elevations below 16 feet are predominantly sand (0.062 to $2.0 \mathrm{~mm}$ diameter), and the deposits at higher elevations are predominantly silt $(0.004$ to $0.062 \mathrm{~mm}$ diameter). This correlation is shown by the grouping of points in figure 151.2, a plot of the median particle 
Flooding and changes in deposition at sedimentation ranges in Mammoth Cave, October 1959 to June 1962

\begin{tabular}{|c|c|c|c|c|c|c|c|c|c|c|c|c|c|c|c|}
\hline \multirow{3}{*}{ Range No. } & \multirow{2}{*}{\multicolumn{3}{|c|}{$\begin{array}{c}\text { Elevation of cave floor (ft) } \\
\text { Oct. } 1959 \mathrm{l}\end{array}$}} & \multicolumn{3}{|c|}{ Oct. 1959 to Aug. 1961} & \multicolumn{3}{|c|}{ Aug. 1961 to Jan. 1962} & \multicolumn{3}{|c|}{ Jan. 1962 to June 1962} & \multicolumn{3}{|c|}{ Oct. 1959 to June 1962} \\
\hline & & & & \multirow{2}{*}{$\begin{array}{c}\text { Times } \\
\text { flooded }{ }^{2}\end{array}$} & \multirow{2}{*}{$\begin{array}{c}\text { Percen- } \\
\text { tage of } \\
\text { days } \\
\text { flooded } 2\end{array}$} & \multirow{2}{*}{$\underset{\text { (ft) }}{\text { Net }}$} & \multirow{2}{*}{$\begin{array}{l}\text { Times } \\
\text { flooded }{ }^{2}\end{array}$} & \multirow{2}{*}{$\begin{array}{c}\text { Percen- } \\
\text { tage of } \\
\text { days } \\
\text { flooded }^{2}\end{array}$} & \multirow{2}{*}{$\underset{\text { change }}{\text { Net }}$} & \multirow{2}{*}{$\begin{array}{l}\text { Times } \\
\text { flooded } 2\end{array}$} & \multirow{2}{*}{$\begin{array}{c}\text { Percen- } \\
\text { tage of } \\
\text { days } \\
\text { flooded } 2\end{array}$} & \multirow{2}{*}{$\underset{\text { (ft) }}{\text { Net }}$} & \multirow{2}{*}{$\begin{array}{c}\text { Times } \\
\text { flooded }^{2}\end{array}$} & \multirow{2}{*}{$\begin{array}{l}\text { Percen- } \\
\text { tage of } \\
\text { days } \\
\text { flooded } 2\end{array}$} & \multirow{2}{*}{$\underset{\text { change }}{\text { Net }}$} \\
\hline & Low & High & Mean & & & & & & & & & & & & \\
\hline & -1.3 & +5.0 & +0.3 & & 100 & +0.48 & & 100 & -0.03 & & 100 & -0.55 & & 100 & -0.10 \\
\hline & -4.9 & -.3 & -2.1 & $\cdots$ & 100 & +.20 & & 100 & $\ldots$ & - & 100 & $3-.45$ & & 100 & -.25 \\
\hline & -3.2 & +1.7 & -1.6 & 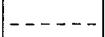 & 100 & +.34 & & 100 & & -- & 100 & $3-.46$ & & 100 & -.12 \\
\hline & -8.0 & +1.5 & -5.4 & $\ldots$ & 100 & .00 & --- & 100 & ------1 & $\ldots$ & 100 & $3+.04$ & $\ldots$ & 100 & +.04 \\
\hline & 5.2 & 18.1 & 9.8 & 18 & 34 & +.22 & 2 & 17 & -.15 & 6 & 58 & -.24 & 26 & 36 & +.31 \\
\hline 6 & 13. 4 & 18.2 & 15.3 & 19 & 12 & -.11 & $\overline{2}$ & 7 & +.08 & 6 & 20 & -.18 & 27 & 12 & +.15 \\
\hline & 11. 2 & 14. 9 & 11. 9 & 18 & 15 & +.01 & 2 & 7 & +.14 & 6 & 23 & +.42 & 26 & 15 & +.57 \\
\hline 8 & 3. 5 & 11.4 & 6. 6 & 15 & 77 & -.10 & 6 & 29 & -.13 & & 100 & +.33 & 21 & 75 & +.10 \\
\hline 9 & 3. 4 & 9. 5 & 5. 6 & 15 & 86 & -.29 & 6 & 44 & +.07 & -- & 100 & +.13 & 21 & 83 & -.09 \\
\hline 10 & 17. 8 & 24.6 & 20.0 & 6 & 4 & +.05 & 1 & 2 & .00 & 3 & 14 & +.13 & 10 & 6 & +.18 \\
\hline 11 & 17.7 & 26. 4 & 20. 3 & 7 & 4 & +.13 & 1 & 2 & +.06 & 3 & 14 & -.02 & 11 & 6 & +.17 \\
\hline $12 \ldots$ & 21.5 & 30.9 & 25.6 & 2 & 1 & -.11 & 0 & &.----- & 3 & 10 & +.28 & 5 & 3 & +.17 \\
\hline $13 \ldots \ldots$ & 31.4 & 34.5 & 32.2 & 0 & & & 0 & & $--\cdot--$ & 1 & 5 & +.20 & 1 & 1 & +.20 \\
\hline
\end{tabular}

${ }_{1}^{1}$ Arbitrary gage datum. $\quad$ 2 Includes both complete flooding and partial flooding. 3 August 1961 to June 1962.

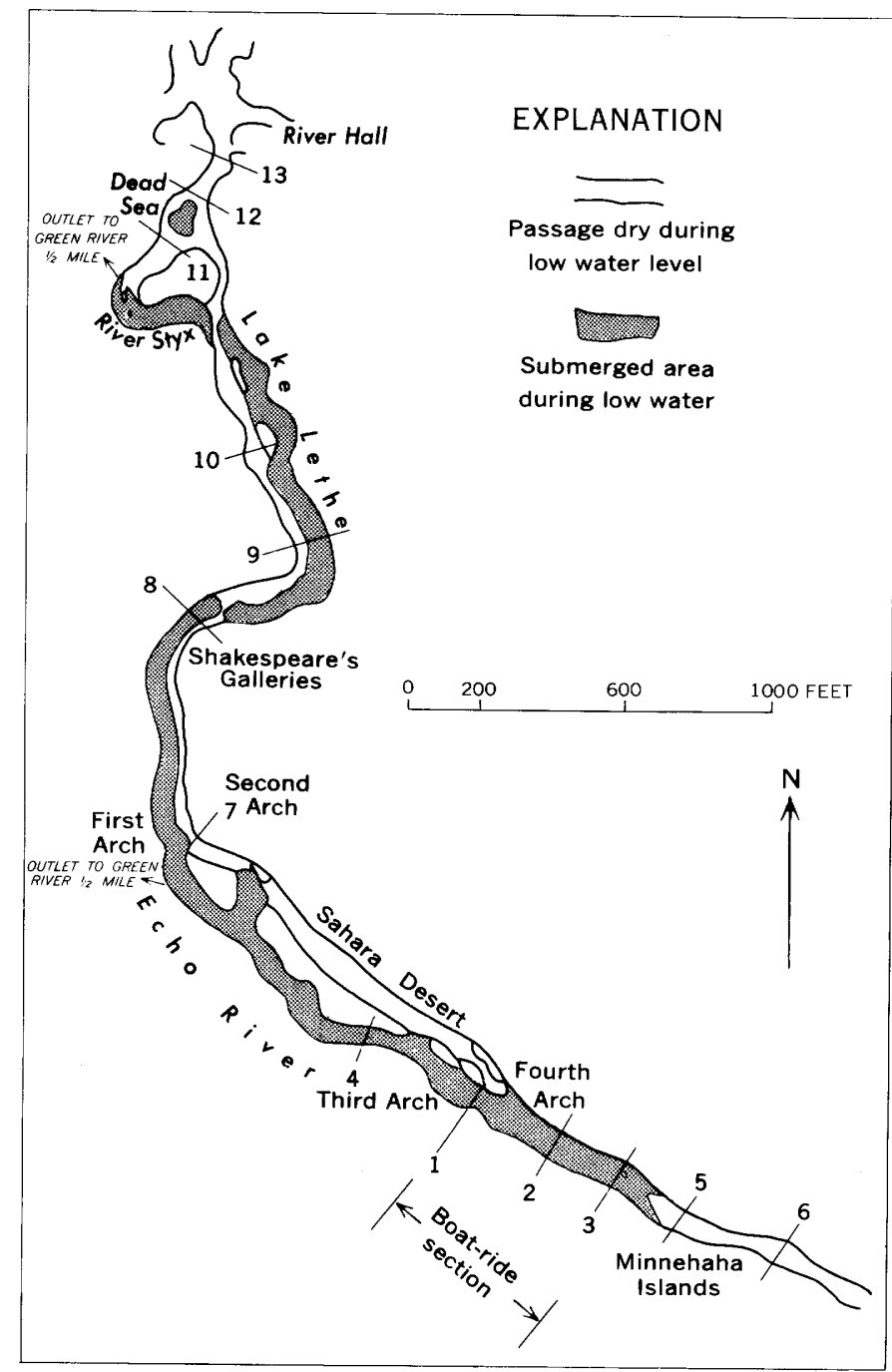

Figure 151.1.-- Map of lower level of Mammoth Cave, showing approximate location of sediment ranges. Pattern indicates area submerged at low water level. Base from National Park Service map, 1935. size against the average elevation of the floor at each range. A noticeable inconsistency in this grouping is the January 1962 sampling from ranges 7 and 8 . The samples from these two ranges included only the surface material, whereas samples at the other ranges were taken at depths of 1 to 4 feet.

The coarser particles tend to migrate by successive floods to higher elevations. This conclusion is supported by the position of the June 1962 triangles in figure 151.2 for elevations between 10 and 25 feet. Sediment deposited at these elevations generally had a larger median diameter after the floods of January to March 1962 than before. This increase in median diameter would occur if, during rising water level, there were sufficient turbulence and velocity to

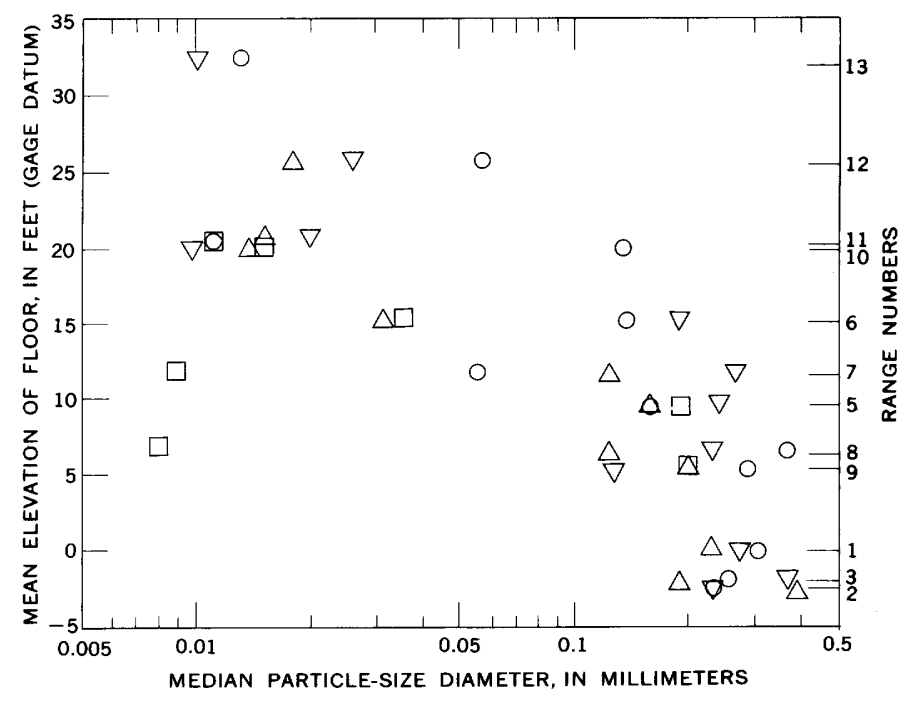

Figure 151.2.- - Relation of median particle size of deposited sediment to mean elevation of floor, Mammoth Cave, Ky. Circles, samples taken October 1959; triangles (point up), August 1961; squares, January 1962; triangles (point down), June 1962. 
transport coarser particles through the passages to settle at higher elevations. Hydrographs of the water level in the cave show that during floods the water generally rises more rapidly than it falls. Turbulence and velocities probably are greatest during the more rapidly changing water levels during the rise of a flood.

Clay particles are more easily transported than silt or sand and therefore are moved for greater distances by floodwater. After every flood, a thin layer of clay is deposited over all the submerged passageways. The record flood in February-March 1962 left an average deposit of 0.2 foot of clay and silt at range 13, elevation 32.2 feet.

The three resurveys of the range lines in Mammoth Cave over a period of less than 3 years provide an indication of sediment movement in the cave. Deposition or erosion during a given flood depends upon (1) the rate at which the water rises, (2) the height of the flood, (3) the duration of the flood, and (4) the rate of fall. The rate of rise or fall and the height of the flood influence the turbulence and velocity of the water in the cave and, therefore, the capacity of the water to transport sediment. The duration of the flood, particularly the period of little change in water level at the flood crest, determines the time available for settling and deposition of the sediment.

\section{REFERENCE}

Hendrickson, G. E., 1961, Sources of water in Styx and Echo Rivers, Mammoth Cave, Kentucky: Art. 308 in U.S. Geol. Survey Prof. Paper 424-D, p. D41-D43. 


\title{
Arricle 152
}

\section{QUATERNARY MUDFLOW DEPOSITS NEAR SANTIAGO, CHILE}

\author{
By KENNETH SEGERSTROM; OCTAVIO CASTILLO U., ${ }^{1}$ and EDUARDO FALCÓN M., ${ }^{1}$ \\ Denver, Colo.; Santiago, Chile
}

Work done in cooperation with the Instituto de. Investigaciones Geologicas de Chile

under the auspices of the Agency for International Development, U.S. Department of State

\begin{abstract}
Mudflows appear to have played an important role in the accumulation of nonsorted, nonstratified Quaternary valley fill in central Chile. Much of the mudflow material in the vicinity of Santiago is pumiceous. A widely accepted hypothesis of glacial origin for these deposits is rejected.
\end{abstract}

Santiago, the capital city of Chile, is in a tectonic depression or graben that forms the Valle Central of Chile (fig. 152.1). The depression is partly filled with unconsolidated sediments of Quaternary age.

Large volumes of nonsorted and virtually nonstratified valley-fill sediments at or near Los Cerrillos, Pudahuel, Cerro Apoquindo, and Puente Alto (fig. 152.2), have been described by various workers as moraines (Brüggen, 1950; Karzulovic, 1958; Muñoz Cristi, 1960). Brief observations by R. F. Flint in April 1959 of some of the deposits, particularly of those containing large volumes of pumiceous ash, cast considerable doubt on a glacial origin. Later and more detailed examination by the authors confirms the nonglacial origin of these deposits, which are now believed to result from mudflow deposition and creep. The general term "diamicton" is applicable to at least some of these nonsorted noncalcareous terrigenous deposits composed of sand and larger particles in a matrix of mud (Flint and others, $1960 \mathrm{a}, \mathrm{b}$ ).

The Valle Central near Santiago is filled to a depth of more than 400 meters with sedimentary materials eroded from the surrounding highlands and transported by running water, mudflows, or as slides. Most of the

\footnotetext{
1 Instituto de Investigaciónes Geológicas.
}

materials are derived from the Cordillera de los Andes to the east; lesser amounts have been eroded from the Cordillera de la Costa to the west. The bedrock in both ranges is mainly igneous, including both volcanic and intrusive types, and is predominantly of Mesozoic age.

The oldest valley-fill sediments known in the area are lacustrine silt, clay, and sand at a depth of as much as $250 \mathrm{~m}$ in stady well 1 , near Pudahuel, and $236 \mathrm{~m}$ in well E3-26, in Santiago (fig. 152.2). The age of these sediments is unknown, although in well 1 , small freshwater gastropods were found in microlaminated clay at a depth of $157 \mathrm{~m}$.

The fine-grained lacustine sediments of the valley are overlain by coarse-grained fluvial materials which in well E3-26 extend to a depth of $150 \mathrm{~m}$ below the surface. Alluvial-fan deposits of the Ríos Lampa, Colina, Mapocho, and Maipo make up the bulk of these materials. Gravels are exposed in terraces along the Río Maipo and in gravel pits around the fringes of Santiago. Colluvium resulting from sheet erosion occurs in narrow zones bordering the valley, particularly north and west of Santiago. Knowledge of the origin and character of the valley fill is especially important in problems of ground-water supply, which are discussed in Article 169 .

Diamicton deposits overlie altered bedrock along the mountain front east of Santiago and interfinger with alluvium in the basin. Pumiceous deposits, which contain large blocks of andesite and granodiorite and cover the fluvial and lacustrine deposits west of Santiago, appear to be of simlar origin. Other pumiceous deposits 


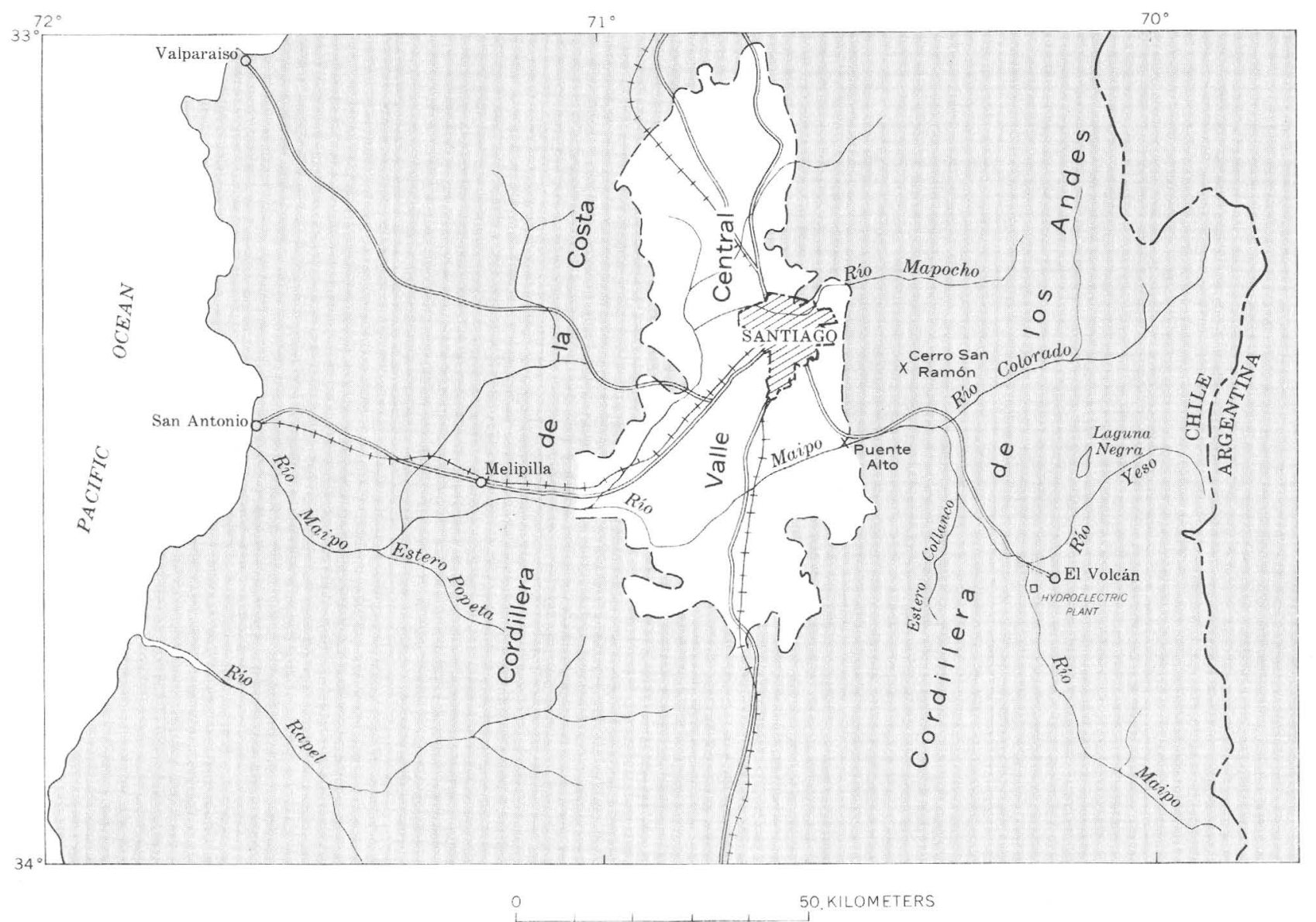

Figure 152.1.- Index map of part of central Chile. Quaternary valley-fill deposits outlined by dashed line.

which do not contain large blocks of other rock, found in the valley of Estero Papeta and in the basin of the Río Rapel, southwest of Santiago (fig. 152.1), appear to be lacustrine (Brüggen, 1950, p. 221).

Within the area of figure 152.1, unquestioned till is limited to the high Cordillera de los Andes. Moraines are found at minimum allitudes of $1,600 \mathrm{~m}$ in one or two valleys (that of the Río Colorado, for example), but most till and all glacial cirques occur above 2,000 $\mathrm{m}$ at lat $33^{\circ}-34^{\circ} \mathrm{S}$. The best exposed and most accessible moraine in the region extends $12 \mathrm{~km}$ along the Río Yeso, between 1,670 and 2,700 $\mathrm{m}$ above sea level, and terminates on the south side of Laguna Negra (fig. 152.1). The till of this moraine has a matrix of gray unweathered rock flour. The included blocks are angular and are of two lithologic types, granodiorite and andesite. The granodiorite blocks are as much as $4 \mathrm{~m}$ across; those of andesite are as much as $1 \mathrm{~m}$ or a little more. Through much of the moraine the two kinds of boulders are segregated into alternate bands subparallel to the valley trend. The bands are boulder trains derived directly from intrusive and volcanic bedrock farther up the valley.

\section{DIAMICTON DEPOSITS}

The diamicton deposits of the region are of two types: one contains little or no pumice, and the other contains abundant pumice.

Diamicton deposits of the first type form a hummocky topography along the foot of the steep Andean front at the east edge of the Valle Central between the Río Mapocho and the Río Maipo (fig. 152.2), in a belt $800 \mathrm{~m}$ to $4 \mathrm{~km}$ wide. An outstanding feature of this belt is a row of hills that extends $5 \mathrm{~km}$ from Loma de los Baños northwest to Cerro Calán. The material that makes up the hillocks is well exposed in a cut between Loma de los Baños and Cerro Apoquindo, where angular to subrounded blocks of granodiorite and andesite as much as $2 \mathrm{~m}$ or $3 \mathrm{~m}$ in diameter are found in a matrix of weathered clasts ranging from clay size to coarse gravel. Here and in other parts of the deposit are scattered lenses, 1 to $2 \mathrm{~m}$ thick and as much as 10 or $15 \mathrm{~m}$ long, of pumiceous ash and sand or gravel, generally consisting of subangular grains. A gravel lens on Cerro Calán contains rounded cobbles. Deposits resembling those exposed in the cut between Loma de los Baños and Cerro Apoquindo crop out on the south 


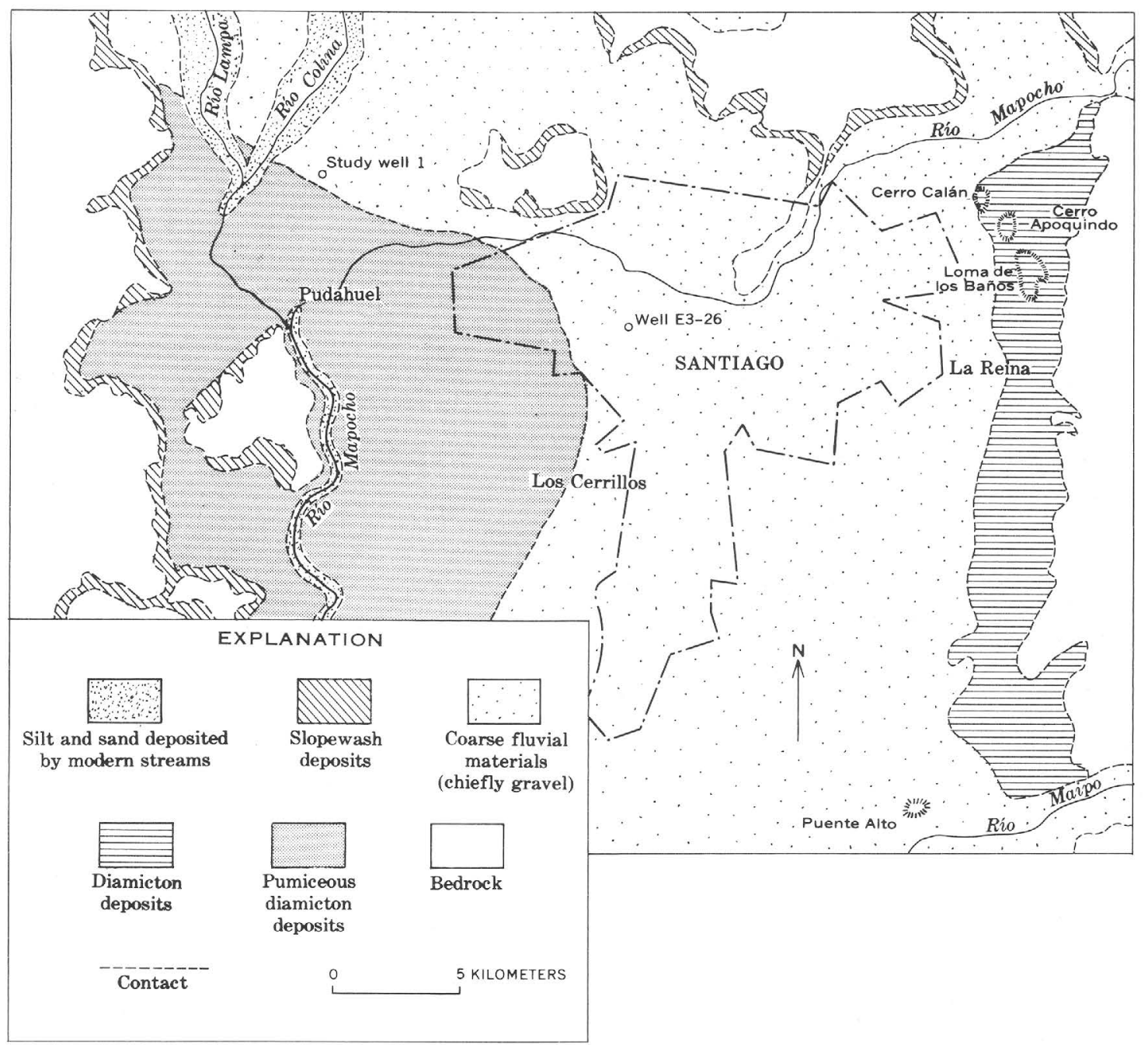

Figure 152.2.-Map of surficial deposits in the vicinity of Santiago.

side of the Río. Mapocho and between Loma de los Baños and the Río Maipo. All these deposits are more than $30 \mathrm{~m}$ thick, and at Cerro Calán they are approximately $100 \mathrm{~m}$ thick. They overlie deeply weathered rock to the east and interfinger with fluvial deposits from the Cordillera de los Andes toward the west.

East of Puente Alto, immediately north of where the Rió Maipo emerges from the Cordillera de los Andes, is an enormous fan-shaped diamicton deposit that extends downward and outward from an amphitheater-shaped hollow in the mountain front to the northeast. Angular blocks of granodiorite within and on top of the mass are so large and numerous that some of the diamicton deposits are easily confused with bedrock. Near the foot of the deposit a small lens of pumiceous sand is exposed in a highway cut $2 \mathrm{~km}$ north of the junction of the Santiago-El Volcán highway with the road to Puente Alto.

The most extensive deposit of the pumiceous diamicton forms a hummocky surface in the lowest part of the valley (Pudahuel-Los Cerrillos), immediately west of the city of Santiago at 450 to $485 \mathrm{~m}$ above sea level (fig. 152.2). It is exposed to depths of $10 \mathrm{~m}$ or less in a dozen or more large quarries, and study of drill cuttings indicates that the deposit extends to depths of as much as $30 \mathrm{~m}$. The material consists of white or grayish fragments of pumice, predominantly of sand size, but including also silt and gravel. The deposits are poorly sorted and without stratification. Irregularly distributed subangular to subrounded blocks of andesite and granodiorite as large as $80 \mathrm{~cm}$ in diameter, some of which are highly decomposed, make up, on an average, about 20 percent of the total volume.

Other pumiceous diamicton sediments crop out on the south side of the valley of the Río Yeso, along the Estero Collanco near its junction with the Río Maipo and in the Melipilla area (fig. 152.1). On the summit and north flank of a ridge between the Río Yeso and EI Volcán, there are small bodies of sand, locally pumiceous and containing scoriaceous fragments as much as 20 
cm long. These deposits fill small depressions and form scattered patches on slopes $300 \mathrm{~m}$ to $450 \mathrm{~m}$ above the valley floor. Pumiceous float is found in colluvial deposits that consist chiefly of andesitic materials as much as $650 \mathrm{~m}$ above the valley. In a stream terrace $30 \mathrm{~m}$ above the lower course of the Estero Collanco a diamicton deposit is exposed that contains angular to subangular blocks as large as $2 \mathrm{~m}$ across in a light-gray ashy, partly pumiceous matrix. The blocks are of varied composition and are decomposed.

The western slope of the Andes is very steep, dropping from 3,200 to $700 \mathrm{~m}$ above sea level in a horizontal distance of $12 \mathrm{~km}$, just east of Santiago. Because of the great relief, mass movement of materials evidently has been a very active process along the Andean front and in the high Andes during Pleistocene and Recent time. A contributing factor is the semiarid climate, which has inhibited the growth of protective forest on the slopes.

Mudflows are a common phenomenon on the western slopes of the Andes under present climatic conditions. Many mudflows were produced on the upper Río Maipo by an exceptionally heavy rainstorm on April 18, 1959. The canal that supplied a hydroelectric plant (fig. 152.1) was destroyed in several places, and the river upstream was dammed by a mudflow that descended a valley south of that of the Río Yeso and formed an unsorted deposit $10 \mathrm{~km}$ long and as much as $100 \mathrm{~m}$ thick. The resulting diamicton deposit, which contains blocks as large as 2 or $3 \mathrm{~m}$ in diameter (Pierre St. Amand, written communication, February 1963), closely resembles the diamictons of the Loma de los Baños-Cerro Calán area in lithology and thickness.

Mass movement presumably produced the great tongue-shaped deposits, later modified by erosion, that extend from Loma de los Baños to Cerro Calán. Other deposits are fan shaped, like the deposit east of Puente Alto. The practically continuous belt of diamicton deposits along the Andean front between the mouths of the canyons of the Ríos Mapocho and Maipo (fig. 152.2) evidently formed by the coalescing of many mudflows.

All degrees of transition between soupy mudflows and other types of mass movement can be recognized in central Chile, depending on steepness of the slope and proportion of water in the total mass as shown in the accompanying table.

The authors agree with Borde (1955) that the pumice immediately west of Santiago was deposited as mudflows. Explosive eruptions of pumiceous ash are known to have taken place in Recent time in the Cordillera de los Andes. Heavy rains presumably washed the easily erodible ash down the slopes and into the valleys,
Types of mass movement in the vicinity of Santiago [Classification after Sharpe, 1938]

\begin{tabular}{|c|c|c|c|c|}
\hline \multicolumn{2}{|c|}{ Movement } & \multirow{2}{*}{$\begin{array}{l}\text { Earth or } \\
\text { rock, dry } \\
\text { or with } \\
\text { minor } \\
\text { amounts } \\
\text { of water }\end{array}$} & \multirow{2}{*}{$\begin{array}{l}\text { Earth or rock, } \\
\text { with water }\end{array}$} & \multirow{2}{*}{ Chiefly water } \\
\hline Type & Rate & & & \\
\hline \multirow[t]{2}{*}{ Flow } & $\begin{array}{c}\text { Usually } \\
\text { imperceptible }\end{array}$ & Creep & & \multirow{2}{*}{$\begin{array}{l}\text { Fluvial } \\
\text { transpor- } \\
\text { tation }\end{array}$} \\
\hline & \multirow{2}{*}{$\begin{array}{l}\text { Perceptible } \\
\text { to rapid }\end{array}$} & & Mudflow & \\
\hline $\begin{array}{l}\text { Slip (land- } \\
\text { slide) }\end{array}$ & & \multicolumn{2}{|c|}{ Debris avalanche } & \\
\hline
\end{tabular}

carrying cobbles and boulders of the pre-existing colluvium with it. Lubricated by abundant water, some of the pumiceous mixture evidently flowed out across the Santiago basin, lost monentum, and stopped in the flat lowlands of the western part. Boulders were dropped enroute because of deceleration of the mudflow, but some of the blocks were carried to the terminus of the flow.

The present authors reject the supposed glacial origin of the relatively unsorted deposits of the Valle Central near Santiago for the following reasons:

1. Similar diamicton deposits have been formed by mudflows in modern times in the same general area.

2. The bedrock underlying the deposits is deeply weathered; mountain glaciers scour deeply and their till commonly rests on fresh rock.

3. The fine matrix of the diamicton sediments is yellowish brown due to limonitization; nowhere is it gray and unweathered like the rock flour of the known glacial deposits of the Río Yeso moraine. The coarse material of the diamicton sediments shows no evidence of glacial transport.

4. Neither U-shaped valleys nor cirques, which characterize glacial sculpture, occur in or near the Santiago area.

5. At the latitude of Santiago, glacial moraines can be traced only as far downslope as 1,600 $\mathrm{m}$ above sea level, more than $1,000 \mathrm{~m}$ higher than the valley floor at Santiago.

\section{REFERENCES}

Borde, Jean, 1955, Las depresiones tectónicas del Maipo inferior-glaciaciones y cenizas volcánicas: Informaciones Geográficas 1, Santiago, Chile, Editorial Universitaria, p. 6-16.

Brüggen, Juan, 1950, Fundamentos de la geología de Chile: Instituto Geográfico Militar, Santiago, $374 \mathrm{p}$.

Castillo, Octavio, Falcón, Eduardo, Doyel, W. W., and Valenzue1a, Manuel, 1963, El agua subterránea de Santiago, Segundo informe: Instituto de Investigaciónes Geológicas de Chile. [In press] 
Flint, R. F., Sanders, J. E., and Rodgers, J., 1960a, Symmictite, a name for nonsorted terrigenous sedimentary rocks that contain a wide range of particle sizes: Geol. Soc. America Bull., v. 71 , p. $507-510$.

1960b, Diamictite, a substitute term for symmictite: Geol. Soc. America Bull., v. 71, p. 1809-1810.

Karzulovic, Juan, 1958, Sedimentos cuaternarios y aguas sub- terráneas en la Cuenca de Santiago: Universidad de Chile, Instituto de Geología, publ. 10, $120 \mathrm{p}$.

Muñoz Cristi, Jorge, 1960, Contribución al conocimiento geológico de la Cordillera de la Costa de la zona central: Minerales, no. 69 , p. $28-47$.

Sharpe, C. F. S., 1938, Landslides and related phenomena: New York, Columbia Univ. Press, 137 p. 
Article 153

\title{
NEW OCCURRENCES OF THE RUGOSE CORAL RHIZOPHYLLUM IN NORTH AMERICA
}

\author{
By WILLIAM A. OLIVER, JR., Washington, D.C.
}

\begin{abstract}
Rhizophyllum is known from Middle or Upper Silurian rocks in Tennessee, Kentucky, Indiana, California, Nevada, Alaska, and Maine; from Lower Devonian rocks in Nevada; and from probable Middle Devonian rocks in Alaska. Four of these occurrences are first noted here, and specimens from Alaska, California, Nevada, and Maine are illustrated. The externally similar Calceola is not known to occur in North America.
\end{abstract}

The genus Rhizophyllum has worldwide distribution in rocks of Late Silurian and Early Devonian age; it occurs less commonly in rocks of probable Middle Silurian (Wenlock) and early Middle Devonian (Eifelian) age. In North America, Rhizophyllum is now known from coast to coast in rocks representing its full age rang'e.

Rhizophyllum is a near relative of the genus Calceola, with which it has often been confused because of external similarity. Calceola is apparently restricted to the Middle Devonian (Eifelian and Givetian) and is widely distributed on most continents but is not known from North America. Reported occurrences of Calceola in North America are numerous, but all so far have been based on the similar-looking Rhizophyllum.

The purpose of this contribution is to illustrate and briefly describe specimens of Rhizophyllum from Alaska, California, Nevada, and Maine, where no specimens have previously been described or in some cases even noted, and to point out that the "Calceola" from Alaska listed by Kindle (1907) and later by Kirk (in Buddington and Chapin, 1929) is actually a Rhizophyllum.

Helen Duncan and C! W. Merriam read the manuscript and made many helpful suggestions which were accepted in the final version; both provided specimens and information on occurrences. Thin sections were prepared by W. C. Pinckney, Jr.; photographs are by the author.

\section{PREVIOUSLY NOTED OCCURRENCES}

Middle or Upper Silurian (Niagaran)-Tennessee, Kentucky, and Indiana

Seven nominal species of Rhizophyllum (as Calceola) were described from the Brownsport Formation in Tennessee and the Louisville Limestone in Kentucky and southern Indiana by Roemer (1854), Safford (1860), Lyon (1879), Hall (1882), and Davis (1887). Prior to this, Troost (1840) had described some Tennessee specimens as Calceola sandalina Lamarck (type species of Calceola). Bassler (1915, p. 157-158) grouped all of these in three species which he referred to "Calceola (Rhizophyllum)". No review of these has since been attempted, but additional specimens of two of the three species were illustrated or described by Foerste (1931) and by Amsden (1949).

The Brownsport and Louisville Formations are of Niagaran (Wenlock or early Ludlow) age.

\section{Middle or Upper Silurian-Great Basin, California, and Nevada}

Stauffer (1930, p. 107, pl. 12, figs. 2-3) described and illustrated a single specimen of "Calceola sandalina Lamarck" from a section near Kearsarge, Calif. that he considered to be Devonian in age (1930, p. 85-89). Subsequently, Waite (1953, p. 1521) reidentified the coral as Rhizophyllum and dated the beds as "late Niagaran or early Cayugan".

Ross (1963) restudied the stratigraphy and named the formations involved. Merriam (in Ross, 1963, p. 83) listed Rhizophyllum among other corals from the Vaughan Gulch Limestone. Through the courtesy of C. W. Merriam, I have been able to examine the specimen he studied, and a brief description is included under Rhizophyllum sp. D. Apparently Merriam's Rhizophyllum is from the same stratigraphic unit and locality as Stauffer's. 
Merriam (1963, p. 37) listed Rhizophyllum from the Silurian at Ikes Canyon, Toquima Range, Ner. This is the first published report of Rhizophyllum from Nevada.

\section{Middle(?) Devonian-southeastern Alaska}

Kindle (1907, p. 325-327) listed fossils from a lower as well as an upper division of the "massive limestone of Long Island, Kasaan Bay". From the upper division (Kindle collection 819) he listed Calceola cf. sandalina Lamarck with a few other corals and 52 species of brachiopods, mollusks, and arthropods. He regarded the upper fauna as Middle Devonian in age.

Kirk (in Buddington and Chapin, 1929, p. 99-101) reexamined Kindle's collections and made minor changes of identification, but repeated Calceola ef. sandalina. Kirk considered Kindle's upper and lower faunas to be the same and thought that they might be Early Devonian but were more likely Middle Devonian in age.

The identification of Calceola cf. sandalina in both reports was based on a single individual which was not sectioned. It is described and illustrated here as Rhizophyllum sp. B.

Corals in the Kindle collection have been sectioned and restudied, and are listed in the following table. New identifications are in the left column, while the names assigned to the same specimens by Kindle and later by Kirk are in the right column.

\begin{tabular}{ll}
\multicolumn{1}{c}{ This report } & \multicolumn{1}{c}{ Kindle(1907) } \\
$\begin{array}{l}\text { Amphiphora sp. (stromatopo- } \\
\text { roid) }\end{array}$ & Syringopora $\mathrm{sp}$. \\
Aulocystis sp. & Cyathophyllum sp. \\
Favosites sp. & Favosites cf. F. radiciformis \\
Thamnopora sp. & Not identified \\
Eddastraea? sp. & Cyathophyllum $\mathrm{sp}$. \\
Rhizophyllum sp. B & Calceola cf. C. sandalina \\
Pseudamplexus sp. cf. P. prin- & Orthophyllum? sp. \\
ceps Etheridge & Cyathophyllum $\mathrm{sp}$. \\
stauriid coral & Zaphrentis $\mathrm{sp}$.
\end{tabular}

The coral assemblage is either Early or Middle Devonian in age. The genus Eddastraea and Pseudamplexus princeps are known from both Lower and Middle Devonian rocks of Australia (Hill, 1956, p. 306; Hill, 1950, p. 142). The stromatoporoid genus $A m-$ phiphora indicates a probable Middle Devonian age for the collection.

\section{Miscellaneous records}

North American examples of Rhizophyllum or "Calceola" have been formally described only from the Tennessee-Kentucky-Indiana area. Other listings and citations known to the author have been discussed in the preceding paragraphs but it is likely that some records have been missed since a comprehensive review of all literature dealing with the Silurian and Devonian of North America is impractical. Bassler (1950) presented extensive lists of corals by formation and geographic area but noted only the TennesseeKentucky-Indiana occurrences of "Calceola" in North America.

Conrad $(1840,1841)$ in his preliminary reports on the paleontology of New York, twice mentioned "Calceola". His Calceola plicata (Conrad 1840, p. 207) is a Platyceras (Hall, 1859, p. 334). His Calceola indenta (nomen nudum, Conrad, 1841, p. 37) was listed as a "univalve" along with gastropods, cephalopods, a conulariid, and a tentaculitid. It seems likely that the 1841 specimen was not a coral, but I have not found a later reference to it or attempted to trace the specimen.

\section{NEW OCCURRENCES}

\section{Upper Silurian-southeastern Alaska}

USGS 1005-SD. Vermont marble prospect, south shore of Kosciusko Island, between Edna Bay and Holbrook. Collection of Edwin Kirk, 1917.

Brachiopods from this locality were described by Kirk and Amsden (1952) with a brief summary of their occurrence and stratigraphy. On the basis of the brachiopods, Kirk and Amsden (1952, p. 53) suggested an "Upper Silurian" age for the collection.

In addition to the brachiopods, collection 1005 includes tabulate and rugose corals and bryozoans. The following corals have been identified by the present author: Heliolites spp., Thamnopora sp., Cystiphyllum sp., Rhizophyllum sp. A, and Tryplasma spp. These are suggestive of a Late Silurian age but are not so restricted. The identification of Rhizophyllum is based on five specimens that are described in a following section.

\section{Silurian(?)—northwestern California}

USGS 5922-SD. Dislocated block of limestone, 4 by 5 by 8 feet, on west bank of Trinity River in the center of sec. 2, T. 32 N., R. 10 W., Weaverville quadrangle, Trinity County. Collected by W. P. Irwin, 1961.

A small collection of fossils, principally corals, was submitted by W. P. Irwin for examination and age determination. In a written communication to Irwin, Helen Duncan (October, 1961) listed "cystiphyllid corals (Rhizophyllum?)" among other forms and indicated that the age of the collection was Silurian or Devonian, more- likely Silurian. With the help of additional sections, the presence of several specimens of Rhizophyllum has been confirmed. These are described below as $R$. sp. C. In addition, the associated corals have been restudied by Miss Duncan and myself, and the following list is the result of our joint efforts: heliolitid coral fragments, Rhizophyllum sp. 
C, Spongophylloides? sp., streptelasmatoid corals, Tryplasma? sp., Zelophyllum? sp. The corals are badly recrystallized and somewhat distorted in shape due to metamorphism, and most of the identifications are queried. In spite of this, the apparent growth form of Rhizophyllum sp. C, the probable presence of Spongophylloides and Zelophyllum, and the internal morphology of the streptelasmatoids, are all strongly suggestive of Wenlock or Ludlow (Middle or Late Silurian) age.

The loose block from which the corals were collected was in an area mapped as Bragdon Formation (in central metamorphic belt of Irwin, 1960, p. 18). The Bragdon is considered to be Mississippian in age but contains fragments of older fossiliferous limestones in some conglomerate beds (Irwin, 1960, p. 18).

\section{Lower Devonian-Nevada}

USGS 6267-SD. Unnamed limestone unit forming a prominent ledge on the east side of Coal Canyon, at an elevation of approximately 6,280 feet; $\mathrm{SE} 1 / 4$ sec. 17, T. 25 N., R. 49 E., northern Simpson Park Mountains, Horse Creek Valley 15-minute quadrangle, Eureka County, Nev.; collected by M. R. Murphy, 1957 (J. G. Johnson, written communication, 1963).

The following corals were present in a collection submitted for identification by J. G. Johnson, California Institute of Technology: Favosites sp., Endophyllum sp., Mucophyllum sp., Papiliophyllum elegantulum Stumm, Rhizophyllum sp. ef. $R$. enorme Etheridge, and cystiphylloid and chonophylioid corals. The identification of the Rhizophyllum is based on a single specimen described below.

Papiliophyllum elegantulum suggests an Early Devonian age as the species is most common in the Spirifer kobehana zone of Merriam (1940, p. 52-53). Merriam considered the zone to be Early Devonian, Oriskany or later, in age, and subsequent workers have agreed with this evaluation. Endophyllum is principally a Devonian coral, but species have been described from the Upper Silurian of Europe (Prantl, 1952). Mucophyllum is a Middle and Upper Silurian genus that has not been described or illustrated from younger rocks although there are incidental references to Devonian occurrences (for example, Wang, 1950, p. 228). The other listed corals could be either Silurian or Devonian.

As a whole, the corals support an Early Devonian age. The presence of Mucophyllum suggests that the fauna may represent an early part of the early Devonian.

According to Johnson (written communication, 1963), who is describing the brachiopods, the unnamed limestone from which the corals were collected is of Gedinnian (early Early Devonian) age and "is overlain by the
Rabbit Hill Formation [Merriam, 1963, p. 42-44] with an upper Gedinnian brachiopod fauna." Further, "the Rabbit Hill is in turn overlain by the Nevada Formation with the zone of Acrospirifer kobehana in which Papiliophyllum elegantulum is typical. Accordingly, the occurrence of $P$. elegantulum in the unnamed limestone extends the range of the species considerably downward".

\section{Upper Silurian-Maine}

USGS 6525-SD. On the boundary line between the Spider Lake and Telos Lake quadrangles, on the shore of Third Lake Mattagamon. Collected by Bradford A. Hall, University of Maine, 1961.

A collection of corals which was submitted for identification by B. A. Hall, includes the following: Cladopora? sp., Favosites sp., Halysites sp., Heliolites sp., Syringopora sp., "Cystiphyllum" sp., Disphyllum sp., Entelophyllum sp., Rhizophyllum sp. cf. $R$. gotlandicum (Roemer), and Triplasma? sp. The coral assemblage is definitely Silurian, either Wenlock or Ludlow in age. Brachiopods from the same collection have been studied by A. J. Boucot, California Institute of Technology; they indicate a Ludlow (Late Silurian) age (Boucot, written communication, 1962).

The identification of Rhizophyllum is based on a single specimen which is described and illustrated below.

\section{SYSTEMATIC DESCRIPTIONS}

\section{Genus Rhizophyllum Lindström}

Rhizophyllum Lindström, 1866a, p. 287; 1866b, p. 411; 1883 , p. 22 ; Sherzer, 1891 , p. 296 ; Hill, 1940, p. 394 ; Wang, 1948, p. 1, 3; Hill, 1956, p. 314.

Calceola of many authors (including all known descriptions or citations of North American specimens).

Type species.-By monotypy, Calceola gotlandica Roemer, 1856, p. 798; Silurian, Island of Gotland, Sweden.

Diagnosis.-Rhizophyllum includes calceoloid rugose corals with a semicircular operculum which articulates on the flat, counter side of the corallum. The interior is filled with arched dissepiments and tabellae arranged in an inverted cone pattern. Septa are acanthine or laminar and are limited to the flat side; the counter septum is commonly longer and thicker than the other septa. The wall on the flat side of the corallum is formed by the fusion of the marginal edges of the septa; the curved part of the wall is apparently formed in the same way, although the septa do not project into the lumen even as septal ridges. The axis is straight or curved. The corallum in some species was supported by radiciform processes.

Discussion.-Lindström $(1866 \mathrm{a}, \mathrm{b})$ established the genus Rhizophyllum to separate the "Calceola" with 
cystiphylloid internal structure from typical Calceola with stereoplasm-filled interiors. He discussed operculated corals at length $(1866 \mathrm{a}, \mathrm{b}, 1883)$ and placed all of the American "Calceola" in two species of Rhizophyllum.

Bassler (1915) considered Rhizophyllum to be a subgenus of Calceola and was followed in this usage by Foerste (1931) and Shimer and Shrock (1944). Sherzer (1891) and Amsden (1949) are the only two American paleontologists who have published taxonomic papers using Rhizophyllum as a genus; European and Australian workers have recognized the genus since its first description.

Rhizophyllum ranges from the Middle Silurian (Wenlock) to the lower Middle Devonian (Eifelian). Species have been described from rocks of both Silurian and Devonian age in Europe, Asia, Australia, and North America. Middle Devonian occurrences are uncommon but have been reported from the Eifelian of Mongolia (Spassky, 1960, p. 124-125) as well as from Alaska (this article). Hill (1942, p. 13-16) reported Rhizophyllum and Calceola from the same limestone in Queensland, but she concluded that the age was latest Early Devonian.

Descriptions.- The following descriptions are of specimens rather than species, 1 being based on 5 specimens, 1 on 10 specimens, and the other 4 on one specimen each. Two of the "species" are compared with previously named species that are morphologically similar; at least one "species" is new but formal description must await the acquisition of more material.

The dimensions of all specimens described are given in millimeters. Length was measured in a straight line from the counter side of the calice margin to the apex; since most specimens are incomplete at one or both ends, the figures represent minimum length. The diameters were measured at the calice margin or at the uppermost complete growth line.

Rhizophyllum sp. A

Figure 153.1 $a-e, 153.2 a-j, 153.3 b$

Description.--Five specimens of solitary Rhizophyllum, lacking radiciform processes probably represent a new species. Two cycles of growth lines are prominent on the exteriors; where the outer surface is worn, the traces of the septa can be scen on both flat and convex sides.

In transverse section the counter septum is two or more times the length of the other septa and is thickened to a spindle shape. The septum is formed of calcite fibers radiating upward and from the center of the spindle within an outer sheath of lamellar tissue. This gives an elongate rosette appearance in transverse section and a fan pattern in longitudinal section.
Other septa are numerous and closely spaced; they are enveloped in lamellar tissue but the microstructure of their inner portions has not been observed.

In longitudinal section, the dissepiments are very steep and elongate near the curved, cardinal side but almost horizontal near the counter margin. From the counter side, the dissepiments steepen toward the eccentric axis about which the tabellae are large and horizontal.

Measurements are as follows:

\begin{tabular}{|c|c|c|c|}
\hline \multirow[b]{2}{*}{ Specimen (USNM No.) } & \multirow[b]{2}{*}{ Length $(m m)$} & \multicolumn{2}{|c|}{ Diameter $(m m)$} \\
\hline & & Major & Minor \\
\hline 121200 & 14 & 12. 7 & 7. 1 \\
\hline 121201 & 19 & 17. 2 & 9.6 \\
\hline 121202 & 26 & 27.2 & 11.8 \\
\hline 121203 & 24 & 21.8 & 11.0 \\
\hline 121204 & - & 18. 5 & 10.1 \\
\hline
\end{tabular}

Discussion.-R. sp. A is characterized by its inflated counter septum. A similar structure is seen in $R$. yotlandicum of Rozkowska (1946, p. 145-146, 154-155, pl. 5, figs. 4a-b) from the Silurian of Podolia. The Podolian material differs in having comparatively few, but large dissepiments and tabellae. $R$. gotlandicum of Soshkina (1937, p. 82, pl. 19, fig. 1-2) from the Upper Silurian of the Urals, lacks the prominent counter septum but is similar in other respects. Typical R. gotlandicum (Lindström, 1866a, p. 287, pl. 30, fig. $10-15$, pl. 31 , fig. $1-8 ; 1883$, p. 23 , pl. 3 , fig. $1-12$, 18, pl. 4, fig. 7) from the Middle and Upper Silurian of Gotland, has a less prominent counter septum and reduced (acanthine?) lateral septa; in addition, typical $R$. gotlandicum has numerous supporting radiciform processes.

Material.-Five specimens from the Upper Silurian of Alaska (USGS 1005-SD; see stratigraphic discussion). Illustrated specimens, USNM 121200 to 121203. Unillustrated specimen, USNM 121204.

\section{Rhizophyllum sp. B}

Figure 153.1f,g

Description.-A single specimen of solitary Rhizophyllum from the Devonian of Alaska, has a curved, conical shape and lachs radiciform processes; dimensions are: length, $15+\mathrm{mm}$; and diameter, 11.4 by $20.7 \mathrm{~mm}$. The exterior is marked by growth rugae. In a transverse section, 26 discrete septa are present along $15 \mathrm{~mm}$ of the straight margin; the septa are vertically discontinuous and may be acanthine. The presumed counter septum is only slightly longer than the other septa. Dissepiments are small and elongate; large tabellae surround the eccentric axis. A neanic section indicates that the dissepimentarium was relatively narrow in early growth stages, but ephebic and neanic sections are similar in other respects. 

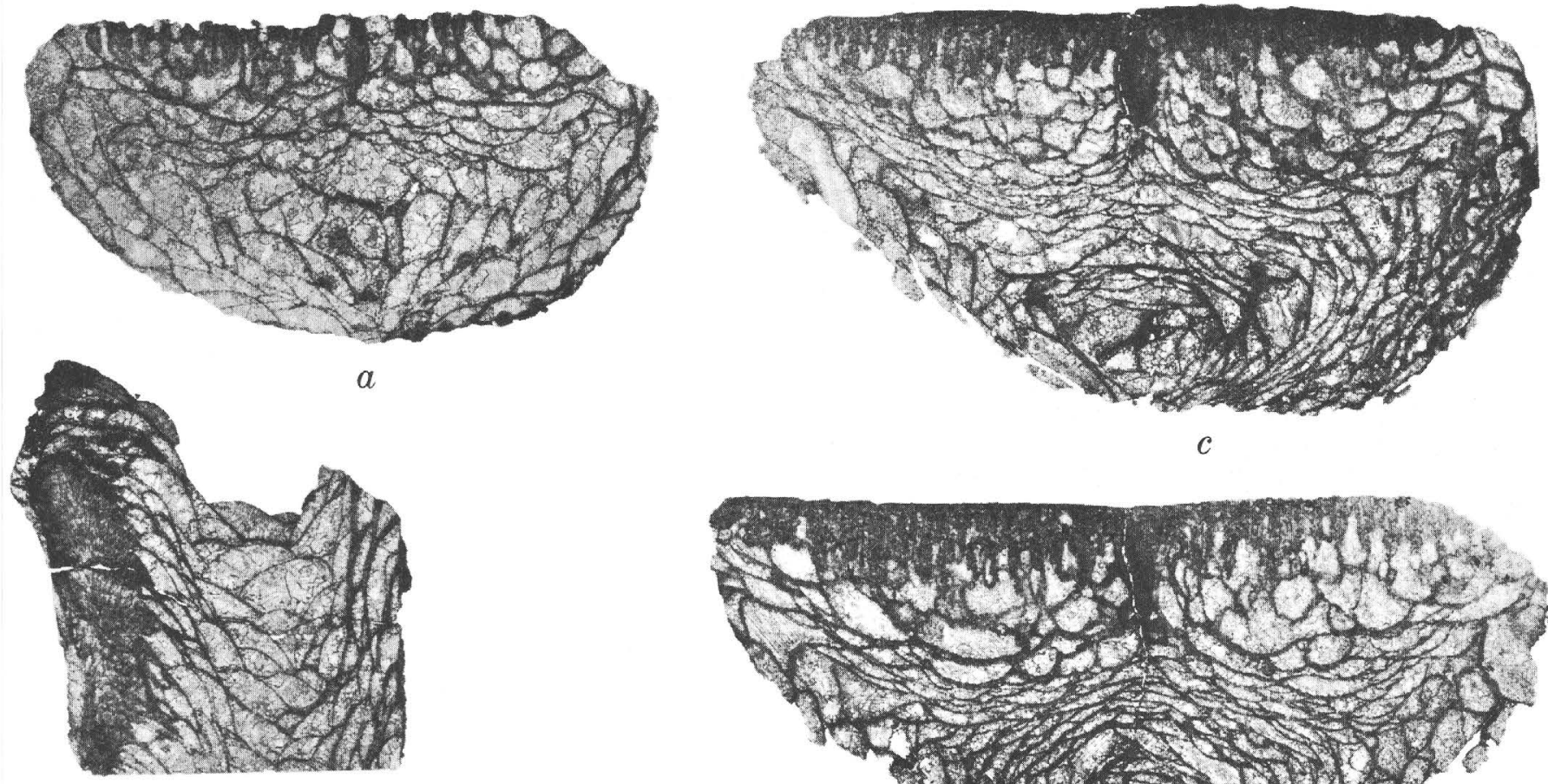

$b$
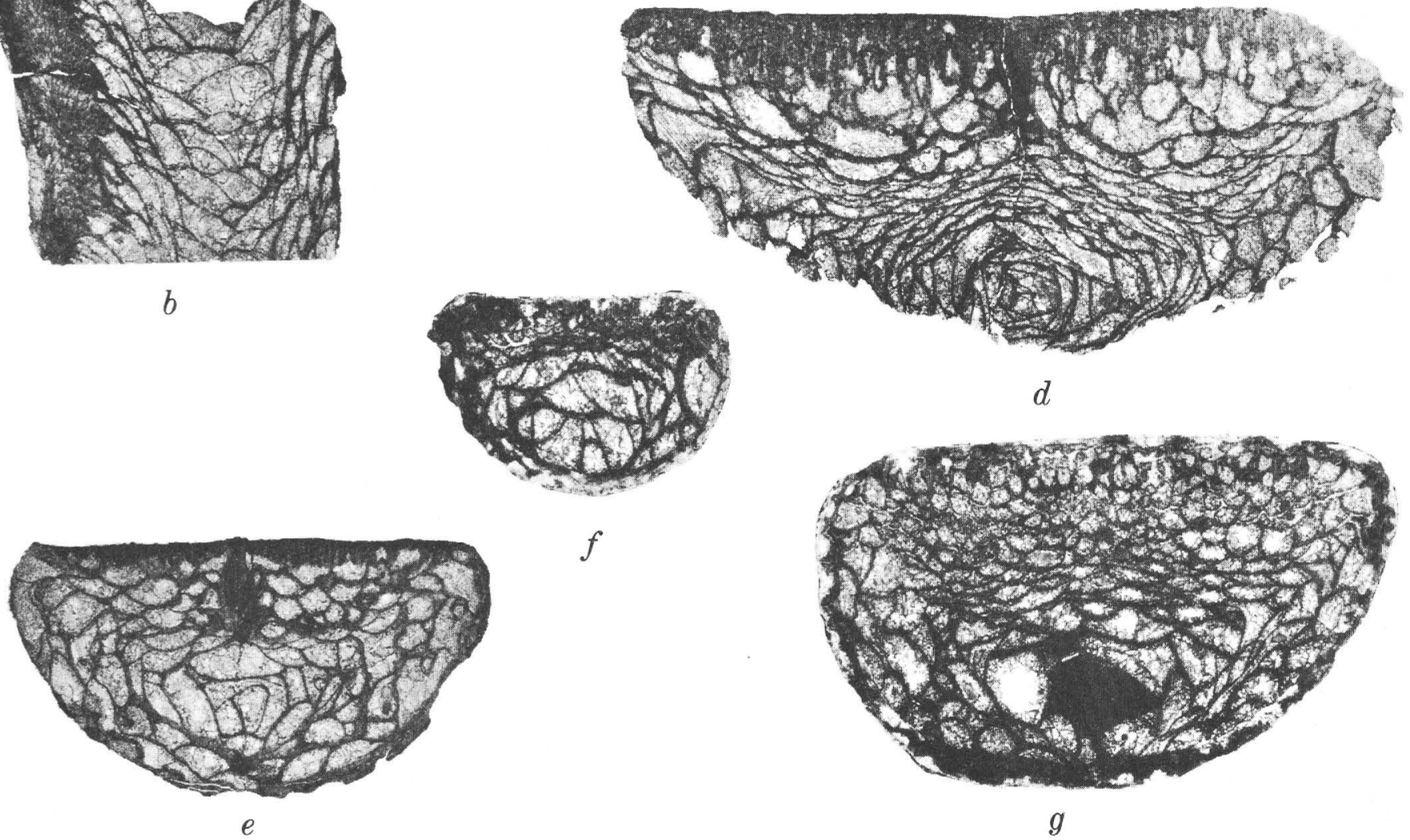

FIGURE 153.1.-Rhizophyllum sp. A and sp. B. The counter septum is toward the top of the plate in the transverse thin sections and to the left in the longitudinal thin section. All specimens $\times 4 . \quad a-e$, Rhizophyllum sp. A; ephebic sections; $a-b$, USNM 121203; $c-d$. USNM 121202; $e$, USNM 121201; Upper Silurian, Alaska. $f-q, R$. sp. B; neanic and ephebic section; USNM 140899; Middle(?) Devonian, Alaska.

Discussion.-The one available specimen is morphologically similar to R. robustum Shearsby $(1906$, p. 548, pl. 26, fig. 1-6; Hill, 1940, p. 396, pl. 11, fig. 11a-b) from the Silurian of New South Wales. $R$. robustum differs in being more erect and in haring finer tabellae and occasional radiciform processes.

Material.-One specimen from the Middle? Deronian of Alaska (Kindle 897; see stratigraphic discussion). Illustrated specimen, USNM 140899; collected by E. M. Kindle, 1905.

\section{Rhizophyllum sp. C}

Figure 153.4 a-e

Description.-Ten or more specimens of a small Rhizophyllum are known from transverse sections only. The specimens were found in 2 groups, 1 with 3 or more individuals and the other with 7 or more; the presence of numerous radiciform processes and the spatial relationships of the individuals suggest that they occurred in clumps or small colonies. Individual diameters range from 2.5 by $3.0 \mathrm{~mm}$ to approximately 5 by 


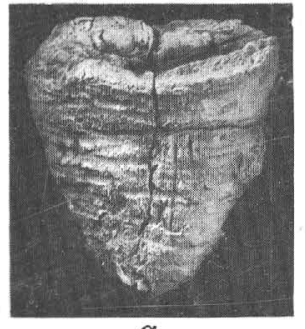

$a$

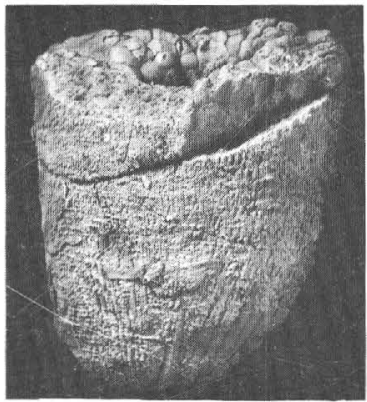

f

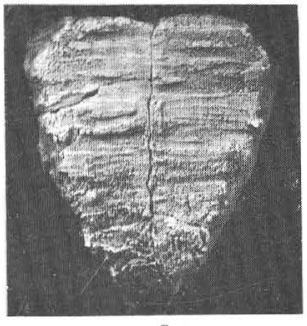

b

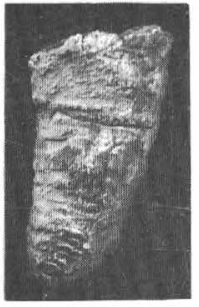

$c$

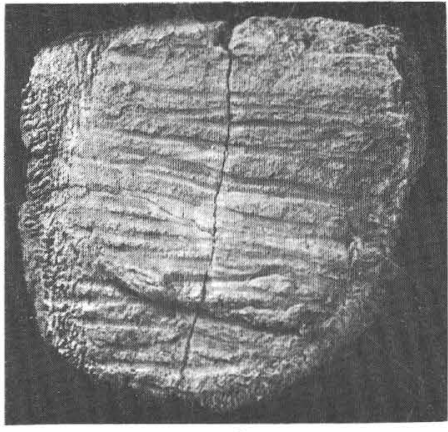

$d$

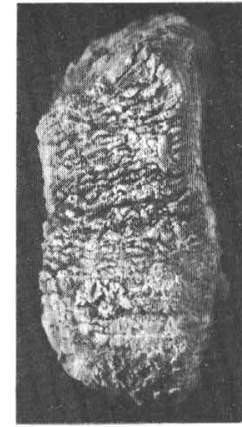

e

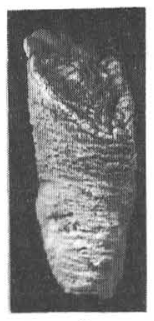

j

Figure 153.2.-Rhizophyllum sp. A; exterior views; Upper Silurian, Alaska. $a-c$, cardinal, counter, and side views; USNM 121201. $d-e$, counter and side views; USNM 121202. $f-g$, cardinal and side views; USNM 121203 . $h-j$, cardinal, counter, and side views; USNM 121200 . All specimens $\times 1 \frac{1}{1} 2$.
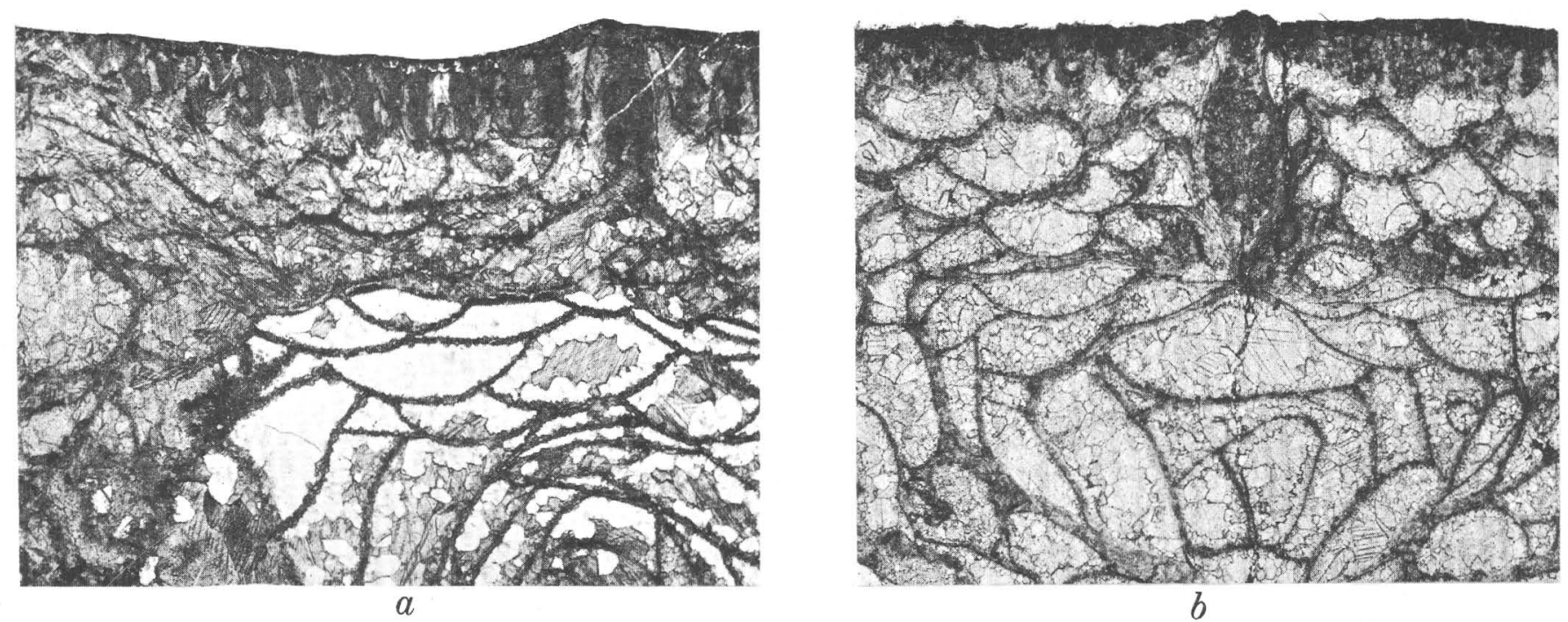

FiguRE 153.3.- a, Rhizophyllum sp. cf. R. enorme; detail of figure 153.5b; USNM 121205; Lower Devonian, Nevada. $b, R$. sp. A; detail of figure 153.1e; USNM 121201; Upper Silurian, Alaska. Transverse thin sections, $\times 10$. 


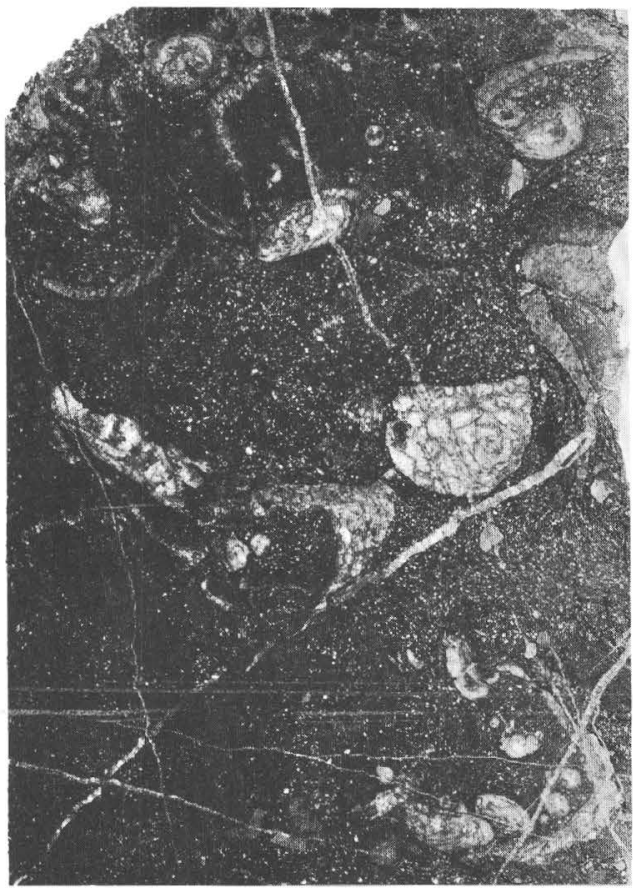

$a$

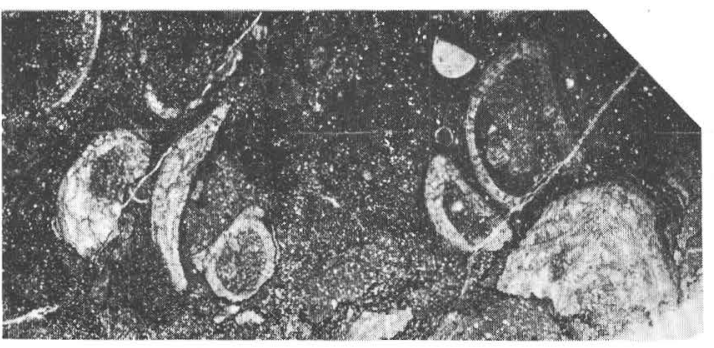

$b$

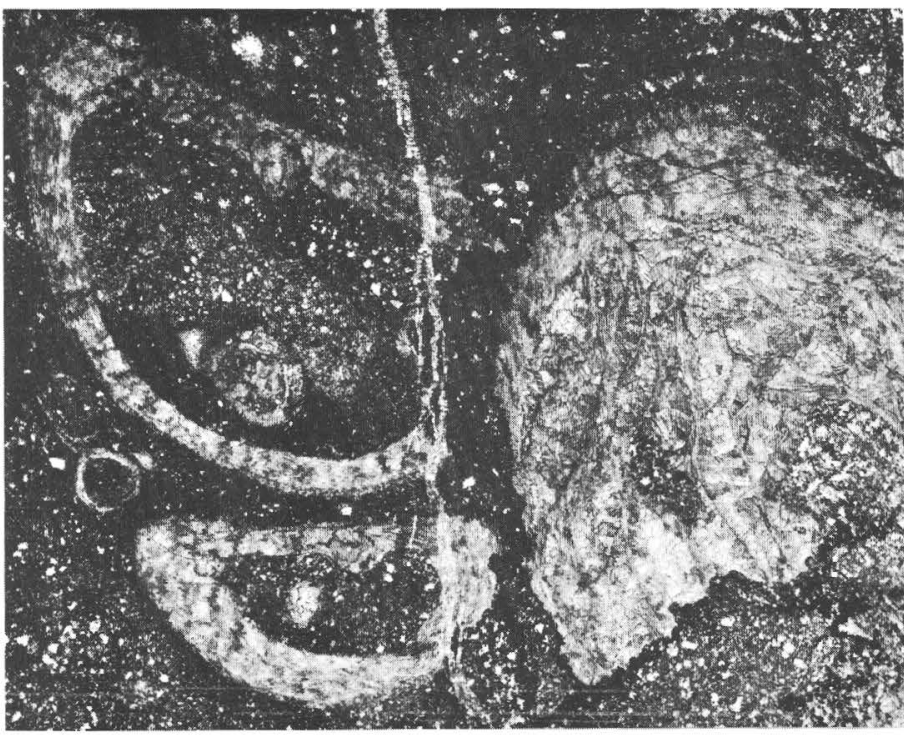

$C$

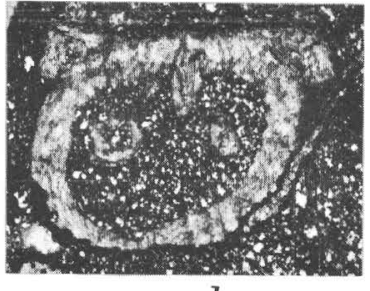

$d$

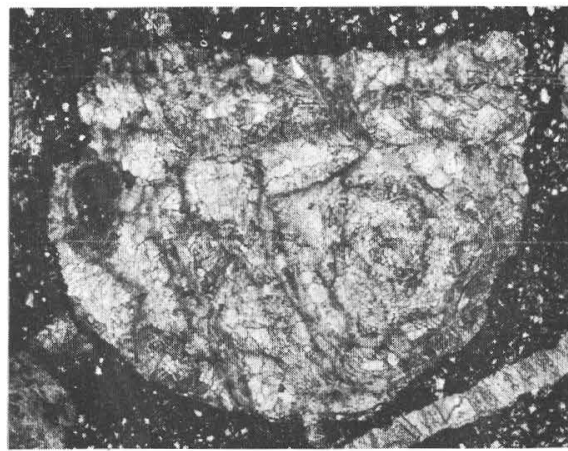

$e$

Figure 153.4.-Rhizophyllum sp. C; USNM 121344; Silurian(?), northwestern California. $a-b$, Sections through group or clum p of specimens, $\times 3$; immature and mature transverse sections of individuals and sections of radiciform processes and probab le opercula are shown. $c$, Detail of $b, \times 10$; transverse sections through neanic portion of two corallites and partial section of ephebic portion of another. $d$, Detail of $b, \times 10$; transverse section of neanic portion of a corallite. $e$, Detail of $a, \times 10$; transverse section of early ephebic portion of a corallite.

$9 \mathrm{~mm}$ (3 specimens). All specimens have a relatively thick wall $(0.3-0.5 \mathrm{~mm})$ with a prominent counter septum on the straight side. In smaller sections (neanic and brephic?; diameter less than 3.5 by $5.0 \mathrm{~mm}$ ) other septa form the wall but do not project into the lumen; one or two dissepiments are present in some of the sections. In the larger sections (ephebic) the lumen is filled with dissepimental plates and septa project slightly from the straight margin. The calice is relatively deep and $V$-shaped. Several cresent-shaped objects in the thin sections may represent the opercula of this species.

Discussion.-In apparent growth form and general morphology, Rhizophyllum sp. C is similar to R. elongatum Lindström (1883, pl. 2) from the Middle or Upper Silurian of Gotland, Sweden, and to R. attenuatum (Lyon) (Lindström, 1883, pl. 3, fig. 17) from the Middle or Upper Silurian, Louisville Limestone in

\footnotetext{
$716-6260-64-11$
}

Kentucky. $R$. sp. C is closer to $R$. attenuatum in size and number of radiciform processes, but adequate comparison is not possible because of the nature of the California specimens. $R$. sp. C may be allied to one of the two clump-forming species or may represent a third species but is, in either case, suggestive of Silurian age.

Material.-Two groups totaling ten or more specimens from the Middle or Upper Silurian of northwestern California (USGS 5922-SD; see stratigraphic discussion). Illustrated group, USNM 121344; unillustrated group, USNM 121345.

\section{Rhizophyllum sp. D}

[?] Calceola sandalina Stauffer, 1930, p. 107, pl. 12, figures 2-3 (not Linnaeus)

Description.-A single specimen of solitary Rhizophyllum from the Silurian of eastern California, has a 
curved conical shape and apparently lacks radiciform processes; dimensions are: length, $43+\mathrm{mm}$; and diameters, $15+$ by $35 \mathrm{~mm}$. The specimen is poorly preserved with beekitized exterior and normally silicified interior. The counter septum projects 2 to $3 \mathrm{~mm}$ in large sections; other septa are half as long, discrete, probably acanthine, and limited to the straight side. Dissepiments are steeply inclined on both sides of the eccentrically located axial zone of tabellae; dissepiments and tabellae are of approximately the same size.

Discussion.-The specimen is too poorly preserved for comparison with other species of the genus, but it is probably conspecific with Stauffer's specimen (see stratigraphic discussion).

Material.--One specimen from the Middle or Upper Silurian of California (USGS 6839-SD). Unillustrated specimen, USNM 121346.

\section{Rhizophyllum sp. cf. $R$. enorme Etheridge}

Figures 153.3a, 153.5a,b

Rhizophyllum enorme Etheridge, 1903, p. 232-233, pl. 47; Hill and Jones, 1940, p. 182, pl. 2, fig. 3-4.

Description.-A single specimen with curved axis is $20+\mathrm{mm}$ in length, with diameters of 15.8 and 27.5 $\mathrm{mm}$; the exterior is poorly preserved but there is no evidence of radiciform processes. In transverse section, 28? septa are present along $14 \mathrm{~mm}$ of the straight margin. The counter septum is twice the length of the adjacent septa and is thickened by a sheath of lamellar tissue.

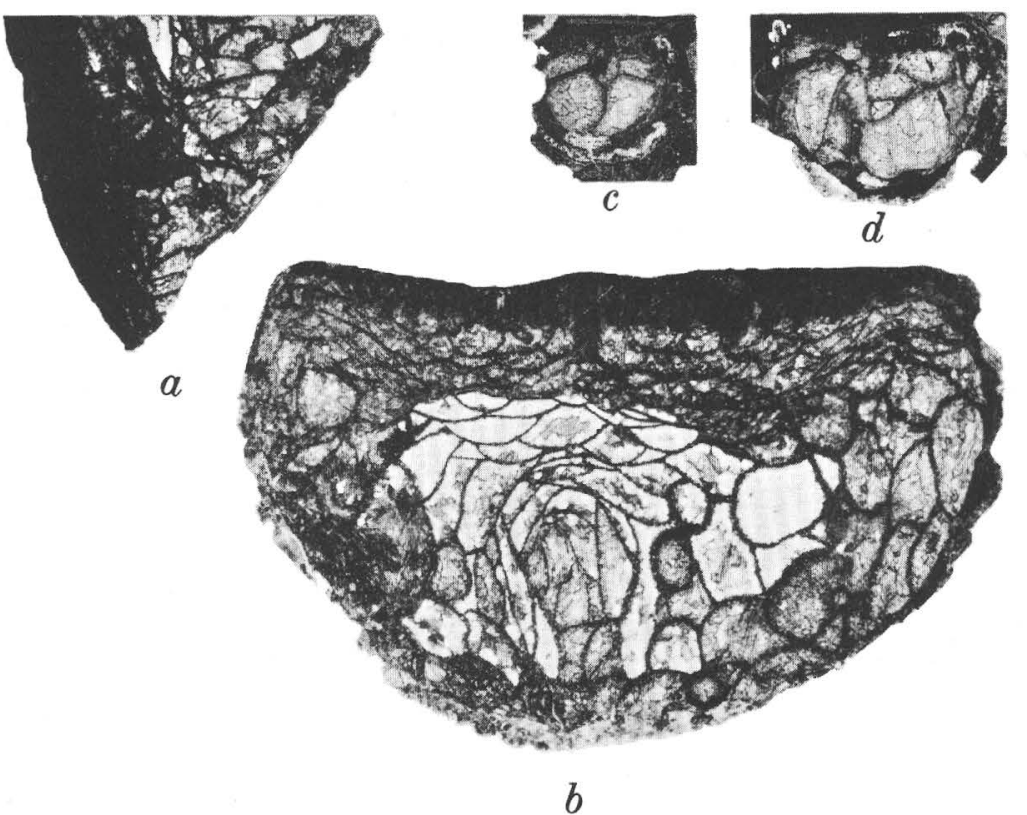

FIGURE 153.5.-Rhizophyllum sp. cf. $R$. enorme and $R$. sp. cf. $R$. gotlandicum. The counter septum is toward the top of the plate in the transverse thin sections and to the left in the longitudinal thin section. All specimens $\times$. $a-b$, Rhizophyllum sp. cf. R. enorme; ephebic longitudinal and transverse sections; USNM 121205 ; Lower Devonian, Nevada. $c-e$, $R$. sp. cf. R. gotlandicum; brephic?, neanic, and ephebic transverse sections; circular and oval bodies above and to the right of the specimen in $e$ are sections of radiciform processes; USNM 121206; Upper Silurian Maine.
A longitudinal section in the cardinal-counter plane shows rather coarse tabellae at the eccentric axis with smaller, elongate, steeply inclined dissepiments on either side. The structure of the septa cannot be determined from available sections but they seem to be laminar.

Discussion.-The described specimen is similar to $R$. enorme as illustrated by Hill and Jones (from the Lower Devonian of New South Wales) in internal structure but is much smaller and has relatively coarser tabellae and dissepiments.

Material.-One specimen from the Lower Devonian of Nevada (USGS 6267-SD; see discussion). Illustrated specimen, USNM 121205.

\section{Rhizophyllum sp. cf. R. gotlandicum (Roemer)}

Figures $153.5 c-e$

Calceola gotlandica Roemer, 1856, p. 798.

Rhizophyllum gotlandicum (Roemer), Lindström, 1866a, p. 287 , pl. 30 , fig. $10-15$, pl. 31 , fig. $1-8 ; 1866$ b, p. $406-411$, pl. 14 , fig. $8-18$; 1883 , p. 23 , pl. 3 , fig. $1-12$, 18 , pl. 4 , fig. 7 .

Description.-One specimen of Rhizophyllum from the Upper Silurian of Maine is incomplete but represents a solitary, erect form with radiciform processes in the apical region; dimensions are: length, $45+\mathrm{mm}$; and diameters, 26 by $16 \mathrm{~mm}$. The appearance of the external surface is not known. In transverse section the counter septum is relatively long and inflated; there is a suggestion of a radiating structure and there is a 
sheath of lamellar tissue. Other septa are short and acanthine.

The dissepiments are elongate and steeply inclined; the axial tabellae are more globose but not much larger than the dissepiments. Both dissepiments and tabellae are thickened with excess stereome deposits.

A neanic section shows a few tabellae with an incomplete marginal row of dissepiments and a short, stumpy counter septum; no other septa are developed. An even earlier section (brephic?) shows only a bulge in the straight side representing the counter septum and a single tabella.

Discussion.- The Maine specimen is remarkably similar to specimens illustrated by Lindström (1883). A weathered longitudinal section is like Lindström's figure 6 and the neanic section (my fig. 153.5d) is close to his figure 5. Lindström did not publish an illustration of an ephebic transverse section but his calice illustrations (1866b, pl. 14, fig. 8-11, 14) suggest that the septal development is similar to that described here for the Maine specimen.

Material.-One individual from the Upper Silurian of Maine (USGS 6525-SD; see stratigraphic discussion). Illustrated specimen, USNM 121206. Collected by Bradford A. Hall, 1961.

\section{REFERENCES}

Amsden, T. W., 1949, Stratigraphy and paleontology of the Brownsport Formation (Silurian) of western Tennessee: Peabody Mus. Nat. Hist., Yale Univ., Bull. 5, 138 p., 34 pl.

Bassler, R. S., 1915, Bibliographic index of American Ordovician and Silurian fossils, v. 1 and 2: Smithsonian Inst., U.S. National Mus. Bull. 92, 1521 p.

1950, Faunal lists and descriptions of Paleozoic corals: Geol. Soc. America Mem. 44, 315 p.

Buddington, A. F., and Chapin, Theodore, 1929, Geology and mineral deposits of southeastern Alaska: U.S. Geol. Survey Bull. 800,398 p.

Conrad, T. A., 1840, Third annual report on the palaeontological department of the Survey: New York Geol. Survey Ann. Rept. 4, p. 199-207.

- 1841, Fifth Annual report on the paleontology of the State of New York: New York Geol. Survey Ann. Rept. 5, p. 25-57.

Davis, W. J., 1887, Kentucky fossil corals, pt. 2: Kentucky Geol. Survey, 139 plates and expl.

Etheridge, Robert, Jr., 1903, An unusually large form of Rhizophyllum lately discovered in New South Wales: Recs. Geol. Survey New South Wales, v. 7, p. 232-233, pl. 47.

Foerste, A. F., 1931, The Silurian fauna: Kentucky Geol. Survey, ser. 6, Paleontology of Kentucky, p. 167-214.

Hall, James, 1859, Descriptions and figures of the organic remains of the Lower Helderberg group and the Oriskany sandstone: New York Geol. Survey, Paleontology of New York, v. 3, text, $532 \mathrm{p}$.

- 1882 , Fossil corals of the Niagara and Upper Helderberg groups: New York State Mus., Ann. Rept. 35, advanced sheets, $59 \mathrm{p}$.
Hill, Dorothy, 1940, The Silurian Rugosa of the Yass-Bowning district, N.S.W.: Linnean Soc. New South Wales Proc., v. 65 , p. $388-420$, pl. 11-13.

1942, The Lower Devonian rugose corals from the Mt. Etna limestone, Qld.: Royal Soc. Queensland Proc., v. 54, p. $13-22$, pl. 1 .

- 1950, Middle Devonian corals from the Buchan district, Victoria: Royal Soc. Victoria Proc., v. 62, p. 137-164, pl. 5-9.

- 1956, Rugosa, in Moore, R. C., ed., Treatise on invertebrate paleontology, pt. F. Coelenterata: Geol. Soc. America and Kansas Univ. Press, Lawrence, Kans., p. 233-324.

Hill, Dorothy, and Jones, O. A., 1940, The corals of the Garra beds, Molong district, New South Wales: Royal Soc. New South Wales Jour. and Proc., v. 74, p. 175-208.

Irwin, W. P., 1960, Geo ogic reconnaissance of the northern Coast Ranges and Klamath Mountains, California: California Div. Mines Bull. 179, $80 \mathrm{p}$.

Kindle, E. M., 1907, Notes on the Paleozoic faunas and stratigraphy of southeastern Alaska: Jour. Geology, v. 15, p. 314-337.

Kirk, Edwin, and Amsden, T. W., 1952. Upper Silurian brachiopods from southeastern Alaska: U.S. Geol. Survey Prof. Paper 233-C, p. 53-66, pl. 7-10.

Lindström, Gustav, 1866a, Nagra iakttagelser ofver zoantharia rugosa: Ofvers. Kongl. Vetensk.-Akad. Forhandl., v. 22, p. 271-294, pl. 30-31.

1866b, Some observations on the Zoantharia Rugosa: Geol. Mag., v. 3, p. 356-362, 406-414, pl. 14 (author translation of 1866 a reference).

- 1883, Om de Palaeozoiska formationernas Operkelbärande Koraller: Bihang Kongl. Svensk. Vetensk.-Akad. Handl., v. 7, 112 p., 9 pl.

Lyon, V. W., 1879, Descriptions of three new species of Calceolidae from the upper Silurian rocks of Kentucky: Acad. Nat. Sci. Philadelphia Proc., p. 43-46.

Merriam, C. W., 1940, Devonian stratigraphy and paleontology of the Roberts Mountains region, Nevada: Geol. Soc. America Spec. Paper. 25, 114 p., 16 pl.

1963, Paleozoic rocks of Antelope Valley, Eureka and Nye Counties, Nevada: U.S. Geol. Survey Prof. Paper 423, $67 \mathrm{p}$.

Prantl, Ferdinand, 1952, The genera Endophyllum Edwards and Haime and Spongophyllum Edwards and Haime in the Silurian and Devonian of Bohemia: Sbornik Geol. Survey Czechoslovakia, v. 18, p. 221-240.

Roemer, F. A., 1852-1854, Erste Periode; Kohlen-Gebirge, in Bronn, H. G., Lethaea Geognostica, 3d ed.: Stuttgart, $788 \mathrm{p}$.

1856, Bericht von einer geologisch-palaontologischen Reise nach Schweden: Neues Jahrb. Min., Geog., Geol,, p. 794-815.

Ross, D. C., 1963, New Cambrian, Ordovician, and Silurian formations in the Independence quadrangle, Inyo County, California: Art. 21 in U.S. Geol. Survey, Prof. Paper 475-B, p. B74-B85.

Rozkowska, Maria, 1946, The Silurian rugose corals from Podolia: Polskiego Towarzystwa Geologicznego, Rocznik, T. 14 , p. $139-157$, pl. $4-5$.

Safford, J. M., 1860, On the species of Calceola found in Tennessee: Am. Jour. Sci., ser. 2, v. 29, p. 248-249.

Shearsby, A. J., 1906, Operculate corals from New South Wales: Geol. Mag., new ser., Decade 5, v. 3, p. 547-552, pl. 26. 
Sherzer, W. H., 1891, A chart of the rugose corals: Am. Geologist, v. 7, p. 273-301.

Shimer, H. W., and Shrock, R. R., 1944, Index fossils of North America: New York, John Wiley and Sons, 837 p.

Soshkina, E. D., 1937, [Corals of the upper Silurian and lower Devonian of the eastern and western slopes of the Urals]: USSR, Acad. Sci., Inst. Paleożool., Tr., v. 6, pt. 4, 112 p., $21 \mathrm{p}$.

Spassky, N. Ya., 1960, [The Devonian rugose corals of the southern Altai and adjoining territories]: Leningrad, Gorny Inst. Records, v. 37, p. 108-131, pl. 1-10.

Stauffer, C. R., 1930, The Devonian of California: California Univ. Pubs. in Geol. Sci., v. 19, no. 4, p. 81-118, pl. 10-14.
Troost, Gerard, 1840, Organic remains discovered in the State of Tennessee: Fifth Geol. Rept. to the 23rd General Assembly of Tennessee, p. 45-75.

Waite, R. H., 1953, Age of the "Devonian" of the Kearsarge area, California [abs.]: Geol. Soc. America Bull., v. 12, p. 1521.

Wang, H. C., 1948, Note on a remarkable Rhizophyllum species from the middle Silurian of Hueitze, northern Yunnan: Palaeont. Soc. China, Palaeont. Novitates, no. 2, 4 p.

1950, A revision of the Zoantharia Rugosa in the light of their minute skeletal structures: Royal Soc. London, Philos. Trans., ser. B, no. 611, v. 234, p. 175-246, pl. 1-9. 


\title{
GLACIAL CHRONOLOGY OF ULLSFJORD, NORTHERN NORWAY
}

\author{
By G. WILLIAM HOLMES and BJORN G. ANDERSEN, \\ Beltsville, Md., and University of Oslo
}

Work done in cooperation with the Air Force Cambridge Research Laboratories

\begin{abstract}
Quaternary features of Ullsfjord record Late Glacial fluctuations of the Fennoscandian ice sheet and of local alpine glaciers. The earliest known advance left erratics and subdued moraines near the coast. The subsequent Breidvika advance formed lateral moraines which continue into the sea as sharp submarine end moraines. Shortly thereafter the Skardmunken advance also resulted in moraines with both terrestrial and marine facies. Radiocarbon dates of marine shells place the Skardmunken maximum between 11,500 and 10,390 years B.P. (late Allerød and Younger Dryas time). A nearly continuous beach level, probably the "main beach level" of northern Norway, is cut in bedrock and unconsolidated materials from the outer coast to the top of the deltaic sediments of the Skardmunken moraine. Shortly after the Skardmunken advance, the Stordal advance left small moraines and deltas at a level slightly below the projection of the "main beach level." Lastly, cirque glaciers deposited steep unweathered moraines in historic time.
\end{abstract}

Ullsfjord is a deep, narrow trough with a total length of 50 kilometers, a maximum width of 5 kilometers, and a maximum relief of nearly 1,700 meters. In places the sides are so steep that no surficial deposits remain. The fiord was eroded along the contact between gabbroic rocks that make up the high, spectacular Lyngen Alps, and schistose rocks that form the slightly lower alpine peaks to the west. Scores of mountain glaciers originated in these mountains during the Pleistocene, and many cirques are still filled with ice. Narrow structural valleys connect Ullsfjord with fiords to the east, west, and south. These troughs were access routes for outlet glaciers of the Fennoscandian ice sheet that invaded the fiord in Pleistocene time. The bottom of the fiord is very irregular, as a result of bedrock relief and glacial deposition. Depths range from about 11 meters over submarine moraines, to 268 meters in the outer fiord.
Although Ullsfjord lies well above the Arctic Circle, its climate is humid temperate, very similar to that of southern Alaska (Haurwitz and Austin, 1944). The nearest weather station, at Troms $\varnothing, 25$ kilometers to the west, has a mean annual temperature of $2.3^{\circ} \mathrm{C}$ and a mean annual precipitation of $940 \mathrm{~mm}$ (Hansen, 1960, p. 46-47).

The glacial record in Ullsfjord is typical of northern Norway. Our studies show that the glacial sequence consists of (1) an unnamed early glaciation, (2) the Breidvika advance, (3) the Skardmunken advance, (4) the Stordal advance, and (5) a Recent advance (see accompanying table and fig. 154.1). One important basis for this chronology is the prominent elevated shoreline (informally referred to here as the "main beach level") that was formed at the time of the

Glacial chronology of Ullsfjord

\begin{tabular}{|c|c|c|c|}
\hline Glaciation & Age & Correlation & Basis for correlation \\
\hline Recent & 18th Century. & "Little Ice Age." & $\begin{array}{l}\text { Near or in contact } \\
\text { with existing glaclers }\end{array}$ \\
\hline Stordal & $\begin{array}{l}\text { Slightly younger } \\
\text { than skard- } \\
\text { munken. }\end{array}$ & Possibly Preboreal. & $\begin{array}{l}\text { Moraines are behind } \\
\text { and (or) at lower } \\
\text { levels than skard- } \\
\text { munken ice margins. }\end{array}$ \\
\hline Skardmunken & $11,500-10,390$ years. & $\begin{array}{l}\text { Equivalent to } \\
\text { Troms } \phi \text {-Lyngen } \\
\text { advance of north- } \\
\text { ern Norway. }\end{array}$ & $\begin{array}{l}\text { Radiocarbon dates are } \\
\text { approximately the } \\
\text { same as the Troms } \phi- \\
\text { Lyngen moraines. } \\
\text { Moraines graded to } \\
\text { "main beach level." }\end{array}$ \\
\hline Breidvika & $\begin{array}{l}\text { Slightly older } \\
\text { than Skard- } \\
\text { munken. }\end{array}$ & $\begin{array}{l}\text { Possibly equivalent } \\
\text { to Skarpnes } \\
\text { advance of north- } \\
\text { ern Norway. }\end{array}$ & $\begin{array}{l}\text { Moraine position is a } \\
\text { short distance be- } \\
\text { yond Skardmunken } \\
\text { moraines. Mo- } \\
\text { raines truncated by, } \\
\text { "main beach level." }\end{array}$ \\
\hline Early & $\begin{array}{c}\text { Somewhat older } \\
\text { than Breidvika. }\end{array}$ & $\begin{array}{l}\text { Possibly equivalent } \\
\text { to one or more } \\
\text { older advances in } \\
\text { southern Norway. }\end{array}$ & $\begin{array}{l}\text { Drift occurs seaward } \\
\text { of Breidvika } \\
\text { moraines. }\end{array}$ \\
\hline
\end{tabular}

ART. 154 IN U.S. GEOL. SURVEY PROF. PAPER 475-D, PAGES D159-D163. 1964. 


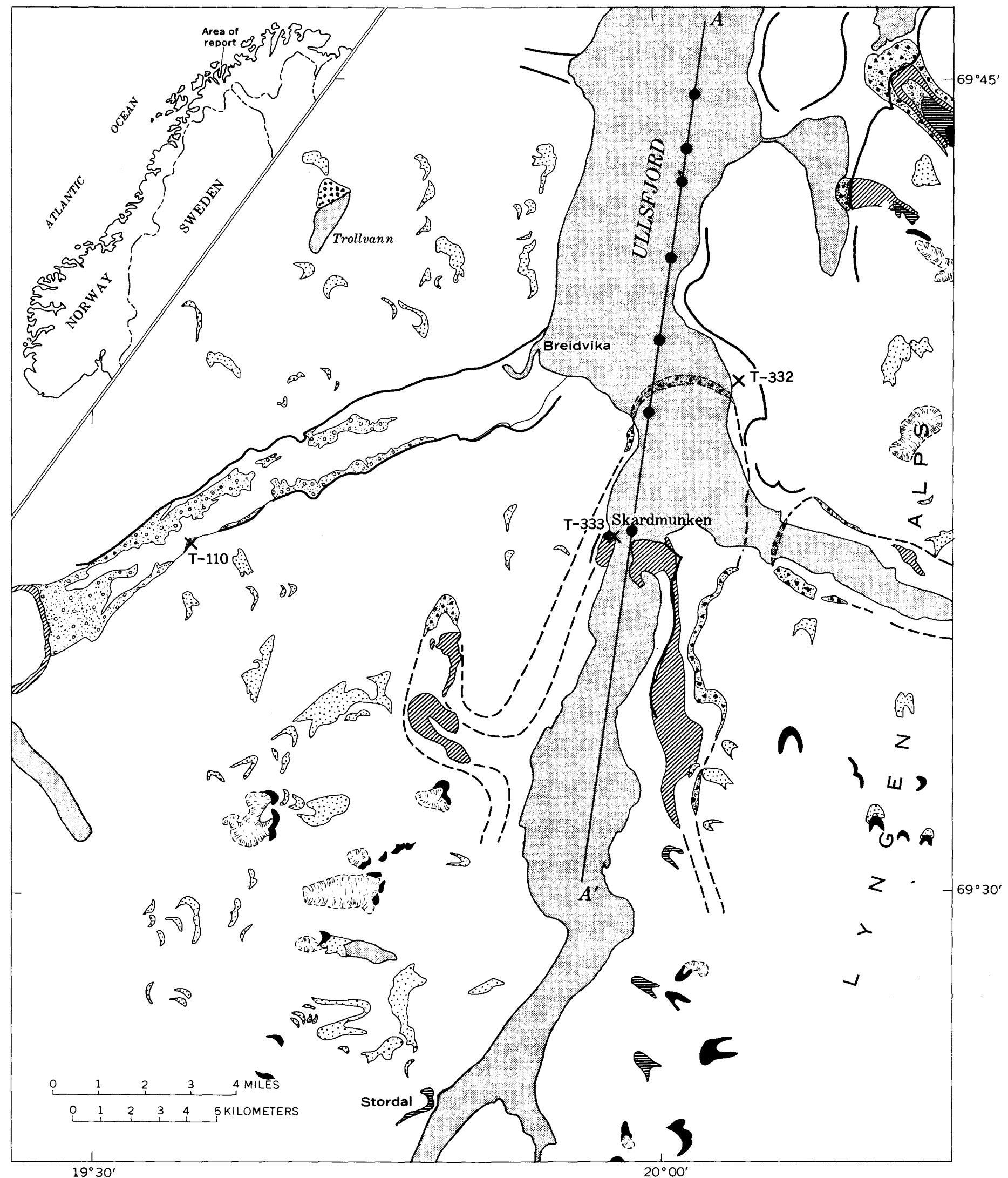

Figure 154.1.-Glacial and marine deposits near Ullsfjord, northern Norway. $A-A^{\prime}$, line of profile shown in figure 154.2, large dots in Ullsfjord are projections of points on the shores where the "main beach level" was measured. 


\section{EXPLANATION}

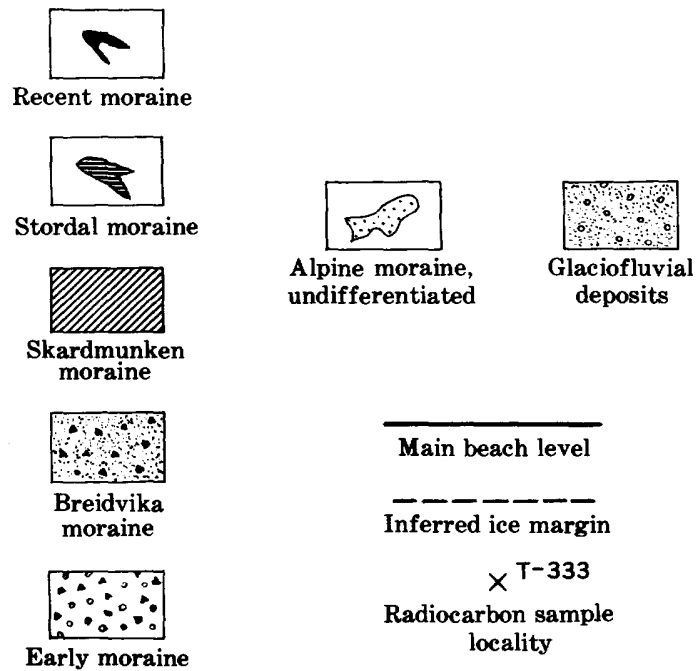

Figu RE 154.1.-Continued

Skardmunken glaciation, between 11,500 and 10,390 years B.P., according to radiocarbon dates. Some moraines in the mountains are not clearly related to datable features and are designated only as alpine moraines, undifferentiated.

\section{SHORELINES}

Elevated, tilted Pleistocene shorelines in northern Norway were first recognized by Bravais in 1838 (Marthinussen, 1960, p. 416) in Altafjord, about 100 kilometers east of IIllsfjord. Their discovery created a basis for the theory of isostatic recovery of glaciated terrain. These shorelines were formed at times when sea level was nearly constant, which in late Pleistocene time probably corresponded to intervals when the sea and the land were rising at the same rate.

The most distinet shoreline in Ullsfjord is informally named the "main beach level." It is nearly continuous from the outer fiord, where it is about 35 meters above sea level, to a few kilometers south of Skardmunken, where it is about 70 meters above sea level. The "main beach level" is cut in bedrock, older moraines, marine till, and gravel deposits. It is about the same age as the Skardmunken moraine, for (1) it is graded to the top of that moraine at about the level that separates the terrestrial and marine portions; (2) it is graded to extensive Skardmunken outwash deposits west of Breidvika; and (3) it does not extend far beyond the Skardmunken moraine, indicating that ice of this advance filled the inner fiord while the shoreline was being cut.

Shorelines related to other glaciations are limited in extent, and are marked primarily by deltas. Sea level was probably changing too rapidly during these in- tervals to create a persistent shoreline. A distinct lower shoreline formed after the "main beach level," but it apparently is not related to a glacial advance and merely represents a second period of sea-level stability.

\section{Early glaciation}

\section{GLACIATION}

The oldest recorded glaciation left scattered erratics, patches of till, a few indistinct moraines, and drainage channels in the northern part of the fiord district. The most distinct feature is a broad moraine that dams Trollvann in the northwestern part of the mapped area. The ice sheet that deposited this drift probably extended north of the present shoreline and covered the continental shelf. The age of this glaciation is not known, but the drift occupies a position analogous to that of the Lista substage, of Oldest Dryas age (more than 13,000 years old), or the Spangereid substage (dated about 13,000 years B.P.) (Andersen, report in preparation).

\section{Breidvika glaciation}

The oldest glaciation in Ullsfjord which left large well-preserved moraines is here named informally the Breidvika advance, for the cove on the west side of the fiord. The largest Fennoscandian outlet glacier moved northward and terminated in the sea just south of Breidvika, leaving a prominent lateral moraine on the east side of the fiord and a small segment on the steeper west side. Profiles of the lateral moraine on the east side of the fiord (fig. 154.2) show that the ice sloped steeply toward its terminus in the fiord.

Echo soundings show a very sharp double ridge (fig. 154.2) on the fiord bottom with a relief of approximately 38 meters. A western arm of this glacier pushed westward out of the fiord, turned north, entered a parallel valley, and deposited a prominent terrestrial end moraine.

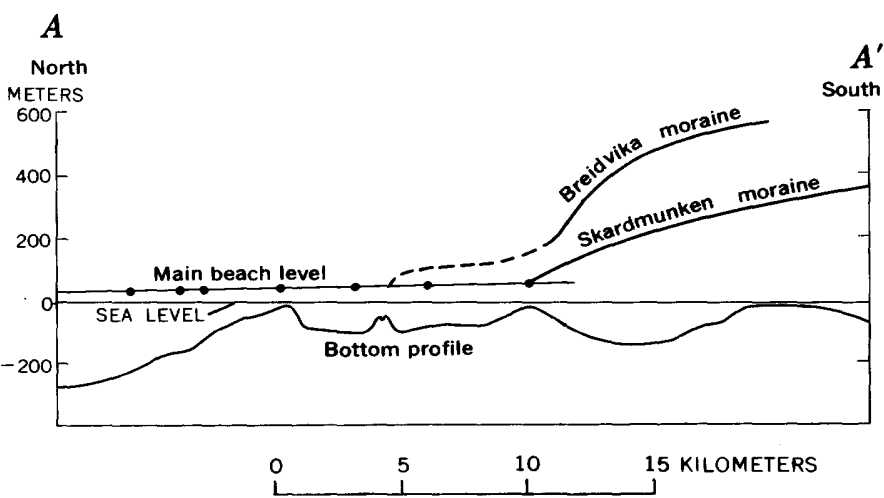

FiguRe 154.2.- Profiles of prominent moraines, shorelines, and submarine ridges in the main part of Ullsfjord. Large dots are projections of points on the shores where the "main beach level" was measured. Location of profile shown in figure 154.1. 
A second large glacier moved westward from Lyngenfjord (east of the mapped area) and the Lyngen Alps down the east arm of the fiord, leaving a smaller pair of lateral ridges and a submarine ridge with a maximum relief of approximately 45 meters (fig. 154.1). The echo profile of this ridge shows many smaller ridges on the east (upglacier) side, but not a sharp reverse slope in that direction.

The age of the Breidvika glaciation is not known. Its moraines appear to be only a little older than the succeeding (Skardmunken) glaciation, and related shorelines are only 2 to 4 meters above the "main beach level," which is roughly the same age as the Skardmunken glaciation. Also, the Breidvika moraines occupy positions analogous to the Skarpnes moraine near Troms $\varnothing$ to the west, which is regarded to be somewhat older than Younger Dryas (Andersen, report in preparation), that is, the age of the Skardmunken glaciation.

\section{Skardmunken glaciation}

The best preserved moraine in Ullsfjord is here named informally for the settlement on the terminal section. This part of the moraine was deposited in the sea and consists of stratified drift displaying foreset bedding which was smoothly planed by subsequent wave action. The submarine part is a smooth ridge crossing the fiord; it is being reworked by strong tidal currents.

The terminal section merges with a large terrestrial lateral moraine on the east side of the fiord. This lateral moraine, which in places branches into several ridges, extends southward for a distance of about 9 kilometers. The glacier that formed this moraine also pushed into the valley joining the fiord on the west. However, ice of this glaciation did not leave a clear record in the east arm of the fiord. A terrestrial moraine of this glaciation was also deposited in the broad trough west of Breidvika by ice which moved from adjoining Balsfjord. Glaciofluvial deposits spread down the valley from this moraine and merged with the "main beach level" along the shores of Ullsfjord.

A minimum and probably close radiocarbon date of 10,390 years B.P. ('T-333, Trondheim Radiological Dating Laboratory, 1962) for the Skardmunken moraine was obtained from mollusk shells (Macoma calcarea(?), Saxicava arctica(?), and Mya truncata(?)). The shells were collected from varved north-dipping sandy marine clay on the proximal side of the end moraine, lying about 30 to 40 meters above sea level and overiying coarse stratified south-dipping drift. The date probably corresponds to the beginning of the retreat of the Skardmunken glacier.
Shells of Portlandia arctica and Macoma calcarea ( $\mathrm{T}-110)$ collected near the top of pebbly glaciomarine clay beds which underlie outwash of Skardmunken age in the valley west of Breidvika (fig. 154.1) were dated at $11,500 \pm 400$ years B.P. The lithology and date of the shell-bearing material suggest it was deposited in a glacial en vironment immediately before the maximum of the Skardmunken advance.

Marine till on the east side of Ullsfjord opposite Breidvika, although not demonstrably related to the Skardmunken moraine, is somewhat younger than the glaciomarine clay west of Breidvika. Shells in the former (Saxicava arctica, Macoma calcarea, and Mya truncata, T-232) have a radiocarbon date of 11,090土 190 years B.P. On the basis of the first two dates, the Skardmunken advance occurred between about 11,500 and 10,390 years B.P., or at approximately the same time as the Tromsø-Lyngen maximum in adjoining fiords (Andersen, report in preparation). These dates span late Allerød and Younger Dryas time in southern Scandinavia (Flint, 1957, p. 397).

\section{Stordal glaciation}

Distinct end moraines occur behind Skardmunken moraines in several valleys, in some places in groups of two or more; none are associated with present glaciers. These minor readvances are here named informally for Stordal, a tributary valley on the west side of the inner fiord. Here is a small but distinct end moraine, at an elevation of about 70 meters, well below the projected level of the Skardmunken glacier and at about the same level as the oldest elevated shoreline in the inner part of the fiord. Similar moraines occur behind terrace-dated Skardmunken moraines in the northeastern corner of the mapped area. The outwash delta from the type Stordal moraine, graded to the oldest elevated marine terrace in the inner part of the fiord, is only about 5 meters below the "main beach level." Thus this advance occurred shortly after the Skardmunken glaciation and is possibly Pre-Boreal in age.

\section{Recent glaciation}

Nearly all the existing glaciers are fronted by small, steep, bouldery, unweathered moraines. These are similar to modern moraines found in most alpine environments throughout the Northern Hemisphere. Although it is generally held that Recent moraines are not necessarily of precisely the same age, those in northern Scandinavia probably formed in the 18th century, as suggested by historical records in Norway (Liestøl, 1960, p. 487). 


\section{REFERENCES}

Flint, R. F., 1957, Glacial and Pleistocene geology: New York, John Wiley and Sons, $553 \mathrm{p}$.

Hansen, S. W., 1960, The Climate, in Vorren, Ø., ed., Norway north of 65: Oslo, Oslo University Press, $271 \mathrm{p}$

Haurwitz, B., and Austin, J. M., 1944, Climatology: New York, McGraw-Hill, $410 \mathrm{p}$.
Liestøl, O., 1960, Glaciers of the present day, in Holtedahl, O. Geology of Norway: Norges Geol. Undersökelse, no. 208, $540 \mathrm{p}$.

Marthinussen, M., 1960, Coast and fjord area of Finnmark, in Holtedahl, O., Geology of Norway: Norges Geol. Undersökelse, no. 208, 540 p. 


\title{
Article 155
}

\section{EFFLUENT COLLECTOR FOR GAS CHROMATOGRAPHY}

\author{
By DONALD F. GOERLITZ and WILLIAM L. LAMAR, \\ Menlo Park, Calif.
}

\begin{abstract}
The authors have designed a convenient effluent collector for gas chromatographic samples. This collector eliminates contamination of one component by another as well as contamination from other sources. The collector provides an individually complete assembly for each component, it pockets and magnifies the sample, and it has its own heat sink. Importantly, the sample is collected close to the end of the analytical column.
\end{abstract}

Gas chromatography is being used increasingly for the analysis of volatile organic compounds and of those substances that can be made volatile. However, the collection of pure fractions of gas chromatographic samples from analytical columns presents a problem, particularly where several close-boiling components are involved. Contamination of one component by another can occur readily in the effluent line and at the exit port. The effluent line can also serve as a condensation chamber in which the column substrate may accumulate.

Although several types of collectors are described in the literature (Grasselli and Snavely, 1962; Hajra and Radin, 1962; Haslam and others, 1961; and Lesser, 1959), all the collectors examined used the existing effluent line and exit port. Some collectors provided excellent trapping, but all were deficient in preventing contamination of one component by another.

To avoid contamination of gas chromatographic samples, the samples must be collected at or near the the end of the analytical column and not at a common exit port supplied by a common effluent line. The collector should pocket the sample so that it can be readily withdrawn by a hypodermic needle. The collector should be relatively inexpensive, easily handled, individually cooled, and conveniently sealed from atmospheric moisture and coolant-bath vapor before and after collection.

An especially designed collector that embodies these principles is shown in figure 155.1. The admission

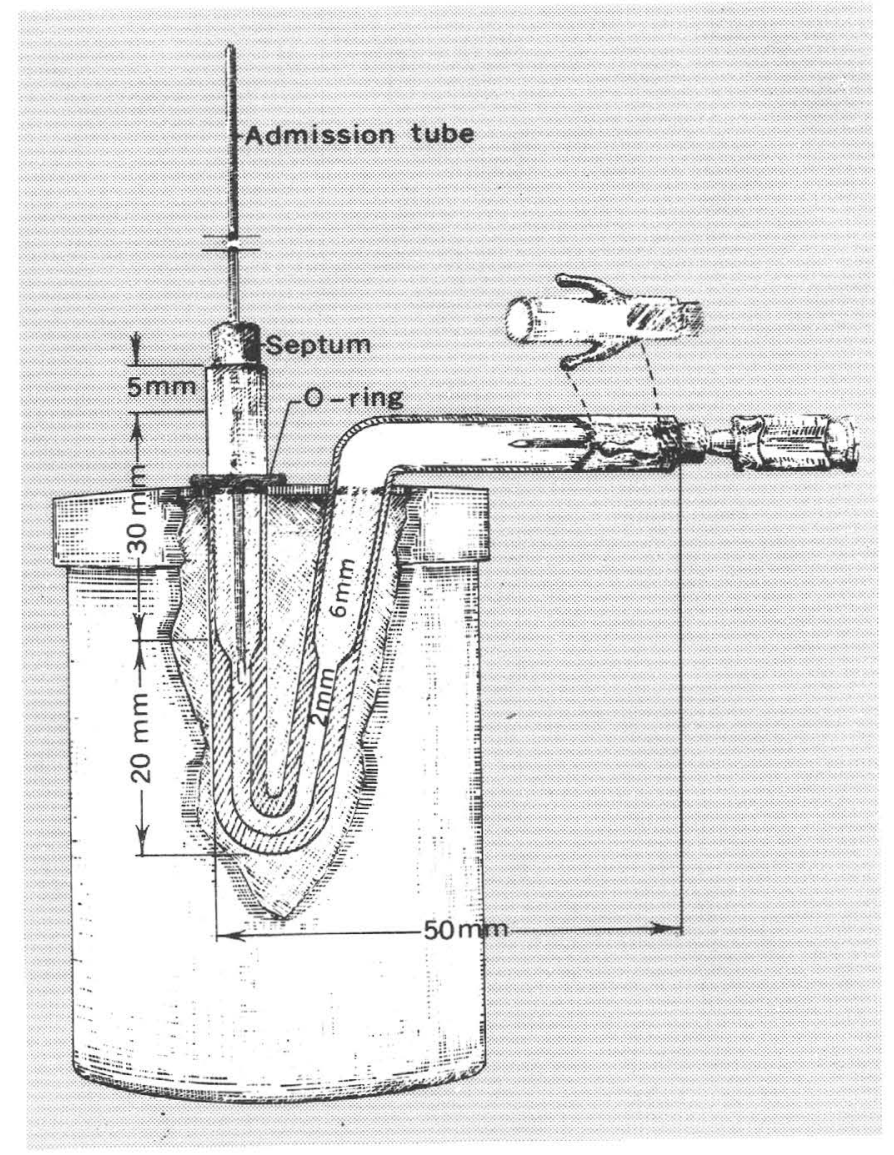

FigURE 155.1.-Effluent collector.

tube is 18-gage stainless-steel hypodermic tubing; it has a 17-degree bent point on one end and a square cut on the other. The part of the admission tube that extends beyond the rubber septum should be just less than the length of the common effluent line, so that when the tube is inserted, the septum will seal the exit port. Before and after use, the end of the admission tube can be sealed with an inverted septum if desired. 
The carrier gas is vented through a hypodermic needle that is inserted in the discharge arm of the collector. The silicone-rubber septums are the standard halfdrilled type that fit 6 -mm ID tubing. The coolantbath holder for each collector consists of a snap-on-cap polyethylene container $1 \frac{1}{2}$ inches in diameter by $2 \frac{1}{4}$ inches high. Two holes and a connecting slit were made in each cap. An O-ring cut from rubber tubing positions the collector in the coolant-bath holder.

The admission tube may be placed in the horizontal or vertical arm of the collector, depending upon the access to the detector vent. In order to reach the detector vent with an admission tube, the gas chromatograph must have a sufficiently straight common effluent line. In some gas chromatographs the end of the column is at the bottom of the instrument and the common effluent line is arranged so that it is not possible to reach the detector vent with an admission tube. However, these gas chromatographs can be modified so that the components can be collected from the bottom of the instrument.

For example, a Perkin-Elmer Model 154-D gas chromatograph was modified by drilling a $5 / 8$-inch hole in the bottom of the oven cabinet. The hole was alined with the exit "tee" of the detector so that a 4-inch length of straight $1 / 8$-inch stainless-steel tubing attached to the exit "tee" just protruded outside the oven chamber. A $1 \frac{3 / 4}{4}$-inch length of $1 / 2$-inch copper tubing was inserted and crimped to line the hole and keep the insulation in place. The exit end of the $1 / 3$-inch stainlesssteel tube was fashioned so that the entry was conical, to facilitate insertion of the admission tube. The inside of the exit tube was polished to a smooth finish with emery powder on a cotton-swab stick. The upstream end of the tube was swaged to the detector-outlet "tee." Access to the new exit port was made by supporting the gas chromatograph cabinet on a frame. The original effluent line was removed.

\section{EFFLUENT COLLECTION PROCEDURE}

The collection apparatus is assembled and a suitable coolant is placed into the coolant receptacle. A sample is injected into the gas chromatograph, and just before the desired component emerges, the admission tube of the collector is started into the exit port of the chromatograph. At the time the recorder indicates the emergence of the component, the admission tube is inserted all the way to the rubber septum and held firmly in place. The uncontaminated component in the carrier gas passes through the individual admission tube and is condensed in the pocket of the glass collector. During waiting periods, the collectors and bath holders may be kept in a flat pan of crushed ice or on a slab of dry ice.

\section{EXPERIMENTAL RESULTS}

Methyl caproate was selected to demonstrate the suitability of the apparatus for collecting components with comparatively low boiling points, and the dimethyl esters of fumaric and malonic acids were used to show the effectiveness of the apparatus for the separate collection of two partially overlapping compounds.

A 20-microliter sample containing $0.00023 \mathrm{~g}$ of methyl caproate in absolute methanol was injected into the gas chromatograph. Collection of the sample was begun when the recorder pen left the base line and ended when the pen returned to the line. The collected sample was transferred from the collector to a microcavity cell $(0.2-0.3 \mu \mathrm{l}$ minimum volume) with a total of $5 \mu \mathrm{l}$ of carbon disulfide by using a microliter syringe. Infrared analysis was made after the solvent was evaporated down to about $1 \mu \mathrm{l}$ under the gentle heat of an infrared heat lamp. Evaporation was halted by closing the cell with a drop of mercury. Another infrared scan was made after replacing the carbon disulfide with carbon tetrachloride by dilution and evaporation. $A \times 4$ infrared beam condenser was used for these analyses.

A 20- $\mu$ l aliquot of a solution containing $0.0124 \mathrm{~g}$ of dimethyl malonate and $0.0119 \mathrm{~g}$ of dimethyl fumarate in $1.00 \mathrm{ml}$ of absolute methanol was injected into the gas chromatograph. As shown in figure 155.2 the resulting chromatograph is a good example of closely eluting, partially overlapping compounds. The collections were timed to eliminate the unseparated part of the elution. The overlapping part, comprising 20 percent of the dimethyl malonate and 40 percent of the dimethyl fumarate, was discarded by venting. The infrared spectrum of each of these components was obtained as described in the preceding paragraph except that only carbon tetrachloride was used with dimethyl fumarate. In addition, the dimethyl fumarate was collected for infrared analysis by the potassium bromide micropellet technique.

\section{RESULTS AND DISCUSSION}

Each component eluted by the gas chromatograph is collected close to the end of the analytical column in an individually complete assembly. An excellent infrared spectrum for methyl caproate was obtained from a single collection of an injection of only $0.00023 \mathrm{~g}$ of the ester. This demonstrated the application of this apparatus for the collection of components with comparatively low boiling points. 


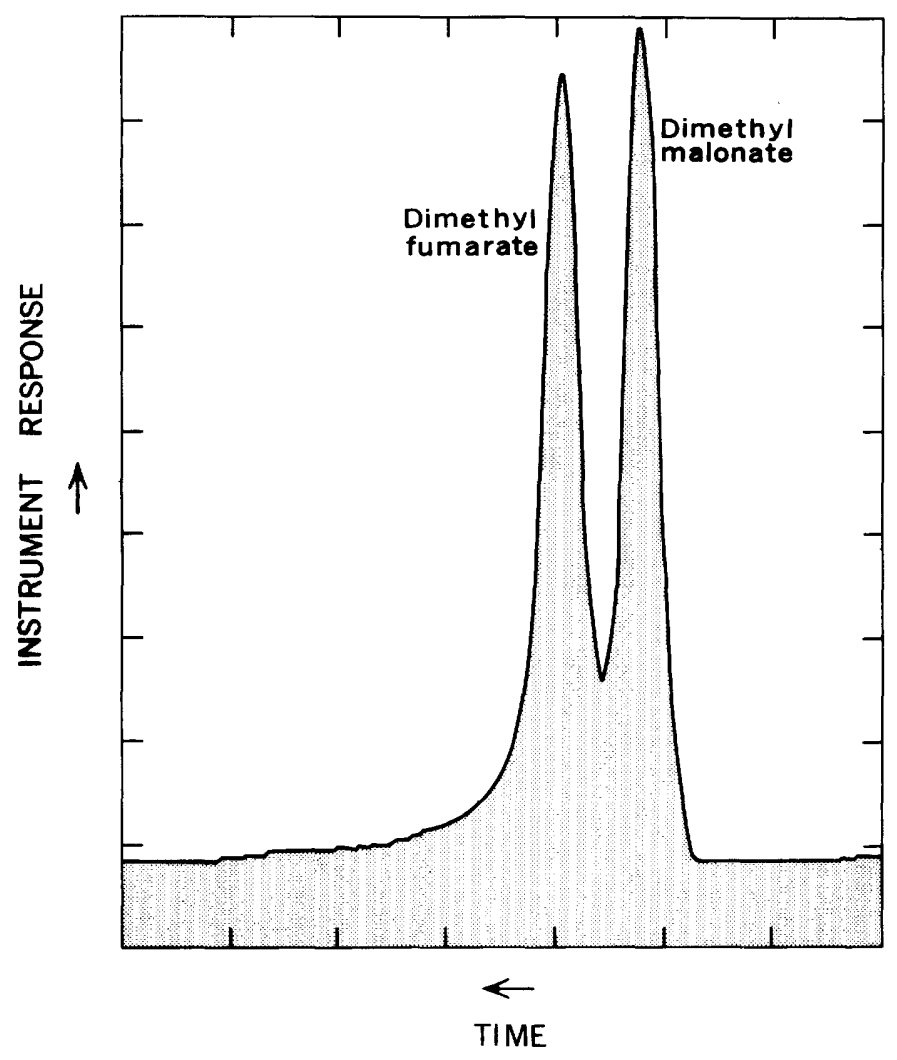

Figure 155.2.-Chromatograph of overlapping compounds.

A separate collection of closely eluting and partially overlapping components was equally successful as demonstrated by the injection of a sample containing dimethyl malonate and dimethyl fumarate. Two injections were required because it was necessary to vent the overlapping part of the elution. Each of the 2 injections contained $0.00025 \mathrm{~g}$ of dimethyl malonate and $0.00024 \mathrm{~g}$ of dimethyl fumarate. From these injections, each component was collected separately and placed in a microcavity cell for infrared analysis. No contamination of one of these esters by the other could be observed in the infrared spectra.
To test another handling technique, two collections of dimethyl fumarate were pressed in a micropellet of potassium bromide. Again, no contamination of this ester was observed in the infrared spectrum that was obtained with a $\times 4$ beam condenser and $\times 5$ scale expansion.

An important feature of the apparatus described here is the completely individual system for the collection of each component very near the end of the column. Thus, contamination of one component by another as well as contamination from condensation of column substrate can be eliminated. This collector has several other distinct advantages. For example, the condensing surface can be easily washed with a small amount of solvent, and the thickened glass section magnifies and pockets the collected material. The collector can be completely sealed during cool-down or waiting periods, thus avoiding contamination by atmospheric moisture and cold-bath solvents. The collector is always maintained in its own heat sink that will not warm up before the collection is completed.

This collector also enhances a collection and reinjection technique developed by the authors. With this technique the components are individually collected and reinjected into a different gas chromatographic column to obtain two characteristic retention volumes for each component. This provides a salient advantage in the identification and confirmation of the organic components in a sample.

\section{REFERENCES}

Grasselli, J. G., and Snavely, M. K., 1962, Analysis of organic reaction products by combined infrared-gas chromatography techniques: Appl. Spectroscopy, v. 16, p. 190-194.

Hajra, A. K., and Radin,. N. S., 1962, Collection of gas-liquid chromatographic effluents: Lipid Research Jour., v. 3, p. 131-134.

Haslam, J., Jeffs, A. R., and Willis, H. A., 1961, Applications of gas-liquid chromatography: Analyst, v. 86, p. 44-53.

Lesser, J. M., 1959, Device for isolation of components separated by gas chromatography: Anal. Chemistry, v. 31, p. 484. 


\title{
USE OF SODIUM-SENSITIVE GLASS ELECTRODES FOR SOLUBILITY DETERMINATIONS
}

\author{
By A. H. TRUESDELL and C. L. CHRIST, Washington, D.C.
}

\begin{abstract}
A method applicable to concentrated solutions is described for converting activities, measured by cation-sensitive glass electrodes, to concentrations. The usual difficulty oi assigning accurate values to activity coefficients is avoided by the use of a dilution technique. The method is applied to the determinations of the solubilities of borax, ulexite, and sodium chloride.
\end{abstract}

Following the initial discovery by Eisenman and others (1957) of practical sodium- and potassiumsensitive glasses, Garrels and others (1962) developed glasses specifically sensitive to divalent cations $\left(\mathrm{Ca}^{+2}\right.$, $\left.\mathrm{Mg}^{+2}, \mathrm{Ba}^{+2}, \mathrm{Sr}^{+2}\right)$. An electrode fashioned from one of these glasses offers a convenient and rapid means of directly measuring cationic activity (conventionally defined), or of indirectly measuring concentration in aqueous solution.

Although only the sodium-sensitive electrode was used to measure the solubilities of sodium salts, the same procedure could be used for any salt containing a cation for which an electrode having the proper response is available, for example, potassium or ammonium salts, or the alkaline-earth salts. Similarly, the solubility of a given salt in the presence of any ionic medium not affording a common cation could be determined.

In general, the conversion of a measured ionic activity $\left(a_{i}\right)$ to a concentration $\left(c_{i}\right)$ requires the use of an accurate value of the appropriate ionic-activity coefficient $\left(\gamma_{i}\right)$, where $c_{i}=a_{i} / \gamma_{i}$. The activity coefficient depends upon the total ionic strength of the solution. In saturated solutions of many readily soluble salts, such as the sodium borates, the concentration, and hence the ionic strength $(I)$ is high, and the cation is complexed in an unknown way. As a result, there is no way to assign accurate values of cation-activity coefficients. We have evolved a technique that bypasses this difficulty. This technique involves making cationactivity measurements on successive ten-fold dilutions of a saturated solution of the salt whose solubility is to be measured. When the solution becomes very dilute, this fact is revealed by its electrochemical behavior. Because the solution is very dilute and any complexing will be vanishingly small, the cation-activity coefficient can be calculated from the Debye-Hückel equation. The concentration of this dilute solution can be calculated, and because the number of dilutions is known, the original concentration can then be established.

Using a sodium-sensitive electrode we have determined the solubilities of borax (at $25^{\circ} \mathrm{C}$ and $40^{\circ} \mathrm{C}$ ), ulexite (at $25^{\circ} \mathrm{C}$, incongruent solution), and sodium chloride (at $25^{\circ} \mathrm{C}$ ). The values determined by the present method are in excellent agreement with those determined by conventional methods, as shown in table 156.1.

\section{PROCEDURE AND THEORETICAL BASIS}

The sodium-sensitive electrode used in this work was the Electronics Instruments Laboratory model $\mathrm{Na}$ GNA 23. This electrode was paired with a saturated$\mathrm{KCl}$ calomel reference electrode (wick type), and the developed potential was measured with a vibrating capacitor high-impedance electrometer, and a potentiometer. Potential measurements were made on solutions maintained at $25^{\circ} \mathrm{C} \pm 0.05^{\circ} \mathrm{C}$ in a constanttemperature bath and stirred with a magnetic stirrer. The voltage measurements were generally accurate to $\pm 0.1 \mathrm{mV}$, with an occasional reading doubtful to \pm 0.2 $\mathrm{mV}$. Because the electrode is also sensitive to hydrogen ions, $\mathrm{pH}$ must be maintained $\geq 7$; at sodium-ion concentrations below about $10^{-4} \mathrm{~m}$ (molal), the hydrogen-ion response of the electrode introduces error. The usual precautions were maintained with regard to adequate electrical shielding in working with the high resistance glass electrode (Mattock, 1961). The electrode was conditioned by soaking for several days in $0.1 \mathrm{~m} \mathrm{NaCl}$ solution. 
TABLE 156.1.-Values of solubilities of sodium chloride, borax, and the sodium-ion concentration resulting from the incongruent solution of ulexite, determined by Na-sensitive electrode, compared with literature values ${ }^{1}$

\begin{tabular}{c|c|c|c|c}
\hline \multicolumn{3}{|c|}{ This study } & \multicolumn{2}{c}{ Literature } \\
\hline$f^{2}$ & $\mathbf{M}^{3}$ & $\begin{array}{c}\text { Weight } \\
\text { percentage 4 4 }\end{array}$ & $\begin{array}{c}\text { Weight } \\
\text { percentage 4 }\end{array}$ & Reference \\
\hline
\end{tabular}

\begin{tabular}{|c|c|c|c|c|}
\hline \multicolumn{5}{|c|}{ Sodium chloride, $25^{\circ} \mathbf{C}$} \\
\hline & \multirow{3}{*}{$\begin{array}{l}5.40 \\
5.41\end{array}$} & \multirow{3}{*}{$\begin{array}{l}26.4 \\
26.4 \\
27.0 \\
26.5\end{array}$} & \multirow{3}{*}{26.48} & Gillespie (1928, p. 105). \\
\hline 4. 62 & & & & $\begin{array}{l}\text { Density }=1.1978 \mathrm{~g} / \mathrm{cm}^{3} \\
\quad \text { (Gillspie, 1928, p. 105) }\end{array}$ \\
\hline 4. 53 & & & & \\
\hline
\end{tabular}

\begin{tabular}{|c|c|c|c|c|}
\hline \multicolumn{5}{|c|}{ Borax (as $\left.\mathrm{Na}_{2} \mathrm{~B}_{4} \mathrm{O}_{7}\right), 25^{\circ} \mathrm{C}$} \\
\hline $\begin{array}{ll}0 . & 151 \\
0 & 150\end{array}$ & & 3.04 & 3. 06 & Menzel and Schulz (1940) \\
\hline 0.152 & -- & $\begin{array}{l}\text { 3. } 05 \\
\text { 3. } 05\end{array}$ & 3.13 & $\begin{array}{l}\text { Blasdale and Slansky } \\
\text { (1939). }\end{array}$ \\
\hline
\end{tabular}

Borax $\left(\right.$ as $\left.\mathrm{Na}_{2} \mathrm{~B}_{4} \mathrm{O}_{7}\right), 40^{\circ} \mathrm{C}$

\begin{tabular}{l|l|l|l|l}
\hline 0.308 & $\ldots .20$ & 6.00 & $\begin{array}{c}\text { Menzel and Schulz (1940), } \\
\text { and Blasdale and Slan- } \\
\text { sky. (1939). }\end{array}$ \\
\hline
\end{tabular}

Ulexite $\left(\mathrm{as} \mathrm{NaCaB}_{5} \mathrm{O}_{9}\right), 25^{\circ} \mathrm{C}$

\begin{tabular}{l|r|r|r|}
\hline & 0.0187 & ${ }^{5} 0.49$ & \\
0.0186 & 0.49 & $\ldots$ & \\
\hline
\end{tabular}

1 The accuracy of the experimental results is best judged by internal consistency, and by comparison with the literature values. The limiting precision is determined by the $\pm 0.1 \mathrm{~m} V$ reproducibility of the voltage measurements; an error of $0.1 \mathrm{mV}$ leads to an error of about 0.4 percent in the solubility determination.

2 Weight dilution method.

4 Grams of solute per $100 \mathrm{~g}$ of solution.

$s$ Incongruent solution; only sodium-ion concentration measured.

The potential of the cell, $E$, is given by a Nernst-type equation

$$
E(\text { volts })=E^{\prime}+(R T / \mathscr{f}) \ln \left[\mathrm{Na}^{+1}\right],
$$

where $R, T$, and $\mathscr{F}$ have their usual significance. $E^{\prime}$ is a constant voltage and includes any liquid junction potential. $E^{\prime}$ has the value $E$ at unit activity of sodium ion, $\left[\mathrm{Na}^{+1}\right]=1$. At $25^{\circ} \mathrm{C}$, equation 1 becomes

$$
E=E^{\prime}+0.0592 \log \left[\mathrm{Na}^{+1}\right] .
$$

In practice, $E^{\prime}$ is not evaluated, but rather the difference in potential of the cell is determined with the unknown solution and with a solution whose sodium ion activity is known. This procedure minimizes the uncertainty due to the liquid-junction potential. From equation 2 we obtain the following operational equation:

or

$$
E_{x}-E_{s}=0.0592\left(\log \left[\mathrm{Na}^{+1}\right]_{x}-\log \left[\mathrm{Na}^{+1}\right]_{s}\right),
$$

$$
E_{x}-E_{s}=0.0592\left(p \mathrm{Na}_{s}-p \mathrm{Na}_{x}\right)
$$

where $x=$ unknown and $s=$ standard. Equation 4 is of exactly the same form as the one on which the measurement of $\mathrm{pH}$ is based (Bates, 1954).

The Na GNA 23 electrode was checked against a series of standard $\mathrm{NaCl}$ solutions $\left(1 \mathrm{~m}\right.$ to $10^{-4} \mathrm{~m}$ ), and found to have exactly the theoretical slope predicted by equation 4 , namely

$$
d E_{s} / d p \mathrm{Na}_{s}=0.0592 \text { volts. }
$$

The sodium molality of each standard solution was converted to sodium activity by the relation

$$
\left[\mathrm{Na}^{+1}\right]=\gamma_{\mathrm{Na}}+1 \times m_{\mathrm{Na}}+1,
$$

where the activity coefficient $\gamma_{\mathrm{Na}}+1$ was obtained by the "mean-salt" method (Garrels, 1960), in which

$$
\gamma_{\mathrm{Na}}+1=\gamma_{ \pm \mathrm{NaCl}}^{2} / \gamma_{ \pm \mathrm{KCl}}
$$

for ionic strength $I \geq 0.1$, and by the Debye-Hückel equation for $I<0.1$ (Klotz, 1950, p. 329). Values of $\gamma_{ \pm \mathrm{KCl}}$ and $\gamma_{ \pm \mathrm{NaCl}}$ were taken from Lewis and Randall (rev. ed., 1961, p. 643), and Robinson and Stokes (1959, p. 492), respectively.

The standard solution used in a given determination was either $0.1 \mathrm{~m} \mathrm{NaCl}$, with $\gamma_{\mathrm{Na}}+1=0.79$ (mean-salt), $p \mathrm{Na}=1.10_{2}$; or $0.01 \mathrm{~m} \mathrm{NaCl}$ with $\gamma_{\mathrm{Na}}+1=0.902$ (DebyeHückel), $p \mathrm{Na}=2.04_{5}$, or both. It was found that the solubility determinations were completely consistent with both of these single-ion activity coefficients, which attests to the validity of their value in practical problems.

Saturated solutions of the salts were prepared by shaking the solutions in contact with excess solids, over a period of about 3 weeks. One method of doing this was to impart mechanically a rocking motion to a 125-ml rubber-stoppered flask containing solution plus solid, in a constant-temperature bath maintained at $\pm 1^{\circ} \mathrm{C}$. In a second method the solution plus solids, contained in $125-\mathrm{ml}$ Teflon bottles, were immersed in a constant-temperature bath held at $\pm 0.1^{\circ} \mathrm{C}$; the bottles were removed twice daily and vigorously shaken by hand. In the case of the mechanically shaken system, the grain size of the excess $\mathrm{NaCl}$ was sufficiently large that the supernatant liquid could be sampled directly with a pipet; this was not true with the less soluble borax and ulexite. In those experiments in which the bottles were shaken by hand all the solids remained finely crystalline, and the liquid was drawn by suction through a coarse-frit filter in order to remove small crystals.

As previously stated, the voltage measurements were all made at $25^{\circ} \mathrm{C}$. For the $25^{\circ} \mathrm{C}$ solubility measurements, the potential of the cell was measured with the 
saturated solution as the test solution. Following this, in one set of experiments, a $10-\mathrm{ml}$ portion of the saturated solution was delivered to a calibrated $100-\mathrm{ml}$ volumetric flask by means of a calibrated pipet, and diluted to $100 \mathrm{ml}$; the potential of this solution was then measured. This procedure was repeated stepwise to and including the $1: 1,000$ dilution.

The volume-dilution procedure leads to concentrations in units of molarity ( $M$, moles of solute per 1,000 $\mathrm{ml}$ solution). In a second set of experiments a weightdilution technique was employed; this technique leads to concentrations in units of formality $(f$, moles of solute per 1,000 solution). Whether volume dilution or weight dilution was used in a particular determination is indicated in table 156.1.

There is an internal formal inconsistency in the calculations because the values of the activity coefficients employed are based on the molal scale $(m$, moles of solute per $1,000 \mathrm{~g}$ solvent). However, for $\gamma_{\mathrm{Na}}+1$ values from the mean-salt method, and especially for $\gamma_{\mathrm{Na}}+1$ values calculated by the Debye-Hückel method for the very dilute range, any changes resulting from a change in scale from molal to molar or formal would be outside the limits of error of the method.

As the test solution becomes progressively dilute, with fewer sodium ions available to ensure stable equilibrium between the electrode surface and the solution, fluctuations in the voltage readings become larger. At the same time, the relative activity of hydrogen ions increases and the electrode begins to respond to these ions. For these reasons a decision must be made concerning the best dilution stage at which to calculate the concentration. This stage will depend upon the solubility of the salt, and will reveal itself through the magnitude of the measured activity. In general, it is best to use the highest concentration that shows the Nernst-type behavior of equation 2. In this study we choose the 1:1,000 dilution (of the saturated solution) of $\mathrm{NaCl}$, the $1: 100$ dilution of borax, and the $1: 10$ dilution of ulexite.

The tabulated values given by Klotz (1950, p. 332) for the Debye-Hückel equation

$$
-\log \gamma_{i}=\frac{A z^{2} I^{\frac{1}{2}}}{1+\mathrm{Ba}_{i} I^{\frac{1}{2}}}
$$

for $10^{8} a_{i}=4$, and for $25^{\circ} \mathrm{C}$, were used to construct a plot of $\gamma_{\mathrm{Na} a+1} v s .1$; values of $\gamma_{\mathrm{Na}^{+}+1}$ were read from this plot for the diluted solutions. The ionic strength, $I=\frac{1}{2} \sum_{i} m_{\imath} z_{i}^{2}$, must be evaluated differently for each substance, depending upon the charges of the anions assumed to be present to balance the $\mathrm{Na}^{+1}$. For $\mathrm{NaCl}, I=m_{\mathrm{Na}+1}$; for borax, in the absence of specific knowledge, it was assumed that each $\mathrm{Na}^{+1}$ is balanced by a singly charged borate anion (Ingri and others, 1957), so that here also $I=m_{\mathrm{Na}+1}$. Ulexite, $\mathrm{NaCaB}_{5} \mathrm{O}_{9} \cdot 8 \mathrm{H}_{2} \mathrm{O}$, in excess, in equilibrium with water at $25^{\circ} \mathrm{C}$, yields a $\mathrm{Na}$-rich borate solution and inyoite, $\mathrm{Ca}_{2} \mathrm{~B}_{6} \mathrm{O}_{11} \cdot 13 \mathrm{H}_{2} \mathrm{O}$ (Kurnakova and Nikolaev, 1948). Thus, the measurement here yields the sodium-ion concentration in equilibrium with excess ulexite and in the presence of inyoite. From the data of Kurnakova and Nikolaev (1948) on the $\mathrm{CaO}-\mathrm{B}_{2} \mathrm{O}_{3}-\mathrm{H}_{2} \mathrm{O}$ system, the solution in equilibrium with inyoite at $25^{\circ} \mathrm{C}$ is $1.32 \times 10^{-2} \mathrm{M}$ with respect to $\mathrm{Ca}^{+2}$. We assume as a rough guess that the presence of the common singly charged borate ion depresses this value to one-half in the case of the solution in equilibrium with both ulexite and inyoite, and calculate the ionic strength on this basis.

In all cases, in calculating $I$ it is first assumed that the measured activity is equal to the molality, and a provisional $\gamma_{i}$ found. This provisional $\gamma_{i}$ is divided into the activity to find the next approximation to the molality and a new $\gamma_{i}$ is looked up, following which a new molality is calculated (see table 156.2); in this work, only two stages of iteration were necessary. Fortunately, $\gamma_{i}$ changes relatively slowly as a function of $I$ over the dilute-solution region, so that no appreciable error results in the calculated concentration in those cases where $I$ cannot be evaluated precisely.

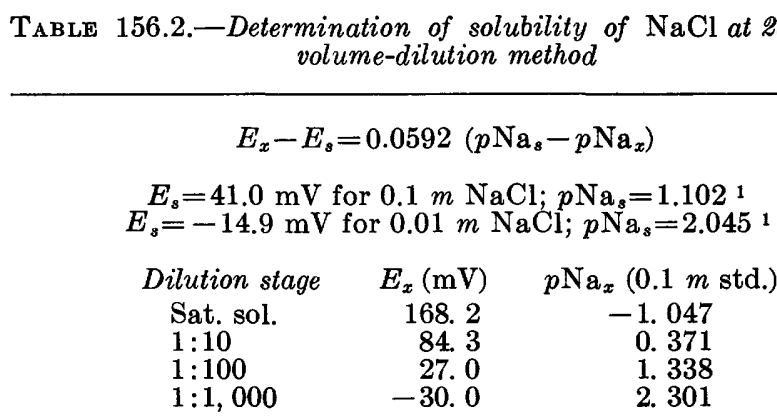

For the 1:1,000 dilution

or

$$
-p \mathrm{Na}_{x}=\frac{-30.0-41.0}{59.2}-1.102=-2.301
$$$$
p \mathrm{Na}_{x}=2.301
$$$$
-p \mathrm{Na}_{x}=\frac{-30.0+14.9}{59.2}-2.045=-2.300
$$$$
p \mathrm{Na}_{x}=2.300^{1}
$$

$\left[\mathrm{Na}^{+1}\right]=5.00 \times 10^{-3} ; \quad \gamma_{1}=0.927 ; \quad c_{1}=\left(5.00 \times 10^{-3}\right) /(0.927)=5.39$ $\times 10^{-3} ; \gamma_{2}=0.925 ; c_{2}=\left(5.00 \times 10^{-3}\right) /(0.925)=5.40 \times 10^{-3} ; M=5.40$

1 Third place after the decimal uncertain.

\section{RESULTS AND SUMMARY}

The final solubility values determined by the electrode method are listed in table 156.1. To show how the experimental procedure leads to a solubility value, 
the details of one determination on $\mathrm{NaCl}$ are given in summary form in table 156.2 .

The investigation reported upon here was an exploratory one only, and had as its sole purpose the testing of the principle of the method; no real attempt was made to achieve the best possible accuracy. It seems clear that this dilution technique can be used to measure solubilities with a fair degree of confidence, even with simple techniques. To measure accurately the solubility of a substance at an elevated temperature, a better technique than that employed by us of separating solids from liquid would be needed.

\section{REFERENCES}

Bates, R. G., 1954, Electrometric pH determinations: New York, John Wiley and Sons, Inc., 331 p.

Blasdale, W. C., and Slansky, C. M., 1939, The solubility curves of boric acid and the borates of sodium: Jour. Am. Chem. Soc., v. 61, p. 917-920.

Eisenman, George, Rudin, D. O., and Casby, J. U., 1957, Glass electrode for measuring sodium ion: Science, v. 126 p. 831-834.

Garrels, R. M., 1960, Mineral equilibria: New York, Harper and Brothers, $254 \mathrm{p}$.

Garrels, R. M., Sato, M., Thompson, M. E., and Truesdell,
A. H., 1962, Glass electrodes sensitive to divalent cations: Science, v. 135, p. 1045-1048.

Gillespie, L. J., ed., 1928, Density (specific gravity) and thermal expansion (under atmospheric pressure) of aqueous solutions of inorganic substance and of strong electrolytes, in Washburn, E. W., and others, eds., International critical tables of numerical data, physics, chemistry and technology: New York, McGraw-Hill Book Co., Inc., v. 3, p. 51-111.

Ingri, Nils, Langerström, G., Frydman, M., and Sillén, L. G., 1957, Equilibrium studies of polyanions. II. Polyborates in $\mathrm{NaClO}_{4}$ medium: Acta Chem. Scand., v. 11, p. 1034-1058.

Klotz, I. M., 1950, Chemical thermodynamics: Englewood Cliffs, N.J., Prentice-Hall, Inc., 369 p.

Kurnakova, A. G., and Nikolaev, A. V., 1948, The solubility isotherm of the system $\mathrm{Na}_{2} \mathrm{O}-\mathrm{CaO}-\mathrm{B}_{2} \mathrm{O}_{3}-\mathrm{H}_{2} \mathrm{O}$ at $25^{\circ}$ : Akad. Nauk. SSSR Izvestria, Otd. Khim. Nauk, no. 1, p. 377-382. [in Russian]

Lewis, G. N., and Randall, Merle, 1961, Thermodynamics; revised by K. S. Pitzer and L. Brewer: New York, McGrawHill Book Co., 723 p.

Mattock, G., 1961, pH measurement and titration: London, Heywood and Co., Ltd., $406 \mathrm{p}$.

Menzel, Heinrich, and Schulz, Hans, 1940, Zur Kenntnis der Borsaüren und borsauren Alkalisalze. X. Der Kernit (Rasorit) $\mathrm{Na}_{2} \mathrm{~B}_{4} \mathrm{O}_{7} .4 \mathrm{H}_{2} \mathrm{O}$ : Zeitschr. anorg. allg. Chem., v. 245 , p. $157-220$.

Robinson, R. A., and Stokes, R. H., 1959, Electrolyte solutions: London, Butterworths Sci. Pubs. 


\title{
SEMIMICRO X-RAY FLUORESCENCE ANALYSIS OF TEKTITES USING 50-MILLIGRAM SAMPLES
}

\author{
By HARRY J. ROSE, JR., FRANK CUTTITTA, MAXWELL K. CARRON, and \\ ROBENA BROWN, Washington, D.C.
}

\begin{abstract}
Semimicro determinations of the major constituents $\left(\mathrm{SiO}_{2}, \mathrm{Al}_{2} \mathrm{O}_{3}\right.$, total iron, $\mathrm{K}_{2} \mathrm{O}, \mathrm{CaO}, \mathrm{TiO}_{2}$, and $\mathrm{MnO}$ ) of tektites were made by $\mathrm{X}$-ray fluorescence spectroscopy using 50 -milligram samples. The X-ray analytical data are comparable to determinations obtained by conventional chemical techniques.
\end{abstract}

X-ray fluorescence spectroscopy has been applied to the determination of the major constituents in relatively large samples of materials of geologic interest (Rose and others, 1962,1963). This technique can also be used for the semimicro analysis of rare mineral specimens or of materials of astrogeologic interest where only very small quantities $(<100 \mathrm{mg}$ ) of material are available. The analysis of the light elements in tektites has been made possible by advances both in instrumentation and in techniques of sample preparation. It is well known that the intensity of the fluorescent radiation decreases sharply with a decrease in the atomic number $(Z)$ of the element being analyzed. This decrease can be attributed to many factors such as diminishing fluorescence yield and absorption of the fluorescent radiation by air, by the sample, by the diffracting crystal, and by the window of the detector. Additionally, as the radiation becomes softer with decreasing atomic number, the depth from which the excited radiation emerges becomes shallower and shallower. Thus the effective radiation involves only those atoms at or near the surface of the sample, a situation that demands precise and reproducible sample preparation.

The elimination of air from the spectrometer by either evacuation of the chamber or by flushing the chamber with helium provides the first necessary step to detecting the radiation. The use of supported thinfilm windows (Balis and others, 1962) on the detectors has resulted in higher intensities by reducing absorption by the window and has extended the useful range of the technique to wavelengths beyond 10 angstroms.

Accurate quantitative determination of the light elements depends primarily on sample preparation and ultimately on the surface of the specimen submitted to the X-ray beam. As mentioned above, the particles at or near the surface provide the effective signal for analysis. Infinite depth, the point beyond which no increase in signal can be observed regardless of increase in sample thickness, is reached for $\mathrm{CaO}$ in less than 100 microns and for $\mathrm{MgO}$ in less than $50 \mu$. It is evident, therefore, that the surface of the prepared specimen must be homogeneous and a true representation of all the layers beneath it.

Fusion of the sample in a mixture of $\mathrm{Li}_{2} \mathrm{~B}_{4} \mathrm{O}_{7}$ eliminates many of the problems inherent in the $\mathrm{X}$-ray fluorescence analysis of powdered samples (Andermann, 1961; Rose and others, 1962), especially those related to particle size and crystal structure. The presence of a strongly absorbing element minimizes absorption differences among samples resulting from variations in matrix, thus obviating the need for absorption corrections or for standards matching the composition of the material under study. $\quad \mathrm{La}_{2} \mathrm{O}_{3}$ was chosen because of its high absorption for the light elements.

The method described initially (Rose and others, 1962) required a 250-milligram sample. Although this amount is considerably less than the quantity used for routine chemical analysis, there are instances when smaller quantities must be analyzed. The effort here was directed toward reducing the sample size to 50 $\mathrm{mg}$ by determining the minimum layer of fused sample necessary to maintain the desired signal for the elements being analyzed. 


\section{X-RAY FLUORESCENCE METHOD}

The fusion mixture consists of $50 \mathrm{mg}$ of sample, 50 $\mathrm{mg} \mathrm{La}_{2} \mathrm{O}_{3}$, and $340 \mathrm{mg} \mathrm{Li}_{2} \mathrm{~B}_{4} \mathrm{O}_{7}$. The components are mixed in a boron carbide mortar, transferred to a graphite crucible having a cone-shaped internal base, and fused at $1,100^{\circ} \mathrm{C}$ for 10 minutes. The bead is allowed to cool in the graphite crucible. Cooling may be accomplished more rapidly by placing the crucible on a large copper plate, which dissipates the heat more readily. Sufficient boric acid is added to bring the weight to $460 \mathrm{mg}$. The boric acid compensates for any losses during ignition and acts as a binder during preparation of the pellet. The glass bead is then ground. The grinding vial consists of a lucite cylinder provided with two caps containing tungsten carbide inserts for covering both ends of the cylinder. The bead, which must be crushed before grinding, is placed cone side up in the grinding vial with one of the caps and inserts in place. A $1 / 2$-inch drive pin punch is placed down the cylinder on top of the bead and is then tapped with a hammer. The weighed boric acid is added to the vial along with a $1 / 4$-inch tungsten carbide ball, and the upper cap is placed on the cylinder. The sample is then ground on a mixer grinder for 10 minutes, which reduces the sample to about 325 mesh. The ground powder is then pressed into a pellet 1 inch in diameter. For additional strength the pellet is prepared as a double layer, using boric acid as backing (Rose and Flanagan, 1962). It is essential that the sample layer be spread uniformly on the surface of the boric acid before final pressure is applied. To obtain maximum intensity for $\mathrm{Si}$ and $\mathrm{Al}$, pressure in excess of 50,000 pounds per square inch must be used. The preparation of samples must be done consistently with attention to all details to insure the best results.

A single-channel spectrometer was used for this study. The types of crystals, wavelengths, and detectors are given in table 157.1. Because the fluorescent radiation of elements $Z \leq 22$ is absorbed by air, the spectrometer chamber is flushed with helium for the determination of these elements. It is generally necessary to flush the chamber for about 1 minute between sample changes to allow the system to come to equilibrium.

Granite G-1, diabase $W-1$, and an equal mixture of the granite and diabase are used as reference standards. National Bureau of Standards standard samples and other samples analyzed at the U.S. Geological Survey serve as additional reference materials to extend the range of the elements being determined. Several reference standards may be mixed in varying proportions to provide desired points on the calibration curve.

The method has been used recently to analyze six samples of tektites from Java supplied by E. C. T. Chao. The results of both chemical and X-ray fluorescence determinations are given in table 157.2.

\begin{tabular}{|c|c|c|c|c|}
\hline Element & $K(A)$ & Crystal & Detector or counter 1 & Path \\
\hline $\mathrm{Si}_{--}$ & 7. 125 & Gypsum. & Proportional. & $\mathrm{He}$ \\
\hline Al. ..... & 8. 337 & do & . . do do..... & $\mathrm{He}$ \\
\hline $\mathrm{Fe}_{\ldots} \ldots$ & 1. 936 & $\mathrm{LiF}^{2}$ - & Scintillation & Air \\
\hline $\mathrm{Ca}$. & 3. 358 & Eddt ${ }^{3}$ & Proportional & $\mathrm{He}$ \\
\hline K & 3. 741 & Gypsum & -... do & $\mathrm{He}$ \\
\hline $\mathrm{Mn}_{\ldots} \ldots \ldots$ & 2. 102 & $\mathrm{LiF}^{2}$ & Scintillation _. . _ & Air \\
\hline $\mathrm{Ti}_{\ldots} \ldots \ldots$ & 2. 748 & $\mathrm{LiF}^{2} \ldots \ldots$ & - do do & He \\
\hline
\end{tabular}

\section{CHEMICAL ANALYTICAL METHODS}

Six javanites were carefully selected from a collection of about 80 specimens to represent the range of the indices of refraction and specific gravities of the Java tektite collection. The specimens are listed in table 157.2 in order of increasing index of refraction. The tektites were analyzed for $\mathrm{SiO}_{2}, \mathrm{Al}_{2} \mathrm{O}_{3}$, total iron as

TABLE 157.2.-Comparison of chemical and X-ray analyses of 6 tektites from Java

[Index of refraction $(N)$ in sodium light; X-ray determination made on a single pellet]

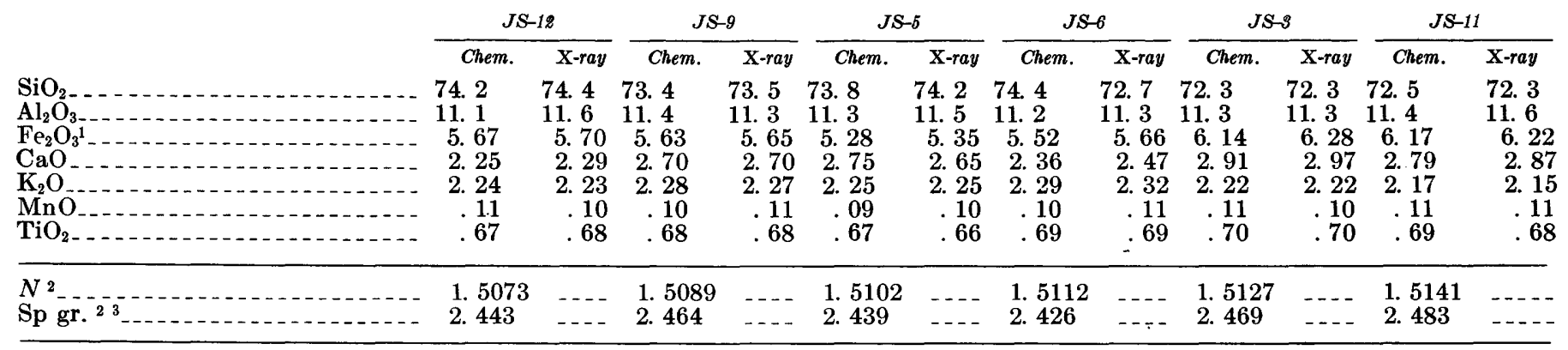

1 Total $\mathrm{Fe}$ as $\mathrm{Fe}_{2} \mathrm{O}_{3}$.

${ }^{2}$ By Janet Marteka and E. C. T. Chao.

${ }^{3}$ Third place after the decimal not certain. 
$\mathrm{Fe}_{2} \mathrm{O}_{3}, \mathrm{CaO}, \mathrm{K}_{2} \mathrm{O}, \mathrm{TiO}_{2}$, and $\mathrm{MnO}_{2}$. The chemical results are averages of duplicate determinations by the various methods. Using these different techniques, the chemical determinations were closely monitored by similar determinations in granite $\mathrm{G}-1$, diabase W-1, and selected National Bureau of Standards certified samples.

Silica was determined spectrophotometrically using a molybdenum-blue method (Bunting, 1944), gravimetrically by a volatilization-formaldehyde method described by Carron and Cuttitta (1962), and also by a combined gravimetric and photometric procedure (Jeffery and Wilson, 1960). Alumina $\left(\mathrm{Al}_{2} \mathrm{O}_{3}\right)$ was determined by measuring the absorbance of the calcium aluminum alizarin red-S complex in a weakly acidic medium ( $\mathrm{pH} \mathrm{4.5)}$ at $485 \mathrm{~m} \mu$ (Parker and Goddard, 1950). Interference from iron was eliminated by use of potassium ferricyanide and thioglycolic acid as complexing agents.

Total iron was determined spectrophotometrically with o-phenanthroline (Cuttitta, 1952, and Sandell, 1959 ) and by a magnetic-susceptibility method developed by Thorpe and others (1963). Calcium oxide was determined by flamephotometry (Kramer, 1957), and by a semimicro, automatic, photometric titration with EDTA in the $\mathrm{pH}$ range 12.1-12.3 at $590 \mathrm{~m} \mu$ using murexide as the indicator. Potassium oxide was determined flamephotometrically at $766 \mathrm{~m} \mu$ using an instrument with a photomultiplier attachment. The sample was analyzed by bracketing between the closest potassium standards (Ray, 1956; Willgallis, 1957; Voimovitch and Debras, 1958). Titanium was determined spectrophotometrically with disodium-1, 2-dihydroxybenzene-3, 5-disulfonate (tiron) (Yoe and Armstrong, 1947). The interference of iron was overcome by reduction with ascorbic acid at $\mathrm{pH}$ 4.7. The purple permanganate color was utilized for the spectrophotometric determination of manganese. The oxidation was effected with ammonium persulfate (peroxysulfate) at the boiling point in a phosphoric-nitric acid medium in the presence of silver nitrate. Manganese was also determined by Janet D. Fletcher using a quantitative spectrographic method similar to that described by Bastron and others (1960).

\section{REFERENCES}

Andermann, George, 1961, Improvements in the X-ray emission analysis of cement raw mix: Anal. Chemistry, v. 33, 16891695 .
Balis, E. W., Bronk, L. B., Pfeiffer, H. G., Welborn, W. W., Winslow, E. H., and Zemany, P. D., 1962, Improved components for the X-ray emission analysis of the light elements: Anal. Chemistry, v. 34, p. 1731-1733.

Bastron, H., Barnett, P. R., and Murata, K. J., 1960, Method for the quantitative spectrochemical analysis of rocks, minerals, ores, and other materials by a powder d-c arc technique: U.S. Geol. Survey Bull. 1084-B, p. 165-182.

Bunting, W. E., 1944, The determination of soluble silica in very low concentration: Indus. and Eng. Chemistry, Anal. Ed., v. 16, p. $612-615$.

Carron, M. K. and Cuttitta, Frank, 1962, Determination of silica in tektites and similar glasses by volatilization: Art. 30 in U.S. Geol. Survey Prof. Paper 450-B, p. B78-B79.

Cuttitta, Frank, 1952, The colorimetric determination of total iron with o-phenanthroline-A spectropotometric study: U.S. Geol. Survey TEIR-223 issued by U.S. Atomic Energy Comm. Tech. Info. Service, Oak Ridge, Tenn.

Jeffery, P. G., and Wilson, A. D., 1960, A combined gravimetric and photometric procedure for determining silica in silicate rocks and minerals: Analyst, v. 85, p. 478-485.

Kramer, H., 1957, Flame photometric determination of calcium in phosphate, carbonate, and silicate rocks: Anal. Chim. Acta, v. 17, p. 521.

Parker, C. A., and Goddard, A. P., 1950, The reaction of aluminum ions with alizarin-3-sulphonate, with particular reference to the effect of calcium ions: Anal. Chim. Acta, v. 4, p. 517-536.

Ray, Norman, 1956, Flame photometric determination of sodium, potassium, calcium, magnesium, and manganese in glass and raw materials. Anal. Chemistry, v. 28, p. 34.

Rose, H. J., Adler, Isidore and Flanagan, F. J., 1962, Use of $\mathrm{La}_{2} \mathrm{O}_{3}$ as a heavy absorber in the X-ray fluorescence analysis of silicate rocks: Art. 31 in U.S. Geol. Survey Prof. Paper 450-B, p. B80-B82.

- 1963, X-ray fluorescence analysis of the light elements in rocks and minerals: Appl. Spec., v. 17, no. 4, p. 81-85.

Rose, H. J., and Flanagan, F. J., 1962, X-ray fluorescence determination of thallium in manganese ores: Art. 32 in U.S. Geol. Survey Prof. Paper 450-B, p. B82-B83.

Sandell, E. B., 1959, Colorimetric determination of traces of metals, 3d ed.: New York, Interscience Publishers, Inc., p. 537-542.

Thorpe, A. N., Senftle, F. E., and Cuttitta, Frank, 1963, Magnetic and chemical investigations of iron in tektites: Nature, v. 197, p. 836-840, March 2, 1963.

Voimovitch, I. A., and Debras, J., 1958, Determination of sodium, potassium, and lithium in silicates by flame photometry: Indus. Ceramics, v. 502, p. 321-27.

Willgallis, A., 1957, Application of flame photometry to alkali analysis of minerals: Zeitscht. anal. Chemie, v. 157, p. 249-257.

Yoe, J. H., and Armstrong, A. R., 1947, Colorimetric determination of titanium with disodium-1, 2-dihydroxybenzene-3, 5-disulfonate: Anal. Chemistry, v. 19, p. 100-102. 


\title{
Article 158
}

\section{DETERMINATION OF TOTAL IRON IN HEMATITIC IRON ORES BY X-RAY FLUORESCENCE SPECTROMETRY}

\author{
By WILLIAM W. NILES, Denver, Colo.
}

\begin{abstract}
A suite of hematitic iron-ore samples was analyzed by X-ray fluorescence spectrometry. Computations were made to derive an empirical equation from which the amount of iron in a sample can be calculated. The changes from true values caused by interfering elements are compensated for by simple calculation. Comparisons with wet chemical analyses are shown
\end{abstract}

A suite of iron-ore samples was analyzed to check the reliability of a field method (Sheldon, 1964) for estimating iron content of hematitic iron ores. X-ray. fluorescence spectrometry was selected because of its relative simplicity, rapidity, reasonable accuracy, and the wide range of elements that can be analyzed without much additional work on the samples. It was found that analyses for iron obtained by X-ray spectrometry were comparable in accuracy to the classical volumetric methods.

The X-ray spectrometric analyses were made using a Norelco $50 \mathrm{KV}$-50MA X-ray spectrometer with heliumpath attachment and an FA-60 X-ray tube with molybdenum target. A lithium fluoride analyzing crystal, a primary collimator tube $3 / 4$ inch square by 4 inches long, and a secondary collimator 4 inches long with 0.005-inch Soller slits were used exclusively. A flow proportional counter using $\mathrm{P}-10$ gas and operated at 1,550 volts was used as a detector.

All samples were crushed to $1 / 4$-inch fragments or smaller in a small jaw crusher and then were ground to 80-100 mesh with a mechanical grinder fitted with ceramic plates. A chart scan of each sample, before preparation, was made at the rate of $1^{\circ}$ of arc per minute in order to estimate roughly the concentration of elements that might interfere with the iron determination through absorption effects. These estimates were made by comparison with an appropriate standard made up with an $\mathrm{SiO}_{2}$ matrix.

In these iron-ore samples, calcium and silicon were the only interfering elements present in appreciable quantities. None of the samples contained more than 25 percent calcium. All samples were prepared as follows: Enough $\mathrm{CaCO}_{3}$ was added to a $0.1500-\mathrm{g}$ sample to make the total calcium equal to approximately 25 percent of the sample by weight $(0.0375 \mathrm{~g}$ calcium). $\mathrm{SiO}_{2}$ was added to bring the total weight of the mixture of sample, $\mathrm{CaCO}_{3}$ and $\mathrm{SiO}_{2}$, to $0.3000 \mathrm{~g}$. Boric acid as a noninterfering diluent was then added to obtain a total weight of $1.500 \mathrm{~g}$. Each sample mixture was ground to an impalpable powder in an agate pestle and mortar under acetone, allowed to dry while grinding, and then pressed at $30,000 \mathrm{lbs}$. for 10 seconds into a pellet with a base of boric acid.

Although the presence of silicon reduced the intensity of the $\mathrm{Fe}$ peak, $\mathrm{SiO}_{2}$ was made the predominant matrix component in the prepared sample. The Fe standards were made up as $\mathrm{Fe}_{2} \mathrm{O}_{3}$ in $\mathrm{SiO}_{2}$. The effect of the small differences between the amounts of $\mathrm{SiO}_{2}$ in the samples and the amount in the standards was negligible because of the predominance of $\mathrm{SiO}_{2}$ as a matrix component. However, one must correct for absorption due to calcium and silicon.

I achances' (written communication, 1960) correction factors, equations 1 and 2 , and his expression for the Iron content, equation 3 , were modified as follows:

$$
\begin{aligned}
F_{\mathrm{Ca}} & =\frac{A-B_{\mathrm{Ca}}}{B_{\mathrm{Ca}} \times \text { percent Ca }} \\
F_{\mathrm{sl}} & =\frac{A-B_{\mathrm{Sl}}}{B_{\mathrm{S} 1} \times \text { percent } \mathrm{Si}}
\end{aligned}
$$

Percent $\mathrm{Fe}=B^{\prime}+\left(B_{\mathrm{Ca}} \times F_{\mathrm{Ca}} \times\right.$ percent $\left.\mathrm{Ca}\right)$

$$
+\left(B_{\mathrm{s}_{1}}^{\prime} \times F_{\mathrm{s}_{1}} \times \text { percent } \mathrm{Si}\right) \text {, }
$$

where $F_{\mathrm{Ca}}=$ factor for absorption due to $\mathrm{Ca}$,

$F_{\mathrm{s} 1}=$ factor for absorption due to $\mathrm{Si}$,

$A=$ actual percentage of $\mathrm{Fe}$ in standard, 
$B=$ apparent percentage of $\mathrm{Fe}$ in same standard with matrix added,

$B_{\mathrm{Ca}}=$ apparent percentage of $\mathrm{Fe}$ in same standard with Ca added,

$B_{\mathrm{St}}=$ apparent percentage of $\mathrm{Fe}$ in same standard with Si added,

$B^{\prime}=$ apparent percentage of $\mathrm{Fe}$ in sample, effected by matrix,

$B^{\prime}{ }_{\mathrm{Ca}}=$ apparent percentage of $\mathrm{Fe}$ in sample, effected by $\mathrm{Ca}$, and

$B^{\prime}{ }_{\mathrm{s} 1}=$ apparent percentage of $\mathrm{Fe}$ in sample, effected by Si.

By substituting equations 1 and 2 in 3 , there is obtained

Percent $\mathrm{Fe}=\frac{B^{\prime}+\left(B_{\mathrm{Ca}} \times\left[A-B_{\mathrm{Ca}}\right] \times \text { percent } \mathrm{Ca}\right)}{B_{\mathrm{Ca}} \times \text { percent Ca }}$

$$
+\frac{\left(B^{\prime}{ }_{\mathrm{s} 1} \times\left[A-B_{\mathrm{S} 1}\right] \times \text { percent } \mathrm{Si}\right)}{B_{\mathrm{S} 1} \times \text { percent } \mathrm{Si}},
$$

and upon simplification this equation becomes

Percent $\mathrm{Fe}=\frac{B^{\prime}+\left(B^{\prime}{ }_{\mathrm{Ca}} \times\left[A-B_{\mathrm{Ca}}\right]\right)}{B_{\mathrm{Ca}}}+\frac{\left(B^{\prime}{ }_{\mathrm{s} 1} \times\left[A-B_{\mathrm{S} 1}\right]\right.}{B_{\mathrm{Sl}}}$

Since the effect of the matrix is equal to the sum of the effects of each component in the matrix, this equation can be rewritten into the following form:

Percent $\mathrm{Fe}=\frac{B^{\prime}+\left(B^{\prime} \times[A-B]\right)}{\bar{B}}=B^{\prime} \frac{(1+[A-B])}{B}$.

The factor $\frac{A-B}{B}$ is practically constant for all percentages of iron sought, and it is constant regardless of instrumental variations caused by normal fluctuations of voltage and temperature from day to day.

Although this suite of iron-ore samples has a comparatively simple matrix composition, the method of computation has been used in analyzing samples containing as many as five interfering elements. The method has the advantage of allowing use of the same set of standards for rock and ores of widely varying matrices.

Tables 158.1 and 158.2 show the accuracy and reproducibility of analytical results obtained by $\mathrm{X}$-ray emission spectrometry of hematitic iron ores. The accuracy is based on the assumption that the chemical results are the absolute values. The chemical analyses were made by the standard dichromate volumetric oxidation-reduction method. Only one determination was made on each sample by each method. X-ray results are given to hundredths of a percent for comparison but should not be considered accurate beyond two figures. The reproducibility of results of the method was determined by analyzing each of the 10 samples 3 times.

TABLE 158.1.-Comparison of results obtained by chemical and $X$-ray spectrographic methods

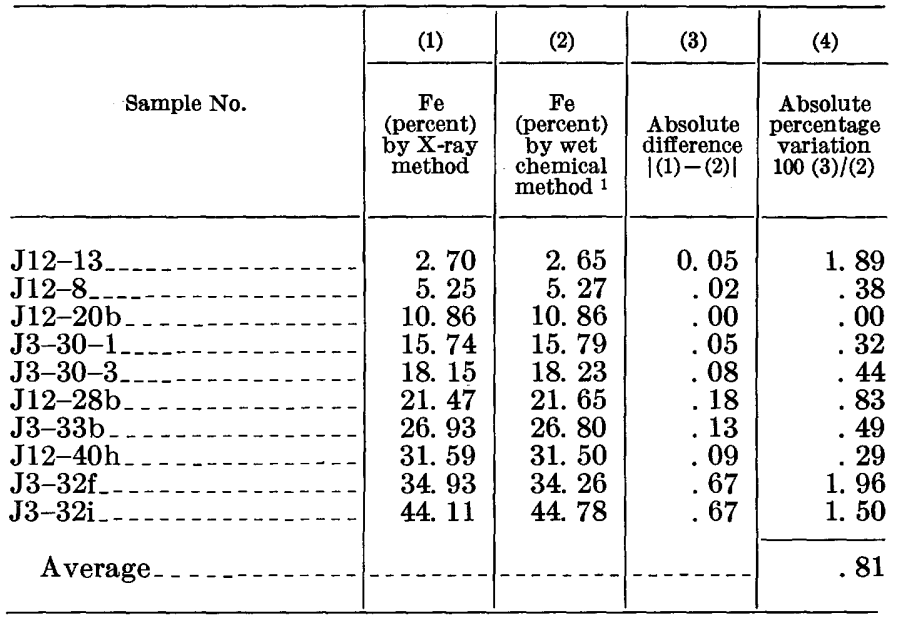

${ }^{1}$ Analyst: Dwight L. Skinner, chemist, U.S. Geological Survey, Denver, Colo.

TABLE 158.2.--Reproducibility of analytical results for iron by $X$-ray emmission spectrography

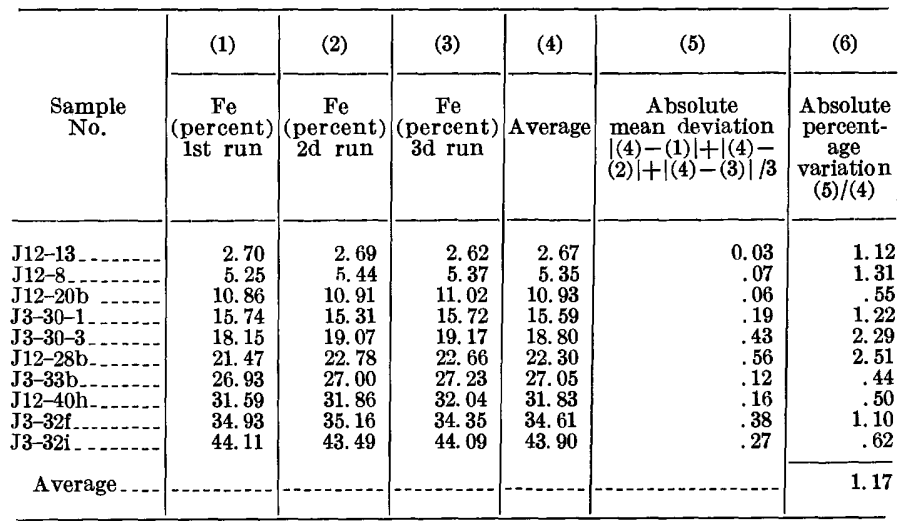

\section{REFERENCE}

Sheldon, R. P., 1964, Relation between specific gravity and iron content of rocks from the Red Mountain Formation, Alabama: U.S. Geol. Survey Bull. 1182-D. [In press] 


\title{
A GAS JET FOR D-C ARC SPECTROSCOPY
}

\author{
By A. W. HELZ, Washington, D.C.
}

\begin{abstract}
A gas jet adaptable to enclosed arc-spark stands is described for use in $d-c$ arc spectrochemical analysis. When used with a nitrogen-free gas, the jet is very effective for suppression of cyanogen bands.
\end{abstract}

The gas jets for spectrochemical analysis described by Annell and Helz (1961) proved to be very effective for arc stabilization and cyanogen-band depression. However, they were designed for open-type arc stands and are difficult to use in spectrographic assemblies with conventional enclosed arc-spark stands. For enclosed stands it was considered desirable to use prefabricated electrodes of standard 1.5-inch length. Figure 159.1 is a drawing of the jet described herein. To minimize the required electrode length, the ceramic cap forming the nozzle, $A$ (fig. 159.1 section $X X^{\prime}$ ) was shortened. To compensate for this loss of control of the gas flow and to try to insure lamellar flow, the internal construction was redesigned as described below. The control gas enters a lower chamber (fig. 159.1, $C$ ) surrounding the electrode, goes up through a ring of small holes (each 0.062 inch in diameter and 0.125 inch long) into an upper conically topped chamber (fig 159.1, $B)$, and finally escapes through the annular space formed by the sample-bearing electrode and the ceramic cap.

The jet was made in the U.S. Geological Survey analytical laboratory shop by J. B. Beasley. The main body of the jet is a 1/4-inch-thick brass plate supported on an electrically insulated post. Self alinement with the arc-stand jaws is augmented by freedom of the frame to swing on the post and by affixing the post to the arc-stand base loosely to permit some translational motion. The plate is effectively water cooled with a $U$-shaped channel. This jet is for use with standard electrodes $1 \frac{1}{2}$ inches long and 0.242 inch in diameter. Thus, if the bottom hole of the brass plate and the central hole in the brass section that separates chambers $B$ and $C$ are each 0.250 inch in diameter, the electrode clearance will be 0.004 inch. At least this much clearance is advisable for convenience in inserting electrodes from above.

The ceramic cap of the jet is a commercially available part used in tungsten-inert gas welding. The number 6 Linde Heliarc cup (Linde Co., division of Union Carbide Corp.) is suitable for use with the $1 / 4$-inchdiameter electrodes. The ceramic cup is shortened from 1.25 inches to 0.72 inch by cutting off the cylindrical tip at the outside circle where the cylindrical and conical parts of the cup meet. This leaves a short cylindrical section inside about 0.062 inch high and 0.375 inch in diameter.

The annular space for the escaping gas is 0.066 inch thick. The assembled height of the jet is 1 inch. In use the lower electrode height is frequently adjusted to keep the burning rim of the crater a constant distance above the rim of the ceramic cup. About 2-millimeters seems optimum for this distance.

This jet is much more compact than the earlier design of Annell and Helz (1961), but it is just as effective in producing a very steady arc and controlling cyanogen band interference. To show the effectiveness of the jet, 10 spectra of the cyanogen-band region are shown in figure 159.2. In addition to the spectrum of the arc in still air, spectra are also shown for the jet described herein, the Stallwood jet (Stallwood, 1954), and the enclosed Stallwood jet (see Spex Industries, Inc., 1962, for a summary status of Stallwood jets) at gas flows of 5, 10, and 15 cubic feet per hour. The control gas used was a mixture of 80 percent argon and 20 percent oxygen. For each spectrum shown in figure $159.2,10$ milligrams of a powdered rock was mixed with $20 \mathrm{mg}$ of graphite and burned in a 15-ampere d-c arc. The spectra were recorded on an SA-1 plate using 38percent transmission and 1-minute exposures. These first-order spectra have a reciprocal linear dispersion of approximately $5 \mathrm{~A} / \mathrm{mm}$.

The difference between the type of gas flow for the jet described in this article and the gas flow of the Stallwood jet is strikingly illustrated by the spectra 

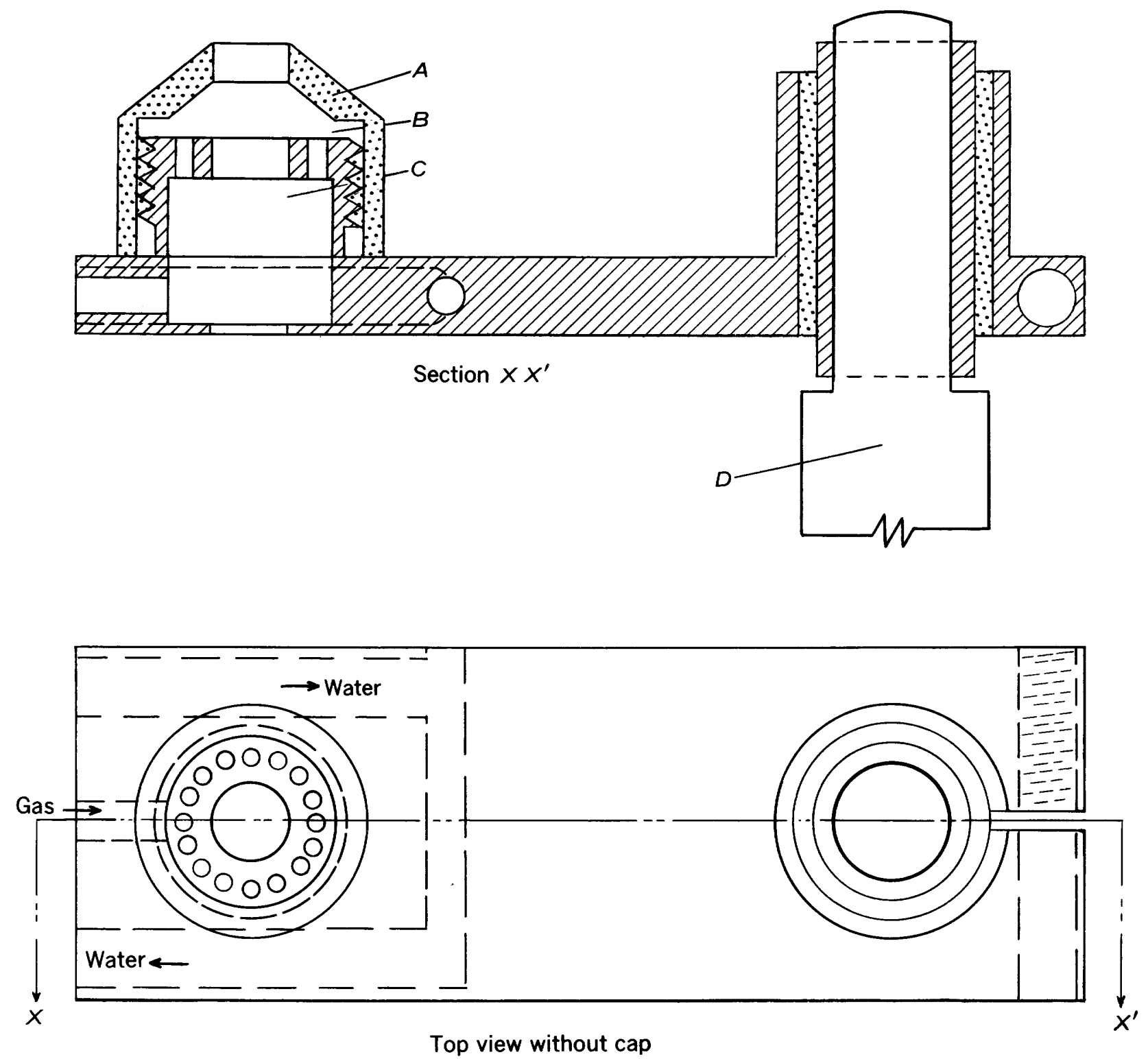

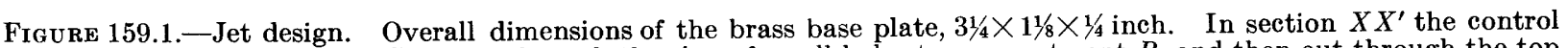
gas enters compartment $C$, passes through the ring of small holes to compartment $B$, and then out through the top of the ceramic cap $A$. $D$ is the supporting post. 


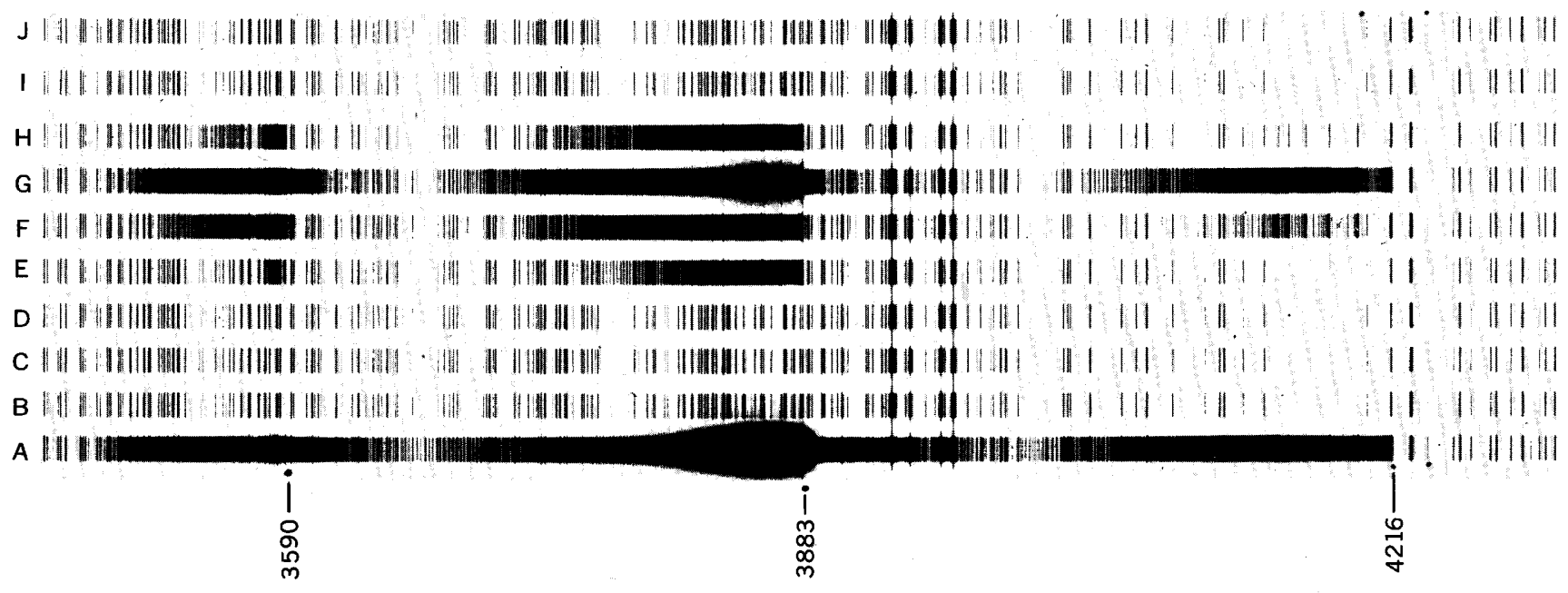

FiguRE 159.2.-Spectra of 15-ampere d-c carbon arcs, cyanogen-band region. $A$, arc in air. $B-D$, enclosed Stallwood jet, 5,10 , and 15 cubic feet per hour, respectively, of a mixture of 80 percent argon and 20 percent oxygen. $E-G$, open Stallwood jet, 5,10 , and 15 cubic feet per hour, respectively, of argon and oxygen mixture. $H-J$, jet described in the report; 5 , 10, and 15 cubic feet per hour, respectively, of argon and oxygen mixture.

for different rates of flow. For the jet described herein the intensity of the cyanogen bands decreases with increasing gas flow (spectra $H, I, J$ ). For the Stallwood jet, intensity increases with the gas flow (spectra $E, F$, and $G$ ). For the enclosed Stallwood jet, though at a much lower level, intensity decreases as the gas flow is increased from 5 to $15 \mathrm{cfh}$ (spectra $B, C$, and $D$ ). Cyanogen bands are absent in spectra $D$ and $J$; that is the gas flow is $15 \mathrm{cfh}$ with either the enclosed Stallwood jet or the jet described in this article. Thus the effec- tive exclusion of cyanogen-band spectra in carbon arcs is obtainable without cumbersome enclosures of the arc.

\section{REFERENCES}

Annell, C. S., and Helz, A. W., 1961, A constant-feed directcurrent arc: U.S. Geol. Survey Bull. 1084-J, p. 231-251.

Spex Industries, Inc., 1962, Spex Speaker VII, no. 3: Scotch Plains, N.J.

Stallwood, B. J., 1954, Air-cooled electrodes for the spectrochemical analysis of powders: Optical Soc. America Jour., v. 44, $171 \mathrm{p}$. 
Article 160

\section{DOLOMITE SOLUBILITY IN GROUND WATER}

\section{By IVAN BARNES and WILLIAM BACK, Washington, D.C.}

\begin{abstract}
The ion-activity product $(\mathrm{IAP})_{d}$ of dolomite has been computed for 87 samples of ground water from a variety of geologic environments. The upper limit of the $(\mathrm{IAP})_{d}$ for samples in or very near equilibrium with calcite agrees with the higher equilibrium constants reported in the literature.
\end{abstract}

Detailed studies of the composition of ground water have been undertaken in an effort to determine the thermodynamic state of reactions between minerals and water. The approach has been to obtain chemical analyses reflecting as closely as possible the composition of the water in its native state by determining alkalinity, $\mathrm{pH}$, and temperature at the time of sampling (Barnes, 1964). Ion activities of the chemical constituents can be calculated from the laboratory data and the DebyeHückel equation. From the activities, the ion-activity product (IAP) can be calculated for a particular reaction, using the law of mass action. Departure from equilibrium is determined by comparing the IAP calculated from the chemical analyses of water with the equilibrium constant, $K$ (Back, 1960). If the IAP is greater than the $K$, the water is supersaturated with respect to the mineral of interest. For calcite,

$$
I A P_{c}=\alpha_{\mathrm{Ca}}+2 \cdot \alpha_{\mathrm{CO}_{3}^{-2}}
$$

and for dolomite,

$$
I A P_{d}=\alpha_{\mathrm{Ca}}+2 \cdot \alpha_{\mathrm{Mg}}+2\left(\alpha_{\mathrm{CO}_{3}^{-2}}\right)^{2}
$$

Figure 160.1 shows values of $\mathrm{IAP}_{d}$ and the ratio IAP/ $K$ for calcite. The $\mathrm{pH}$, temperature, and bicarbonate concentrations for all these samples were determined in the field; the ionic strength of all samples plotted is less than 0.1 the limit for the Debye-Hückel equation.

For samples in equilibrium with calcite, that is, those with an IAP/ $K$ ratio of $1.0 \pm$ about 0.12 , the data show that the maximum IAP for dolomite is $2.87 \times 10^{-17}$ (see shaded area in fig. 160.1). The data indicate that the

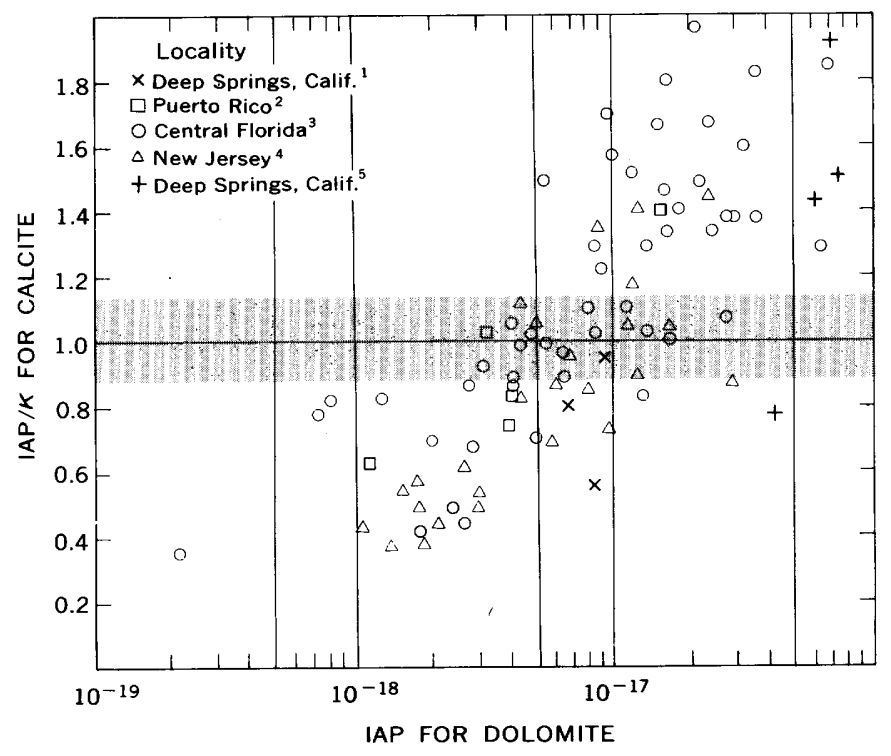

1 Barnes (unpublished analyses, 1962).
2 J. W. Crooks (oral communication, i962).

3 Back (1963).

4 Seaber (1962)

FIGURE 160.1.-Graph showing relation of 1on-activity product for dolomite and the $\mathrm{IAP} / K$ ratio for calcite. Shaded area represents samples in equilibrium with calcite.

upper limiting value for the IAP for dolomite in ground waters in equilibrium with calcite lies between approximately $1.5 \times 10^{-17}$ and $3 \times 10^{-17}$. Owing to the sluggishness of the dolomite precipitation, water supersaturated with calcite probably is supersaturated also with dolomite.

These IAP data for dolomite may be compared with reported equilibrium constants for dolomite, as follows:

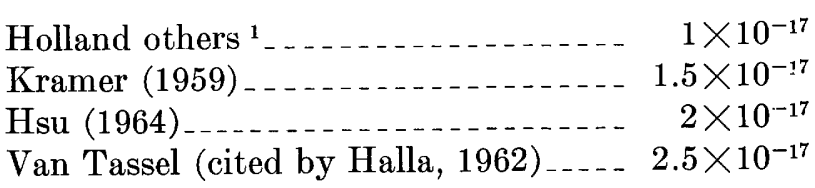

1 Holland, H. D., Kirsipu, T. V., Huebner, J. S., and Oxbough, V. M., 1962, On some aspects of the chemical evolution of cave waters: Princeton Univ., technical report (duplicated). 
Halla and Ritter (cited by Kramer, 1959)

$3 \times 10^{-17}$

Robie (cited by Halla, 1962) $6.6 \times 10^{-19}$

Garrels and others (1960) $4.7 \times 10^{-20}$

If the lower solubilities of Garrels and Robie are accepted, all water samples used in this study are supersaturated with dolomite. On the other hand, if we postulate that dolomite reacts with aqueous solutions and tends toward an equilibrium, the equilibrium constant would appear to be on the order of 2 to $3 \times 10^{-17}$. In any event, the observed characteristics of the ground waters sampled are closer to the properties predicted at equilibrium with the higher solubilities reported than with the lower solubilities.

\section{REFERENCES}

Back, William, 1960, Calcium carbonate saturation in ground water from routine analyses: U.S. Geol. Survey WaterSupply Paper 1535-D, $14 \mathrm{p}$.
Back, William, 1963, Preliminary results of a study of the calcium carbonate saturation of ground water in central Florida: Internat. Assoc. Sci. Hydrology, v. 8, No. 3, p. 43-51.

Barnes, Ivan, 1964, Field measurements of alkalinity and $\mathrm{pH}$ : U.S. Geol. Survey Water-Supply Paper 1535-H. [In press] Garrels, R. M., Thompson, M. E., and Siever, Raymond, 1960, Stability of some carbonates at $25^{\circ} \mathrm{C}$ and one atmosphere total pressure: Am. Jour. Sci., v. 258, p. 402.

Halla, Franz, 1962, The free energy of the formation of dolomite from its carbonate components: Sedimentology, v. 1, p. 191.

Hsu, K. J., 1964, Solubility of dolomite estimated on the basis of the chemical composition of Florida ground-waters, in Abstracts for 1963: Geol. Soc. America Spec. Paper. [In press]

Jones, B. F., 1961, Zoning of saline minerals at Deep Spring Lake, California: Art. 83 in U.S. Geol. Survey Prof. Paper 424-B, p. B199-B202.

Kramer, J. R., 1959, Correction of some earlier data on calcite and dolomite in sea water: Jour. Sed. Petrology, v. 29, p. 465.

Seaber, P. R., 1962, Cation hydrochemical facies of ground water in the Englishtown formation, New Jersey: Art. 51 in U.S. Geol. Survey Prof. Paper 450-B, p. B124-B126. 


\title{
EFFECT OF TREE LEAVES ON WATER QUALITY IN THE CACAPON RIVER, WEST VIRGINIA
}

\author{
By KEITH V. SLACK, Washington, D.C.
}

\begin{abstract}
Accumulation of leaf litter in pools at low flow increases water color and results in marked changes in water composition. Temperature decreases rapidly from surface to bottom in the shallow pools. Dissolved-oxygen concentration decreases, but concentrations of many other solutes increase directly with water color. A film, believed to be ferric hydroxide, occurs on the surface of pools in which decomposition of litter is especially intense. Flushing of the pools by a rise in stream stage reduces the color and improves water quality.
\end{abstract}

Changes in water composition resulting from natural additions of organic matter were investigated as part of a study of biological influences on water quality of streams. Previous work in Indiana indicated that the autumnal accumulation of tree leaves in streams coincident with the annual low-flow period occurs widely and is important in cycling of elements in nature. This accumulation is unusual in that it represents a natural environment in which decomposition greatly exceeds production of new organic matter. The environment is marked by low dissolved-oxygen concentration and considerable water color, which presumably is due to decomposition of plant material. Although of short duration, the condition seriously degrades water quality and can result in the death of aquatic organisms.

The literature contains many references to the effects of leaf litter on the chemical quality of streams; for example, Schneller (1955) and Slack (1955) reported that the decay of leaves in pools generally resulted in greater water color and in the formation of free $\mathrm{CO}_{2}$ and lower dissolved-oxygen concentrations. Sylvester (1959) reported that replacement of native coniferous forests with deciduous trees in the Wenatchee River basin, W ashington, resulted in increased water color. Hynes (1960) described Huet's (1951) work, which indicated that a substance toxic to fish was derived from needles of spruce and red cedar. Chase and Ferullo (1958) showed that leaves deplete dissolved oxygen under aerobic conditions in the laboratory; after 386 days, maple leaves had consumed a weight of oxygen equivalent to 75 percent of their initial dry weight. In the same length of time, oak leaves and pine needles exerted oxygen demands of about 50 percent of their dry weight. Myers (1961) suggested that manganese in San Clemente Reservoir, Calif., was leached from oak trees in the watershed. Robinson and others (1958) showed that leaves of hickory trees concentrated rare-earth elements to a remarkable degree. Thus, various species of trees may make widely differing chemical contributions to streams through leaf litter.

Discolored water is neither a perennial phenomenon nor does it occur in all streams. Frequent rains during the peak leaf-fall period may flush the organic load downstream and dilute substances leached from the fresh leaves. The most favorable conditions for development of discolored water are a pooled stream with little or no surface flow and with stands of deciduous trees near the channel.

Discoloring of water begins when tree leaves begin to drop, usually in September. The freshly shed leaves accumulate at the downstream end of pools, where they float on the surface at first but gradually sink to form a blanket over the streambed; later arrivals replenish the surface layer. Eventually the lower ends of pools become filled with a waterlogged mass of leaves that may inhibit flow over riffles. Unless there is a rise in stage and a flushing and exchange of water in the pool, a critical period is established.

As the waterlogged leaves decompose by bacterial action, the supply of dissolved oxygen in the pool is depleted. Although decomposition of the leaves causes an increase in the mineral content of the water, the amount of the increase attributable to factors such as leaching of soluble substances from leaves, concentration by evaporation, mineral-matter release from sedi- 
ments by organic complexing and chemical reduction, and bacterial breakdown of leaf tissue is not known. The literature indicates that all these processes must be considered. In early stages of decomposition the color of the pool water closely resembles that of bog water. Under extreme conditions, the water acquires an inky appearance, which gives rise to the name "black water" in parts of the Midwest where discoloration is common.

\section{STUDY OF THE CACAPON RIVER, W. VA.}

A reach of the Cacapon River, Morgan County, W. Va., about 14 stream miles above the mouth where a series of elongate wooded islands extend parallel to the river bank, was selected for detailed study. At times of low flow, the channel which normaliy separates these islands from the right bank of the river becomes dry or is reduced to a few pools. Discolored water was general in the pools and in partly isolated marginal waters along this reach in October 1961.

Three different environments, shown on figure 161.1, were sampled: (a) a riffle of the Cacapon River about 18 centimeters deep; (b) a slightly colored pool or backwater channel, which was connected with the river and in which the intensity of color increased with distance from the river, sampled at the upper end, about 5 meters from its junction with the main stream; and (c) an isolated highly colored pool about $6 y_{2} \times 3$ $m$ in area, at the base of a steep bank. In addition,

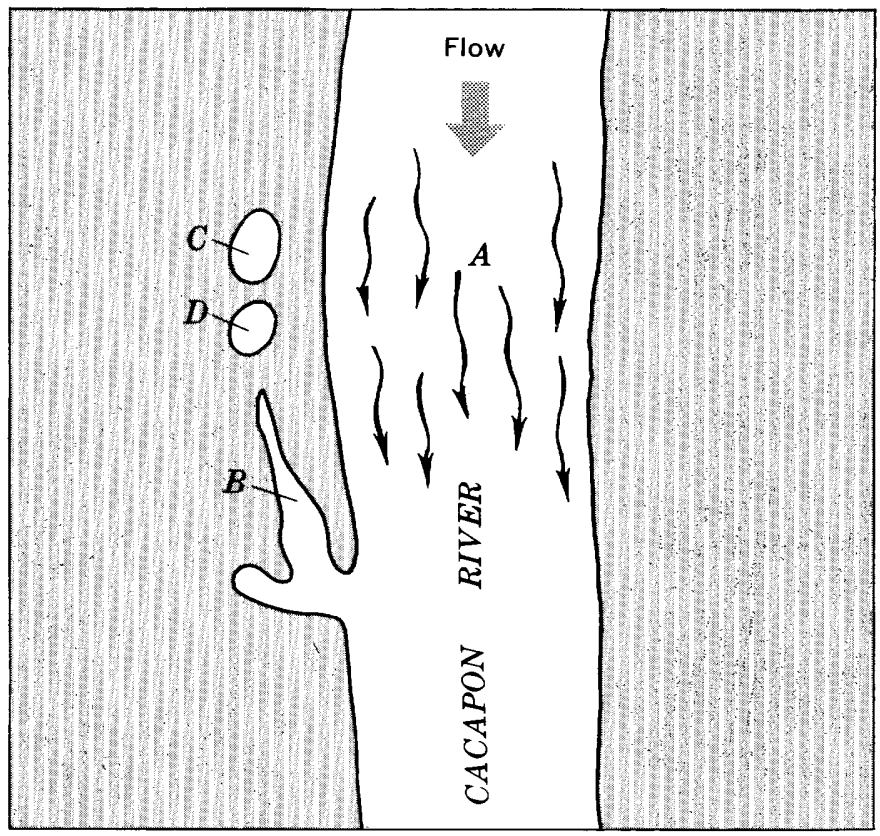

FIGURE 161.1-Sketch showing sampling sites on the Cacapon River, Morgan County, W. Va. $A$, riffle on the river; $B$, slightly colored pool; $C$, highly colored pool; and $D$, moderately colored pool. a moderately colored pool (d) was sampled as part of a temperature study on October 30, 1961 (table 161.3). The reach of river studied was shaded by a hardwood forest consisting of the following kinds of trees: maple, cottonwood, tulip tree, blue beech, sycamore, elm, dogwood, aspen, and oak. Many kinds of deciduous leaves were visible in the water on October 22, 1961, the date of the initial sampling, and most had sunk to the bottom.

\section{Chemical composition}

The chemical composition of the water of the river and the pools is shown in tables 161.1 and 161.2, which permit comparison between sampling sites on a single date and on different dates. The tables show that concentrations of many substances tend to increase as water color increases, although calcium, bicarbonate alkalinity, dissolved solids, and specific conductance, all were higher in the slightly colored pool $(B)$ than in the highly colored pool $(C)$. The appearance of the ground on October 22 and 29 suggested that water from the main channel had recently flowed into the highly colored pool $(C)$, although the composition of water of the channel and the pool differed greatly. Pool $\mathrm{C}$ was separated from the river by a low mound of wet leaves and rocks about $1 \mathrm{~m}$ in width. Wet masses of a green alga (Oedogonium) covered much of this barrier; however, the fresh appearance of the algae must have resulted from a light rain recorded on October 21, because streamflow records show no significant rise of the river during October.

The low calcium and carbonate concentrations of the highly colored pool $(C)$ could be explained in various ways; for example, much of its water could have been derived from local runoff or dilute ground water containing alkalies leached from the leaves. Another possibility is that ion-exchange reactions between the leaf material and the pool water produced water enriched in alkalies but depleted in calcium and bicarbonate (Hutchinson, 1957, p. 573). Still another explanation is that snails (Gyraulus) inhabiting this isolated pool extracted calcium carbonate from solution for shell formation, thus causing a lower calcium concentration. The volume of the highly colored pool was roughly 2,000 liters, indicating a deficit of 18.5 milligrams of calcium per liter compared with the calcium content of the other waters sampled, or a total loss of 37 grams. If this quantity were spread among an estimated population of 100 snails, the necessary uptake of $0.37 \mathrm{~g}$ calcium or $0.92 \mathrm{~g}$ calcium carbonate per animal would seem excessive for this thin-shelled form. However, without better population data the possibility of biological utilization cannot be excluded as a factor causing depletion of calcium carbonate in the highly colored 
TABLE 161.1.-Water properties at three sampling sites, Cacapon River, W. Va., during autumn $1961^{1}$

[Analyses by H. R. Feltz, Washington, D.C.]

\begin{tabular}{|c|c|c|c|c|c|c|c|c|c|}
\hline & \multicolumn{3}{|c|}{ October 22} & \multicolumn{3}{|c|}{ October 29} & \multicolumn{3}{|c|}{ November 19} \\
\hline $\begin{array}{l}\text { Color (platinum-cobalt scale units) } \\
\text { Chemical constituents (ppm) : } \\
\text { Silica. } \\
\text { Iron } \\
\text { Manganese } \\
\text { Calcium } \\
\text { Magnesium } \\
\text { Sodium } \\
\text { Potassium } \\
\text { Bicarbonate } \\
\text { Sulfate } \\
\text { Chloride } \\
\text { Fluoride } \\
\text { Nitrate } \\
\text { Phosphate } \\
\text { I)issolved solids (ppm) (residue at 180 } \\
\text { Hardness (ppm) } \\
\text { Free carbon dioxide (ppm) } \\
\left.\text { Specific conductance (micromhos at } 25^{\circ} \mathrm{C}\right) \\
\text { pH } \\
\text { Ignition loss (ppm) }\end{array}$ & $\begin{aligned} 7 \\
2.0 \\
.08 \\
.00 \\
28 . \\
5.8 \\
1.7 \\
1.5 \\
106 \\
10 \\
1.5 \\
.1 \\
.1 \\
107 \\
95 \\
4.2 \\
197 \\
7.6 \\
\end{aligned}$ & $\begin{array}{l}20 \\
7.3 \\
1.1 \\
28.93 \\
7.1 \\
5.6 \\
7.5 \\
134.5 \\
4.4 \\
3.0 \\
.2 \\
.4 \\
.08 \\
143 \\
100 \\
34 \\
233 \\
6.8 \\
15\end{array}$ & $\begin{array}{r}120 \\
6.2 \\
1.9 \\
2.8 \\
9.5 \\
3.0 \\
3.1 \\
6.8 \\
44 . \\
8.2 \\
\text { 3. } 0 \\
.2 \\
1.2 \\
78.12 \\
36 \\
56 \\
106 \\
6.1 \\
18\end{array}$ & $\begin{array}{c}4 \\
2.6 \\
.1 \\
.00 \\
31 . \\
5.2 \\
1.7 \\
1.6 \\
110 \\
11 \\
1.5 \\
.1 \\
.1 \\
.06 \\
115 \\
99 \\
4.4 \\
205 \\
7.6 \\
-. . .--\end{array}$ & $\begin{array}{c}60 \\
8.3 \\
1.1 \\
.40 \\
30 \\
7.8 \\
4.8 \\
8.2 \\
142 \\
4.4 \\
3.5 \\
.2 \\
.6 \\
.05 \\
155 \\
108 \\
28 \\
244 \\
6.9 \\
22\end{array}$ & $\begin{array}{c}90 \\
7.9 \\
2.2 \\
3.0 \\
9.5 \\
4.5 \\
3.1 \\
6.8 \\
55 \\
6.0 \\
3.0 \\
.1 \\
.8 \\
.12 \\
80 \\
42 \\
55 \\
117 \\
6.2 \\
12\end{array}$ & $\begin{array}{c}2 \\
4.1 \\
.02 \\
.02 \\
30 \\
4.0 \\
1.9 \\
1.8 \\
99 \\
11 \\
2.5 \\
.0 \\
.1 \\
.01 \\
103 \\
90 \\
4.0 \\
190 \\
7.6\end{array}$ & $\begin{array}{c}3 \\
6.1 \\
.02 \\
.08 \\
27 \\
4.3 \\
2.5 \\
2.5 \\
97 \\
9.8 \\
3.0 \\
.1 \\
.1 \\
.01 \\
105 \\
85 \\
12 \\
184 \\
7.1\end{array}$ & $\begin{array}{c}3 \\
7.8 \\
.02 \\
.01 \\
18 \\
3.9 \\
2.2 \\
2.2 \\
69 \\
8.0 \\
3.0 \\
.1 \\
.2 \\
701 \\
62 \\
14 \\
138 \\
6.9\end{array}$ \\
\hline
\end{tabular}

${ }^{1}$ Sample locations shown on fgure 161.1.

TABLE 161.2.-Spectrographic analyses of minor-element content, in micrograms per liter, of three types of water, Cacapon River, W. Va., during autumn 19611

[Analyses by W. D. Silvey, Sacramento, Calif.]

\begin{tabular}{|c|c|c|c|c|c|c|c|c|}
\hline & \multicolumn{3}{|c|}{ October 22} & \multicolumn{3}{|c|}{ October 29} & \multicolumn{2}{|c|}{ November 19} \\
\hline & $\begin{array}{l}\text { Main } \\
\text { stream } \\
(A)\end{array}$ & $\begin{array}{l}\text { Slightly } \\
\text { colored } \\
\text { pool }(B)\end{array}$ & $\begin{array}{l}\text { Highly } \\
\text { colored } \\
\text { pool }(C)\end{array}$ & $\begin{array}{c}\text { Main } \\
\text { stream } \\
(A)\end{array}$ & $\begin{array}{l}\text { Slightly } \\
\text { colored } \\
\text { pool }(B)\end{array}$ & $\begin{array}{l}\text { Highly } \\
\text { colored } \\
\text { pool }(C)\end{array}$ & $\begin{array}{c}\text { Main } \\
\text { stream } \\
(A)\end{array}$ & $\begin{array}{l}\text { Highly } \\
\text { colored } \\
\text { pool }(C)\end{array}$ \\
\hline Aluminum & & 32 & 93 & 15 & 14 & 82 & 22 & \\
\hline Cobalt. & $\leqq 3.3$ & $\leqq 3.3$ & $\leqq 3.3$ & $<3.3$ & $\leqq 3.3$ & $\leqq 3.3$ & $\leqq 3.3$ & $\leqq 3.3$ \\
\hline Coppe & 7.3 & $<3.3$ & $<3.3$ & $<3.3$ & $<3.3$ & $<3.3$ & 3.3 & $<3.3$ \\
\hline Iron. & 35 & $>100$ & $>100$ & 28 & $>100$ & $>100$ & 47 & $>100$ \\
\hline Manganese & 11 & $>200$ & $>200$ & 31 & $>200$ & $>200$ & 9.3 & 33 \\
\hline Molybder & $<.67$ & $<.67$ & $<.67$ & $<.67$ & $\leqq .67$ & $\leqq 6.7$ & $<.67$ & $<.67$ \\
\hline Nickel_. & $\leqq 67$ & 3.6 & 7.0 & $<.67$ & 4.5 & 6.7 & .87 & 1.5 \\
\hline Lead... & $=98$ & 27 & 80 & 20 & $<3.3$ & 32 & 13 & 8.0 \\
\hline Titanium & $<1.3$ & 3.4 & $\leqq 1.3$ & $<1.3$ & $\leqq 1.3$ & $\leqq 1.3$ & $<1.3$ & $<1.3$ \\
\hline Vanadium. & $<.67$ & $<.67$ & $\leqq .67$ & $<.67$ & $<.67$ & $\leqq .67$ & $<.67$ & $<.67$ \\
\hline
\end{tabular}

1 Sample locations shown on figure 161.1.

pool. Both Slack (1955) and Schneller (1955) found that alkalinity increased with color in all their samples of leaf-colored waters in Indiana.

Some differences between the highly colored pool $(C)$ and the slightly colored pool $(B)$, as noted in the October 22 and 29 samples, may have resulted from differences in redox potentials, which could explain the greater concentrations of iron, manganese, and free $\mathrm{CO}_{2}$ in the more nearly anaerobic, highly colored pool $(C)$. Just the opposite was observed for magnesium, sodium, and potassium, which were more concentrated in the slightly colored pool $(B)$. In both colored waters $(B, C)$, sulfate values were lower than in the river water $(A)$. This may have resulted from reduction of sulfate to sulfide. Although one might expect the sulfate con- centration to be lowest in the highly colored pool $(C)$, minimum values were found in the slightly colored pool $(B)$.

Concentrations of aluminum and nickel increased as water color increased (table 161.2). Similarly, iron and manganese concentrations were higher in the colored waters than in the main stream. The distribution of lead in the different environments resembled that of sulfate in that the slightly colored water $(B)$ contained lower concentrations than either the main stream or the highly colored water $(C)$. Data for other minor elements are inconclusive.

It is tentatively concluded that the compositional differences observed between the river and the colored waters resulted from leaching and decomposition of leaf litter in isolated environments. Differences between the highly colored and slightly colored pools probably reflect differences in source of the water.

Between October 22 and 29 the solute concentration in the highly colored water $(C)$ increased somewhat, possibly due to evaporation. Although the pool was still isolated on November 19, its color had disappeared; the pool probably had been flooded and flushed by a rise in river stage on November 7 and 8 . Discharge at the gaging station about 7 miles downstream from the sampling sites increased from 59 cubic feet per second on October 29 to $240 \mathrm{cfs}$ on November 8, but decreased to $82 \mathrm{cfs}$ on November 19.

On October 22, small patches of a thin inflexible surface film were present on the highly colored pool. 
A week later the entire surface was covered with a film in which there were only a few breaks or tears. The film probably was composed of ferric hydroxide, which formed where air oxidized ferrous iron in the water. Pearsall and Mortimer (1939) described such a condition on stagnant pools in bogs. The contribution of other metallic ions, for example manganese, to a surface film is unknown. In the colored pools under discussion, the films tended to remain in the center of an open space. Reducing conditions may have been so intense near the margins of pools that formation of the oxidized film was impossible. The effect of a surface film on reactions at the air-water interface may be important. For example, evaporation and reaeration probably are inhibited.

Colored water resulting from leaf decay generally is accompanied by low concentrations of dissolved oxygen. Analysis, by the Alsterberg (azide) modification of the Winkler method, of two samples of highly colored pool water gave an average of 0.09 parts per million dissolved oxygen or about 0.8 percent of saturation on October 30 . This method is not recommended for samples containing $1 \mathrm{mg}$ or more of ferrous iron per liter or appreciable quantities of sulfite (Rainwater and Thatcher, 1960, p. 233). Because of the effects of interfering substances, the dissolved-oxygen values reported here may be too low, but they indicate very low concentrations. A few measurements made with a polarographic oxygen electrode (Kanwisher, 1959), on October 23, supported this conclusion. Readings in the highly colored pool $(C)$ were 2 percent of saturation at the bottom (24.5 $\mathrm{cm})$, and a maximum of 6 percent at other places.

On October 30 , the slightly colored pool $(B)$ had a dissolved-oxygen concentration of $1.9 \mathrm{ppm}$ (18 percent of saturation) and the main stream of the river $(A)$ had $10.3 \mathrm{ppm}$ (99 percent of saturation). As with most other quality factors, water color correlated well with dissolved-oxygen content. The lowest oxygen concentration, $0.06 \mathrm{ppm}$, was measured near the upstream end of the highly colored pool $(C)$, where decomposition of litter seemed to be especially far advanced.

A further indication of low-dissolved oxygen content was the presence of many snails (Gyraulus) on leaves at the water surface along the margins of the highly colored pool $(C)$. These snails are able to withstand unfavorable enrivonments better than most mollusks, owing to their ability to breathe air at the surface. Similar groups of snails were not observed in the slightly colored pool $(B)$, which retained a connection with the oxygenated river water.

\section{Water temperature}

Temperature measurements made on two dates (table 161.3) indicated marked thermal stratification during the study period. On October 23 , the temperature of the highly colored pool $(C)$ increased from $6.6^{\circ} \mathrm{C}$ at a depth of $2.5 \mathrm{~cm}$ to $10^{\circ} \mathrm{C}$ at a depth of $11.5 \mathrm{~cm}$. Below $11.5 \mathrm{~cm}$ the water was isothermal, although the thermometer used did not permit determination of the exact inflection points on the temperature-depth curve. On October 30, the water temperature of all colored pools decreased with increasing depth (table 161.3). The steepness of the thermal gradients in the three pools tested varied directly with intensity of water color. This relationship suggests that the mechanism involved was the rapid absorption of solar radiation near the surface by the colored water. No differences in temperature were noted in the main stream at comparable depths. The river-water temperature was highest and the temperature of the highly colored pool $(C)$ was lowest on 4 of 5 days for which bottom-water temperatures were measured. Bottom-water temperature of the slightly colored pool $(B)$ was always higher than that of the highly colored pool $(C)$. This could have resulted from slow mixing with warmer river water from the downstream end of the slightly colored pool. It could also have resulted from a flow of cool ground water from the highly colored pool $(C)$ through the moderately colored pool $(D)$ into the slightly colored pool $(B)$. The October 30 series of bottom temperatures seems to support this possibility.

In summary, the effect of leaves on stream-water quality and temperature is a localized interaction be-

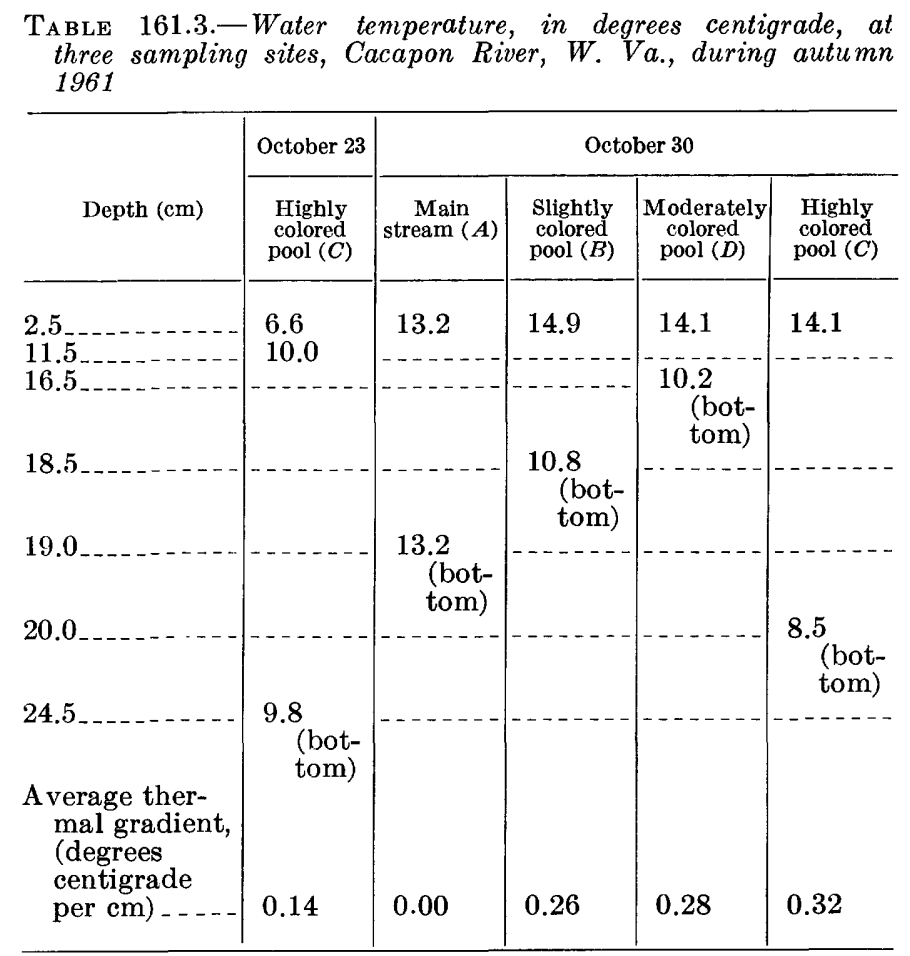


tween the marginal vegetation and the water in lowflow pools, in backwater, or flood-plain pools. Leaf litter from other parts of the drainage area contributes also to the particulate and dissolved load of the stream. Probably this effect is delayed until heavy rains produce sufficient runoff to transport these materials downstream and out of the basin or into larger water bodies where their effects are less noticeable.

\section{REFERENCES}

Chase, E. S., and Ferullo, A. F., 1958, Oxygen demand of leaves in water: Water and Sewage Works, v. 105, no. 5, p. 204205.

Huet, M., 1951, Nocivite des boisements en Epiceas (Picea excelsa Link.) pour certains cours d'eaux de l'Ardenne Belge: Verh. int. Ver. Limnol., v. 11, p. 189-200.

Hutchinson, G. E., 1957, Geography, physics, and chemistry, v. 1 of A treatise on limnology: New York, John Wiley and Sons, Inc., $1015 \mathrm{p}$.

Hynes, H. B. N., 1960, The biology of polluted waters: Liverpool, England, Liverpool Univ. Press, 202 p.

Kanwisher, John, 1959, Polarographic oxygen electrode: Limnology and Oceanography, v. 4, no. 2 , p. 210-217.
Myers, H. C., 1961, Manganese deposits in western reservoirs and distribution systems: Am. Water Works Assoc. Jour., v. 53 , no. 5 , p. $579-588$.

Pearsall, W. H., and Mortimer, C. H., 1939, Oxidation-reduction potentials in waterlogged soils, natural waters and muds: Jour. Ecology, v. 27, p. 483-501.

Rainwater, F. H., and Thatcher, L. L., 1960, Methods for collection and analysis of water samples: U.S. Geol. Survey Water-Supply Paper 1454, 301 p.

Robinson, W. O., Bastron, Harry, and Murata, K. J., 1958, Biogeochemistry of the rare-earth elements with particular reference to hickory trees: Geochim. et Cosmochim. Acta, v. 14 , p. 55-67, 2 figs.

Schneller, M. V., 1955, Oxygen depletion in Salt Creek, Indiana, in v. 4 of Investigations of Indiana Lakes and Streams: Indiana Univ. Dept. Zoology, p. 163-175.

Slack, K. V., 1955, A study of the factors affecting stream productivity by the comparative method, in v. 4 of Investigations of Indiana Lakes and Streams: Indiana Univ. Dept. Zoology, p. 3-47.

Sylvester, R. O., 1959, Water quality study of Wenatchee and Middle Columbia Rivers before dam construction: U.S. Fish and Wildlife Service, Spec. Sci. Rept.-Fisheries, no. 290. 


\title{
Article 162
}

\section{RELATION OF PERCENT SODIUM TO SOURCE AND MOVEMENT OF GROUND WATER, NATIONAL REACTOR TESTING STATION, IDAHO}

\author{
By F. H. OLMSTED, Yuma, Ariz.
}

Work done on behalf of the U.S. Atomic Energy Commission

\begin{abstract}
Most of the ground water in the National Reactor Testing Station is of the calcium magnesium bicarbonate type. The percent sodium decreases northwestward, where the source of recharge is a limestone and dolomite terrane, and increases southeastward, where the source is in silicic volcanic rocks and lacustrine deposits.
\end{abstract}

The National Reactor Testing Station occupies an area of about 900 square miles in the norch-central part of the eastern Snake River Plain in Idaho. Ground water occurs in a regional zone of saturation in flatlying basalt flows and subordinate interbedded sediments of Quaternary age. The most important waterbearing openings are voids in the basalt adjacent to interflow contacts, openings in cinders, scoria, and blocky zones; and interstitial pores in the sedimentary deposits. The upper part of the regional ground-water body is unconfined in most places, but quasi-artesian conditions are common at depths of more than a few tens of feet below the water table. Depths to the water table within the station range from about 200 feet to more than $\mathbf{7 0 0}$ feet. Regional ground-water movement is south to southwest (fig. 162.1), although locally the water moves in other directions for short distances.

A study of the chemical character of ground water in the station was based on analyses of 148 samples collected from 92 wells during the period 1949-61. Most of the water is of the calcium magnesium bicarbonate type, with calcium plus magnesium constituting more than 70 percent of the total cations, in equivalents per million, and bicarbonate more than 70 percent of the total anions. Other chemical types, chiefly chloride waters, are present in some areas as the result of contamination by liquid waste from the operation of atomic facilities, by return flow from irrigation in the Mud Lake area northeast of the station, and probably by natural sources as yet not identified. A small body of ground water with a high sulfate content has been formed by seepage from a waste-disposal pond at one of the atomic facilities. As of 1961, none of this water, which is perched above a layer of basalt, had reached the regional ground-water body.

Except for small bodies of water that are high in chloride or sulfate content and contain as much as 1,000 parts per million of dissolved solids, the range in chemical characteristics of the water is not large. In most of the bicarbonate water the concentration of dissolved solids ranges from about 180 to $240 \mathrm{ppm}$. The generally low mineralization of the ground water reflects the low solubility of the rocks with which the water has been in contact and the moderate to abundant precipitation in the mountainous areas that furnish the principal recharge. Recharge from precipitation on the Snake River Plain is believed to be minor.

The chemical characteristics of the ground water do not appear to vary greatly with depth except near waste-discharge facilities and where deep wells penetrate thick extensive lacustrine deposits. Percent sodium as high as 80 in water from these wells probably results from cation exchange with the lacustrine clays.

Areal differences in ionic ratios in the ground water beneath the station help to identify the sources of the water and to corroborate the inferred paths of water movement. In this respect, the variation in sodium plus potassium (chiefly sodium) in terms of percent of total cations (in equivalents per million) is particularly revealing.

The available information indicates that at most places the chemical character of the ground water is fairly uniform to depths as great as 200 feet below the water table - that is, in the upper 200 feet of the 


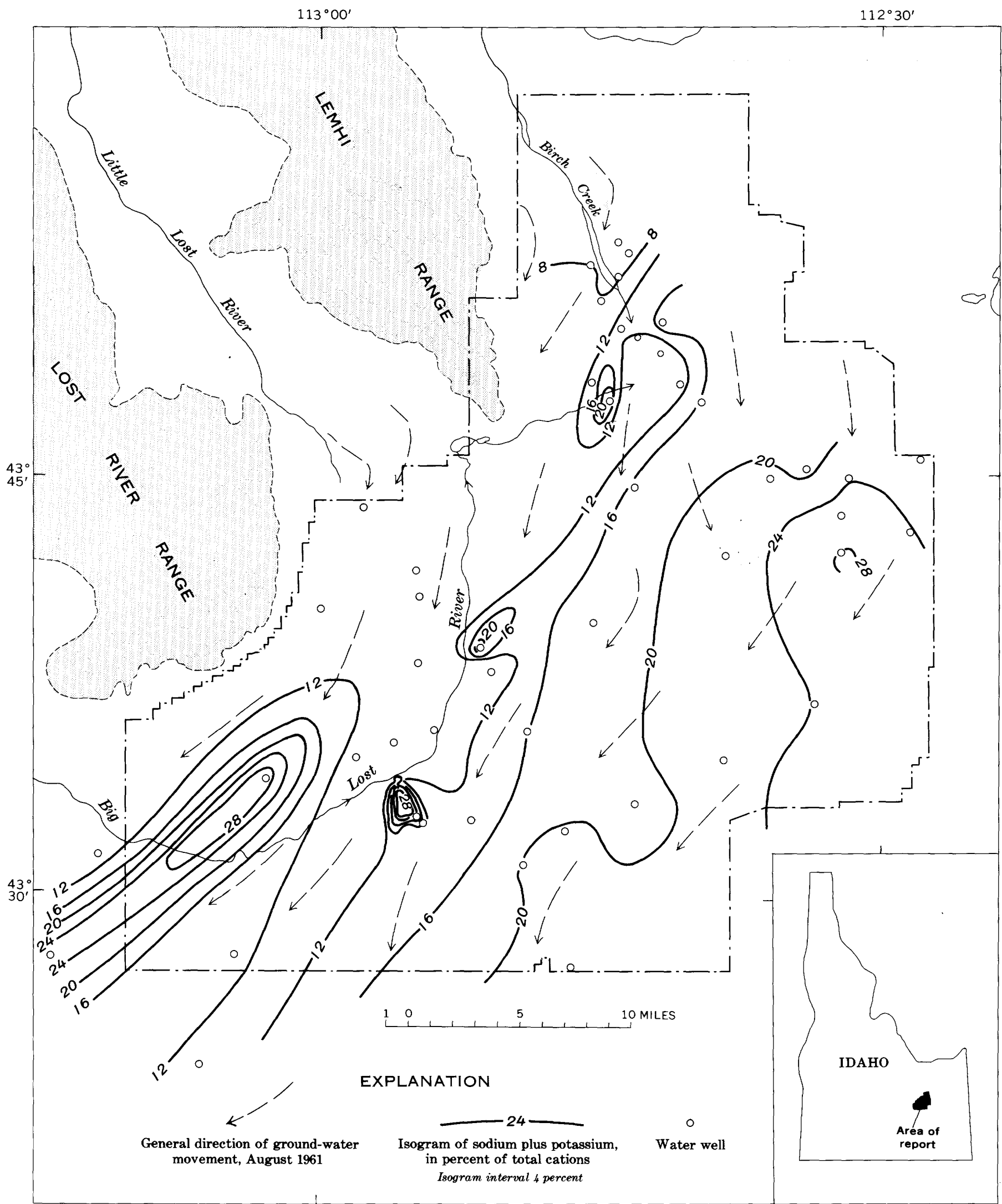

Figure 162.1.-Map of the National Reactor Testing Station, Idaho, showing percent sodium plus potassium in ground water in the upper 200 feet of the ground-water body. 
regional ground-water body. The chemical character of the water below that zone is not well known; accordingly, only analyses of ground water in the zone from the water table to 200 feet below the water table were used in the present study (fig. 162.1).

In general, the percent sodium plus potassium increases gradually from about 8 percent along the northwest boundary of the station to more than 24 percent in the southeast. Exceptions to this general pattern are the two southernmost bodies of water high in percent sodium, which consist of contaminated water also high in chloride, and two small bodies of highsodium water farther northeast, which are believed to be affected by upward flow in wells of sodium bicarbonate water from depths greater than 200 feet below the water table.

The isograms in figure 162.1 have a general southsouthwesterly trend-parallel to the regional groundwater flow lines inferred from water-level contour maps. The lower percent sodium plus potassium in the water beneath the northwestern part of the station reflects the extensively exposed limestone and dolomite in the Lost River and Lemhi Ranges to the northwest, and the higher percent sodium plus potassium in the water beneath the southeastern part of the station reflects the abundance of silicic volcanic rocks in the region to the north and northeast. Some of the water from the north and northeast also has moved through a considerable volume of fine-grained lacustrine deposits in the Mud Lake region and, therefore, may have been affected by cation exchange. The basalt, which forms the main aquifer system, appears to have little effect on the chemical character of the water moving through it.

The gradual, rather than abrupt, southeastward increase in percent sodium plus potassium in the upper 200 feet of the ground-water body is believed to indicate a progressive decrease in the proportion of lowsodium water derived from the northwest and a progressive increase in the proportion of water higher in sodium content derived from the north and northeast. Variations in the rate of replenishment from these sources are indicated by substantial changes with time in the direction of ground-water flow, which are inferred from observed changes in the configuration of the water table in the northern part of the station. 
Article 163

\title{
RELATION OF FLUORIDE CONTENT TO RECHARGE AND MOVEMENT OF GROUND WATER IN OASIS VALLEY, SOUTHERN NEVADA
}

\author{
By GLENN T. MALMBERG and T. E. EAKIN, Carson City, Nev.
}

Work done in cooperation with the Nevada Department of Conservation and Natural Resources

\begin{abstract}
Although most of the ground water contains excessive fluoride, a local supply that meets Federal standards for public water supplies was located by means of a hydrogeochemical reconnaissance. Elsewhere in the Great Basin where waterquality problems exist, similar studies could be applied in locating usable ground water.
\end{abstract}

An unusually high content of certain minor constituents, such as boron or fluoride, or of total dissolved solids renders ground water unfit for various uses in many valleys in the Great Basin. In Oasis Valley, Nev., about 100 miles northwest of Las Vegas, nearly all the ground water has a fluoride content higher than permissible limits established by the U.S. Public Health Service (1962) for public supply. A hydrogeocnemical reconnaissance by the authors (1962) indicated favorable possibilities for developing ground-water supplies of low fluoride content. Subsequent test drilling has confirmed the predictions.

Oasis Valley is about 430 square miles in extent and is drained by the Amargosa River (fig: 163.1). The Amargosa is an intermittent stream which rises in a group of springs in Oasis Valley and drains southward toward the Amargosa Desert. The discharge from six springs in the alluvial fill adjacent to the flood plain of the river, about a mile northeast of Beatty, has long been the water supply for that town (population 500). As the fluoride content of this water is about 4.5 parts per million, most of the children, the native Indian population, and some adults who have resided in the community since childhood suffer from dental fluorosis. Water from wells and other springs along the Amargosa River also has high concentrations of fluoride.

Most of the Oasis Valley drainage area is underlain by Tertiary and Quacernary volcanic rocks consisting of tuff and other pyroclastic rocks, welded tuff, and flows (fig. 163.1). Minor amounts of Paleozoic limestone, dolomite, shale, and sandstone make up the rest of the bedrock. Quaternary alluvial fill underlies about 65 square miles of the valley floor. The alluvial fill is saturated with ground water to within a foot or two of the land surface and forms the principal groundwater reservoir.

Virtually all recharge to the alluvial fill is derived from precipitation in the drainage basin north and east of the Amargosa River and from ground-water underflow through bedrock from beyond the surficial drainage area to the north and northeast (Malmberg and Eakin, 1962). Only a minor amount of recharge is derived from infiltration of precipitation on the Bullfrog Hills, and virtually no recharge occurs from infiltration of precipitation on the valley floor and the low rolling hills adjacent to the valley floor.

Analysis for fluoride and other mineral constituents of water samples throughout Oasis Valley indicated that ground water beneath the floor of the valley contained up to $5 \mathrm{ppm}$ of fluoride and that throughout most of the drainage area, fluoride concentrations exceeded $1.6 \mathrm{ppm}$, the safe limit for public water supplies that would apply in the Beatty area (U.S. Public Health Service, 1962). Moreover, ground-water underflow toward the Amargosa River from the principal area of recharge north and east of the river contained higher concentrations of fluoride than ground-water underflow from the Bullfrog Hills.

Fluoride in the ground water in Oasis Valley probably is derived from weathering of fluorite and fluoridebearing minerals which commonly occur as sublimation products associated with volcanic rocks. Chemical 


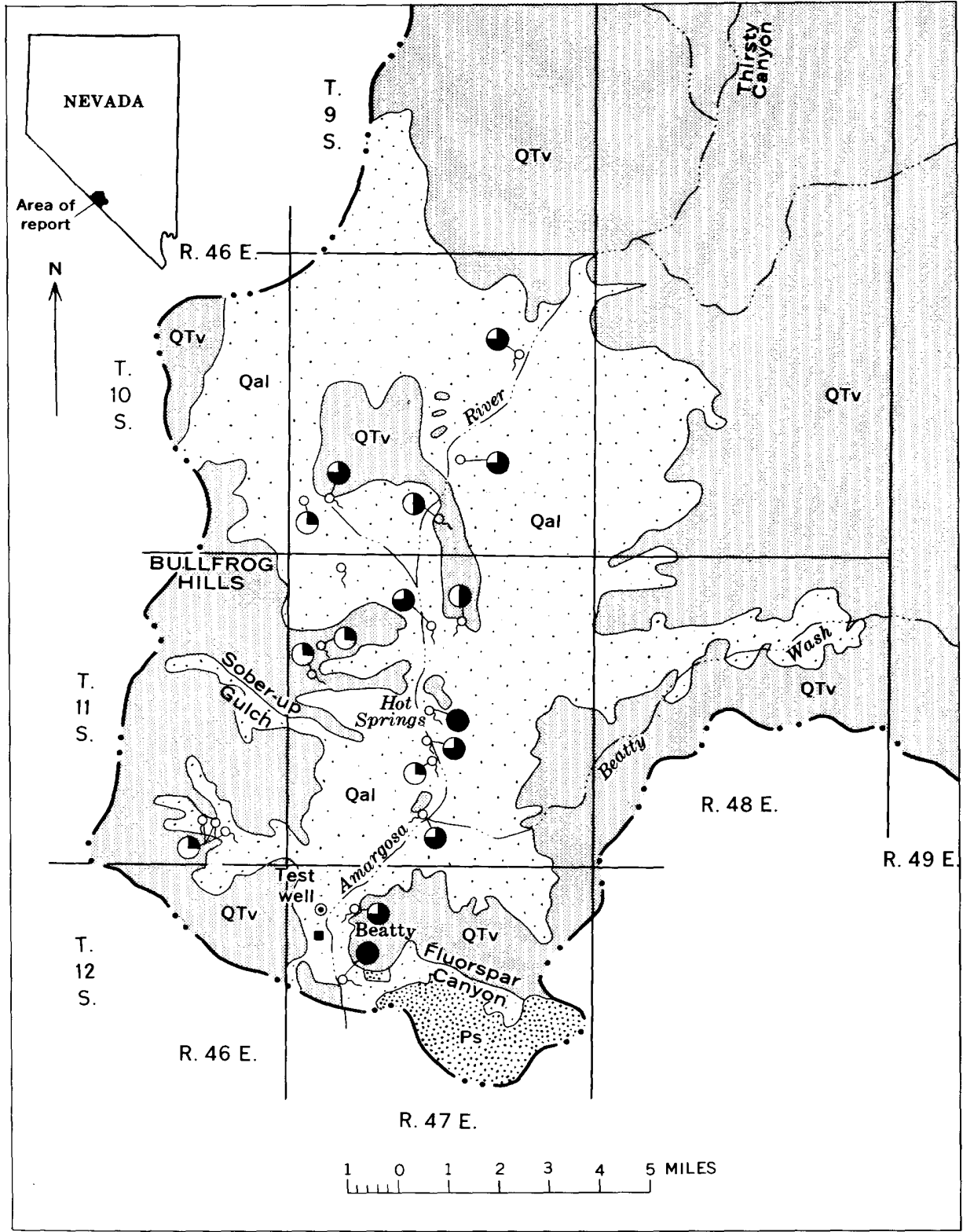

EXPLANATION

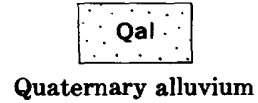

OTV

Tertiary and Quaternary consolidated rocks of volcanic origin

Composed principally of tuffs

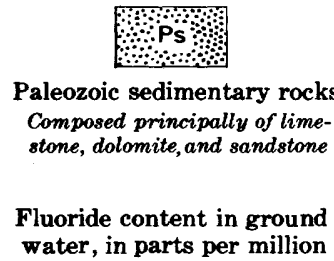

water, in parts per million

() $0-1.5$

(1.6-3.0

3.1-4.5

4.6-6

o

Well

$\rho$

Spring

Frgure 163.1.-Generalized geologic map of Oasis Valley, Nye County, Nev. Dashed outline enclosing patterned area is boundary of that part of the Amargosa River basin in the report area.

decomposition and subsequent leaching of fluoridebearing minerals disseminated throughout the volcanic rocks probably are the major causes of fluoride in the ground water in the area.

The high concentration of fluoride in the water samples from the Hot Springs and other thermal springs in Oasis Valley suggests that additional fluoride may be derived from hydrothermal solutions emanating from underlying magmatic rocks. All the large springs along the flood plain of the Amargosa River issue from volcanic rocks or from alluvial fill adjacent to volcanic rocks and yield thermal waters of high fluoride content.
Leaching of lenses and veins of fluorite in carbonate rocks exposed in Fluorspar Canyon southeast of Beatty undoubtedly accounts for high concentrations of fluoride in the ground water downstream from that area.

Chemical analyses of water from several small springs in the unnamed canyon about a mile north of Beatty and in Sober-Up Gulch, 4 miles north of Beatty indicated fluoride concentrations of less than $1.5 \mathrm{ppm}$ (fig. 163.1). Analyses of water from a few wells in Oasis Valley suggested that fluoride concentrations in ground water near the base of the Bullfrog Hills is generally lower than in other parts of the valley but 
increases progressively toward the Amargosa River. This led to specific consideration of areas near the Bullfrog Hills for a possible supply of low-fluoride water. Because ground water in the volcanic rocks presumably would have a high fluoride content, only areas underlain by alluvium were considered. Accordingly, the alluvial fan at the mouth of the unnamed canyon north of Beatty and at the mouth of Sober-Up Gulch were considered the most likely places where ground-water supplies of relatively low fluoride content could be developed.

The average annual recharge from precipitation in the catchment area of each of these basins was estimated to be about 20 acre-feet per year. Although there has been some hydrothermal alteration and mineral enrichment of the rocks in the Bullfrog Hills, underflow in the alluvium of these small tributary basins is in contact with the volcanic rock for a relatively short distance and short time and, consequently, has a minimum opportunity to dissolve fluoride. Furthermore, because the ground water in and near the areas of recharge is higher than that beneath the valley floor, there is little opportunity for deep circulation through the consolidated rock and mixing with ground water of high fluoride content. Thus, the chemical, geologic, and hydrologic data suggest that the alluvial fans at the mouth of these two canyons would be the most favorable location for developing ground water with a low fluoride content.

Large withdrawals in either of the areas described above undoubtedly would cause ground-water levels to decline below the water level beneath the floor of Oasis Valley, and the resulting reversal of the hydraulic gradient would cause movement of water of high fluoride content from beneath the valley floor to the area of ground-water development. Withdrawals sufficient to meet the entire municipal demand could not be supplied entirely from this source on a perennial basis without depleting the low-fluoride water in storage and inducing inflow of high-fluoride water. However, if withdrawals in these areas were limited to the drinking-water requirements of the town of Beatty and if pumping was carefully managed to minimize drawdown, the low fluoride content might be maintained indefinitely.

Since the publication of the report by Malmberg and Eakin (1962), a test well was drilled in the lower part of the alluvial fan at the mouth of the unnamed canyon north of Beatty (fig. 163.1). The well produced about 60 gallons per minute and the fluoride content of the water from the test well was $0.04 \mathrm{ppm}$ after 36 hours of pumping (W. W. White, Director, Nevada Department of Environmental Health, oral communication, 1963).

The success of the test drilling in locating lowfluoride ground water in this area is a good example of the value of the reconnaissance techniques used in this investigation.

\section{REFERENCES}

Malmberg, G. T., and Eakin, T. E., 1962, Ground-water appraisal of Sarcobatus Flat and Oasis Valley, Nye and Esmeralda Counties, Nev.: Nevada Dept. Conserv. and Nat. Resources, Ground-Water Resources Reconn. Ser. Rept. 10, $39 \mathrm{p}$.

U.S. Public Health Service, 1962, Drinking water standards: Federal Register, March 6, p. 2152-2155.

Webb, Barbara, and Wilson, Roland, 1962, Progress geologic map of Nevada: Nevada Bur. Mines Map 16. 


\title{
Article 165
}

\section{ENVIRONMENTAL FACTORS AFFECTING ATTACHED MACRO-ORGANISMS, PATUXENT RIVER ESTUARY, MARYLAND}

\author{
By ROBERT L. CORY, Washington, D.C.
}

\begin{abstract}
Periodic measurements of water temperature, salinity, and dissolved oxygen content were made at various depths during the period October through December 1962. Temperature was found to be the most significant variable affecting the growth of the organisms. Four principal organisms attached during October and November; growth was rapid in October but slight during the other months.

An algal-tubeworm association, in which a yellow-green alga thrived on the waste from tubeworms, was noted and may prove useful as an indicator of organic pollution.
\end{abstract}

A large steam-generating plant at Chalk Point, Md., on the Patuxent River, will begin operation in the spring of 1964. The plant is expected to discharge large amounts of heated water into the estuary which at times may be equal to or greater than the total freshwater inflow. To establish a basis for the future understanding of the effect of the heated water on the biota, the State of Maryland has initiated a comprehensive study of the entire river. Presently over 40 investigators representing State, Federal, and private organizations are studying a wide variety of problems.

Although the estuary is close to a highly urbanized area, there has been little urban development along its shores. The value of oysters, fish, and crabs taken from the estuary annually is about half a million dollars, and the estuary is known as one of the best oystergrowing areas of the Chesapeake Bay.

It is believed that any changes occuring in the estuary due to the heated water will be reflected in attached macro-organisms (chiefly barnacles, bryozoans, tubebuilding amphipods, and tubeworms) and marine borers (none were observed during the period reported on here). Study of these two types of organisms offers certain advantages because a dozen or more species representing at least eight phyla can be studied qualitatively and quantitatively at one time. Most of the mature organisms are fixed or only slightly mobile, so they are at the mercy of their immediate environment. They can be collected from uniform substrates, measured areas, and over known lengths of time, thus ruling out some of the questionable factors inherent in other quantitative biological studies. Preliminary results of the Geological Survey investigation, based on observations from October 1962 through March 1963, are reported here.

Two types of test panels, wood, for marine borers, and asbestos-cement are to be exposed for periods of 1 month, 3 months, 1 year, and for the duration of the study before and after plant operation begins. The wood panels are $260 \mathrm{sq} \mathrm{cm}$ in area and the asbestoscement panels are $290 \mathrm{sq} \mathrm{cm}$. At each point of observation one of each type is exposed for the periods indicated. The panels are collected and preserved in alcohol, then analyzed in the laboratory.

Monthly and quarterly panels have been set out and collected from the surface, middepth, and bottom (7 meters) at the center of Benedict Bridge; from middepth (2 meters) at the west end of Benedict Bridge; and from middepth (1 meter) at the end of the pier of the Chesapeake Biological Laboratory at Solomons Island, Md. (fig. 165.1). The Benedict Bridge sampling site is in the region of expected high temperatures. The Solomons Island site was chosen as a control because it will be beyond the effect of unnatural heating.

Accumulations of marine macro-organisms on the monthly panels for October and November and on the quarterly panels for October through December 1962 were measured and are reported in table 165.3. No attachment occurred during the cold months of December, January, and February, hence no accumulations are reported.

\section{ENVIRONMENTAL CHARACTERISTICS}

Water-quality data collected once a month at the Benedict Bridge site ${ }^{1}$ indicate that temperature was

1 Data furnished by the State of Maryland Water Pollution Control Commission. Samples were taken at the center of the bridge. 

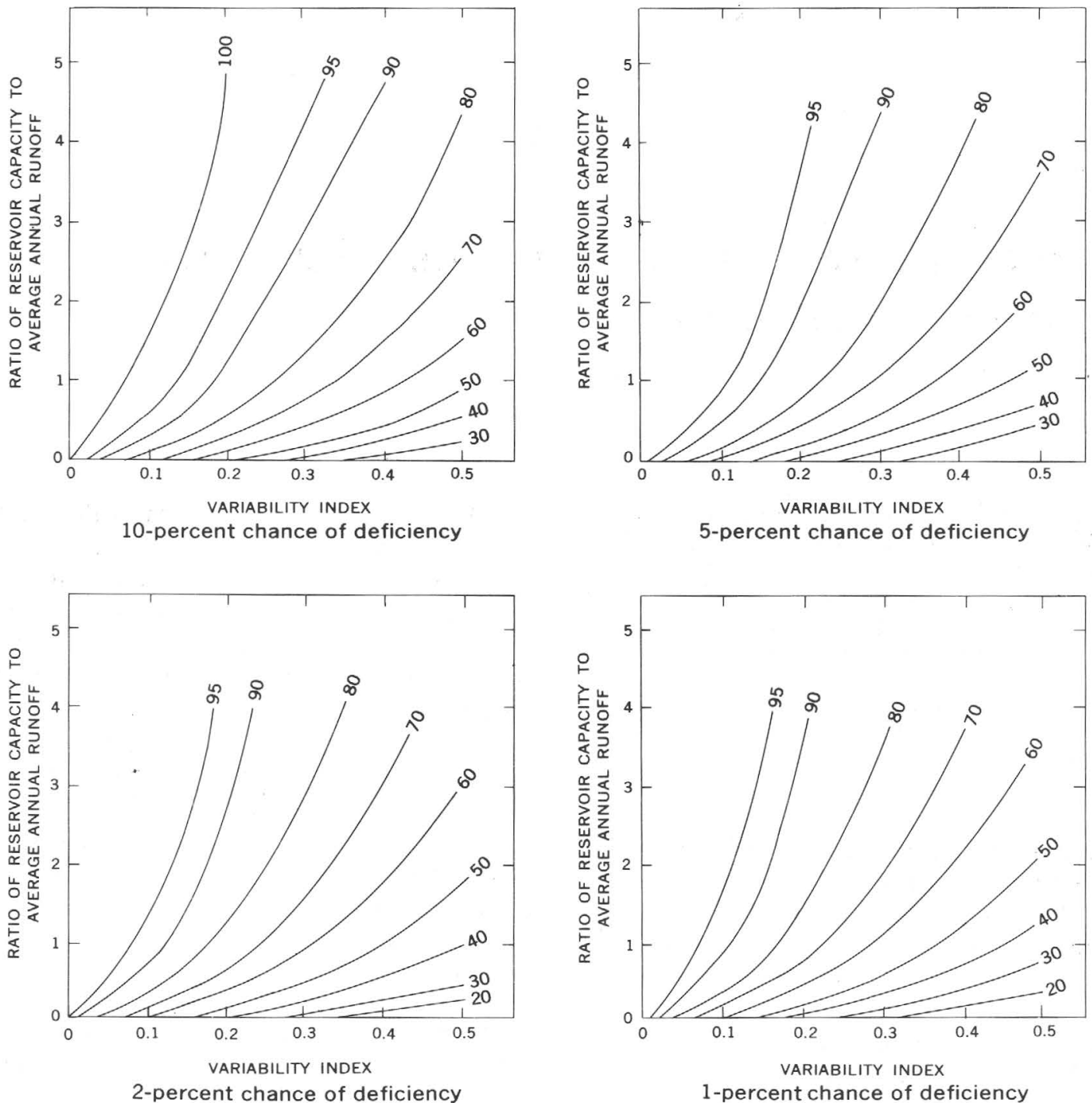

FIGURE 164.1.-Diagrams showing carryover storage requirements for log-normal distributions of annual discharge. Variability index is the logarithmic standard deviation of annual discharge. Parameter is constant-draft rate in percentage of mean flow. Percentage chance of deficiency is the percentage of years that the indicated reservoir capacity would be insufficient.

probability routing of the actual distribution would be required.

\section{REFERENCES}

Hardison, C. H., and Furness, L. W., 1963, Discussion of "Reservoir Mass Analysis by a Low-Flow Series", by J. B. Stall: Am. Soc. Civil Engineers Proc., v. 89, Sanitary Engineering Div., Jour. no. SA2, pt. 1, p. 119-122.
Lane, E. W., and Lei, Kai, 1950, Stream flow variability: Am. Soc. Civil Engineers Trans., v. 115, p. 1084-1134.

Langbein, W. B., 1958, Queuing theory and water storage: Am. Soc. Civil Engineers Proc., v. 84, Hydraulies Div. Jour., no. HY 5, pt. 1.

- 1961, Reservoir storage-general solution of a queue model: Art. 298 in U.S. Geol. Survey Prof. Paper 424-D, p. D13-D17. 


\title{
ENVIRONMENTAL FACTORS AFFECTING ATTACHED MACRO-ORGANISMS, PATUXENT RIVER ESTUARY, MARYLAND
}

\author{
By ROBERT L. CORY, Washington, D.C.
}

\begin{abstract}
Periodic measurements of water temperature, salinity, and dissolved oxygen content were made at various depths during the period October through December 1962. Temperature was found to be the most significant variable affecting the growth of the organisms. Four principal organisms attached during October and November; growth was rapid in October but slight during the other months.

An algal-tubeworm association, in which a yellow-green alga thrived on the waste from tubeworms, was noted and may prove useful as an indicator of organic pollution.
\end{abstract}

A large steam-generating plant at Chalk Point, Md., on the Patuxent River, will begin operation in the spring of 1964. The plant is expected to discharge large amounts of heated water into the estuary which at times may be equal to or greater than the total freshwater inflow. To establish a basis for the future understanding of the effect of the heated water on the biota, the State of Maryland has initiated a comprehensive study of the entire river. Presently over 40 investigators representing State, Federal, and private organizations are studying a wide variety of problems.

Although the estuary is close to a highly urbanized area, there has been little urban development along its shores. The value of oysters, fish, and crabs taken from the estuary annually is about half a million dollars, and the estuary is known as one of the best oystergrowing areas of the Chesapeake Bay.

It is believed that any changes occuring in the estuary due to the heated water will be reflected in attached macro-organisms (chiefly barnacles, bryozoans, tubebuilding amphipods, and tubeworms) and marine borers (none were observed during the period reported on here). Study of these two types of organisms offers certain advantages because a dozen or more species representing at least eight phyla can be studied qualitatively and quantitatively at one time. Most of the mature organisms are fixed or only slightly mobile, so they are at the mercy of their immediate environment. They can be collected from uniform substrates, measured areas, and over known lengths of time, thus ruling out some of the questionable factors inherent in other quantitative biological studies. Preliminary results of the Geological Survey investigation, based on observations from October 1962 through March 1963, are reported here.

Two types of test panels, wood, for marine borers, and asbestos-cement are to be exposed for periods of 1 month, 3 months, 1 year, and for the duration of the study before and after plant operation begins. The wood panels are $260 \mathrm{sq} \mathrm{cm}$ in area and the asbestoscement panels are $290 \mathrm{sq} \mathrm{cm}$. At each point of observation one of each type is exposed for the periods indicated. The panels are collected and preserved in alcohol, then analyzed in the laboratory.

Monthly and quarterly panels have been set out and collected from the surface, middepth, and bottom (7 meters) at the center of Benedict Bridge; from middepth (2 meters) at the west end of Benedict Bridge; and from middepth (1 meter) at the end of the pier of the Chesapeake Biological Laboratory at Solomons Island, Md. (fig. 165.1). The Benedict Bridge sampling. site is in the region of expected high temperatures. The Solomons Island site was chosen as a control because it will be beyond the effect of unnatural heating.

Accumulations of marine macro-organisms on the monthly panels for October and November and on the quarterly panels for October through December 1962 were measured and are reported in table 165.3. No attachment occurred during the cold months of December, January, and February, hence no accumulations are reported.

\section{ENVIRONMENTAL CHARACTERISTICS}

Water-quality data collected once a month at the Benedict Bridge site ${ }^{1}$ indicate that temperature was

\footnotetext{
1 Data furnished by the State of Maryland Water Pollution Control Commission.
} Samples were taken at the center of the bridge. 


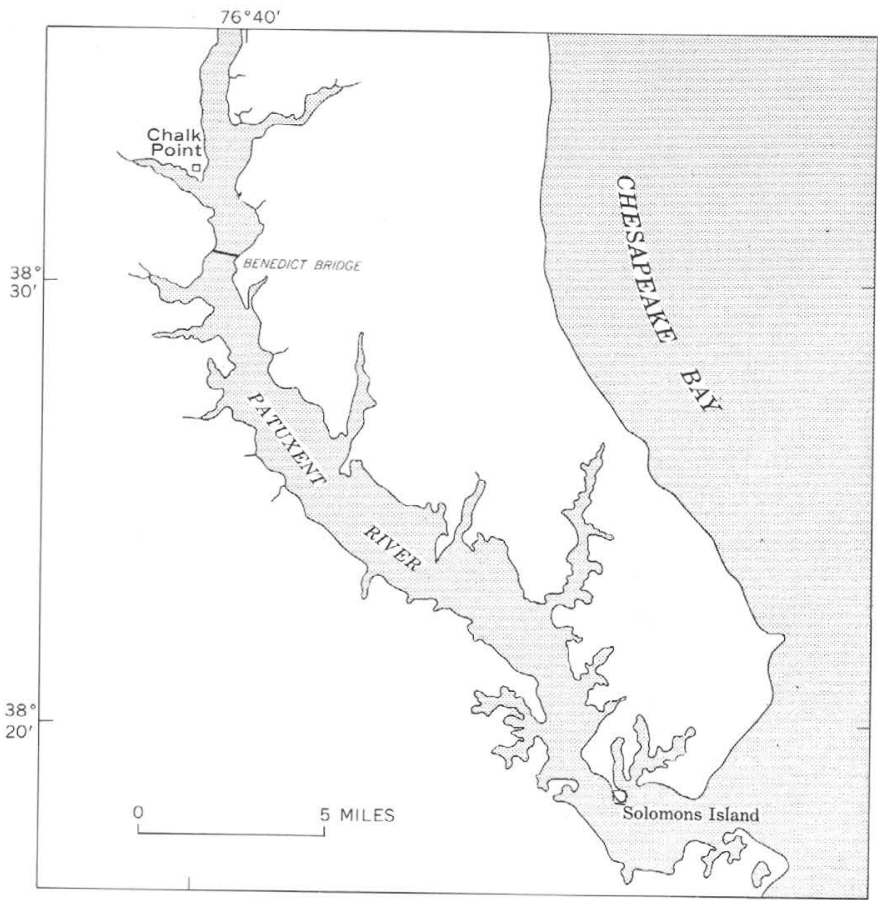

Figure 165.1.- Index map of Patuxent River estuary.

the most significant variable during the period of observations (October 1962 through February 1963). Temperatures decreased from a high of about $21.5^{\circ} \mathrm{C}$ in October 1962 (fig. 165.2) to a low of $0^{\circ} \mathrm{C}$ in January 1963. Salinity at the bridge was generally between 12 and 17 parts per thousand, and vertical variations were slight. However, the sampling program does not take into account the short-term variations caused by local weather changes and daily tidal fluctuations. Dissolved oxygen gradually increased as the temperature decreased and was high enough to support aquatic life throughout the period.

Continuous recordings of temperature and daily salinity readings have been taken since 1938 at the laboratory pier at Solomons Isıand. ${ }^{2}$ During the study reported here, the mean daily surface temperatures gradually decreased from a high of $21^{\circ} \mathrm{C}$ in October 1962 to a low of $0.5^{\circ} \mathrm{C}$ when the quarterly panels were collected. Salinity ranged from 14.8 to 17.3 ppt during the same period.

\section{DISTRIBUTION OF ORGANISMS}

The density of the principal attached macroorganisms is shown in figure 165.3. Note, however, that the number of bryozoan colonies, rather than individuals, is shown, and that the number of organisms does not indicate the total mass contributed by each group. Microscopic organisms also covered much of the surface of the panels. These forms added

\footnotetext{
${ }^{2}$ Data furnished by the Chesapeake Biological Laboratory, Solomons Island, Md.
}
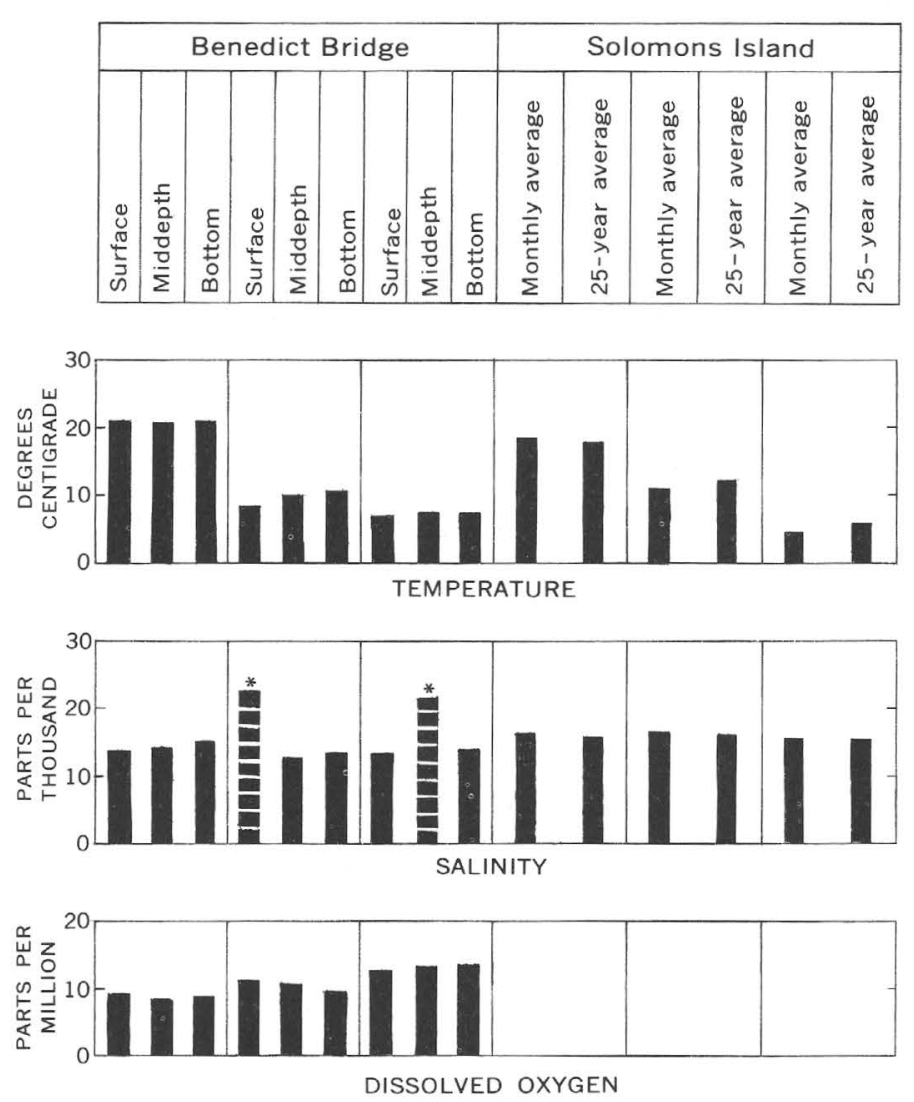

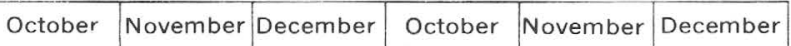

Figure 165.2.-Monthly temperature, salinity, and dissolved oxygen content of water of Patuxent River estuary at Solomons Island and Benedict Bridge, October-December, 1962. *Data questionable.

little to the total mass but are important in forming microscopic substrates, which often precede attachment of the larger forms.

Attachment by marine macro-organisms occurred only during October and November-no macro-organisms attached to monthly test panels during December, January, or February. During October, barnacles, tubeworms, tube-building amphipods, and colonial bryozoans dominated the complex. At Benedict Bridge, barnacles were the dominant form during October and increased during November (fig. 165.3). At Solomons Island mud tubeworms were dominant in October and bryozoans in November. At Benedict Bridge, where test panels were placed at three depths, the populations varied with depth (fig. 165.3).

The quarterly panels (October-December) for Benedict Bridge showed about the same organisms as the October panels, but those at Solomons Island did not have tubeworms and amphipods, which were attached to the October panels. Bryozoans were prominent and covered large areas of the panels, although the number of colonies was small. They were the dominant form 


\begin{tabular}{|c|c|c|c|c|c|c|c|c|c|c|c|}
\hline \multicolumn{9}{|c|}{$\begin{array}{c}\text { Benedict Bridge } \\
\text { Center }\end{array}$} & \multicolumn{4}{c|}{ Solomons Island } \\
end
\end{tabular}
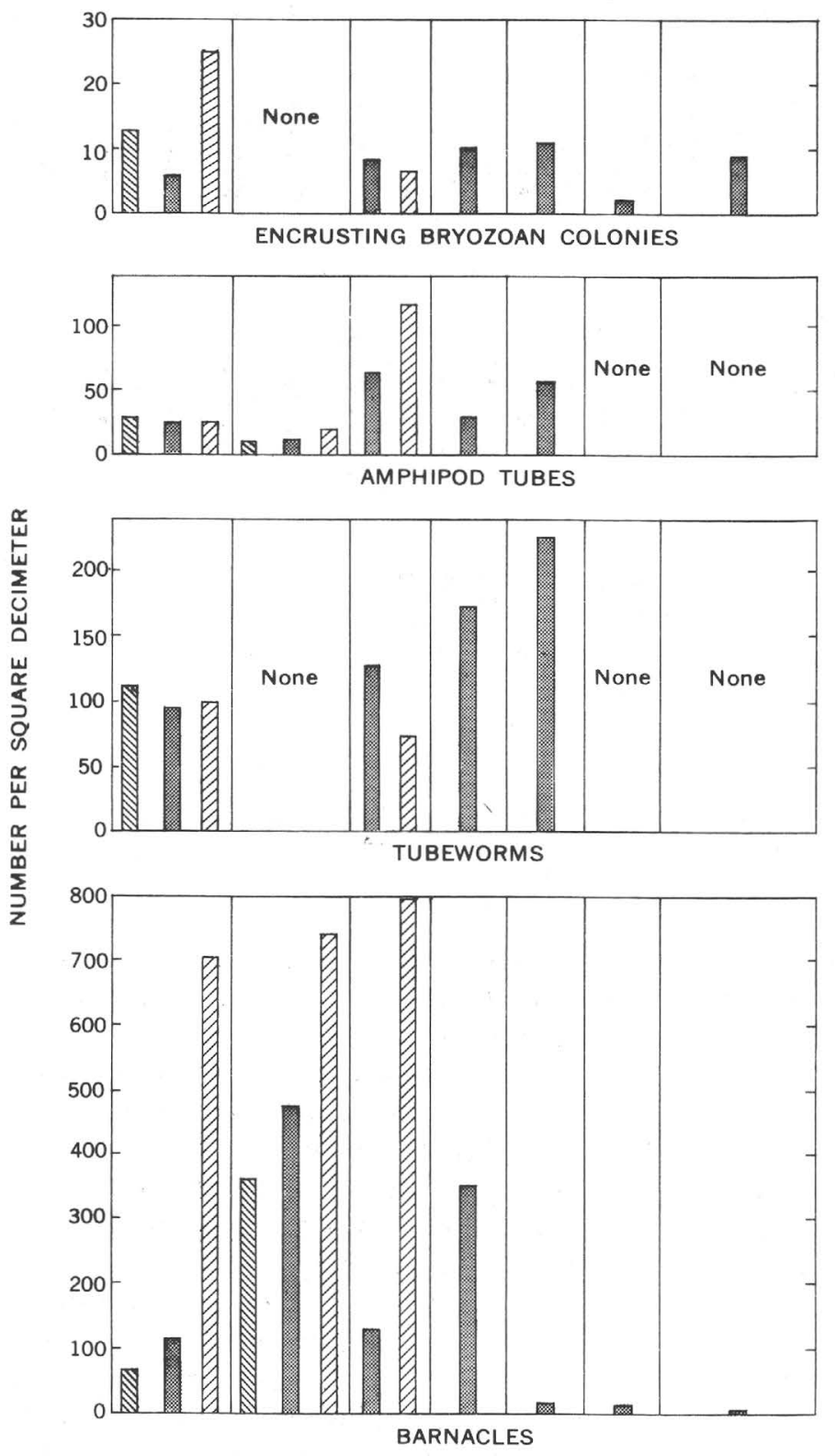

\begin{tabular}{|c|c|c|c|c|c|}
\hline Oct. & Nov. & $\begin{array}{c}\text { Oct.-Dec. } \\
(3 \mathrm{mos} .)\end{array}$ & Oct. & Nov. & $\begin{array}{c}\text { Oct.- Dec. } \\
(3 \mathrm{mos} .)\end{array}$ \\
\hline
\end{tabular}

FIGURE 165.3.-Density of principal attachment organisms collected on test panels at Benedict Bridge and Solomons Island, October-December, 1962. at Solomons Island, where a single colony covered an area of 961 square millimeters. Many young barnacles were overgrown and killed by these bryozoan encrustations.

\section{GROWTH}

Even though attachment of new individuals ceased after November, the quarterly panels indicate that total accumulations of the organisms continued. Gravid tubeworms and their eggs were present, amphipods were active on freshly collected panels, and new growth by the bryozoan colonies could be observed-evideirce that all of these forms were still quite active when the panels were collected.

Measurements of barnacle basal areas on the monthly panels show that growth of individuals was vigorous during October, diminished greatly in November, and was negligible the remainder of the winter. The growth varied both with depth and location. (See table 165.1.) Maximum sizes were attained at Solomons Island.

The mean basal-area data are somewhat misleading. For example, although the October value for the bottom at Benedict Bridge is less than at middepth and surface, this panel not only had a great many more barnacles than those at the other two depths, but many appeared to have attached a day or two before collection. This difficulty is inherent in a monthly datacollecting program and can only be resolved by more frequent observations. Also, the high mean basal area for the Solomons Island quarterly panel was based on measurement of only 10 individuals, the total number on the panel. Note the large differences between mean and maximum basal areas for the quarterly and monthly panels. A probable explanation for this is that the organisms that attach the earliest have the advantage in gathering food and utilizing space. By the end of October all available space was occupied;

TABLE 165.1.-Basal area of barnacles

[Rostrocarinal-lateral measurements]

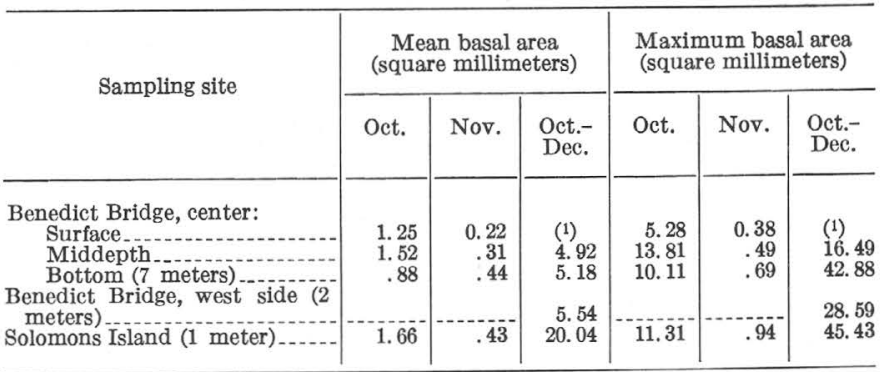

1 Panel scoured by ice. 
therefore, the size measurements are representative of individuals that attached during that month. Barnacle growth was slight in November and December. The mean basal area of barnacles on a special panel exposed for growth studies at middepth at Benedict Bridge from November 8 to March 8 was only 0.65 square millimeters as compared to a mean basal area of 4.92 square $\mathrm{mm}$ for barnacles on the panel exposed from October through December (table 165.1)

Attachment and growth of the colonial bryozoans also varied with depth and location. Unlike barnacles, they grew actively in the colder winter water, and newly formed zooecia were observed on the colonies when the quarterly panels were collected. Mean and maximum areas of bryozoan colonies were considerably less at Benedict Bridge than at Solomons Island on both the monthly and quarterly panels (table 165.2). For some unknown reason, attachment and growth were less at middepth at the center of the bridge than at the surface or bottom.

TABLE 165.2.-Area of bryozoan colonies, autum and winter, 1962

\begin{tabular}{|c|c|c|c|c|c|c|}
\hline \multirow{2}{*}{ Sampling site } & \multicolumn{3}{|c|}{$\begin{array}{l}\text { Mean area } \\
\text { (square millimeters) }\end{array}$} & \multicolumn{3}{|c|}{$\begin{array}{l}\text { Maximum area } \\
\text { (square millimeters) }\end{array}$} \\
\hline & Oct. & Nov. & $\begin{array}{l}\text { Oct.- } \\
\text { Dec. }\end{array}$ & Oct. & Nov. & $\begin{array}{l}\text { Oct.- } \\
\text { Dec. }\end{array}$ \\
\hline $\begin{array}{l}\text { Benedict Bridge, center: } \\
\text { Surface }\end{array}$ & & & & & & \\
\hline $\begin{array}{l}\text { Middepth } \\
\text { Bottom (7me }\end{array}$ & 3.92 & & 98. 96 & 4.1 & & 201.0 \\
\hline $\begin{array}{l}\text { Benedict Bridge, west side (2 } \\
\text { meters) }\end{array}$ & & & 182.4 & & & 282 \\
\hline Solomons Island (1 meter) & 40.5 & & 297.1 & 380.2 & 9.4 & 96. \\
\hline
\end{tabular}

\section{WEIGHT OF ORGANIC MATERIAL}

The weight of organic carbon (dry, minus ash weight) produced by the attachment organisms varied with time, depth, and location (table 165.3). In order to obtain a figure to compare the standing crop at each location regardless of species, whether shelled or nonshelled, the material was scraped from the wooden panels, oven dried, weighed, ashed at $500^{\circ} \mathrm{C}$, and reweighed. The weight was slight in November, compared to October, and negligible from December through February. Organic weight on the quarterly panels was highest at the bottom at Benedict Bridge and lowest at Solomons Island. Variations in organic weight undoubtedly reflect the relative abundance of the various species involved; however, measurements of single groups were not made.

\begin{tabular}{|c|c|c|c|c|c|c|}
\hline \multirow{2}{*}{ Sampling site } & \multirow{2}{*}{$\frac{\begin{array}{c}\text { Total } \\
\text { dry } \\
\text { weight }\end{array}}{\mathrm{g} / \mathrm{m}^{2}}$} & \multicolumn{2}{|c|}{ Ash } & \multicolumn{2}{|c|}{$\begin{array}{l}\text { Organic } \\
\text { matter }\end{array}$} & \multirow{2}{*}{$\begin{array}{l}\text { Expo- } \\
\text { sure of } \\
\text { panel } \\
\text { (days) }\end{array}$} \\
\hline & & $\mathrm{g} / \mathrm{m}^{2}$ & $\begin{array}{l}\text { Per- } \\
\text { cent }\end{array}$ & $\mathrm{g} / \mathrm{m}^{2}$ & $\begin{array}{l}\text { Per- } \\
\text { cent }\end{array}$ & \\
\hline \multicolumn{7}{|c|}{ October } \\
\hline $\begin{array}{l}\text { Benedict Bridge, center: } \\
\text { Surface } \\
\text { Middepth } \\
\text { Bottom (7 meters) } \\
\text { Solomons Island ( } 1 \text { meter) }\end{array}$ & $\begin{array}{l}9.3 \\
\text { 19. } 7 \\
25.05 \\
4.72\end{array}$ & $\begin{array}{r}7.08 \\
15.22 \\
15.34 \\
3.17\end{array}$ & $\begin{array}{l}76.1 \\
77.4 \\
61.1 \\
67.1\end{array}$ & $\begin{array}{l}2.22 \\
4.48 \\
9.7 \\
1.55\end{array}$ & $\begin{array}{l}23.9 \\
22.6 \\
38.9 \\
32.9\end{array}$ & $\begin{array}{l}30 \\
30 \\
30 \\
30\end{array}$ \\
\hline \multicolumn{7}{|c|}{ November } \\
\hline $\begin{array}{l}\text { Benedict Bridge, center: } \\
\text { Surface- } \\
\text { Middepth } \\
\text { Bottom (7 meters) } \\
\text { Solomons Island (1 meter) }\end{array}$ & $\begin{array}{l}\text { 2. } 99 \\
2.46 \\
1.98 \\
\text { (1) }\end{array}$ & $\begin{array}{l}2.13 \\
1.67 \\
1.45 \\
\text { (1) }\end{array}$ & $\begin{array}{l}71.2 \\
68.0 \\
73.4 \\
(1)\end{array}$ & $\begin{array}{l}0.86 \\
.79 \\
.53 \\
(1)\end{array}$ & $\begin{array}{l}28.8 \\
32.0 \\
26.6 \\
(1)\end{array}$ & $\begin{array}{l}30 \\
30 \\
30 \\
30\end{array}$ \\
\hline \multicolumn{7}{|c|}{ October-December } \\
\hline $\begin{array}{l}\text { Benedict Bridge, center: } \\
\text { Surface, } \\
\text { Middepth } \\
\text { Bottom (7 meters) }\end{array}$ & $\begin{array}{l}(2) \\
117.36 \\
248.78\end{array}$ & $\begin{aligned}(2) \\
91.56 \\
170.35\end{aligned}$ & $\begin{array}{l}(2) \\
78.0 \\
68.5\end{array}$ & $\begin{array}{l}(2) \\
25.80 \\
78.43\end{array}$ & $\begin{array}{l}(2) \\
22.0 \\
31.5\end{array}$ & $\begin{array}{l}88 \\
88 \\
88\end{array}$ \\
\hline $\begin{array}{l}\text { Benedict Br!dge, west side (2 } \\
\text { meters) } \\
\text { Solomons Island (1 meter) }\end{array}$ & $\begin{array}{r}114.67 \\
49.92\end{array}$ & $\begin{array}{l}73.45 \\
31.09\end{array}$ & $\begin{array}{l}64.1 \\
62.4\end{array}$ & $\begin{array}{l}41.22 \\
18.83\end{array}$ & $\begin{array}{l}35.9 \\
37.6\end{array}$ & $\begin{array}{l}93 \\
88\end{array}$ \\
\hline
\end{tabular}

1 Weight negligible.

2 Panel scoured by ice.

\section{ALGAE AND TUBEWORM ASSOCIATION}

The quarterly panel from the west side of Benedict Bridge showed an interesting association between the tubeworms and a yellow-green alga. Prominent tufts of the alga, 8-12 $\mathrm{mm}$ long, were scattered over the panel. Close examination revealed that these tufts were located at the anal end of the worm tubes. The algae appeared to profit from the organic enrichment of the water at this location. This relationship suggests that algae of this type may prove to be a useful indicator of other types of organic pollution. 


\title{
Article 166
}

\section{ANOMALOUS STREAMFLOW-GROUND-WATER REGIMEN IN THE MAD RIVER BASIN, NEAR SPRINGFIELD, OHIO}

\author{
By WILLIAM P. CROSS and ALVIN J. FEULNER, \\ Columbus, Ohio, and Anchorage, Alaska
}

Work done in cooperation with the Ohio Department of Natural Resources, Division of Water

\begin{abstract}
Streamflow measurements of the Mad River downstream from Springfield to the mouth of Mud Run indicated a loss in flow in this reach. Precise measurements of ground-water levels showed that ground-water flow had been diverted by drainage ditches, thereby reversing the normal ground-water gradient.
\end{abstract}

The Mad River, in west-central Ohio, has the best sustained dry-weather flow of any major stream in the State, a situation indicative of large potential groundwater supplies in the basin. Because widespread and thick permeable gravels underlie most of the Mad River valley the river is an effluent, or gaining, stream throughout most of its length. However, spot measurements of streamflow indicated that, at least at some times under dry-weather conditions, there was a loss in flow downstream from Springfield. This anomaly suggested that for some reason the yield of aquifers in that reach was lower than would be expected from the known hydrogeology. As ground-water withdrawals, recharged by infiltration from the river, were being increased in both the Springfield and Dayton areas, an investigation was made during 1959 and 1960 with the purpose of accounting for the loss in streamflow.

The Mad River rises on the eastern side of the Bellefontaine outlier, a bedrock high in Logan County, the highest terrain in the State. The river flows southward across Champaign and northern Clark Counties over a gravel-filled buried valley as much as 3 miles wide. At Springfield the valley fill is constricted by a bedrock gorge approximately $1 / 8$ mile wide. The drainage area above the stream-gaging station west of Springfield, at the lower end of the gorge, is 485 square miles. Downstream from Springfield the river flows west-southwest across a gravel-filled valley as much as 2 miles wide in Clark County and the northwestern corner of Greene County. Near the boundary between Greene and Montgomery Counties the river enters a second constriction, a bedrock gorge at Huffman Dam, one of five flood-control dams of the Miami Conservancy District. The dam forms a dry detention-type reservoir, and does not affect low and medium stages of flow. Between Huffman Dam and the mouth of the river at Dayton, the Mad River again flows over a gravel-filled valley. The drainage area above the gage just downstream from Huffman Dam is 632 square miles. Figure 166.1 shows the main features of the drainage basin and the inferred direction of ground-water movement.

Except at the two gorge sections, the Mad River valley is underlain by large volumes of highly permeable gravels. Some of this highly permeable material is hydraulically connected to the stream, and as the hydraulic gradient is toward the stream, large inflows are contributed to the river. A series of flow measurements along such a stream, called a seepage investigation or seepage run, reveals the zones of ground-water contribution by showing large increases in flow between measuring points. Lack of gains indicated by the measurements does not eliminate the possibility that permeable water-bearing deposits are separated from the stream by relatively impermeable material or that the hydraulic gradient is not toward the stream. It was such a lack of gains in a seepage investigation in September 1948 that focused attention on the reach downstream from Springfield.

The glacial features of the Mad River valley in Clark County have been described by Goldthwait 


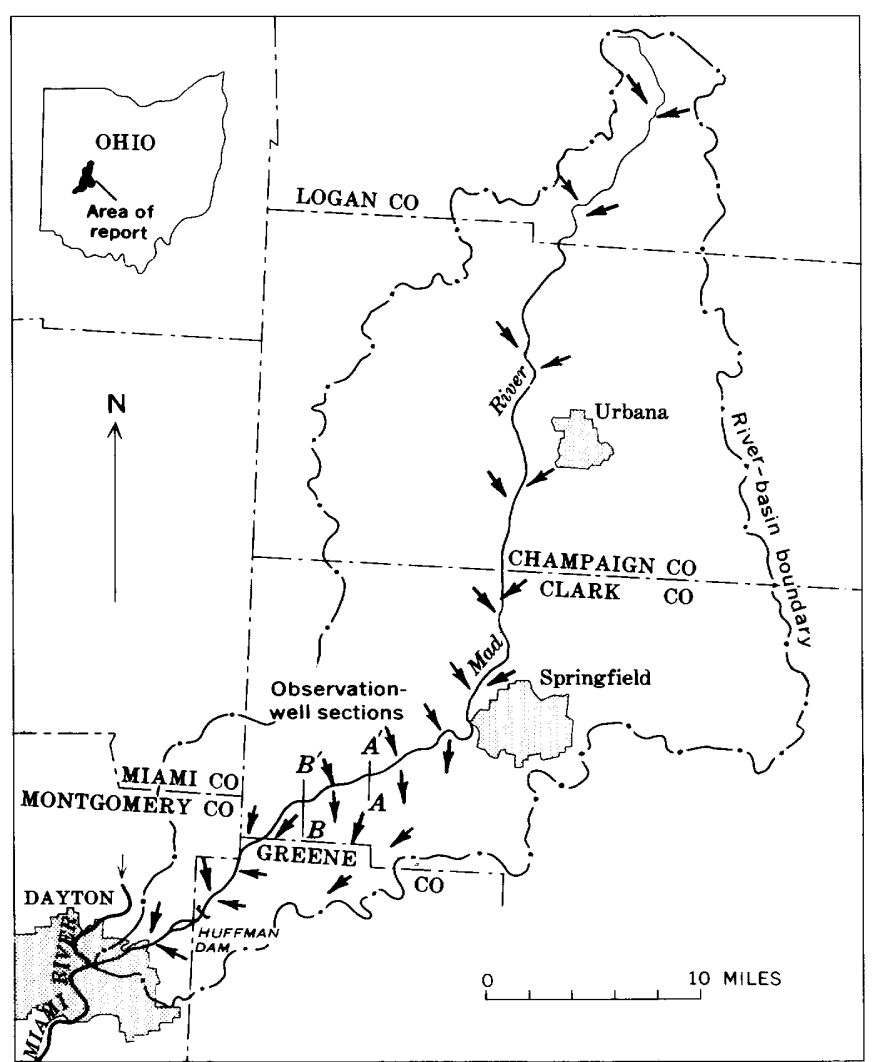

Figure 166.1.-Mad River drainage basin and inferred direction of ground-water movement (arrows) in the basin.

(Norris and others, 1952, p. 44-51), and those of Greene County by Norris and others (1950, p. 13-19). In its upper reaches the Mad River flows over a buried valley filled with sediments deposited in an interlobate zone between the Scioto (east) and the Miami (west) lobes of the Wisconsin glacier. This valley fill consists largely of permeable sand and gravel lain down as kames, kame terraces, high-level outwash, and valley-train deposits. The gorge through which the stream passes at Springfield is cut in limestone. This gorge, as well as the one which cuts through limestone and shale at Huffman Dam, has relatively impermeable bedrock walls. Downstream from each of the gorges the buried valley again widens, and is filled with highly permeable glaciofluvial deposits.

Estimates of the permeability of the gravel deposits both upstream and downstream from the Springfield gaging station have been made at various times. An average for the permeability of all gravel deposits in the Mad River valley is between 2,500 and 4,000 gallons per day per square foot. This high value is in marked contrast to that of the relatively impermeable limestone and shale that form the valley walls in the two gorge sections. Walton and Scudder (1960, p. 38) estimate that the amount of water passing through the bedrock constriction as underflow beneath Huff- man Dam is about 0.6 million gallons per day. The ungaged underflow at the gage near Springfield probably is less than this figure.

On the basis of extensive stream gaging at many selected locations during a period of low flow in September 1948, it is estimated that additions of ground water to the Mad River in Champaign County exceed $1 \mathrm{mgd}$ per day per mile of stream. Farther south, in Clark County, more than 2 mgd per mile of stream was added during this low-flow period. Cross $(1949$, p. 563) estimated the amount of water stored in the gravel deposits contributing to streamflow north of the Springfield gaging station to be as much as 2 to 3 billion cubic feet ( 15 to 22 billion gallons).

The following low-flow measurements were made on September 15, 1948, west of Springfield: 204 cubic feet per second at the gage near Springfield, $191 \mathrm{cfs}$ at Spangler Road ( $B-B^{\prime}$, figs. 166.1 and 166.2), and 201 cfs at the gage downstream from Huffman Dam (Mad River near Dayton) (Norris, and others, 1952, p. 29). Because of the limitations in the accuracy of currentmeter measurements, the flow loss in this reach cannot be reliably determined, but there undoubtedly was some loss. Flow-duration curves for the two stations indicate that on the average there are no losses, even at extreme low flows (Norris and others, 1952, p. 26).

Increases in flow between Springfield and Dayton are less than the contributions north of Springfield, but generally they are substantial. The low flow at Midway (Spangler Road) suggested that the river was losing water within this area, and to study this condition the U.S. Geological Survey and the Division of Water, Ohio Department of Natural Resources, cooperated in constructing 18 observation wells, leveling to the wells, making observations of water levels, and obtaining streamflow measurements. All the observation wells except four, which are near the Springfield gaging station, are shown on figure 166.2. The wells averaged about 18 feet in depth, and the screened portion of the casing was placed in gravel deposits below the normal water level in the area. The holes were drilled along two cross-section lines, extending to both sides of the Mad River. Elevations of ground surface and measuring points were determined by a level traverse, including elevations of measuring points at four stream crossings. Twelve sets of well observations and four sets of streamflow measurements were made during 1959 and 1960. Two of the sets of observations are illustrated in the cross sections of figure 166.3. 'I'hese are for May 21, 1959, when the flow in the river was about the mean, and for August 25, 1959, when the water levels were at the lowest point during the period of observation. The other 10 sets of observations are 


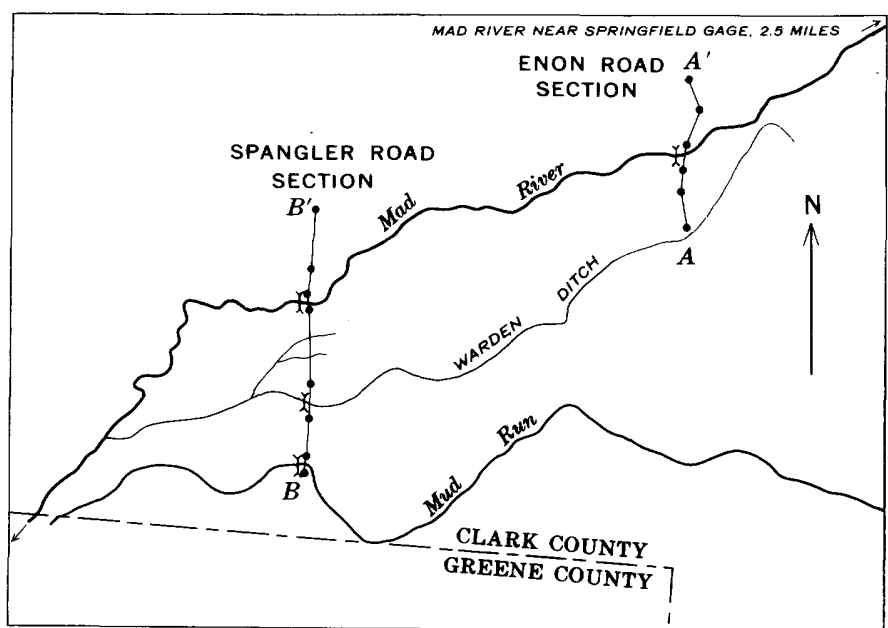

I MILE

FigURE 166.2.-Map of the Mad River basin south of Springfield, showing observation-well locations.

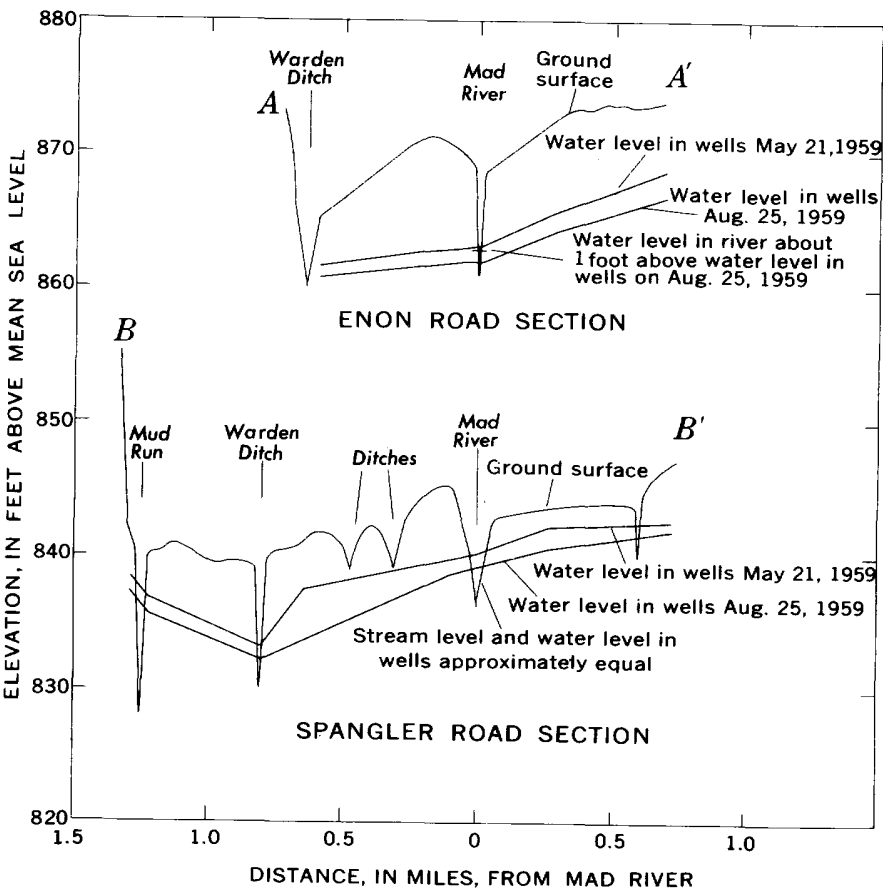

Figure 166.3.-Cross sections of the Mad River valley southwest of Springfield, showing water levels on May 21 and August 25, 1959 .

intermediate between the two extremes shown, but have the same general shape in cross section.

The reason for the losses in the reach of the Mad River from Springfield to Huffman Dam is apparent from figure 166.3. The low area south of the river must have been very swampy in earlier times as the topographic map surveyed in 1904 shows an extensive system of drainage ditches. The map surveyed in 1955 shows that the channel now called Warden Ditch had been deepened and its drainage area more than doubled by capture of the upstream ends of other ditches between 1904 and 1955. As the ditches are lower than the river bottom, and the gravels of the valley fill are highly permeable, the direction of ground-water flow is from north to south, under the river, to Warden Ditch, which flows into the river above Huffman Dam. There is no indication of ground-water flow out of the drainage basin to the Little Miami River tributaries to the south. The accompanying table confirms these conclusions by indicating a loss (a slight gain occurred on August 30, 1960) between the Springfield gage and Spangler Road which is recovered at the Huffman Dam gage (Mad River near Dayton). Thus the Mad River is an influent or losing stream for all stages up to the mean, in the reach between Springfield and the mouth of Warden Ditch.

Streamflow measurements for the Mad River between Springfield and Dayton, Ohio, 1959 and 1960

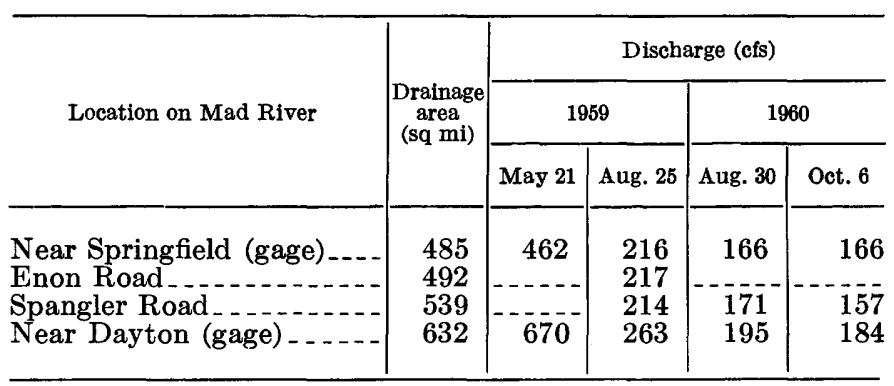

The investigation illustrates the one-sided nature of a seepage run as a reconnaissance tool for locating potential ground-water supplies. Analogous to the null hypothesis of statistics, the hypothesis of potential ground-water supplies may be accepted if there is gain in the seepage run. On the other hand, in the event of a lack of gain, additional information is needed before a decision can be made. In this specific situation, the potential ground-water yield was there, but gains were not measured in the reach because the hydraulic gradient had been reversed locally, perhaps inadvertently, by drainage ditches.

\section{REFERENCES}

Cross, W. P., 1949, The relation of geology to dry-weather streamflow in Ohio: Trans. Am. Geophysical Union, v. 30, p. 563566.

Kaser, Paul, 1962, Ground-water levels in the vicinity of Eagle City, Clark County, Ohio: Ohio Dept. Nat. Resources, Div. Water, Report to Ohio Water Commission, p. 1-82.

Norris, S. E., Cross, W. P., and Goldthwait, R. P., 1950, The Water Resources of Greene County, Ohio: Ohio Dept. Nat. Resources, Div. Water Bull. 19, p. 1-52. 
Norris, S. E. and others, 1952, The Water Resources of Clark County, Ohio: Ohio Dept. Nat. Resources, Div. Water Bull. 22, p. 1-82.
Walton, W. C., and Scudder, G. D., 1960, Ground-water resources of the valley-train deposits in the Fairborn area, Ohio: Ohio Dept. Nat. Resources, Div. Water Tech. Rept. 3, p. 1-51. 


\title{
Article 167
}

\section{HEIGHT-FREQUENCY RELATIONS FOR NEW JERSEY FLOODS}

\author{
By D. M. THOMAS, Trenton, N.J.
}

\begin{abstract}
Regional relations among height, discharge, and frequency are defined for New Jersey floods having annual recurrence intervals of 1.5 to 50 years. Separate relations are shown for Coastal Plain and non-Coastal Plain streams, and they can be used to predict flood heights at sites where mean annual flood discharge is known or can be estimated.
\end{abstract}

Regional relations among height, discharge, and frequency have been defined for New Jersey floods. These relations, which were developed from a study of streamgaging station records, can be used to predict flood heights at sites where mean annual flood discharge is known or can be estimated. The relations are similar to the depth-discharge-frequency relations found by Leopold and Maddock (1953).

Leopold and Maddock (1953) determined for less than bankfull streamflow that a basin-wide relation exists between stream depth and discharge when discharge is of equal frequency of occurrence at all sites. They showed this relation as a simple power function of the form $d=c Q^{f}$, where $d$ is average cross-section depth, $Q$ is discharge of a given frequency at the section, and $c$ and $f$ are constants for a given frequency.

The simple power function also proved satisfactory for defining the New Jersey flood relations. However, for ease of field application, different measures of the two variables were used. Flood height $(h)$ was used rather than average cross-section depth $(d)$ because it is simply measured as a vertical distance. Flood height is defined as height of the water surface above the average channel bottom determined at time of median (50-percent duration) discharge. Mean annual flood discharge $\left(Q_{2.33}\right)$ was found to be a satisfactory index of flood sizes for the desired flood-frequency range, and it was used for all frequencies rather than actual discharge $(Q)$. With these variables the equation of the New Jersey flood height-frequency relations is $h=c Q^{\mathrm{t}}{ }_{2.33}$.
Records of 46 stream-gaging stations were used to define the flood-height-frequency relations by evaluating the $c$ and $f$ constants for annual flood recurrence intervals of 1.5 to 50 years. These gaging stations, which have mean annual flood discharges ranging from 117 to 140,000 cubic feet per second, are located at sites where natural flood flows and flood heights could be determined. Thirteen of the gaging stations are in the Coastal Plain physiographic province of southern New Jersey. Different $c$ values were determined for these gaging stations than for the gaging stations outside the Coastal Plain. For the Coastal Plain, $c$ ranged from 0.49 for a 1.5-year flood to 1.35 for a 50-year flood, while for the non-Coastal Plain sites $c$ ranged from 0.33 for a 1.5-year flood to 0.90 for a 50-year flood. The $f$ values for both Coastal Plain and non-Coastal Plain sites ranged from 0.360 for a 1.5 -year flood to 0.314 for a 50-year flood. Figures 167.1 and 167.2 show graphically the defined relations.

Accuracy of the defined relations was checked by using them to estimate flood heights at the 46 gaging stations and comparing the estimated and measured values. As a check on the accuracies expected at ungaged sites, the flood heights were estimated using mean annual flood discharges computed from drainagebasin characteristics by preliminary methods developed in another study. Two out of three estimates at gaging stations agreed with measured flood heights within \pm 23 percent for a 2.33-year flood, within \pm 16 percent for both a 10 -year and a 25 -year flood, and within \pm 21 percent for a 50 -year flood. Maximum errors for a 2.33-year flood were +54 percent and -47 percent, and maximum errors for a 50-year flood were +36 percent and -49 percent. No significant accuracy differences appeared between estimates for Coastal Plain and non-Coastal Plain streams. 


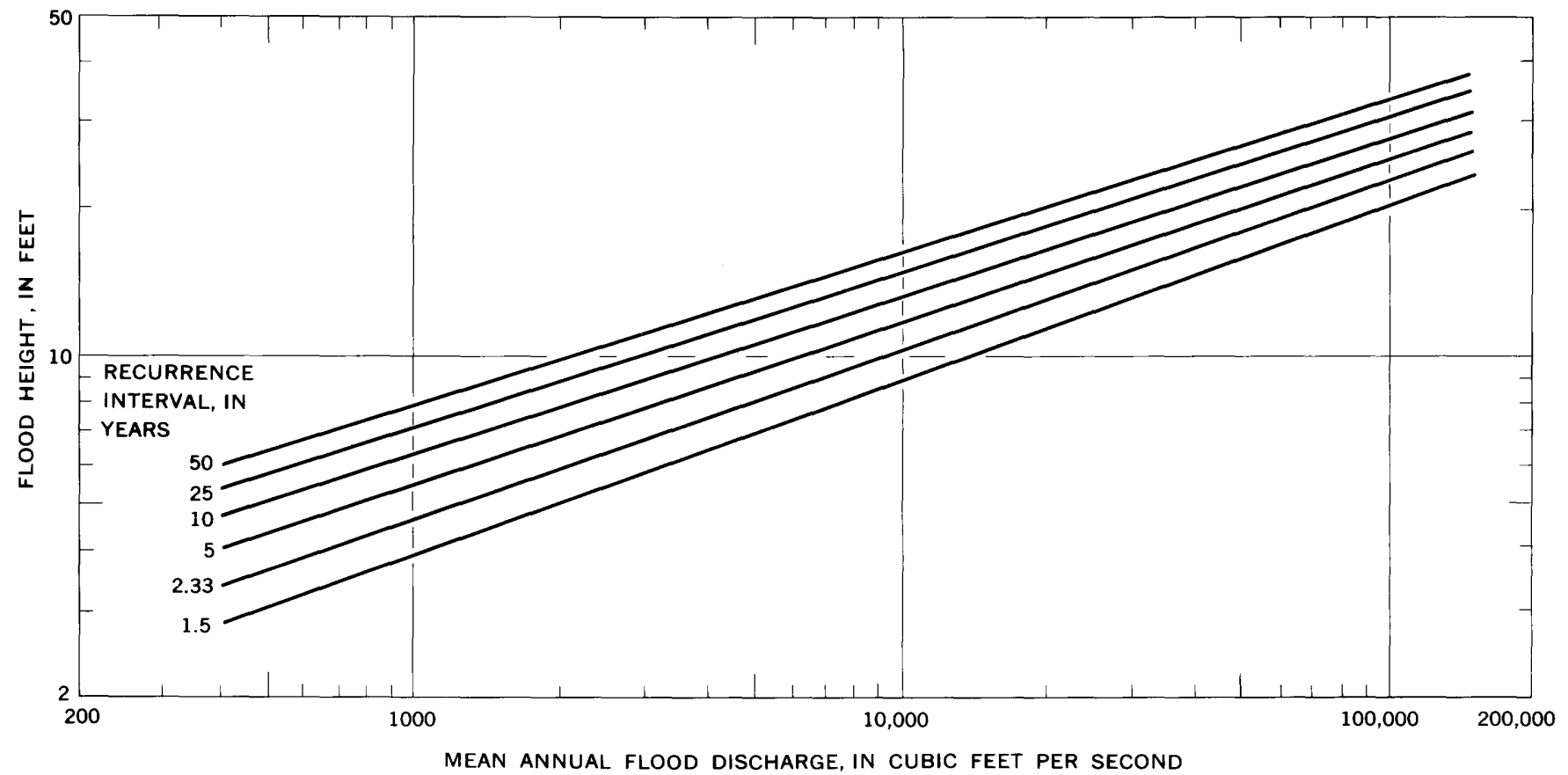

FIGURE 167.1.-Flood height-discharge-frequency relations for non-Coastal Plain streams in New Jersey.

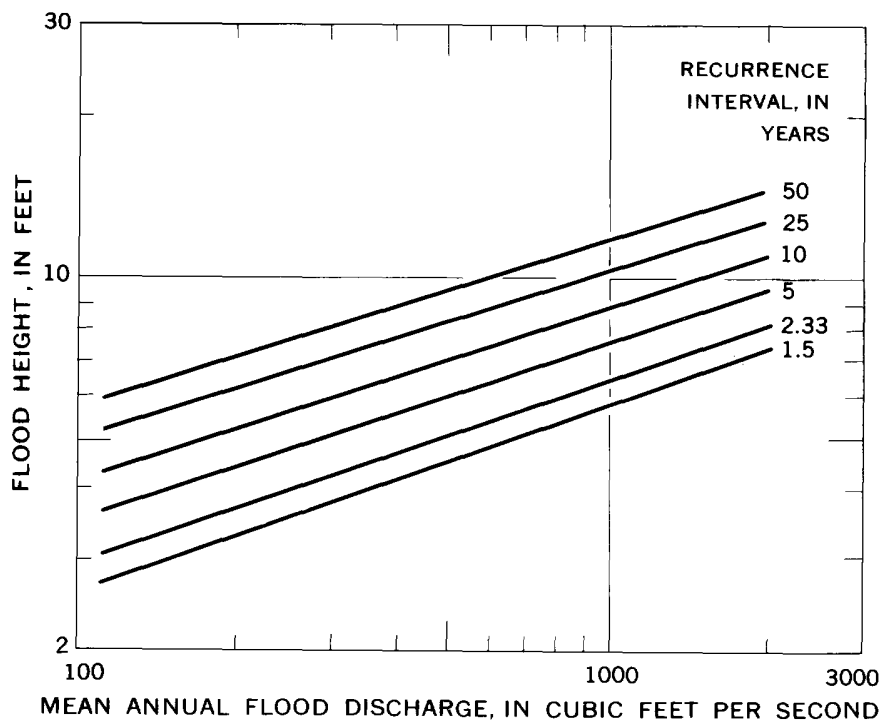

Although flood heights estimated by the areal relations are considered less reliable than those obtained from field surveys and hydraulic computations, the ease and simplicity of their determination are expected to make them useful for many purposes.

\section{REFERENCE}

Leopold, Luna B., and Maddock, Thomas, Jr., 1953, The hydraulic geometry of stream channels and some physiographic implications: U.S. Geol. Survey Prof. Paper 252.

Figure 167.2.-Flood height-discharge-frequency relations for Coastal Plain streams in New Jersey.

$716-6260-64-14$ 


\title{
Article 168
}

\section{SEASONAL TEMPERATURE FLUCTUATIONS IN SURFICIAL SAND NEAR ALBANY, NEW YORK}

\author{
By RALPH C. HEATH, Albany, N.Y.
}

Work done in cooperation with the

New York Water Resources Commission

\begin{abstract}
Subsurface temperature fluctuations are due to thermal waves that originate at the land surface in response to changes in air temperature. The annual average temperature of the zone of saturation, 6 to 18 feet below land surface, is about $3^{\circ} \mathrm{F}$ higher than the annual average air temperature.
\end{abstract}

The temperature of ground water at the top of the zone of saturation in most places corresponds closely to the mean annual air temperature. Collins (1925) pointed out that the temperature of ground water between depths of 30 and 60 feet is generally $2^{\circ} \mathrm{F}$ to $3^{\circ} \mathrm{F}$ above the mean annual air temperature. The temperature of shallow ground water under natural conditions is affected by (1) air temperature, (2) character of the land surface and ground cover (Pluhowski and Kantrowitz, 1963), (3) thermal conductivity of the zone of aeration, (4) temperature of recharge reaching the zone of saturation, and (5) heat from the earth's interior. Of these, the first three are the most important. The tem perature of recharge generally has a significant effect only where the water table is relatively close to the land surface or where the zone of aeration is composed of highly permeable material. Heat from the earth's interior increases the temperature of ground water approximately $1{ }^{\circ} \mathrm{F}$ for each 65 feet of increase in depth in northern New York. The effect of the earth's heat on the temperature of shallow ground water cannot be determined until the direct and indirect effects of the other factors are better known.

A study of the seasonal fluctuation of soil and groundwater temperatures was started in July 1959 in a residential area in the unincorporated village of McKnownville, N.Y., a suburb just west of Albany. The land surface is a gently rolling plain covered principally by grass and scattered trees. The surficial deposit, about 20 feet thick, consists of fine to medium sand and mantles a series of interbedded silts and clays approximately 100 feet thick. The sand layer contains water under unconfined conditions. Because the sand is stratified, its horizontal permeability is substantially greater than its vertical permeability.

Temperatures were measured at 5 levels within the surficial sand: 2 in the zone of aeration, and 3 in the zone of saturation. Temperature measurements were made in the zone of aeration with indoor-outdoor thermometers having steel-encased fluid reservoirs buried at 1.5 and 3 feet. The temperature within the zone of saturation was measured at depths of $6.4,11.1$, and 17.7 feet below land surface in 3 wells driven to depths of 8,13 , and 20 feet, respectively. The bulbs of the thermometers were imbedded in sand in the lower part of small open glass bottles that were left submerged between temperature readings.

Two homes are located about 50 feet downgradient from the temperature-measurement site, and several others are within a few hundred feet downgradient. Other homes are located 100 to 200 feet upgradient. All domestic wastes from these homes, except those originating in the bathrooms, are disposed of through sewers. Bathroom wastes are disposed of through septic tanks, the nearest of which is 32 feet downgradient from the site.

The data collected during 1960 at the temperaturemeasurement site are summarized in the accompanying table. Also summarized in the table are the air temperatures measured by the U.S. Weather Bureau station at the Albany, N.Y., airport, 5 miles to the northeast. As the snow cover during the winter of 1959-60 was 
Summary of monthly air and subsurface temperatures, 1960, in degrees Fahrenheit

\begin{tabular}{|c|c|c|c|c|c|c|}
\hline \multirow{2}{*}{ Measuring point } & \multicolumn{2}{|c|}{$\begin{array}{l}\text { Monthly average } \\
\text { maximum tempera- } \\
\text { ture }\end{array}$} & \multicolumn{2}{|c|}{$\begin{array}{c}\text { Monthly average } \\
\text { minimum tempera- } \\
\text { ture }\end{array}$} & \multirow{2}{*}{$\begin{array}{l}\text { Range in } \\
\text { monthly } \\
\text { average } \\
\text { tempera- } \\
\text { tures }\end{array}$} & \multirow{2}{*}{$\begin{array}{c}\text { Annual } \\
\text { average } \\
\text { temper- } \\
\text { ature }\end{array}$} \\
\hline & Month & $\begin{array}{l}\text { Tem- } \\
\text { pera- } \\
\text { ture }\end{array}$ & Month & $\begin{array}{l}\text { Tem- } \\
\text { pera- } \\
\text { ture }\end{array}$ & & \\
\hline $\begin{array}{l}\text { Air, at a beight of } \\
5 \text { feet. } \\
\text { Subsurface, at indi- } \\
\text { catted depth } \\
\text { (feet): }\end{array}$ & July & 180.6 & January... & 114.9 & 46.8 & 48.6 \\
\hline $\begin{array}{l}1.5 \\
\mathbf{3 . 0} 4 \\
11.1 \\
17.7\end{array}$ & 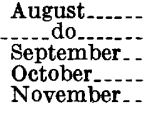 & $\begin{array}{l}270 \\
269 \\
59.5 \\
55.9 \\
53.1\end{array}$ & $\begin{array}{l}\text { March.... } \\
\text { Mado } \\
\text { April. } \\
\text { May...... }\end{array}$ & \begin{tabular}{l|}
27 \\
35 \\
43.2 \\
46.4 \\
49.5
\end{tabular} & $\begin{array}{r}\mathbf{4 3} \\
\mathbf{3 4} \\
16.3 \\
\mathbf{3} \mathbf{9 . 5} \\
\mathbf{3 . 6}\end{array}$ & $\begin{array}{r}48 \\
52 \\
51.5 \\
351.3 \\
51.3\end{array}$ \\
\hline
\end{tabular}

1 U.S. Weather Bureau station at Albany, N.Y., airport.

2 Record incomplete.

thin, and so did not have a detectable effect on subsurface temperatures, no data on it are included in the table.
Each measurement of subsurface temperature made during the period July 1, 1959, to December 31, 1960, is plotted in the upper graph on figure 168.1. Also plotted in the upper graph are the monthly average maximum air temperatures and the monthly average minimum air temperatures. Measurements of the depth to water in the well used for making temperature measurements at a depth of 11.1 feet are plotted in the lower graph in figure 168.1.

Subsurface temperatures respond principally to temperature waves originating at the land surface in response to changes in air temperature. There are at least three waves of different period and amplitude. The depth of penetration of the waves is proportional to their period, and the magnitude of the subsurface temperature fluctuations is proportional to both the amplitude and the period of the waves and to the thermal diffusivity of the subsurface materials. The shortest waves are generated by diurnal changes in air
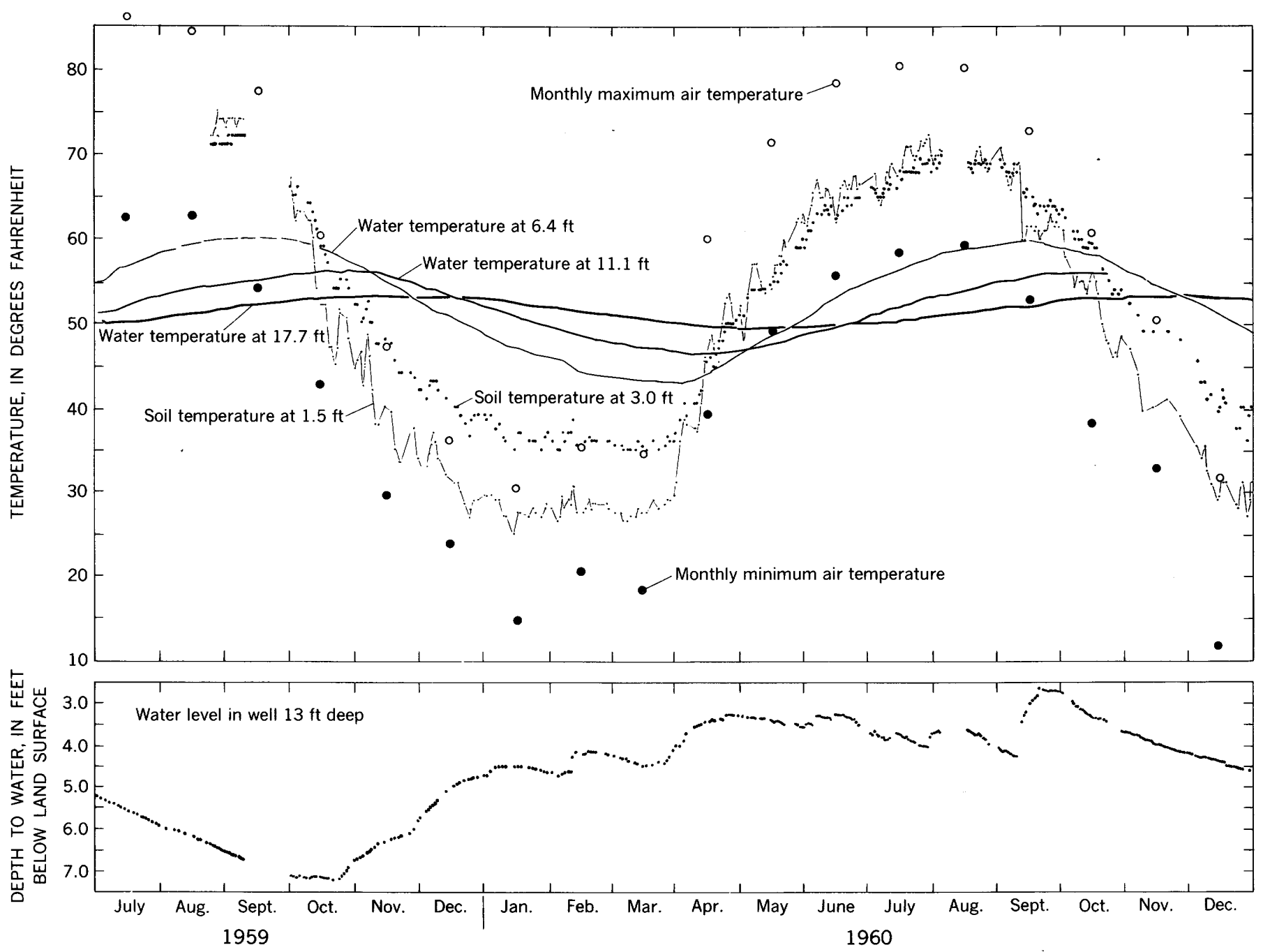

FiguRe 168.1.-Air and subsurface temperatures and hydrograph of water-table fluctuations at the temperature-measurement site in McKnownville, N.Y. 
temperature and thus have a period of 1 day. Because of their short period, their effect can be detected only 1 to 2 feet below land surface. The next longest waves are those generated by the passage of frontal weather systems. The period of these waves is variable, ranging from a few days to a week or two. Their effect on the temperature of the soil is detectable to depths of a few feet. The longest waves are those generated by seasonal changes in air temperature and thus have a period of 1 year. Depending on geologic and hydrologic conditions, these waves penetrate to depths of as much as 60 feet.

The fluctuations of subsurface temperature in response to frontal weather systems and seasonal changes in air temperature are readily apparent at depths of 1.5 and 3.0 feet below land surface (fig. 168.1). During the passage of frontal weather systems, the daily average air temperature over a period of several days may change as much as $30^{\circ} \mathrm{F}$. The irregular, short-period fluctuations of soil temperature, which at a depth of 1.5 feet range from about $2^{\circ} \mathrm{F}$ or $3^{\circ} \mathrm{F}$ to as much as $10^{\circ} \mathrm{F}$, show the fluctuations caused by these changes in air temperature. The fluctuations of soil temperature at a depth of 3.0 feet in response to frontai weather systems is much less than at the shallower depth.

As may be seen from its consistent position about midway between the average maximum and average minimum air temperature for each month, the soil temperature at a depth of 1.5 feet closely approximates the annual average air temperature throughout the year. In 1960, the average air temperature was $48.6^{\circ} \mathrm{F}$ and the average temperature at a depth of 1.5 feet was $48^{\circ} \mathrm{F}$. From April to early September, when the flow of heat is downward from the land surface, the temperature at 1.5 feet generally was a degree or two above the temperature at 3.0 feet. During the fall, when the average air temperature declined rapidly, the temperature at a depth of 1.5 feet dropped progressively lower than the temperature at 3.0 feet. The divergence was greatest in December when the temperature at 1.5 feet averaged about 8 degrees lower than that at 3.0 feet. The difference remained relatively constant until the spring thaw at the end of March and then was completely eliminated within a few days. The average temperature at 3.0 feet was $52^{\circ} \mathrm{F}$, or 4 degrees higher than the average temperature at 1.5 feet and about the same as the average temperature of the ground water (see table).

The ground-water temperature at three levels within the saturated zone is shown in figure 168.1. In 1960 the temperature at the uppermost level, 6.4 feet below land surface, fluctuated through a range of $16.3^{\circ} \mathrm{F}$, whereas that at the lowest level, 17.7 feet below land surface, fluctuated only $3.6^{\circ} \mathrm{F}$. The average groundwater temperature at all 3 levels was about $51.4^{\circ} \mathrm{F}$, or $2.8^{\circ} \mathrm{F}$ above the annual average air temperature (see table). The graph of maximum and minimum temperatures in figure 168.2 suggests that there would be

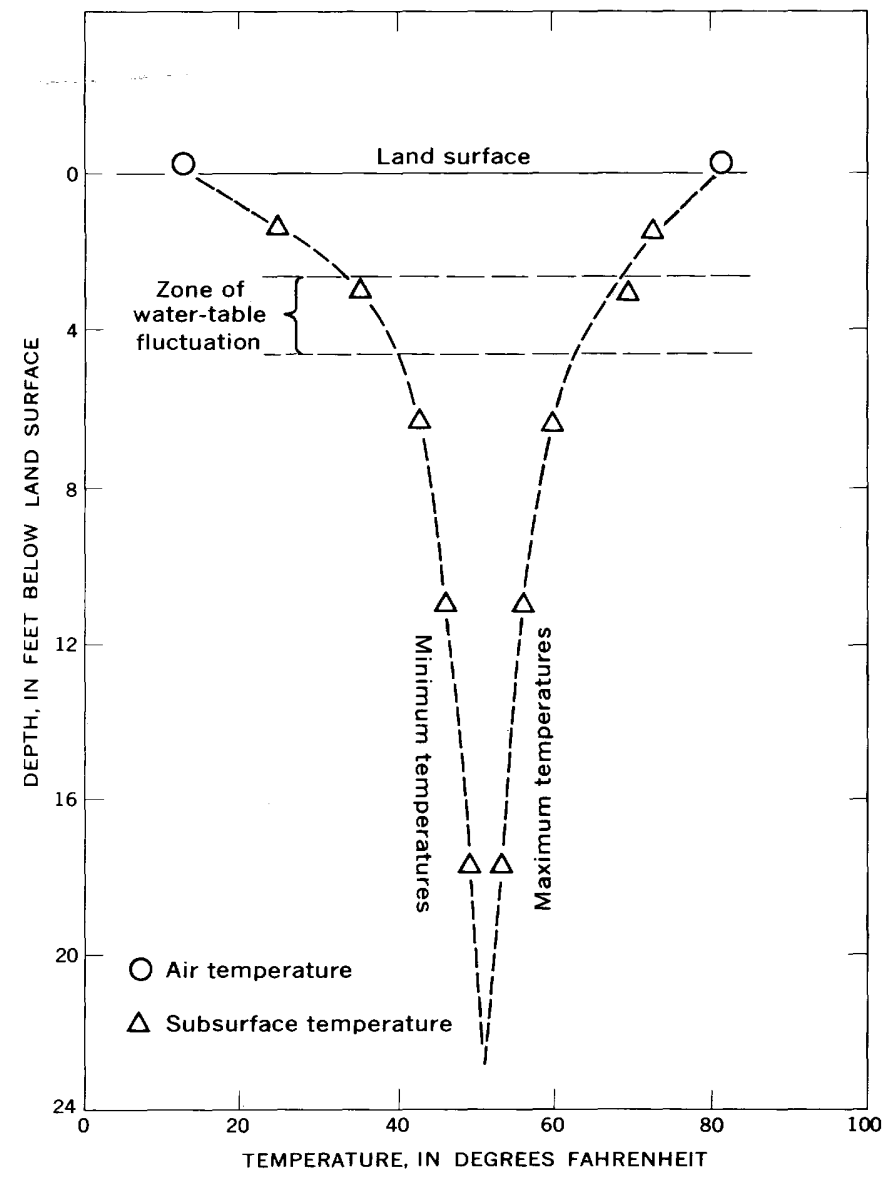

Figure 168.2.-Maximum and minimum air and subsurface temperatures in 1960 . Air temperatures are monthly average minimum temperatures in December 1959 and monthly average maximum temperatures in July 1960 .

no appreciable seasonal fluctuation below a depth of about 23 feet. This depth closely coincides with the base of the surficial sand, which the available data indicate is at a depth of about 20 to 21 feet. The relative lack of ground-water circulation in the silt and clay underlying the sand doubtless affects the depth of penetration of detectable seasonal temperature fluctuations in this area.

The temperature of recharge reaching the zone of saturation had only a small effect on the ground-water temperature. The temperature at 6.4 feet declined about $1.5^{\circ} \mathrm{F}$ in February 1960 in response to recharge with cold water during a brief thaw (fig. 168.1). The cooling effect at the water table, which at the time was about 2 feet above the thermometer, doubtless was much greater. 


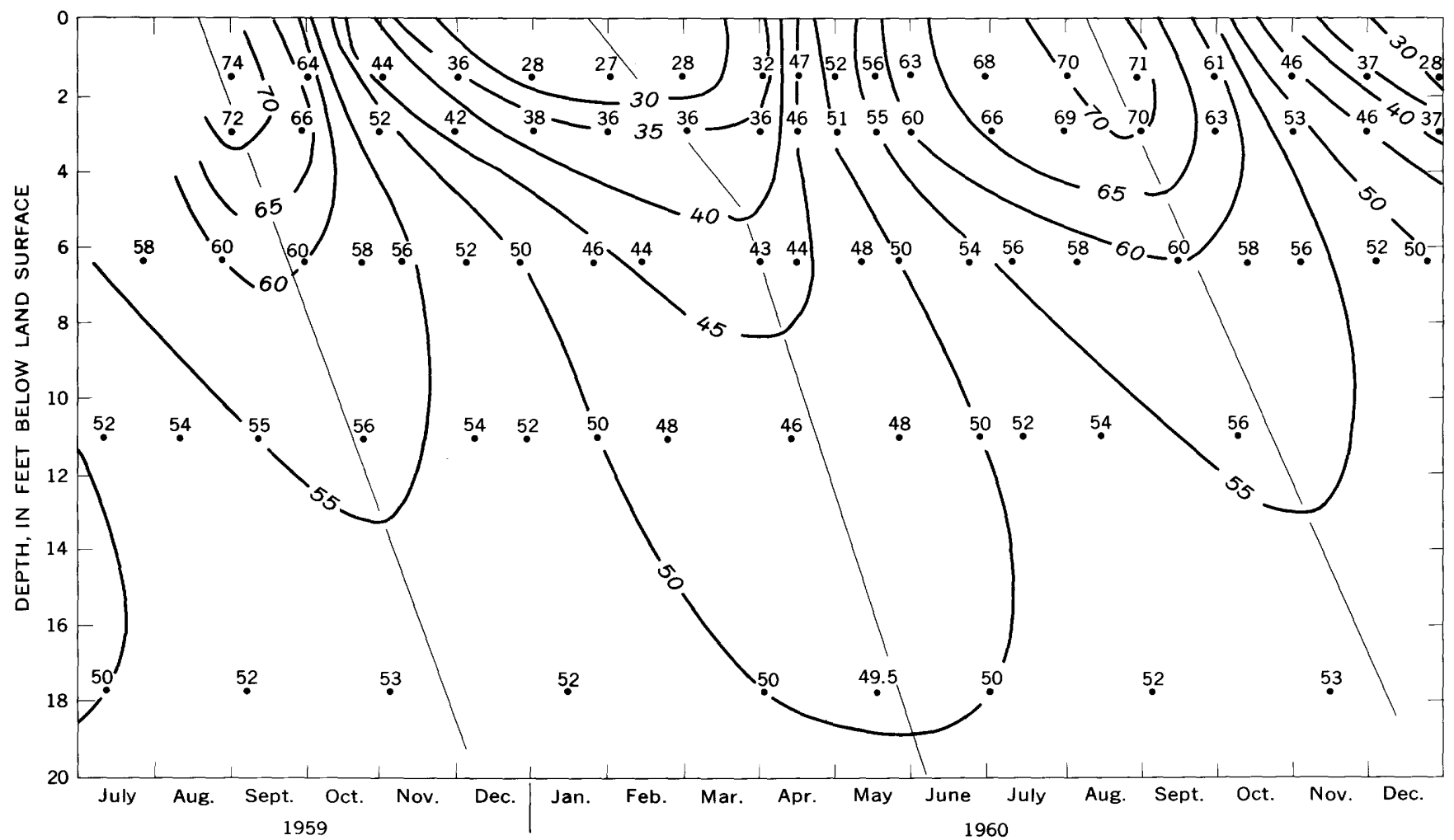

FIGURE 168.3.-Isotherms of subsurface temperatures, in degrees Fahrenheit. (Interval) $5^{\circ} \mathrm{F}$.

The differences in the temperature gradient of soil between the depths of 1.5 and 3.0 feet in summer and winter is one of the most striking features of the graphs shown in figure 168.1. The downward gradient during the spring and summer was only about one-eighth the upward gradient during the fall and winter. However, the temperature gradient of water in the zone of saturation, as shown by the temperatures at depths of 6.4 , 11.1, and 17.7 feet, was not significantly different in summer and winter. The explanation for the steeper thermal gradient across the zone of aeration during the fall and winter is not readily apparent. It suggests either a marked decrease in thermal diffusivity or the disturbing influence of septic-tank discharge.

Figure 168.3 shows the differences in temperature with respect to time of year and depth. The diffusivity can be computed from the relationship of the lag in time of either the maximum or the minimum temperature with depth (Singer and Brown, 1956, p. 747). Sloping straight lines representing the lag in temperature with depth are shown in the figure. Note that the slopes of the lines through the maximum isotherms and the slope of the line through the minimum isotherms in the zone of saturation (from 5 to 20 feet) are virtually the same. The diffusivity as determined from the maximum isotherms in the fall of 1960 is 0.007 $\mathrm{cm}^{2}$ per second. The slope of the line through the minimum isotherms in the zone of aeration is difficult to determine, but the line drawn in figure 168.3 seems to fit the data fairly well. The diffusivity based on this line is $0.005 \mathrm{~cm}^{2}$ per second.

Because of the higher moisture content of the soil during the winter, as indicated by the intermittent rises in the water table starting in late October 1959 (fig. 168.1), and the presence of ice in the soil to a depth of 2 to 3 feet, the diffusivity during the winter should be substantially higher than during the summer. Therefore, the diffusivity of $0.005 \mathrm{~cm}^{2}$ per second computed for the zone of aeration during the winter probably is considerably less than the actual value.

Although this anomaly cannot be definitely explained, it probably reflects the influence of septic-tank discharge. As noted above, a septic tank is located about 32 feet from the temperature-measurement site. However, the position of the septic-tank drain field with respect to the site is not known. Even if the position of the drain field were known, it would be difficult if not impossible to determine the effect of stratification of the soil zone on the movement of the septic-tank effluent. If the septic-tank effluent does affect the temperatures in the zone of aeration, the anomalous changes in gradient might be explained by assuming that the effluent acts as a weak heat source in the spring and summer and as a strong heat source in the fall and winter. 
The writer wishes to acknowledge the assistance of Charles O'Donnell, U.S. Geological Survey, in the computation of diffusivities.

\section{REFERENCES}

Collins, W. D., 1925, Temperature of water available for industrial use in the United States: U.S. Geol. Survey WaterSupply Paper 520, p. 97-104.
Pluhowski, E. J., and Kantrowitz, I. H., 1963, Influence of landsurface conditions on ground-water temperatures in southwestern Suffolk County, Long Island, New York: Art. 51 in U.S. Geol. Survey Prof. Paper 475-B, p. B186-B188.

Singer, I. A., and Brown, R. M., 1956, The annual variation of sub-soil temperatures about a 600-foot circle: Am. Geophys. Union Trans., v. 37, no. 6, p. 743-748. 
Article 169

\title{
HYDROGEOLOGY OF THE SANTIAGO AREA, CHILE
}

\author{
By WILLIAM W. DOYEL, ROBERT J. DINGMAN, and OCTAVIO CASTILLO U., ${ }^{1}$ \\ Washington, D.C., Lawrence, Kans., and Santiago, Chile
}

Work done in cooperation with the Instituto de Investigaciones Geologicas de Chile under the auspices of the Agency for International Development, U.S. Department of State

\begin{abstract}
Wells tapping unconsolidated valley fill in the Valle Central supply a large part of the water needs of Santiago. The east side of the valley is underlain by unconfined deposits that yield hard water whose mineral content increases westward in the direction of ground-water flow. Flowing wells on the west side of the valley tap a confined aquifer that yields bicarbonate water of lower mineral content and hardness.
\end{abstract}

The Santiago area is a part of the Cuenca de Santiago (Santiago basin), the northernmost portion of the great Valle Central (Central Valley) of Chile. The Valle Central lies between the snow-capped Cordillera de los Andes and the lower Cordillera de la Costa (Coastal Range) and extends from the Cuesta de Chacabuco southward to Puerto Montt (fig. 169.1). The many streams that discharge into the Valle Central from the Cordillera de los Andes are used extensively for irrigation and, in the Santiago area, for a part of the water supply of the city. Santiago, with a population of $2,093,000$ in 1961 , uses approximately 8.0 cubic meters per second of water, 40 percent $\left(3.2 \mathrm{~m}^{3} / \mathrm{sec}\right)$ of which is ground water. Approximately one-fourth of the ground water is obtained from a system of collection galleries in the Vitacura area (fig. 169.2); the remainder is obtained from 339 privately and publicly owned wells that range in depth from 12.6 to $236 \mathrm{~m}$ (Castillo and others 1963). The ground water is used for public water supply (74 percent), industry (23 percent), and irrigation ( 3 percent).

The Valle Central is the topographic expression of a great north-trending graben that separates the Cordillera de los Andes from the geologically older Cordillera de la Costa (W. D. Carter, written communication,

1 Geologist, Instituto de Investigaciónes Geológicas de Chile.
1962). Although the geologic age of ash-flow deposits in similar structural valleys in northern Chile indicates that downwarping in those valleys occurred in the early or middle Tertiary (Dingman, 1963), the major downward movement in the Valle Central probably occurred near the end of the Tertiary. The total thickness of unconsolidated sediments in the Cuenca de Santiago is not known because the few wells that completely penetrate the fill are located near rock outcrops. As the bedrock was subjected to erosion and tectonism after formation of the graben, its surface is characterized by high relief; Cerro Santa Lucia and Cerro Renca are the tops of bedrock hills whose lower slopes have been buried beneath valley fill. A gravity survey made by Edgar Kausel (written communication, 1960) showed the maximum depth to bedrock to be between 300 and $500 \mathrm{~m}$, but until proved by test drilling these depths must be considered only approximate. In 1962, the first of a series of deep wells was being drilled in Santiago to explore for deeper aquifers and to determine the thickness of the fill.

The surficial deposits in the basin are colluvial, fluvial, and fluvioglacial materials of Quaternary age. Some unconsolidated deposits in the vicinity of Santiago, which were described as glacial moraines by Brüggen (1950), Karzulovic (1958), and others, have since been examined by R. F. Flint, R. W. Lemke, Ernest Dobrovolny, Kenneth Segerstrom (Art. 152), and the authors, all of whom agree that the deposits were laid down by mudflows as a relatively thin slurry. At present, ground-water supplies are obtained from fluvial materials, possibly valley-train deposits, consisting of interconnected lenses of highly permeable sand and gravel interbedded with thick layers of clayrich mudflows of low permeability. Most of the drilled 


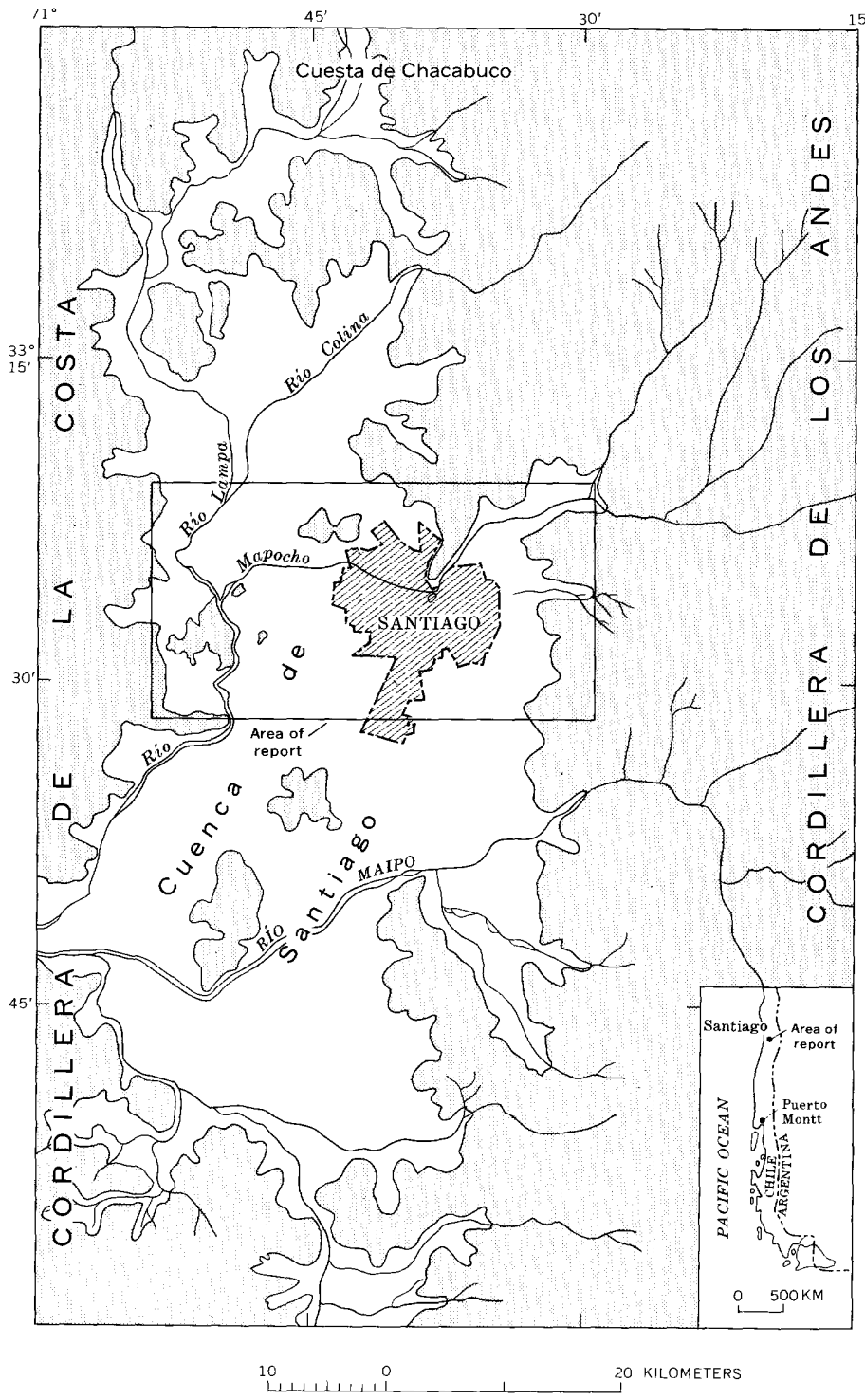

Figure 169.1-Map of the Santiago area, Chile.

wells in the Santiago area produce ground water from depths of 50 to $100 \mathrm{~m}$.

The character of the deeper unconsolidated sediments in the valley is not known; they probably are of continental origin and consist of detrital material derived chiefly from erosion of the Cordillera de los Andes and, to a lesser extent, from erosion of the Cordillera de la Costa. The deeper deposits may be largely of lacustrine origin. Approximately 50 kilometers north of Santiago, the Valle Central is terminated by bedrock hills that rise $200 \mathrm{~m}$ or more above the present valley floor. About $50 \mathrm{~km}$ south of Santiago is a bedrock hill that does not completely close the present valley but marks the southern end of Cuenca de Santiago and may have formed a barrier behind which a lake may have formed during Pleistocene time.
Flowing wells with yields of up to 200 liters per second have been obtained from deltaic sediments that were deposited in a large glacial lake formed by glacial damming in the San Carlos area of the Valle Central, $300 \mathrm{~km}$ south of Santiago. It is conceivable that, during one of the Pleistocene glacial stages, similar ice tongues may have extended into the Cuenca de Santiago, blocking the drainage and forming a glacial lake. Sediments deposited in such a lake may have formed an areally extensive aquifer, which would be in contrast to the lenticular, fluvial deposits which now are the source of ground water for Santiago.

At present almost all the sediments being deposited in the Valle Central are derived from the Cordillera de los Andes, where heavy precipitation and steep gradients combine to produce rapid erosion. The Cordillera de la Costa has a much slower rate of erosion because the rainfall is less and the gradients are gentler. Colluvium and some alluvial sediments derived from the Cordillera de la Costa are present, however, along the western side of the valley.

Ground water presently used in and near Santiago is obtained from an unconfined aquifer in which the water table slopes generally southwestward. The average hydraulic gradient is about $10 \mathrm{~m} / \mathrm{km}$ in the eastern part of Santiago but decreases to about $3 \mathrm{~m} / \mathrm{km}$ in the southwestern part of the city. Although infiltrating rainfall and irrigation water are sources of some recharge in the central part of the basin, the principal source of recharge is runoff from the west slope of the Cordillera de los Andes. The Río Colina and Río Lampa in the northern part of the basin, the Río Mapocho, which flows through Santiago, and the Río Maipo, approximately $25 \mathrm{~km}$ south of Santiago, contribute a large percentage of the recharge along the eastern side, as shown by the slope of the water table away from those rivers (Castillo and others, 1963). The remainder of the recharge infiltrates through the alluvial and colluvial sediments that lap up onto the flanks of the Andean foothills.

Because the more permeable water-bearing materials are lenticular or narrowly enlongate, nearby wells may penetrate different bodies of water-bearing material; however, comparable water levels and similar responses to ground-water withdrawals demonstrate that the principal aquifer is hydraulically continuous throughout the central and eastern parts of the area. Perched bodies of ground water are found near the Río Mapocho as a result of the lenticularity of the sediments and the relative impermeability of the underlying beds.

Available information is insufficient to determine the area or areas of ground-water discharge. The relation of the streams in the central part of the Santiago 


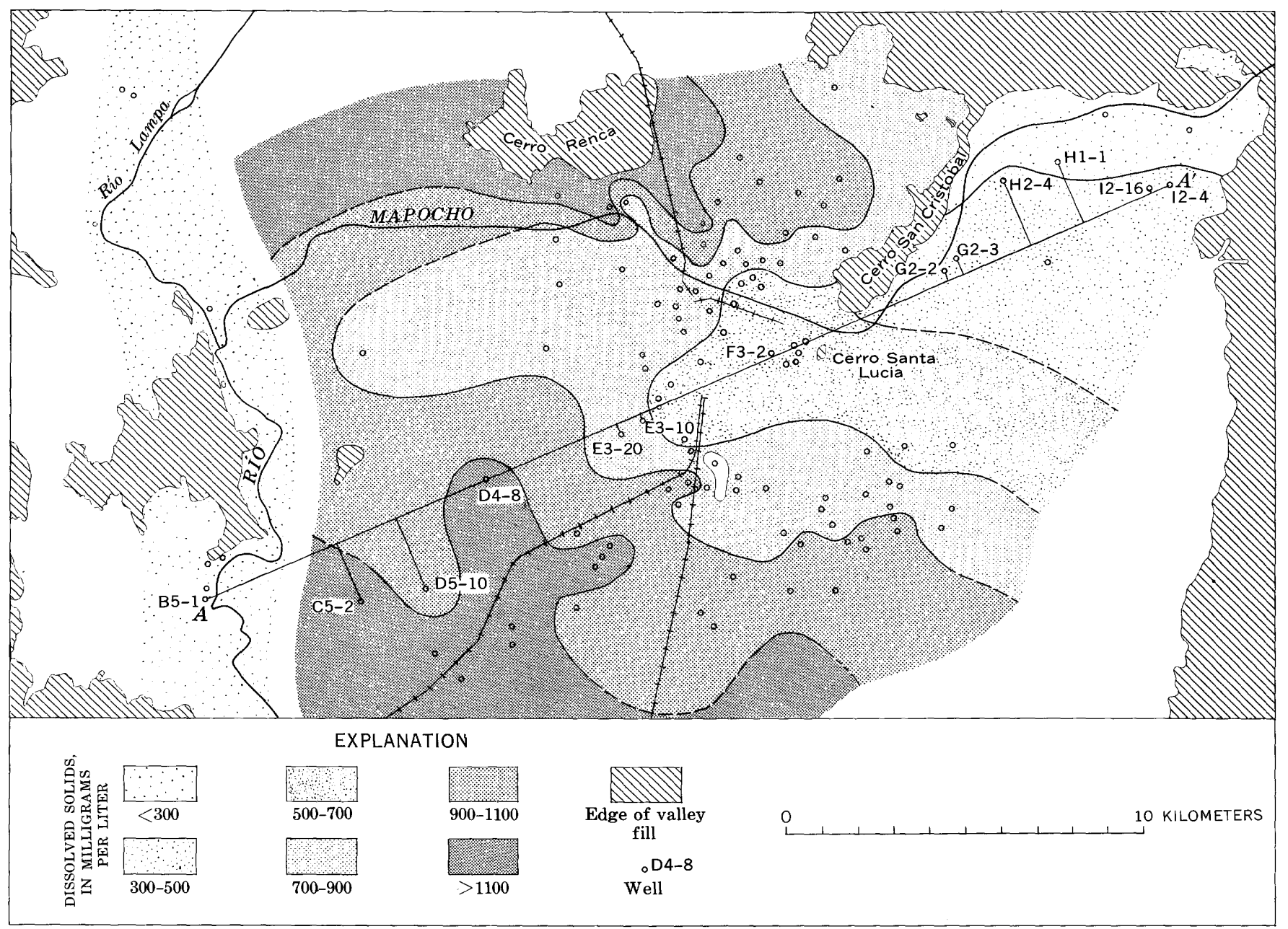

FIGURE 169.2.-Map showing dissolved-solids content in ground water of the Santiago area, Chile. Analyses made in the laboratory of the Instituto de Investigaciones Geologicas de Chile in 1960-61.

area to the water table has not been studied, nor are data available regarding the movement of ground water south of the report area. The Río Mapocho, however, probably serves as a ground-water drain in the western part of the basin.

The relatively few wells drilled along the western side of the Cuenca de Santiago are flowing artesian wells. Although evidence of a geological separation, such as might result from faulting, is lacking, the difference in the chemical quality and temperature between the water from the flowing wells in the western part and from the water-table wells in the central and eastern part of the area indicates the existence of some sort of barrier, either geologic or hydraulic, the nature of which is not yet understood.

Figure 169.2 shows the distribution of dissolved solids in the Santiago area, based on analyses reported by Castillo and others (1963). The ground water has a low dissolved-solids content, 200-300 milligrams per liter, near the Río Mapocho in the east- ern part of the area. The dissolved-solids content increases in the direction of ground-water movement to as much as $700 \mathrm{mg} / \mathrm{l}$ in the central part of the area and to more than $1,000 \mathrm{mg} / \mathrm{l}$ to the southwest. The dissolved-solids content of water from flowing wells along the western side of the basin, however, is less than $300 \mathrm{mg} / \mathrm{l}$. As shown in figures 169.2 and 169.3, the change is rather abrupt from the more highly mineralized water yielded by wells tapping the unconfined aquifer to the east.

The hardness of the water presents the same general picture as the dissolved-solids content. Close to the Rió Mapocho in the eastern section of Santiago the hardness is relatively low, less than $400 \mathrm{mg} / \mathrm{l}$ (computed as $\mathrm{CaCO}_{3}$ ), but it increases to nearly $800 \mathrm{mg} / \mathrm{l}$ southwestward. However, the water from flowing wells on the western side of the basin has a hardness of less than $200 \mathrm{mg} / \mathrm{l}$. Moreover, the water from flowing wells on the west side of the basin is characterized by a higher proportion of sodium and a lower proportion of sulfate 


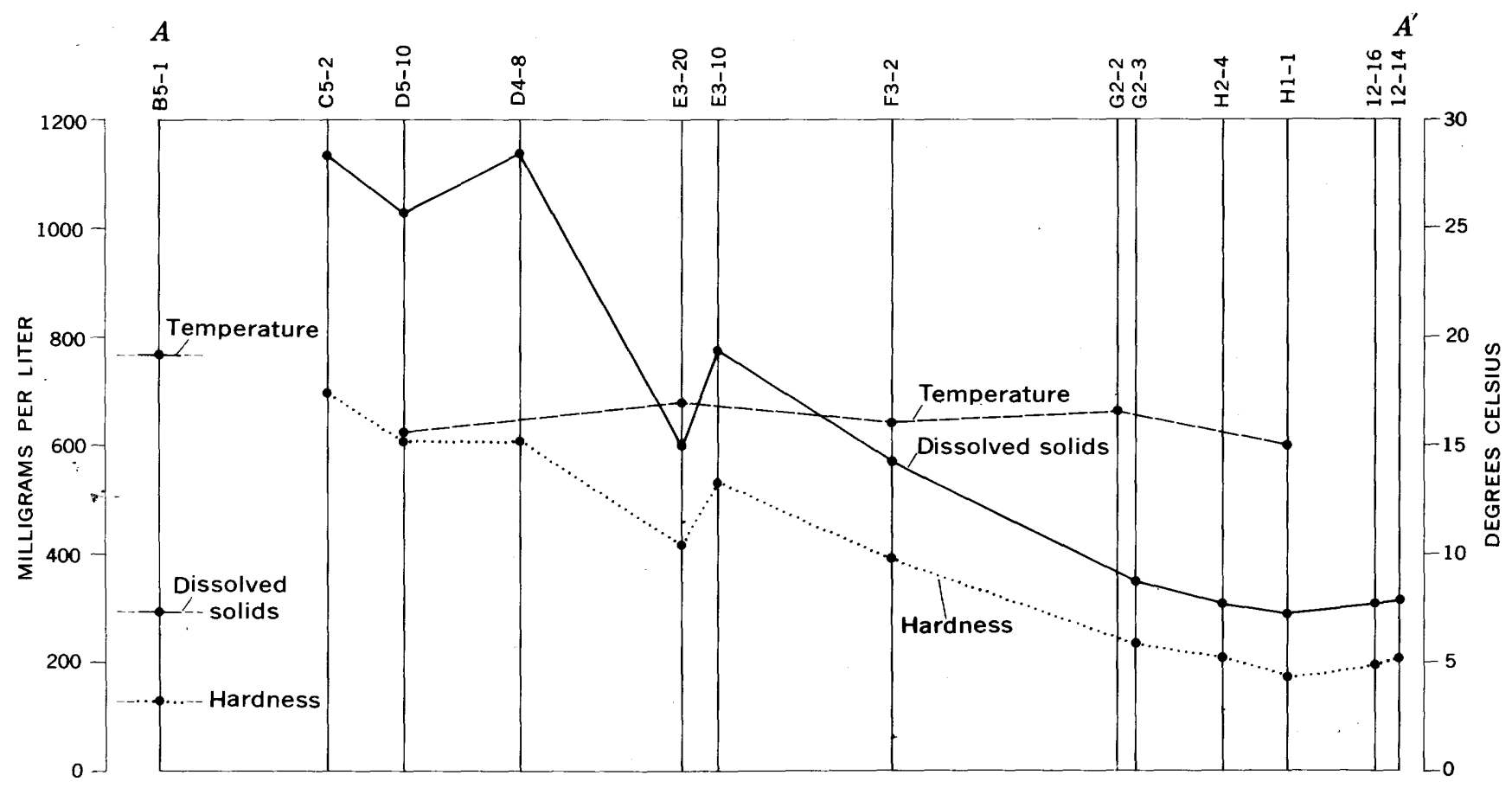

Figure 169.3.-Changes in dissolved-solids content, hardness, and temperature of ground water along line $A-A^{\prime}$ (fig. 169.2).

and chloride as compared to the water from wells east of the Rio Mapocho. The low proportion of sulfate and chloride is reflected in the noncarbonate hardness, which commonly is very low in the well water of the west side of the basin. These differences in chemical quality suggest that there is little or no interconnection between the unconfined aquifers of the east and central parts of the area and the confined aquifers tapped in the western part.

The problem of the marked differences in water quality cannot be resolved on the basis of geologic information now available. The differences may be due to geologic barriers such as faults or facies changes. On the other hand, the artesian water of the west side may be characteristic of a confined aquifer that passes beneath the unconfined aquifers to the east. Should such a deeper aquifer be present it would be of considerable economic importance to the area.

Additional geological and hydrological data are necessary to define the control mechanism of the ground- water system in the Cuenca de Santiago, particularly the separation between the artesian and nonartesian waters. The test-drilling program now in progress (1963), as well as the continuing investigations by the Instituto de Investigaciones Geologicas de Chile, should provide sufficient information for a better understanding of ground-water conditions and for a better utilization of ground-water resources.

\section{REFERENCES}

Brüggen, Juan, 1950, Fundamentos de la geologia de Chile: Instituto Geográfico Militar, Santiago, 374 p.

Castillo, Octavio, Falcón, Eduardo, Doyel, W. W., and Valenzuela, Manuel, 1963, El agua subterranea de Santiago, segundo informe 1958-1962: Instituto de Investigaciónes Geológicas de Chile. [In press]

Dingman, R. J., 1963, Geology of the Tulor quadrangle: Instituto de Investigaciónes Geológicas de Chile. [In press]

Karzulovic, Juan, 1958, Sediments cuaternarios de aguas subterraneas en la Cuenca de Santiago: Universidad de Chile, Instituto de Geologia, Pub. 10, 120 p. 


\title{
GROUND WATER IN THE ARICA AREA, CHILE
}

\author{
By WILLIAM W. DOYEL, Washington, D.C.
}

Work done in cooperation with the Instituto de Investigaciones Geologicas de Chile and the Corporacion de Fomento de la Produccion under the auspices of the Agency for International Development, U.S. Department of State

\begin{abstract}
The water supply for the city of Arica presently is obtained from a water-table aquifer in the lower Valle de Azapa. Water levels are declining owing to overdevelopment; an additional supply is needed to meet present demands. An artesian aquifer underlying the Pleistocene coastal terrace north of Arica apparently is the only other source of large supplies of usable water in the area.
\end{abstract}

The present (1962) water supply for Arica, the northernmost coastal city in Chile, is obtained from wells tapping a water-table aquifer in the lower Valle de Azapa $^{1}$ (fig. 170.1). In 1960 an estimated 400 liters per second was being withdrawn for the public supply and for irrigation in the part of the valley extending 40 kilometers inland from Arica (Kleiman and Torres, 1960). Water use both for the city and for irrigation has increased, and withdrawals have exceeded the capacity of the aquifer to yield water. The resulting rapid decline of the water table is forcing the city to search elsewhere for additional water supplies.

Rainfall west of the foothills (Pre-Cordillera) of the Cordillera de los Andes is negligible; only traces of rainfall have been recorded in Arica at intervals of several years. One perennial stream, the Río Lluta, flows through the area, but the water is too highly mineralized for other than limited agricultural or industrial use. The Río San José, which flows through the Valle de Azapa, is perennial in its upper reaches and intermittent in the lower part of the valley. The river discharges into the ocean only every 4 or 5 years when it is in flood stage, which may last a few days or a few weeks. A small amount of the floodwater is used for irrigation, but most of it is lost into the Pacific Ocean.

1 Spanish terminology is used for geographic names; for example, Valle for valley and Quebrada for valley containing dry or intermittent stream.
Water from the Rio Lauca, on the Altiplano approximately $100 \mathrm{~km}$ east of Arica, has been diverted by means of canals and a tunnel into the Valle de Azapa and will help alleviate the water shortage in the area.

Arica lies at the northern end of the Cordillera de la Costa (Coast Range), at the mouth of the Río San José. Extending northward from Arica into Peru is La Concordia, a plain bounded on its eastern side by a north-south scarp and on its western side by the Pacific Ocean. The plain, which slopes gently westward to the ocean, widens northward and is approximately $8 \mathrm{~km}$ wide at the Peruvian border.

The scarp marks the westernmost extent of a thick section of conglomerate, sand, and pyroclastic deposits of late Tertiary and early Pleistocene age, the upper surface of which forms a westward-sloping plain extending seaward from the Pre-Cordillera. The Ríos San José and Lluta, which issue onto La Concordia from steep-walled valleys, as well as the stream that formed the Quebrada Gallinazos and now is intermittent and flows only at widely spaced intervals, have dissected the highland in the Chilean territory.

La Concordia was formed as a depositional terrace during the Pleistocene and is underlain by interbedded marine and continental sediments with a thickness of at least 200 meters. The surface is composed of at least three erosional terraces, each marking a stage in the recession of the sea. The Ríos Gallinazos (Quebrada Gallinazos) and San José have incised steepwalled channels into the surface of the plain, and the Río Lluta has cut a valley containing a series of terraces that can be correlated with successive stages in the lowering of the base level of the river. The Ríos Lluta and Gallinazos have built alluvial fans onto the most recent erosional terrace along the present shoreline, and the Río San José is building a delta. 


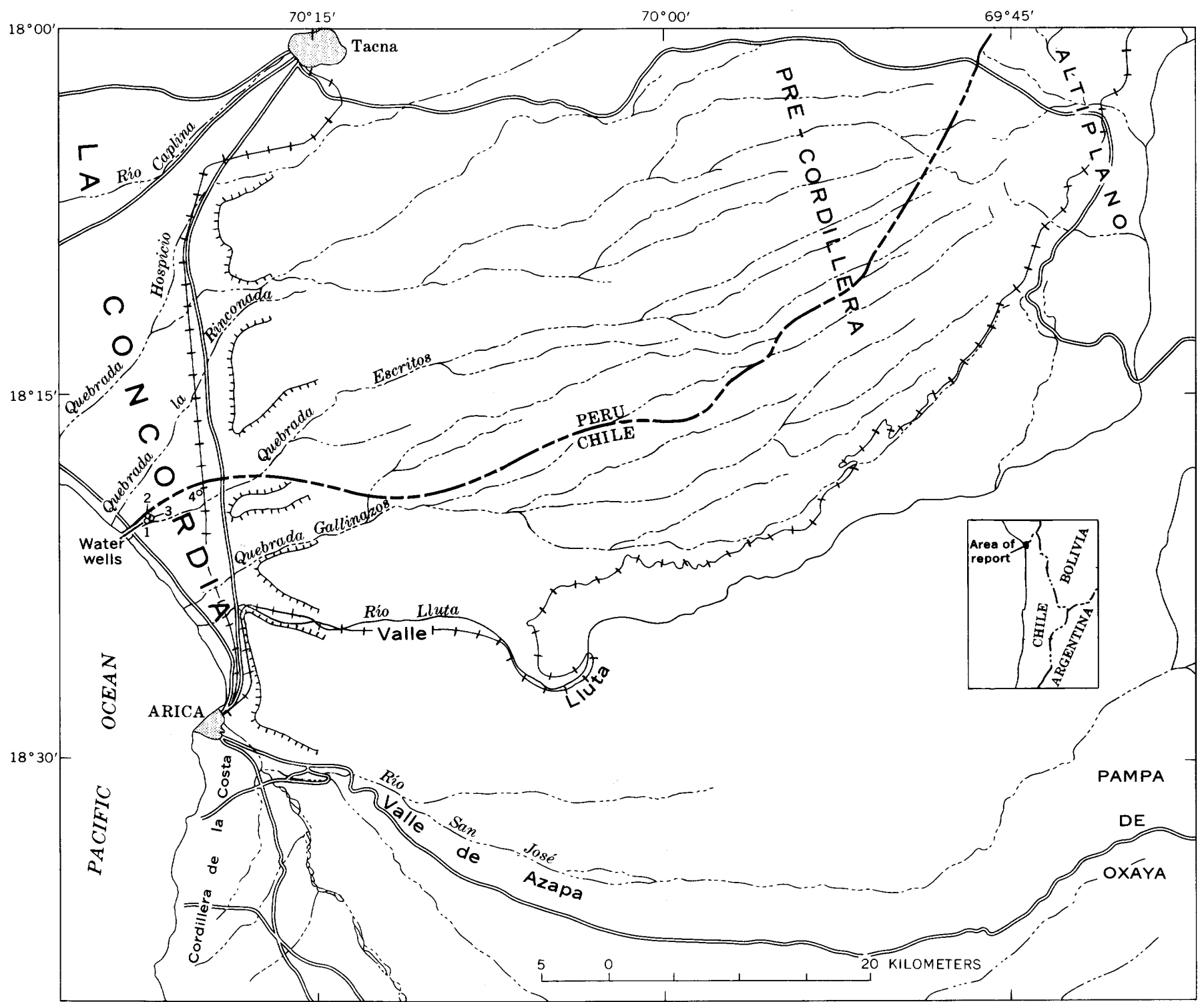

Figure 170.1.-Map of the Arica area, Chile.

Recent sediments are present in the form of colluvium, as alluvial deposits of the rivers, and as windblown sand covering much of the area. The face of the scarp that forms the eastern border of La Concordia and the surface of the high plain are covered in the Arica area with a concretelike layer of salt-cemented sandy or tuffaceous material.

The only possibilities for developing substantial additional ground-water supplies in the Arica area are in the Valle de Azapa, which is presently overdeveloped, the Valle Lluta, and on La Concordia; that is, from the Pleistocene and Recent sediments. Some of the older sediments probably contain and could transmit water, but lack of recharge and the effects of diastrophism preclude the possibility of developing substantial water supplies from the pre-Pleistocene sediments.
Ground water in the Valle de Azapa occurs in an unconfined aquifer in the alluvial deposits, which are less than $100 \mathrm{~m}$ thick. The aquifer has been exploited for several centuries, at least as far back as Inca times, but since the advent of drilled wells and large-capacity pumps it has been overdeveloped. As predicted by Taylor (1949), overdevelopment has resulted in a declining water table, which, in turn, has led to the abandonment of many hand-dug wells in the Arica area. In addition, all the springs have ceased to flow. Recharge to the aquifer comes from seepage and underflow from the upstream portion of the Río San José and also from floods and irrigation water. The water table slopes toward the Pacific Ocean, and fresh ground water probably is being discharged by evaporation and as seeps along the present shoreline near 
Arica. Salt-water intrusion may be taking place but definitive data are not available.

Test wells drilled in the Valle Lluta have shown that the valley fill will yield little ground water.

About 10 years ago several successful water wells were drilled on La Concordia Peruana (the part of La Concordia in Peru), $7 \mathrm{~km}$ north of the Chile-Peru border. La Concordia Chilena (the part of La Concordia in Chile) is geographically and geologically similar to La Concordia Peruana, and 4 exploratory wells were drilled on it between the Quebrada Escritos and the border to determine whether the productive aquifer extended into Chile. All 4 wells struck artesian water that rose to within $15 \mathrm{~m}$ of the surface. The water occurs in sand and gravel strata between 75 and $130 \mathrm{~m}$ below the surface. Well 2 (fig. 170.1) was pumped at 150 liters per second (approximately 2,400 gallons/minute) for 120 hours, and as the maximum drawdown was $8.5 \mathrm{~m}$, the specific capacity of the well was 17.6 liters per second per meter of drawdown. At the end of the test the water contained 835 milligrams per liter of total dissolved solids, $247 \mathrm{mg} / 1$ of chloride, $172 \mathrm{mg} / \mathrm{l}$ of sulfate, and $368 \mathrm{mg} / \mathrm{l}$ of total hardness.

The artesian head, the slope of the piezometric surface, and the water quality indicate that there is recharge to the artesian aquifer, although they give no information regarding the quantity. Test drilling has shown that there is no recharge reaching the aquifer from either the Valle Lluta or Valle de Azapa, and that recharge is probably coming from the northeast, from Peru. Ground water on La Concordia should not be developed without consideration of the possibility of intrusion of sea water, or possibly of inflow of salty marine connate water from unflushed parts of the aquifer as the artesian pressure declines.

A shallow water-table aquifer, penetrated in wells 1 , 2 , and 3, about $18 \mathrm{~km}$ north-northwest of Arica (fig. 170.1 ), probably is recharged from the infrequent rains in the area and could not support large-scale sustained withdrawals.

The artesian aquifer underlying La Concordia presents the best possibility for developing large additional water supplies in the Arica area. The diversion of water from the Río Lauca is increasing the ground water available in the Valle de Azapa, both by furnishing additional recharge and by replacing water supplies formerly withdrawn from the water-table aquifer. Artificial recharge by means of check dams and off-stream ponds also would increase the amount of recharge during periods of flood flow in the valley. Improvements in methods of irrigation could reduce the amount of water required per hectare, which would make additional water available in the Arica area. However, if the Arica area continues to develop, the Valle de Azapa, even with the Río Lauca diversions, cannot furnish sufficient water for irrigation, public supply, and industrial use.

The artesian aquifer beneath La Concordia has been supplying water for irrigation on La Concordia Peruana for 10 years without any significant lowering of water levels. This fact, together with the information now available (1962) as a result of the test-drilling program, indicates that the artesian aquifer beneath La Concordia Chilena could be exploited to supply additional water to the Arica area. Even if the water could not be used for irrigation on La Concordia, owing to the salinity of the soil, it could be used for public and industrial supplies, thus releasing ground water in the Valle de Azapa for irrigation.

Additional investigations, including drilling of test wells spaced throughout La Concordia Chilena, are being carried out by the Instituto de Investigaciones Geológicas de Chile and the Corporación de Fomento de la Producción de Chile to determine the ground-water potential of the artesian aquifer beneath La Concordia, as well as the maximum amount of water that can be withdrawn from the water-table aquifer in the Valle de Azapa without causing progressive water-level declines.

\section{REFERENCES}

Kleiman, Pablo, and Torres, Juan, 1960, El agua subterranea en el Valle de Azapa: Ministerio de Obras Públicas, Dirección de Riego, mimeo. rept., $47 \mathrm{p}$.

Taylor, G. C., Jr., 1949, Geology and ground water of the Azapa Valley, Province of Tarapacá, Chile: Econ. Geology, v. 44, no. 1 , p. $40-62$. 


\title{
Article 171
}

\section{"LAZY" THERMOMETERS AND THEIR USE IN MEASURING GROUND-WATER TEMPERATURES}

\author{
By RALPH C. HEATH, Albany, N.Y.
}

Work done in cooperation with the New York Water Resources Commission

\begin{abstract}
The temperature of ground water at selected depths in unpumped, nonflowing wells can be measured in place with high-lag "lazy" thermometers. These thermometers are constructed by enclosing the bulb of liquid-in-glass thermometers with material of high specific heat, a layer of insulation, and a protective case.
\end{abstract}

Data on ground-water temperatures have been applied successfully in recent years to a variety of problems, and such data promise to become one of the most useful tools in ground-water hydrology. In most ground-water investigations, temperature measurements are obtained only for water being discharged from flowing or pumped wells. Such measurements are of limited usefulness because they represent a weighted average of the temperature of the producing zone open to the well, which in some places may be more than 100 feet thick.

Measurements of water temperature in wells have been made with thermometers inserted in bottles and lowered down the wells. There are drawbacks to this method and, unless special precautions are taken, the measurements may be in error by several degrees. The most precise way to measure the temperature of water in place in wells is with an electrical thermometer. Such thermometers, accurate to $0.1^{\circ} \mathrm{F}$, are available from several manufacturers. However, because electrical thermometers are fairly expensive, and somewhat delicate, they are not practical for many field investigations.

Where it is desirable to measure the temperature at the same depth in the same well periodically, satistory data can be obtained with so-called "lazy" thermometers. These thermometers are made by enclosing the bulb of an ordinary liquid-in-glass thermometer in such a manner that its response to change in temper- ature is delayed. Figure 171.1 shows the features of a lazy thermometer recently built by the author. It consists of four parts:

1. Standard liquid-in-glass thermometer in a metal case

2. Layer of material of high specific heat

3. Layer of insulation

4. Outer protective metal case.

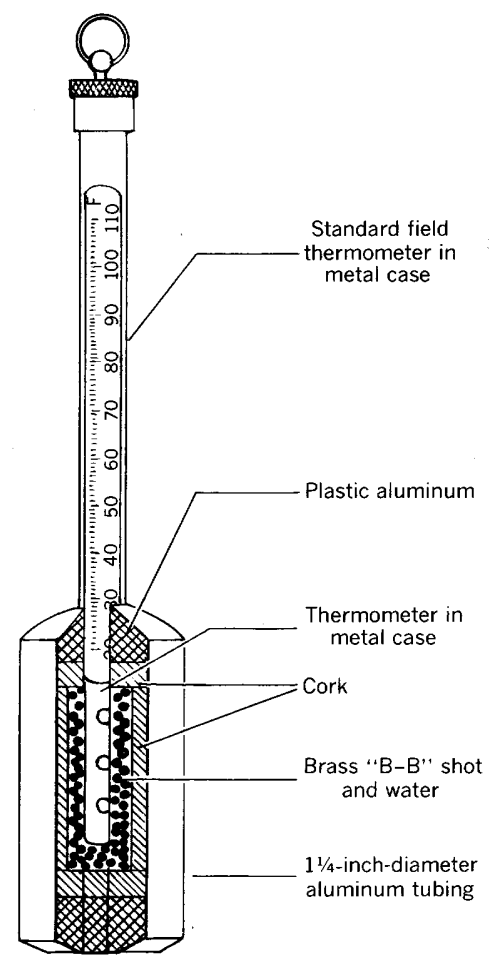

Figure 171. 1-Detail of a "lazy" thermometer.

ART. 171 IN U.S. GEOL. SURVEY PROF. PAPER 475-D, PAGES D216-D218. 1964. 
Many materials are probably suitable for use in constructing lazy thermometers. The author uses aluminum tubing for the outer case. A layer of cork about 0.15 inch thick is used for insulation, and a layer of brass "B-B" shot is inserted between the thermometer case and the insulation. The top and bottom are sealed with plastic aluminum. However, because the annular space between the thermometer and its metal case is difficult to seal at the top, water displaces the air in the pores between the brass shot when the thermometer is submerged. This is, in fact, desirable because of the high specific heat of water.

In order to determine whether a lazy thermometer is suitable for the use intended, its inertial characteristics must be determined. This is done by immersing the thermometer in water of a constant temperature, either above or below the air temperature. After the thermometer reaches the same temperature as the water, the thermometer is removed and a record is made of the change in temperature with time as the thermometer approaches the air temperature. The time is recorded to the nearest second and the temperature estimated to the nearest 0.1 degree. A graph is plotted of log of the time, in seconds, versus log of the change in temperature, in degrees Fahrenheit, divided by the difference between water and air temperatures. The time, in seconds, during which different percentage changes of temperature occur may be determined directly from the graph.

The next step depends on the accuracy desired in the temperature measurements for which the lazy thermometers are to be used. Many field investigators read thermometers only to the nearest degree or nearest half degree. With care, however, the thermometer in common field use in the Water Resources Division of the U.S. Geological Survey can be read to 0.1 degree with an error of \pm 0.1 degree. (It is recognized, of course, that many field thermometers are not accurate to 0.1 degree. A part of this difficulty can be resolved by calibrating the field thermometer to a laboratorytested master). Therefore, if it is desired to read the lazy thermometer to the nearest 0.1 degree, the problem is to determine the length of time required for a change of 0.1 degree at the maximum expected difference between water and air temperature at the locality in which the thermometer is to be used. Figure 171.2 shows the time required for a change of $0.1^{\circ} \mathrm{F}$ in one of several lazy thermometers built by the author.

For comparison, the inset in the upper right-hand corner of figure 171.2 shows the time required for the standard field thermometer in its metal case to change $1.0^{\circ} \mathrm{F}$. It may be seen that its lag is one-fortieth that of the lazy thermometer.

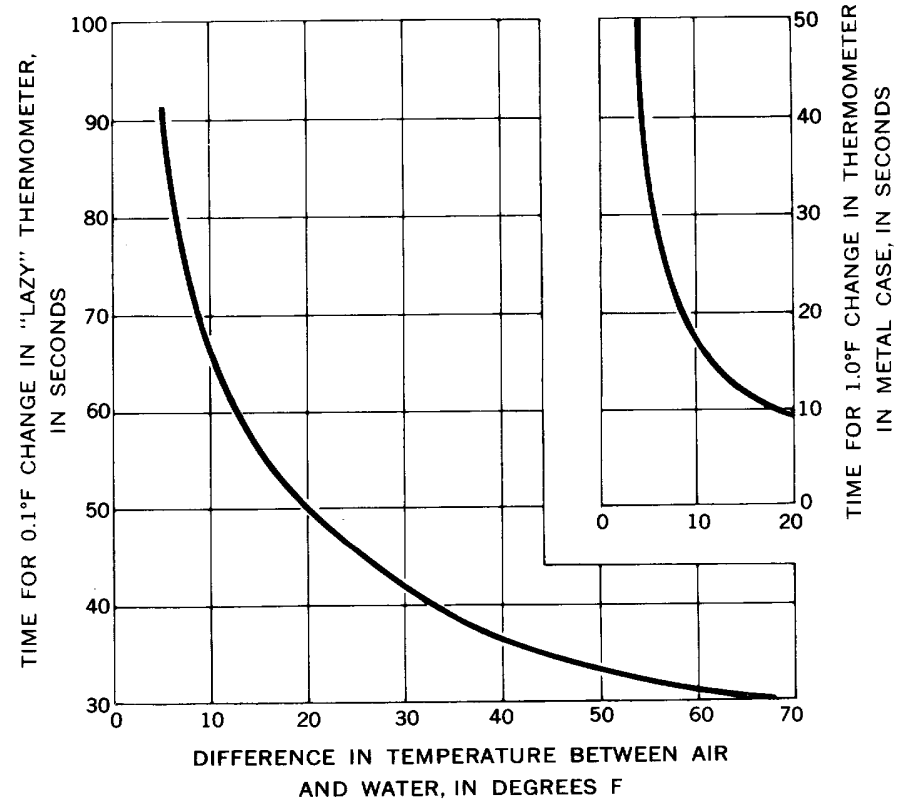

FIgURE 171.2.-Inertial characteristics of a "lazy" thermometer.

Whether a specific lazy thermometer can be used in a given well depends on (1) the inertial characteristics of the thermometer, (2) the depth at which temperatures are to be measured, and (3) the maximum expected difference in temperature between the water and the air. In normal practice the thermometer is left submerged at the desired depth between readings. (Parachute cord has been found to be highly satisfactory for holding the thermometers). Therefore, the time required to withdraw the thermometer from the well and read the temperature is the limiting factor in precision.

Thermometers can be withdrawn from wells at a rate of about 3 feet per second and can be read in 5 to 10 seconds, depending on the skill of the observer. To determine the maximum depth at which a particular lazy thermometer can be used, it is necessary to determine the lag, in seconds, at the expected maximum difference between water and air temperature, subtract 10 seconds, and multiply the remainder by 3 . For example, the expected maximum difference between water and air temperature at Albany, N.Y., is about $60^{\circ}$. The "lazy" thermometer for which data are plotted in figure 171.2 has a lag of 31 seconds at this difference. Therefore, by subtracting 10 seconds and multiplying by 3 , it is found that this thermometer can be used at any depth down to about 60 feet. If measurements accurate to 0.2 degree were acceptable or if the expected maximum difference between water and air temperature was only $30^{\circ}$, the thermometer could be used to a depth of about 90 feet. As seasonal fluctuations of ground-water temperature, regardless 
of whether they are caused by stream infiltration or is obvious that lazy thermometers are an economical changes in air temperature, occur at depths greater and practical tool for monitoring fluctuations in groundthan about 60 feet only under unusual conditions, it water temperatures. 


\title{
TELEVISION APPARATUS FOR BOREHOLE EXPLORATION
}

\author{
By J. E. EDDY, Washington, D.C.
}

\begin{abstract}
A closed-circuit television system has been developed which operates in 8-inch-diameter and larger holes to depths of approximately 1,000 feet in either dry or water-filled holes.
\end{abstract}

A closed-circuit television system for use in water wells has been developed that can be operated in boreholes 8 inches in diameter and larger. The equipment is well adapted for locating and examining fractures and solution openings, and for identifying changes in lithology in uncased holes drilled in consolidated rock. It is useful also for examining the position and condition of screens, casing, and obstructions in cased holes. The equipment was designed to be as simple as possible and to operate at a maximum hydrostatic pressure of 1,000 feet of water.

The system uses a high-resolution Kin Tel camera and monitor modified for use in boreholes. The monitor and camera provide a full 500-line resolution, which is about twice that of home television receivers. A 14-inch aluminized picture tube with a Polaroid filter mounted in front provides a bright clear picture even in high ambient light.

The control unit was designed to provide a high degree of flexibility for both camera and monitor. The unit includes a video amplifier of 8-megacycle bandwidth to furnish the 500-line resolution. Remote camera controls including horizontal and vertical centering controls may be used to shift the field of vision electronically. Fully automatic electronic target control provides self adjustment of the image intensity over a range of 4,000 to 1 . Service and operation of the unit have been simplified by placing all the control adjustments on the front panel and building the chassis so that it may be removed readily from the front of the mount.

Two cameras were used in the development of the present equipment. The first was a Kin Tel model 1990 enclosed in a metal tube $17^{3 / 4}$ inches long by 6 inches in diameter. This camera was fitted with a lens with motor-driven focus and iris adjustments, and a mirror attached to the front of the case for viewing the side of the borehole. Several combinations of lenses and closeup attachments were used, but the results were generally unsatisfactory.

The second camera was built from a Kin Tel model 1986-C studio camera, modified to fit into an aluminum tube 36 inches long with a $4 \frac{1}{2}$-inch outside and a $3 \frac{1}{2}$-inch inside diameter. The lower end is fitted with a quartzglass plate a quarter of an inch thick, specially cut from glass having a tensile strength of $2,000 \mathrm{psi}$. Both the viewing end and the upper end of the camera case are fitted with O-rings and sealed with silastic rubber. A high-pressure coupling with neoprene sleeves joins the conductor cable to the camera. The camera (with attached cable) has been tested successfully in a pressure chamber to simulated depths of 950 feet of water.

The camera assembly uses a very wide angle fixedfocus lens-a French-made Kinoptick "fish eye" lens with a focal length of $5.7 \mathrm{~mm}$, a field of view of $117^{\circ}$, and an overall diameter of $3 \frac{1}{2}$ inches. This lens has a depth of field of from 4 inches to infinity, thus making it possible to see the lighted area of the well bore very close to the camera and eliminating the problems involved in the motor-driven iris and focus controls. The camera is shown in figure 172.1.

The most difficult problem of design has been adequate illumination in the viewed area when the camera is below water level in a well. Absorption and dispersion of the light in water reduce greatly both the contrast and intensity of the image received. The problem of lighting becomes increasingly difficult in designing lights for relatively small diameter holes. The most satisfactory lights used were 3-inch quartz iodide lamps rated at 600 watts each, wired in parallel. In larger holes, 3 lamps directed ahead at a $45^{\circ}$ angle were placed 8 to 10 inches to the side of the camera.

In small holes the best results were obtained with 3 lights positioned $120^{\circ}$ apart and mounted on the lower 


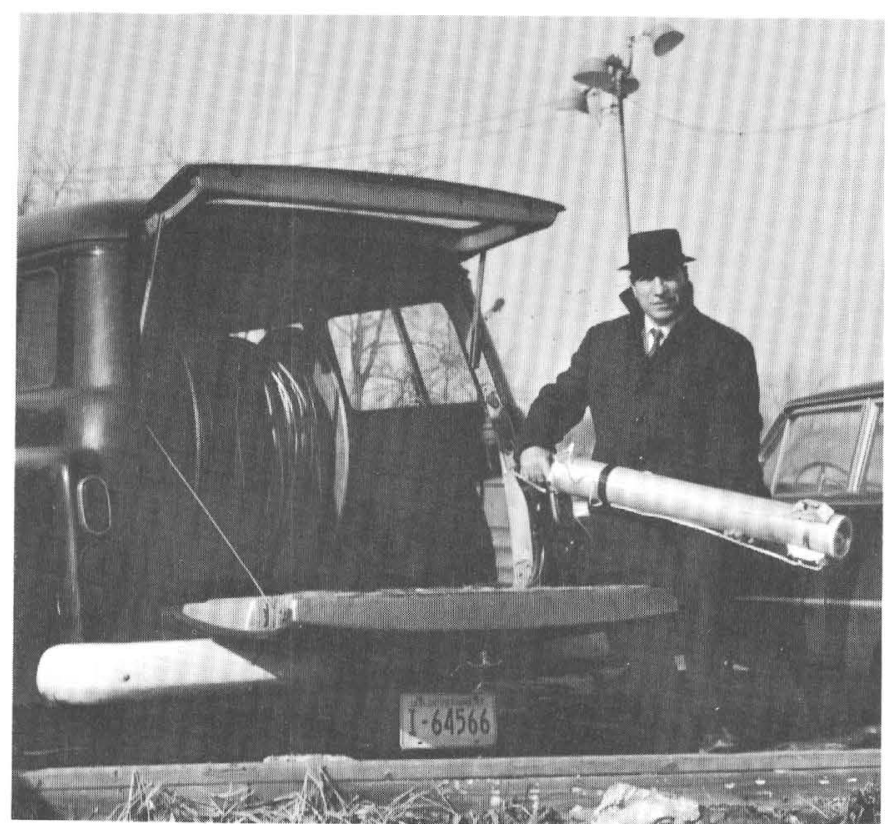

Figure 172.1.-Camera with attached lights. A reel, wound with 1,300 feet of 24 -conductor cable, is mounted in the truck.

end of the camera case (fig. 172.1). With the lamps in this position, light is directed both outward and downward on the sidewall of the hole. In an 8-inch hole the lighted area of view extends from approximately 4 inches to 30 inches in front of the camera. Because of the heat generated, the quartz iodide lamp can be used for prolonged periods only when immersed in water. At present the lighting is only adequate; it is expected that future experimentation will improve this important part of the system.

A municipal well at Hampstead, Md., was used for experimental tests of the equipment. The well, which is 8 inches in diameter and was drilled by the cable-tool method, penetrates fractured gneiss and schist of the Piedmont physiographic province. It is 400 feet deep and is cased to a depth of 60 feet. Tests were limited, however, to depths of about 200 feet because the reel assembly was not equipped with a motor.

In the piedmont, ground water is produced largely from joints and fractures in the rock. Fractures, irregularities of the hole, changes from lighter to darker rock, and quartz veins were clearly distinguishable on the TV monitor. Figure 172.2 is a typical closeup photograph of the monitor showing some of the features observed in the uncased part of the borehole. Like home TV, the picture is sharper when viewed directly rather than from a photograph of the image.

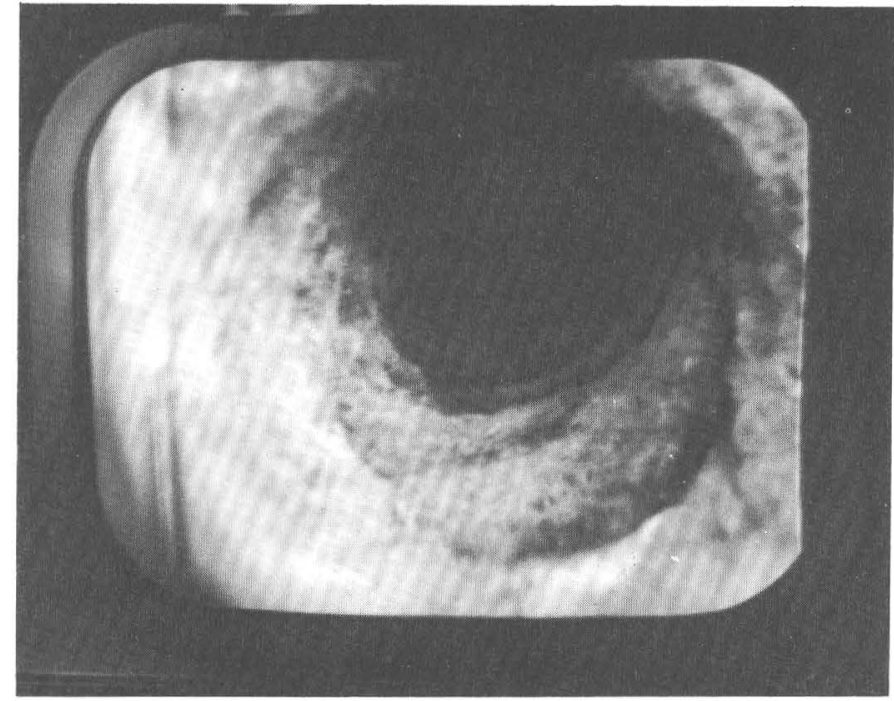

FIGURE 172.2.- Joints enlarged by drilling, in well at Hampstead.

The experiments indicate the usefulness of the TV apparatus, particularly where ground water occurs in joints or solution openings. Although the present equipment is fully operational, additional improvements are being designed; for example, except for the vidicon tube, the camera circuit can be completely transistorized. This will make it feasible to provide a part of the camera power through self-contained batteries, and will reduce the number of conductors required from 24 to perhaps 12 -permitting a sizable reduction in cable weight and cable-spool size.

Transistorizing the camera also makes it feasible to reduce the diameter of the metal case containing the camera and accompanying circuit. It is expected that a modified camera assembly, without the light assembly, can be built with a $3 \frac{1}{2}$-inch outside diameter. Depending upon the lighting arrangement, this may make it possible to operate the equipment in 6 -inch diameter holes.

A number of lighting changes are under consideration, but most of these improvements will be based on experiments in boreholes. Proper lighting appears to be a question of correctly positioning and directing the lights. Commonly, if the lights are improperly positioned, a "hot spot" or intensely lighted area saturates the picture tube. Possibly, monochromatic light with a wavelength selected to coincide with the most sensitive range of the vidicon tube may reduce light dispersion and absorption. Experiments are planned to test the feasibility of using such a lighting system. 


\section{SUBJECT INDEX}

[For major subject headings such as "Economic geology," "Geophysics," "Sedimentation," see under State names or refer to table of contents.]

\section{A}

Age determinations. See Potassium-argon, Radiocarbon, and Rubidiumstrontium age determinations.

Alaska, oil shale, Brooks Range foothills....... D131

Andrew Formation, Mississippi, definition...

\section{B}

Bachelor Mountain Rhyolite, Colorado, definition

Barstow Formation, California, paleontologyBoreholes, exploration by television.........-.

\section{C}

Cadmium, in the Pierre Shale

California, geochronology, Sonoma County_ paleontology, Mojave Desert.

stratigraphy, Mojave Desert...................... San Joaquin Valley

structural geology, northern Coast Ranges.

Canadian Shield, geochronology

Carboniferous. See Mississippian, Pennsylvanian.

Cation exchange, effect on thermal behavior of clinoptilolite and heulandite......-

Caves, fluvial sedimentation.

Chile, geomorphology, Santiago ground water, northern part Santiago.

Clay deposits, residual, thorium and uranium content...

Clinoptilolite, effect of cation exchange on thermal behavior

Colorado, petrology, Leadville area.........-..-petrology, San Juan Mountains......-.... stratigraphy, San Juan Mountains........ San Miguel County

structural geology, San Juan Mountains. San Miguel County

33

Copper, in alluvium, geochemical prospecting - 79, 98

Corals, Silurian and Devonian, North America_ 149

Creede Formation, Colorado, redefinition..... $\quad 62$

Cretaceous, California, geochronology........- 105

California, structural geology

Great Plains, cadmium in Pierre Shale...

Massachusetts, stratigraphy

Mississippi, stratigraphy

Crustal studies, Nevada, Las Vegas area......

Cyanogen bands, suppression.

\section{D}

Dantzler Formation, Mississippi, redefinition.

Devonian, North America, paleontology

Diatons, California, San Joaquin Valley

Differentiation, magmatic, in volcanic rocks--

Dilution technique, for solubility determination.

Dolomite, solubility in ground water......-

\section{$\mathbf{E}$}

Eddies, as flow indicators in rhyolite......-.Electrodes, cation-sensitive glass, for solubility determinations.

Page
Eocene, Mississippi, stratigraphy

Page

Estuaries, factors affecting attached orga-

nisms

\section{F}

Farmers Creek Rhyolite, Colorado, definition Fisher Quartz Latite, Colorado, redefinition. Floods, height-frequency relations.

Flow direction, determination in rhyolite.... Fluoride, in ground water.

Franciscan rocks, California, geochronology California, structural geology -

Friction carpet, at base of thrust sheets

\section{G}

Gas chromatography, effluent collector

Gas jet, d-c arc spectrosco

Geochemical prospecting, copper in allu-

vium

molybdenum in alluvium . . .

sampling-error effects........................

time variations in mineral abundance....

Glaucophane, in schist, isotopic age determination.

Gravity studies, Nevada, Las Vegas area...-.

Ground water, effect of diversion by drainage ditches. .......................... odified thermometer for temperature studies.

reaction with dolomite

temperature variations.

Gypsum Valley salt anticline, Colorado, lat growth. ...................

\section{H}

Hawail, geophysies, island of Hawaii

Hematite, determination of iron content..... Heulandite, effect of cation exchange on thermal behavior

Huerto Formation, Colorado, redefinition....

\section{I}

Idaho, ground water, National Reactor Testing Station

quality of water, National Reactor Testing Station.

stratigraphy, south-central part structural geology, south-central part... Ion-activity product, dolomite

Ion-exchange capacity, improved determinaion

Iron, determination in hematitic iron ore.....$$
\text { J }
$$

Jurassic, Alaska, oil shale California, geochronology structural geology.

Mississippi, stratigraphy

\section{K}

Kentucky, sedimentation, Mammoth Cave..- $\quad 141$
L

Page

La Garita Quartz Latite, Colorado, definition_ D57

M

Mackinawite, new mineral, properties.

Maine, geochemical prospecting, Aroostook County.-.:-

Mammoth $\begin{gathered}\text { Mountain Rhyolite, Colorado, } \\ \text { redefinition. }\end{gathered}$

Marine organisms, effect of temperature on.-.-

Maryland, oceanography, Patuxent River estuary

Massachusetts, geophysics, Cape Cod....... stratigraphy, Cape Cod.

Mineral solubility, in ground water.-.-

Miocene, California, paleontology .............

Mississippi, stratigraphy ................

Mississippi, stratigraphy, southeastern part..

Mississippian, Idaho, stratigraphy

Idaho, structural geology.

Nevada, stratigraphy.

structural geology.

Molybdenum, in aluvium, geochemical prospecting

Monazite, thorium and uranium content..... Montana, geochemistry, eastern part.-.--... Mudflow deposits, Quaternary, in Chile...... 194 118 118 118
179 43

\section{$\mathbf{N}$}

Nebraska, geochemistry, northwestern part-.. Nelson Mountain Quartz Latite, Colorado, redefinition.

Nevada, geochemistry, Nevada Test Site..... geophysics, Las Vegas area.....-.......... ground water, Oasis Valley...---.---.--.. quality of water, Oasis Valley ............. stratigraphy, Esmeralda and Nye Counties.

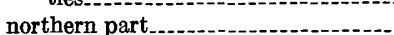
structural geology, northern part.........

New Jersey, floods.......-.-.-.-.-.-... New Mexico, sedimentation, Rio Grande.-... New York, ground water, Albany area....... North Carolina, stratigraphy, Burke County North Dakota, geochronology, Williston basin - 100

Norway, glacial chronology, Ullsfjord...-...-.. $\quad 159$

\section{o}

Ohio, ground water, Springfield area.......... 198 surface water, Springfield area _........... 198 Oil shale, Alaska, Jurassic Oligocene, Mississippi, stratigraphy........-. 43

\section{P}

Paleocene, Mississippi, stratigraphy

Pennsylvanian, Idaho, stratigraphy Idaho, structural geology Mississippi, stratigraphy . . . . . Nevada, stratigraphy... structural geology
73 61 93 108 189 24 1 202 138 100 59 81
43 


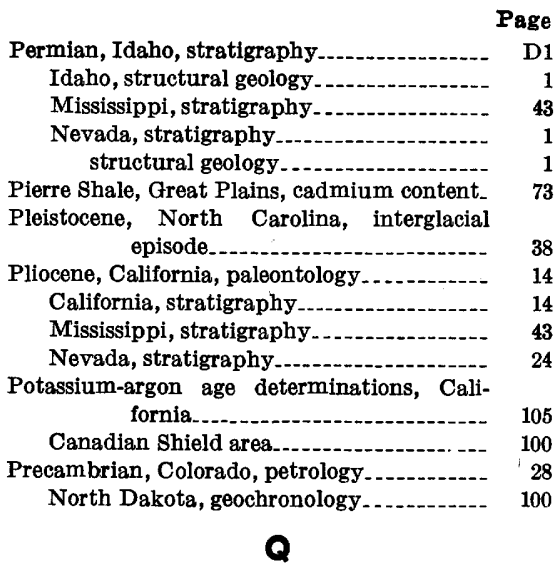
episode.

Pliocene, California, paleontology ........

California, stratigraphy

Mississippi, stratigraphy

Nevada, stratigraphy.

Potassium-argon age determinations, California.

Canadian Shield area North Dakota, geochronology.

Q

Page

Quality of water, effect of tree leaves on..... Quaternary, Chile, geomorphology.

Massachusetts, stratigraphy

Mississippi, stratigraphy See also Pleistocene.

\section{$\mathbf{R}$}

Radiocarbon age determinations, Norway...Rat Creek Quartz Latite, Colorado, redefini-

tion.

Reservoirs, storage-draft curves.

Rhizophyllum, Silurian and Devonian, North America

Rhyolite flows, determination of flow direction.

Rubidium-strontium age determinations, California........................ D1

38

14

4

24

105

100

28

100

181

144

118

159

159

60

192

149

70

105

105

\section{S}

St. Kevin Granite, Colorado, definition __ D28

Salt anticlines, Colorado, interpretation of growth.

Sampling error, effects in geochemical prospecting.

Saprolite, thorium and uranium in monazite Sediment concentrations, spatial and velocityweighted.

Sedimentation, storage of fine sediment in islands and point bars.

Seismic studies, island of Hawaii.............

Nevada, Las Vegas area....................

Shallow Creek Quartz Latite, Colorado, definition.

Silurian, North America, paleontology

Showshoe Mountain Quartz Latite, Colorado, definition.-.-.-.-.-.-.-.

Solubility determination, in concentrated solutions.

South Dakota, geochemistry, Black Hill area.

Spectrochemical analysis, d-c arc, gas jet...-.Spectrometry, X-ray fluorescence, in iron determination

Streamflow, regulation by storage..... relation to ground-water movement

\section{$\mathbf{T}$}

Tatum Limestone Member, Catahoula Sandstone, Mississippi, definition..... Tektites, semimicro X-ray fluorescence anal-

$$
\text { ysis }
$$

Television, use in borehole exploration.....-.

Temperature studies, ground water, New York

modified thermometer for ground water. river water.
Page

Tertiary, Colorado, stratigraphy

Colorado, structural geology

128

Massachusetts, stratigraphy...............- 118

See also Eocene, Miocene, Oligocene, Paleocene, Pliocene.

Texas, sedimentation, Rio Grande-..-...-.-.- 138

Thermometer, "lazy," for ground-water studies.

Thirsty Canyon Tuff, Nevada, definition

Thorium, in monazite from saprolite.........-. 128

Tree leaves, effect on water quality

Tuff, zeolitic, ion-exchange capacity-.

Uranium, in monazite from saprolite _...... 128 Utah, geochèmical prospecting, Rocky Range.

\section{V}

Valleriite, from Washington, properties...-.-Vertebrate fossils, Miocene, California.-...... Volcanism, Colorado, San Juan Mountains...

\section{W}

Washington, mineralogy, Snohomish County. mineralogy, Spokane County West Virginia, quality of water, Cacapon

$$
\text { River- }
$$

Wyoming, geochemistry, Black Hills area...

\section{$X Y Z$}

X-ray fluorescence analysis, small samples.--- 


\section{AUTHOR INDEX}

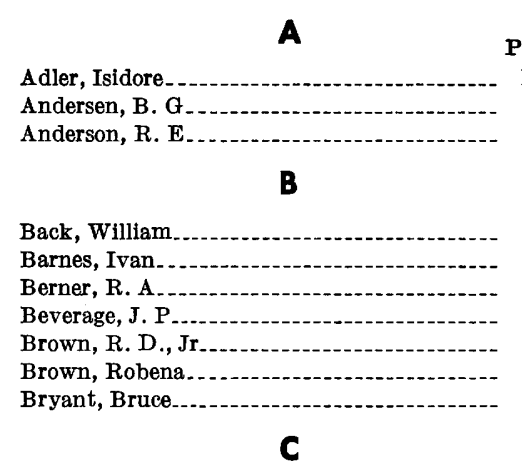

Canney, F. C

Carron, M. K.

Cater, F. W

Chao, E. C. T

Christ, C. L

Coleman, R. G

Collier, C. R.

Connor, J. J

Cory, R. L.

Cross, W. P

Cummings, David. . . .

Outtitta, Frank

D

Dingman, R. J. ............ 209

Doyel, W. W 209,213

E

Eakin, T. E.

Eargle, D. H

Eddy, J. E.

Ekren, E. B

Evans, H. T., Jr.

$\mathbf{F}$

Falcón M., Eduardo.

Feulner, A. J

Page

D64 24

\section{9} 79

167

09

3

64

141
84

84

198

70

\section{Lee, D. E}

Leopold, E. B

Lewis, G. E.

Lohman, K. E.

Hardison, C. H.

Heath, R. C

Helz, A. W

Holmes, G. W

Hosterman, J. W

Huffman, Claude, Jr

1

Ingram, Blanche

Klausing, R. L

K

Koyanagi, R. Y.

L

M

Malmberg, G. T

Marvin, R. F.

Mead, Cynthia

Miesch, A. T....
Milton, Charles.

\section{M}

\section{$\mathbf{N}$}

Niles, W. W

Noble, D. C

Nordin, C. F., Jr.

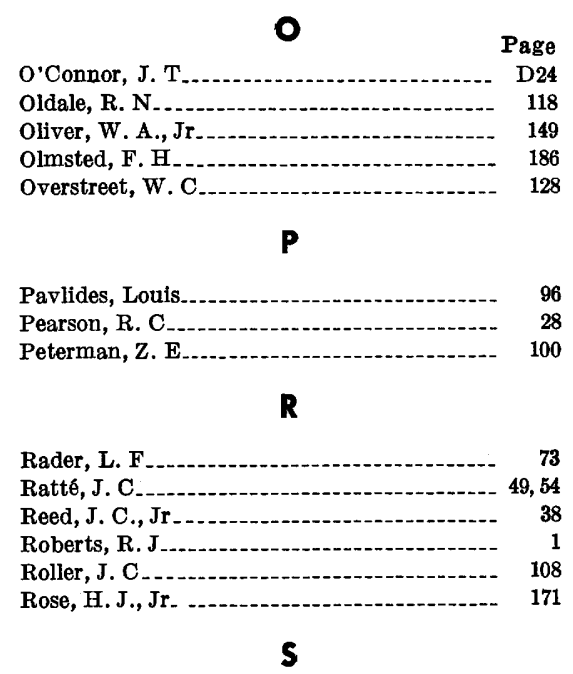

Segerstrom, Kenneth............ 144 Shepard, A. O. Simons, D. B.

Slack, K. V

Starkey, H. C.-_-

Steven, T. A. A

\section{$\mathbf{T}$}

Tailleur, I. L

Thomas, D. M.

Thomas, H. H

Thomasson, M. R

Tourtelot, H. A

(13

\section{W}

Warr, J. J., Jr.

Weiler, Louise 


